\title{
Effects of Spray-Irrigated Treated Effluent on Water Quantity and Quality, and the Fate and Transport of Nitrogen in a Small Watershed, New Garden Township, Chester County, Pennsylvania
}

By Curtis L. Schreffler, Daniel G. Galeone, John M. Veneziale, Leif E. Olson, and David L. O'Brien

In cooperation with the Chester County Water Resources Authority and the

Pennsylvania Department of Environmental Protection

Scientific Investigations Report 2005-5043

U.S. Department of the Interior

U.S. Geological Survey 


\title{
U.S. Department of the Interior Gale A. Norton, Secretary
}

\author{
U.S. Geological Survey \\ P. Patrick Leahy, Acting Director
}

\section{U.S. Geological Survey, Reston, Virginia: 2005}

\author{
For sale by U.S. Geological Survey, Information Services \\ Box 25286, Denver Federal Center \\ Denver, CO 80225 \\ For more information about the USGS and its products: \\ Telephone: 1-888-ASK-USGS \\ World Wide Web: http://www.usgs.gov/ \\ Any use of trade, product, or firm names in this publication is for descriptive purposes only and does not imply \\ endorsement by the U.S. Government. \\ Although this report is in the public domain, permission must be secured from the individual copyright owners to \\ reproduce any copyrighted materials contained within this report.
}

\section{Suggested citation:}

Schreffler, C.L., Galeone, D.G., Veneziale, J.M., Olson, L.E., and O'Brien, D.L., 2005, Effects of spray-irrigated treated effluent on water quantity and quality, and the fate and transport of nitrogen in a small watershed, New Garden Township, Chester County, Pennsylvania: U.S. Geological Survey Scientific Investigations Report 2005-5043, 158 p. 


\section{Contents}

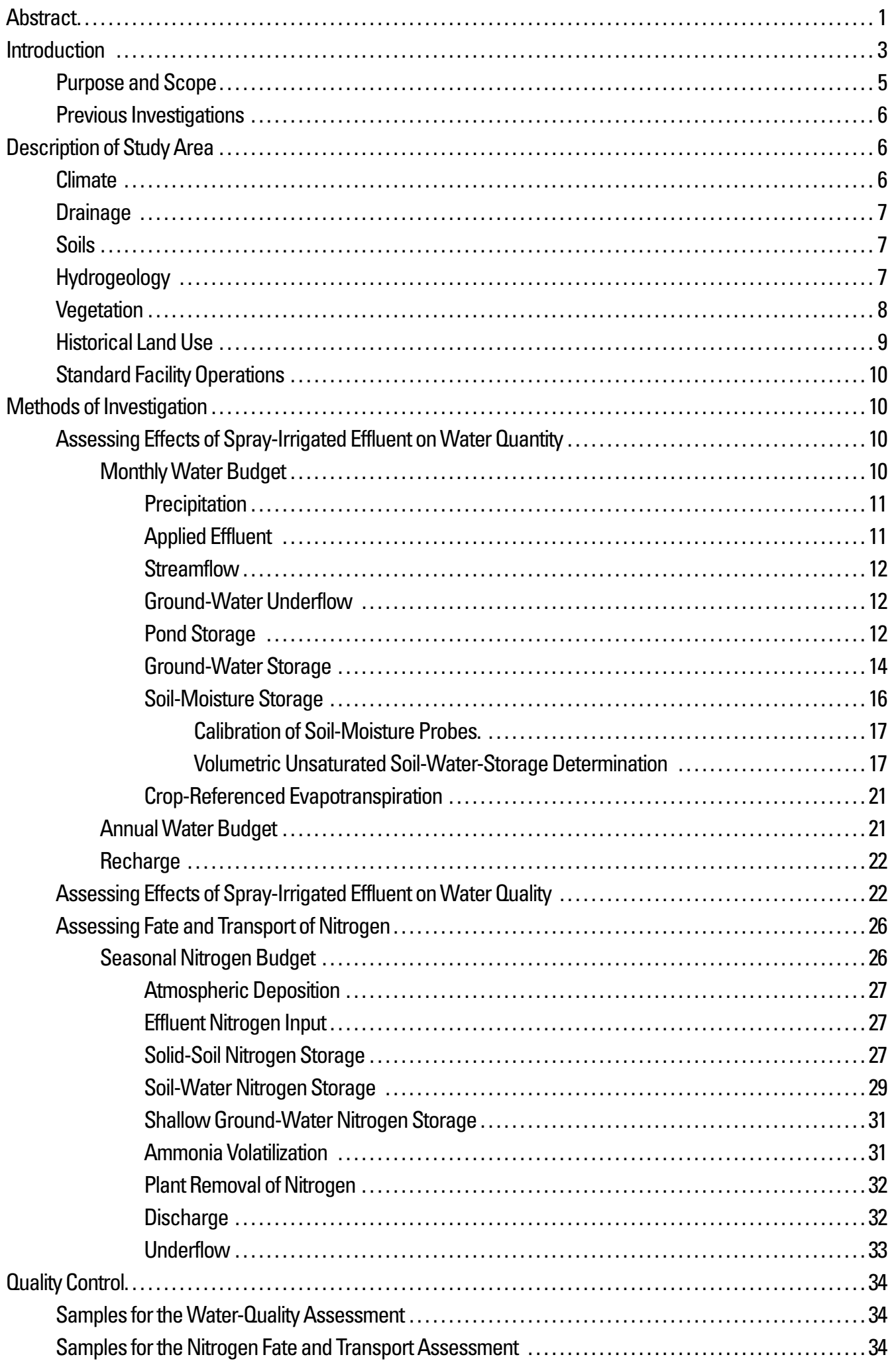




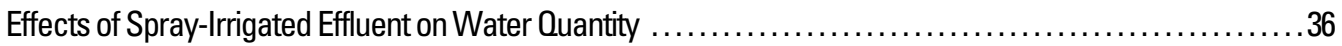

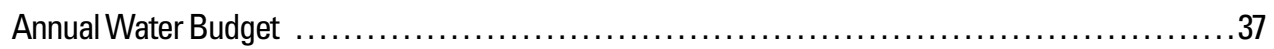

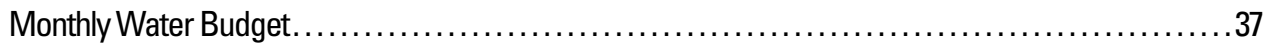

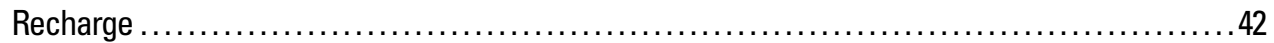

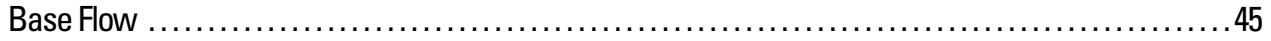

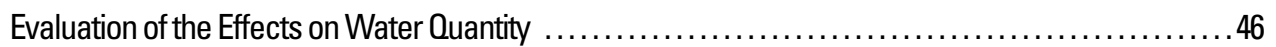

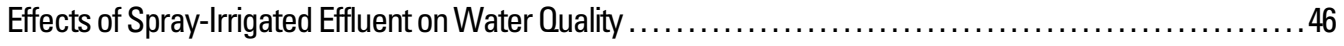

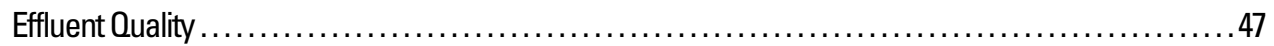

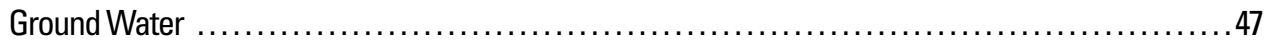

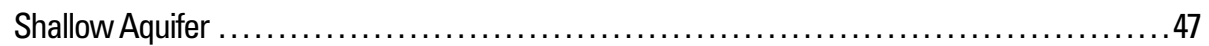

Physical Properties and Chemical Constituents Measured in the Field ................49

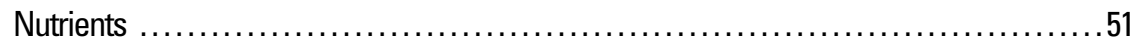

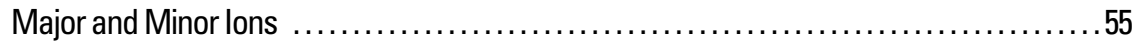

Metals and Other Trace Constituents ....................................5

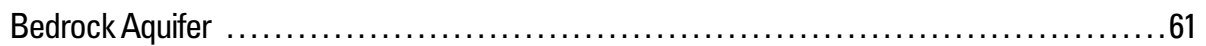

Physical Properties and Chemical Constituents Measured in the Field ................61

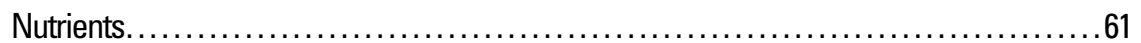

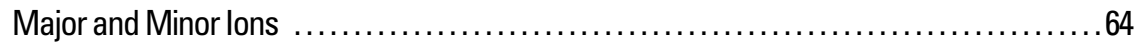

Metals and Other Trace Constituents.......................................64

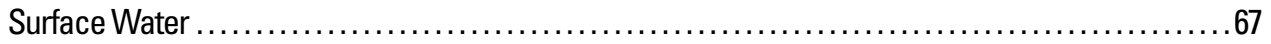

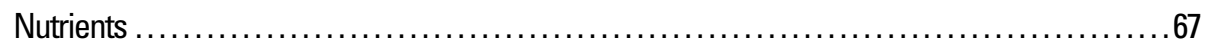

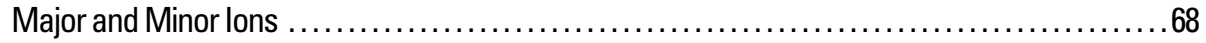

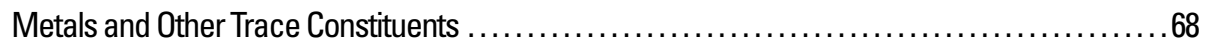

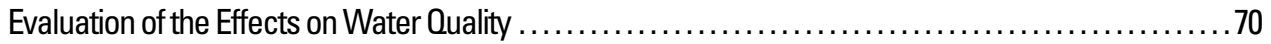

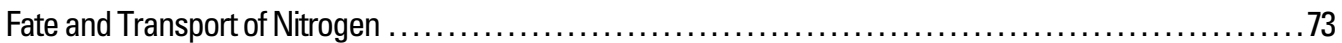

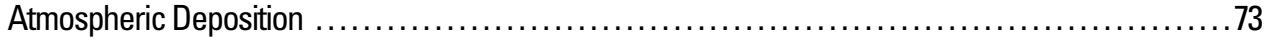

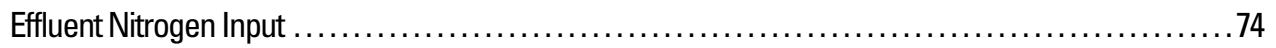

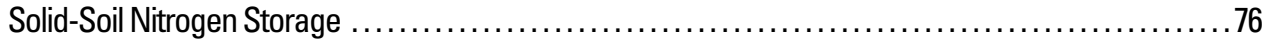

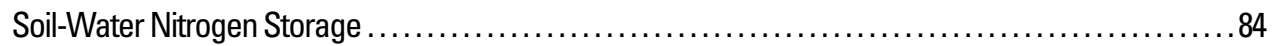

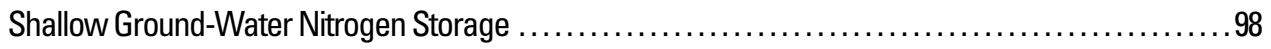

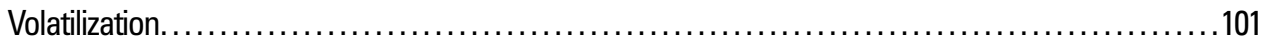

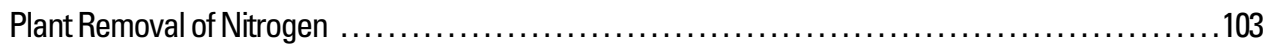

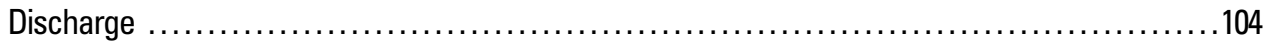

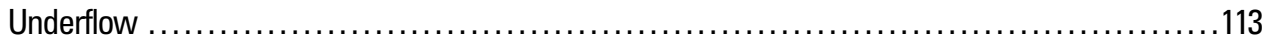

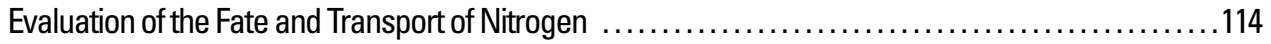

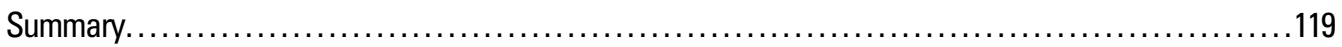

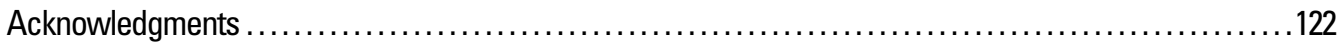

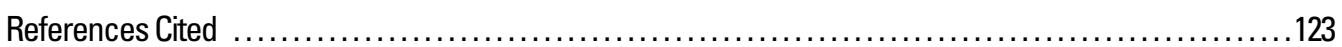

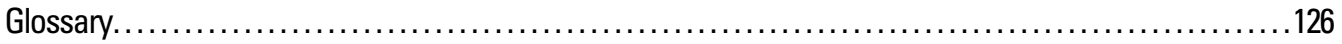

Appendix 1. Results of chemical and physical analyses of effluent, wet and dry deposition, soil, pan, and plant samples collected at the New Garden Township spray-irrigation site, Chester

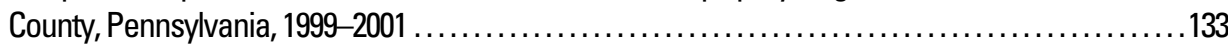




\section{Plates}

[In pocket]

1. Location of New Garden Township spray-irrigation site and instrumentation, Chester County, Pennsylvania

\section{Figures}

1. Map showing location of New Garden Township spray-irrigation site, Chester

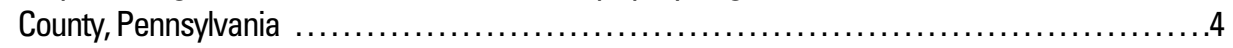

2. Project timeline with major events for the spray-irrigation study, New Garden Township . .........5

3. Map showing locations of soil borings and soil-test pits, New Garden Township spray-

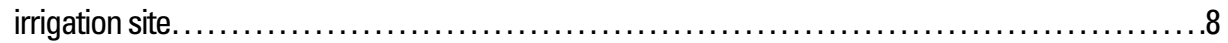

4. Sketch showing estimated thickness of unconsolidated material on west-east and

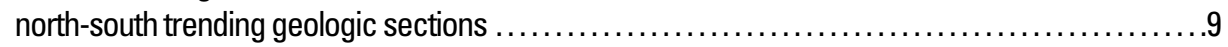

5. Sketch showing location of cross-sectional areas used in ground-water underflow estimates ... 13

6-13. Maps showing:

6. Locations of the eight ground-water storage sub-unit areas and monitor wells used in the monthly ground-water storage analysis 15

7. Locations of the soil-water storage sub-unit areas and soil-moisture probes used in

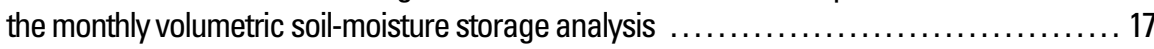

8. Locations of the monitor wells, township well, and estimated water-level data used to estimate the thickness of the unsaturated-soil layer ............................. 18

9. Maximum and minimum thickness of unsaturated-soil layer ....................... 20

10. Maximum thickness of unsaturated-soil layer for sub-unit area $4 \ldots \ldots \ldots \ldots \ldots \ldots \ldots \ldots \ldots \ldots \ldots \ldots$

11. Drainage area above streamflow-gaging station Red Clay Creek near Kennett Square,

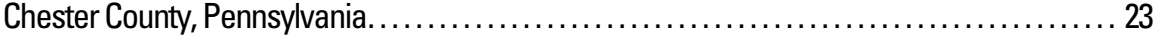

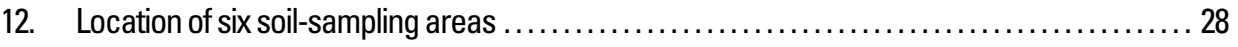

13. Water-table altitude and conceptual ground-water-flow directions................... 38

14-21. Graphs showing:

14. Crop-referenced and calculated evapotranspiration, spray-irrigated effluent, and monthly precipitation, September 1999 through December 2001 ....................... 39

15. Depth to water in well Ch-5173, September 1999 through December $2001 \ldots \ldots \ldots \ldots \ldots \ldots 41$

16. Monthly estimated recharge, spray-irrigated effluent, and precipitation, September 1999 through December 2001

17. Monthly total-recharge estimates and daily ground-water levels in well Ch-5173, September 1999 through December 2001

18. Double-mass curve of cumulative monthly base flow for unnamed tributary to West Branch Red Clay Creek at Kennett Square, Pa., and Red Clay Creek near Kennett Square, Pa., May 1998 through December 2001.

19. Specific conductance of water samples from well Ch-5180, 1999-2001 ................. 49

20. Concentrations of dissolved nitrate nitrogen in water from wells Ch-5179 and Ch-5180 on the eastern application area and well Ch-5173 on the western application area prior to and during effluent application, 1998-2001 ....

21. Concentrations of dissolved nitrate nitrogen in water from wells Ch-5177 and Ch-5181 in the valley-bottom area prior to and during effluent application, 1998-2001

22. Boxplots showing concentrations of nitrate nitrogen in water from monitor wells $\mathrm{Ch}-5173$ and Ch-5175 on the western application area and well Ch-5179 on the eastern application area prior to and during effluent application, 1998-2001 
23. Boxplots showing concentrations of nitrate nitrogen in water from wells Ch-5177 and Ch-5181

in the valley-bottom area prior to and during effluent application, 1998-2001 ................ 53

24. Graph showing concentrations of dissolved phosphorus in water from well Ch-5179 on the eastern application area and control well Ch-5183, 1998-2001 ........................... 54

25. Graphs showing concentrations of chloride in water from shallow monitor wells Ch-5173, Ch-5180, Ch-5179, Ch-5177, and Ch-5183, 1998-2001 ................................. 55

26. Boxplots showing concentrations of chloride in water from wells Ch-5173, Ch-5175, and Ch-5179 collected prior to and during effluent application 56

27-36. Graphs showing:

27. Concentration of dissolved nitrate nitrogen in water from hilltop bedrock well Ch-5172 and valley-bottom bedrock well Ch-5176, 1998-2001 ..........................6 6

28. Concentration of dissolved phosphorus in water from bedrock wells Ch-5172 and Ch-5182, 1998-2001

29. Chloride concentration in water from hilltop bedrock monitor well Ch-5172, 1998-2001 . . . . . 64

30. Concentrations of dissolved nitrate nitrogen in water from the pond and weir, 1998-2001 ... 67

31. Concentrations of manganese in water from the pond and the weir, 1998-2001 ............69

32. Concentrations of nitrate nitrogen in water from hilltop application shallow wells Ch-5173 and Ch-5180, hillside application area shallow well Ch-5179, and concentrations of chloride in water from wells Ch-5179 and Ch-5180, 1998-2001. ...

33. Concentrations of calcium, magnesium, sodium, and potassium in water from eastern application area shallow well Ch-5179, 1998-2001 .............................. 71

34. Concentrations of chloride and dissolved nitrate nitrogen in water samples from wells Ch-5172 and Ch-5173, 1998-2001.

35. Concentrations of chloride and nitrate nitrogen in water samples from valley-bottom bedrock well Ch-5176, 1998-2001 72

36. Ratio of nitrate-nitrogen to chloride concentrations in effluent samples, 1999-2001 .........74

37. Map showing location of soil-sampling areas and known spent mushroom substrate areas. . . . 77

38-64. Graphs showing:

38. Concentration of nitrogen per unit mass of soil for soil samples collected from depths of 0-8 inches, $>8-24$ inches, and >24-48 inches, 1999-2001 .

39. Concentration of nitrate nitrogen per unit mass of soil for soil samples collected from depths of 0-8 inches, $>8-24$ inches, and $>24-48$ inches, 1999-2001 ...

40. Concentration of ammonium nitrogen per unit mass and identification of significant time trends in ammonium nitrogen for soil samples collected from depths of 0-8 inches, $>8-24$ inches, and >24-48 inches, 1999-2001

41. Oxidation-reduction potential (redox) and identification of significant time trends in redox for soil samples collected from depths of 0-8 inches, $>8-24$ inches, and

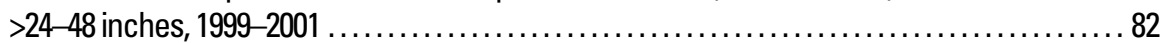

42. Concentrations of dissolved nitrogen for the network of soil-suction lysimeters, 1999-2001 . . 85

43. Concentrations of dissolved chloride for the network of soil-suction lysimeters, 1999-2001 . . 88

44. Different forms of nitrogen that make up the dissolved fraction for the network of soil-suction lysimeters, June 1999 through December 2001

45. Concentrations of dissolved nitrate nitrogen and identification of significant time trends in nitrate nitrogen for the network of soil-suction lysimeters, 1999-2001

46. Concentrations of dissolved organic nitrogen and identification of significant time trends in organic nitrogen for the network of soil-suction lysimeters, 1999-2001. ....

47. Ratio of nitrate-nitrogen to chloride concentrations and identification of significant time trends in the ratio of nitrate-nitrogen to chloride for the network of soil-suction lysimeters, 1999-2001 
48. Estimated volumetric soil moistures at time of lysimeter sample collection for lysimeters in sub-unit areas 2, 4, and 6, 1999-2001 ...................................... 95

49. Estimated pounds of nitrogen in micropore soil water for sub-unit areas 2, 4, and 6 to

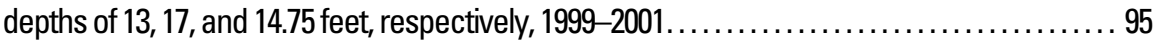

50. Estimated pounds of chloride in micropore soil water or sub-unit areas 2, 4, and 6 to

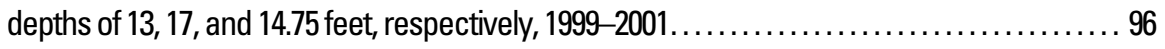

51. Daily water-level altitudes for wells Ch-5173, Ch-5175, and Ch-5177 and the dates

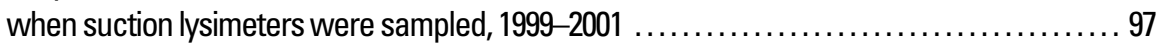

52. Concentrations of ammonia nitrogen in spray effluent and PAN samples, 1999-2001 ....... 101

53. Monthly differences in concentrations of ammonia nitrogen in spray effluent and

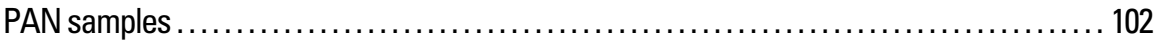

54. Concentrations of nitrogen in dry plant material harvested from different soil-

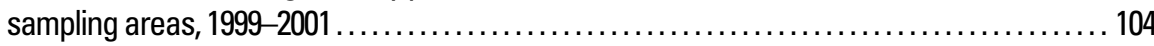

55. Hydrograph of daily values for discharge through the flume and monthly values for

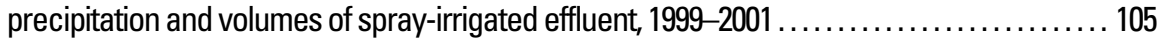

56. Instantaneous discharge at the time of grab-sample collection from the outlet of the

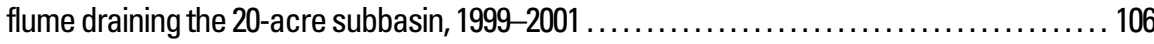

57. Concentrations of total and dissolved forms of nitrogen over time and identification of significant time trends for grab samples collected at the outlet of the flume, 1999-2001 . . 107

58. Concentration of dissolved chloride for grab samples collected at the outlet of the

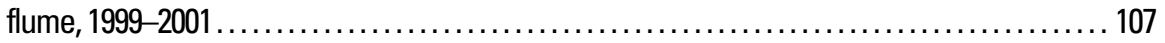

59. Mean discharge for storm events sampled at the flume draining the 20-acre

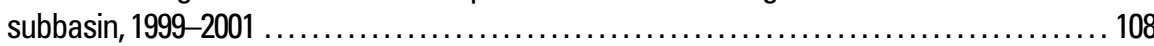

60. Concentrations of total and dissolved forms of nitrogen and identification of significant time trends for storm samples collected at the flume, $1999-2001 \ldots \ldots \ldots \ldots \ldots \ldots \ldots \ldots . \ldots . \ldots 108$

61. Concentration of dissolved chloride for storm samples collected at the flume, 1999-2001 ... 109

62. Ratio of nitrate-nitrogen to chloride concentrations for low-flow and stormflow

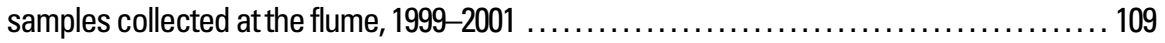

63. Instantaneous loads of total and dissolved forms of nitrogen and identification of significant time trends for grab samples collected at the outlet of the flume, 1999-2001 ..... 110

64. Loads of total and dissolved forms of nitrogen and identification of significant time trends for storm samples collected at the flume, 1999-2001

\section{Tables}

1. Monthly permitted hydraulic-loading rates for New Garden Township spray-irrigation site,

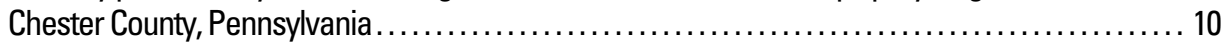

2. Summary of monitor-well construction characteristics ............................... 14

3. Ground-water storage sub-unit areas used to determine watershed specific yield............. 15

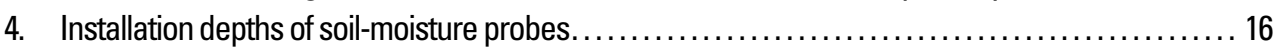

5. Total surface area of soil-water storage sub-unit areas used to determine volumetric

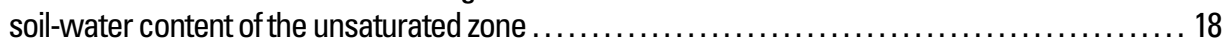

6. Assigned thickness of unsaturated-soil layer and polygon areas used to determine the weighted thickness for sub-unit area 4

7. Summary of analyzed chemical constituents in the monthly, quarterly, and annual sampling schedules and laboratory minimum reporting limits for the New Garden Township spray-irrigation study.

8. Number and type of samples collected for the water-quality objective of the New Garden Township spray-irrigation study . 
9. Lysimeter nest designation, local names, depth below land surface, and altitude of

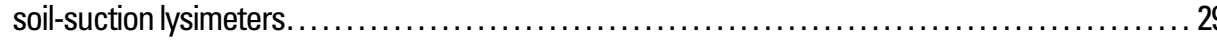

10. Summary of median percentage differences for replicate samples collected for the water-quality objective of the New Garden Township spray-irrigation study $\ldots \ldots \ldots \ldots \ldots \ldots \ldots \ldots \ldots \ldots$

11. Summary of median percentage differences for nitrogen species and chloride for replicate samples collected from either suction lysimeters or the flume outlet 35

12. Summary of median percentage differences for nitrogen species, redox, and extractable chloride for replicate samples collected from the solid-soil matrix.

13. Annual water budgets for the study watershed, New Garden Township spray-irrigation site and Red Clay Creek watershed above the Kennett Square streamflow-gaging station (01479820), Chester County, Pennsylvania, for the period May 1998 through April 1999 prior to effluent application and for calendar years 2000 and 2001 during effluent application .......... 39

14. Summary of monthly water-budget parameters, September 1999 through December 2001 ....... 40

15. Summary of monthly estimated recharge, precipitation, and spray-irrigated effluent volumes

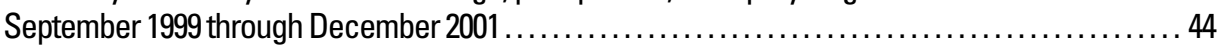

16. Summary of physical and chemical properties, major and selected minor ions, nutrients, and metal concentrations in effluent, May 1999 to December 2001.

17. Summary of Wilcoxon rank-sum test, Mann-Kendall test for trends, and median values of $\mathrm{pH}$, water temperature, specific conductance, alkalinity, and dissolved oxygen in water from shallow wells collected prior to and during effluent application, May 1998 through December 2001

18. Summary of Wilcoxon rank-sum test, Mann-Kendall test for trends, and median concentrations of dissolved nutrients in water from shallow monitor wells collected prior to and during effluent application, May 1998 through December 2001

19. Summary of concentrations of dissolved phosphorus and dissolved orthophosphate phosphorus in water from shallow wells collected prior to and during effluent application, 1998-2001.

20. Summary of Wilcoxon rank-sum test, Mann-Kendall test for trends, and median concentrations of dissolved major and minor ions in water from shallow wells collected prior to and during effluent application, May 1998 through December 2001 . .

21. Summary of concentrations of metal and trace constituents in water from shallow monitor wells on the application area, the valley bottom, and the control area, May 1998 through December 2001

22. Summary of Wilcoxon rank-sum test, Mann-Kendall test for trends, and median values of $\mathrm{pH}$, water temperature, specific conductance, alkalinity, and dissolved oxygen in water from bedrock wells collected prior to and during effluent application, May 1998 through December 2001

23. Summary of Wilcoxon rank-sum test, Mann-Kendall test for trends, and median concentrations of dissolved nitrogen species in water from bedrock monitor wells collected prior to and during effluent application, May 1998 through December 2001 .

24. Summary of Wilcoxon rank-sum test, Mann-Kendall test for trends, and median concentrations of dissolved major and minor ions in water from bedrock monitor wells collected prior to and during effluent application, May 1998 through December 2001 .

25. Summary of median concentrations of barium and strontium in water from deep bedrock monitor wells, May 1998 through December 2001 ...

26. Summary of concentrations of total and dissolved nitrogen and phosphorus species in water from the pond and immediately downstream of the weir collected prior to and during effluent application, May 1998 through December 2001.

27. Summary of concentrations of major and selected minor ions in water from the pond and downstream of the weir collected prior to and during effluent application, May 1998 through December 2001 
28. Quarterly loads of nitrogen, ammonia nitrogen, nitrate nitrogen, and organic nitrogen deposited from wet and dry deposition over the 20-acre subbasin, August 1999 through December 2001

29. The total volume of effluent applied and the load of dissolved chloride, total and dissolved ammonia nitrogen, dissolved nitrate nitrogen, dissolved nitrite nitrogen, dissolved and total organic nitrogen, and dissolved and total nitrogen applied to the 20-acre subbasin from spray applications, June 1999 through December 2001

30. Mean soil concentrations of total nitrogen, nitrate nitrogen, and ammonium nitrogen for soil samples collected in the six different soil-sampling areas for depths of $0-8,>8-24,>24-48$, 0-48 inches, April 1999 through October 2001.

31. Total estimated masses of nitrogen, nitrate nitrogen, and ammonium nitrogen in the solid-soil matrix to a depth of 4 feet for the six different soil-sampling areas, 1999-2001

32. Range of estimates for the total mass of nitrogen stored in the solid-soil matrix for depths of 4 feet to the depth of competent bedrock for the four different soil-sampling areas within the 20-acre subbasin, April 1999 through October 2001.

33. Regression equations relating concentrations of dissolved nitrogen and chloride to time (in days) for soil-suction lysimeter data, June 1999 through December 2001 . ...

34. Total estimated masses of nitrogen and chloride in micropore soil water for sub-unit areas

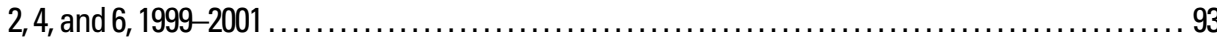

35. Estimates of the mass of nitrogen in sub-unit area 2 for depths below land surface from

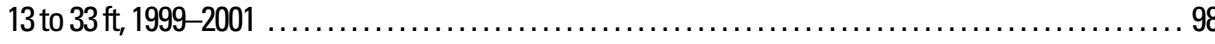

36. Results for nitrogen-isotope samples collected from the lysimeter network,

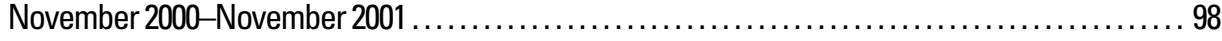

37. Total estimated masses of nitrogen and chloride from the average depth of the water table to the depth of competent bedrock for sub-unit areas 2, 4, and 6, 1999-2001................. 99

38. Results for nitrogen-isotope samples collected from the monitor-well network, May 1999-November 2000. 100

39. Amount of nitrogen removed during plant harvest in the soil-sampling areas of the 20-acre subbasin and control areas, 1999-2001. ... 103

40. Amount and forms of nitrogen transported during low flow and stormflow through the flume draining the 20-acre subbasin, July 1999 through December 2001 . ...

41. Monthly estimates of the mass of dissolved $\mathrm{N}$ leaving the 20-acre subbasin as underflow, the weighted $\mathrm{N}$ concentration for the saturated water column above competent bedrock, and the estimated volume of underflow leaving the 20-acre subbasin, September 1999 through December 2001. 115

42. Summary of inorganic and organic nitrogen inputs and outputs for the 20-acre subbasin, April 1999 through December 2001. 116

43. Summary of inorganic and organic nitrogen storage for the 20-acre subbasin, April 1999 through December 2001

\section{Appendix 1}

1-1. Results of chemical and physical analyses of effluent samples collected, May 1999 through December 2001

1-2. Results of chemical analyses of wet-precipitation samples collected, August 1999 through December 2001

1-3. Results of chemical analyses of dry-deposition samples collected, November 1999 through October 2001

1-4. Chemical and physical properties of soil samples collected, April 1999 through October 2001 .... 142

1-5. Results of chemical analyses of PAN samples collected, July 1999 through October 2001 ....... 150

1-6. Nitrogen-concentration data for plant samples collected immediately prior to, during, or immediately after cutting for harvest, May 1999 through September 2001 


\section{Conversion Factors and Datum}

\begin{tabular}{|c|c|c|}
\hline Multiply & By & To obtain \\
\hline \multicolumn{3}{|c|}{ Length } \\
\hline inch (in.) & 2.54 & centimeter $(\mathrm{cm})$ \\
\hline foot $(\mathrm{ft})$ & 0.3048 & meter $(\mathrm{m})$ \\
\hline mile (mi) & 1.609 & kilometer $(\mathrm{km})$ \\
\hline \multicolumn{3}{|c|}{ Area } \\
\hline acre & 4,047 & square meter $\left(\mathrm{m}^{2}\right)$ \\
\hline square inch $\left(\mathrm{in}^{2}\right)$ & 6.452 & square centimeter $\left(\mathrm{cm}^{2}\right)$ \\
\hline square foot $\left(\mathrm{ft}^{2}\right)$ & 0.09290 & square meter $\left(\mathrm{m}^{2}\right)$ \\
\hline square mile $\left(\mathrm{mi}^{2}\right)$ & 2.590 & square kilometer $\left(\mathrm{km}^{2}\right)$ \\
\hline \multicolumn{3}{|c|}{ Volume } \\
\hline gallon (gal) & 3.785 & liter (L) \\
\hline million gallons (Mgal) & 3,785 & cubic meter $\left(\mathrm{m}^{3}\right)$ \\
\hline \multicolumn{3}{|c|}{ Flow rate } \\
\hline inch per day (in/d) & 0.0254 & meter per day $(\mathrm{m} / \mathrm{d})$ \\
\hline foot per day (ft/d) & 0.3048 & meter per day $(\mathrm{m} / \mathrm{d})$ \\
\hline cubic foot per second $\left(\mathrm{ft}^{3} / \mathrm{s}\right)$ & 0.02832 & cubic meter per second $\left(\mathrm{m}^{3} / \mathrm{s}\right)$ \\
\hline cubic foot per day $\left(\mathrm{ft}^{3} / \mathrm{d}\right)$ & 0.02832 & cubic meter per day $\left(\mathrm{m}^{3} / \mathrm{d}\right)$ \\
\hline gallon per minute (gal/min) & 0.06309 & liter per second $(\mathrm{L} / \mathrm{s})$ \\
\hline \multicolumn{3}{|c|}{ Mass } \\
\hline pound, avoirdupois (lb) & 0.4536 & kilogram (kg) \\
\hline ton, short $(2,000 \mathrm{lb})$ & 0.9072 & megagram $(\mathrm{Mg})$ \\
\hline \multicolumn{3}{|c|}{ Pressure } \\
\hline pound per square inch $\left(\mathrm{lb} / \mathrm{in}^{2}\right)$ & 6.895 & kilopascal (kPa) \\
\hline \multicolumn{3}{|c|}{ Density } \\
\hline pound per cubic foot $\left(\mathrm{lb} / \mathrm{ft}^{3}\right)$ & 0.01602 & gram per cubic centimeter $\left(\mathrm{g} / \mathrm{cm}^{3}\right)$ \\
\hline \multicolumn{3}{|c|}{ Specific capacity } \\
\hline $\begin{array}{l}\text { gallon per minute per foot } \\
[(\mathrm{gal} / \mathrm{min}) / \mathrm{ft})]\end{array}$ & 0.2070 & $\begin{array}{l}\text { liter per second per meter } \\
{[(\mathrm{L} / \mathrm{s} / \mathrm{m}]}\end{array}$ \\
\hline
\end{tabular}




\begin{tabular}{|c|c|c|}
\hline Multiply & By & To obtain \\
\hline \multicolumn{3}{|c|}{ Hydraulic conductivity } \\
\hline foot per day (ft/d) & 0.3048 & meter per day $(\mathrm{m} / \mathrm{d})$ \\
\hline \multicolumn{3}{|c|}{ Hydraulic gradient } \\
\hline foot per mile ( $\mathrm{ft} / \mathrm{mi})$ & 0.1894 & meter per kilometer $(\mathrm{m} / \mathrm{km})$ \\
\hline \multicolumn{3}{|c|}{ Application rate } \\
\hline inch per acre (in/acre) & 5.682 & centimeter per hectare $(\mathrm{cm} / \mathrm{acre})$ \\
\hline \multirow[t]{2}{*}{$\begin{array}{l}\text { inch per acre per week } \\
\text { [(in/acre }) / \text { week] }\end{array}$} & 5.682 & $\begin{array}{l}\text { centimeter per hectare per week } \\
{[(\mathrm{cm} / \text { acre }) / \text { week }]}\end{array}$ \\
\hline & 1.121 & \\
\hline pounds per acre (lb/acre) & & kilograms per hectare $(\mathrm{kg} / \mathrm{ha})$ \\
\hline $\begin{array}{l}\text { pounds per acre per year } \\
{[(\mathrm{lb} / \mathrm{acre}) / \mathrm{yr}]}\end{array}$ & 1.121 & $\begin{array}{l}\text { kilograms per hectare per year } \\
{[(\mathrm{kg} / \mathrm{ha}) / \mathrm{yr}]}\end{array}$ \\
\hline
\end{tabular}

Temperature in degrees Celsius $\left({ }^{\circ} \mathrm{C}\right)$ may be converted to degrees Fahrenheit $\left({ }^{\circ} \mathrm{F}\right)$ as follows:

$$
{ }^{\circ} \mathrm{F}=\left(1.8 \times{ }^{\circ} \mathrm{C}\right)+32
$$

Temperature in degrees Fahrenheit $\left({ }^{\circ} \mathrm{F}\right)$ may be converted to degrees Celsius $\left({ }^{\circ} \mathrm{C}\right)$ as follows:

$$
{ }^{\circ} \mathrm{C}=\left({ }^{\circ} \mathrm{F}-32\right) / 1.8
$$

Vertical coordinate information is referenced to the National Geodetic Vertical Datum of 1929 (NGVD 29).

Horizontal coordinate information is referenced to the North American Datum of 1988 (NAVD 88). Altitude, as used in this report, refers to distance above the vertical datum.

Specific conductance is given in microsiemens per centimeter at 25 degrees Celsius $(\mu \mathrm{S} / \mathrm{cm}$ at $\left.25^{\circ} \mathrm{C}\right)$.

Concentrations of chemical constituents in water are given either in milligrams per liter $(\mathrm{mg} / \mathrm{L})$ or micrograms per liter $(\mu \mathrm{g} / \mathrm{L})$.

Nitrogen isotope data are given in per mil units (\%o).

$<$, less than

$>$, greater than 



\title{
Effects of Spray-Irrigated Treated Effluent on Water Quantity and Quality, and the Fate and Transport of Nitrogen in a Small Watershed, New Garden Township, Chester County, Pennsylvania
}

\author{
By Curtis L. Schreffler, Daniel G. Galeone, John M. Veneziale, Leif E. Olson, and David L. O'Brien
}

\section{Abstract}

An increasing number of communities in Pennsylvania are implementing land-treatment systems to dispose of treated sewage effluent. Disposal of treated effluent by spraying onto the land surface, instead of discharging to streams, may recharge the ground-water system and reduce degradation of streamwater quality. The U.S. Geological Survey (USGS), in cooperation with the Pennsylvania Department of Environmental Protection (PaDEP) and the Chester County Water Resources Authority (CCWRA) and with assistance from the New Garden Township Sewer Authority, conducted a study from October 1997 through December 2001 to assess the effects of spray irrigation of secondary treated sewage effluent on the water quantity and quality and the fate and transport of nitrogen in a 38acre watershed in New Garden Township, Chester County, Pa.

On an annual basis, the spray irrigation increased the recharge to the watershed. Compared to the annual recharge determined for the Red Clay Creek watershed above the USGS streamflow-gaging station (01479820) near Kennett Square, $\mathrm{Pa}$., the spray irrigation increased annual recharge in the study watershed by approximately 8.8 in. (inches) in 2000 and 4.3 in. in 2001. For 2000 and 2001, the spray irrigation increased recharge 65-70 percent more than the recharge estimates determined for the Red Clay Creek watershed. The increased recharge was equal to 30-39 percent of the applied effluent.

The spray-irrigated effluent increased base flow in the watershed. The magnitude of the increase appeared to be related to the time of year when the application rates increased. During the late fall through winter and into the early spring period, when application rates were low, base flow increased by approximately 50 percent over the period prior to effluent application. During the early spring through summer to the late fall period, when application rates were high, base flow increased by approximately 200 percent over the period prior to effluent application.
The spray-irrigated effluent affected the ground-water quality of the shallow aquifer differently on the hilltop and hillside topographic settings of the watershed where spray irrigation was being applied (application area). Concentrations of nitrate-nitrogen (nitrate $\mathrm{N}$ ) and chloride $(\mathrm{Cl})$ in the effluent were higher than concentrations of these constituents in shallow ground water from wells on the hilltop and hillside prior to start of spray irrigation. In water from wells on the hilltop, concentrations of nitrate $\mathrm{N}$ and $\mathrm{Cl}$ increased in samples collected during effluent application compared to samples collected prior to effluent application. Also, increasing trends in concentration of these two constituents were evident through the study period. In water from wells on the hillside, which were on the eastern part of the application area, nitrate $\mathrm{N}$ and $\mathrm{Cl}$ concentrations increased in samples collected during effluent application compared to samples collected prior to effluent application. Also, increasing trends in concentration of these two constituents were evident through the study period. However, on the hillside of the western application area, the ground-water quality was not affected by the spray-irrigated effluent because of the greater thickness of unconsolidated material and higher amounts of clay present in those unconsolidated sands.

Although nitrate $\mathrm{N}$ concentrations increased in water from hilltop and hillside wells in the application area, the nitrate $\mathrm{N}$ concentrations were below the effluent concentration. A combination of plant uptake, biological activity, and denitrification may be the processes accounting for the lower nitrate $\mathrm{N}$ concentrations in shallow ground water compared to the spray-irrigated effluent. $\mathrm{Cl}$ concentrations in water from hilltop western application area well Ch-5173 increased during the study period but were an order of magnitude less than the input effluent concentration. $\mathrm{Cl}$ concentrations in shallow ground water in the eastern application area approached the median chloride concentration in the spray-irrigated effluent of $90 \mathrm{mg} / \mathrm{L}$ (milligrams per liter). The chloride concentrations in water from wells Ch-5180 and Ch-5179 were 74 and $61 \mathrm{mg} / \mathrm{L}$ in samples collected in December 2001, which was when data collection ended. 


\section{Effects of Spray-Irrigated Effluent on Water Quantity and Quality, and the Fate and Transport of Nitrogen}

The spray-irrigated effluent affected the ground-water quality of the shallow aquifer in the valley bottom, which was outside the application area. Nitrate $\mathrm{N}$ concentrations were lower and $\mathrm{Cl}$ concentrations were higher in the effluent than concentrations of these constituents in shallow ground water in the valley bottom because of past land-use practices. Historically, spent mushroom substrate was disposed of in this area. The spent mushroom substrate leached nitrate $\mathrm{N}$ into the shallow aquifer causing elevated concentrations of nitrate $\mathrm{N}$ (>25 mg/L). In water in the valley bottom, nitrate $\mathrm{N}$ concentrations decreased and chloride concentrations increased when comparing samples collected prior to application to samples collected during effluent application. The increased hydraulic loading of spray-irrigated effluent flushed out the higher concentrated nitrate $\mathrm{N}$ water from the area. $\mathrm{Cl}$ concentrations started to increase after approximately 1 year of effluent being applied, which may be due to lag time of the effluent water reaching the valley bottom.

Spray-irrigated effluent did affect ground water in the bedrock aquifer on the hilltop application area and in the valley bottom but ground water in the bedrock aquifer on the hillside application areas was not affected. Concentrations of nitrate $\mathrm{N}$ and $\mathrm{Cl}$ increased slightly in water from wells on the hilltop probably because vertical downward head (water-level) differences between the shallow and bedrock aquifers were greatest on the hilltop. The overall effect in the valley bottom was the dilution of higher concentrations of nitrate N, Cl and other constituents present in the in-situ ground water because of the increased hydraulic loading.

As of the end of this investigation in December 2001, the spray-irrigated effluent did not affect the water quality of the pond or the stream base flow leaving the watershed with respect to concentrations of nitrate N. Stormflow or loadings were not assessed. However, because the shallow aquifer under the application area was affected, the water quality of the pond and stream base flow will most likely be affected sometime in the future, but the timing can not be determined.

The effects of effluent application on $\mathrm{N}$ fate and transport were studied in a 20 -acre subbasin within the 38 -acre watershed. Possible $\mathrm{N}$ inputs to the system include atmospheric deposition, effluent spray irrigation, and $\mathrm{N}$ fixation by leguminous plants. Possible N outputs include loss through volatilization of ammonia in spray water during irrigation, denitrification processes in subsurface zones, water discharge from the subbasin, and plant uptake and subsequent removal during harvest. Changes in $\mathrm{N}$ storage can occur in the soil matrix, both in the solid and liquid phase, and in the ground-water system.

$\mathrm{N}$ inputs to the 20-acre subbasin from June 1999 through December 2001 averaged about $190 \mathrm{lb}$ (pounds) per month; about 91 percent of this was input from spray-irrigated effluent and the remaining was from precipitation events. Approximately 70 percent of the 5,420 lb of $\mathrm{N}$ applied in effluent from June 1999 through December 2001 was inorganic N. Measured atmospheric deposition of $\mathrm{N}$ from August 1999 through December 2001 was $490 \mathrm{lb}$. The forms of $\mathrm{N}$ in atmospheric deposition were almost equally distributed between nitrate $\mathrm{N}$
(36 percent), organic $\mathrm{N}$ (33 percent), and ammonia $\mathrm{N}$ (30 percent). Inputs from precipitation were distributed relatively evenly throughout the year; spray-irrigation inputs were highest during the growing season (75 percent of the spray-irrigated effluent was applied from April through September). It was assumed that $\mathrm{N}$ fixation by microorganisms was zero over the study period.

The primary $\mathrm{N}$ output from the 20 -acre subbasin was from plant harvesting. Plant harvesting removed about 4,560 lb of $\mathrm{N}$ during the three growing seasons from 1999 to 2001 or about 77 percent of the total $\mathrm{N}$ output during the study period. Assuming that only the inorganic-N portion of the spray-irrigated effluent was available to plants, the additional $\mathrm{N}$ taken up by plants was from the store of $\mathrm{N}$ in the soil matrix. These data indicate the importance of plant harvesting at spray-irrigation sites and the importance of timing applications with plant growth so that some of the applied $\mathrm{N}$ is recovered by plants.

Water discharge and ammonia volatilization accounted for the remaining 23 percent of the $\mathrm{N}$ output from the 20 -acre subbasin. Water discharge from the subbasin occurred as underflow (beneath a swale) and water captured by the swale and discharged from the subbasin through a flume. $N$ output from underflow accounted for about 18 percent (or about 1,060 lb) of the total $\mathrm{N}$ output from the 20 -acre subbasin. Approximately 94 percent of the dissolved $\mathrm{N}$ leaving the 20-acre subbasin in underflow was in the form of nitrate with the remaining fraction organic N. Water discharge through the flume accounted for about 4 percent (or about $250 \mathrm{lb}$ of $\mathrm{N}$ ) of the total $\mathrm{N}$ output from the 20 -acre subbasin. The primary forms of $\mathrm{N}$ in water discharged through the flume were organic $N$ (57 percent) and nitrate $\mathrm{N}$ (36 percent). Ammonia volatilization was another seasonally dependent component that was found to occur only during the growing season when air temperatures were higher than during the rest of the year. Loss of $\mathrm{N}$ through ammonia volatilization was estimated to be about $60 \mathrm{lb}$ during the study period.

$\mathrm{N}$ stored in the solid-soil phase was the predominant form of $\mathrm{N}$ in the 20 -acre subbasin. The average amount of $\mathrm{N}$ in the solid-soil phase over the entire 20-acre subbasin for soil depths of 0-4 ft was $170,000 \mathrm{lb}$. Approximately 98-99 percent of $\mathrm{N}$ in the $0-4 \mathrm{ft}$ depth interval was in organic form. Inorganic forms of $\mathrm{N}$ in the solid-soil phase from 0 to $4 \mathrm{ft}$ indicated an increase from spring 1999 to fall 2001. The mass of ammonium ions increased from approximately $700 \mathrm{lb}$ in spring 1999 to $1,600 \mathrm{lb}$ in fall 2001 (at depths from 0-4 ft). Concentrations of nitrate ions in the solid-soil phase basically indicated no change over the same period. Unlike nitrate, which is transported through the soil system relatively rapidly, ammonium ions are retained in the soil.

$\mathrm{N}$ stored in the soil water and shallow ground water substantially decreased over the study period in the 20-acre subba$\sin$. The mass of $\mathrm{N}$ in the soil water and shallow ground-water compartments in spring-summer 1999 was about twice as much as the mass of $\mathrm{N}$ for the last samples collected in 2001. Approximately $86-87$ percent of $\mathrm{N}$ in soil water and ground water to the depth of competent bedrock was in the form of nitrate $\mathrm{N}$. The mass of $\mathrm{N}$ in shallow ground water was reduced even though 
shallow wells at the top of the 20-acre subbasin indicated significant increases in concentrations of nitrate $\mathrm{N}$ during the study period. Effluent application helped to flush the soil nitrate from the spent mushroom substrate out of the system, thus decreasing the mass of stored $\mathrm{N}$ in the shallow aquifer.

The $\mathrm{N}$ balance for the site indicated that spray irrigation did not cause any increasing trend in $\mathrm{N}$ losses in water discharging from the 20-acre subbasin from June 1999 through December 2001. There was also no net increase in the storage of inorganic $\mathrm{N}$ in subsurface compartments. Plant uptake of $\mathrm{N}$ appeared to be the primary factor in minimizing the loss of $\mathrm{N}$ from the 20-acre subbasin. Seventy-five percent of the $\mathrm{N}$ load from spray-irrigated effluent was applied from April through October. This spray site was designed so that some $\mathrm{N}$ applied during effluent application would eventually be removed from the site through harvesting of plant material.

\section{Introduction}

Because the suburban population in southeastern Pennsylvania is rapidly growing, there is interest in expanding the use of wastewater-treatment and disposal technologies that help sustain the water quality and water balance of watersheds. Increasing the amount of wastewater discharge to surface waters degrades stream-water quality. Also, interbasin transfers of water may increase, resulting in a net export of water from the originating watershed. These transfers may result in decreased streamflow in the originating watershed. The assimilative capacity of all streams is limited, and interbasin transfers of water can reduce the assimilative capacity and flow-based habitat conditions in these watersheds.

Both the Pennsylvania Department of Environmental Protection (PaDEP) and the Chester County Water Resources Authority (CCWRA) have adopted policies to minimize the quantity of contaminants discharged to streams and of interbasin transfers of water. The Report of the Pennsylvania $21^{\text {st }}$ Century Environment Commission states among its goals to "strive continually to reduce loadings by methods that process and treat discharges to remove or minimize the pollutants they carry" and "...to maintain the natural hydrology of all streams and watersheds... To maintain that healthy balance, the transfer of water out of watersheds should be limited, properly treated wastewater should be recharged to the ground water, preferably at the same location or higher (in altitude) in the watershed from the place where it was removed." (Pennsylvania 21st Century Environment Commission, 1998, p. 46). Two policies of Chester County's Comprehensive Plan (Chester County, 1996, p. 114) are to "preserve and enhance the existing network of stream valleys and their aquatic habitats and encourage a sustainable water-cycle balance within watersheds as development occurs."

The PaDEP and Chester County government agencies are encouraging alternative disposal methods for wastewater other than instream discharges. One alternative treatment and disposal method is land application. Chester County's Landscapes
(Chester County, 1996, p. 122) promotes the use of land application of treated effluent, as reflected by the policy to "encourage innovative wastewater-treatment and disposal systems with preference given to land application of treated wastewater." The Pennsylvania 21st Century Environment Commission (1998, p. 46) further promotes "encouraging closed-loop systems or land application (spray irrigation) of wastewater will help maintain a stable and adequate base flow in a watershed."

Land-application treatment is defined as the controlled spraying of effluent onto the land surface to achieve treatment through natural physical, chemical, and biological processes within the plant-soil-water matrix. In southeastern Pennsylvania, the most widely used type of land treatment is the "slow rate" method where effluent is sprayed onto the land surface; the primary disposal of effluent is through evapotranspiration, infiltration, and percolation, and nutrients are reduced by plant uptake (Chester County Planning Commission, 1990).

With increasing interest in expanding the use of landapplication technologies at the State, county, and municipal levels, the CCWRA asked the U.S. Geological Survey (USGS) to investigate the effects of a targeted land-application technology on water resources. The New Garden Township spray-irrigation study focused on determining the effects of spraying secondarytreated effluent on a small watershed in southern Chester County, Pa. (fig. 1). The New Garden Township spray-irrigation site was selected from five potential study sites in Chester County. The selection was based on the topographic and geologic setting of the site, the PaDEP permit status, and the start date of operation. At the New Garden Township spray-irrigation site, the vast majority of effluent was to be applied on three fields. One spray field was entirely within the small watershed, and approximately half of a second spray field was in the watershed. The third spray field was not in the watershed. In addition to the three main spray fields, two spray fields were constructed to receive limited amounts of applied effluent. Part of one of these fields was in the watershed.

The New Garden Township spray-irrigation site is underlain by crystalline rocks. Most of southern Chester County is underlain by crystalline rocks with a similar general GlenelgManor-Chester soil association (Kunkle, 1963). Other areas of southeastern Pennsylvania share similar geologic settings; therefore, study results are transferable to other areas of southeastern Pennsylvania. Once this site was selected, New Garden Township and the New Garden Township Sewer Authority became partners in the study.

In Pennsylvania, land application of effluent is a waterquality concern and is under the jurisdiction of the PaDEP, Water Management Program. Land-application sites are investigated for suitability for this type of wastewater treatment. If the site is deemed suitable, PaDEP issues a water-quality-management permit for land application of effluent. The New Garden Township spray-irrigation site received a PaDEP permit during spring 1997.

The timing of spray-field construction and the planned start of wastewater application (fig. 2) were such that data could be collected before any effluent was applied. Wells were drilled 


\section{Effects of Spray-Irrigated Effluent on Water Quantity and Quality, and the Fate and Transport of Nitrogen}

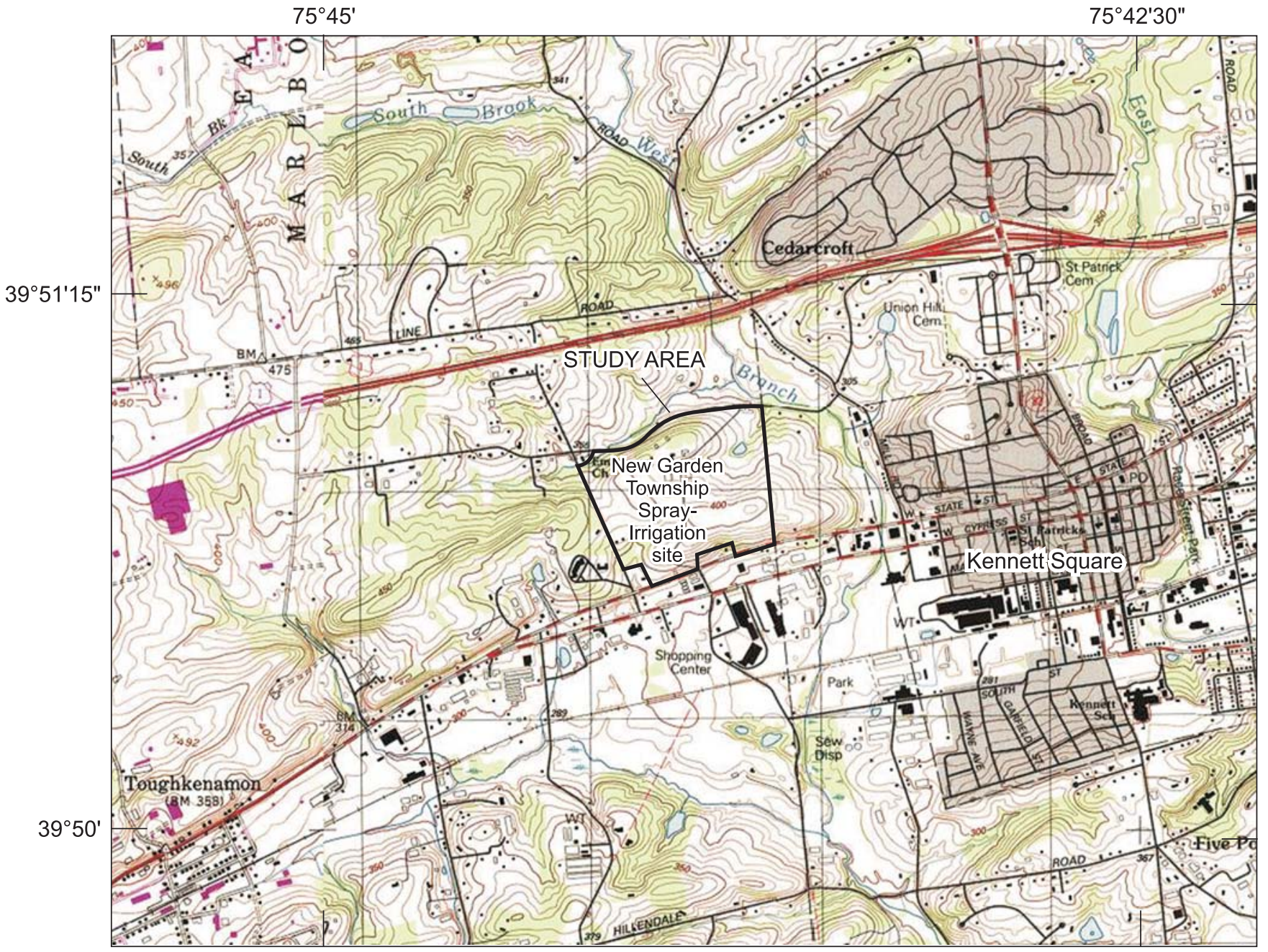

Base from U.S. Geological Survey

Kennett Square, PA-DEL, 1:24,000, 1993

West Grove, PA-DEL, 1:24,000, 1973
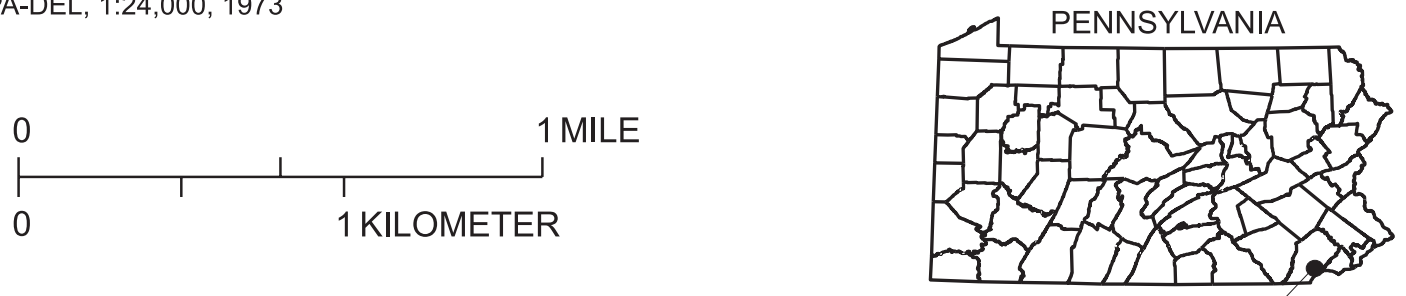

Study Area

Figure 1. Location of New Garden Township spray-irrigation site, Chester County, Pennsylvania. 
Well drilling started

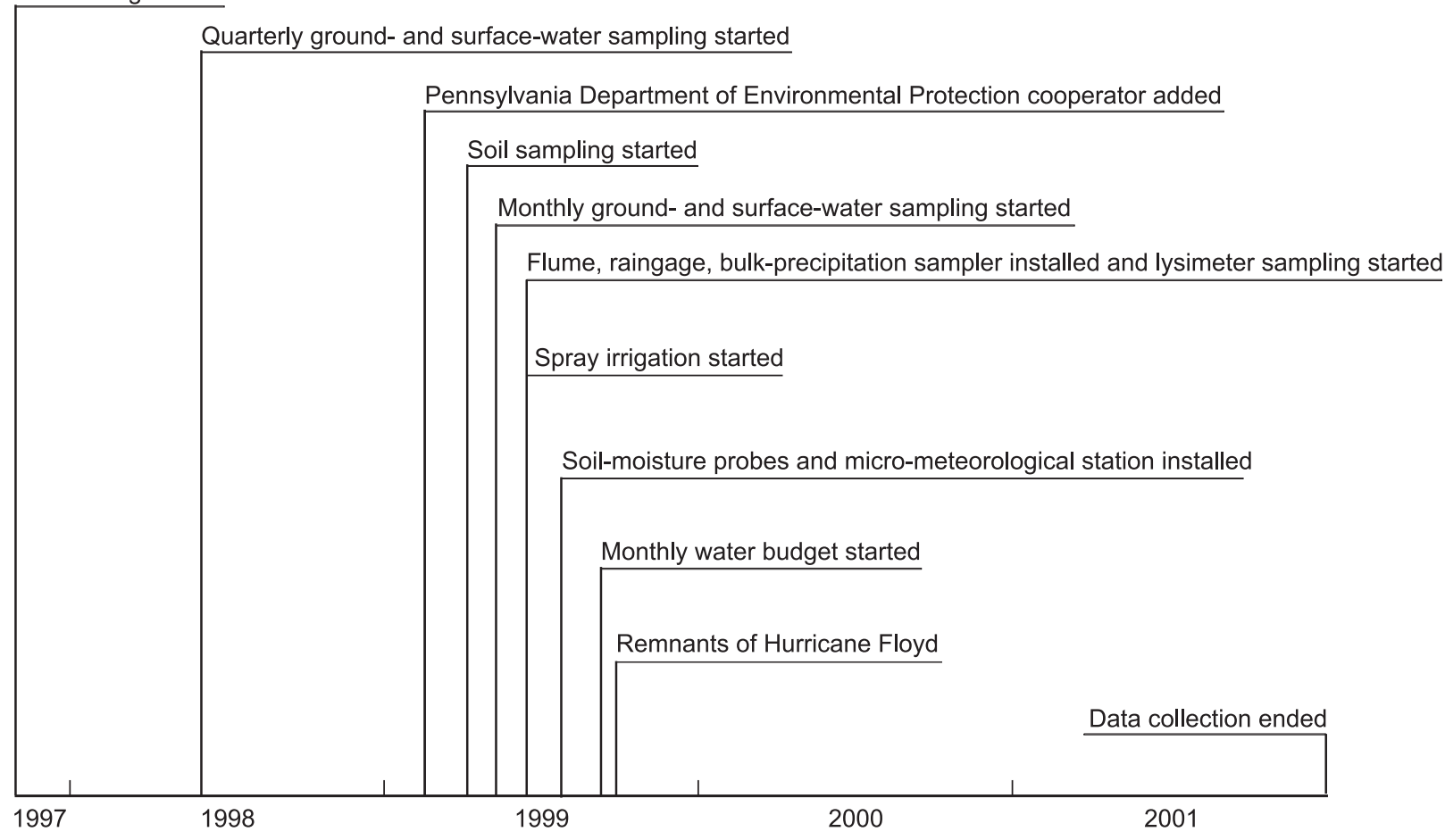

Figure 2. Project timeline with major events for the spray-irrigation study, New Garden Township, Chester County, Pennsylvania.

in the fall of 1997, and the first round of water-quality samples were collected in the spring of 1998. Initial testing of the spray system started in May 1999; daily operation of the spray-irrigation system started in June 1999. Initially, the study was a cooperative project between CCWRA, USGS, and the New Garden Township Sewer Authority. The initial objectives of the study were to determine the effects of spray-irrigated effluent on water quantity and quality for the watershed on an annual basis. In the spring of 1999, a new cooperator, the PaDEP, was added to the project. Because of the addition of PaDEP, the scope and objectives of the study were expanded to determine the effects of spray-irrigated effluent on water quantity and quality for the watershed on a monthly basis and to determine a nitrogen $(\mathrm{N})$ budget for the watershed.

The expanded objectives addressed two PaDEP issues concerning the effects of land application of effluent. The issues were the (1) monthly hydraulic loading of wastewater, and (2) N-species fate and transport within a watershed. The monthly hydraulic-loading issue is important because permitted effluent-application rates are tied to monthly permitted hydraulic-loading rates, which are a part of standard operating procedures for a land-application treatment facility. These permitted monthly hydraulic-loading rates allow for more effluent application during the summer and less effluent application during the winter. An assessment of the monthly water-quantity budget may assist the PaDEP in evaluating monthly hydraulic-loading rates at land-application sites. The seasonal variation of $\mathrm{N}$ spe- cies at land-application sites is another issue. Land application of effluent allows for ammonia volatilization, some denitrification prior to recharge, and removal of $\mathrm{N}$ through biological uptake. These processes reduce $\mathrm{N}$ loads to water bodies and decrease the potential for transportation of excessive concentrations of $\mathrm{N}$ species to water bodies. Quantifying the removal of $\mathrm{N}$ along a flow path prior to entering any water bodies is crucial to municipalities concerned with excessive loads of nitrate and ammonia from effluent application entering aquifers and surface-water systems.

This study was designed to assess the effects of land application of treated effluent on a small watershed by a treatment facility working under normal operating conditions and procedures. Normal operating conditions can vary because of day-to-day site conditions. On some occasions, wastewater could have been applied to the fields but was not because of operational problems of the facility, such as broken pipes, pump maintenance, crop harvesting, or waiting for the crop to dry before harvesting.

\section{Purpose and Scope}

This report summarizes the effects of spray-irrigating treated effluent on the water quantity and quality of a 38-acre watershed in southern Chester County, $\mathrm{Pa}$. The report also summarizes the fate and transport of $\mathrm{N}$ on a 20-acre subbasin of the watershed on which the wastewater was applied. Methods used 


\section{Effects of Spray-Irrigated Effluent on Water Quantity and Quality, and the Fate and Transport of Nitrogen}

to determine (1) the effects of the spray-irrigated treated effluent on water quantity and quality in the watershed and (2) the fate and transport of $\mathrm{N}$ in the 20 -acre subbasin of the watershed are described.

The effects on ground-water and surface-water quantity were determined using a monthly water-budget approach. Ground-water-level and streamflow monitoring began in May and April 1998, respectively, and continued until December 2001. Annual water budgets also were determined and compared to a larger nearby watershed to assess the effects of applying treated effluent. Ground-water and surface-water quality were characterized from chemical analyses of water samples collected monthly. Ground-water and surface-water sampling began in May 1998 and continued until December 2001. Results of statistical analyses of ground- and surface-water samples collected prior to and during effluent application were used to determine the effects of the applied effluent on groundand surface-water quality. Additional statistical analyses of ground-water-sample results from wells on the application area and wells outside the application area, control wells, were done to assess the effects of the applied effluent on ground-water quality. The fate and transport of $\mathrm{N}$ was assessed as it moved from the effluent into the soil, soil water, ground water, crops, discharge to surface water, and volatilized or denitrified to the atmosphere using a seasonal N-budget approach. Collection of $\mathrm{N}$ fate and transport data began in April 1999 and continued until December 2001.

\section{Previous Investigations}

Tofflemire (1976) compiled a literature review of papers dealing with land application of wastewater. Research is extensive on land application of effluent and wastewater reuse in arid and semi-arid regions of the world, where water reuse is a necessity. Numerous studies on land application of effluent on water systems have been done in the State of Florida and in the southwestern United States. In Pennsylvania, extensive research on land application of wastewater has been done at the Pennsylvania State University wastewater-disposal site (Sopper, 1976). However, limited research has been done on quantifying ground-water recharge caused by land application; Sopper (1976) estimated annual ground-water recharge over a 12 -year period that ranged from 40.5 to 68 in. with an average year-round application rate of approximately 2 in. per week at the Pennsylvania State University site.

Various reports presenting results of water-resource investigations in southern Chester County, Pa., have been published. Poth (1968) described the hydrology of the metamorphic and igneous rocks of central Chester County. Sloto (1994) described the ground-water resources of Chester County. Vogel and Reif (1993) described the geohydrology, summarized the water quality, and simulated the ground-water flow in the Red Clay Creek watershed in Chester County. Senior (1996) described the ground-water quality of the Red Clay Creek watershed and characterized the relation between ground-water quality and hydrogeology, land use, and surface-water quality.

\section{Description of Study Area}

The spray-irrigation site is on approximately 100 acres owned by the New Garden Township Sewer Authority in New Garden Township, southern Chester County, Pa. The site is 0.75 mi west of Kennett Square Borough and 3.25 mi northwest of the Pennsylvania/Delaware State line. The site is within the Red Clay Creek watershed; Red Clay Creek is a tributary to the Christina River.

A small closed surface-water drainage basin on the site (plate 1) was instrumented for determining the monthly water budget. This watershed is approximately 38 acres. A smaller subbasin of the watershed (approximately 20 acres) that included about half of spray field 1, spray field 2, and the area downgradient from those fields was instrumented for determining the fate and transport of $\mathrm{N}$. Two areas outside of the 38-acre watershed were instrumented and used as control areas for the study.

Many natural, physical, and anthropogenic factors affect onsite characteristics and, subsequently, can affect study results. Natural and physical factors include climate, drainage, soils, and hydrogeology. Anthropogenic factors include onsite vegetation, historical land-use practices, and standard facility operations.

\section{Climate}

The study area in southeastern Chester County has a modified humid continental climate. Summers typically are warm and humid, and winters are mild to moderately cold. The mean monthly 30-year (1971-2000) normal temperatures at West Chester, Pa., which is about 12 mi northeast of the site, for the coldest month, January, is $30.1^{\circ} \mathrm{F}$ and for the warmest month, July, is $74.7^{\circ} \mathrm{F}$ (National Oceanic and Atmospheric Administration, 2002). January is the only month that has a mean monthly temperature below freezing; however, frozen ground is common during November through March. The typical growing season in southeastern Pennsylvania is from the end of April until the beginning of October.

The mean annual 30-year (1971-2000) normals for precipitation at West Chester (about 12 mi northeast of the study area) and Chadds Ford (about $7 \mathrm{mi}$ east of the study area), Pa., are 47.89 and 47.56 in., respectively (National Oceanic and Atmospheric Administration, 2002). Precipitation is distributed fairly evenly throughout the year. The mean monthly 30 -year normal precipitation at West Chester ranges from 3.05 in. for February to 4.75 in. for September. The mean monthly 30-year normal precipitation at Chadds Ford ranges from 3.13 in. for February to 5.11 in. for September.

Various extreme climatic events were recorded during the study. Drought conditions were present from June through mid- 
September 1999 and again from July through December 2001. Nearly 9 in. of rain from the remnants of Hurricane Floyd fell within the watershed in a 24-hour period on September 16, 1999. The effects of these extreme events on the results of this study are not fully understood.

\section{Drainage}

The 38-acre watershed drains to an unnamed tributary to the West Branch Red Clay Creek. The tributary is an ephemeral stream that flows to the northeast and flows to the West Branch Red Clay Creek approximately 1,200 ft downstream from the site.

Maximum altitudes are along the southern and western boundaries of the watershed at $405 \mathrm{ft}$ above NGVD 29. The altitude of the streambed near the outflow from the watershed is about $300 \mathrm{ft}$ above NGVD 29. The surface-water drainage flows mostly to the north and east. A 0.8 -acre pond is in the watershed near the outflow at an altitude of about $315 \mathrm{ft}$ above NGVD 29.

The $\mathrm{N}$ fate and transport component focused on a 20-acre subbasin (plate 1). In order to capture and collect surface runoff from precipitation, drainage modifications were constructed to divert surface runoff to an area just east of the pond. A berm was constructed to direct runoff from the 20 -acre subbasin directly through a flume (plate 1).

\section{Soils}

A detailed soils evaluation of the New Garden Township spray-irrigation site was conducted as part of the PaDEP permitting process for the spray facility (DelVal Soil and Environmental Consultants, written commun., August 18, 1994, and November 27, 1995). The evaluation included 12 auger borings drilled to depths of 15 or $37 \mathrm{ft}$ below land surface (fig. 3). The borings were made on October 17-18, 1994. In addition, 20 soil-test pits were excavated to a minimum depth of $6 \mathrm{ft}$ below land surface (fig. 3). The soil-test pits were excavated on August 3, 1994, and November 17, 1995.

The auger borings revealed a thick layer of saprolite (from 27 to $62 \mathrm{ft}$ ). Saprolite is derived from the in-place weathering of the underlying crystalline rock (Vogel and Reif, 1993, p. 12). The underlying bedrock or parent material consists mainly of metamorphosed rocks (quartzite, gneiss, and mica schist). The saprolite consists of various colors (brown, orange, gray, and (or) white), particle sizes (fine, medium, and (or) coarse), and textures (sand, silt loam, silt, silty clay loam, and silty clay) with fragments of mica schist rock and (or) veins of quartzite. In addition to the soils formed in place, there may be soils formed from localized deposition of transported materials from ridge and side slopes to drainage areas and wetland areas and from mushroom-growing activities associated with disposal of spent mushroom substrate.

The former Soil Conservation Service of the U. S. Department of Agriculture, now the Natural Resource Conservation
Service, mapped the soils at the spray-irrigation site (Kunkle, 1963). The dominant soils are the Glenelg-Manor-Chester soil association, including the following specific soil types:

- Glenelg silt loam-The Glenelg soils (Typic Hapludults) are considered deep, well-drained soils occurring on upland landscape positions.

- Glenville silt loam-The Glenville soils (Aquic Fragiudults) are deep, moderately well to somewhat poorly drained soils on low-lying areas and around the heads of streams where the water table is seasonally high.

- Worsham silt loam-The Worsham soils (Typic Ochraquuluts) are deep, poorly drained soils associated with wetlands and are found along streams and creeks.

The soil-test pits revealed that all soils in the proposed spray areas were deep, well-drained Glenelg soils. Soil-profile descriptions were prepared for each test pit and are published in the permit report (Woodward-Clyde, 1995). The proposed spray-field delineation was designed to avoid areas where the evaluation of the test pit revealed restricted drainage, as represented by redoximorphic features (soil-drainage mottles), within 40 in. of the ground surface. Areas of the site with drainage problems, such as wetlands, were not subject to the detailed soils evaluation. Although the soil-survey maps did not indicate the presence of any hydric soils, wetland vegetation at the base of the side slope near the area of the berm and flume indicates these soils are present on the site.

\section{Hydrogeology}

The spray-irrigation site has two distinct aquifer systems - a bedrock system and a shallow (unconsolidated material or saprolite) system. The bedrock-aquifer system is composed of crystalline rocks of the Setters Formation and amphibolite facies felsic gneiss. On the site, the Setters Formation/felsic gneiss geologic contact lies just north of the watershed. Geologic logs from wells drilled onsite indicated the Setters Formation was less than $5 \mathrm{ft}$ thick on the southern hilltop of the watershed where it was thickest. All bedrock wells were screened in the felsic gneiss. Ground water flows through interconnecting fractures in the crystalline rocks that have little storage. A 12-hour aquifer test by consultants for the New Garden Sewer Authority indicated the bedrock-aquifer system on the site to be anisotropic with hydraulic conductivity greater along an east-west trend (Woodward-Clyde, 1996). Deeper waterbearing zones are under higher hydrostatic pressures and are confined. For example, a bedrock well was drilled to a depth of $200 \mathrm{ft}$, and a water-bearing zone was encountered at $175 \mathrm{ft}$ below land surface. Water-level altitudes in the bedrock wells consistently were higher than the water-level altitudes in the shallow wells completed in unconsolidated material, indicating semi-confined or confined conditions occur with depth. 


\section{Effects of Spray-Irrigated Effluent on Water Quantity and Quality, and the Fate and Transport of Nitrogen}

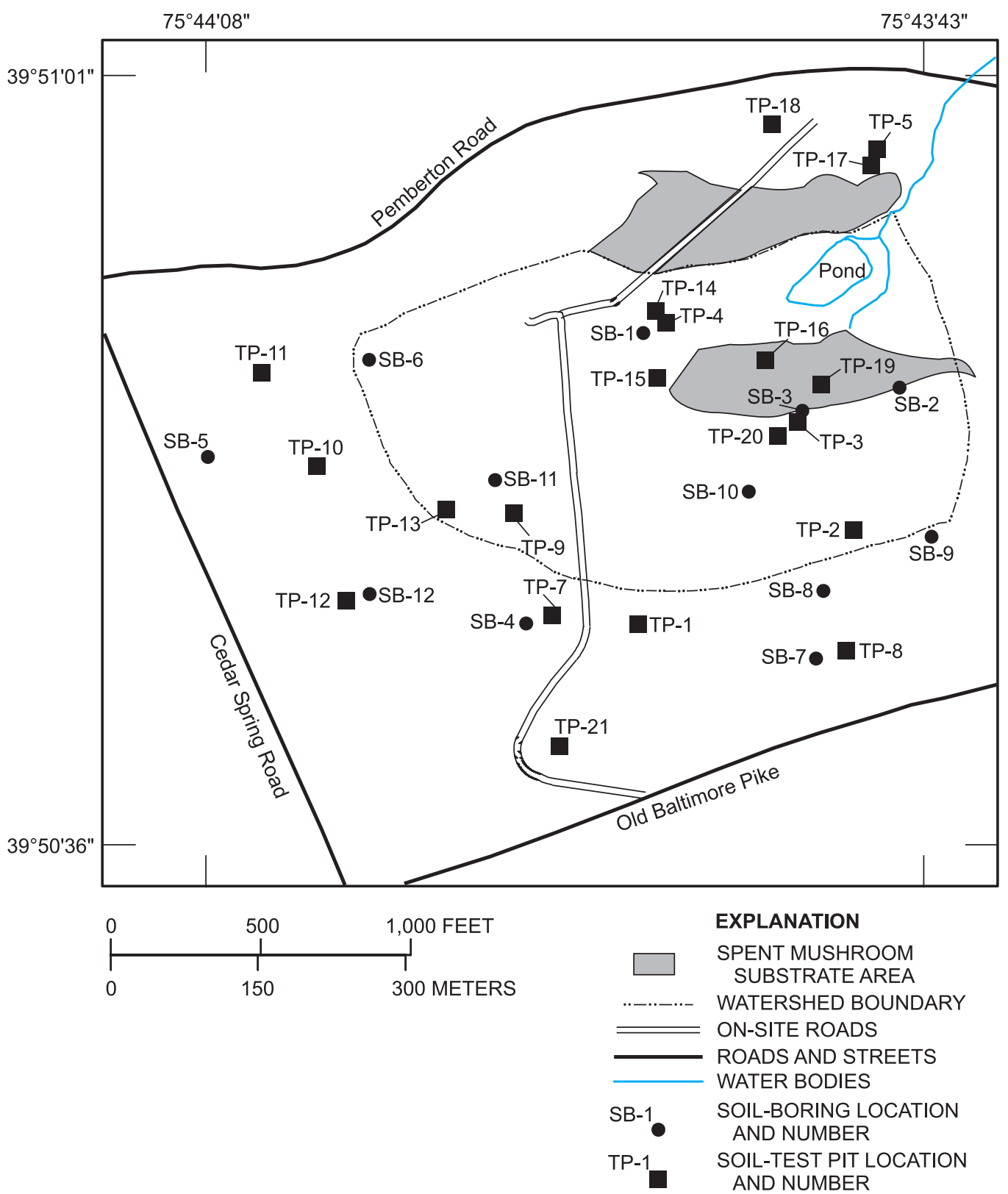

Figure 3. Locations of soil borings and soil-test pits, New Garden Township spray-irrigation site, Chester County, Pennsylvania.

The shallow-aquifer system is composed of sand with some clay and rock fragments. Ground water flows through and is stored in intergranular openings in the saturated zone of the unconsolidated sand. The shallow aquifer is a water-table system. The thickness of the unconsolidated material ranged from 27 to $62 \mathrm{ft}$. A stratigraphic software package was used to estimate the thickness of the unconsolidated material across the site (fig. 4). In the eastern part of the spray fields, bedrock is approximately $30 \mathrm{ft}$ below land surface, and in the western part of the site, bedrock is approximately $55 \mathrm{ft}$ below land surface.

Geologic logs collected during well drilling indicated the unconsolidated materials on the eastern part of the site are uniform with little clay content. Clay content of the unconsolidated material increased in the western part of the spray fields. The increase in clay content restricts the rates of water infiltration and ground-water flow in those areas.

\section{Vegetation}

Typically, specific vegetative covers are required for spray-irrigation sites. Prior to effluent application, herbicide, used to kill all undesirable species, was applied to the part of the site deemed suitable for effluent application. Orchard grass was planted in 1998 in order to get it established prior to the initiation of spray irrigation in 1999. Vegetative cover at the beginning of effluent application in 1999 was primarily orchard grass; however, weed species, such as thistle, poison ivy, clo- 

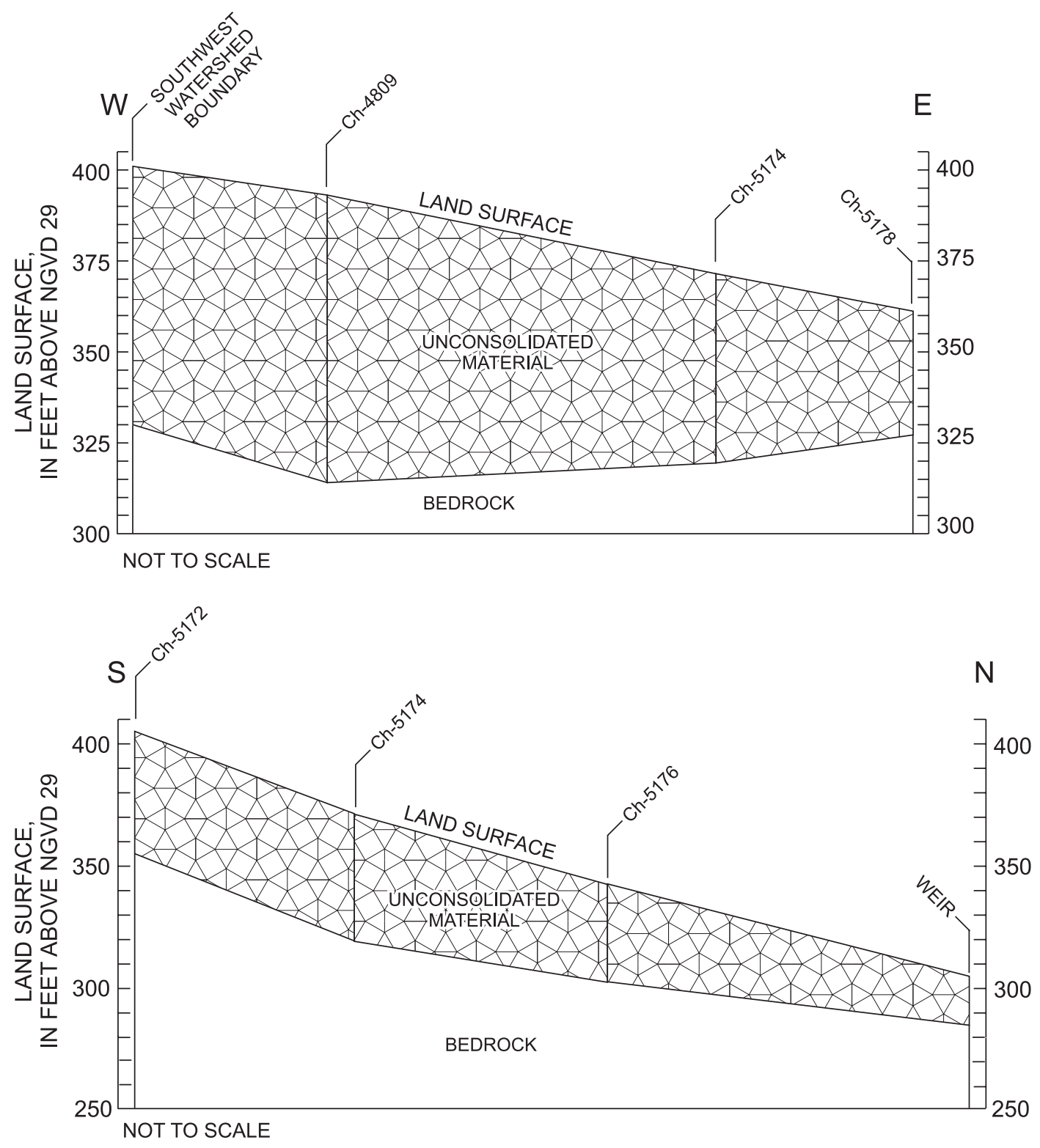

Figure 4. Estimated thickness of unconsolidated material on west-east and north-south trending geologic sections, New Garden Township spray-irrigation site, Chester County, Pennsylvania.

ver, horse nettle, and others, had invaded the site by late summer 1999. During the study period, the predominant vegetation in the study area was orchard grass. There was also approximately 1-2 acres of alfalfa in the western edge of spray field 2 and the eastern edge of spray field 4 (plate 1) throughout the study period. The perimeter of the study area outside of the spray fields was covered with trees that were either planted or allowed to regrow from a past clearing of the land.

\section{Historical Land Use}

The historical land-use information was obtained from conversations with a previous land owner. Prior to use as a spray-irrigation site, the land was used primarily for agriculture.
The site was used for mushroom production from the 1920s to the late 1980s. A common problem at mushroom facilities is the disposal of spent mushroom substrate. Some spent mushroom substrate was deposited onsite. The buildings used for mushroom production were removed prior to construction of the spray fields in 1998. The site also was used for cattle and crop production. Dairy cattle were present in the 1920s, and beef cattle were present for a short time in the 1950s. Potatoes and peas were produced from the 1920 s to 1950 . Following 1950, agricultural land (outside of the buildings used for mushroom production) was used for pasture and hay. The pond within the study area was constructed in the early 1950s. The pond was not lined during construction because springs discharge directly into the pond. 


\section{Standard Facility Operations}

The site is permitted for the use of six spray fields that are each designed to be about 9 acres in size (plate 1). Currently (2004), five of the six spray fields (Spray fields 1, 2, 3, 4, and 5) are constructed and operating. Each field is permitted for $50,000 \mathrm{gal} / \mathrm{d}$ capacity of applied effluent averaged over 7 days. The fields are equipped with fixed spray heads spaced approximately $100 \mathrm{ft}$ apart. Permitted hydraulic-loading rates vary throughout the year from 0.5 to 2.5 in/acre per week (table 1). Applications are not allowed on frozen soil or during prolonged heavy rainfall. Effluent may not be applied if more than $0.5 \mathrm{in}$. of rain fell during the previous 24 -hour period.

\section{Methods of Investigation}

Various field and analytical methods were used during the study. To determine the effects the spray-irrigated effluent may have on ground-water and surface-water quantity, a monthly water-budget approach was developed and used. Also, annual water budgets were determined for the 38-acre watershed and for the watershed upstream of the USGS streamflow-gaging station Red Clay Creek near Kennett Square, Pa., and were compared to assess the effects the spray-irrigated effluent may have on surface-water quantity. Monthly water samples were collected and analyzed to determine the effects the spray-irrigated effluent may have on ground-water and surface-water quality. A seasonal $\mathrm{N}$ budget was developed and used to determine the effects the spray-irrigated effluent may have on the fate and transport of $\mathrm{N}$ in the subbasin of the watershed.

Table 1. Monthly permitted hydraulic-loading rates for New Garden Township spray-irrigation site, Chester County, Pennsylvania.

\begin{tabular}{cl}
\hline $\begin{array}{c}\text { Hydraulic-loading rates } \\
\text { (inches per acre } \\
\text { per week) }\end{array}$ & \multicolumn{1}{c}{ Months } \\
\hline 0.5 & January, February, December \\
1.5 & March, April \\
1.75 & November \\
2.0 & May, October \\
2.5 & June, July, August, September \\
\hline
\end{tabular}

\footnotetext{
${ }^{1}$ Pennsylvania Department of Environmental Protection, Water Quality Management Permit 1596417, issued April 1997.
}

\section{Assessing Effects of Spray-Irrigated Effluent on Water Quantity}

To assess the effects spray-irrigated effluent had on water quantity in the watershed, a monthly and annual water-budget approach was developed and used. The amount of water coming into the watershed must equal the amount of water leaving and being added and released from storage in the watershed. Waterbudget parameters, such as the amount of precipitation and effluent that evaporates, transpires, percolates as recharge, and runs off as streamflow, needed to be quantified.

\section{Monthly Water Budget}

A water budget requires water inputs equal the outputs from the watershed plus or minus changes in storage. Inputs for the monthly water budget are precipitation $(\mathrm{P})$ and applied effluent (APP). Outputs are evapotranspiration (ET), streamflow (SF), and ground-water underflow (UF). Storage terms are changes in ground-water storage ( $\Delta \mathrm{GW})$ and soil-moisture storage $(\Delta \mathrm{SM})$. Output of evaporation off the free water surface from the pond and change in storage of the pond were combined into an $\triangle \mathrm{PD}$ term. Locations of the precipitation gage, micrometeorological station, streamflow-gaging station, monitor wells, soil-moisture probes, and pond stage recorder are shown in plate 1.

The monthly water-budget equation is given as equation 1 below. Because all variables except evapotranspiration are measurable quantities or can be estimated, equation 1 is rearranged to solve for evapotranspiration (eq. 2). The resulting evapotranspiration estimate includes all the combined error values that occur in measuring or estimating the other variables in the monthly water-budget equation. As a check of the monthly values of evapotranspiration derived from the water-budget calculation, estimates of crop-referenced evapotranspiration were determined at the site by measuring certain meteorological variables and using the Penman-Monteith equation (Smith and others, 1992). The monthly water-budget equation is

$$
\begin{aligned}
& P+A P P=E T+S F+U F+\Delta P D+\Delta G W+\Delta S M, \\
& E T=P+A P P-S F-U F-\Delta P D-\Delta G W-\Delta S M,
\end{aligned}
$$

where

$$
\begin{aligned}
P & \text { is precipitation, in inches; } \\
A P P & \text { is spray-irrigated effluent, in inches; } \\
E T & \text { is evapotranspiration, in inches; } \\
S F & \text { is streamflow, in inches; } \\
U F & \text { is ground-water underflow, in inches; } \\
\triangle P D & \text { is free water surface evaporation and change } \\
& \text { in pond storage, in inches; } \\
\Delta G W & \text { is change in ground-water storage, in inches; } \\
& \text { is change in unsaturated-zone soil-moisture } \\
\triangle S M & \text { storage, in inches. }
\end{aligned}
$$$$
\text { and }
$$ 


\section{Precipitation}

A vibrating-wire precipitation gage was installed to measure precipitation $(\mathrm{P})$. The precipitation gage was in the watershed but outside the application area and did not measure any applied effluent (plate 1). Precipitation was measured and recorded every 15 minutes, and daily totals were calculated. Prior to installation of the onsite precipitation gage (April 1998 through June 1999), a combination of precipitation data from USGS station, Trout Run at Avondale, Pa., and National Oceanic and Atmospheric Administration (NOAA) climatic data from Newark, Del., were used to determine precipitation totals.

\section{Applied Effluent}

The volume of spray-irrigated effluent (APP) was measured by New Garden Township Sewer Authority and reported to USGS. The effluent is pumped from the sewagetreatment facility about $0.5 \mathrm{mi}$ south of the spray fields. Pumped effluent flows to a manifold and is distributed to each spray field. Manual valves were opened and closed to direct effluent to the different spray fields on the basis of the operational plan for the facility.

New Garden Township provided totals of effluent volumes that were treated at the plant and pumped to the spray fields. Effluent volumes were provided from June 1999 through December 2001. Data were initially reported by indicating the total volume applied on a daily basis and the spray fields that received the effluent. This level of reporting continued through 2000. Data provided for 2001 were totals for all the spray fields combined with no reliable information available as to which fields were receiving the effluent. Therefore, the method to determine total volume applied by spray field changed during the course of the study. Even though this change made it more difficult to determine the total volume by spray field, it did not compromise the data.

Pressure transducers were installed in-line of the piping system for three of the spray fields (spray fields 1, 2, and 3) (plate 1) in order to determine the amount of effluent applied to these spray fields. These transducers were installed in each spray field as close to the manifold distribution system as possible. New Garden Township had installed analog pressure sensors in each spray field at locations close to the manifold, and the pressure transducers were installed with these analog sensors. Data loggers attached to the pressure transducers were programmed to output and store data when there was a change in pressure of 1 psi (pounds per square inch) over 1 minute.

The original study design was based on the premise that spray fields 4 and 5 would not be used during the study; however, this was not the case because of operational necessities. One pressure sensor was installed in spray field 4 after it was realized that the fields were going to be used, but the $100 \mathrm{psi}$ limit of the transducer was exceeded because of operational testing. This testing destroyed the sensor, and it was never replaced.

Using the total effluent application data received from New Garden Township from 1999 through 2000, the pressure- transducer data from each field were summed on a daily basis in order to determine the volume of effluent applied to each spray field. That is, it was necessary to sum the values of (pressure $\times$ time) in each spray field, then proportionally distribute the applied effluent volume for that day. For each day and spray field, the time interval (in minutes) was multiplied by the pressure (in pounds per square inch) for that time interval, yielding a (pressure $\times$ time) value for each interval. The intervals for each day and spray field were summed to yield daily values of (pressure $\times$ time) for each spray field. These daily summed values for spray fields 1,2 , and 3 were added together. The summed value for each spray field was divided by the summed value for all spray fields to determine the percentage of the total effluent applied to each spray field. This percentage was then multiplied by the total volume (as reported by New Garden Township) to determine the total volume of effluent applied to each spray field.

From 1999 through 2000, there was an occasional malfunction with one of the pressure transducers in spray fields 1 , 2 , and 3 . When this malfunction occurred, it was necessary to verify which spray fields were receiving effluent. A review of the data collected during effluent application indicated that the ratio (EFFRAT) of total effluent applied to the summed values of (pressure $\times$ time) for spray fields 1,2 , and 3 was fairly consistent depending on how many fields were receiving effluent. If effluent was distributed to two fields, EFFRAT was higher than if three fields were active.

Beginning in 2001, it was necessary to use the EFFRAT values, along with the actual pressure-sensor data from the different spray fields, to determine which spray fields were receiving effluent and the volumes for each field. The daily effluent application rates received from New Garden Township for 2001 were summed to produce weekly totals. This was necessary because pressure-sensor data did not always match the days effluent was applied (according to data received from New Garden Township). Therefore, the daily data from New Garden Township was reviewed and a good relation between weekly totals from New Garden Township and pressure-sensor data was apparent. Using an iterative approach, daily application rates to each spray field were estimated. Although there was likely some error involved in producing the daily application rates to each field, the weekly summed application rates for each field were more robust.

An additional problem with 2001 data occurred if one of the pressure sensors in spray fields 1, 2, and 3 malfunctioned. There were about 50 days in 2001 when one of the sensors was not working properly. When this problem occurred, EFFRAT values were reviewed to determine how many spray fields were active. Field notes were reviewed to determine which spray fields were visually identified as active during the period when one of the pressure sensors was malfunctioning. Finally, it was also apparent through review of data with all sensors working properly, that if spray field 1 was active, spray field 2 was typically active. Spray field 3 was used less frequently because of its close proximity to Baltimore Pike. The operational relation between the fields was only used in a few instances when it was 


\section{Effects of Spray-Irrigated Effluent on Water Quantity and Quality, and the Fate and Transport of Nitrogen}

not clear whether spray fields 1,2 , or 3 were active, or whether spray fields 4 and 5 were active. When all pressure sensors were working properly, EFFRAT helped to identify when spray fields 4 and 5 were active.

\section{Streamflow}

In April 1998, a 36- by 24-in. steel-plate weir was installed in the stream near the outlet of the watershed to provide a control for measuring stream stage. The weir opening was a 1-ft deep $90^{\circ} \mathrm{v}$-notch. A 6-in. PVC stilling well was installed in the weir pool and was equipped with a shaft encoder float system to measure stream stage. A data logger recorded stream stage every 15 minutes. A stage-streamflow relation was established to determine the volume of streamflow leaving the watershed on the basis of standard USGS methods (Rantz and others, 1982). On January 15, 1999, the weir was washed out during a storm. On April 28, 1999, a second weir was installed at the same location. The second weir was constructed of plywood with the 1-ft deep $90^{\circ} \mathrm{v}$-notch steel plate attached. This new design allowed flows above $2.5 \mathrm{ft}^{3} / \mathrm{s}$ to be determined because the plywood acted as a rectangular weir with a width of $10 \mathrm{ft}$. Streamflow from January 15 to April 28, 1999, was estimated using USGS hydrographic comparison methods (Rantz and others, 1982).

Hydrograph separation using the local minimum method (Pettyjohn and Henning, 1979) was done on streamflow data collected at the weir and from the USGS streamflow-gaging station (01479820) Red Clay Creek near Kennett Square using the computer program HYSEP (Sloto and Crouse, 1996) to determine the base-flow component of streamflow at each site. The base-flow component of streamflow was used in determining the amount of recharge to the 38 -acre watershed and to the watershed upstream from Red Clay Creek near Kennett Square.

\section{Ground-Water Underflow}

Ground-water underflow from the site was suspected to be a major output because of the small areal size of the watershed and the thick and transmissive shallow aquifer. The underflow is ground water that is not being captured as base flow leaving the watershed at the weir location (fig. 5, cross-section B). McGuinness and others (1961), in a study investigating a relation between watershed drainage-area size and average annual streamflow in central Ohio, observed that average annual streamflow increased by about 60 percent as drainage-area size increased from 30 to 1,000 acres. They attributed the increased annual streamflow in the larger watersheds (1,000 acres) to the stream channel cutting deeper into the geologic column and capturing more ground water.

Heebner and Toran (2000), in evaluating a sensitivity analysis of a 3-dimensional ground-water-flow model for the study site and the associated effects of the irrigation on groundwater mounding, found if values of hydraulic conductivity assigned to the unconsolidated zone (shallow aquifer) were greater than $82 \mathrm{ft} / \mathrm{d}(25 \mathrm{~m} / \mathrm{d})$, horizontal ground-water flow was dominant. Because of the dominant horizontal-flow directions, water-level mounding onsite was negligible at application rates ranging from 0.28 to $7.0 \mathrm{in} / \mathrm{d}$. At the higher values of hydraulic conductivity (greater than $82 \mathrm{ft} / \mathrm{d}$ ), they found that less water was discharged to the stream because water levels were low enough so that water exited the watershed by way of groundwater underflow. At lower hydraulic conductivities between 3.28 and $82 \mathrm{ft} / \mathrm{d}$, they reported that water-level mounding did occur at the high irrigation rates and, consequently, more water was discharged to the stream. However, ground-water underflow losses still occurred because not all the water was captured by the headwater stream.

Darcy's equation below for ground-water flow through porous media was used to determine an average monthly loss of ground water not captured by the stream.

$$
Q=K A(d h / d l)
$$

where

$$
\begin{array}{ll}
Q & \text { is volume, in cubic feet per day; } \\
K & \text { is hydraulic conductivity, in feet per day; } \\
A & \text { is cross-sectional area, in square feet; }
\end{array}
$$

and

$$
d h / d l \quad \text { is hydraulic gradient. }
$$

A small cross-sectional area of shallow aquifer northeast of the weir (cross-section A) was used in Darcy's equation as the area in which underflow is occurring (fig. 5). An average head (water-level) gradient from the valley-bottom area near wells Ch-5177 and Ch-5181 was used in the analysis. Also, the linear distance from wells Ch-5177 and Ch-5181 to the small cross-sectional area was determined. The estimate used for hydraulic conductivity of the shallow aquifer was $10 \mathrm{ft} / \mathrm{d}$. The hydraulic conductivity used in the equation was based on the model by Heebner and Toran (2000), a 12-hour aquifer test done in a bedrock well onsite, that assumed the hydraulic conductivity of the shallow aquifer is slightly greater than the hydraulic conductivity of the bedrock aquifer. WoodwardClyde (1996) estimated the hydraulic conductivity of the bedrock to be $4 \mathrm{ft} / \mathrm{d}$. Substituting these parameters into Darcy's equation for ground-water flow, an estimate of ground-water underflow loss was calculated for the study period. To represent this loss on a monthly basis, the loss during the study period was prorated according to the monthly base flow. Therefore, the magnitude in monthly underflow losses would increase and decrease dependent on the magnitude of increase and decrease in monthly base flow.

\section{Pond Storage}

Two factors relating to the pond in the monthly waterbudget determination are direct evaporation from the free water surface of the pond and changes in pond storage. Daily open pan evaporation averages for May through October inclusive from the Landisville, Pa., NOAA station were used in determining direct evaporation from the pond (Pennsylvania State Univer- 

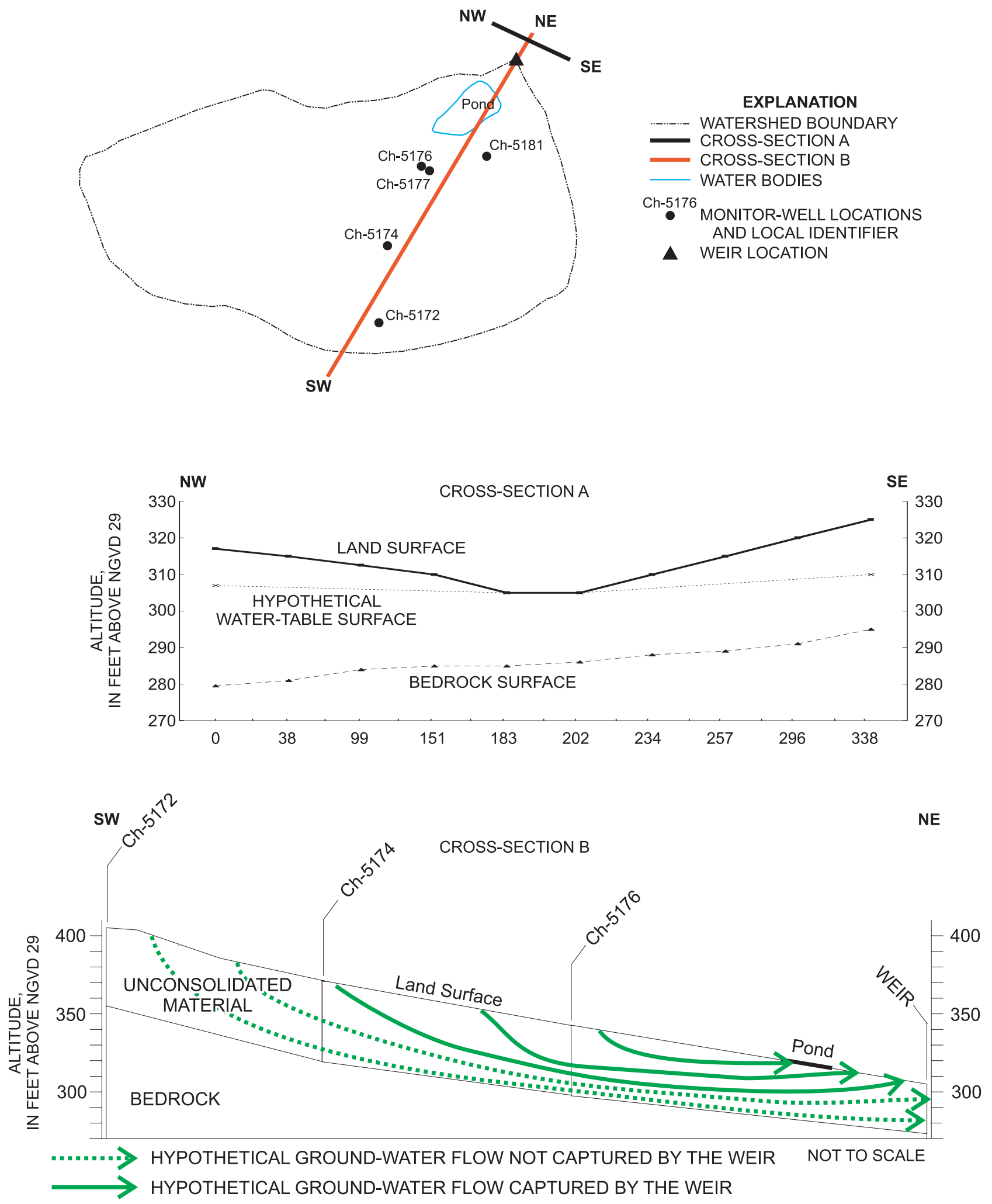

Figure 5. Location of cross-sectional areas used in ground-water underflow estimates, New Garden Township sprayirrigation site, Chester County, Pennsylvania. 
sity, College of Earth and Mineral Science, 2003). The open pan evaporation daily averages were multiplied by 0.78 to convert to free water surface evaporation (Farnsworth and Thompson, 1982). The surface area of the pond was digitized from maps and the area determined using a geographic information system (GIS). The pond area was multiplied by the adjusted daily evaporation averages and summed for each month. The monthly totals were then normalized to the watershed area.

A 4-in. PVC stilling well was installed in the pond and equipped with a shaft encoder float system and data logger to measure and record pond stage every 15 minutes. Pond stage recorded on the first day of a month was subtracted from the pond stage recorded on the first day of the previous month; the resulting difference was multiplied by the surface area of the pond to give the change in the volume of pond storage per month. The volume was then normalized to the watershed area. However, minimal amounts of water were stored in the pond because the pond had been breached, which allowed for constant outflow of water. All outflow from the pond flowed into the stream above the weir location. During large storm events, the pond did store water, but the stored water usually was released a few days after the storm. The delayed release of stored storm water from the pond had no effect on the monthly water-budget results.

\section{Ground-Water Storage}

A network of 14 wells was drilled to measure groundwater levels (plate 1). Ten wells were within the watershed, and four control wells were outside the watershed. The 10 wells in the watershed were along several transects parallel to the conceptual ground-water-flow paths. Ground-water flow is from the hilltop, the conceptual recharge area, to the valley bottom, the conceptual discharge area.

Nested well pairs were constructed consisting of a shallow well completed in the unconsolidated material and a deep well drilled into the bedrock and screened at the first water-bearing zone. Downhole pressure transducers and data loggers that measured and recorded water-level data hourly were installed. Monitor-well construction characteristics are summarized in table 2.

The amount of precipitation and applied effluent that percolates as recharge and is either stored or released from the shallow- and bedrock-aquifer systems must be estimated. To make this estimate, it was assumed that changes in ground-water storage in the bedrock aquifer were negligible compared to the storage changes in the shallow aquifer because the unconsolidated material has much higher porosity than the bedrock aquifer and water-table fluctuations occurred in the unconsolidated material. Therefore, the reported estimates of changes in groundwater storage in the monthly water-budget results are only from the analysis of ground-water data from the shallow aquifer.

Estimates of monthly ground-water storage were based on the specific yield of the shallow aquifer, topographical setting, and the areas of application in the watershed. Specific yield is defined as the volume of water that an unconfined aquifer
Table 2. Summary of monitor-well construction characteristics, New Garden Township spray-irrigation site, Chester County, Pennsylvania.

[Locations of monitor wells are shown on plate 1]

\begin{tabular}{ccccc}
\hline $\begin{array}{c}\text { U.S.Geological } \\
\text { Survey } \\
\text { monitor-well } \\
\text { identification } \\
\text { number }\end{array}$ & $\begin{array}{c}\text { Well } \\
\text { depth } \\
\text { (feet below } \\
\text { land } \\
\text { surface) }\end{array}$ & $\begin{array}{c}\text { Screened } \\
\text { interval } \\
\text { (feet below } \\
\text { land surface) }\end{array}$ & $\begin{array}{c}\text { Casing } \\
\text { diameter } \\
\text { (inches) }\end{array}$ & $\begin{array}{c}\text { Approxi- } \\
\text { mate } \\
\text { yield } \\
\text { (gallons } \\
\text { per minute) }\end{array}$ \\
\hline Ch-5172 & 125 & $96.5-121.5$ & 4 & 2 \\
Ch-5173 & 62 & $42-62$ & 2 & .5 \\
Ch-5174 & 99.4 & $79-99$ & 4 & 1 \\
Ch-5175 & 56.5 & $36.5-56.5$ & 2 & .5 \\
Ch-5176 & 89 & $69-89$ & 4 & 2 \\
& & & & \\
Ch-5177 & 35 & $23-33$ & 2 & 2 \\
Ch-5178 & 89.9 & $69-89$ & 4 & 1 \\
Ch-5179 & 39 & $24-39$ & 2 & .5 \\
${ }^{1}$ Ch-5180 & 32 & $20-30$ & 4 & 2 \\
Ch-5181 & 40 & $30-40$ & 4 & .5 \\
& & & & \\
${ }^{2}$ Ch-5182 & 195 & $165-195$ & 4 & .5 \\
${ }^{2}$ Ch-5183 & 90 & $70-90$ & 4 & 10 \\
${ }^{2}$ Ch-5721 & 101 & $91-101$ & 2 & 1 \\
${ }^{2}$ Ch-5722 & 42 & $25-42$ & 2 & .5 \\
\hline
\end{tabular}

${ }^{1} \mathrm{Ch}-5180$ was dry during some time intervals.

${ }^{2}$ Control well.

releases from storage per unit surface area of aquifer per unit decline in the water table (Freeze and Cherry, 1979, p. 61). Olmsted and Hely (1962, p. A-16) present a method for determining the long-term gravity yield, which is approximate to the specific yield, of rocks or soils in the Brandywine Creek watershed. The method estimates the specific yield by calculating the ratio of ground-water discharge of a winter-time recession period to the change in ground-water levels over the corresponding time period. Theoretically, the analysis is to be done during periods of no evapotranspiration and no recharge to the ground-water system. These ideal conditions seldom, if ever, occur (Olmsted and Hely, 1962, p. A-16). However, the baseflow recession curve for winter represents conditions when the evapotranspiration loss from ground water is relatively small (Olmsted and Hely, 1962, p. A-16).

For the analysis of specific yield, the 38 -acre watershed was divided on the basis of topographic setting and application area into eight areal ground-water storage sub-units (fig. 6, table 3). Because fluctuations in ground-water levels are the greatest in hilltop areas and the least in valley-bottom areas, ground-water storage was determined for each sub-unit area on the basis of ground-water-level data associated with that subunit area. Also, ground-water levels in areas where effluent was applied had larger fluctuations than areas outside the application area because of the additional recharge. The resulting ground-water fluctuations for each ground-water storage subunit area were normalized to the total watershed area. The total 


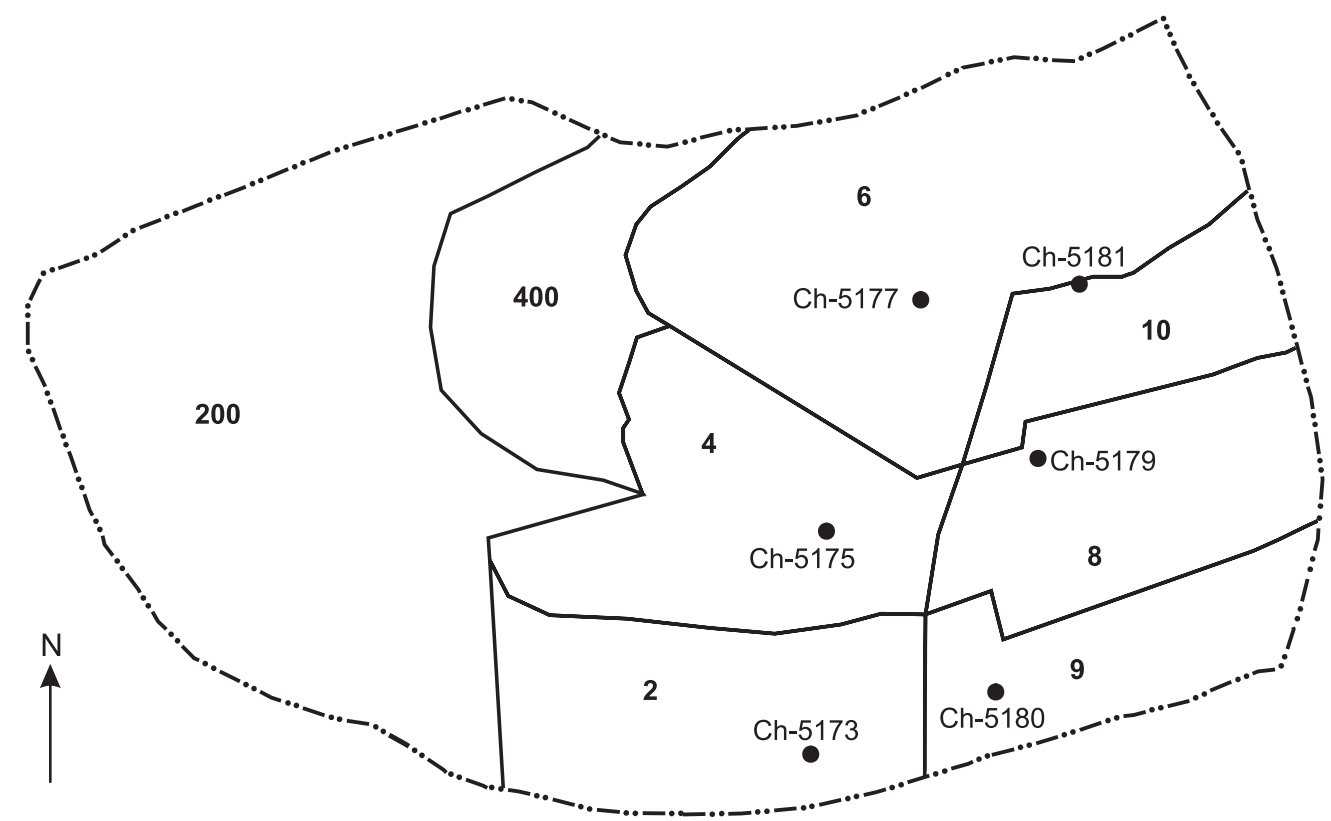

EXPLANATION
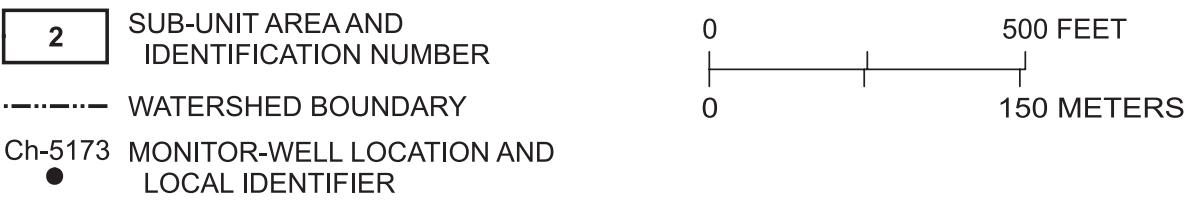

Figure 6. Locations of the eight ground-water storage sub-unit areas and monitor wells used in the monthly ground-water storage analysis, New Garden Township spray-irrigation site, Chester County, Pennsylvania.

Table 3. Ground-water storage sub-unit areas used to determine watershed specific yield, New Garden Township spray-irrigation site, Chester County, Pennsylvania.

[Ground-water storage sub-unit areas are shown on figure 6]

\begin{tabular}{clccl}
\hline $\begin{array}{c}\text { Ground-water storage } \\
\text { sub-unit area number }\end{array}$ & $\begin{array}{l}\text { Topographical } \\
\text { setting }\end{array}$ & $\begin{array}{c}\text { Area } \\
\text { (square feet) }\end{array}$ & $\begin{array}{c}\text { Areal weighted } \\
\text { percentage }\end{array}$ & Effluent application \\
\hline 2 & Hilltop & 150,100 & 8.9 & Applied \\
4 & Hillside & 196,200 & 11.7 & Applied \\
6 & Valley bottom & 353,200 & 21.0 & Not applied \\
8 & Hillside & 163,600 & 9.7 & Applied \\
& & & & \\
9 & Hilltop & 107,400 & 6.4 & Applied \\
10 & Valley bottom & 95,500 & 5.7 & Not applied \\
200 & Hilltop & 473,200 & 28.2 & Not applied \\
400 & Hillside & 141,100 & 8.4 & Not applied \\
\hline
\end{tabular}


base flow and underflow over the winter-time recession periods were divided by the average weighted ground-water-level fluctuations and the quotient was the specific yield. Three wintertime recession periods were used in determining the specific yield of the shallow aquifer. The averaged specific yield $(0.17)$ from these periods was used in the analysis.

To determine monthly ground-water storage, the same ground-water storage sub-unit areas and associated weighting factors were used as in the determination of specific yield. Ground-water levels recorded on the first day of a month in monitor wells for each ground-water storage sub-unit area were subtracted from the ground-water levels recorded on the first day of the previous month. Monitor-well locations in which water-level data were used in the analysis and associated ground-water storage sub-unit area are shown in figure 6. For ground-water storage sub-unit 200, water-level data from monitor well Ch-5183 were used in the analysis and for groundwater storage sub-unit 400, water-level data from well Ch-5722 were used in the analysis (plate 1). Ground-water levels had to be estimated during some periods because of equipment failure. The levels were estimated by use of the hydrograph comparison method. The differences in monthly ground-water levels were multiplied by the area of each sub-unit to obtain a volume. The resulting volumes were multiplied by the specific yield and the corresponding sub-unit weighting factor, which yielded an areal-weighted volume. These areal-weighted volumes for each sub-unit area were totaled to yield monthly change in groundwater storage.

\section{Soil-Moisture Storage}

A network of 14 time domain reflectometer (TDR) soilmoisture probes (plate 1) was installed to measure volumetric soil-moisture content of the unsaturated zone. Two soil-moisture probes were installed at seven locations. Shallow probes were installed approximately 16 to $22 \mathrm{in}$. below the land surface. Data from these probes represent volumetric soil content in the root zone. Deep probes were installed approximately 38 to 42 in. below the land surface. Data from these probes represent volumetric soil content of the upper part of the unsaturated soil zone below the root zone. The bottom of the unsaturated soil zone is the water table, where the soil is fully saturated. Depths of installation and soil horizon for soil-moisture probes are summarized in table 4 . Mean daily percent soil moisture was computed from hourly soil-moisture readings.

Soil-moisture probes were calibrated to field conditions. Calibration curves that converted sensor output to percent soil moisture were developed. The volume of water stored in the soil was estimated from the percent soil-moisture data. To determine the amount of water stored in the unsaturated-soil zone per month, the volume of unsaturated soil had to be estimated. The volume of the unsaturated-soil zone was dynamic because of the fluctuating water table - as water levels rose, less of the unsaturated-soil zone was available to store water, and as water levels declined, more of the unsaturated-soil zone was available to store water.

Table 4. Installation depths of soil-moisture probes, New Garden Township spray-irrigation site, Chester County, Pennsylvania.

[Soil-water storage sub-unit areas are shown on figure 7]

\begin{tabular}{cccl}
\hline $\begin{array}{c}\text { Soil-water storage } \\
\text { sub-unit area }\end{array}$ & $\begin{array}{c}\text { Soil-moisture } \\
\text { probe local identifier }\end{array}$ & $\begin{array}{c}\text { Depth of installation } \\
\text { (inches below land surface) }\end{array}$ & Soil horizon \\
\hline 2 & SM-01S & 20 & Middle root zone \\
& SM-01D & 39 & Below root zone \\
9 & SM-09S & 19 & Middle root zone \\
& SM-09D & 40 & Below root zone \\
4 & SM-04S & 20 & Middle root zone \\
& SM-04D & 40 & Below root zone \\
8 & SM-07S & 22 & Middle root zone \\
& SM-07D & 40 & Below root zone \\
6 & SM-06S & 18 & Middle root zone \\
& SM-06D & 36 & Below root zone \\
10 & SM-10S & 21 & Middle root zone \\
& SM-10D & 36 & Below root zone \\
& ${ }^{1}$ CSM-01S & 20 & Middle root zone \\
& ${ }^{1}$ CSM-01D & 40 & Below root zone \\
\hline
\end{tabular}

\footnotetext{
${ }^{1}$ Soil-moisture probes were outside the study watershed. Locations of probes are shown in plate 1.
} 


\section{Calibration of Soil-Moisture Probes}

Three sets of soil-moisture samples were collected to calibrate the soil-moisture probes. On June 5 and July 6, 2001, and January 25, 2002, soil samples were collected at depths and locations near the installed probes. A 12 -in. long by 1-in. diameter core-sampling barrel was hammered into the soil to a depth just above the sampling interval. This core was discarded. Then, a soil sample was collected in that hole approximately 3 in. above to 3 in. below the location of the soil-moisture probe. The sampling procedure was repeated next to the first hole. For each of the 14 probe locations, two soil cores were composited and placed into a pre-weighed glass jar.

Soil-moisture samples and the jars were weighed, placed in an oven at $100^{\circ} \mathrm{C}$ for 24 hours, cooled, and weighed again. The difference between the weight of the soil samples before and after drying was divided by the dry soil mass to yield the gravimetric soil-water content (eq. 4).

Gravimetric soil-water content $=$ (wet soil mass - dry soil mass) / dry soil mass

Soil-moisture probes measured volumetric soil-water content not gravimetric soil-water content. Therefore, to be useful for calibrating the TDR probes, the gravimetric soil-water content determined from core samples had to be multiplied by the soil-bulk density (see "Solid-Soil Nitrogen Storage," p. 76) to determine volumetric soil-water content (eq. 5). Soil-bulk density was determined as part of the $\mathrm{N}$ fate and transport component of the study.
$($ Gravimetric soil-water content $)($ soil-bulk density $)=$
volumeteric soil-water content

Once the volumetric soil-water content was determined, comparisons were made between percent soil moisture of the collected samples and the TDR output, which was converted to percent soil moisture using standard calibration curves supplied by the manufacturer. Calibration curves were developed to convert TDR sensor output to the field-verified percent soil moisture.

\section{Volumetric Unsaturated Soil-Water-Storage Determination}

The watershed was divided into eight soil-water storage sub-unit areas (fig. 7) that differed slightly from the sub-unit areas used in the analysis of specific yield and ground-water storage. These sub-unit areas were based on topographic setting, application area, and the thickness of the underlying unconsolidated material. Two soil-moisture probes were in each sub-unit area except for sub-unit areas 44 and 100 (fig. 7). Sub-unit area 44 was part of spray field 4 , where effluent was applied intermittently throughout the study for equipment testing. However, the contribution of effluent to the watershed was considered negligible. Sub-unit area 100 was the part of the watershed outside the application fields. Because the amount of effluent applied to sub-unit area 44 was negligible, sub-unit areas 44 and 100 were combined for the analysis of soil-moisture storage. Total surface area for each sub-unit was determined using a GIS (table 5).

In each soil-water storage sub-unit area, the unconsolidated material was divided vertically into a root-zone layer and

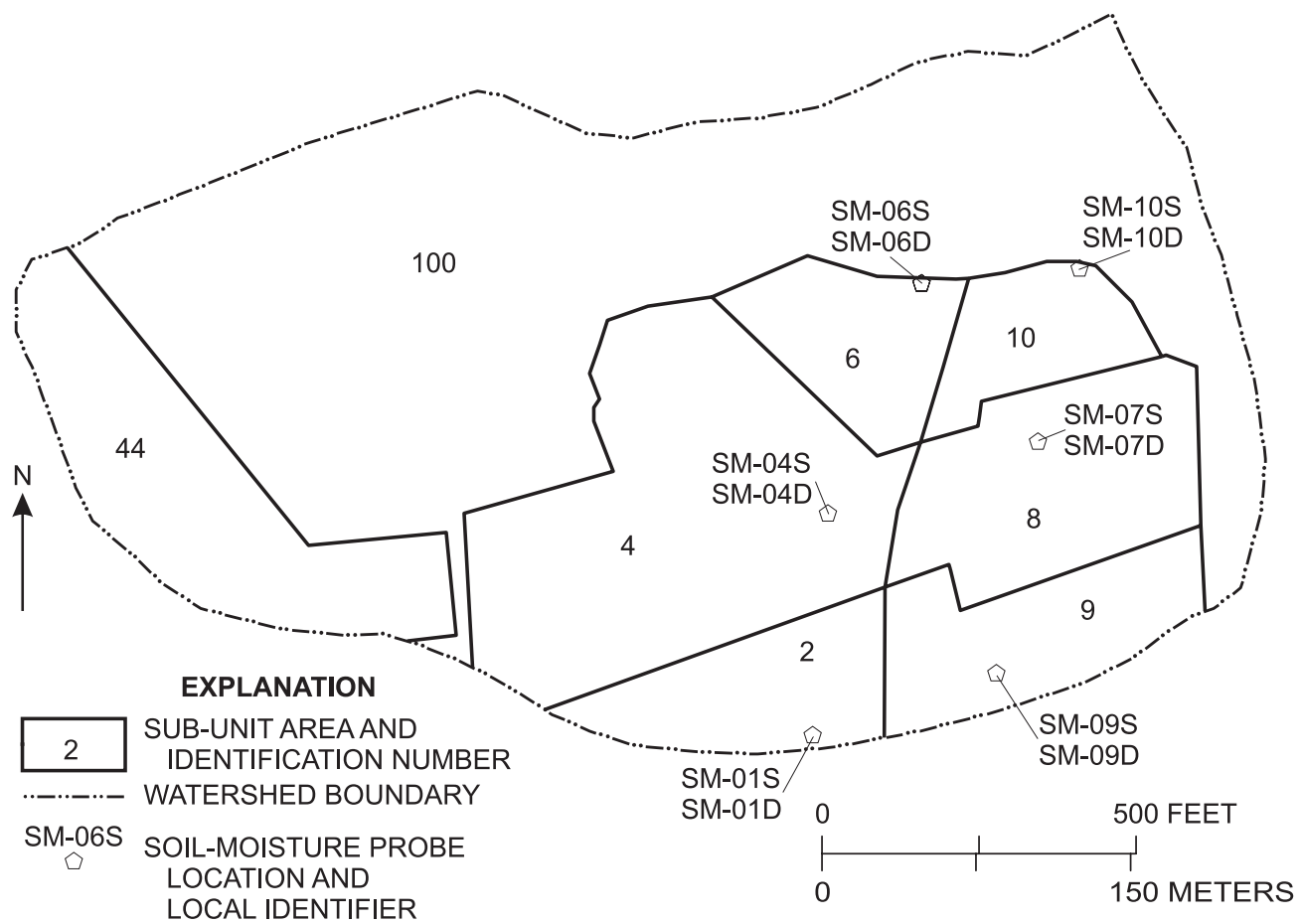

Figure 7. Locations of the soil-water storage sub-unit areas and soil-moisture probes used in the monthly volumetric soil-moisture storage analysis, New Garden Township spray-irrigation site, Chester County, Pennsylvania. 


\section{Effects of Spray-Irrigated Effluent on Water Quantity and Quality, and the Fate and Transport of Nitrogen}

Table 5. Total surface area of soil-water storage sub-unit areas used to determine volumetric soil-water content of the unsaturated zone, New Garden Township spray-irrigation site, Chester County, Pennsylvania.

[Soil-water storage sub-unit areas are shown on figure 7]

\begin{tabular}{clrc}
\hline \multirow{2}{*}{$\begin{array}{c}\text { Soil-water } \\
\text { storage sub- } \\
\text { unit area }\end{array}$} & Topographical setting & \multicolumn{2}{c}{ Area } \\
\cline { 3 - 4 } & & Square feet & Acres \\
\hline 2 & Hilltop & 83,000 & 1.90 \\
9 & Hilltop & 96,600 & 2.21 \\
4 & Hillside & 281,000 & 6.45 \\
8 & Hillside & 135,800 & 3.11 \\
& & & \\
6 & Valley bottom & 73,300 & 1.68 \\
10 & Valley bottom & 59,200 & 1.36 \\
44 & Hilltop & 168,600 & 3.87 \\
100 & Hilltop, hillside, and valley & 782,600 & 18.0 \\
& bottom & & \\
\hline
\end{tabular}

an unsaturated-soil layer. The root-zone layer was defined as being from the land surface to a depth of $2.5 \mathrm{ft}$ below land surface, which was the depth midway between the shallow and deep soil-moisture probes. The unsaturated-soil layer was defined as being from $2.5 \mathrm{ft}$ below land surface to the top of the water table.
The volume of soil in the root zone and the unsaturatedsoil layer for each soil-water storage sub-unit area was determined on a monthly basis. The volume of soil in the root zone was constant in each sub-unit area and was determined by multiplying sub-unit surface area by $2.5 \mathrm{ft}$, the thickness of the root zone. The volume of soil in the unsaturated-soil layer was dynamic because of changes in the water table, which changed the thickness of the unsaturated soil layer. The unsaturated-soil layer became thicker as the water table lowered and thinner as the water table rose.

The volume of the unsaturated-soil layer was determined on the basis of ground-water-level data in monitor wells completed in the shallow aquifer. Monitor wells were located in each soil-water storage sub-unit area except sub-units 44 and 100. Ground-water-level data from monitor wells Ch-5183 (control area 2) and Ch-5722 (control area 1) (plate 1) were used in the analysis for these soil-water storage sub-unit areas. Because monitor wells were not located throughout the watershed and in order to complete the areal coverage of water-level data over the entire watershed, water-level data from a well installed prior to the study (Ch-4809) and a monitor well installed during the study by the New Garden Township Sewer Authority (NG-6) were added to the data set. Also, water-level data were estimated at six locations along the boundary and two locations within the watershed. Ground-water-level data were estimated at these eight locations on the basis of topographic settings and ground-water-level data from wells Ch-5183 and Ch-5722 (plate 1). Data points used in the analysis, except for control wells, are shown in figure 8 .

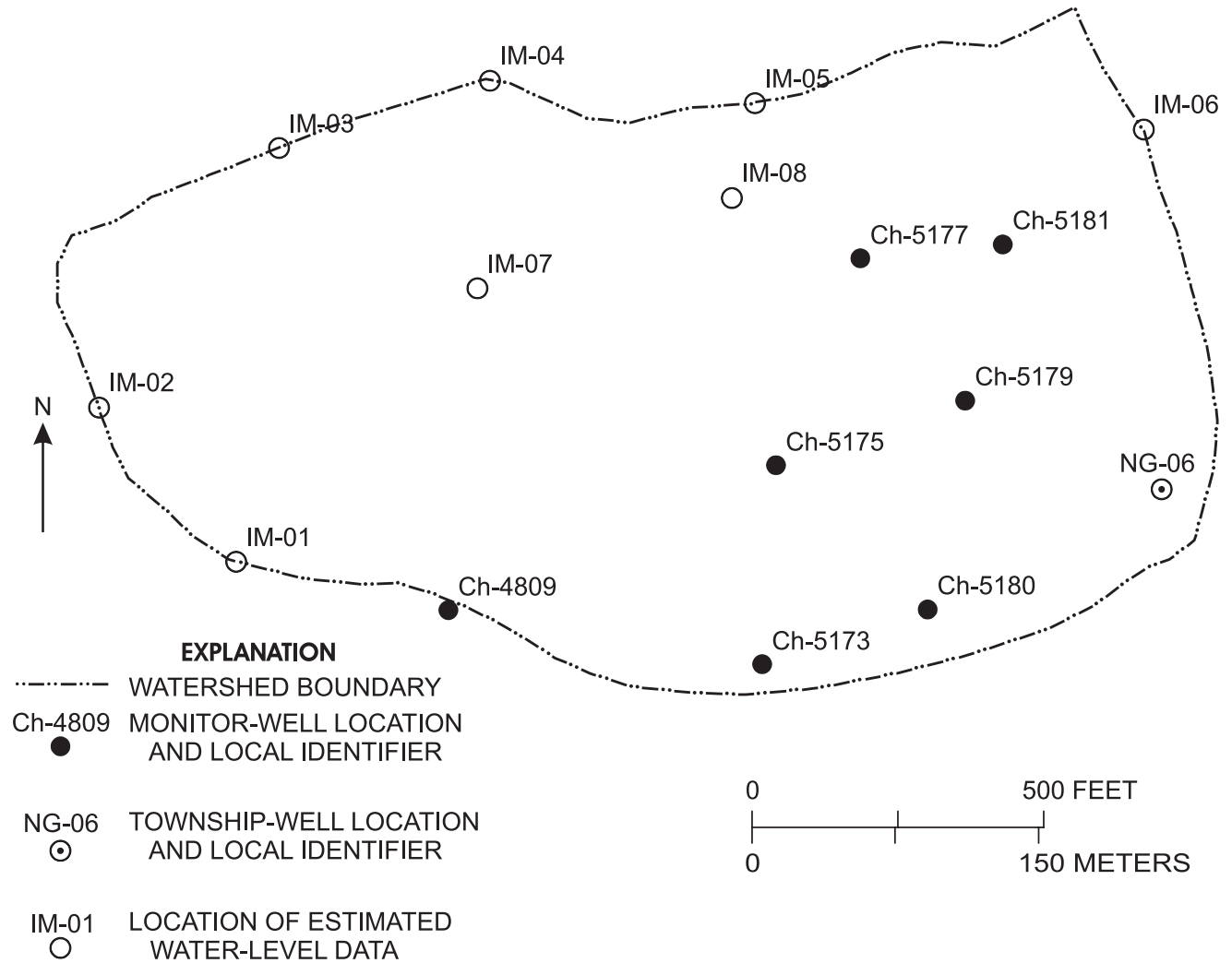

Figure 8. Locations of the monitor wells, township well, and estimated water-level data used to estimate the thickness of the unsaturated-soil layer, New Garden Township spray-irrigation site, Chester County, Pennsylvania. 
Thickness of the unsaturated-soil layer varied across the watershed because of water-level fluctuations. The method used to determine the thickness of the unsaturated-soil layer was based on determining the maximum and minimum water levels during the study period. To determine the maximum thickness of the unsaturated-soil layer, the lowest water-level altitudes for each soil-water storage sub-unit area were compiled. These water-level altitudes along with surface topographic altitudes, minus $2.5 \mathrm{ft}$ for the root zone, were entered into a spatially oriented stratigraphic software package. Subtracting the water-level altitudes from the bottom of the rootzone altitudes resulted in the thickness of the unsaturated-soil layer. Thickness of the capillary fringe at the unsaturated zone/ water-table interface was assumed to be negligible. Lines of equal unsaturated zone thickness, or isopach contour lines, were constructed. These contours represented the maximum thickness of the unsaturated-soil layer in the watershed during the study period (fig. 9A). To determine the minimum thickness of the unsaturated-soil layer for the watershed, the highest waterlevel altitudes for each soil-water storage sub-unit area were compiled. The same process was used to compute lines of equal thickness from this data set. These contours represented the minimum thickness of the unsaturated-soil layer in the watershed during the study period (fig. 9B).

Once the isopach maps were constructed, a spatial analysis was done using a GIS to determine average thicknesses for each sub-unit area based on the maximum and minimum thicknesses and water levels. For example, the maximum thickness for subunit area 4 is shown in figure 10 . The corresponding water level was $21.94 \mathrm{ft}$ below land surface in monitor well Ch-5175 (347.46 ft above NGVD 29). Thickness was assigned to zones between the contour lines. These zones combined with sub-unit boundaries created polygons. To determine the average thickness, the thickness of each polygon was weighted by multiplying by the percentage of the polygon surface area in the sub-unit (table 6) to yield a weighted thickness for each polygon. The weighted thicknesses were summed to obtain the average thickness for the sub-unit area (table 6). Therefore, for a water level $21.94 \mathrm{ft}$ below land surface in sub-unit area 4, the calculated average thickness of the unsaturated-soil layer was $24.4 \mathrm{ft}$. The same analysis was done for the minimum thicknesses and the corresponding water level. The lowest and highest water levels for each sub-unit area were plotted against the corresponding maximum and minimum unsaturated-soil thicknesses. The relation is assumed linear, and an equation for a straight line was determined. Thus, substituting the monthly water levels into the equation, which will always be between the lowest and highest water levels, yielded the average thickness for the month.

Once monthly average thicknesses were determined, the volumetric soil-water content in the root zone and in the unsaturated-soil layer were estimated for each sub-unit area on a monthly basis. To determine volumetric soil-water content of the root-zone layer, root-zone volumes were multiplied by the percent volumetric soil moisture measured by shallow TDR probes on the first day of the month.
Table 6. Assigned thickness of unsaturated-soil layer and polygon areas used to determine the weighted thickness for sub-unit area 4, New Garden Township spray-irrigation site, Chester County, Pennsylvania.

\begin{tabular}{ccc}
\hline $\begin{array}{c}\text { Assigned } \\
\text { thickness } \\
\text { (feet) }\end{array}$ & $\begin{array}{r}\text { Polygon area } \\
\text { (square feet) }\end{array}$ & $\begin{array}{c}\text { Weighted } \\
\text { thickness } \\
\text { (feet) }\end{array}$ \\
\hline 13 & 700 & 0.03 \\
15 & 11,900 & .64 \\
17 & 22,000 & 1.3 \\
19 & 28,900 & 2.0 \\
21 & 33,400 & 2.5 \\
& & \\
23 & 37,900 & 3.1 \\
25 & 31,600 & 2.8 \\
27 & 34,400 & 3.3 \\
29 & 33,800 & 3.5 \\
& & \\
31 & 24,800 & 2.7 \\
33 & 15,600 & 1.8 \\
34 & 6,000 & .73 \\
Total & $\mathbf{2 8 1 , 0 0 0}$ & $\mathbf{2 4 . 4}$ \\
\hline Average thickness & & \\
\hline
\end{tabular}

To determine volumetric soil-water content in the unsaturated-soil layer below the root zone to the top of the water table, the following method was developed. Because soil moisture increases from below the root zone to total soil saturation at the water table, percent soil moisture at total saturation had to be estimated. The percent soil moisture at total saturation for hilltop, hillside, and valley-bottom areas was estimated from bulkdensity values determined from soil samples collected and using a particle density of $2.6 \mathrm{~g} / \mathrm{cm}^{3}$ for all samples (Brady, 1974, p. 50). The estimated percentages for hilltop, hillside, and valley-bottom areas were 43,36 , and 38 percent, respectively.

The increase in soil moisture from below the root zone to the top of the water table was assumed to be linear. The volumetric soil-water content throughout the soil profile was determined per vertical 1 -ft increments for each soil-water storage sub-unit area from $2.5 \mathrm{ft}$ below land surface down to the monthly average thicknesses, which represented the top of the water table. The percent soil moisture measured by the deep TDR probes on the first day of the month was used in the 1-ft interval from 2.5 to $3.5 \mathrm{ft}$. Then, the percent soil moisture was increased incrementally per vertical foot from the measured percentage to the total saturation percentage. For example, the monthly average thickness of hillside sub-unit area 8 was $10.3 \mathrm{ft}$ and the percent soil moisture measured by the deep TDR probe was 22 percent. The difference between total saturation percent (36) and the measured soil-moisture percentage (22) is 14 percent. Therefore, percent soil moisture was increased incrementally per vertical foot by 1.36 percent (equal to 

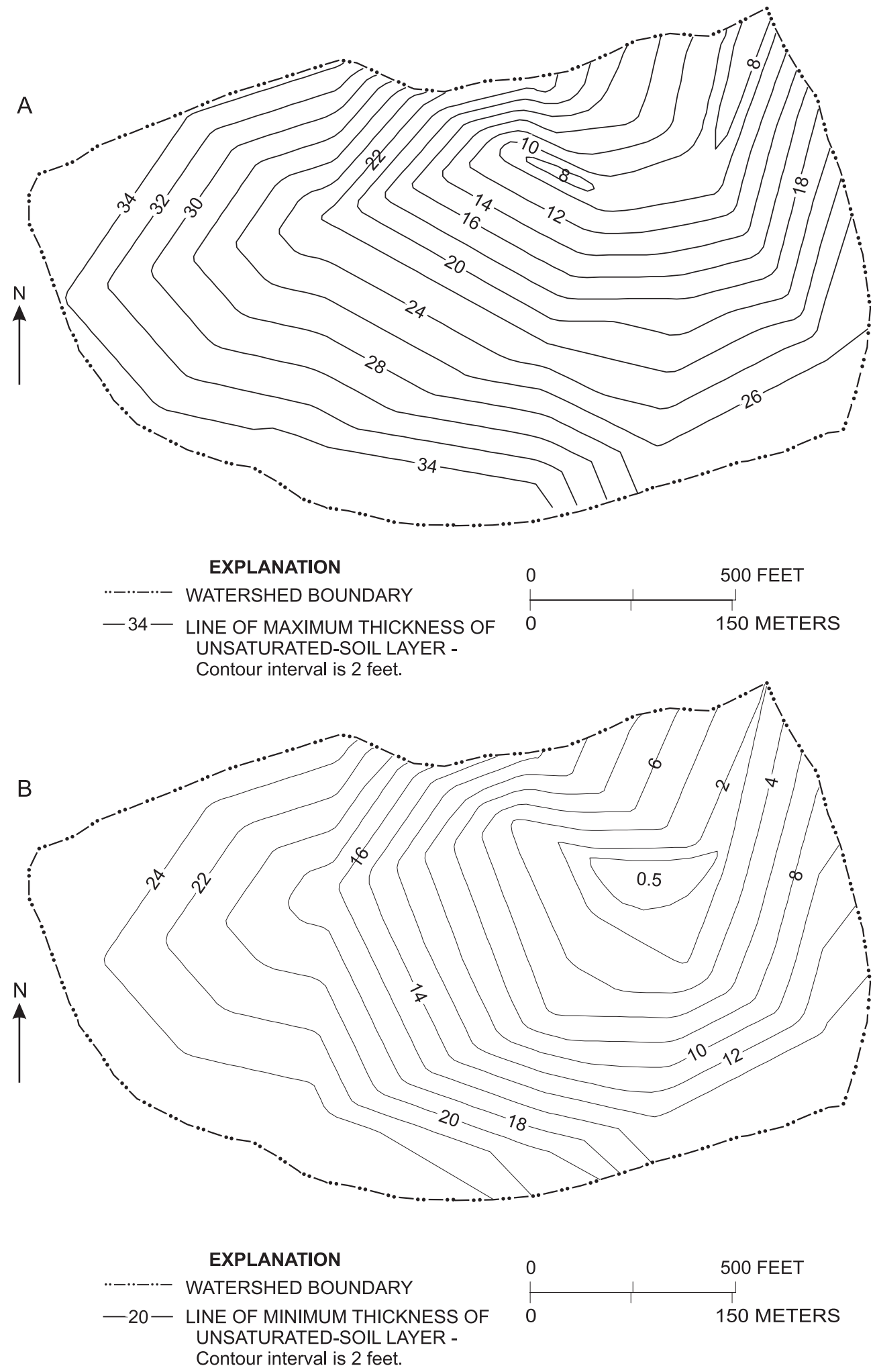

Figure 9. Maximum (A) and minimum thickness (B) of unsaturated-soil layer, New Garden Township spray-irrigation site, Chester County, Pennsylvania. 


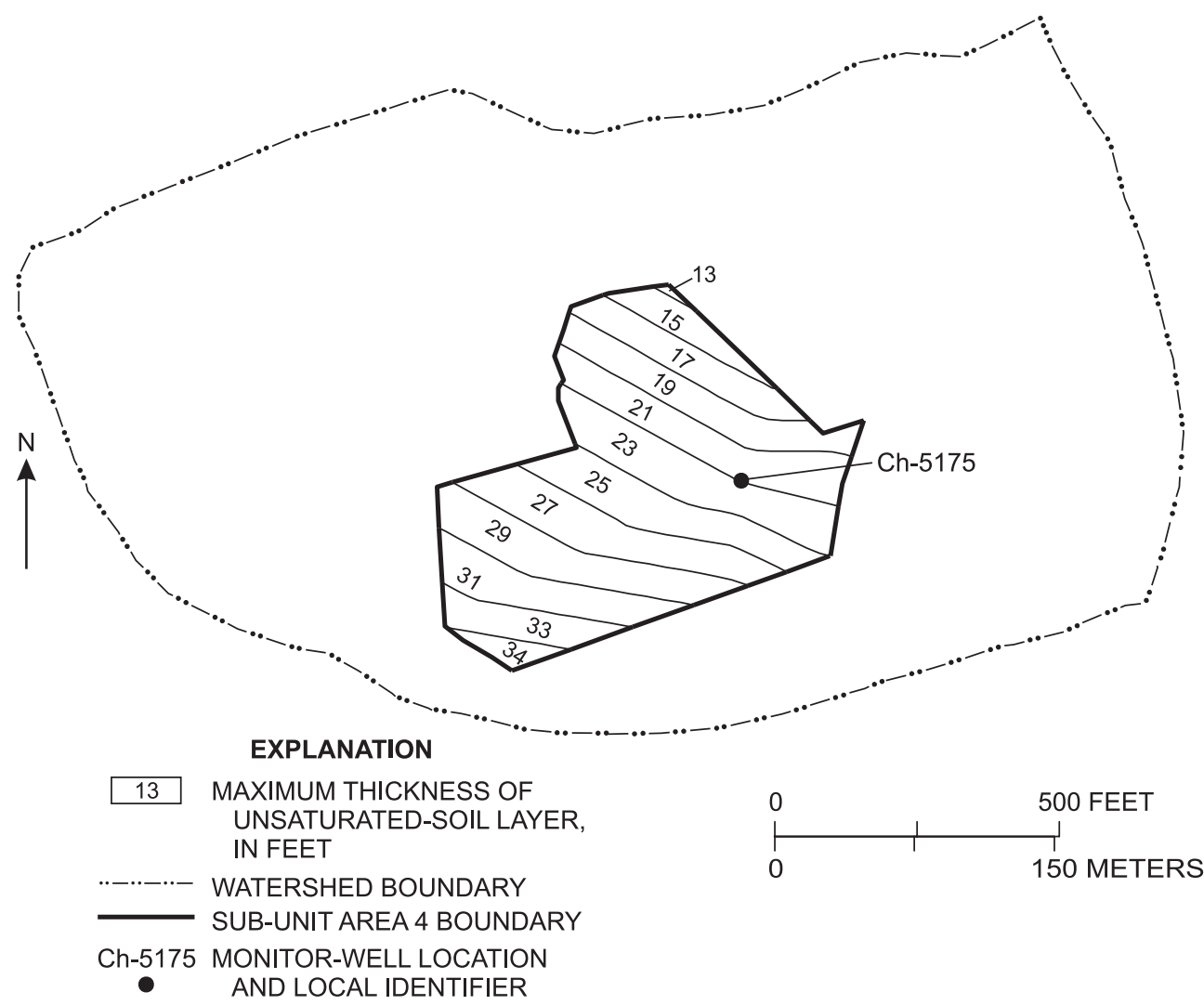

Figure 10. Maximum thickness of unsaturated-soil layer for subunit area 4, New Garden Township spray-irrigation site, Chester County, Pennsylvania.
14 percent divided by $10.3 \mathrm{ft}$ ) from $3.5 \mathrm{ft}$ below land surface to $10.3 \mathrm{ft}$. The total surface area of sub-unit area 8 was multiplied by the per foot volumetric soil water content, which resulted in the water volume for each foot of unsaturated soil. The sum of these 1-ft incremental volumetric soil-water quantities yielded the volume of water in the unsaturated-soil layer.

Water volumes for the root zone and the unsaturated-soil layer were summed for all sub-unit areas to yield total volumetric water content stored in the soil during a month. Total soilwater content was normalized to the watershed area and the monthly change in soil-moisture content was calculated.

\section{Crop-Referenced Evapotranspiration}

Crop-referenced evapotranspiration was used in this study as a check of the calculated monthly evapotranspiration that resulted from the monthly water-budget equation. Calculated monthly evapotranspiration was assumed to represent actual evapotranspiration from the watershed. Crop-referenced evapotranspiration is analogous to potential evapotranspiration. Crop-referenced evapotranspiration can vary from actual evapotranspiration by 15 percent or more (Allen and others, 1998).

Crop-referenced evapotranspiration is defined as the rate of evapotranspiration from a hypothetical reference crop with an assumed crop height of $12 \mathrm{~cm}$ (4.72 in.), a fixed crop-surface resistance and albedo (0.23), closely resembling the evapotranspiration from an extensive surface of green grass cover of uniform height, actively growing, completely shading the ground, and with adequate water (Smith and others, 1997, p. 6). Crop- referenced evapotranspiration can be estimated by measuring certain meteorological variables and using the Penman-Monteith equation (Smith and others, 1992). In the Penman-Monteith equation, measurements of absorbed radiant energy, wind, and atmospheric vapor deficit are used to estimate crop-referenced evapotranspiration. In the agricultural irrigation disciplines, the estimate of crop-referenced evapotranspiration determined from meteorological variables is multiplied by a crop coefficient to determine actual crop evapotranspiration. The crop coefficient is based on characteristics of the crop such as the stage of growth and development. The crop coefficient is used for determining irrigation needs to sustain a specific crop. Because sustainable crop growth was not an objective of this study and crop-development data were not collected, the crop coefficient was not determined.

A micro-meteorological station that included solar radiation, relative humidity, wind speed, and air temperature sensors was installed onsite (plate 1). Meteorological parameters were measured every 2 minutes and averaged over an hour. Averaged hourly values for absorbed radiant energy, wind, and atmospheric vapor deficits were input for a computer program that calculated the Penman-Monteith equation. Mean daily crop-referenced evapotranspiration was determined from the calculated hourly crop-referenced evapotranspiration.

\section{Annual Water Budget}

Annual water budgets were determined for the 38 -acre watershed and for the watershed upstream from the USGS streamflow-gaging station (01479820) Red Clay Creek near 
Kennett Square, Pa., which represented a non-effluent affected control watershed (fig. 11). The drainage area above Red Clay Creek near Kennett Square is $28.3 \mathrm{mi}^{2}$. Annual water budgets were determined for three periods, May 1998 through April 1999 , the period prior to effluent application, and JanuaryDecember 2000 and 2001, two periods during effluent application.

To determine an annual water budget for the study watershed, precipitation, streamflow, and ground-water underflow were totaled on an annual basis and the storage terms were accumulated throughout each 12-month period. To determine an annual water budget for Red Clay Creek near Kennett Square, precipitation data from the site and other sources were totaled on an annual basis. Total annual streamflow was determined from the streamflow-gaging station Red Clay Creek near Kennett Square. Change in ground-water storage was determined from monthly water-level measurements from three monitor wells in the Chester County drought-monitoring network-Ch-28, Ch-38, and Ch-1921 - which are in the Red Clay Creek watershed. Only water-level measurements collected at the beginning and end of the annual period were used to determine changes in ground-water storage. The change in water levels was multiplied by a specific yield of 0.08 (Vogel and Reif, 1993). No net gain or loss of water from the soil zone was assumed, and the change in soil-moisture content for the Red Clay Creek annual water budgets was assumed to be zero. Also, ground-water underflow was assumed to be zero.

\section{Recharge}

Monthly and annual recharge estimates were calculated using equation 6 for the study watershed and Red Clay Creek watershed $\left(28.3 \mathrm{mi}^{2}\right)$ upstream of the USGS streamflow-gaging station near Kennett Square, Pa. (01479820).

$$
R=B F+U F+\Delta G W S
$$

where

$$
\begin{aligned}
& R \text { is recharge, in inches; } \\
& B F \text { is the base-flow component of total } \\
& \text { streamflow, in inches; } \\
& \mathrm{UF}^{1} \text { is estimated ground-water underflow, } \\
& \text { in inches; }
\end{aligned}
$$

and

$$
\begin{aligned}
& \Delta G W S \quad \text { is change in ground-water storage, } \\
& \text { in inches. }
\end{aligned}
$$

\section{Assessing Effects of Spray-Irrigated Effluent on Water Quality}

To assess the effects of the spray-irrigated effluent on water quality, ground water was sampled from 12 monitor

\footnotetext{
${ }^{1}$ Assumed to be 0.0 for Red Clay Creek.
}

wells, surface water was sampled from the stream immediately downstream of the weir and the pond downgradient of the spray fields, and effluent was sampled from a spigot in the spray fields. Water-quality samples collected from May 1998 through April 1999 were analyzed at the USGS National Water-Quality Laboratory (NWQL) in Arvada, Colo. All samples collected after April 1999 were analyzed at the PaDEP Laboratory in Harrisburg, Pa. All water-quality results from the ground-water and surface-water samples were published in USGS WaterData Reports, Volume 1, for water years ${ }^{2} 1999,2000$, and 2001 (Durlin and Schaffstall, 2000, 2001, 2002). All water-quality analyses results for the effluent are given in appendix 1 , table 1-1.

Water-quality samples were collected monthly from ground water, surface water, and the effluent. Field water-quality characteristics $(\mathrm{pH}$, specific conductance, water temperature, dissolved oxygen, and alkalinity) were measured for each ground-water and surface-water sample collected. Alkalinity only was measured for one effluent sample. For some samples, particularly from the wells completed in the shallow aquifer, dissolved oxygen was not measured because of a lack of water and aeration of the sample caused by bailing. All field characteristics were measured using established methods (U.S. Geological Survey, 1997 to present).

Three different laboratory schedules - a monthly, a quarterly, and an annual schedule-were used. The analyzed constituents for the monthly schedule were nutrients consisting of $\mathrm{N}$ and phosphorus $(\mathrm{P})$ species. The analyzed constituents for the quarterly schedule were the nutrient species from the monthly schedule plus dissolved major ions and selected metals, and the analyzed constituents for the annual schedule were the compounds from the quarterly schedule plus an expanded list of metals. The constituents for the different schedules and USGS and PaDEP Laboratories constituent minimum reporting limits are listed in table 7.

Ground-water samples were collected by the methods outlined in the "National Field Manual for the Collection of WaterQuality Data" (U.S. Geological Survey, 1997). Dedicated submersible pumps were installed in some wells. In other wells, a submersible pump was installed at the time of sampling or the well was bailed. A minimum of three well volumes of water was extracted prior to collecting the sample. If the well was low yielding $(<1 \mathrm{gal} / \mathrm{min})$, the water level was pumped down to the total depth and allowed to recover before sampling. During pumping and bailing, water levels were monitored with an electric tape, and water temperature and specific conductance were measured. Samples were collected only after water temperature and specific conductance had stabilized. After each sample was collected, all equipment was rinsed with de-ionized water. All ground-water samples were filtered through a 0.45 micrometer encapsulated filter.

Water-quality sampling was conducted 34 times from wells Ch-5172, Ch-5173, Ch-5174, Ch-5175, Ch-5176, Ch-5177, Ch-5178, Ch-5179, Ch-5181, Ch-5182, and Ch-5183

\footnotetext{
${ }^{2}$ Water year is the 12-month period October 1 through September 30 and is designated by the calendar year in which it ends.
} 


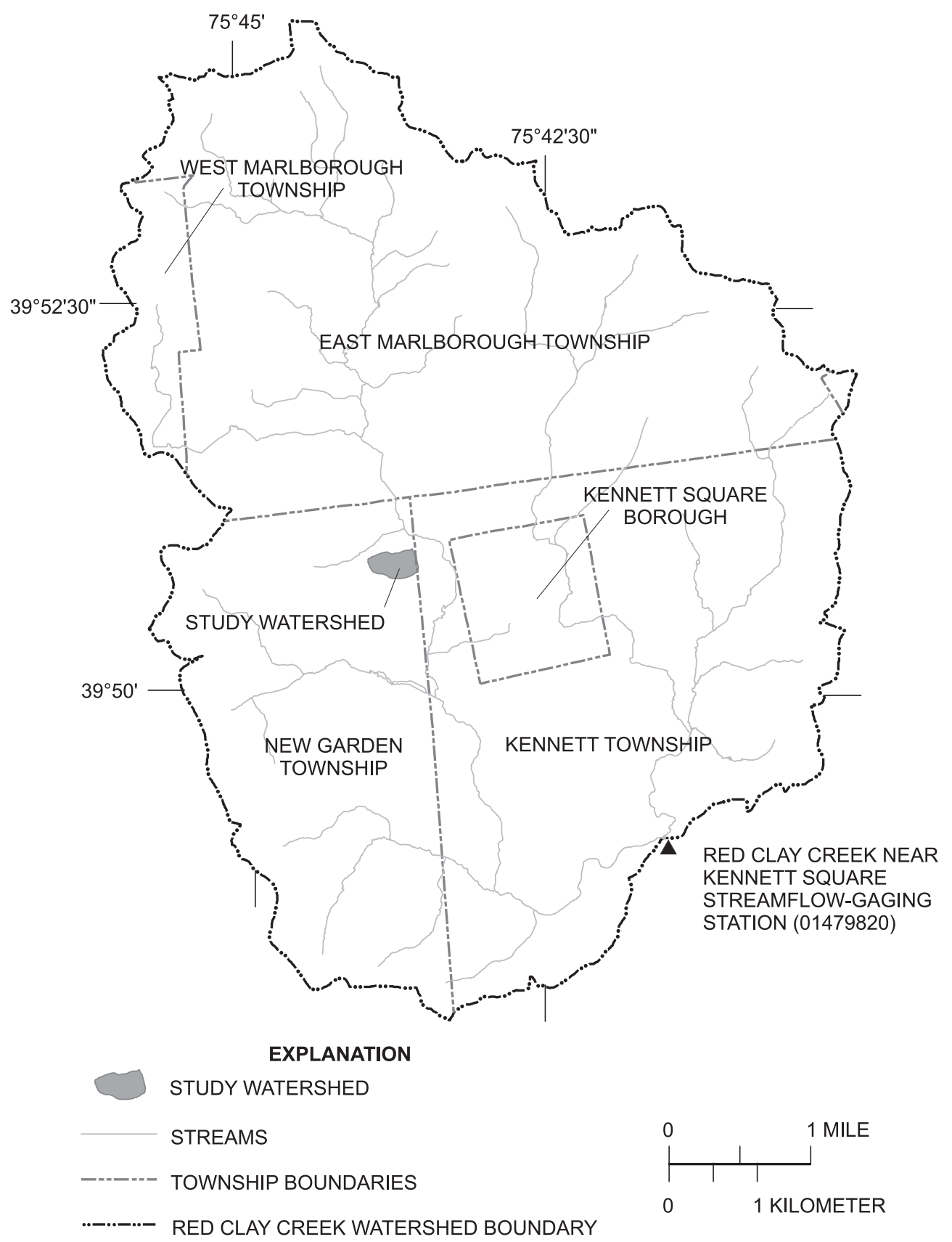

- StREAMFLOW-GAgING StATION

Figure 11. Drainage area above streamflow-gaging station Red Clay Creek near Kennett Square, Chester County, Pennsylvania. 
Table 7. Summary of analyzed chemical constituents in the monthly, quarterly, and annual sampling schedules and laboratory minimum reporting limits for the New Garden Township spray-irrigation study, Chester County, Pennsylvania.

[mg/L, milligrams per liter; $\mu \mathrm{g} / \mathrm{L}$, micrograms per liter; ${ }^{\circ} \mathrm{C}$, degrees Celsius; —, constituent was not analyzed]

\begin{tabular}{|c|c|c|c|c|c|c|c|c|}
\hline \multirow[b]{2}{*}{ Constituents and units } & \multicolumn{2}{|c|}{ Minimum reporting limit } & \multirow[b]{2}{*}{ Constituents and units } & \multicolumn{2}{|c|}{ Minimum reporting limit } & \multirow[b]{2}{*}{ Constituents and units } & \multicolumn{2}{|c|}{ Minimum reporting limit } \\
\hline & $\begin{array}{c}\text { U.S. } \\
\text { Geological } \\
\text { Survey } \\
\text { Laboratory }\end{array}$ & $\begin{array}{c}\text { Pennsylvania } \\
\text { Department } \\
\text { of } \\
\text { Environ- } \\
\text { mental } \\
\text { Protection } \\
\text { Laboratory }\end{array}$ & & $\begin{array}{l}\text { U.S. } \\
\text { Geological } \\
\text { Survey } \\
\text { Laboratory }\end{array}$ & $\begin{array}{c}\text { Pennsylvania } \\
\text { Department } \\
\text { of } \\
\text { Environ- } \\
\text { mental } \\
\text { Protection } \\
\text { Laboratory }\end{array}$ & & $\begin{array}{c}\text { U.S. } \\
\text { Geological } \\
\text { Survey } \\
\text { Laboratory }\end{array}$ & $\begin{array}{c}\text { Pennsylvania } \\
\text { Department } \\
\text { of } \\
\text { Environ- } \\
\text { mental } \\
\text { Protection } \\
\text { Laboratory }\end{array}$ \\
\hline \multicolumn{3}{|c|}{ Monthly laboratory schedule } & \multicolumn{3}{|c|}{ Quarterly laboratory schedule } & \multicolumn{3}{|c|}{ Annual laboratory schedule } \\
\hline Nitrogen, dissolved ${ }^{1}$ (mg/L) & - & 0.02 & \multicolumn{2}{|l|}{ Monthly laboratory schedule plus: } & & \multicolumn{2}{|c|}{ Quarterly laboratory schedule plus: } & \\
\hline Nitrogen, total ${ }^{2}(\mathrm{mg} / \mathrm{L})$ & 0.05 & .06 & Calcium, dissolved (mg/L) & 0.012 & 0.03 & Antimony, dissolved $(\mu \mathrm{g} / \mathrm{L})$ & 1.0 & 2.0 \\
\hline $\begin{array}{l}\text { Nitrate nitrogen, dissolved } \\
(\mathrm{mg} / \mathrm{L})\end{array}$ & .02 & .04 & $\begin{array}{l}\text { Magnesium, dissolved } \\
(\mathrm{mg} / \mathrm{L})\end{array}$ & .008 & .01 & Arsenic, dissolved $(\mu \mathrm{g} / \mathrm{L})$ & 1.0 & 4.0 \\
\hline $\begin{array}{l}\text { Nitrite nitrogen, dissolved } \\
(\mathrm{mg} / \mathrm{L})\end{array}$ & .01 & .04 & Potassium, dissolved (mg/L) & .11 & 1.0 & Barium, dissolved ( $\mu \mathrm{g} / \mathrm{L})$ & .9 & 2.0 \\
\hline $\begin{array}{l}\text { Ammonia nitrogen, dissolved } \\
(\mathrm{mg} / \mathrm{L})\end{array}$ & .02 & .02 & Sodium, dissolved (mg/L) & .09 & .20 & Cadmium, dissolved $(\mu \mathrm{g} / \mathrm{L})$ & 8.0 & 10.0 \\
\hline $\begin{array}{l}\text { Ammonia nitrogen, total } \\
(\mathrm{mg} / \mathrm{L})\end{array}$ & - & .02 & Bromide, dissolved (mg/L) & .03 & .20 & Chromium, dissolved $(\mu \mathrm{g} / \mathrm{L})$ & 1.0 & 4.0 \\
\hline Phosphorus, dissolved (mg/L) & .05 & .01 & Chloride, dissolved (mg/L) & .33 & .50 & Copper, dissolved $(\mu \mathrm{g} / \mathrm{L})$ & 1.0 & 4.0 \\
\hline $\begin{array}{l}\text { Orthophosphate phosphorus, } \\
\text { dissolved (mg/L) }\end{array}$ & .01 & .01 & Fluoride, dissolved (mg/L) & .11 & .20 & Lead, dissolved $(\mu \mathrm{g} / \mathrm{L})$ & 1.0 & 1.0 \\
\hline \multirow[t]{8}{*}{ Phosphorus, total ${ }^{2}$ (mg/L) } & .01 & .01 & Silica, dissolved (mg/L) & .13 & 1.07 & Lithium, dissolved $(\mu \mathrm{g} / \mathrm{L})$ & 4.0 & 25.0 \\
\hline & & & $\begin{array}{l}\text { Total dissolved solids at } \\
180 \mathrm{OC}(\mathrm{mg} / \mathrm{L})\end{array}$ & 10.0 & 2.0 & Mercury, dissolved ( $\mu \mathrm{g} / \mathrm{L})$ & .011 & .2 \\
\hline & & & $\begin{array}{l}\text { Carbon, organic, dissolved } \\
(\mathrm{mg} / \mathrm{L})\end{array}$ & .33 & .50 & Nickel, dissolved ( $\mu \mathrm{g} / \mathrm{L})$ & 2.0 & 4.0 \\
\hline & & & Aluminum, dissolved $(\mu \mathrm{g} / \mathrm{L})$ & 1.0 & 10.0 & Selenium, dissolved $(\mu \mathrm{g} / \mathrm{L})$ & 2.0 & 7.0 \\
\hline & & & Boron, dissolved (mg/L) & 16 & 200 & Strontium, dissolved $(\mu \mathrm{g} / \mathrm{L})$ & 6 & 10.0 \\
\hline & & & Iron, dissolved (mg/L) & 10.0 & 20.0 & & & \\
\hline & & & $\begin{array}{l}\text { Manganese, dissolved } \\
(\mathrm{mg} / \mathrm{L})\end{array}$ & 1.6 & 10.0 & & & \\
\hline & & & Zinc, dissolved (mg/L) & 20.0 & 10.0 & & & \\
\hline
\end{tabular}

\footnotetext{
${ }^{1}$ Pennsylvania Department of Environmental Protection Laboratory only.
}

${ }^{2}$ Surface-water and effluent samples only. 
(plate 1). Water-quality sampling was conducted 27 times at well Ch-5180, which was dry prior to effluent application and went dry during the study. A summary of the number and type of samples collected for each well is listed in table 8 .

Surface-water samples were collected by the methods outlined in Ward and Harr (1990). Streamflow samples from the unnamed tributary to Red Clay Creek were collected immediately downstream of the weir (table 8). A 14-L churn splitter was filled at least three-quarters full, and the sample was split out of the churn. Pond samples were collected from a boat using a peristaltic pump to extract a depth integrated sample while the boat slowly traversed the pond (table 8). Streamflow and pond samples were processed from the churn splitter to bottles using a different peristaltic pump than was used to collect the samples. Water was filtered through a 0.45 micrometer encapsulated filter for the dissolved-constituent samples and raw water was bottled for total-constituent samples.

Effluent samples were collected from a spigot in the discharge pipes before the redirection to specific spray fields at the site. Typical operating procedures at the New Garden Township Wastewater Treatment Plant involved spray irrigation beginning around 0700 and ending around 1700. Effluent samples were collected no sooner than 45 minutes after spray irrigation began on any day. This procedure was followed to ensure that water sitting in the pipes overnight was discharged from the irrigation system prior to sample collection. The spigot was allowed to discharge water for 10 minutes prior to sample collection, again to ensure that "fresh" effluent was collected.

A sample tube was attached to the spigot so that filtered and raw water samples could be collected. Water was filtered through a 0.45 micrometer encapsulated filter for the dissolved-constituent samples, and raw water was bottled for total-constituent samples.

A total of 33 effluent samples were collected; 7 samples were analyzed using the quarterly schedule, and 2 samples were analyzed using the annual schedule. The following constituents were added to some laboratory schedules: chloride $(\mathrm{Cl})$, zinc, iron, and manganese. In the effluent samples, $\mathrm{Cl}$ and zinc were analyzed 26 times, and iron and manganese were analyzed 13 times.

Water-quality data were analyzed with two nonparametric statistical tests to determine the effects of spray irrigation on water quality. The nonparametric Wilcoxon rank sum test was done on constituent concentrations of two data groups - the data collected during effluent application and the data collected prior to effluent application. The test was done to determine if one group of data, data collected prior to application, tended to contain larger or smaller values than the other group of data, data collected during the effluent application (Helsel and Hirsch, 1992). This test determined if a statistical difference was present between median constituent concentrations of those two groups. The basic premise of a step-wise increase or decrease in median constituent concentrations may be present between the two groups of data, which may be an affect of the spray-irrigated effluent. Test results were considered statistically significant at a $p$-value of less than 0.05 . The MannKendall test for trends was done on a combined data set of data collected both prior to and during effluent application to determine if a statistically significant increase or decrease in constituent concentrations occurred over the study period (Helsel and Hirsch, 1992). To determine the statistical significance of the trend analysis, two resultant statistical parameters, Kendall's tau and a $p$-value, were analyzed. Kendall's tau value lies between -1 and +1 . A value close to 0 indicates that either no trend is present or a weak trend may be present. A value close to -1 indicates a strong decreasing trend in constituent concentration, and a value close to +1 indicates a strong increasing trend in constituent concentration. Statistical significance was attained at a $p$-value less than 0.05 . The possibility may be present that a significant difference could occur in median concentrations of a particular constituent between the two groups of data but no significant trend is present and, conversely, because of perhaps a large variance in the data collected during effluent application and the assumption that the trend is monotonic and linear.

Table 8. Number and type of samples collected for the water-quality objective of the New Garden Township spray-irrigation study, Chester County, Pennsylvania.

$[-$, samples not collected $]$

\begin{tabular}{|c|c|c|c|c|c|c|c|}
\hline \multirow{2}{*}{ Site } & \multirow{2}{*}{$\begin{array}{l}\text { Number of } \\
\text { samples }\end{array}$} & \multicolumn{2}{|c|}{$\begin{array}{c}\text { Monthly } \\
\text { laboratory schedule }\end{array}$} & \multicolumn{2}{|c|}{$\begin{array}{c}\text { Quarterly } \\
\text { laboratory schedule }\end{array}$} & \multicolumn{2}{|c|}{$\begin{array}{c}\text { Annual } \\
\text { laboratory schedule }\end{array}$} \\
\hline & & $\begin{array}{c}\text { Prior to } \\
\text { application }\end{array}$ & $\begin{array}{c}\text { During } \\
\text { application }\end{array}$ & $\begin{array}{c}\text { Prior to } \\
\text { application }\end{array}$ & $\begin{array}{c}\text { During } \\
\text { application }\end{array}$ & $\begin{array}{c}\text { Prior to } \\
\text { application }\end{array}$ & $\begin{array}{c}\text { During } \\
\text { application }\end{array}$ \\
\hline All wells except Ch-5180 & 34 & - & 14 & 4 & 11 & 1 & 4 \\
\hline Well Ch-5180 1 & 27 & - & 13 & - & 10 & - & 4 \\
\hline Unnamed tributary & 33 & - & 11 & 4 & 12 & 1 & 5 \\
\hline Pond & 35 & - & 13 & 4 & 12 & 1 & 5 \\
\hline
\end{tabular}

\footnotetext{
${ }^{1}$ Well was dry prior to application and went dry during the study.
} 


\section{Assessing Fate and Transport of Nitrogen}

Fate and transport of $\mathrm{N}$ was studied within a 20-acre subbasin of the watershed from May 1999 through December 2001. This area encompassed all of spray field 2 and 46 percent of spray field 1 (plate 1). Two sites within the study area but outside the 20-acre subbasin also were studied to determine background processes affecting $\mathrm{N}$ fate and transport. These areas were in spray field 5 and at the future location of spray field 6 (plate 1). The presence of spent mushroom substrate within the 20-acre subbasin and at other locations in the study area warranted the use of $\mathrm{N}$ isotopes so that a chemical signature could be associated with the $\mathrm{N}$ present in different compartments of the subbasin. The development of a $\mathrm{N}$ budget for the site required a variety of sampling techniques and a varied frequency of sampling depending on the media sampled. Although some compartments were sampled on a biweekly basis, other compartments were sampled on a seasonal basis. Thus, it was necessary to develop a $\mathrm{N}$ budget in the context of seasonal variations of hydrologic and climatic conditions.

\section{Seasonal Nitrogen Budget}

A seasonal $\mathrm{N}$ budget consisting of inputs, outputs, and storage compartments was developed for the 20 -acre subbasin for the period from June 1999 through December 2001. Other areas within the New Garden Township spray-irrigation site but outside the 20-acre subbasin were used as "control" areas; however, a true "control" area was difficult to identify. Spray fields 4 and 5 were partially active during the course of the study because operational necessities required use of the fields. The presence of spent mushroom substrate in the proposed location of spray field 6 confounded the use of this area as a true control. However, given that field data collection did not begin until after spray irrigation began at the site in spring 1999, it was imperative to select areas outside of the 20 -acre subbasin for the purpose of comparative analysis.

For a site where effluent is applied, numerous pathways and compartments need to be considered. $\mathrm{N}$ is input to the system through atmospheric deposition, spray-irrigated effluent, and $\mathrm{N}$ fixation by leguminous plants. It was assumed that $\mathrm{N}$ fixation by legumes at the site was zero. $\mathrm{N}$ outputs from the system include loss through volatilization of ammonia during spray irrigation, denitrification processes in subsurface zones, water discharge through surface-water and subsurface (underflow) pathways, and plant uptake and subsequent removal during harvest. Changes in $\mathrm{N}$ storage can take place in the soil matrix, both in the solid and liquid phase, and in the ground-water system.
The $\mathrm{N}$ budget equation used was:

$$
\begin{gathered}
\mathrm{N}_{(\text {atm })}+\mathrm{N}_{(\text {spray })}=\mathrm{N}_{(\text {vol })}+\mathrm{N}_{(p l t)}+\mathrm{N}_{(f l o w)}+\mathrm{N}_{(\text {und })}+ \\
\Delta \mathrm{N}_{(\text {soil })}+\Delta \mathrm{N}_{(\text {sw })}+\Delta \mathrm{N}_{(g w)}
\end{gathered}
$$

where

$$
\begin{aligned}
& \mathrm{N}_{(\mathrm{atm})} \quad \text { is } \mathrm{N} \text { input from wet and dry atmo- } \\
& \text { spheric deposition, } \\
& \mathrm{N}_{(\text {spray })} \quad \text { is } \mathrm{N} \text { input from spray-irrigated efflu- } \\
& \text { ent, }
\end{aligned}
$$

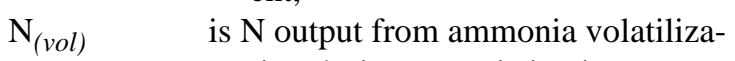

$$
\begin{aligned}
& \text { tion during spray irrigation, } \\
& \mathrm{N}_{(p l t)} \quad \text { is } \mathrm{N} \text { output from plant harvesting, } \\
& \mathrm{N}_{\text {(flow) }} \quad \text { is } \mathrm{N} \text { output from surface-water dis- } \\
& \text { charge, } \\
& \mathrm{N}_{\text {(und) }} \quad \text { is } \mathrm{N} \text { output from underflow, }
\end{aligned}
$$

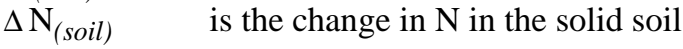

$$
\begin{aligned}
& \text { matrix, } \\
& \Delta \mathrm{N}_{(s w)} \quad \text { is the change in } \mathrm{N} \text { in soil water, } \\
& \Delta \mathrm{N}_{(g w)} \quad \text { is the change in } \mathrm{N} \text { in ground water. }
\end{aligned}
$$

and

To aid in determining the source of $\mathrm{N}$ quantified in the system, certain compartments were sampled for $\mathrm{N}$ isotopes. $\mathrm{N}$ possesses two stable isotopes in the biosphere, ${ }^{15} \mathrm{~N}$ and ${ }^{14} \mathrm{~N}$ (Létolle, 1980). ${ }^{15} \mathrm{~N}$ in the atmosphere is stable, and this constant value is used to normalize data collected from other media for ${ }^{15} \mathrm{~N}$ (Karr and others, 2001). $\mathrm{N}$ isotope data are expressed as $\delta^{15} \mathrm{~N}$, which is defined as the relative difference in the ${ }^{15} \mathrm{~N}$ to

${ }^{14} \mathrm{~N}$ ratio between the sample and atmospheric $\mathrm{N}$ (Karr and others, 2001). Values for $\delta^{15} \mathrm{~N}$ are reported as the per mil (\%o) difference from the stable atmospheric constant. Thus,

$$
\begin{aligned}
\delta^{15} \mathrm{~N}= & {\left[\left(\left({ }^{15} \mathrm{~N} /{ }^{14} \mathrm{~N}\right)_{\text {sample }} /\left({ }^{15} \mathrm{~N} /{ }^{14} \mathrm{~N}\right)\right.\right.} \\
& \times 1,000(\text { air })-1] \\
& \text { Létolle, } 1980)
\end{aligned}
$$

$\mathrm{N}$ isotopic analysis can be conducted on any $\mathrm{N}$ species. For this study, isotopic analysis was conducted on nitrate $\mathrm{N}$ because it was the predominant form of $\mathrm{N}$ in the system. The isotopic signature of the $\mathrm{N}$ depends on the source. Values for $\delta^{15} \mathrm{~N}$ in precipitation range from - 10 to $5 \%$ (Létolle, 1980; Heaton, 1986) and in animal or human waste typically range from 10 to $20 \%$ (Heaton, 1986; Mariotti and others, 1988). N derived from naturally occurring soil processes or from application of inorganic fertilizers generally range from 3 to $8 \%$ (Heaton, 1986; Hübner, 1986). Processes such as denitrification can cause enrichment of ${ }^{15} \mathrm{~N}$ in the remaining $\mathrm{N}$ pool (Karr and others, 2001), and this can elevate $\delta^{15} \mathrm{~N}$ values to as high as $43 \%$ o (Komor and Anderson, 1993).

The primary use of the $\mathrm{N}$-isotope samples was to identify the source of the $\mathrm{N}$ in the media sampled; the potential sources were spray-irrigated effluent, atmospheric deposition, natural soil mineralization, or mineralization of $\mathrm{N}$ from spent mush- 
room substrate. A secondary objective was to use the $\mathrm{N}$-isotope information to help determine if denitrification occurred in the system.

\section{Atmospheric Deposition}

One input of $\mathrm{N}$ to the site was atmospheric deposition. The location of the bulk precipitation sampler was in the northeast corner of the study site (plate 1). The site was selected to maximize the distance from any active spray field and reduce interference from tree canopy cover. It was necessary to place the bulk precipitation sampler in the study area because of the localized effects of agricultural activities on atmospheric deposition of N (Langland, 1992; Fahey and others, 1999). New Garden Township is home to numerous mushroom-growing facilities that could be a source of airborne $\mathrm{N}$ species; thus, placement outside of the study area was not feasible. Samples of wet and dry deposition were collected using the same sampling device but different procedures. A 12-in. diameter funnel was placed atop a polyvinyl chloride (PVC) pipe that held a 2-L sample bottle.

For wet-deposition samples, the funnel was cleaned of any debris then rinsed with inorganic blank water (IBW) no more than 1 day prior to any sampling event. Wet-deposition samples were collected within 24 hours of the end of the precipitation event with events sampled on a monthly to bimonthly basis. Samples were submitted to the PaDEP Laboratory for chemical analyses. Two snowpack samples also were collected within the study area for chemical analyses. Wet-deposition samples were analyzed for total forms of $\mathrm{N}$, ammonia $\mathrm{N}$, nitrite $\mathrm{N}$, nitrate $\mathrm{N}$, dissolved $\mathrm{Cl}$, dissolved zinc, specific conductance, and $\mathrm{pH}$. The wet-deposition load of $\mathrm{N}$ to the 20 -acre subbasin was estimated using the wet-deposition chemistry data and the continuous record of precipitation quantity recorded at the precipitation gage in the study area. Data were tested to determine if wet-precipitation chemistry was related to precipitation intensity, season, and duration of dry interval between precipitation events. If no significant relations were identified, sampling events were plotted over time and chemistry from samples collected was interpolated between sample events. Interpolated concentrations were applied to unsampled events in order to determine $\mathrm{N}$ loads from wet deposition to the 20-acre subbasin.

For dry-deposition samples, the funnel was cleaned of any debris then rinsed with IBW. After 1 to 4 days, the funnel was again rinsed with IBW and the water was captured in a collection bottle. Approximately $1 \mathrm{~L}$ of water was used for rinsing; rinse volumes were measured to the milliliter. The water collected was then analyzed at the PaDEP Laboratory for total forms of $\mathrm{N}$, ammonia $\mathrm{N}$, nitrite $\mathrm{N}$, nitrate $\mathrm{N}$, dissolved $\mathrm{Cl}$, and dissolved zinc. The dry-deposition load for storms sampled was determined by multiplying the sample concentrations by the total volume of water used to wash the dry particles from the collection funnel to the bottle. The known area of the funnel was then divided into the mass of $\mathrm{N}$ in the sample to calculate a load per unit area. This load was then extrapolated over the 20 -acre subbasin. Data were tested to determine if dry-deposition chem- istry was related to season and duration of the dry interval prior to the collection of the dry-deposition sample. If no significant relations were identified, sampling events were plotted over time and chemistry from samples collected was interpolated between dry-deposition sample events. Interpolated concentrations were applied to all days when no wet precipitation occurred. If more than $0.10 \mathrm{in}$. of wet precipitation occurred on a day, then it was assumed that no dry deposition occurred. If measurable precipitation occurred but was less than $0.10 \mathrm{in}$., the estimated $\mathrm{N}$ load from wet precipitation was determined; if this value exceeded the $\mathrm{N}$ load from dry deposition estimated using interpolated values, it was assumed that no dry deposition occurred. If the $\mathrm{N}$ load estimate for wet precipitation for a day with $0.01-0.10$ in. of precipitation was less than the $\mathrm{N}$ load estimate for dry deposition, the bulk deposition for the day included estimates for both wet deposition and dry deposition. Thus, the partitioning of $\mathrm{N}$ loads from wet and dry deposition for days with minimal precipitation (less than $0.10 \mathrm{in}$.) was dependent on the loads determined from sampling events and the comparison between wet-deposition and dry-deposition loads of $\mathrm{N}$.

\section{Effluent Nitrogen Input}

Primary input of $\mathrm{N}$ to the site was from spray-irrigated effluent. Effluent generally was sampled on a monthly basis from a spigot in the discharge pipes before the redirection to specific spray fields at the site. Effluent samples were collected to determine the overall water quality of the effluent and also to determine $\mathrm{N}$ loads to the 20-acre subbasin. Effluent samples were analyzed for constituents listed in table 7, and three samples were collected for $\mathrm{N}$ isotopic analysis. All $\mathrm{N}$ isotopic samples were submitted to the USGS NWQL for analysis.

Measured concentrations of $\mathrm{N}$ species and $\mathrm{Cl}$ at the spigot were used to estimate inputs of the different constituents to the 20 -acre subbasin. Estimated inputs were determined by plotting the sample dates over time then extrapolating the measured chemical concentrations among the samples collected. Extrapolated concentrations were applied to unsampled dates and volumes of spray applied to the 20-acre subbasin on those dates in order to determine monthly $\mathrm{N}$ and $\mathrm{Cl}$ inputs from the sprayed effluent to the 20 -acre subbasin.

\section{Solid-Soil Nitrogen Storage}

One storage compartment that acts as a sink and source of $\mathrm{N}$ is the soil system. $\mathrm{N}$ inputs to the system can be retained in the soil matrix and at the same time some $\mathrm{N}$ stored in the soil matrix can be released to the water table through leaching processes. Three major forms of nongaseous $\mathrm{N}$ that occur in the soil are organic $\mathrm{N}$ associated with organic matter such as humus, ammonium $\mathrm{N}$ fixed onto the surface of clay minerals, and soluble forms of ammonium, nitrate, and nitrite (Young and Aldag, 1982; Brady, 1974).

Soil sampling to characterize $\mathrm{N}$ held in the soil matrix was conducted eight times: spring, summer, and fall of 1999 and 2000 and summer and fall of 2001. Sampling was conducted at six different areas within the study site (fig. 12). Within the 


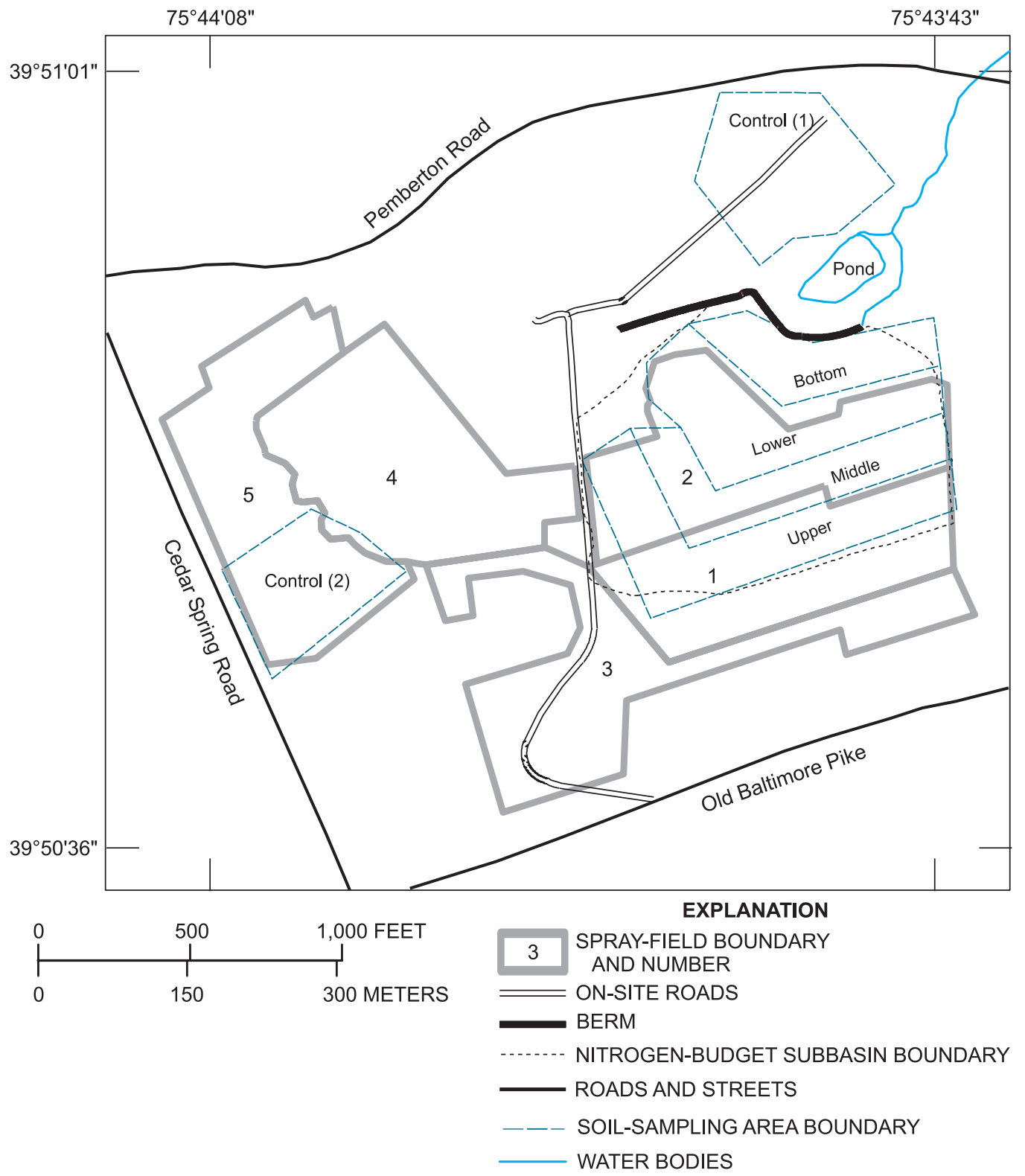

Figure 12. Location of six soil-sampling areas, New Garden Township spray-irrigation site, Chester County, Pennsylvania.

20-acre subbasin, four different areas were delineated and named Upper, Middle, Lower, and Bottom. The area designated as Bottom was not within a spray field. Two areas outside the 20-acre subbasin, designated as Control (1) and Control (2), also were sampled. Control (1) was not in an active spray field, but part of the area in this field was historically used as a disposal area for spent mushroom substrate. Control (2) was in spray field 5 . Three depths were sampled in each of the soilsampling areas $-0-8$ in., $>8-24$ in., and $>24-48$ in. For any one sampling event, samples were collected at all three depths for each of the soil-sampling areas plus the two control areas. For each depth and area, approximately 20 samples were collected with a hammer auger and an attachment to retrieve 1-in.-diameter samples. Samples from each area and depth were collected in separate sampling containers, but the 20 samples from each specific area and depth were composited prior to chemical analyses. Samples were air-dried and pulverized with a mortar and pestle. Samples from each container were subsampled and submitted to the Colorado State University Plant and Environmental Soil Testing (CSU) Laboratory for chemical analyses.

During sample collection, separate samples were collected at each sampling area and depth to determine soil-bulk densities. Bulk-density samples were collected with the same auger device as the soil-chemical samples; however, only two bulkdensity samples were collected in each field and depth for each of the sampling collection periods. Bulk-density samples were collected in clear butyrate tubes and capped. The length of the soil in the tube was measured, and the soil was removed from 
the tube to dry. Soil mass was weighed after drying, and the dry weight was divided by the filled volume of the butyrate tube to determine a bulk density. These bulk densities were necessary to determine the mass of soil in a given volume. These data were then used along with the chemical analyses results to determine the mass of $\mathrm{N}$ at the site.

The mass of $\mathrm{N}$ for the six different areas sampled was determined using the $\mathrm{N}$-concentration data and the bulk-density data. $\mathrm{N}$ masses for each of the different depths sampled were summed so that a $\mathrm{N}$ mass for a 4-ft thick layer of soil extending over the entire extent of the sample area was determined. This determination was done for each sampling. Differences in the $\mathrm{N}$ masses between the first samples collected in April 1999 and the last samples collected in October 2001 were determined in order to quantify the effect of spray irrigation and background conditions on the storage of $\mathrm{N}$ in the solid soil matrix.

$\mathrm{N}$ mass from a depth of $4 \mathrm{ft}$ below land surface to competent bedrock was determined for each of the sample areas within the 20-acre subbasin. The depth to competent bedrock below the soil-sample areas was determined using drilling notes from the nearest well nest to the sampling area or to a well nest within the specific soil-sampling area. Soil samples were not collected below a depth of $4 \mathrm{ft}$; thus, estimates for $\mathrm{N}$ concentrations and bulk densities were required. Non-linear regressions relating bulk density and $\mathrm{N}$ concentration to depth were generated using data collected from the $0-8$ in., >8-24 in., and >24-48 in. depths. The relations generated were then used to estimate bulk density and $\mathrm{N}$ concentration at depths of $4 \mathrm{ft}$ to competent bedrock. $\mathrm{N}$ masses were estimated in 4 -ft increments.

\section{Soil-Water Nitrogen Storage}

Suction lysimeters (2-in. outside diameter) with porous ceramic cups were installed at seven locations in the study area (table 9 and plate 1). Lysimeter nests Lys\#1, Lys\#2, Lys\#3, and Lys\#7 were within the 20-acre subbasin. Lysimeter nests Lys\#3 and Lys\#7 were not in active spray fields but were immediately downgradient of spray field 2. Multiple lysimeters were installed at lysimeter nests Lys\#1 to Lys\#5 with depths ranging from 3 to $15 \mathrm{ft}$ below land surface. Lysimeter nests Lys\#1 to Lys\#5, installed in May 1999, were positioned in proximity to monitor wells in the study area. Lysimeter nests Lys\#6 (Ch-5448) and Lys\#7 (Ch-5449), installed in August 2000, included only one lysimeter per nest. The locations of these two lysimeters were selected to estimate the effects of spent mushroom substrate on the concentrations of $\mathrm{N}$ in the soil water underlying the deposited substrate. Spent mushroom substrate can be a source of dissolved mineralized and organic $\mathrm{N}$ for a number of years after initial deposition (Guo and others, 2000a; 2000b). Lysimeter nests Lys\#4 and Lys\#5 were outside the 20 -acre subbasin to monitor $\mathrm{N}$ concentrations not affected by spray-irrigated effluent.

Lysimeters were either installed with three to four lysimeters per hole or one lysimeter per hole. For the multiple lysimeter holes, a hand auger was used to excavate a 3-4 in. diameter hole extending $15 \mathrm{ft}$ below land surface. Lysimeters were com-
Table 9. Lysimeter nest designation, local names, depth below land surface, and altitude of soil-suction lysimeters, New Garden Township spray-irrigation site, Chester County, Pennsylvania.

[Locations of lysimeters nests are shown on plate 1. Altitude is referenced to the National Geodetic Vertical Datum of 1929 (NGVD 29).]

\begin{tabular}{|c|c|c|c|}
\hline $\begin{array}{l}\text { Lysimeter } \\
\text { nest }\end{array}$ & $\begin{array}{l}\text { Local } \\
\text { lysimeter } \\
\text { name }\end{array}$ & $\begin{array}{l}\text { Depth below } \\
\text { land surface } \\
\text { (feet) }\end{array}$ & $\begin{array}{l}\text { Altitude of lysimeter } \\
\text { ceramic cup } \\
\text { (feet above NGVD 29) }\end{array}$ \\
\hline \multirow[t]{3}{*}{ Lys\#1 } & Ch-5211 & 3.0 & 403 \\
\hline & Ch-5212 & 7.0 & 399 \\
\hline & Ch-5213 & 11.0 & 395 \\
\hline \multirow[t]{4}{*}{ Lys\#2 } & Ch-5215 & 3.0 & 372 \\
\hline & Ch-5216 & 7.0 & 368 \\
\hline & Ch-5217 & 11.0 & 364 \\
\hline & Ch-5218 & 15.0 & 361 \\
\hline \multirow[t]{4}{*}{ Lys\#3 } & Ch-5219 & 3.0 & 337 \\
\hline & Ch-5564 & 6.0 & 334 \\
\hline & Ch-5565 & 9.5 & 330 \\
\hline & Ch-5566 & 13.0 & 327 \\
\hline \multirow[t]{3}{*}{ Lys\#4 } & Ch-5567 & 3.0 & 309 \\
\hline & Ch-5568 & 7.0 & 305 \\
\hline & Ch-5570 & 15.0 & 297 \\
\hline \multirow[t]{4}{*}{ Lys\#5 } & Ch-5571 & 3.0 & 382 \\
\hline & Ch-5572 & 7.0 & 378 \\
\hline & Ch-5573 & 11.0 & 374 \\
\hline & Ch-5574 & 15.0 & 370 \\
\hline Lys\#6 & Ch-5448 & 3.0 & 357 \\
\hline Lys\#7 & Ch-5449 & 3.0 & 352 \\
\hline
\end{tabular}

pleted by lining the bottom of the hole with native soil. Silica flour was then deposited in the hole and the lysimeter was placed in the hole so that the ceramic cup was surrounded by silica flour. Sand and native soil were then packed thoroughly around the lysimeter. Bentonite was then used to seal the top of the lysimeter from water infiltrating from the soil surface or migrating down the augered hole. When a multiple lysimeter hole was used, native soil or sand was deposited atop the bentonite, and the procedures outlined above were again followed.

Water samples were collected from each lysimeter on a monthly basis when sample water was available. One to 2 days prior to sample collection, the lysimeters were evacuated of any water that passively entered the ceramic cup and then placed under vacuum pressure of about 60-70 centibars. The average pore size of the ceramic cup was 1 micrometer; thus, it was necessary to filter the water through a 0.45 micrometer filter in order to process a "dissolved" sample. Given the limited amount of water, the lysimeter water was not used to rinse the capsule filter or sample bottles. The filtered water was submitted to the PaDEP Laboratory for analysis of dissolved $\mathrm{N}$, ammonia $\mathrm{N}$, nitrite $\mathrm{N}$, nitrate $\mathrm{N}$, dissolved $\mathrm{Cl}$, and dissolved zinc. If there was enough sample water, $\mathrm{pH}$ and specific conductance were measured in the field. Eh also was measured, but 


\section{Effects of Spray-Irrigated Effluent on Water Quantity and Quality, and the Fate and Transport of Nitrogen}

only for the final 2 months of sampling. Eh is a measure of the oxidation reduction (redox) potential (Thorstenson, 1984) of the system. This potential can be used to determine if the reductive capability of the system is sufficient for denitrification to occur (Hinson and others, 1995).

Denitrification is a process by which nitrate $\mathrm{N}$ is converted to $\mathrm{N}$ gas (Payne, 1981; Firestone, 1982; Knowles, 1982). This process can lead to appreciable losses of nitrate $\mathrm{N}$ to $\mathrm{N}$ gas if environmental conditions are favorable. Soil-water nitrate $\mathrm{N}$ needs to exceed a certain concentration (about $0.1 \mathrm{mg} / \mathrm{L}$ nitrate N) before denitrification can occur; however, excessive concentrations of nitrate $\mathrm{N}$ can inhibit intermediate reactions that convert nitrous oxides to $\mathrm{N}$ gas (Knowles, 1981). Another requirement for denitrification is a predominantly anaerobic environment that generally is indicative of high soil-moisture content (Knowles, 1981; 1982). As redox decreases below +300 millivolt ( $\mathrm{mv}$ ), the rate of denitrification increases (Knowles, 1981). A wastewater spray-irrigation site has environmental conditions favorable for denitrification processes to occur (Ryden and others, 1981; Monnett and others, 1995; Barton and others, 1999). The conversion of nitrate $\mathrm{N}$ to $\mathrm{N}$ gas in the soil-water matrix was estimated using changes in the nitrate $\mathrm{N}$ to $\mathrm{Cl}$ ratios. $\mathrm{Cl}$ is a conservative ion; thus, $\mathrm{Cl}$ moves freely through soil and does not typically adsorb to soil particles nor is important in biochemical reactions (Hem, 1985). Conversely, nitrate $\mathrm{N}$ can be affected by biochemical reactions such as denitrification. Nitrate $\mathrm{N}$ is also a major source of $\mathrm{N}$ to plants. Thus, changes in the nitrate $\mathrm{N}$ to $\mathrm{Cl}$ ratio below the root zone can give some indication of nitrate $\mathrm{N}$ loss through denitrification.

To determine the amount of nitrate $\mathrm{N}$ lost through denitrification or other changes in the storage of $\mathrm{N}$ in the soil-water system, the volume of soil water per unit volume of soil must be known. Soil-moisture data were available from the soil-moisture probe network discussed earlier. Soil-moisture probes were near lysimeter nests Lys\#1, Lys\#2, and Lys\#3. The depths of the soil-moisture probes (table 4, p. 16) varied depending on location; however, the uppermost lysimeters in nests Lys\#1, Lys\#2, and Lys\#3 were above and below the shallow and deep soil-moisture probes at each nest. Soil-moisture values used for the location of the uppermost lysimeter were a distanceweighted mean. For example, if the lysimeter was $2 \mathrm{ft}$ below the uppermost soil-moisture probe and $3 \mathrm{ft}$ above the lower probe, the moisture value would be 60 percent of the daily mean value for the uppermost probe plus 40 percent of the daily mean value for the lower probe. Soil-moisture values for lysimeter locations below the uppermost lysimeter were interpolated from the soilmoisture value for the uppermost lysimeter and the soil-moisture value for saturated conditions. Saturated conditions were present at the water table below or bisecting the lysimeter nests. Daily mean water levels from the shallow wells near the lysimeter nests were used to determine the distance to the water table at the time of lysimeter sampling. The percent soil moisture at total saturation estimated for the water-quantity objective of this study was used to define the lower endpoint of soil-moisture conditions with increasing depth. Lysimeter nest Lys\#1 was considered to be on a hilltop; nest Lys\#2 on a hillside; and nest Lys\#3 in a valley bottom. It was assumed that the percent soil moisture changed linearly with depth. Thus, soil-moisture values for lysimeter locations below the uppermost lysimeter were linearly interpolated from the daily mean soil-moisture value for the uppermost lysimeter and the saturated conditions at the water table. The soil-moisture values estimated for each lysimeter location for each sample event were applied to areas previously defined as soil-water storage sub-unit areas 2, 4, and 6 (fig. 7, p. 17). Within each sub-unit area, estimated soil-moisture values for the lysimeter locations were used to estimate the amount of soil water with changes in depth. The soil was incremented into sections so that the soil moisture for the location of the uppermost lysimeter was used for soil depths of zero to onehalf the distance between the uppermost lysimeter and the next most shallow lysimeter; subsequent blocks were based on dividing the distances between lysimeters. For example, for lysimeter nest Lys\#1, the soil-moisture data for lysimeter Ch-5211 was used to define the soil moisture from a depth of 0 to a depth of $5 \mathrm{ft}$; soil-moisture data for lysimeter Ch-5212 was used to define the soil moisture from a depth of 5 to $9 \mathrm{ft}$; and data for lysimeter Ch-5213 was used to define the soil moisture from a depth of 9 to $13 \mathrm{ft}$. Soil-water storage sub-unit areas 2, 4 , and 6 were each divided into two sections in order to determine the amount of $\mathrm{N}$ in storage unless the water table was above the deepest lysimeter. The upper section covered the depths from 0 to 1-2 ft below the deepest lysimeter in the subunit area. The lower section went from the bottom of the upper section to the water table, unless the water table was above the deepest lysimeter. The water table was above the deepest lysimeter for nest Lys\#3; thus, soil-water storage sub-unit area 6 only had an upper section defined for purposes of determining soilwater $\mathrm{N}$ storage. Water collected from suction lysimeters below the water table was considered to be soil water collected under saturated conditions. At this site, this would also be water from the shallow aquifer, but, for brevity, all water collected by lysimeters is considered soil water.

Once soil-moisture values were estimated for the subsurface zones extending from the soil surface to either the water table or the bottom of the lysimeter network, N-concentration data were merged with the soil-moisture data to estimate the mass of $\mathrm{N}$. The amount of $\mathrm{N}$ in the micropore soil water was estimated for the days when samples were collected from the lysimeter network. $\mathrm{N}$ concentrations below the lysimeter network and above the water table were estimated using the N-concentration data from the deepest lysimeter and the shallow monitor well in each sub-unit area. However, because estimates of $\mathrm{N}$ in the soil water were determined for days when the lysimeters were sampled, $\mathrm{N}$-concentration data for the shallow monitor wells were either interpolated between sample events or regressed using relations to either time or water-table altitude. Once the $\mathrm{N}$ concentration for the shallow well was defined, the $\mathrm{N}$ concentrations between the deepest lysimeter and the shallow well were used as endpoints to define the $\mathrm{N}$ concentration between the lysimeter and the well. $\mathrm{N}$ concentrations between these endpoints were estimated approximately every $4 \mathrm{ft}$, then 
applied to soil-moisture data in order to estimate the mass of $\mathrm{N}$ in the soil water.

$\mathrm{N}$-isotope samples were collected from selected lysimeters three times during the study. One liter of water was needed for $\mathrm{N}$-isotope samples, and for certain lysimeters, the collection of $1 \mathrm{~L}$ of water required evacuation and reapplication of the pressure vacuum more than once. Samples were not filtered prior to analysis. These samples were used to help in the identification of denitrification processes and also to help determine the source of the $\mathrm{N}$ recovered in the lysimeter samples.

\section{Shallow Ground-Water Nitrogen Storage}

Another system compartment that stores $\mathrm{N}$ is the ground water underlying the site. A description of the ground-water monitor wells in the study area was given in an earlier section. Ten wells were within the 20 -acre subbasin, and four others wells were in the study area but outside the 20 -acre subbasin (plate 1). Changes in ground-water storage of $\mathrm{N}$ were estimated only for shallow ground water. The mass of $\mathrm{N}$ in the shallow ground water was estimated for the same areas previously defined as ground-water storage sub-unit areas 2, 4, and 6 (fig. 6, p. 15). The shallow wells in ground-water storage subunit areas 2, 4, and 6 were Ch-5173, Ch-5175, and Ch-5177, respectively. Changes in ground-water $\mathrm{N}$ storage were estimated for days when the wells were sampled. N-concentration data for the shallow wells on the sample dates were assumed to be the concentration in shallow ground water for that specific sub-unit area $(2,4$, or 6$)$. Changes in the ground-water storage of $\mathrm{N}$ were estimated from the average top of the water table or the bottom of the lysimeter network (whichever was further below land surface) to the depth of competent bedrock. Therefore, the actual subsurface volume for which the change in ground-water $\mathrm{N}$ storage was estimated did not change; only changes in $\mathrm{N}$ concentrations for the shallow wells affected $\mathrm{N}$ storage values. Within this fixed volume of subsurface space, it was assumed that subsurface materials were saturated with water. The soil-moisture values for saturated conditions for the different sub-unit areas were available from the water-quantity component of this study.

Besides the standard monthly sampling of monitor wells, $\mathrm{N}$-isotope samples were collected three times from selected wells. Samples were collected from shallow and deep wells inside and out of the 20-acre subbasin. These samples were collected during the typical monthly sampling, so protocols described in earlier sections for purging and sampling wells were followed.

\section{Ammonia Volatilization}

One potential loss of $\mathrm{N}$ from spray-irrigated effluent is ammonia volatilization (Ryden and others, 1981). The amount of ammonia volatilization is controlled by the difference in vapor pressure between a solution (in this case, effluent) and the atmosphere (Freney and others, 1983). The primary driving mechanisms that attempt to equilibrate the pressures in solution and air are meteorological factors. Generally, as temperature and wind speed increase, the rate of ammonia volatilization increases (Freney and others, 1983; Meisinger and Jokela, 2000).

The rate of ammonia volatilization prior to the spray infiltrating the soil was determined by comparing concentrations of samples collected within the spray field with simultaneous samples collected at the spigot. Nalgene containers (hereinafter referred to as PAN) that hold an approximate volume of $42 \mathrm{~L}$ were placed at two different locations within the 20 -acre subbasin to intercept spray-irrigated effluent prior to infiltrating the soil. Two PAN samples were collected concurrently with a sample of effluent from the spigot. PAN samples were analyzed at the PaDEP Laboratory for the same constituents as the effluent samples. Specific conductance and $\mathrm{pH}$ were measured in the field. Differences in concentrations of ammonia $\mathrm{N}$ at the spigot and at the soil surface were used to quantify the volatilization rate of ammonia N. PAN samples were collected monthly from spring through fall. Initially, samples were collected during the winter; however, a data review indicated that volatilization did not occur during the winter and subsequent sampling in the winter months was discontinued.

The total amount of ammonia $\mathrm{N}$ lost through volatilization (prior to effluent infiltrating the soil surface) within the 20-acre subbasin was estimated by first determining the quantity of ammonia $\mathrm{N}$ lost on the basis of the samples collected. Losses were then regressed against air temperature and wind speed (which were collected at the micro-meteorological station onsite) at the time of sample collection to determine if a relation was evident. Studies on land-applied slurries of cattle manure have shown ammonia volatilization increases exponentially with an increase in temperature (Sommer and others, 1991; Sommer and Olesen, 1991) and also increases linearly with an increase in wind speed to a speed of $6 \mathrm{mph}$ (miles per hour); wind speeds greater than $6 \mathrm{mph}$ did not cause increased volatilization above that caused by a $6 \mathrm{mph}$ wind speed (Sommer and others, 1991). For spray irrigation, the effluent is not in slurry form; thus, above ground contact with atmospheric conditions was limited because ponding of effluent within the 20 -acre subbasin rarely occurred. If data show that ammonia volatilization loss during effluent spraying was related to wind speed and (or) air temperature, these meteorological data were used to estimate volatilization losses on days when PAN samples were not collected. Once spray effluent enters the soil matrix, the potential for ammonia loss through volatilization is reduced. Studies have shown that incorporation of manure slurries into soils (instead of surface application) appreciably reduces ammonia volatilization (Meisinger and Jokela, 2000); thus, it was assumed that no ammonia volatilization occurred once the effluent water infiltrated the soil. If data did not indicate a significant relation between ammonia loss and meteorological parameters, then the determination of ammonia-N loss through volatilization was based on sample differences between ammonia- $\mathrm{N}$ concentrations at the spigot and ammonia- $\mathrm{N}$ concentrations for the PAN samples. The calculated differences based on samples collected were applied to the effluent load estimation for ammonia N. As stated earlier, the effluent load to the 20- 


\section{Effects of Spray-Irrigated Effluent on Water Quantity and Quality, and the Fate and Transport of Nitrogen}

acre subbasin was interpolated on a daily basis for the entire study period based on days when samples were collected. Thus, the calculated differences were applied to the interpolated data to determine ammonia- $\mathrm{N}$ volatilization losses for the entire study.

\section{Plant Removal of Nitrogen}

Plant harvest across the 20 -acre subbasin was another Noutput. The mass of $\mathrm{N}$ leaving the site through plant harvest was quantified by subsampling the plant material immediately prior to crop removal. Hay was harvested from the site eight times from May 1999 through December 2001; plant material was collected prior to each of these harvests. Samples were collected in the same areas as the soil samples (fig. 12). From each of the six fields sampled, plant material was collected systematically across the field. Samples were air dried and two samples from each field were submitted to the CSU Laboratory for analysis of total $\mathrm{N}$.

The total number of bales removed during each harvest was recorded by the farm operator who harvested the site. Site maps were distributed to the operator so that the number of bales collected inside the 20 -acre subbasin and other areas could be documented. The farm operator provided the approximate weight and moisture content of the bales for each harvest event. These data, along with the N-concentration data for the dry plant material, were used to estimate the total amount of $\mathrm{N}$ removed during plant harvest.

Clover, a leguminous plant, was part of the vegetative community within the 20-acre subbasin. Legumes form symbiotic relations with $\mathrm{N}$-fixing bacteria. Nodules form on the roots of legumes and bacteria in the nodules fix $\mathrm{N}$ gas to ammonia $\mathrm{N}$ (Havelka and others, 1982). Leguminous crops can annually fix amounts of $\mathrm{N}$ ranging from about 60 to $270 \mathrm{lb} / \mathrm{acre}$; red clover was found to have the highest $\mathrm{N}$-fixing capability (Postgate, 1982, p. 147). Coverage of clover at the site was estimated to be less than 5 percent. Using $270 \mathrm{lb} /$ acre as a maximum $\mathrm{N}$ fixing rate, this 5 percent cover would extrapolate to about 10-15 lb/acre of $\mathrm{N}$ fixed annually. However, the existence of sufficient concentrations of available $\mathrm{N}$ inhibits $\mathrm{N}$ fixation. Postgate (1982, p. 92-93) indicates that, for a free-living $\mathrm{N}$ fixing bacterium, more than 90 percent of the enzymatic activity necessary for $\mathrm{N}$ fixation is inhibited by available ammonia. For this study, it was assumed that $\mathrm{N}$ fixation by clover was essentially zero because of the availability of ammonia and nitrate within the 20 -acre subbasin. Some of the $\mathrm{N}$ fixed by the cloverroot nodules was removed during plant harvest. Clover-root nodules remaining after harvest can still fix $\mathrm{N}$, and this $\mathrm{N}$ was not removed during plant harvest. $\mathrm{N}$ fixed by the root nodules was accounted for in the solid-soil sampling.

\section{Discharge}

Another $\mathrm{N}$ output of the system was water discharge from the 20 -acre subbasin. Surface discharge was captured by reexcavation of an old swale along the lowest altitude of the subbasin and positioning of a standardized flume to capture and measure discharge before water left the subbasin (plate 1). Different sources contributed to the water discharging from the 20acre subbasin. Water inputs to the 20 -acre subbasin were sprayirrigated effluent and precipitation. Both sources helped to elevate soil moistures relative to pre-spray conditions. Increasing soil moisture would tend to increase the area contributing water to the swale and also would increase the likelihood of overland runoff during storm events.

It should be noted that even though there was a known standard rating for the flume, some check measurements were conducted to verify the accuracy of the standard rating. Measurements indicated the rating was accurate. Discharge from the 20-acre subbasin was recorded continuously from June 1999 through December 2001 by installing a shaft encoder wired to an electronic data logger near the flume outflow. The shaft encoder measured the height of the water in the flume, and the standard rating was used to convert stage to discharge. The electronic recorder was housed near the flume along with an automatic water sampler.

Low-flow and stormflow samples were collected at the flume. Grab samples were collected at the outlet of the flume during low-flow periods, approximately one or two times per month. The automatic sampler was activated by the electronic data logger to collect stormflow samples. The logger would send a signal to the automatic sampler if the stage increased by approximately $0.02-0.04 \mathrm{ft}$ over a 5 - to 10 -minute period. Once in sampling mode, stormflow samples were collected every 2 to 10 minutes depending on the rate of change in the stage. Stormflow samples were collected within the flume approximately $5 \mathrm{ft}$ above the outlet. The sampler was turned off by the data logger if the stage receded back to "pre-storm" conditions; otherwise, the length of the storm sampled was dependent on the number of bottles (24) in the sampler. One to two storms were sampled monthly if stormflow occurred during the month. Storm samples were retrieved within a day of event completion and chilled prior to sample processing. Samples collected during each storm were composited into one sample per event. Aliquots pipeted from bottles were flow weighted so the composite sample represented mean conditions for the storm event. Both low-flow (or grab) and stormflow samples were analyzed for total and dissolved forms of $\mathrm{N}$ and ammonia $\mathrm{N}$, dissolved nitrate $\mathrm{N}$, nitrite $\mathrm{N}, \mathrm{Cl}$, boron, and zinc by the PaDEP Laboratory. Other analyses were conducted by the PaDEP Laboratory, and a complete listing of the constituents and results is available from Durlin and Schaffstall (2000, 2001, and 2002). Three samples for $\mathrm{N}$-isotopic analysis also were collected at the flume outflow during low-flow periods. Field measurements were recorded only for grab samples, and characteristics measured included $\mathrm{pH}$, specific conductance, dissolved oxygen, water temperature, and Eh (only during the last 2 months of data collection).

The continuous record of stage (and subsequently discharge) at the flume and results from the chemical analysis of water samples were used to estimate monthly loads of $\mathrm{N}$ discharging from the 20 -acre subbasin through the flume. Prior to statistical analysis, data for grab and stormflow samples were 
separated into two data sets. Instantaneous loads were estimated from grab-sample data. For grab samples, the discharge at the time of data collection along with the concentration was used to estimate a daily load of $\mathrm{N}$. The load of $\mathrm{N}$ for storm samples was determined by using the mean discharge during the storm along with the mean concentration. The concentration and load of $\mathrm{N}$ species were then regressed against discharge and time to determine if these explanatory variables had any appreciable effect on $\mathrm{N}$-species concentrations and loads. If significant relations were present, these regression relations were used to estimate the flux of $\mathrm{N}$ exiting the 20 -acre subbasin through the flume. If no significant relations existed, a graphical method was used. The graphical method involved plotting the constituent values over time, and interpolating between the sample collection dates so that concentrations could be multiplied by the discharge record to estimate daily fluxes of $\mathrm{N}$ from the 20 -acre subbasin. The discharge record from the flume was separated into low-flow and stormflow periods prior to these flux estimations; thus, low-flow and stormflow $\mathrm{N}$ fluxes were estimated on a monthly basis.

\section{Underflow}

One potential loss of $\mathrm{N}$ from the 20 -acre subbasin was through underflow. Underflow was water that discharged from the 20 -acre subbasin but was not captured by the flume at the outlet of the 20-acre subbasin. Monthly underflow values were estimated as part of the monthly water-budget component of this study. The volume of water leaving the site from underflow was estimated for a 38 -acre watershed as opposed to the 20 -acre subbasin used to study the fate and transport of $\mathrm{N}$.

The original source of water leaving the 38 -acre watershed as underflow was from either effluent application or precipitation. All the spray fields in the 20 -acre subbasin were also within the 38-acre watershed; thus, any effluent applied to the 20 -acre subbasin was also applied to the 38 -acre watershed. Precipitation inputs to the 20 -acre subbasin were proportionally (based on drainage area) less than for the 38-acre watershed.
Volumes of water input to the 20 -acre subbasin and 38 -acre watershed were totaled on a monthly basis. The monthly totals for the 20-acre subbasin divided by the totals for the 38 -acre watershed was used as a monthly correction factor in order to estimate the amount of underflow from the 20-acre subbasin. Thus, the amount of underflow reported as part of the monthly water budget was an upper maximum for the amount of underflow estimated for the 20 -acre subbasin. If no precipitation occurred for the month, the amount of underflow for the 20 -acre subbasin and 38-acre watershed were equal. If no effluent was applied for the month, then the amount of underflow for the 20acre subbasin was 0.53 (the proportional difference in drainage area) multiplied by the amount of underflow reported for the 38-acre watershed.

Underflow from the 20-acre subbasin had to occur from the water-table altitude down to the depth of competent bedrock. The depth to competent bedrock at the bottom of the 20acre subbasin was $35 \mathrm{ft}$. The underflow loss of $\mathrm{N}$ from the 20 -acre subbasin was estimated for the days when suctionlysimeter samples were collected. N-concentration data for water samples collected from Lysimeter nest Lys\#3 and shallow well Ch-5177 were used to estimate the monthly amount of $\mathrm{N}$ output from the 20-acre subbasin. Ch-5177 was not sampled on the same day as the suction lysimeters, so the N concentrations for Ch-5177 were interpolated between monthly sample dates in order to estimate an $\mathrm{N}$ concentration for the days the suction lysimeters were sampled. $\mathrm{N}$ concentrations from Lysimeter nest Lys\#3 and Ch-5177 were weighted to reflect the altitude of the water table for that sample date. The weighted concentration was then applied to the monthly volume of underflow in order to estimate $\mathrm{N}$ outputs in underflow on a monthly basis. 


\section{Quality Control}

Quality-control samples were collected to insure low bias and variability of the data. Quality-control samples were collected from ground water, surface water, suction lysimeter water, low flow and stormflow at the flume, atmospheric deposition, solid soil, and plant matter.

\section{Samples for the Water-Quality Assessment}

A total of 49 quality-control samples ( 8 percent of the total samples) was collected from the ground-water and surfacewater sites. Of these quality-control samples collected, 8 were blanks and 41 were replicates. All three laboratory schedules were used for analysis of the quality-control samples. The quality-control samples were collected from each of the 16 sampling locations onsite.

Types of quality-control blank samples collected were ambient, pump, and source-solution. The ambient, pump, and source-solution blanks were collected as described in the "National Field Manual for the Collection of Water-Quality Data" (U.S. Geological Survey, 1997 to present). Distilled water was used for the quality-control blank samples except for one ambient and two source-solution blank samples for which certified IBW was used.

In two of five ambient blanks, dissolved $\mathrm{P}$ was detected at concentrations of 0.018 and $0.014 \mathrm{mg} / \mathrm{L}$. However, dissolved P was not detected in the other three blanks so no corrective action was necessary. No other constituents were detected above the reporting limits in the ambient blanks. A pump blank was run on the peristaltic pump used to sample the pond, and dissolved nitrate $\mathrm{N}$ was detected above the reporting limit. The concentration of dissolved nitrate $\mathrm{N}$ detected was $0.23 \mathrm{mg} / \mathrm{L}$. However, median concentrations of dissolved nitrate $\mathrm{N}$ for pond samples collected prior to and during effluent application were 8.2 and $7.8 \mathrm{mg} / \mathrm{L}$, respectively. Therefore, the contamination was not appreciable and no corrective action was taken. For the two source-solution blanks, IBW was used with the annual sampling schedule. Only dissolved aluminum was detected above the reporting limit; all other constituents were reported near or below the reporting limit.

The remaining 41 quality-control samples were replicates. Thirty replicate samples were from ground-water samples, and three were from surface-water samples. These samples were sent to the PaDEP Laboratory for analysis. Additionally, eight replicate samples were collected concurrently and sent to both the USGS NWQL and the PaDEP Laboratory for analysis.

To analyze the replicate samples, the percentage difference in constituent concentrations between the original sample and the replicate sample was calculated. The median percentage differences in constituent concentrations for all replicate samples are listed in table 10. Median percentage differences in constituent concentrations that were less than or equal to 10 per- cent were considered acceptable and no corrective action was taken (Witt and others, 1992). The only constituent that did not meet this criteria was dissolved aluminum. The median percentage difference in concentration for dissolved aluminum in replicate samples was 19 percent.

Four replicate samples were split and two source-solution blanks were sent to both the USGS NWQL and the PaDEP Laboratory to determine the source of the aluminum contamination. Concentrations of dissolved aluminum for the split replicate samples reported by the USGS NWQL ranged between $<1$ and $1 \mu \mathrm{g} / \mathrm{L}$, and the concentrations of dissolved aluminum for these same samples reported by the PaDEP Laboratory ranged between 17 and $19 \mu \mathrm{g} / \mathrm{L}$. Concentrations of dissolved aluminum for the source-solution blanks reported by the USGS NWQL were both $<1 \mu \mathrm{g} / \mathrm{L}$, and the concentrations of dissolved aluminum reported by the PaDEP Laboratory for these samples were 19.2 and $11.7 \mu \mathrm{g} / \mathrm{L}$.

Split replicate samples were collected concurrently using the same filter by first filtering the PaDEP samples and then filtering the USGS NWQL samples. The collection processes were identical for both samples. The filters are certified to $0.1 \mu \mathrm{g} / \mathrm{L}$ for dissolved aluminum. The same lot of acid preservative was used in the samples. However, different sampling bottles were used. Bottles supplied by the PaDEP Laboratory were certified to $<80 \mu \mathrm{g} / \mathrm{L}$ for dissolved aluminum. For the source-solution blank samples, the IBW was certified to $0.300 \mu \mathrm{g} / \mathrm{L}$ of dissolved aluminum. The PaDEP reporting limit for dissolved aluminum was $10 \mu \mathrm{g} / \mathrm{L}$, with an accuracy at this level of approximately 20 percent. The source of the contamination was not determined but the PaDEP-reported concentrations were within the bottle certification of $<80 \mu \mathrm{g} / \mathrm{L}$. Therefore, concentrations of dissolved aluminum were compromised and were not used in the water-quality analysis for the study.

\section{Samples for the Nitrogen Fate and Transport Assessment}

Samples collected as part of the $\mathrm{N}$ fate and transport objective of the study were submitted to two laboratories, the PaDEP Laboratory and the CSU Laboratory. A total of 657 water samples from suction lysimeters, low flow and stormflow from the outlet of the flume, PAN (to collect spray at land surface), and atmospheric deposition were submitted to the PaDEP Laboratory. Five percent of these samples were quality-control samples. A total of 132 solid-soil samples and 108 plant-matter samples were sent to CSU Laboratory for analyses. Eight percent of the solid-soil samples were quality-control samples. Fifty percent of the 108 plant-matter samples were replicates from each of the fields sampled.

Numerous types of water-quality-control samples were collected over the study period. Seventeen blank samples were submitted to the PaDEP Laboratory to insure that sampling equipment and procedures were not contributing to the concentration of constituents measured at the site. Replicate samples 
Table 10. Summary of median percentage differences for replicate samples collected for the water-quality objective of the New Garden Township spray-irrigation study, Chester County, Pennsylvania.

[mg/L, milligrams per liter; ${ }^{\circ} \mathrm{C}$, degrees Celsius; $\mu \mathrm{g} / \mathrm{L}$, micrograms per liter]

\begin{tabular}{|c|c|}
\hline Constituent and units of measurement & $\begin{array}{l}\text { Median percentage } \\
\text { difference }^{1}\end{array}$ \\
\hline \multicolumn{2}{|l|}{ Monthly laboratory schedule } \\
\hline Nitrogen, dissolved (mg/L) & 1.3 \\
\hline Nitrate nitrogen, dissolved (mg/L) & .43 \\
\hline Nitrite nitrogen, dissolved (mg/L) & 0 \\
\hline Ammonia nitrogen, dissolved (mg/L) & 0 \\
\hline Ammonia nitrogen, total $^{2}(\mathrm{mg} / \mathrm{L})$ & 0 \\
\hline Phosphorus, dissolved (mg/L) & 7.0 \\
\hline Orthophosphate phosphorus, dissolved (mg/L) & 5.7 \\
\hline \multicolumn{2}{|l|}{ Quarterly laboratory schedule } \\
\hline Calcium, dissolved (mg/L) & 1.8 \\
\hline Magnesium, dissolved (mg/L) & 1.5 \\
\hline Potassium, dissolved (mg/L) & 5.0 \\
\hline Sodium, dissolved (mg/L) & 2.2 \\
\hline Bromide, dissolved (mg/L) & 0 \\
\hline Chloride, dissolved (mg/L) & .68 \\
\hline Fluoride, dissolved (mg/L) & 0 \\
\hline Silica, dissolved (mg/L) & 1.1 \\
\hline Sulfate, dissolved (mg/L) & .75 \\
\hline Total dissolved solids at $180^{\circ} \mathrm{C}(\mathrm{mg} / \mathrm{L})$ & 10 \\
\hline Carbon, organic, dissolved (mg/L) & 0 \\
\hline Aluminum, dissolved $(\mu \mathrm{g} / \mathrm{L})$ & 19 \\
\hline Boron, dissolved ( $\mu \mathrm{g} / \mathrm{L})$ & 0 \\
\hline Iron, dissolved $(\mu \mathrm{g} / \mathrm{L})$ & 0 \\
\hline Manganese, dissolved $(\mu \mathrm{g} / \mathrm{L})$ & 0 \\
\hline Zinc, dissolved $(\mu \mathrm{g} / \mathrm{L})$ & 0 \\
\hline
\end{tabular}

Annual laboratory schedule

\begin{tabular}{ll}
\hline Antimony, dissolved $(\mu \mathrm{g} / \mathrm{L})$ & 0 \\
Arsenic, dissolved $(\mu \mathrm{g} / \mathrm{L})$ & 0 \\
Barium, dissolved $(\mu \mathrm{g} / \mathrm{L})$ & 3.2 \\
Cadmium, dissolved $(\mu \mathrm{g} / \mathrm{L})$ & 0 \\
Chromium, dissolved $(\mu \mathrm{g} / \mathrm{L})$ & 0 \\
Copper, dissolved $(\mu \mathrm{g} / \mathrm{L})$ & 0 \\
Lead, dissolved $(\mu \mathrm{g} / \mathrm{L})$ & 0 \\
Lithium, dissolved $(\mu \mathrm{g} / \mathrm{L})$ & 0 \\
Mercury, dissolved $(\mu \mathrm{g} / \mathrm{L})$ & 0 \\
Nickel, dissolved $(\mu \mathrm{g} / \mathrm{L})$ & 0 \\
Selenium, dissolved $(\mu \mathrm{g} / \mathrm{L})$ & 0 \\
Strontium, dissolved $(\mu \mathrm{g} / \mathrm{L})$ & 4.8 \\
\hline
\end{tabular}

${ }^{1}$ If one of the concentrations in the duplicate samples was below the reporting limit, the value of the reporting limit was used to determine the percentage difference.

${ }^{2}$ Surface-water and effluent samples only. were used to assess the adequacy of sample-collection methods in obtaining representative samples (Witt and others, 1992). One split sample was submitted to the PaDEP Laboratory and USGS NWQL to check analyte concentrations between laboratories. One nutrient reference sample with known concentrations was submitted to PaDEP Laboratory to check laboratory accuracy. Finally, two grab samples were collected at the outlet of the flume during a storm to check the capacity of the automatic-sampler intakes to retrieve representative storm samples.

Blank samples were processed using IBW or deionized water from the PaDEP Laboratory that was regularly tested and known to have virtually no inorganic constituents. Sample-collection bottles, tubing and filters used to collect the different water-quality samples were all tested for contamination and virtually no contamination was detected. Two of the 17 blanks had concentrations of total $\mathrm{N}$ of $0.1 \mathrm{mg} / \mathrm{L}$, which was slightly above the detection limit of $0.064 \mathrm{mg} / \mathrm{L}$. The identification of the total $\mathrm{N}$ necessitated retesting; subsequent tests did not detect total $\mathrm{N}$ above $0.064 \mathrm{mg} / \mathrm{L}$. Contamination could have stemmed from either slightly contaminated blank water or inappropriate sampling techniques. However, retesting and subsequent concentrations below the detection limit alleviated any concerns about consistent problems in sample collection.

Results from the collection of replicate samples indicated low variability in the percentage difference between samples (table 11). The highest median difference in replicate samples for the pertinent constituents was 3.5 percent for total N. This percentage difference was well below the acceptable criteria of 10 percent (Witt and others, 1992). Replicate samples were collected from suction lysimeters and at the outlet of the flume.

The volume of water purged from the suction lysimeters limited the number of replicates that could be collected. Excluding quality-control samples, 627 samples were collected from suction lysimeters, the outlet of the flume, PANs, and atmospheric

Table 11. Summary of median percentage differences for nitrogen species and chloride for replicate samples collected from either suction lysimeters or the flume outlet, New Garden Township spray-irrigation site, Chester County, Pennsylvania.

\begin{tabular}{lc}
\hline \multicolumn{1}{c}{ Constituent } & Median percentage difference \\
\hline Nitrogen, total & 3.5 \\
Nitrogen, dissolved & 2.3 \\
Ammonia nitrogen, total & 10 \\
Ammonia nitrogen, dissolved & 0 \\
Nitrite nitrogen, dissolved & 0 \\
Nitrate nitrogen, dissolved & 1.2 \\
Chloride, dissolved & .1 \\
\hline
\end{tabular}

\footnotetext{
${ }^{1}$ If one of the concentrations in the duplicate samples was below the reporting limit, the value of the reporting limit was used to determine the percentage difference.
} 
deposition. Seventy percent of these samples were collected from lysimeter locations. Typical volumes of water purged from the lysimeters were from 250 to $1,200 \mathrm{~mL}$. Sample submission to the PaDEP Laboratory required anywhere from 200 to $1,200 \mathrm{~mL}$; therefore, water from suction lysimeters for replicate samples was limited. This limitation was the main reason why only 5 percent of the total samples collected for the N-budget component of the project were quality-control samples. The collection of PAN samples at the site also helped to reduce the number of replicate samples collected. For each of the 20 days a PAN sample was collected, two pans were placed in the field to collect spray. The collection of two PAN samples per sample event was considered adequate and no replicates of one of the two samples per day were submitted to the PaDEP Laboratory for analyses. The only constituent of concern in the PAN samples was dissolved ammonia $\mathrm{N}$, and quality control for this constituent in the spray was addressed in the quality-control methods used for effluent samples.

Other quality-control water-quality samples collected at the site for the N-budget component of the project did not reveal any problems associated with water-quality data collection and analyses. The split water sample submitted to the USGS NWQL and PaDEP Laboratory did not indicate any significant differences between the analytical results. The known reference sample submitted to PaDEP Laboratory indicated laboratory results deviated from mean recovery values by only 0.76 to 2.5 percent for the $\mathrm{N}$ species in the sample.

Two quality-control grab samples collected at the outlet of the flume for comparison to samples collected concurrently by the automatic sampler indicated a mean difference of 3 percent. The mean discharge at the time of sample collection was $0.22 \mathrm{ft}^{3} / \mathrm{s}$ (the height of the water in the flume was approximately $0.3 \mathrm{ft}$ ). This discharge was considered to be representative of most storms sampled. Even though these quality-control samples indicated virtually no difference between grab samples and samples collected by the automatic sampler, it was possible that as the height of the water increased in the flume, the position of the sample intake in the water column could affect the representativeness of the sample. The sample intake height above the bottom of the flume increased as the height of the water in the flume increased. However, because the flume surface was cleaned regularly to remove any deposited debris, it was unlikely that as the height of the water changed, the proportion of suspended materials (the proportion of suspended materials recovered compared to the actual concentration of suspended materials discharging through the flume) pulled by the sample intake changed. Thus, it was concluded that the automatic sampler was collecting representative samples during storm events.

Replicate samples collected from the soil matrix indicated median percent differences (table 12) were higher than the differences detected in water-quality replicate samples (table 11). The median percent difference in soil-replicate samples for pertinent constituents ranged from 4.4 percent for redox to 22 percent for the total mass of $\mathrm{N}$. The higher variability in the solid-soil samples was expected given the difference in the
Table 12. Summary of median percentage differences for nitrogen species, redox, and extractable chloride for replicate samples collected from the solid-soil matrix, New Garden Township sprayirrigation site, Chester County, Pennsylvania.

\begin{tabular}{lc}
\hline \multicolumn{1}{c}{ Constituent } & Median percentage difference \\
\hline Nitrogen & 22. \\
Ammonium nitrogen & 16. \\
Nitrate nitrogen & 7.0 \\
Redox potential & 4.4 \\
Chloride (water extractable) & 21.7 \\
\hline
\end{tabular}

media. Dissolved and suspended materials in water are, in general, homogeneously dispersed throughout the medium. Soil, on the other hand, can be homogenous, but there is a much greater probability for differences in concentration if only a small aliquot of the soil is measured, and only small aliquots can be measured in typical soil-laboratory settings. The variability within one sample highlights the reason why 20 discrete samples were collected over each field and composited prior to chemical analyses.

\section{Effects of Spray-Irrigated Effluent on Water Quantity}

Limiting the interbasin transfer of water, from a watermanagement perspective, is a benefit of land-treatment effluent disposal. Through land application, the treated effluent is added as recharge back to a watershed if disposal hydraulic loading rates exceed the potential evapotranspiration rates of the site. Testing of the spray system began in May 1999 and daily operations started in June 1999. A annual water budget was determined for the period May 1998 through April 1999 prior to effluent application. Two water budgets were determined for calendar years 2000 and 2001 when effluent was being applied. Monthly water-budget estimates were started in September 1999, after the installation of the soil-moisture instruments, and ended in December 2001.

Annual water budgets were determined for the study watershed and the control Red Clay Creek watershed upstream from the USGS streamflow-gaging station (01479820) Red Clay Creek near Kennett Square, Pa. These annual water budgets were compared to assist in evaluating the effects of spray-irrigated effluent on the water quantity. Annual evapotranspiration totals and the percentage of precipitation accounted for by evapotranspiration for both watersheds were compared and evaluated to determine a relation between the two watersheds. If evapotranspiration rates and the percentage of precipitation accounted for by evapotranspiration in the watersheds were similar, then a relation was present and comparing base flow and recharge quantities between the watersheds was applicable. The base flow and estimated 
recharge comparisons were used to evaluate the effects of spray-irrigated effluent on the study watershed.

\section{Annual Water Budget}

The water-budget equation (eq. 2, p. 10) was used to calculate an annual budget for the study watershed and the Red Clay Creek watershed for the period May 1998 through April 1999 prior to effluent application (table 13). At the study watershed site, input from spray-irrigated effluent was zero, and the change in soil-moisture storage was assumed to be zero. Precipitation totals were compiled from nearby sources and averaged 35.3 in. Ground-water storage was calculated from the difference in water levels from seven monitor wells that were measured in May 1998 and again in April 1999. For the Red Clay Creek watershed, ground-water storage was determined from three monitor wells in the watershed. Ground-water underflow from the Red Clay Creek watershed was assumed to be zero.

The ground-water underflow in the study watershed was determined by first constructing water-table maps to determine the directions of ground-water flow (fig. 13). Darcy's equation was used to determine the quantity. Ground water was flowing to the northeast in the direction of the stream. The linear distance from wells Ch-5177 and Ch-5181 to cross-sectional area A was $600 \mathrm{ft}$ (fig. 5, p. 13). The average head (water-level) change from the valley-bottom area near wells $\mathrm{Ch}-5177$ and Ch-5181 was estimated to be $20 \mathrm{ft}$. The hydraulic conductivity used was $10 \mathrm{ft} / \mathrm{d}$. An average estimate of monthly ground-water underflow loss was $0.5 \mathrm{in}$. The loss of $0.5 \mathrm{in}$. of water per month over the length of the study period totaled 13.4 in. of water losses attributable to underflow. To represent this loss on an annual basis, the monthly losses were summed over the annual period.

Annual water budgets for the study watershed and the Red Clay Creek watershed were determined for a period prior to effluent application, May 1998 through April 1999. Evapotranspiration in the study watershed totaled 24.8 in., which accounted for 70 percent of precipitation. Evapotranspiration in the Red Clay Creek watershed totaled 24.2 in., which accounted for 68 percent of precipitation. Because the evapotranspiration totals of the two watersheds were comparable for the period prior to effluent application, it was assumed that the Red Clay Creek watershed could serve as an unaffected control watershed.

Annual water budgets were determined for Red Clay Creek watershed for calendar years 2000 and 2001 (table 13). These water budgets were started in January and ended in December, when the soil-moisture deficit for the year was assumed to be zero. Evapotranspiration accounted for 55 and 67 percent of total precipitation for 2000 and 2001, respectively.

Annual water budgets for the study watershed were determined for calendar years 2000 and 2001 during effluent application. Calculated evapotranspiration for calendar years 2000 and 2001 was 32.9 and 32.5 in., respectively, and calculated evapotranspiration accounted for 50 and 64 percent, respectively, of the total precipitation plus the amount of spray-irrigated effluent. The calculated evapotranspiration percentages in the study watershed were similar to the calculated evapotranspiration percentages for the Red Clay Creek watershed, which were 55 percent in 2000 and 67 percent in 2001.

The annual crop-referenced evapotranspiration determined from data collected at the meteorological station for calendar years 2000 and 2001 was 30.7 and 31.5 in., respectively. In calendar year 2000, the annual calculated evapotranspiration for the study watershed was 7 percent higher than the annual determined crop-referenced evapotranspiration, and in calendar year 2001, the annual calculated evapotranspiration for the study watershed was 3 percent higher than the annual crop-referenced evapotranspiration. Therefore, it was assumed that the calculated evapotranspiration values determined from the monthly water budget analysis should be near the monthly cropreferenced evapotranspiration values.

\section{Monthly Water Budget}

Monthly water budgets were calculated for the period September 1999 through December 2001 using equation 2 (p. 10). A summary of the monthly water-budget parameters is listed in table 14. Using the assumption that the calculated values of monthly evapotranspiration, which represent actual evapotranspiration from the watershed, should be near the values of cropreferenced evapotranspiration, which represent potential evapotranspiration. The calculated evapotranspiration values, however, also include the accumulation of errors in measuring precipitation and streamflow, estimating application volumes, estimating application that was applied within the watershed, determining aquifer specific yield, estimating the change in ground-water storage, estimating free water surface evaporation from the pond, and determining the volume of water stored in the unsaturated zone. The largest error is in the determination of the volume of water stored in the unsaturated zone because of the numerous estimations and assumptions used in the development of the method. The actual errors in any of the aforementioned measurements or determinations are unknown and are not quantifiable. However, the cumulative error in all the estimates and assumptions is probably more than \pm 25 percent of the crop-referenced evapotranspiration.

Monthly total input of precipitation and spray-irrigated effluent to the watershed, calculated monthly evapotranspiration from equation 2, and monthly crop-referenced evapotranspiration for the period are shown in figure 14. Negative calculated evapotranspiration values were set to zero in figure 14 because it is not physically possible for evapotranspiration to be negative. The error bars on the values of crop-referenced evapotranspiration represent \pm 25 percent.

The negative evapotranspiration values are manifestations of error in determining the budget terms in the monthly waterbudget equation and the limitations of the developed monthly water-budget method. The developed method is less reliable 


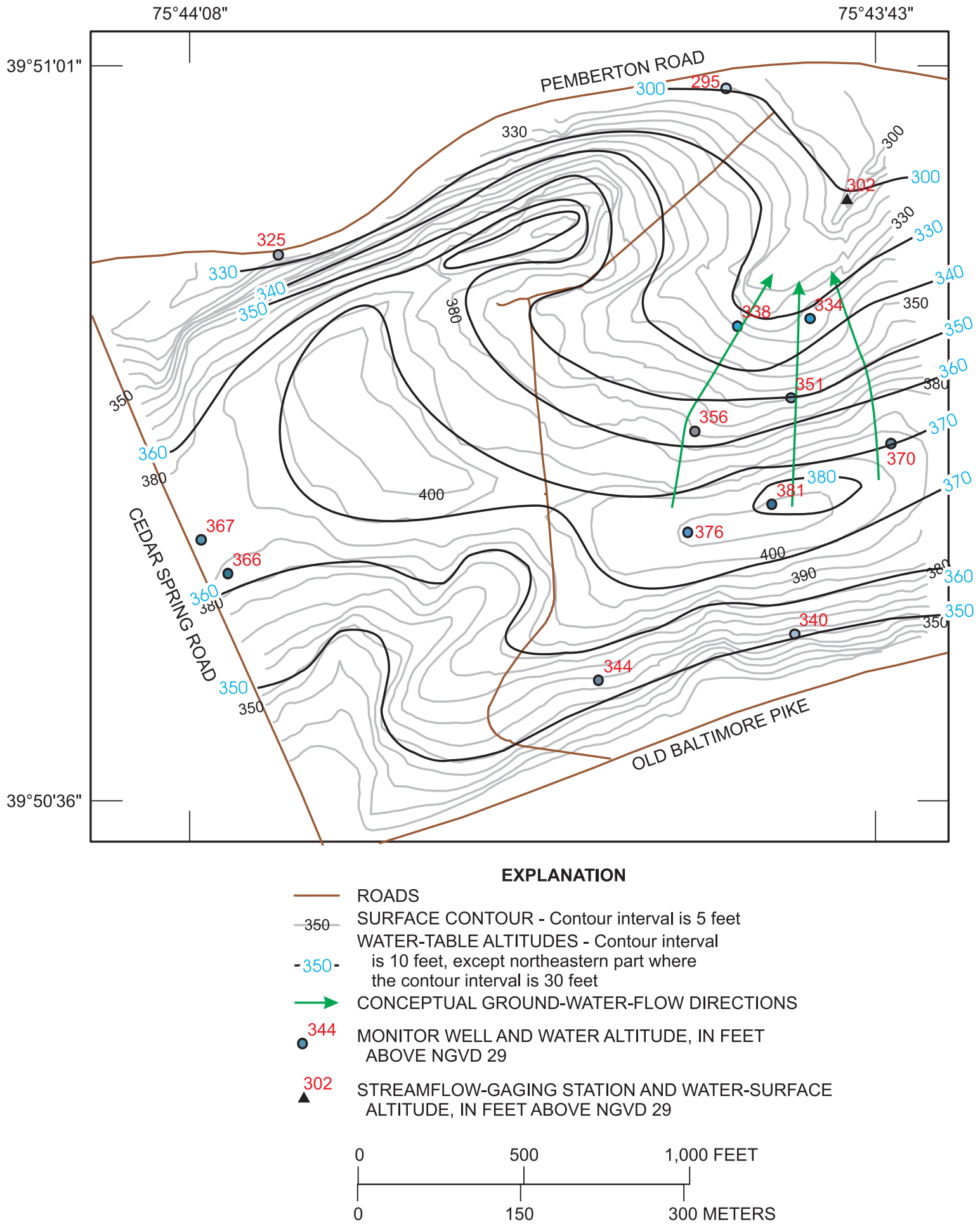

Figure 13. Water-table altitude and conceptual ground-water-flow directions, New Garden Township sprayirrigation site, Chester County, Pennsylvania. 


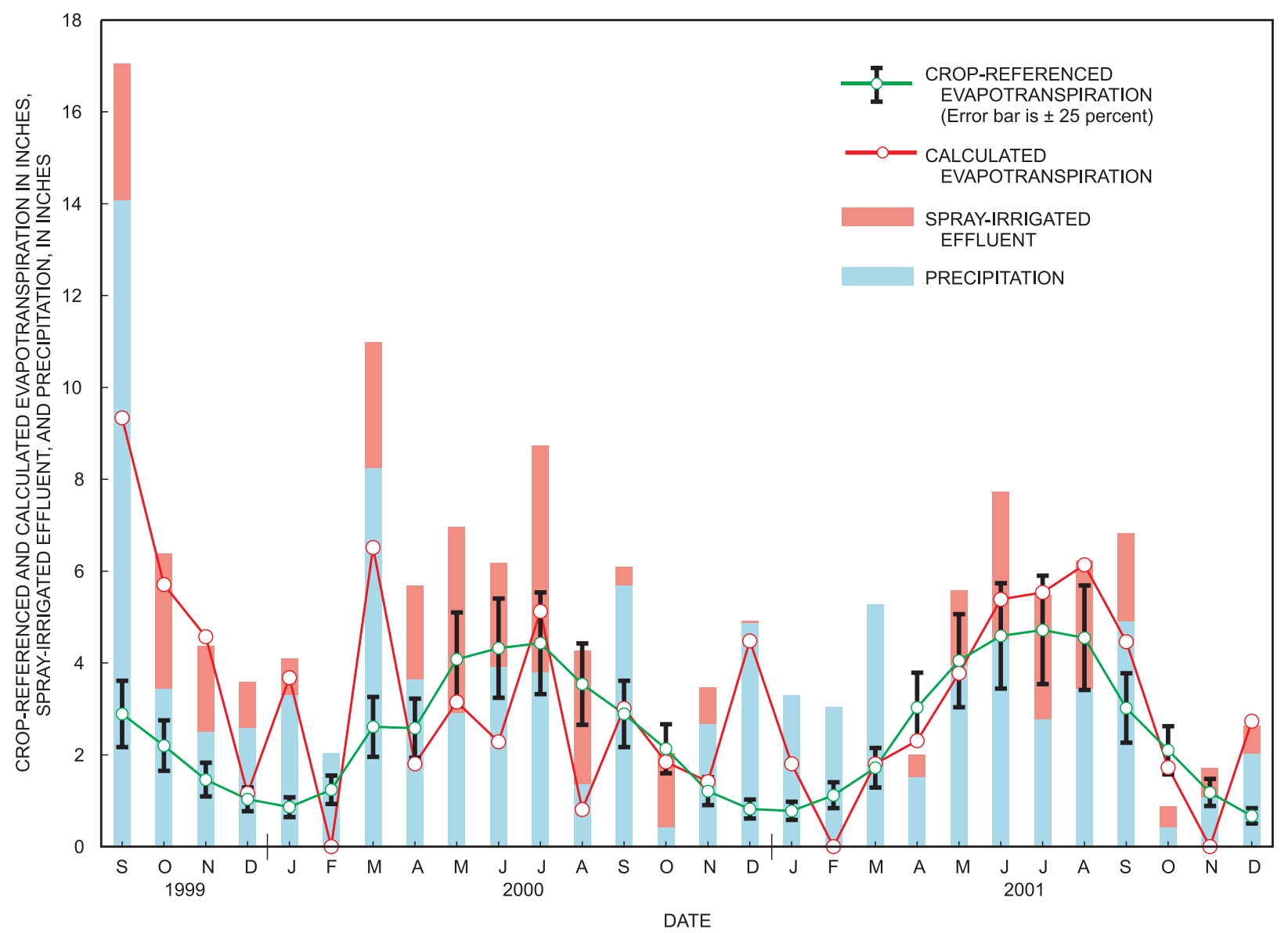

Figure 14. Crop-referenced and calculated evapotranspiration, spray-irrigated effluent, and monthly precipitation, New Garden Township spray-irrigation site, Chester County, Pennsylvania, September 1999 through December 2001.

Table 13. Annual water budgets for the study watershed, New Garden Township spray-irrigation site and Red Clay Creek watershed above the Kennett Square streamflow-gaging station (01479820), Chester County, Pennsylvania, for the period May 1998 through April 1999 prior to effluent application and for calendar years 2000 and 2001 during effluent application.

[-, not determined; N/A, not applicable $]$

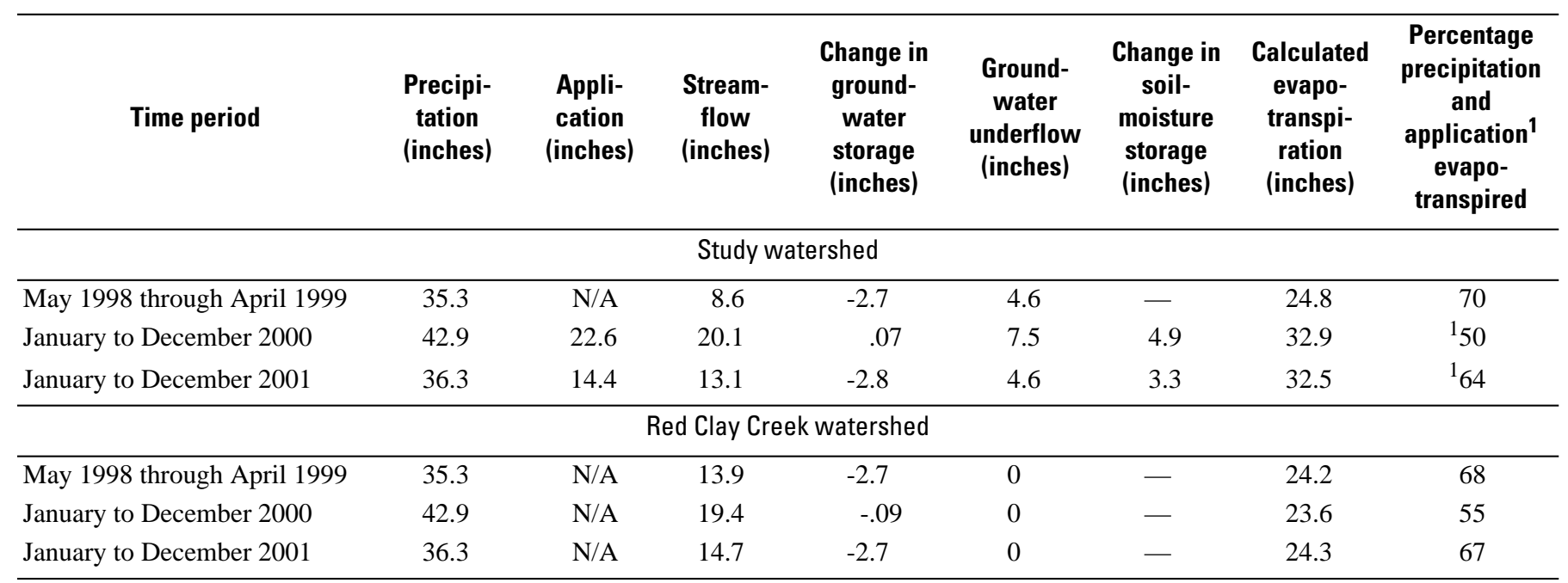

\footnotetext{
${ }^{1}$ Applies only to study watershed for calendar years 2000 and 2001.
} 
Table 14. Summary of monthly water-budget parameters for the New Garden Township spray-irrigation site, Chester County, Pennsylvania, September 1999 through December 2001.

\begin{tabular}{|c|c|c|c|c|c|c|c|c|c|c|}
\hline \multirow[b]{2}{*}{ Month and year } & \multicolumn{2}{|c|}{ Inputs (inches) } & \multicolumn{3}{|c|}{ Evapotranspiration (inches) } & \multicolumn{5}{|c|}{ Outputs and Changes in Storage (inches) } \\
\hline & $\begin{array}{l}\text { Precipi- } \\
\text { tation }\end{array}$ & $\begin{array}{c}\text { Spray- } \\
\text { irrigated } \\
\text { effluent }\end{array}$ & $\begin{array}{c}\text { Calculated } \\
\text { evapo- } \\
\text { transpi- } \\
\text { ration }{ }^{1}\end{array}$ & $\begin{array}{l}\text { Crop- } \\
\text { referenced } \\
\text { evapo- } \\
\text { transpi- } \\
\text { ration }\end{array}$ & $\begin{array}{c}\text { Difference } \\
\text { in } \\
\text { calculated } \\
\text { and crop- } \\
\text { referenced } \\
\text { evapo- } \\
\text { transpi- } \\
\text { ration }\end{array}$ & $\begin{array}{l}\text { Stream- } \\
\text { flow }\end{array}$ & $\begin{array}{l}\text { Ground- } \\
\text { water } \\
\text { underflow }\end{array}$ & $\begin{array}{l}\text { Pond } \\
\text { evapo- } \\
\text { ration } \\
\text { and } \\
\text { change in } \\
\text { storage }\end{array}$ & $\begin{array}{l}\text { Change } \\
\text { in } \\
\text { ground- } \\
\text { water } \\
\text { storage }\end{array}$ & $\begin{array}{c}\text { Change in } \\
\text { volumetric } \\
\text { soil } \\
\text { moisture }\end{array}$ \\
\hline September 1999 & 14.1 & 3.0 & 9.3 & 2.9 & 6.4 & 4.1 & 0.2 & 0.1 & 5.5 & -5.9 \\
\hline October 1999 & 3.45 & 2.9 & 5.7 & 2.2 & 3.5 & 1.0 & .4 & .04 & 1.0 & -1.7 \\
\hline November 1999 & 2.51 & 1.9 & 4.6 & 1.5 & 3.1 & 1.0 & .4 & .0 & -.9 & -.7 \\
\hline December 1999 & 2.60 & .99 & 1.2 & 1.0 & .1 & 1.4 & .5 & .0 & .3 & .2 \\
\hline January 2000 & 3.31 & .79 & 3.7 & .9 & 2.8 & 1.0 & .4 & .0 & -.2 & -.8 \\
\hline February 2000 & 2.04 & .00 & -1.7 & 1.2 & -2.9 & 1.6 & .4 & -.01 & -.7 & 2.4 \\
\hline March 2000 & 8.25 & 2.7 & 6.5 & 2.6 & 3.9 & 2.7 & .4 & .0 & 3.0 & -1.7 \\
\hline April 2000 & 3.64 & 2.0 & 1.8 & 2.6 & -.8 & 2.2 & .9 & .0 & 3.6 & -2.8 \\
\hline May 2000 & 2.91 & 4.0 & 3.2 & 4.1 & -.9 & 1.9 & 1.0 & .08 & 1.1 & -.2 \\
\hline June 2000 & 3.91 & 2.3 & 2.3 & 4.3 & -2.0 & 1.6 & .7 & .1 & -1.0 & 2.4 \\
\hline July 2000 & 3.80 & 4.9 & 5.1 & 4.4 & .7 & 1.7 & .8 & .1 & 1.3 & -.3 \\
\hline August 2000 & 1.36 & 2.9 & .8 & 3.5 & -2.7 & 1.5 & .8 & .06 & -1.1 & 2.2 \\
\hline September 2000 & 5.69 & .41 & 3.0 & 2.9 & .1 & 1.5 & .6 & .07 & -2.3 & 3.3 \\
\hline October 2000 & .42 & 1.6 & 1.8 & 2.1 & -.3 & 1.2 & .6 & .03 & -1.6 & -.02 \\
\hline November 2000 & 2.68 & .79 & 1.4 & 1.2 & .2 & .9 & .5 & .0 & -1.6 & 2.2 \\
\hline December 2000 & 4.87 & .10 & 4.5 & .8 & 3.7 & 2.3 & .3 & .0 & -.4 & -1.8 \\
\hline January 2001 & 3.29 & .00 & 1.8 & .8 & 1.0 & 1.8 & .2 & .0 & -1.2 & .7 \\
\hline February 2001 & 3.04 & .00 & -.2 & 1.1 & -1.3 & 1.2 & .4 & .03 & -.7 & 2.2 \\
\hline March 2001 & 5.28 & .00 & 1.8 & 1.7 & .1 & 1.3 & .4 & -.01 & .06 & 1.6 \\
\hline April 2001 & 1.51 & .49 & 2.3 & 3.0 & -.7 & .8 & .4 & -.03 & .1 & -1.6 \\
\hline May 2001 & 3.96 & 1.6 & 3.8 & 4.0 & -.3 & .7 & .3 & .08 & .5 & .2 \\
\hline June 2001 & 4.51 & 3.2 & 5.4 & 4.6 & .8 & 2.0 & .6 & .1 & 2.1 & -2.5 \\
\hline July 2001 & 2.78 & 2.7 & 5.5 & 4.7 & .8 & 1.0 & .4 & .1 & .9 & -2.4 \\
\hline August 2001 & 3.45 & 2.8 & 6.1 & 4.6 & 1.6 & .7 & .4 & .1 & -.2 & -1.0 \\
\hline September 2001 & 4.91 & 1.9 & 4.5 & 3.0 & 1.4 & .8 & .3 & .07 & -.9 & 2.0 \\
\hline October 2001 & .43 & .45 & 1.7 & 2.1 & -.4 & 1.7 & .5 & .04 & -1.8 & -1.2 \\
\hline November 2001 & 1.08 & .63 & -1.8 & 1.2 & -3.0 & .6 & .3 & .0 & -2.2 & 4.8 \\
\hline December 2001 & 2.03 & .60 & 2.7 & .7 & 2.1 & .5 & .3 & .0 & -1.3 & .4 \\
\hline
\end{tabular}

${ }^{1}$ Total inputs minus the outputs and changes in storage may not equal calculated evapotranspiration because of rounding. 
during months when certain climatic conditions occur because of the temporal limitations of the data analysis. All analyses, particularly estimates of changes in ground water and soilmoisture storage, are calculated using data measured on the first day of the month. The effects of previous monthly antecedent conditions, such as snowfall or large amounts of rainfall that occur near the end of the previous month manifest in the following month but are not properly accounted for in this method. Snowfall that occurs during a month but does not melt until the end of the month or the following month has an adverse effect on the estimates of monthly soil-moisture storage. These effects are illustrated on figure 14. The graph of crop-referenced evapotranspiration exhibits a regular sinusoidal pattern based on temporal seasons, whereas the graph of calculated evapotranspiration is more erratic, which results because of previous monthly antecedent conditions, climatic conditions that occur during a month, and error in determining budget terms.

Negative values of calculated monthly evapotranspiration occurred during the months of February 2000, February 2001, and November 2001 (table 14). The negative calculated evapotranspiration for February 2000 was because of snowfall that fell near the end of January 2000 but did not melt until the end of February 2000. The melting snow infiltrated the unsaturated zone, which increased the measured soil-moisture percentages at the end of the month, but the volume of water in the melting snow was not sufficient to recharge the water table. The water levels in February 2000 were receding (shaded area, fig. 15), which increased the volume of unsaturated soil available to store water. Because the soil-moisture profile in the unsaturated zone is assumed to be linear and the measured percent soil moisture at the end of February 2000 was near the total saturation percentage, the volume of water in the unsaturated zone was overestimated. Therefore, the estimated soil-moisture storage for February 2000 was large because of climatic events that occurred in January 2000.

The negative calculated evapotranspiration for February 2001 was because of a snow event on Feb. 22 and a rainfall event on Feb. 25 that dramatically increased the measured percent soil moisture at the end of the month. The high measured percent soil moisture at the end of the month combined with the receding water level in well Ch-5173 (shaded area, fig. 15) caused an overestimate of soil-moisture storage for February 2001. The increased soil-moisture storage was because of climatic events during the month.

The negative calculated evapotranspiration for November 2001 was because of dry conditions during the months of October and November 2001. Precipitation and the amount of sprayirrigated effluent totaled 0.43 and 0.45 in., respectively, for October, and 1.08 and 0.63 in., respectively, for November (table 14). The water level was receding during both months (shaded area, fig. 15). The dry conditions near the end of October resulted in low measured percent soil moisture. A storm deposited 0.91 in. of rain on November 24-25 and increased the measured percent soil moisture at the end of November to near total saturation. The precipitation did not appreciably recharge the water-table system and the water level continued to recede, which increased the volume of unsaturated soil available to store water. Therefore, soil-moisture storage for November

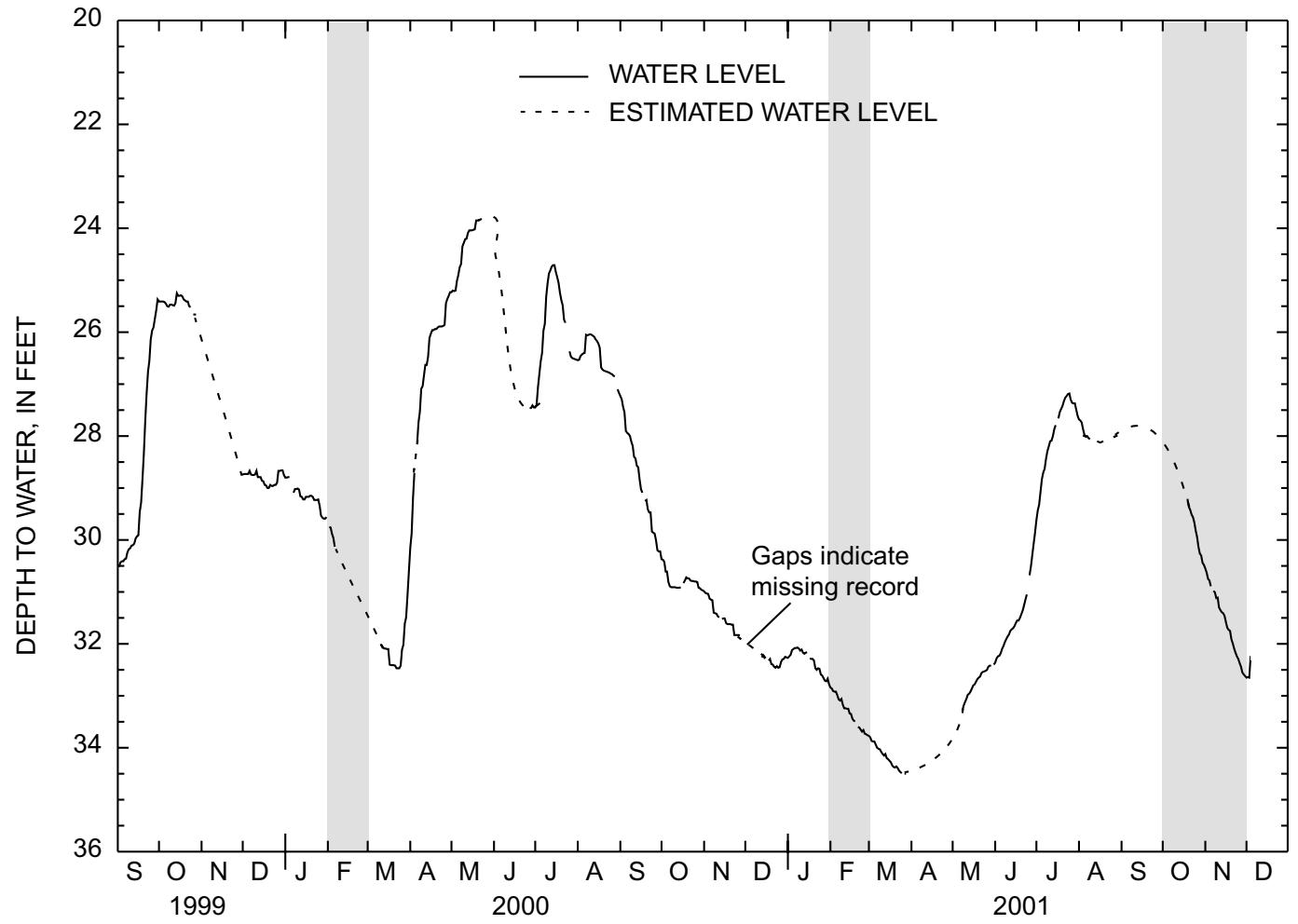

Figure 15. Depth to water in well Ch-5173, New Garden Township spray-irrigation site, Chester County, Pennsylvania, September 1999 through December 2001. [Shaded areas on graph indicate periods of high measured percent soil moisture and receding water levels.] 
2001 was overestimated because of the high measured percent soil moisture at the end of November 2001 and the receding water level.

The method is less reliable during months with high precipitation amounts combined with normal application volumes. The largest differences between monthly calculated and cropreferenced evapotranspiration totals were during months of extreme climatic conditions. On September 16, 1999, rainfall from the remnants of Hurricane Floyd totaled 8.9 in. of rain in a 24-hour period in the watershed. Combining the September 1999 precipitation and the amount of spray-irrigated effluent, the total input of water for the month was 17.1 in. The difference between the calculated and crop-referenced evapotranspiration for this month was $6.4 \mathrm{in}$., which was the largest difference of any month in the study period. Also, the effects of the remnants of Hurricane Floyd appeared to last into the months of October and November of 1999. Differences between the calculated and crop-referenced evapotranspiration were 3.5 and 3.1 in., respectively, for October and November 1999. The second largest difference between calculated and crop-referenced evapotranspiration was in March 2000, when precipitation plus the amount of spray-irrigated effluent totaled 11 in.; the difference was 3.9 in.

The monthly calculated and crop-referenced evapotranspirations were summed over calendar years 2000 and 2001. The negative calculated monthly evapotranspiration values were used in the annual accumulations. For calendar year 2000, the cumulative calculated evapotranspiration was 32.4 in. and the crop-referenced evapotranspiration was 30.6 in., which is a difference of 5.5 percent. For calendar year 2001, the cumulative calculated evapotranspiration was 33.6 in. and the crop-referenced evapotranspiration was $31.5 \mathrm{in}$., which is a difference of 6.8 percent. Summing the monthly evapotranspiration values may lessen the temporal climatic variability that occurs on a monthly basis. Therefore, the developed method and results may be better applied on a cumulative annual basis.

\section{Recharge}

Estimated annual recharge for the study watershed and Red Clay Creek watershed was calculated for the period May 1998 through April 1999 prior to effluent application. Annual recharge was $6.3 \mathrm{in}$. in the study watershed and $7.0 \mathrm{in}$. in the Red Clay Creek watershed (using eq. 6, p. 22).

Estimated annual recharge for Red Clay Creek watershed above Kennett Square, Pa., determined for calendar years 2000 and 2001 was 12.5 and 6.6 in., respectively. Estimated annual recharge for the study watershed for 2000 and 2001 was 21.3 and 10.9 in., respectively. On an annual basis, when compared to Red Clay Creek watershed above Kennett Square, Pa., the spray irrigation increased recharge in the watershed by approximately 8.8 in. in 2000 and approximately 4.3 in. in 2001. The year-to-year difference in recharge is related directly to the amount of water delivered to the watershed. Total water input was 65.4 in. in 2000 (42.9 in. of precipitation and 22.6 in. of spray-irrigated effluent). For 2001, when drought conditions existed from July 2001 through December 2001, total water input was 50.7 in. (36.3 in. of precipitation and 14.4 in. of sprayirrigated effluent). Also, during 2001, effluent was not applied during January, February, and March, when recharge to aquifers usually occurs.

In 2000, the 8.8-in. increase in recharge represented a 70-percent increase above that of the Red Clay Creek watershed and was equal to 39 percent of the total annual spray-irrigated effluent. In 2001, the 4.3-in. increase in recharge represented a 65-percent increase above that of the Red Clay Creek watershed and was equal to 30 percent of the total annual spray-irrigated effluent.

Monthly recharge estimates for the study watershed were calculated using equation 6 (p. 22). Monthly recharge estimates, precipitation, spray-irrigated effluent, base flow, change in ground-water storage, and ground-water underflow are listed in table 15 . Because monthly estimated ground-water underflow is related directly to base flow in this method of estimating a monthly water budget, any error in base-flow determination would cause increased error in the ground-water underflow term and increased error in the subsequent recharge estimate. Also, ground-water underflow was estimated to be 13.4 in. over the study period. Error in this estimate would directly affect the amount of recharge calculated.

Monthly recharge estimates, precipitation, and quantities of spray-irrigated effluent for the study are shown in figure 16. A seasonal trend in recharge is apparent. Typically, recharge increases during the winter and spring months and decreases during the summer through the fall months. Estimated monthly recharge equalled or exceeded 3.5 in. per month in September 1999; March, April, May, and July 2000; and June 2001 (table 15). Monthly recharge estimates for September 1999 and March 2000 were high because of high monthly precipitation. The high recharge estimate for April 2000 was because of high precipitation and high amounts of spray-irrigated effluent applied during March 2000, which saturated the application area. Because of the saturated application area, precipitation and spray-irrigated effluent, which fell in April, were not evapotranspired or stored in the unsaturated zone and infiltrated to the ground-water system. High monthly recharge estimates for May 2000, July 2000, and June 2001 were because of the high amounts of spray-irrigated effluent.

In southeastern Pennsylvania, recharge rates typically are high in the spring months of March, April, and May when evapotranspiration rates are low and percent soil moisture in the unsaturated zone is high. Recharge rates decline through the summer and are the lowest in the fall. Recharge rates in the study watershed exhibited the same seasonal trend with a few exceptions. Monthly total-recharge estimates and daily groundwater levels in well Ch-5173 are shown in figure 17. High recharge rates did occur in two summer months because of large volumes of spray-irrigated effluent being applied. Monthly amounts of spray-irrigated effluent for July 2000 and June 2001 totaled 4.9 and 3.2 in., respectively. Precipitation and spray- 


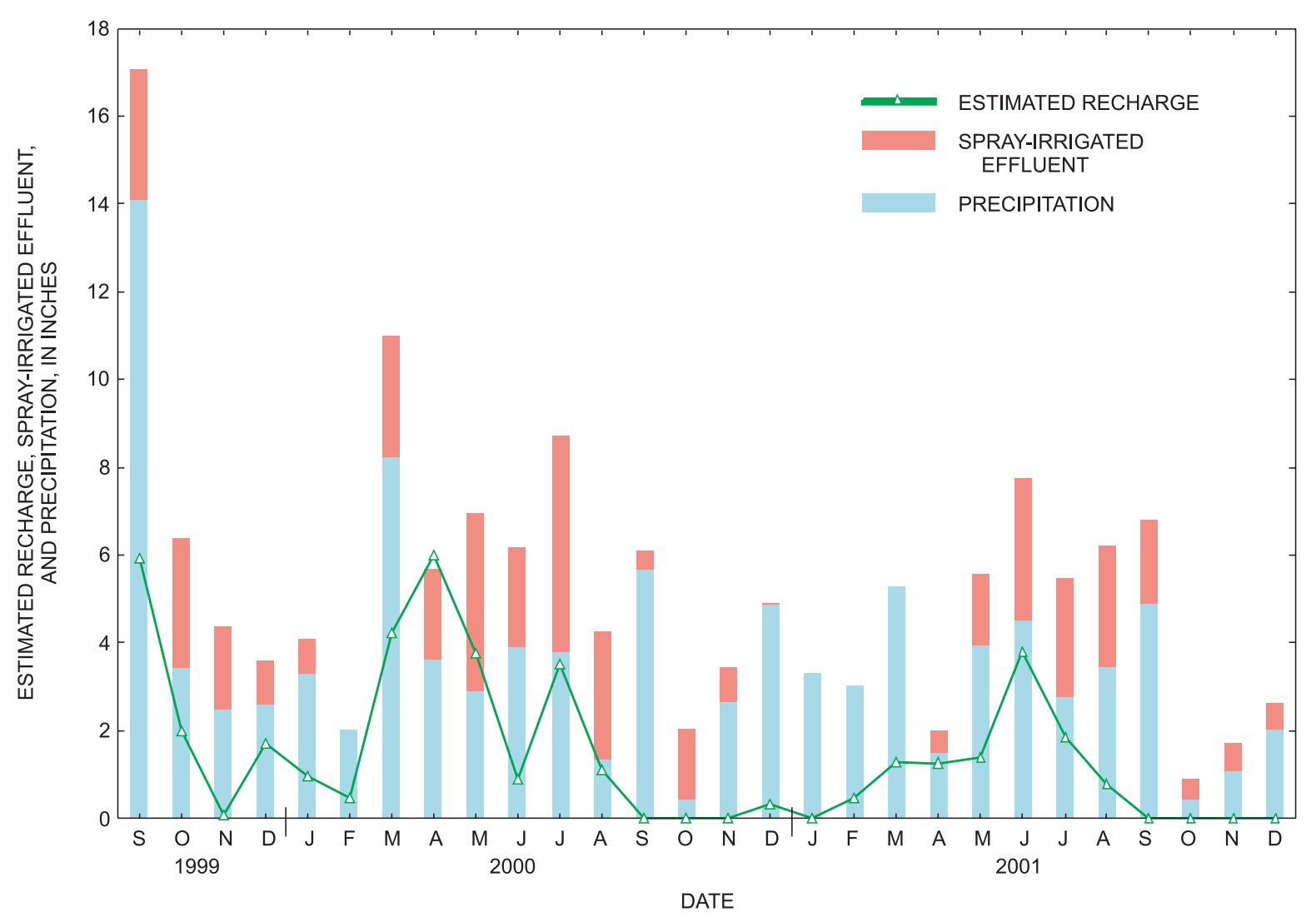

Figure 16. Monthly estimated recharge, spray-irrigated effluent, and precipitation, New Garden Township sprayirrigation site, Chester County, Pennsylvania, September 1999 through December 2001.

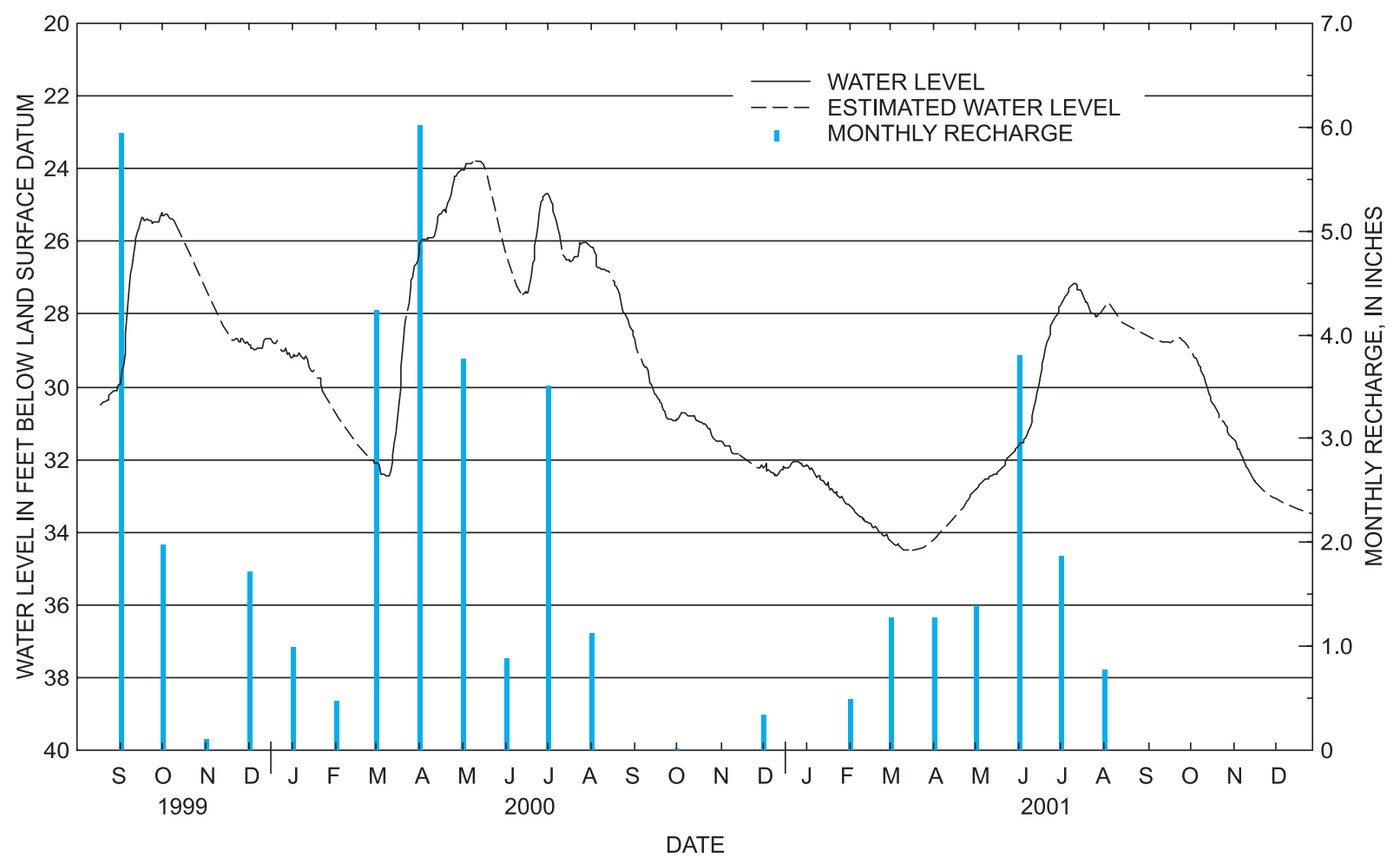

Figure 17. Monthly total-recharge estimates and daily ground-water levels in well Ch-5173, New Garden Township spray-irrigation site, Chester County, Pennsylvania, September 1999 through December 2001. 
Table 15. Summary of monthly estimated recharge, precipitation, and spray-irrigated effluent volumes, New Garden Township spray-irrigation site, Chester County, Pennsylvania, September 1999 through December 2001.

\begin{tabular}{|c|c|c|c|c|c|c|}
\hline Month and year & $\begin{array}{l}\text { Precipitation } \\
\text { (inches) }\end{array}$ & $\begin{array}{c}\text { Spray- } \\
\text { irrigated } \\
\text { effluent } \\
\text { (inches) }\end{array}$ & $\begin{array}{c}\text { Base flow } \\
\text { (inches) }\end{array}$ & $\begin{array}{c}\text { Change in } \\
\text { ground-water } \\
\text { storage } \\
\text { (inches) }\end{array}$ & $\begin{array}{l}\text { Ground-water } \\
\text { underflow } \\
\text { (inches) }\end{array}$ & $\begin{array}{l}\text { Recharge } \\
\text { estimates } \\
\text { (inches) }^{1}\end{array}$ \\
\hline September 1999 & 14.1 & 3.0 & 0.2 & 5.5 & 0.2 & 5.9 \\
\hline October 1999 & 3.45 & 2.9 & .6 & 1.0 & .4 & 2.0 \\
\hline November 1999 & 2.51 & 1.9 & .6 & -.9 & .4 & .1 \\
\hline December 1999 & 2.60 & .99 & .9 & .3 & .5 & 1.7 \\
\hline January 2000 & 3.31 & .79 & .8 & -.2 & .4 & 1.0 \\
\hline February 2000 & 2.04 & 0 & .7 & -.7 & .4 & .5 \\
\hline March 2000 & 8.25 & 2.7 & .8 & 3.0 & .4 & 4.2 \\
\hline April 2000 & 3.64 & 2.0 & 1.6 & 3.6 & .9 & 6.0 \\
\hline May 2000 & 2.91 & 4.0 & 1.7 & 1.1 & 1.0 & 3.8 \\
\hline June 2000 & 3.91 & 2.3 & 1.2 & -1.0 & .7 & .9 \\
\hline July 2000 & 3.80 & 4.9 & 1.4 & 1.3 & .8 & 3.5 \\
\hline August 2000 & 1.36 & 2.9 & 1.4 & -1.1 & .8 & 1.1 \\
\hline September 2000 & 5.69 & .41 & 1.0 & -2.3 & .6 & ${ }^{2} 0$ \\
\hline October 2000 & .42 & 1.6 & 1.0 & -1.6 & .6 & 0 \\
\hline November 2000 & 2.68 & .79 & .8 & -1.6 & .5 & 0 \\
\hline December 2000 & 4.87 & .04 & .4 & -.4 & .3 & .3 \\
\hline January 2001 & 3.29 & 0 & .4 & -1.2 & .2 & 0 \\
\hline February 2001 & 3.04 & 0 & .7 & -.7 & .4 & .5 \\
\hline March 2001 & 5.28 & 0 & .8 & .1 & .4 & 1.3 \\
\hline April 2001 & 1.51 & .49 & .7 & .1 & .4 & 1.3 \\
\hline May 2001 & 3.96 & 1.6 & .6 & .5 & .3 & 1.4 \\
\hline June 2001 & 4.51 & 3.2 & 1.1 & 2.1 & .6 & 3.8 \\
\hline July 2001 & 2.78 & 2.7 & .6 & .9 & .4 & 1.9 \\
\hline August 2001 & 3.45 & 2.8 & .6 & -.2 & .4 & .8 \\
\hline September 2001 & 4.91 & 1.9 & .5 & -.9 & .3 & 0 \\
\hline October 2001 & .43 & .45 & .8 & -1.8 & .5 & 0 \\
\hline November 2001 & 1.08 & .63 & .5 & -2.2 & .3 & 0 \\
\hline December 2001 & 2.03 & .60 & .5 & -1.3 & .3 & 0 \\
\hline
\end{tabular}

\footnotetext{
${ }^{1}$ The recharge estimates may not equal the sum of base flow, change in ground-water storage, and ground-water underflow because of rounding.

${ }^{2}$ Negative calculated recharge set to 0 .
}

irrigated effluent totaled 8.7 and 7.7 in. for those months and estimated monthly recharge was 3.5 and 3.8 in., respectively.

No recharge was estimated for the months of September, October, and November 2000 and January, September, October, November, and December 2001 because of a combination of lower amounts of monthly precipitation during the month or in the preceding months and lower amounts of effluent applied during the month or in the preceding months. Therefore, the quantity of water that either fell as precipitation or was applied as effluent was not sufficient to increase soil moisture in the unsaturated zone to allow recharge. For September 2001, pre- cipitation totaled 4.9 in. and spray-irrigated effluent totaled 1.9 in. Although September 2001 precipitation total was above normal, 4.4 in. of the total monthly precipitation fell in just 3 days, which was probably to short of a duration of precipitation to sufficiently increase soil moisture to allow recharge.

Recharge is dependent on the amount of water in the unsaturated zone and the volume and timing of applied effluent with respect to the timing of precipitation events. If a spray event occurs in which the volume of spray-irrigated effluent is sufficient to saturate the soil and is followed by a precipitation event, larger amounts of precipitation that would have been absorbed 
to saturate the soil will now infiltrate the unsaturated zone and recharge the watershed. Because of this infiltration, it is difficult to determine the amount of spray-irrigated effluent that recharges the ground-water system on a monthly basis.

\section{Base Flow}

An increase in the base-flow component of streamflow caused by spray-irrigated effluent occurred in the watershed. A double-mass analysis was done on monthly base-flow totals from the unnamed tributary at the spray site (01479678) and the streamflow-gaging station at Red Clay Creek near Kennett Square (01479820). Cumulative monthly base-flow totals from May 1998 through December 2001 were used in the analysis (fig. 18). Assuming no changes that would affect base flow have taken place in the Red Clay Creek watershed above the streamflow-gaging station, the double-mass curve should be a straight line with a constant slope. A change in slope of the double-mass curve indicates a change in the relation between these two stations (Searcy and Hardison, 1960). An increase in the slope of the double-mass curve indicates an increase in base flow at the unnamed tributary at the spray site relative to that at Red Clay Creek near Kennett Square.

The slope of the double-mass curve for the period from May 1998 to June 1999, prior to effluent application, was 0.38 (fig. 18). The slope changed substantially in October 1999. The slope of the double-mass curve from October 1999 to April 2000 was 0.64 . During that time period, base flow in the study watershed increased 1.7 times. The increase was because of a combination of spray-irrigated effluent and the remnants from Hurricane Floyd. Drought conditions were present from June to September 1999 and much of the spray-irrigated effluent was either evapotranspired or stored in the unsaturated zone. Precipitation input from the remnants of Hurricane Floyd increased soil moisture to total saturation in the unsaturated zone, which allowed inputs from the spray-irrigated effluent and precipitation to recharge the ground-water system and, subsequently, increase base flow.

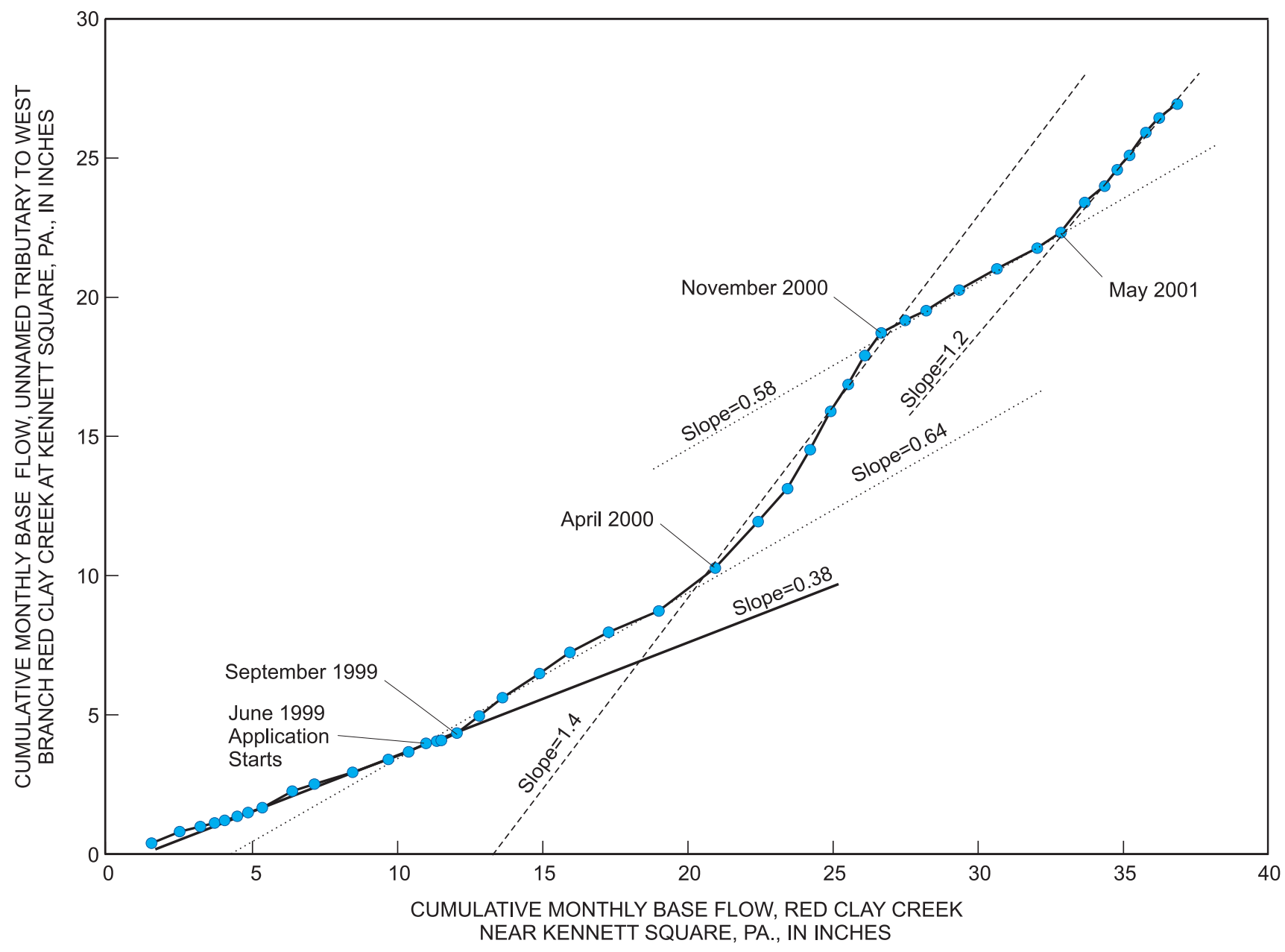

Figure 18. Double-mass curve of cumulative monthly base flow for unnamed tributary to West Branch Red Clay Creek at Kennett Square, Pa., and Red Clay Creek near Kennett Square, Pa., May 1998 through December 2001. 
The slope of the double-mass curve from April 2000 to November 2000 was 1.4. Base flow increased by more than a factor of 2 from the previous period and by a factor of 3.5 from the period prior to effluent application. This break in slope is related directly to the increased quantity of effluent applied during the late spring through summer and early fall months. The slope of the double-mass curve from November 2000 to May 2001 was 0.58 . Base flow decreased by a factor of 2 from the previous period but was still 1.5 times greater than the period prior to effluent application. This break in slope is related directly to the decreased quantity of effluent applied during the late fall through winter and early spring months. The slope of the double-mass curve from May 2001 to December 2001 was 1.2. Base flow increased by a factor of 2 from the previous period and increased by a factor of 3 from the period prior to effluent application. This break in slope is related directly to the increased quantity of effluent applied during the late spring through summer and early fall months.

\section{Evaluation of the Effects on Water Quantity}

- High monthly volumes of spray-irrigated effluent did not always relate directly to increased monthly recharge because recharge depends on the antecedent soil moisture and the volume and timing of spray-irrigated effluent with respect to the timing of precipitation events. For this reason, the actual amount of spray-irrigated effluent that recharges the ground-water system on a monthly basis is difficult to quantify.

- On an annual basis, the spray irrigation increased the recharge to the watershed. Spray irrigation increased annual recharge in the study watershed by approximately 8.8 in. in 2000 and 4.3 in. in 2001. The 8.8-in. increase in 2000 represented a 70-percent increase in recharge in the study watershed above that of the Red Clay Creek watershed and is equal to 39 percent of the total annual amount of spray-irrigated effluent. The 4.3-in. increase in 2001 represented a 65-percent increase in recharge above that of the Red Clay Creek watershed and was equal to 30 percent of the total annual amount of spray-irrigated effluent. Therefore, the spray-irrigated effluent increased recharge 6570 percent over the Red Clay Creek watershed, and the increased recharge was equal to 30-39 percent of the amount of spray-irrigated effluent over a 2-year period.

- Spray-irrigated effluent increased base flow in the watershed. The magnitude of the increase appeared to be related to the time of year when the application rates increased. During the late fall through winter and into the early spring, when application rates were low, base flow increased by approximately 50 percent over the period prior to effluent application. During the early spring through summer to the late fall period, when application rates were high, base flow increased by approximately 200 percent over the period prior to effluent application.

- It was assumed that calculated monthly evapotranspiration, which represented actual evapotranspiration, and crop-referenced evapotranspiration, which represented potential evapotranspiration, should be similar in value. Calculated monthly evapotranspiration also included the accumulation of errors in measuring, estimating, or determining all the water-budget terms in the monthly water-budget equation. Summing the monthly evapotranspiration values may lessen the temporal climatic variability that occurs on a monthly basis. Therefore, the developed method and results may be better applied on a cumulative annual basis. Values of monthly calculated and crop-referenced evapotranspiration were summed over calendar years 2000 and 2001. For calendar year 2000, the cumulative calculated evapotranspiration was 32.4 in. and the crop-referenced evapotranspiration was 30.7 in., which is a difference of 5.5 percent. For calendar year 2001, the cumulative calculated evapotranspiration was $33.7 \mathrm{in}$. and the crop-referenced evapotranspiration was $31.5 \mathrm{in}$., which is a difference of 6.8 percent.

\section{Effects of Spray-Irrigated Effluent on Water Quality}

Land-treatment systems utilize the natural processes of plant uptake of nutrients and soil adsorption of metals and nutrients to assimilate the effluent. The disposal of treated effluent onto the land surface does not directly degrade streamwater quality, unlike instream discharges. However, the disposal may indirectly degrade streamflow if ground-water quality, which contributes to streamflow as base flow, is affected by the spray-irrigated effluent. In Chester County, ground-water discharge to streams makes up 57 to 75 percent of streamflow (Sloto, 1994, p. 52). An assessment was done to first characterize the effluent quality and second to determine if the effluent was degrading the ground water and surface water of the watershed. Changes in median concentrations of waterquality constituents in ground water and surface water were evaluated prior to and during effluent application to determine the effects of effluent (see page 25). Also, time trends or seasonal trends in ground-water and surface-water-quality constituents were evaluated (see page 25).

A particular concern in effluent management is the treating or assimilation of nutrients. N-rich ground water or subsurface flow can discharge to streams and degrade the quality of surface water. Because of seasonal changes within the growing season, land-application rates are adjusted to avoid potential groundwater and surface-water $\mathrm{N}$-enrichment problems. A comprehensive analysis of nutrients was done to determine if nutrient concentrations were increasing in the ground water. 
The past land-use practices of disposing of spent mushroom substrate in parts of the watershed complicated interpretations of water-quality data in the disposal areas, particularly in the valley bottom near wells Ch-5176, Ch-5177, and Ch-5181 (plate 1). In these areas, concentrations of nutrients in ground water were elevated $(>25 \mathrm{mg} / \mathrm{L})$, even prior to the onset of spray irrigation.

\section{Effluent Quality}

The effluent quality was characterized by analyzing samples collected from May 1999 through December 2001. Data on physical and chemical constituents collected in the field, nutrients, major ions, minor ions, dissolved organic carbon, and total dissolved solids of the effluent are summarized in table 16 .

Concentrations of dissolved oxygen are higher in the winter months and lower in the summer months because of water temperatures and bacteriological activity in the storage lagoon. Higher water temperatures promote higher bacteriological activity, which consumes oxygen.

The median effluent concentrations of total and dissolved $\mathrm{N}$ were 11 and $9.8 \mathrm{mg} / \mathrm{L}$, respectively. Most of the $\mathrm{N}$ was in the form of nitrate $\mathrm{N}$ and organic $\mathrm{N}$. However, elevated concentrations of dissolved and total ammonia $\mathrm{N}$, greater than $4.0 \mathrm{mg} / \mathrm{L}$, were measured in March 2000 and April and June 2001. Elevated concentrations of dissolved and total ammonia $\mathrm{N}$ in the effluent are the result of storage over winter months. Stratification of low dissolved oxygen waters in the lagoon lends itself to the higher ammonia- $\mathrm{N}$ concentrations because ammonia $\mathrm{N}$ will stay in solution in the reducing environment of the storage lagoon. Ammonia $\mathrm{N}$ commonly is oxidized to form nitrate $\mathrm{N}$ where oxygen is present.

The median concentrations of total and dissolved $\mathrm{P}$ in the effluent were 3.26 and $2.52 \mathrm{mg} / \mathrm{L}$, respectively. Most of the dissolved $\mathrm{P}$ was in the form of orthophosphorus.

The concentrations of major and minor ions in the effluent are representative of the chemical signatures of the different sources of water to the facility, chemicals inherent in sewage effluent, and chemicals associated with the treatment of sewage effluent. The majority of the source water to the facility is from local residential developments that have wells for their water supply. The geology of the surrounding area is underlain predominately by the Cockeysville Marble, which is a carbonate rock. Ground water in the Cockeysville Marble has higher concentrations of calcium and magnesium than ground water in other geologic formations of the Red Clay Creek watershed (Senior, 1996). Median concentrations of calcium and magnesium in water from eight ground-water samples collected in the Cockeysville Marble were 73 and $38.6 \mathrm{mg} / \mathrm{L}$, respectively (Senior, 1996). The spray site is underlain primarily by a felsic gneiss. Median concentrations of calcium and magnesium in water from 16 ground-water samples collected in the felsic gneiss were of 24 and $7.5 \mathrm{mg} / \mathrm{L}$, respectively. The median concentrations of calcium and magnesium in the effluent were 39.9 and $17.5 \mathrm{mg} / \mathrm{L}$, respectively. Also, ground water in the Cock- eysville Marble typically contains higher concentrations of sulfate and lower concentrations of silica and iron than other bedrock aquifers of the Red Clay Creek watershed (Senior, 1996). Chemicals such as fluoride, sodium, boron, and bromide are associated with sewage effluent. Median concentrations for these constituents are summarized in table 16 . The median concentration of chloride in water collected from 16 wells completed in the felsic gneiss was $9 \mathrm{mg} / \mathrm{L}$ (Senior, 1996). The median concentration of chloride in eight wells completed in the Cockeysville marble was $26 \mathrm{mg} / \mathrm{L}$. Chlorine is used to treat sewage and residual $\mathrm{Cl}$ results from the process. The concentration of $\mathrm{Cl}$ ranged from 65.7 to $180 \mathrm{mg} / \mathrm{L}$; the median concentration was $89.5 \mathrm{mg} / \mathrm{L}$.

Two effluent samples were analyzed using the annual schedule, which contained an expanded trace metals list. These samples were collected on October 7, 1999, and December 12, 2001. Arsenic was detected in the sample collected on October 7,1999 , at a concentration of $5.4 \mu \mathrm{g} / \mathrm{L}$. Barium was detected in both samples at concentrations of 4.9 and $10.3 \mu \mathrm{g} / \mathrm{L}$. Copper was detected in both samples at concentrations of 7.2 and $9.4 \mu \mathrm{g} / \mathrm{L}$. Nickel was detected in both samples at concentrations of 17.6 and $14.9 \mu \mathrm{g} / \mathrm{L}$. Strontium was detected in both samples at concentrations of 118 and $130 \mu \mathrm{g} / \mathrm{L}$. Senior (1996) reported a median strontium concentration of $105 \mu \mathrm{g} / \mathrm{L}$ in 16 water sampled collected in the Red Clay Creek watershed. Antimony, cadmium, chromium, lead, lithium, mercury, and selenium were not detected above the reporting limit in the samples.

\section{Ground Water}

The effects of spray-irrigated effluent on ground-water quality in the watershed was determined by nonparametric comparison tests between the median constituent concentrations in ground-water samples collected prior to and during effluent application. Nonparametric trend tests were done on all water-quality data for each well to determine statistically significant trends. Data from the shallow and bedrock aquifers were analyzed separately. Also, water-quality data from the control wells were compared to water-quality data from the application area and downgradient wells. The ground-water-quality analyses are presented for each physical property or chemical constituent and are summarized on the basis of topographical setting and application area. Furthermore, the application area was partitioned into eastern and western application areas because of the differing thicknesses and composition of the unconsolidated material. The unconsolidated sands of the eastern application area are approximately $30 \mathrm{ft}$ thick with little clay content. The unconsolidated sands of the western application area are approximately $55 \mathrm{ft}$ thick with an increased amount of clay compared to the eastern part (fig. 4, p. 9).

\section{Shallow Aquifer}

Shallow wells Ch-5173 and Ch-5175 (62 and $56.5 \mathrm{ft}$, respectively) were on the hilltop and hillside, respectively, in 
Table 16. Summary of physical and chemical properties, major and selected minor ions, nutrients, and metal concentrations in effluent, New Garden Township spray-irrigation site, Chester County, Pennsylvania, May 1999 to December 2001.

[Unless otherwise noted, all constituents are dissolved; mg/L, milligrams per liter; $\mu \mathrm{g} / \mathrm{L}$, micrograms per liter; $\mu \mathrm{S} / \mathrm{cm}$, microsiemens per centimeter; ${ }^{\circ} \mathrm{C}$, degrees Celsius; $<$, less than]

\begin{tabular}{|c|c|c|c|c|c|c|}
\hline $\begin{array}{l}\text { Physical property or } \\
\text { dissolved constituent }\end{array}$ & $\begin{array}{c}\text { Number } \\
\text { of } \\
\text { samples }\end{array}$ & Minimum & $\begin{array}{c}\text { 25th } \\
\text { percentile }\end{array}$ & $\begin{array}{c}\text { Median } \\
\text { (50th } \\
\text { percentile) }\end{array}$ & $\begin{array}{c}\text { 75th } \\
\text { percentile }\end{array}$ & Maximum \\
\hline \multicolumn{7}{|c|}{ Physical or chemical property (field measurement) } \\
\hline Dissolved oxygen $(\mathrm{mg} / \mathrm{L})$ & 25 & 0.3 & 1.0 & 6.4 & 8.5 & 15.0 \\
\hline pH (standard units) & 32 & 6.9 & 7.4 & 8.4 & 9.6 & 10.2 \\
\hline Specific conductance $(\mu \mathrm{S} / \mathrm{cm})$ & 32 & 580 & 626 & 654 & 698 & 726 \\
\hline Temperature $\left({ }^{\circ} \mathrm{C}\right)$ & 28 & 6.2 & 10.2 & 16.2 & 22.6 & 25.8 \\
\hline \multicolumn{7}{|l|}{ Nutrients } \\
\hline Nitrogen (mg/L) & 32 & 3.0 & 7.1 & 9.8 & 11.0 & 19 \\
\hline Ammonia nitrogen (mg/L) & 33 & $<.02$ & .27 & .69 & 1.5 & 7.3 \\
\hline Nitrate nitrogen (mg/L) & 33 & .88 & 2.9 & 5.8 & 7.7 & 15.0 \\
\hline Nitrite nitrogen (mg/L) & 33 & .07 & .20 & .57 & .68 & 2.1 \\
\hline Total nitrogen (mg/L) & 33 & 5.0 & 9.2 & 11 & 13 & 19 \\
\hline Total ammonia nitrogen (mg/L) & 32 & $<.02$ & .34 & .92 & 1.78 & 7.94 \\
\hline Phosphorus (mg/L) & 30 & .26 & .71 & 2.52 & 3.26 & 5.33 \\
\hline Orthophosphate phosphorus (mg/L) & 31 & .13 & .57 & 2.04 & 2.81 & 4.48 \\
\hline Total phosphorus (mg/L) & 30 & 1.17 & 2.00 & 3.26 & 4.12 & 12.5 \\
\hline \multicolumn{7}{|l|}{ Major ions } \\
\hline Calcium (mg/L) & 7 & 32.0 & 38.6 & 39.9 & 40.8 & 41.7 \\
\hline Magnesium (mg/L) & 7 & 16.5 & 17.2 & 17.5 & 20.5 & 23.1 \\
\hline Sodium (mg/L) & 7 & 47.7 & 52.2 & 56.5 & 58.7 & 62.9 \\
\hline Potassium (mg/L) & 7 & 15.2 & 16.0 & 16.6 & 16.9 & 17.1 \\
\hline Chloride (mg/L) & 26 & 65.7 & 82.4 & 89.5 & 96.4 & 180 \\
\hline Fluoride (mg/L) & 7 & .40 & .45 & .50 & .50 & .70 \\
\hline Sulfate (mg/L) & 7 & 41.0 & 52.3 & 55.2 & 57.3 & 58.8 \\
\hline Silica (mg/L) & 7 & 6.8 & 7.6 & 7.9 & 8.9 & 11.3 \\
\hline \multicolumn{7}{|l|}{ Minor ions } \\
\hline Bromide (mg/L) & 6 & $<.20$ & $<.20$ & $<.20$ & .21 & .32 \\
\hline Boron $(\mu \mathrm{g} / \mathrm{L})$ & 9 & $<200$ & $<200$ & $<200$ & 216 & 310 \\
\hline Iron $(\mu \mathrm{g} / \mathrm{L})$ & 13 & $<20$ & $<20$ & 40 & 60 & 750 \\
\hline Manganese $(\mu \mathrm{g} / \mathrm{L})$ & 13 & $<10$ & $<10$ & 30 & 130 & 190 \\
\hline Zinc $(\mu \mathrm{g} / \mathrm{L})$ & 26 & $<10$ & 15 & 57 & 100 & 920 \\
\hline \multicolumn{7}{|l|}{ Other constituents and properties } \\
\hline Carbon, organic (mg/L as C) & 7 & 11 & 13 & 14 & 14 & 16 \\
\hline Total dissolved solids ${ }^{1}$ (mg/L) & 7 & 46 & 240 & 424 & 447 & 518 \\
\hline
\end{tabular}

${ }^{1}$ Measured residue on evaporation to dryness at $180^{\circ} \mathrm{C}$. 
the western application area. Shallow wells Ch-5180 and Ch-5179 (32 and $39 \mathrm{ft}$, respectively) were on the hilltop and hillside, respectively, in the eastern application area. Shallow wells Ch-5177 and Ch-5181 (35 and $40 \mathrm{ft}$, respectively) were in the valley bottom, downgradient from the application area (plate 1). These wells were on or near historical mushroom composting areas. The presence of the spent mushroom substrate and the leaching of compounds from the spent mushroom substrate did affect the ground-water quality in these wells. Shallow well Ch-5183 was in Control (2) on the hilltop (plate 1).

Some constituents in water samples from control well Ch-5183 had significant differences in the median concentrations of samples collected prior to and during effluent application. These differences were either because of the inherent climatic conditions during the study or the effects of some effluent that was sprayed infrequently on Control (2). Because of these differences, direct comparisons between median concentrations from the control wells and the application wells were not made. However, percentage differences in median concentrations in control wells prior to and during application were compared to percentage differences in median concentrations in applicationarea wells.

\section{Physical Properties and Chemical Constituents Measured in the Field}

The median values of physical properties and chemical constituents measured in the field in water samples from shallow monitor wells collected prior to and during effluent application and results of the Wilcoxon rank sum test and the MannKendall test for trends are summarized in table 17. Because some effluent was applied to Control (2), comparison statistical tests of data from Control (2) collected prior to and during effluent application were done. No significant differences between samples collected prior to or during effluent application were evident, and no trends over the length of the study period were evident for $\mathrm{pH}$ and water temperature in water from shallow wells on the application area and the valley-bottom area or the control well.

Median specific conductances were significantly different in water samples collected from wells Ch-5173, Ch-5179, Ch-5181, and Ch-5183 prior to and during effluent application. Statistically significant upward trends in specific conductance were evident in water samples from wells Ch-5179 and Ch-5180 in the eastern application area and the control well Ch-5183. A statistically significant downward trend in specific conductance was evident in water samples from well Ch-5181 in the valley-bottom area.

Median alkalinity concentrations were significantly different in water samples collected from well Ch-5179 prior to and during effluent application. Statistically significant upward trends in alkalinity concentrations were evident in water samples from wells Ch-5179 and Ch-5180 in the eastern application area and the control well Ch-5183.
Median concentrations of dissolved oxygen were significantly different in water samples collected from well Ch-5179 and Ch-5181 prior to and during effluent application. Statistically significant downward trends in concentrations of dissolved oxygen were evident in water samples from wells Ch-5177 and Ch-5179 and control well Ch-5183. The data for concentrations of dissolved oxygen were insufficient to analyze for differences in medians prior to or during effluent application or trends in water from wells Ch-5173, Ch-5175, and Ch-5180.

Of the physical properties and chemical constituents measured in the field, it is apparent that the spray-irrigated effluent is increasing the specific conductance of water from wells Ch-5179 and Ch-5180, which are on the eastern application area. The median specific conductance of the effluent was $654 \mu \mathrm{S} / \mathrm{cm}$. The median application specific conductance was greater than the median in water collected from well Ch-5179 prior to effluent application, and an upward time trend was evident. The median specific conductance in water from well Ch-5179 during the application period was 87 percent higher than in the period prior to effluent application. In water from control well Ch-5183, the percentage increase in median specific conductance for the periods prior to and during effluent application was 6.6 percent. Because no samples were collected from well Ch-5180 prior to effluent application, comparisons could not be made. However, a significant upward trend in specific conductance for water from well Ch-5180 was evident (fig. 19). Specific-conductance values for Ch-5180 at the start of the effluent application were less than $100 \mu \mathrm{S} / \mathrm{cm}$ but were approximately $400 \mu \mathrm{S} / \mathrm{cm}$ at the end of the study period. The increase in specific conductance in the eastern application area probably was because of the high sand content and the thinner unconsolidated material, which was approximately $30 \mathrm{ft}$ thick, compared to a 50- to 60-ft thickness on the western application area.

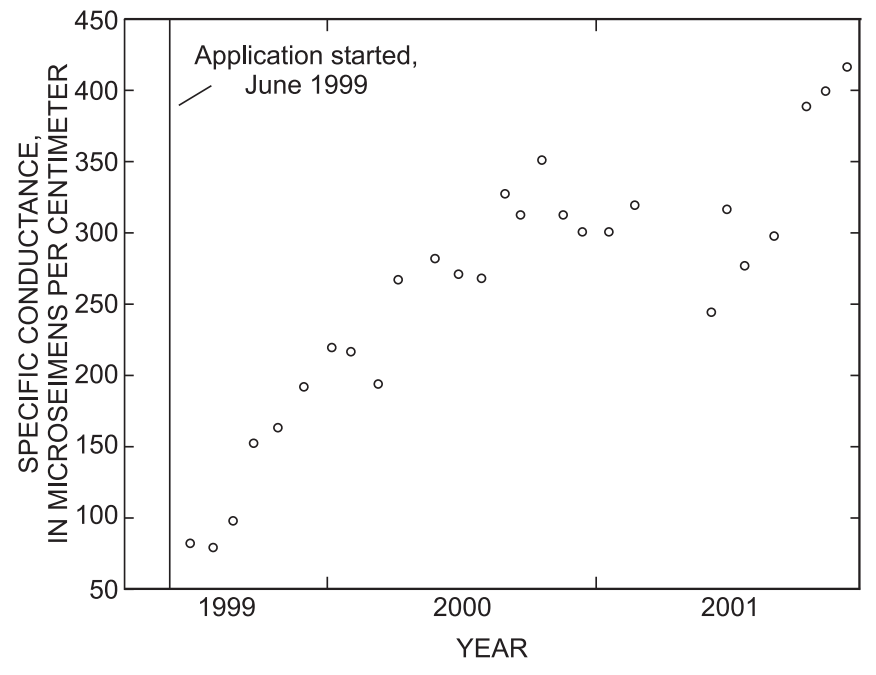

Figure 19. Specific conductance of water samples from well Ch-5180, New Garden Township spray-irrigation site, Chester County, Pennsylvania, 1999-2001. 
Table 17. Summary of Wilcoxon rank-sum test, Mann-Kendall test for trends, and median values of pH, water temperature, specific conductance, alkalinity, and dissolved oxygen in water from shallow wells collected prior to and during effluent application, New Garden Township spray-irrigation site, Chester County, Pennsylvania, May 1998 through December 2001.

[Shaded areas indicate a significant difference between water samples collected prior to and during effluent application according to Wilcoxon rank-sum test results; ${ }^{\circ} \mathrm{C}$, degrees Celsius; $\mu \mathrm{S} / \mathrm{cm}$, microsiemens per centimeter; mg/L, milligrams per liter; —, no significant trend; U, significant upward trend; D, significant downward trend; N, no samples collected; NA, not applicable]

\begin{tabular}{|c|c|c|c|c|c|c|c|c|c|c|}
\hline \multirow{4}{*}{ Constituent } & \multicolumn{10}{|c|}{ Western application area } \\
\hline & \multicolumn{5}{|c|}{ Ch-5173 (Hilltop) } & \multicolumn{5}{|c|}{ Ch-5175 (Hillside) } \\
\hline & \multicolumn{2}{|c|}{ Median } & \multicolumn{3}{|c|}{ Mann-Kendall trend } & \multicolumn{2}{|c|}{ Median } & \multicolumn{3}{|c|}{ Mann-Kendall trend } \\
\hline & $\begin{array}{l}\text { Prior to } \\
\text { appli- } \\
\text { cation }\end{array}$ & $\begin{array}{l}\text { During } \\
\text { appli- } \\
\text { cation }\end{array}$ & Trend & $\begin{array}{c}\text { Kendall's } \\
\text { tau }\end{array}$ & $p$-value & $\begin{array}{l}\text { Prior to } \\
\text { appli- } \\
\text { cation }\end{array}$ & $\begin{array}{l}\text { During } \\
\text { appli- } \\
\text { cation }\end{array}$ & Trend & $\begin{array}{c}\text { Kendall's } \\
\text { tau }\end{array}$ & $p$-value \\
\hline Number of samples & 5 & 29 & & & & 5 & 29 & & & \\
\hline pH (standard units) & 6.2 & 6.0 & - & - & - & 6.3 & 6.4 & - & - & - \\
\hline Water temperature $\left({ }^{\circ} \mathrm{C}\right)$ & 13.5 & 13.0 & - & - & - & 13.0 & 13.0 & - & - & - \\
\hline Specific conductance $(\mu \mathrm{S} / \mathrm{cm})$ & 162 & 126 & - & - & - & 133 & 129 & - & - & - \\
\hline Alkalinity (mg/L) & 14 & 17 & - & - & - & 33 & 29 & - & - & - \\
\hline Dissolved oxygen $(\mathrm{mg} / \mathrm{L})$ & $\mathrm{N}$ & $\mathrm{N}$ & NA & NA & NA & $\mathrm{N}$ & $\mathrm{N}$ & NA & NA & NA \\
\hline \multirow{4}{*}{ Constituent } & \multicolumn{10}{|c|}{ Eastern application area } \\
\hline & \multicolumn{5}{|c|}{ Ch-5180 (Hilltop) } & \multicolumn{5}{|c|}{ Ch-5179 (Hillside) } \\
\hline & \multicolumn{2}{|c|}{ Median } & \multicolumn{3}{|c|}{ Mann-Kendall trend } & \multicolumn{2}{|c|}{ Median } & \multicolumn{3}{|c|}{ Mann-Kendall trend } \\
\hline & $\begin{array}{l}\text { Prior to } \\
\text { appli- } \\
\text { cation }\end{array}$ & $\begin{array}{l}\text { During } \\
\text { appli- } \\
\text { cation }\end{array}$ & Trend & $\begin{array}{c}\text { Kendall's } \\
\text { tau }\end{array}$ & $p$-value & $\begin{array}{l}\text { Prior to } \\
\text { appli- } \\
\text { cation }\end{array}$ & $\begin{array}{l}\text { During } \\
\text { appli- } \\
\text { cation }\end{array}$ & Trend & $\begin{array}{c}\text { Kendall's } \\
\text { tau }\end{array}$ & $p$-value \\
\hline Number of samples & 0 & 27 & & & & 5 & 29 & & & \\
\hline pH (standard units) & $\mathrm{N}$ & 5.7 & - & - & - & 5.9 & 6.0 & - & - & - \\
\hline Water temperature $\left({ }^{\circ} \mathrm{C}\right)$ & $\mathrm{N}$ & 12.8 & - & - & - & 12.5 & 12.6 & - & - & - \\
\hline Specific conductance $(\mu \mathrm{S} / \mathrm{cm})$ & $\mathrm{N}$ & 276 & $\mathrm{U}$ & +0.70 & 0.0000 & 130 & 243 & $\mathrm{U}$ & +0.66 & 0.0000 \\
\hline Alkalinity (mg/L) & $\mathrm{N}$ & 27 & $\mathrm{U}$ & +.45 & .0020 & 25 & 35 & $\mathrm{U}$ & +.42 & .0006 \\
\hline Dissolved oxygen (mg/L) & $\mathrm{N}$ & $\mathrm{N}$ & NA & NA & NA & 9.6 & 8.0 & $\mathrm{D}$ & -.52 & .0000 \\
\hline \multirow{4}{*}{ Constituent } & \multicolumn{10}{|c|}{ Downgradient valley bottom } \\
\hline & \multicolumn{5}{|c|}{ Ch-5177 } & \multicolumn{5}{|c|}{ Ch-5181 } \\
\hline & \multicolumn{2}{|c|}{ Median } & \multicolumn{3}{|c|}{ Mann-Kendall trend } & \multicolumn{2}{|c|}{ Median } & \multicolumn{3}{|c|}{ Mann-Kendall trend } \\
\hline & $\begin{array}{l}\text { Prior to } \\
\text { appli- } \\
\text { cation }\end{array}$ & $\begin{array}{l}\text { During } \\
\text { appli- } \\
\text { cation }\end{array}$ & Trend & $\begin{array}{c}\text { Kendall's } \\
\text { tau }\end{array}$ & $p$-value & $\begin{array}{l}\text { Prior to } \\
\text { appli- } \\
\text { cation }\end{array}$ & $\begin{array}{l}\text { During } \\
\text { appli- } \\
\text { cation }\end{array}$ & Trend & $\begin{array}{l}\text { Kendall's } \\
\text { tau }\end{array}$ & $p$-value \\
\hline Number of samples & 5 & 30 & & & & 5 & 29 & & & \\
\hline pH (standard units) & 5.8 & 5.9 & - & - & - & 6.2 & 6.6 & - & - & - \\
\hline Water temperature $\left({ }^{\circ} \mathrm{C}\right)$ & 12.6 & 12.4 & - & - & - & 14.0 & 12.8 & - & - & - \\
\hline Specific conductance & 409 & 397 & - & - & - & 271 & 243 & $\mathrm{D}$ & -0.67 & 0.0000 \\
\hline Alkalinity & 33 & 39 & - & - & - & 51 & 53 & - & - & - \\
\hline Dissolved oxygen & 7.0 & 6.6 & $\mathrm{D}$ & -0.43 & 0.0005 & 4.0 & 1.9 & - & - & - \\
\hline & & & ol area & & & & & & & \\
\hline & & & 183 & & & & & & & \\
\hline Constituent & & & Man & In-Kendall t & rend & & & & & \\
\hline 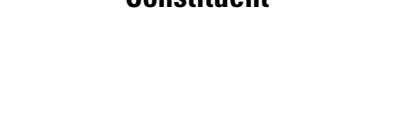 & $\begin{array}{l}\text { Prior to } \\
\text { appli- } \\
\text { cation }\end{array}$ & $\begin{array}{l}\text { During } \\
\text { appli- } \\
\text { cation }\end{array}$ & Trend & $\begin{array}{c}\text { Kendall's } \\
\text { tau }\end{array}$ & $p$-value & & & & & \\
\hline Number of samples & 5 & 29 & & & & & & & & \\
\hline pH (standard units) & 6.8 & 6.8 & - & - & - & & & & & \\
\hline Water temperature $\left({ }^{\circ} \mathrm{C}\right)$ & 12.0 & 12.2 & - & - & - & & & & & \\
\hline Specific conductance $(\mu \mathrm{S} / \mathrm{cm})$ & 195 & 208 & $\mathrm{U}$ & +0.60 & 0.0000 & & & & & \\
\hline Alkalinity (mg/L) & 69 & 76 & $\mathrm{U}$ & +.37 & .0029 & & & & & \\
\hline Dissolved oxygen (mg/L) & 7.3 & 6.8 & $\mathrm{D}$ & -.26 & .0301 & & & & & \\
\hline
\end{tabular}


Nutrients

In ground water from shallow wells, nearly all $\mathrm{N}$ (from 73 to 97 percent) was in the form of dissolved nitrate $\mathrm{N}$ with median concentrations of dissolved nitrate $\mathrm{N}$ ranging from 0.23 to $24 \mathrm{mg} / \mathrm{L}$. Dissolved $\mathrm{P}$, primarily ortho $\mathrm{P}$ was found in low concentrations in water from all shallow wells with median concentrations ranging from $<0.01$ to $0.05 \mathrm{mg} / \mathrm{L}$. Median concentrations of dissolved nitrate $\mathrm{N}$ in water samples collected from wells Ch-5173, Ch-5175, Ch-5179, Ch-5177, Ch-5181, and Ch-5183 prior to and during effluent application were significantly different. No samples were collected from well Ch-5180 prior to effluent application, and median comparisons were not done. No significant differences between median concentrations of dissolved nitrite $\mathrm{N}$ and dissolved ammonia $\mathrm{N}$ in samples collected prior to and during effluent application were evident. The results of the Wilcoxon rank-sum test, the MannKendall test for trends, and the median concentrations of $\mathrm{N}$ species in water samples from shallow wells collected prior to and during effluent application are summarized in table 18.

Time trends for concentrations of dissolved $\mathrm{N}$ and dissolved nitrate were evident. Because dissolved nitrate $\mathrm{N}$ made up 73, 84, and 81 percent of dissolved $\mathrm{N}$ in water from wells Ch-5173, Ch-5179, and Ch-5180, respectively, the trend analysis was done for dissolved nitrate-N concentrations, not dissolved N. Statistically significant upward trends in concentrations of dissolved nitrate $\mathrm{N}$ were evident in water from well Ch-5173 on the western application area and wells Ch-5179 and Ch-5180 on the eastern application area (fig. 20). Because dissolved nitrate $\mathrm{N}$ made up 85 percent of dissolved $\mathrm{N}$ in water from well Ch-5183, the trend analysis was done for dissolved nitrate-N concentrations, not dissolved N. Statistically significant upward trends in concentrations of dissolved nitrate $\mathrm{N}$ were evident in water from control well Ch-5183. Because dis-

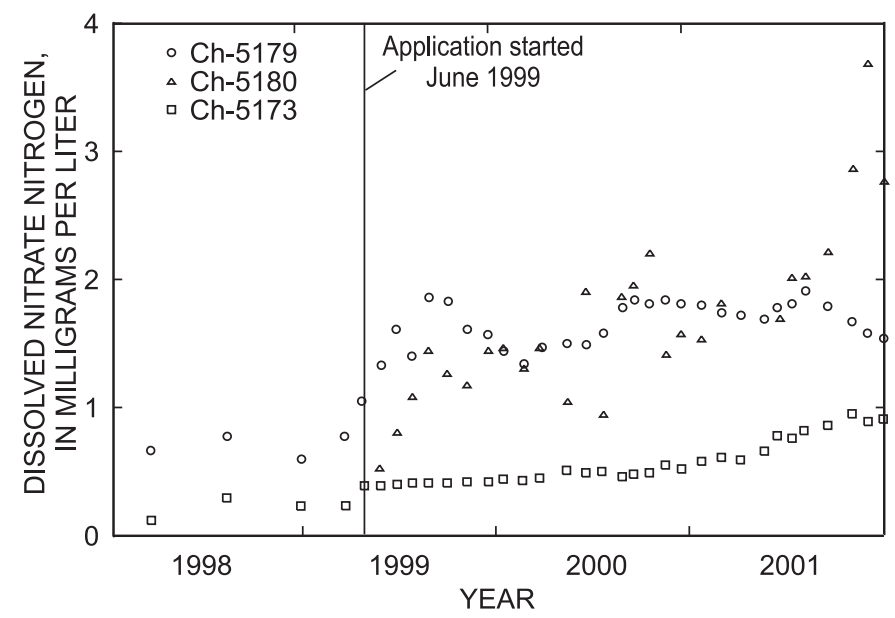

Figure 20. Concentrations of dissolved nitrate nitrogen in water from wells Ch-5179 and Ch-5180 on the eastern application area and well Ch-5173 on the western application area prior to and during effluent application, New Garden Township spray-irrigation site, Chester County, Pennsylvania, 1998-2001. solved nitrate $\mathrm{N}$ made up 97 and 88 percent of dissolved $\mathrm{N}$ in water from wells Ch-5177 and Ch-5181, respectively, the trend analysis was done for dissolved nitrate-N concentrations, not dissolved N. Statistically significant downward trends in concentrations of dissolved nitrate $\mathrm{N}$ were evident in water from valley-bottom wells Ch-5177 and Ch-5181 (fig. 21). No time trends were evident for dissolved nitrite $\mathrm{N}$ and dissolved ammonia $\mathrm{N}$ in water from all wells completed in the shallow aquifer.

Spray-irrigated effluent increased the concentration of dissolved nitrate $\mathrm{N}$ in ground water in well $\mathrm{Ch}-5173$ on the western application hilltop area and wells Ch-5179 and Ch-5180 on the eastern application area. The distribution of concentrations of dissolved nitrate $\mathrm{N}$ in monitor wells $\mathrm{Ch}-5173$, Ch-5175, and Ch-5179 prior to and during effluent application are shown in figure 22. The percentage increase in median concentrations of dissolved nitrate $\mathrm{N}$ for water collected from wells Ch-5173, Ch-5175, and Ch-5179 prior to and during effluent application was 115,7 , and 155 percent, respectively; the percentage increase in median concentrations of dissolved nitrate $\mathrm{N}$ for water collected from control well Ch-5183 prior to and during effluent application was 18.3 percent. For water samples from well Ch-5180, concentrations of dissolved nitrate $\mathrm{N}$ at the start of effluent application were less than $1 \mathrm{mg} / \mathrm{L}$; concentrations of dissolved nitrate $\mathrm{N}$ steadily increased throughout the study period and were greater than $3 \mathrm{mg} / \mathrm{L}$ at the end of the study period. The median concentration of dissolved nitrate $\mathrm{N}$ in the effluent applied to the surface in spray irrigation was $5.8 \mathrm{mg} / \mathrm{L}$.

Spray-irrigated effluent did not increase the concentration of dissolved nitrate $\mathrm{N}$ in well $\mathrm{Ch}-5175$ on the western hillside application area during the study period. Perhaps because of the less-permeable higher clay content in the unconsolidated mate-

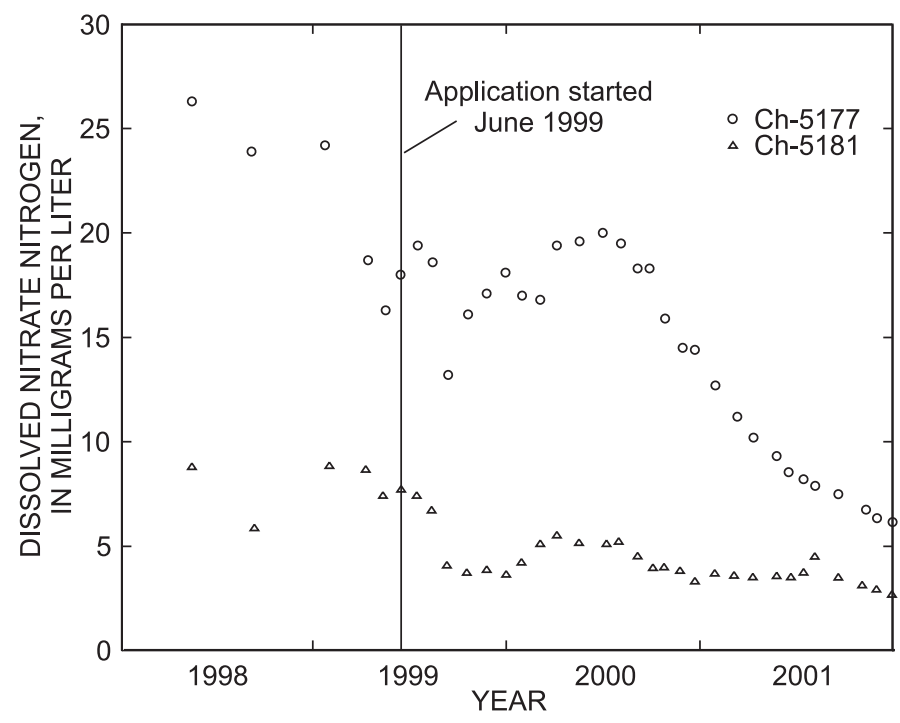

Figure 21. Concentrations of nitrate nitrogen in water from wells Ch-5177 and Ch-5181 in the valley-bottom area prior to and during effluent application, New Garden Township spray-irrigation site, Chester County, Pennsylvania, 1998-2001. 
Table 18. Summary of Wilcoxon rank-sum test, Mann-Kendall test for trends, and median concentrations of dissolved nitrogen species in water from shallow monitor wells collected prior to and during effluent application, New Garden Township spray-irrigation site, Chester County, Pennsylvania, May 1998 through December 2001.

[All constituents are in milligrams per liter. Shaded areas indicate a significant difference between water samples collected prior to and during effluent application according to Wilcoxon rank-sum test results. —, no significant trend; U, significant upward trend; D, significant downward trend; N, no samples collected; <, less than]

\begin{tabular}{|c|c|c|c|c|c|c|c|c|c|c|}
\hline \multirow{4}{*}{ Constituent } & \multicolumn{10}{|c|}{ Western application area } \\
\hline & \multicolumn{5}{|c|}{ Ch-5173 (Hilltop) } & \multicolumn{5}{|c|}{ Ch-5175 (Hillside) } \\
\hline & \multicolumn{2}{|c|}{ Median } & \multicolumn{3}{|c|}{ Mann-Kendall trend } & \multicolumn{2}{|c|}{ Median } & \multicolumn{3}{|c|}{ Mann-Kendall trend } \\
\hline & $\begin{array}{l}\text { Prior to } \\
\text { appli- } \\
\text { cation }\end{array}$ & $\begin{array}{l}\text { During } \\
\text { appli- } \\
\text { cation }\end{array}$ & Trend & $\begin{array}{c}\text { Kendall's } \\
\text { tau }\end{array}$ & $p$-value & $\begin{array}{l}\text { Prior to } \\
\text { appli- } \\
\text { cation }\end{array}$ & $\begin{array}{l}\text { During } \\
\text { appli- } \\
\text { cation }\end{array}$ & Trend & $\begin{array}{c}\text { Kendall's } \\
\text { tau }\end{array}$ & $p$-value \\
\hline Number of samples & 5 & 30 & & & & 5 & 30 & & & \\
\hline Dissolved nitrate nitrogen & .23 & .50 & $\mathrm{U}$ & +0.93 & 0.0000 & .77 & .83 & - & - & - \\
\hline Dissolved nitrite nitrogen & $<.01$ & $<.04$ & - & - & - & $<.01$ & $<.04$ & - & - & - \\
\hline Dissolved ammonia nitrogen & $<.02$ & $<.02$ & - & - & - & $<.02$ & $<.02$ & - & - & - \\
\hline \multirow{4}{*}{ Constituent } & \multicolumn{10}{|c|}{ Eastern application area } \\
\hline & \multicolumn{5}{|c|}{ Ch-5180 (Hilltop) } & \multicolumn{5}{|c|}{ Ch-5179 (Hillside) } \\
\hline & \multicolumn{2}{|c|}{ Median } & \multicolumn{3}{|c|}{ Mann-Kendall trend } & \multicolumn{2}{|c|}{ Median } & \multicolumn{3}{|c|}{ Mann-Kendall trend } \\
\hline & $\begin{array}{l}\text { Prior to } \\
\text { appli- } \\
\text { cation }\end{array}$ & $\begin{array}{l}\text { During } \\
\text { appli- } \\
\text { cation }\end{array}$ & Trend & $\begin{array}{c}\text { Kendall's } \\
\text { tau }\end{array}$ & $p$-value & $\begin{array}{l}\text { Prior to } \\
\text { appli- } \\
\text { cation }\end{array}$ & $\begin{array}{l}\text { During } \\
\text { appli- } \\
\text { cation }\end{array}$ & Trend & $\begin{array}{c}\text { Kendall's } \\
\text { tau }\end{array}$ & $p$-value \\
\hline Number of samples & $\mathrm{N}$ & 27 & & & & 5 & 29 & & & \\
\hline Dissolved nitrate nitrogen & $\mathrm{N}$ & 1.5 & $\mathrm{U}$ & +0.68 & 0.0000 & .66 & 1.69 & $\mathrm{U}$ & +0.41 & 0.0006 \\
\hline Dissolved nitrite nitrogen & $\mathrm{N}$ & $<.04$ & - & - & - & $<.01$ & $<.04$ & - & - & - \\
\hline \multirow[t]{5}{*}{ Dissolved ammonia nitrogen } & $\mathrm{N}$ & $<.02$ & - & - & - & $<.02$ & $<.02$ & - & - & - \\
\hline & \multicolumn{10}{|c|}{ Downgradient valley bottom } \\
\hline & \multicolumn{5}{|c|}{ Ch-5177 } & \multicolumn{5}{|c|}{ Ch-5181 } \\
\hline & \multicolumn{2}{|c|}{ Median } & \multicolumn{3}{|c|}{ Mann-Kendall trend } & \multicolumn{2}{|c|}{ Median } & \multicolumn{3}{|c|}{ Mann-Kendall trend } \\
\hline & $\begin{array}{l}\text { Prior to } \\
\text { appli- } \\
\text { cation }\end{array}$ & $\begin{array}{l}\text { During } \\
\text { appli- } \\
\text { cation }\end{array}$ & Trend & $\begin{array}{c}\text { Kendall's } \\
\text { tau }\end{array}$ & $p$-value & $\begin{array}{l}\text { Prior to } \\
\text { appli- } \\
\text { cation }\end{array}$ & $\begin{array}{l}\text { During } \\
\text { appli- } \\
\text { cation }\end{array}$ & Trend & $\begin{array}{c}\text { Kendall's } \\
\text { tau }\end{array}$ & $p$-value \\
\hline Number of samples & 5 & 30 & & & & 5 & 29 & & & \\
\hline Dissolved nitrate nitrogen & 23.9 & 15.2 & $\mathrm{D}$ & -0.68 & 0.0000 & 8.65 & 3.86 & $\mathrm{D}$ & -0.68 & 0.0000 \\
\hline Dissolved nitrite nitrogen & $<.01$ & $<.04$ & - & - & - & .04 & $<.04$ & - & - & - \\
\hline Dissolved ammonia nitrogen & $<.02$ & $<.02$ & - & - & - & .11 & $<.02$ & - & - & - \\
\hline \multirow{4}{*}{ Constituent } & \multicolumn{5}{|c|}{ Control area } & & & & & \\
\hline & \multicolumn{5}{|c|}{ Ch-5183 } & & & & & \\
\hline & \multicolumn{2}{|c|}{ Median } & Mar & In-Kendall t & trend & & & & & \\
\hline & $\begin{array}{l}\text { Prior to } \\
\text { appli- } \\
\text { cation }\end{array}$ & $\begin{array}{l}\text { During } \\
\text { appli- } \\
\text { cation }\end{array}$ & Trend & $\begin{array}{c}\text { Kendall's } \\
\text { tau }\end{array}$ & $p$-value & & & & & \\
\hline Number of samples & 5 & 29 & & & & & & & & \\
\hline Dissolved nitrate nitrogen & 2.89 & 3.42 & $\mathrm{U}$ & +0.71 & 0.0000 & & & & & \\
\hline Dissolved nitrite nitrogen & $<.01$ & $<.04$ & - & - & - & & & & & \\
\hline Dissolved ammonia nitrogen & $<.02$ & $<.02$ & - & - & - & & & & & \\
\hline
\end{tabular}




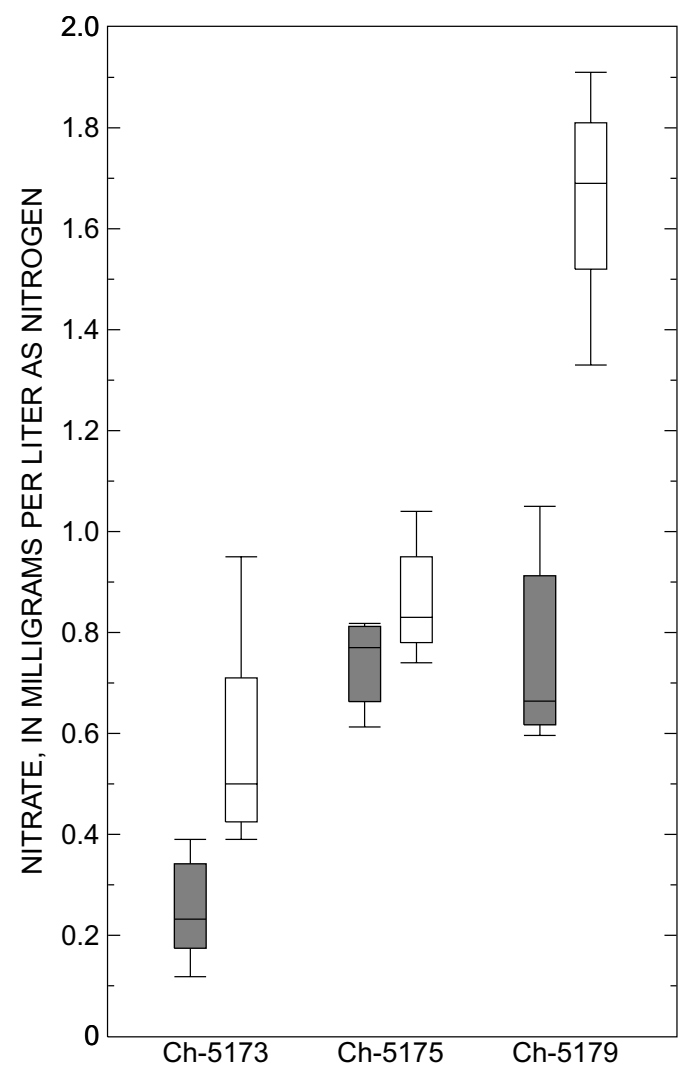

EXPLANATION

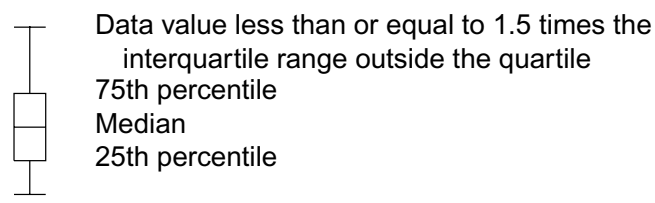

PRIOR TO EFFLUENT APPLICATION

DURING EFFLUENT APPLICATION

Figure 22. Concentrations of nitrate nitrogen in water from monitor wells $\mathrm{Ch}-5173$ and $\mathrm{Ch}-5175$ on the western application area and well Ch-5179 on the eastern application area prior to and during effluent application, New Garden Township spray-irrigation site, Chester County, Pennsylvania, 1998-2001.

rial near well Ch-5175, water has longer residence time in the soil, and nitrate $\mathrm{N}$ is consumed by plant and microbial activity.

Concentrations of dissolved nitrate $\mathrm{N}$ in valley-bottom wells Ch-5177 and Ch-5181 decreased (fig. 23). The hydraulic loading of the effluent, which contains a lower concentration of $\mathrm{N}$, was flushing the nitrate $\mathrm{N}$ from the areas of spent mushroom substrate and lowering the nitrate- $\mathrm{N}$ concentrations. The median concentrations of nitrate $\mathrm{N}$ for water collected from

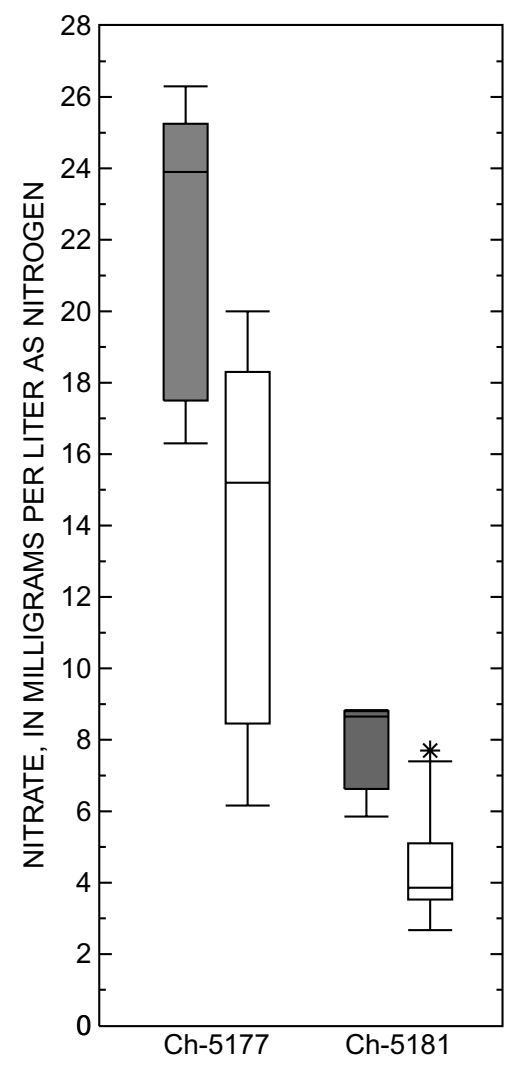

\section{EXPLANATION}

* Outlier data value less than or equal to 3 interquartile range outside the quartile

Data value less than or equal to 1.5 times the interquartile range outside the quartile 75th percentile

Median

25th percentile

PRIOR TO EFFLUENT APPLICATION DURING EFFLUENT APPLICATION

Figure 23. Concentrations of dissolved nitrate nitrogen in water from wells Ch-5177 and Ch-5181 in the valley-bottom area prior to and during effluent application, New Garden Township spray-irrigation site, Chester County, Pennsylvania, 1998-2001.

wells Ch-5177 and Ch-5181 during effluent application were 15.0 and $3.9 \mathrm{mg} / \mathrm{L}$, respectively.

The median concentrations of dissolved $\mathrm{P}$ and dissolved orthophosphate $\mathrm{P}$ in samples collected from wells in the shallow aquifer during effluent application were $<0.05 \mathrm{mg} / \mathrm{L}$. The USGS NWQL reporting limit for dissolved P was $0.05 \mathrm{mg} / \mathrm{L}$, and the reporting limit for dissolved orthophosphate $\mathrm{P}$ was $0.01 \mathrm{mg} / \mathrm{L}$. The PaDEP Laboratory reporting limit for dissolved $\mathrm{P}$ and dissolved orthophosphate $\mathrm{P}$ was $0.01 \mathrm{mg} / \mathrm{L}$. Concentra- 


\section{Effects of Spray-Irrigated Effluent on Water Quantity and Quality, and the Fate and Transport of Nitrogen}

tions of dissolved $\mathrm{P}$ and dissolved orthophosphate $\mathrm{P}$ from water samples collected from shallow wells prior to and during effluent application are summarized in table 19. Concentrations of dissolved $\mathrm{P}$ and dissolved orthophosphate $\mathrm{P}$ in all shallow wells decreased over time. Concentrations of dissolved $\mathrm{P}$ in water from well Ch-5179 in the eastern application area and control well Ch-5183 are shown in figure 24 . The median concentrations of dissolved $\mathrm{P}$ and dissolved orthophosphate $\mathrm{P}$ in the effluent applied to the site were 2.52 and $2.04 \mathrm{mg} / \mathrm{L}$, respectively. The dissolved $\mathrm{P}$ and dissolved orthophosphate $\mathrm{P}$ constituents in the effluent were not affecting shallow ground water at the site

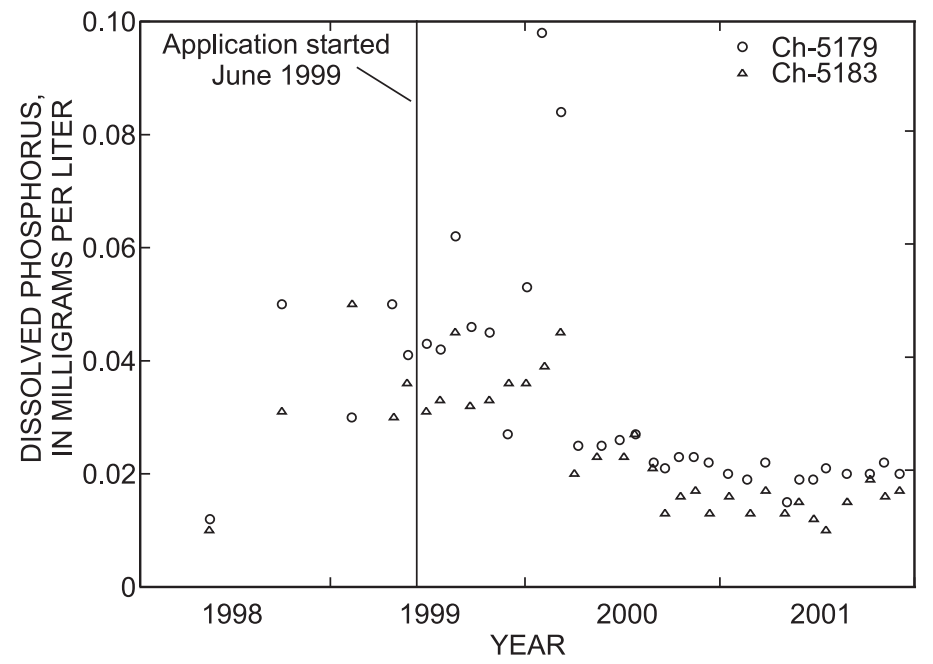

Figure 24. Concentrations of dissolved phosphorus in water from well Ch-5179 on the eastern application area and control well Ch-5183, New Garden Township spray-irrigation site, Chester County, Pennsylvania, 1998-2001.

Table 19. Summary of concentrations of dissolved phosphorus and dissolved orthophosphate phosphorus in water from shallow wells collected prior to and during effluent application, New Garden Township spray-irrigation site, Chester County, Pennsylvania, $1998-2001$.

[mg/L, milligrams per liter; <, less than; N, no samples collected]

\begin{tabular}{|c|c|c|c|c|c|c|c|c|c|c|}
\hline \multirow{3}{*}{$\begin{array}{c}\text { U.S. Geological } \\
\text { Survey } \\
\text { well-identification } \\
\text { number }\end{array}$} & \multirow{2}{*}{\multicolumn{2}{|c|}{$\begin{array}{c}\text { Number } \\
\text { of } \\
\text { samples }\end{array}$}} & \multicolumn{4}{|c|}{ Dissolved phosphorus } & \multicolumn{4}{|c|}{ Dissolved orthophosphate phosphorus } \\
\hline & & & \multirow{2}{*}{$\begin{array}{l}\text { Median } \\
\text { prior to } \\
\text { application } \\
\text { (mg/L) }\end{array}$} & \multicolumn{3}{|c|}{ During application } & \multirow{2}{*}{$\begin{array}{l}\text { Median } \\
\text { prior to } \\
\text { application } \\
\text { (mg/L) }\end{array}$} & \multicolumn{3}{|c|}{ During application } \\
\hline & $\begin{array}{l}\text { Prior to } \\
\text { appli- } \\
\text { cation }\end{array}$ & $\begin{array}{l}\text { During } \\
\text { appli- } \\
\text { cation }\end{array}$ & & $\begin{array}{l}\text { Minimum } \\
\text { (mg/L) }\end{array}$ & $\begin{array}{l}\text { Median } \\
\text { (mg/L) }\end{array}$ & $\begin{array}{c}\text { Maximum } \\
(\mathrm{mg} / \mathrm{L})\end{array}$ & & $\begin{array}{l}\text { Minimum } \\
(\mathrm{mg} / \mathrm{L})\end{array}$ & $\begin{array}{l}\text { Median } \\
\text { (mg/L) }\end{array}$ & $\begin{array}{c}\text { Maximum } \\
\text { (mg/L) }\end{array}$ \\
\hline${ }^{1} \mathrm{Ch}-5173$ & 5 & 30 & $<0.05$ & $<0.01$ & 0.02 & 0.08 & 0.01 & $<0.01$ & 0.01 & 0.03 \\
\hline${ }^{1} \mathrm{Ch}-5175$ & 5 & 30 & .08 & .04 & .05 & .19 & .05 & .03 & .05 & .13 \\
\hline${ }^{1} \mathrm{Ch}-5177$ & 5 & 30 & $<.05$ & .02 & .03 & .09 & .03 & $<.01$ & .02 & .04 \\
\hline${ }^{2} \mathrm{Ch}-5179$ & 5 & 29 & $<.05$ & .02 & .02 & .10 & .03 & $<.01$ & .022 & .03 \\
\hline${ }^{2} \mathrm{Ch}-5180$ & $\mathrm{~N}$ & 27 & $\mathrm{~N}$ & $<.01$ & .02 & .14 & $\mathrm{~N}$ & $<.01$ & $<.01$ & .25 \\
\hline${ }^{2} \mathrm{Ch}-5181$ & 5 & 29 & $<.05$ & $<.01$ & $<.01$ & .03 & $<.01$ & $<.01$ & $<.01$ & .014 \\
\hline${ }^{3} \mathrm{Ch}-5183$ & 5 & 29 & $<.05$ & $<.01$ & .02 & .05 & .02 & $<.01$ & .02 & .05 \\
\hline
\end{tabular}

${ }^{1}$ Monitor well on the western part of the application area.

${ }^{2}$ Monitor well on the eastern part of the application area.

${ }^{3}$ Control well. 


\section{Major and Minor lons}

Of all major and minor ions evaluated, increasing concentrations of $\mathrm{Cl}$ in water from shallow wells were the pervasive trend. Statistically significant upward trends in concentrations of $\mathrm{Cl}$ were evident in water samples from wells $\mathrm{Ch}-5173$, Ch-5179, Ch-5180, Ch-5177, and Ch-5183. Increasing concentrations of $\mathrm{Cl}$ indicated the spray-irrigated effluent was affecting ground water in the shallow aquifer. The median concentrations of major and minor ions in water samples collected from shallow monitor wells prior to and during effluent application and results of the Wilcoxon rank sum test and the Mann-Kendall test for trends are summarized in table 20 .

On the hilltop western application area, $\mathrm{Cl}$ concentrations in water from well Ch-5173 were increasing (fig. 25). Cl concentrations in water collected from well Ch-5173 prior to effluent application ranged from 1.3 to $1.7 \mathrm{mg} / \mathrm{L}$ and concentrations remained in that range until January 2000, 8 months after efflu-

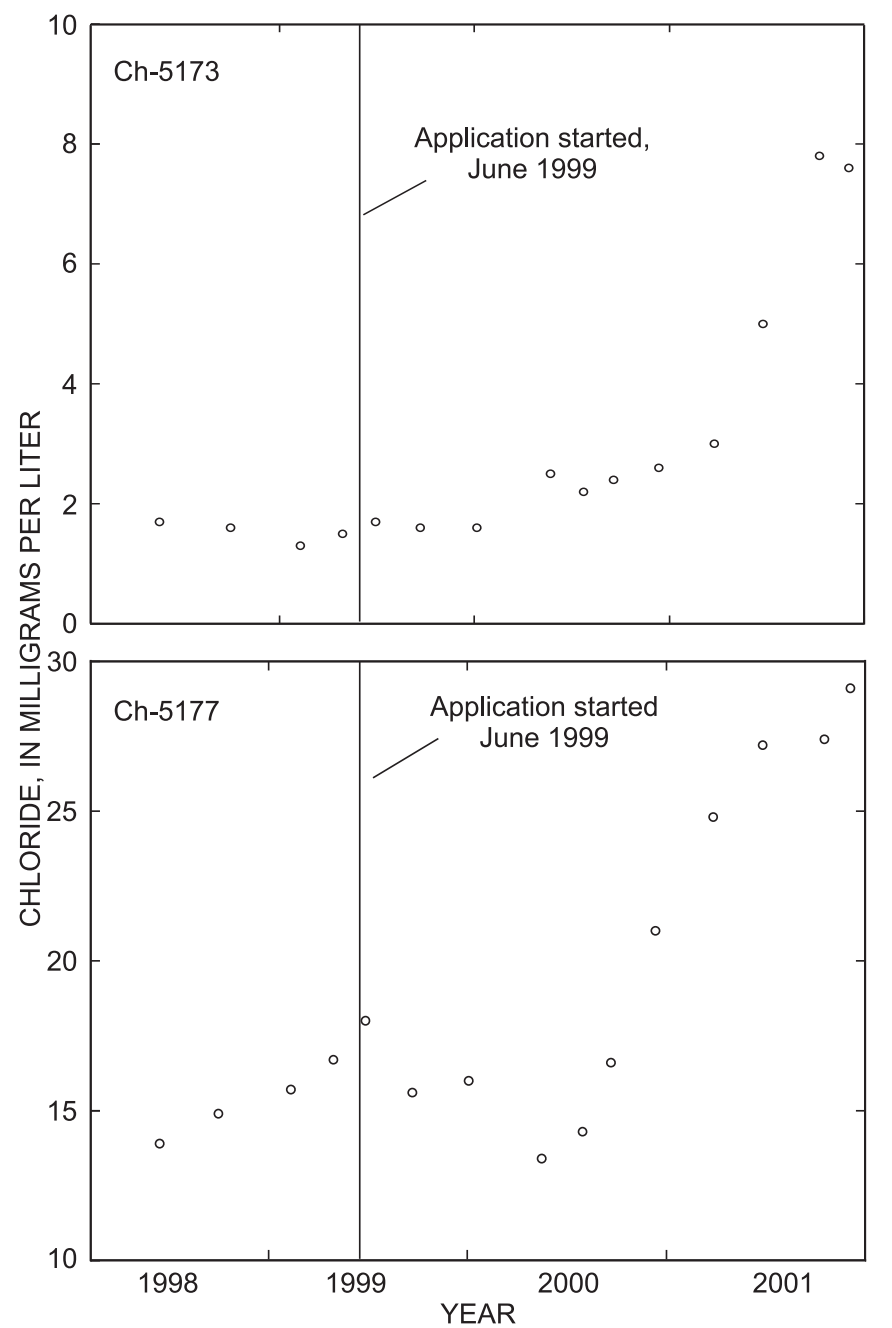

ent application began. During the 2000 calendar year, the $\mathrm{Cl}$ concentrations ranged from 2.2 to $2.6 \mathrm{mg} / \mathrm{L}$. During calendar year 2001, a marked increase in $\mathrm{Cl}$ concentrations occurred and increased from $3 \mathrm{mg} / \mathrm{L}$ in March 2001 to $7.6 \mathrm{mg} / \mathrm{L}$ in December 2001. The increase may be the start of the breakthrough of $\mathrm{Cl}$ that has occurred in wells Ch-5179 and Ch-5180 where the $\mathrm{Cl}$ concentrations in ground water increased to near the median $\mathrm{Cl}$ concentration of the spray-irrigated effluent (89.5 mg/L). However, no trend was evident in western hillside well Ch-5175. On the hilltop and hillside eastern application area, $\mathrm{Cl}$ concentrations in water from wells Ch-5180 and Ch-5179 increased (fig. 25). The distributions of concentrations of dissolved $\mathrm{Cl}$ in monitor wells Ch-5173, Ch-5175, and Ch-5179 prior to and during effluent application are shown in figure 26. Concentrations of $\mathrm{Cl}$ did not increase on the western hillside application area because of the less permeable sands and clays present in this area near monitor well Ch-5175.

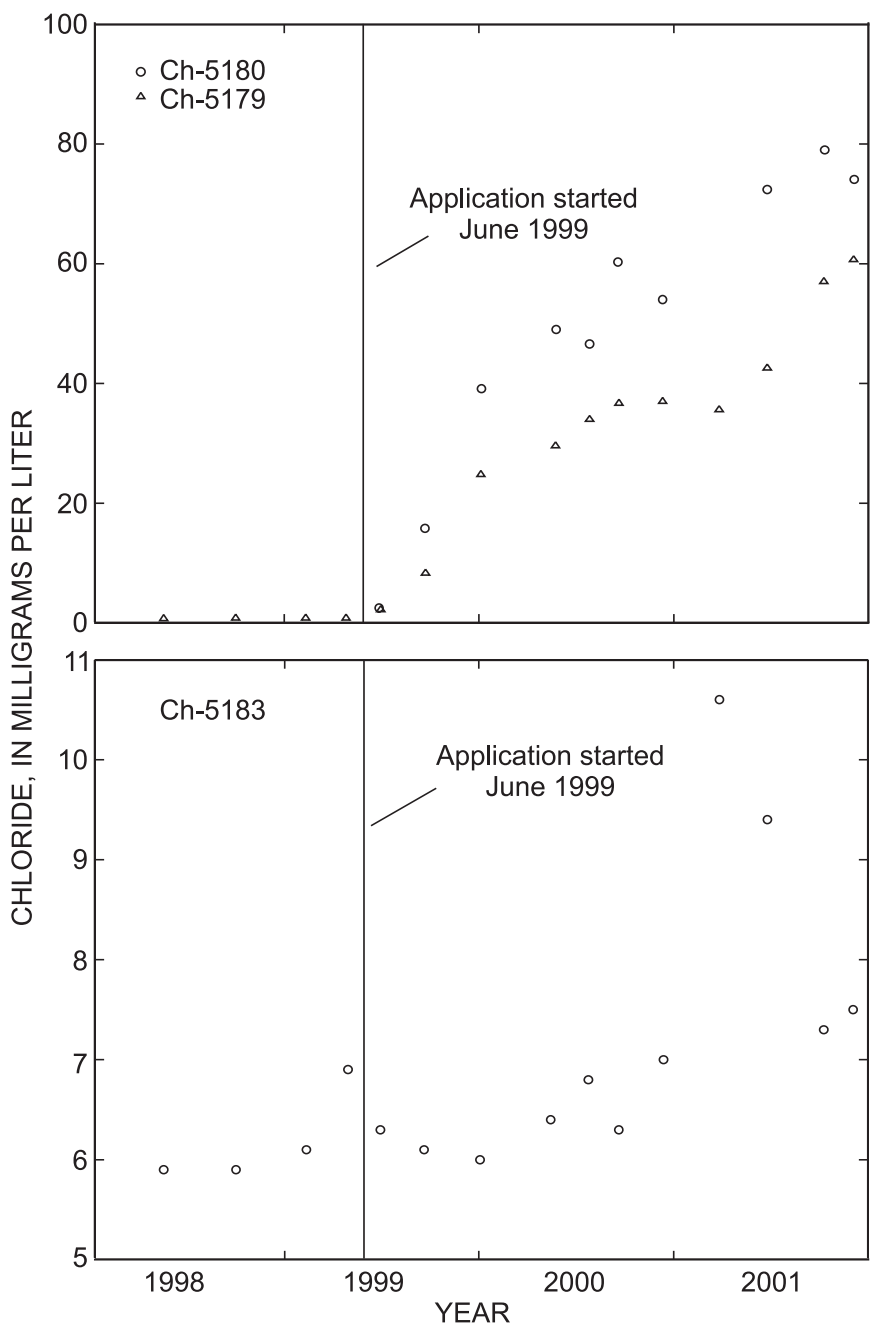

Figure 25. Concentrations of chloride in water from shallow monitor wells Ch-5173 (western application area hilltop well), Ch-5180 (eastern application area hilltop well), Ch-5179 (eastern application area hillside well), Ch-5177 (downgradient valley-bottom well), and Ch-5183 (control area well), New Garden Township spray-irrigation site, Chester County, Pennsylvania, $1998-2001$. 


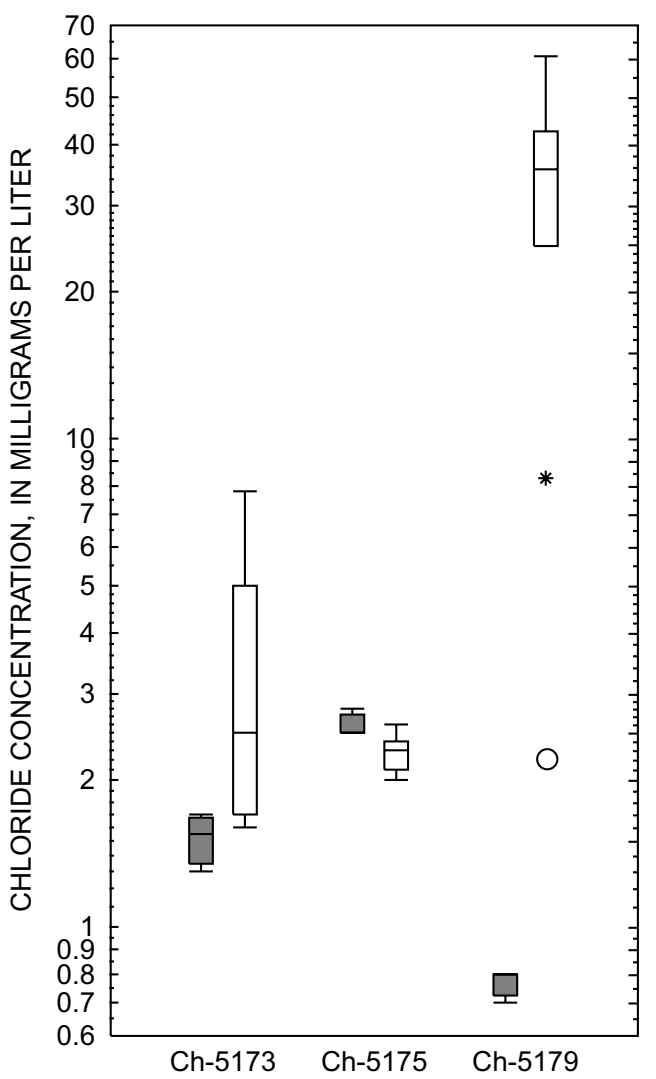

EXPLANATION

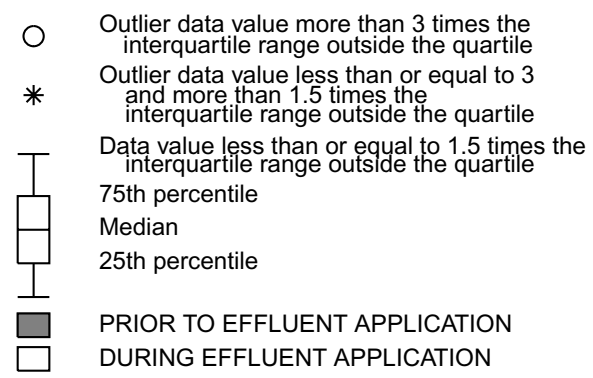

Figure 26. Concentrations of chloride in water from wells Ch-5173, Ch-5175, and Ch-5179 collected prior to and during effluent application, New Garden Township spray-irrigation site, Chester County, Pennsylvania. 
Table 20. Summary of Wilcoxon rank-sum test, Mann-Kendall test for trends, and median concentrations of dissolved major and minor ions in water from shallow wells collected prior to and during effluent application, New Garden Township spray-irrigation site, Chester County, Pennsylvania, May 1998 through December 2001.

[Shaded areas indicate a significant difference between water samples collected prior to and during effluent application according to Wilcoxon rank-sum test results. mg/L, milligrams per liter; $\mu \mathrm{g} / \mathrm{L}$, micrograms per liter; - , no significant trend; $\mathrm{U}$, significant upward trend; D, significant downward trend; N, no samples collected; <, less than]

\begin{tabular}{|c|c|c|c|c|c|c|c|c|c|c|}
\hline \multirow{4}{*}{ Constituent } & \multicolumn{10}{|c|}{ Western application area } \\
\hline & \multicolumn{5}{|c|}{ Ch-5173 (Hilltop) } & \multicolumn{5}{|c|}{ Ch-5175 (Hillside) } \\
\hline & \multicolumn{2}{|c|}{ Median } & \multicolumn{3}{|c|}{ Mann-Kendall trend } & \multicolumn{2}{|c|}{ Median } & \multicolumn{3}{|c|}{ Mann-Kendall trend } \\
\hline & $\begin{array}{l}\text { Prior to } \\
\text { appli- } \\
\text { cation }\end{array}$ & $\begin{array}{l}\text { During } \\
\text { appli- } \\
\text { cation }\end{array}$ & Trend & $\begin{array}{c}\text { Kendall's } \\
\text { tau }\end{array}$ & $p$-value & $\begin{array}{l}\text { Prior to } \\
\text { appli- } \\
\text { cation }\end{array}$ & $\begin{array}{l}\text { During } \\
\text { appli- } \\
\text { cation }\end{array}$ & Trend & $\begin{array}{c}\text { Kendall's } \\
\text { tau }\end{array}$ & $p$-value \\
\hline Number of samples & 4 & 11 & & & & 4 & 11 & & & \\
\hline Calcium (mg/L) & 18 & 12 & - & - & - & 13 & 13 & - & - & - \\
\hline Magnesium (mg/L) & 3.2 & 2.8 & - & - & - & 2.4 & 2.5 & - & - & - \\
\hline Sodium (mg/L) & 6.0 & 6.5 & - & - & - & 8.0 & 5.5 & - & - & - \\
\hline Potassium (mg/L) & 5.2 & 3.6 & - & - & - & 1.6 & 1.5 & - & - & - \\
\hline Chloride (mg/L) & 1.6 & 2.5 & $\mathrm{U}$ & +0.73 & 0.0002 & 2.5 & 2.3 & - & - & - \\
\hline Fluoride (mg/L) & $<.10$ & $<.20$ & - & - & - & $<.10$ & $<.20$ & - & - & - \\
\hline Sulfate (mg/L) & 41 & 33 & $\mathrm{D}$ & -.82 & .0000 & 21 & 21 & - & - & - \\
\hline Silica (mg/L) & 20 & 20 & - & - & - & 21 & 21 & - & - & - \\
\hline Bromide (mg/L) & $\mathrm{N}$ & $<.20$ & - & - & - & $\mathrm{N}$ & $<.20$ & - & - & - \\
\hline Boron $(\mu \mathrm{g} / \mathrm{L})$ & $<16$ & $<200$ & - & - & - & $<16$ & $<200$ & - & - & - \\
\hline Iron $(\mu \mathrm{g} / \mathrm{L})$ & 35 & 20 & - & - & - & $<10$ & $<20$ & - & - & - \\
\hline Manganese $(\mu \mathrm{g} / \mathrm{L})$ & 59 & 21 & - & - & - & 14 & $<10$ & - & - & - \\
\hline \multirow[t]{3}{*}{ Zinc $(\mu \mathrm{g} / \mathrm{L})$} & 164 & 18 & - & - & - & 178 & $<10$ & - & - & - \\
\hline & \multicolumn{10}{|c|}{ Eastern application area } \\
\hline & \multicolumn{5}{|c|}{ Ch-5180 (Hilltop) } & \multicolumn{5}{|c|}{ Ch-5179 (Hillside) } \\
\hline \multirow[t]{2}{*}{ Constituent } & \multicolumn{2}{|c|}{ Median } & \multicolumn{3}{|c|}{ Mann-Kendall trend } & \multicolumn{2}{|c|}{ Median } & \multicolumn{3}{|c|}{ Mann-Kendall trend } \\
\hline & $\begin{array}{l}\text { Prior to } \\
\text { appli- } \\
\text { cation }\end{array}$ & $\begin{array}{l}\text { During } \\
\text { appli- } \\
\text { cation }\end{array}$ & Trend & $\begin{array}{l}\text { Kendall's } \\
\text { tau }\end{array}$ & $p$-value & $\begin{array}{l}\text { Prior to } \\
\text { appli- } \\
\text { cation }\end{array}$ & $\begin{array}{l}\text { During } \\
\text { appli- } \\
\text { cation }\end{array}$ & Trend & $\begin{array}{c}\text { Kendall's } \\
\text { tau }\end{array}$ & $p$-value \\
\hline Number of samples & $\mathrm{N}$ & 10 & & & & 4 & 11 & & & \\
\hline Calcium (mg/L) & $\mathrm{N}$ & 25 & $\mathrm{U}$ & +0.82 & 0.0013 & 12 & 25 & $\mathrm{U}$ & +0.70 & 0.0004 \\
\hline Magnesium (mg/L) & $\mathrm{N}$ & 14 & $\mathrm{U}$ & +.91 & .0003 & 4.1 & 9.2 & $\mathrm{U}$ & +.80 & .0000 \\
\hline Sodium (mg/L) & $\mathrm{N}$ & 4.9 & $\mathrm{U}$ & +.96 & .0002 & 4.1 & 4.9 & $\mathrm{U}$ & +.84 & .0000 \\
\hline Potassium (mg/L) & $\mathrm{N}$ & 2.4 & $\mathrm{U}$ & +.78 & .0024 & 2.0 & 2.5 & $\mathrm{U}$ & +.80 & .0000 \\
\hline Chloride (mg/L) & $\mathrm{N}$ & 52 & $\mathrm{U}$ & +.87 & .0007 & .80 & 36 & $\mathrm{U}$ & +.93 & .0000 \\
\hline Fluoride (mg/L) & $\mathrm{N}$ & $<.20$ & - & - & - & $<.10$ & $<.20$ & - & - & - \\
\hline Sulfate (mg/L) & $\mathrm{N}$ & 15 & $\mathrm{U}$ & +.64 & .0123 & 33 & 22 & D & -.74 & .0001 \\
\hline Silica (mg/L) & $\mathrm{N}$ & 8.2 & - & - & - & 17 & 15 & $\mathrm{D}$ & -.41 & .0377 \\
\hline Bromide (mg/L) & $\mathrm{N}$ & $<.20$ & - & - & - & $\mathrm{N}$ & $<.20$ & - & - & - \\
\hline Boron $(\mu \mathrm{g} / \mathrm{L})$ & $\mathrm{N}$ & $<200$ & - & - & - & $<16$ & $<200$ & - & - & - \\
\hline Iron $(\mu \mathrm{g} / \mathrm{L})$ & $\mathrm{N}$ & $<20$ & - & - & - & $<10$ & $<20$ & - & - & - \\
\hline Manganese $(\mu \mathrm{g} / \mathrm{L})$ & $\mathrm{N}$ & $<10$ & - & - & - & $<4$ & $<10$ & - & - & - \\
\hline $\operatorname{Zinc}(\mu \mathrm{g} / \mathrm{L})$ & $\mathrm{N}$ & 54 & - & - & - & 21 & $<10$ & - & - & - \\
\hline
\end{tabular}


Table 20. Summary of Wilcoxon rank-sum test, Mann-Kendall test for trends, and median concentrations of dissolved major and minor ions in water from shallow wells collected prior to and during effluent application, New Garden Township spray-irrigation site, Chester County, Pennsylvania, May 1998 through December 2001.—Continued

[Shaded areas indicate a significant difference between water samples collected prior to and during effluent application according to Wilcoxon rank-sum test results. mg/L, milligrams per liter; $\mu \mathrm{g} / \mathrm{L}$, micrograms per liter; - , no significant trend; $\mathrm{U}$, significant upward trend; $\mathrm{D}$, significant downward trend; N, no samples collected; <, less than]

\begin{tabular}{|c|c|c|c|c|c|c|c|c|c|c|}
\hline \multirow{4}{*}{ Constituent } & \multicolumn{10}{|c|}{ Valley bottom } \\
\hline & \multicolumn{5}{|c|}{ Ch-5177 } & \multicolumn{5}{|c|}{ Ch-5181 } \\
\hline & \multicolumn{2}{|c|}{ Median } & \multicolumn{3}{|c|}{ Mann-Kendall trend } & \multicolumn{2}{|c|}{ Median } & \multicolumn{3}{|c|}{ Mann-Kendall trend } \\
\hline & $\begin{array}{l}\text { Prior to } \\
\text { appli- } \\
\text { cation }\end{array}$ & $\begin{array}{l}\text { During } \\
\text { appli- } \\
\text { cation }\end{array}$ & Trend & $\begin{array}{l}\text { Kendall's } \\
\text { tau }\end{array}$ & $p$-value & $\begin{array}{l}\text { Prior to } \\
\text { appli- } \\
\text { cation }\end{array}$ & $\begin{array}{l}\text { During } \\
\text { appli- } \\
\text { cation }\end{array}$ & Trend & $\begin{array}{c}\text { Kendall's } \\
\text { tau }\end{array}$ & $p$-value \\
\hline Number of samples & 4 & 11 & & & & 4 & 11 & & & \\
\hline Calcium (mg/L) & 48 & 47 & - & - & - & 27 & 27 & - & - & - \\
\hline Magnesium (mg/L) & 10 & 9.8 & - & - & - & 6.5 & 6.5 & - & - & - \\
\hline Sodium (mg/L) & 12 & 11 & - & - & - & 7.2 & 7.3 & - & - & - \\
\hline Potassium (mg/L) & 2.3 & 2.2 & - & - & - & 6.4 & 5.4 & - & - & - \\
\hline Chloride (mg/L) & 15 & 18 & $\mathrm{U}$ & +0.62 & 0.0015 & 7.5 & 7.0 & - & - & - \\
\hline Fluoride (mg/L) & $<.10$ & $<.20$ & - & - & - & $<.10$ & $<.20$ & - & - & - \\
\hline Sulfate (mg/L) & 50 & 56 & $\mathrm{U}$ & +.70 & .0001 & 36 & 33 & $\mathrm{D}$ & -0.45 & 0.0228 \\
\hline Silica (mg/L) & 23 & 23 & - & - & - & 19 & 17 & - & - & - \\
\hline Bromide (mg/L) & $\mathrm{N}$ & $<.20$ & - & - & - & $\mathrm{N}$ & $<.20$ & - & - & - \\
\hline Boron $(\mu \mathrm{g} / \mathrm{L})$ & $<16$ & $<200$ & - & - & - & $<16$ & $<200$ & - & - & - \\
\hline Iron $(\mu \mathrm{g} / \mathrm{L})$ & $<10$ & $<20$ & - & - & - & 220 & 60 & - & - & - \\
\hline Manganese $(\mu \mathrm{g} / \mathrm{L})$ & $<4$ & $<10$ & - & - & - & 160 & 54 & - & - & - \\
\hline Zinc $(\mu \mathrm{g} / \mathrm{L})$ & 164 & 18 & - & - & - & 61 & 16 & - & - & - \\
\hline \multirow{4}{*}{ Constituent } & \multicolumn{5}{|c|}{ Control area } & & & & & \\
\hline & \multicolumn{5}{|c|}{ Ch-5183 } & & & & & \\
\hline & \multicolumn{2}{|c|}{ Median } & \multicolumn{3}{|c|}{ Mann-Kendall trend } & & & & & \\
\hline & $\begin{array}{l}\text { Prior to } \\
\text { appli- } \\
\text { cation }\end{array}$ & $\begin{array}{l}\text { During } \\
\text { appli- } \\
\text { cation }\end{array}$ & Trend & $\begin{array}{c}\text { Kendall's } \\
\text { tau }\end{array}$ & $p$-value & & & & & \\
\hline Number of samples & 4 & 11 & & & & & & & & \\
\hline Calcium (mg/L) & 28 & 30 & $\mathrm{U}$ & +0.77 & 0.0001 & & & & & \\
\hline Magnesium (mg/L) & 3.3 & 3.9 & $\mathrm{U}$ & +.77 & .0001 & & & & & \\
\hline Sodium (mg/L) & 4.2 & 4.5 & - & - & - & & & & & \\
\hline Potassium (mg/L) & 2.1 & 2.1 & - & - & - & & & & & \\
\hline Chloride (mg/L) & 6.0 & 6.8 & $\mathrm{U}$ & +.65 & .0009 & & & & & \\
\hline Fluoride (mg/L) & $<.10$ & $<.20$ & - & - & - & & & & & \\
\hline Sulfate (mg/L) & 1.6 & 2.0 & - & - & - & & & & & \\
\hline Silica (mg/L) & 21 & 22 & - & - & - & & & & & \\
\hline Bromide (mg/L) & $\mathrm{N}$ & $<.20$ & - & - & - & & & & & \\
\hline Boron $(\mu \mathrm{g} / \mathrm{L})$ & $<16$ & $<200$ & - & - & - & & & & & \\
\hline Iron $(\mu \mathrm{g} / \mathrm{L})$ & $<10$ & $<20$ & - & - & - & & & & & \\
\hline
\end{tabular}


In water samples from the valley-bottom well, Ch-5177, which is in the spent mushroom substrate area, concentrations of $\mathrm{Cl}$ increased (fig. 25). The increase in $\mathrm{Cl}$ concentrations, which occurs at the end of calendar year 2000, was probably a result of the breakthrough of applied effluent in the valley-bottom area. $\mathrm{Cl}$ concentrations in water from control well Ch-5183 also increased (fig. 25). The cause of the slight increase in median concentrations $(6.0$ to $6.8 \mathrm{mg} / \mathrm{L})$ prior to and during effluent application is unknown but may have been the result of the limited spraying of effluent on this area.

Statistically significant upward trends in concentrations of calcium, magnesium, sodium, and potassium were evident in water from eastern application area wells, Ch-5179 and Ch-5180 (table 20). The spray-irrigated effluent increased concentrations of these ions in the eastern part of the application area. Median concentrations of calcium, magnesium, sodium, and potassium in the effluent were $39.9,17.5,56.5,16.6 \mathrm{mg} / \mathrm{L}$, respectively, and the median concentrations of calcium, magnesium, sodium, and potassium in water from well Ch-5179 prior to spray-irrigated effluent being applied were 12.0, 4.1, 4.1, and $2.0 \mathrm{mg} / \mathrm{L}$, respectively. The median concentrations of calcium, magnesium, sodium, and potassium in water collected from we Ch-5179 during effluent application were 25, 9.2, 4.9, and $2.5 \mathrm{mg} / \mathrm{L}$, respectively. The increases are a result of the low clay content and thickness of the unconsolidated material in this area.

A statistically significant upward trend in concentrations of calcium and magnesium also was evident in water from control well Ch-5183, but the percentage difference between concentrations measured prior to and during effluent application was much smaller than in water from well Ch-5179. The percentage increase in median concentrations of calcium and magnesium for water collected from well Ch-5179 prior to and during effluent application was 108 and 124 percent, respectively; the percentage increase in median concentrations of calcium and magnesium for water collected from control well Ch-5183 prior to and during effluent application was 7 and 18 percent, respectively. Concentrations of potassium and sodium did not increase in water from control well Ch-5183.

\section{Metals and Other Trace Constituents}

The number of detections of metal and trace constituents in water samples from shallow monitor wells in the application area, the valley bottom, and the control area are summarized in table 21. Antimony, arsenic, cadmium, chromium, copper, lead, mercury, and selenium were not detected above the reporting limit in any water samples collected from shallow wells on the application area.

Barium and strontium were detected in water from all shallow wells (table 21). Both constituents occur naturally. In the Red Clay Creek watershed, median concentrations of barium and strontium in 16 water samples collected from wells completed in the felsic gneiss were 59 and $105 \mu \mathrm{g} / \mathrm{L}$, respectively (Senior, 1996). The average concentrations of barium and strontium in two effluent samples were 7.6 and
$124 \mu \mathrm{g} / \mathrm{L}$, respectively. The median concentrations of barium in water from wells completed in the shallow aquifer ranged from 39 to $141 \mu \mathrm{g} / \mathrm{L}$. In all water samples from shallow wells, concentrations of barium were above the concentration of barium in the effluent (Durlin and Schaffstall, 1999, 2000, 2001). Therefore, concentrations of barium are assumed to be from natural sources. The median concentrations of strontium in water from wells completed in the shallow aquifer ranged from 57 to $170 \mu \mathrm{g} / \mathrm{L}$. The average concentration of strontium in the effluent was below the median concentrations of strontium in water from wells Ch-5179 and Ch-5180, which were on the application area. Also, the median concentration of strontium in water from valley bottom well $\mathrm{Ch}-5177$ was above the average concentration in the effluent. The median concentration of strontium in water from wells Ch-5173 and Ch-5175, which were on the application area, were below the average concentration of strontium in the effluent, however, strontium concentrations in water from these wells did not increase throughout the study (Durlin and Schaffstall, 1999, 2000, 2001). Therefore, concentrations of strontium detected at the site are from natural sources.

Lithium was detected in 2 of 19 water samples collected from shallow wells on the application area. The maximum lithium concentration detected was $42 \mu \mathrm{g} / \mathrm{L}$ in water from well Ch-5175. Lithium was not detected above the reporting limit in the two effluent samples collected. Nickel was detected in 4 of 19 water samples collected in shallow wells on the application area. Of the four samples with detectable nickel concentrations, two samples were collected prior to application (background samples) and the concentrations ranged from 5 to $9.2 \mu \mathrm{g} / \mathrm{L}$. The maximum nickel concentration was $11 \mu \mathrm{g} / \mathrm{L}$ in water from well Ch-5173, which is near background levels. Nickel was detected in the two samples collected from the effluent at concentrations of 17.6 and $14.9 \mu \mathrm{g} / \mathrm{L}$. Based on background nickel concentrations in ground water collected prior to application, the metals and trace constituents detected are not attributable to the sprayirrigated effluent (appendix 1, table 1-1).

Antimony, arsenic, cadmium, chromium, mercury, nickel, and selenium were not detected above the reporting limit in any water samples collected from shallow wells in the valley-bottom area. Copper and lithium were detected in 1 of 19 water samples. The copper and lithium concentrations detected were 110 and $34 \mu \mathrm{g} / \mathrm{L}$, respectively, in water from well Ch-5181. Lead was detected in 2 of 19 water samples collected from shallow wells in the valley-bottom area. The maximum lead concentration detected was $4.6 \mu \mathrm{g} / \mathrm{L}$ in water from well $\mathrm{Ch}-5181$. Lithium and lead were not detected above the reporting limit in the two effluent samples collected. Copper was detected in both effluent samples; however, the concentrations were 7.2 and $9.4 \mu \mathrm{g} / \mathrm{L}$. Therefore, the metals and trace constituents detected are not attributable to the spray-irrigated effluent. The wells in the valley-bottom area are downgradient from the spent mushroom substrate, which could be a source of the metals (Guo and others, 2000b). 
Table 21. Summary of concentrations of metal and trace constituents in water from shallow monitor wells on the application area, the valley bottom, and the control area, May 1998 through December 2001, New Garden Township spray-irrigation site, Chester County, Pennsylvania.

[All constituent concentrations are in micrograms per liter; —, not applicable]

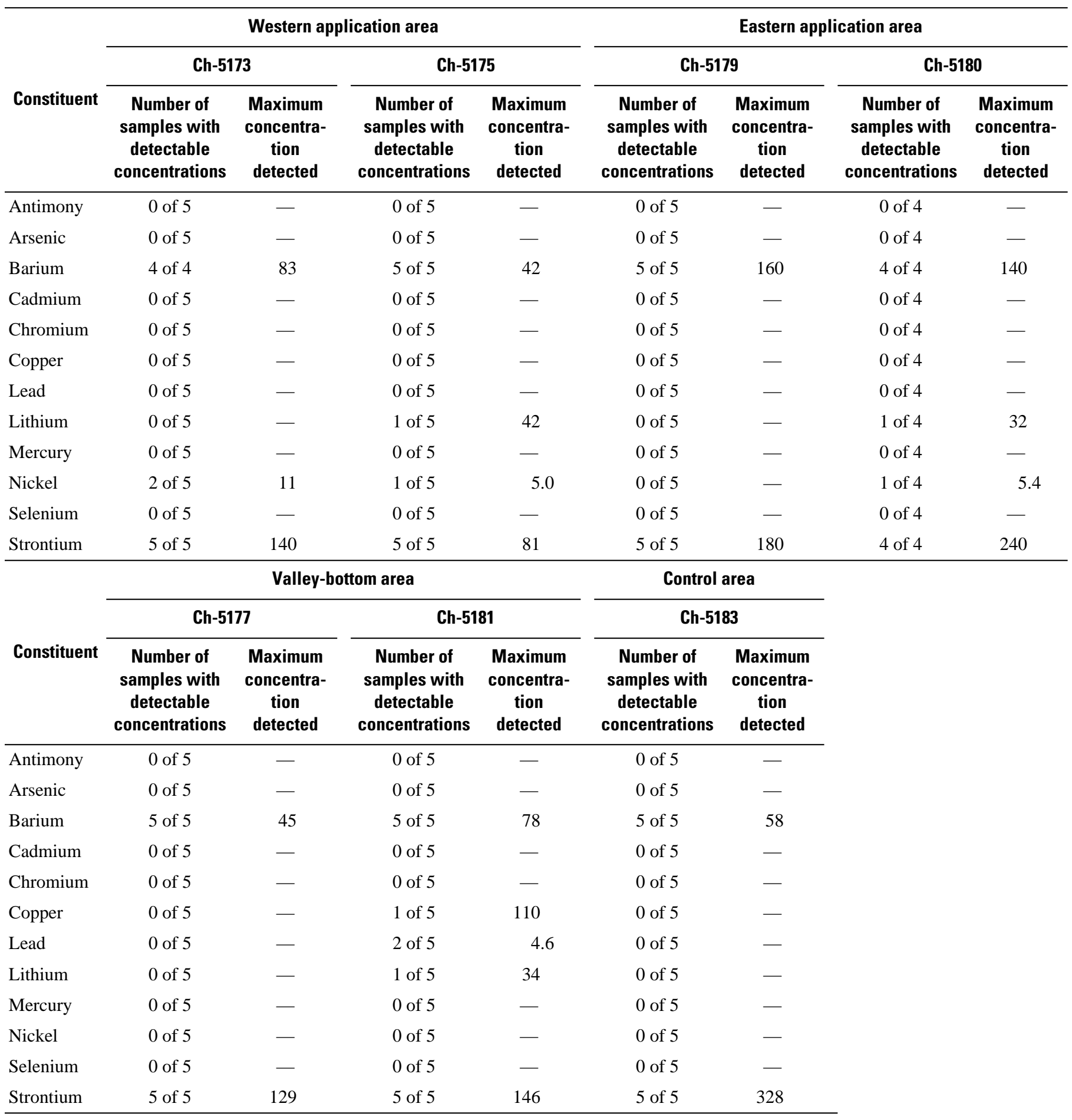




\section{Bedrock Aquifer}

Bedrock wells Ch-5172 and Ch-5174 were on the hilltop and hillside, respectively, in the western application area. Bedrock well Ch-5178 was on the hillside in the eastern application area. Bedrock well Ch-5176 was downgradient of the application area in the valley bottom north of well Ch-5174. Bedrock well Ch-5182 was on Control area (2) on a hilltop.

Statistically significant differences in median concentrations from samples collected prior to and during effluent application and trends during the study period for physical properties and other chemical constituents measured in the field, nutrients, major and minor ions, metals and other trace constituents were determined.

\section{Physical Properties and Chemical Constituents Measured in the Field}

For the physical properties and chemical constituents measured in the field, spray-irrigated effluent did not affect the bedrock ground-water quality in the application area. Specific conductances in water samples from wells Ch-5172 and Ch-5178 decreased, which may be part of a natural cycle (table 22). The decrease in $\mathrm{pH}$ in water from well Ch-5172 and the decrease in dissolved oxygen in water from well Ch-5174 also may be a natural cycle. The downward trend in specific conductance in water from well Ch-5176 probably was attributable to the increase in hydraulic loading. The increased hydraulic loading diluted the in-situ water of the spent mushroom substrate. The cause of the increase in alkalinity in water from this well is unknown and may be part of a natural cycle.

\section{Nutrients}

In ground water from bedrock wells, most $\mathrm{N}$ (74 to 87 percent) was in the form of dissolved nitrate $\mathrm{N}$ with median concentrations of dissolved nitrate $\mathrm{N}$ ranging from $<0.04$ to $27 \mathrm{mg} / \mathrm{L}$. Dissolved P, primarily ortho-P was found in low concentrations in water from all bedrock wells with median concentrations ranging from $<0.01$ to $0.016 \mathrm{mg} / \mathrm{L}$. No significant differences between the median concentrations of nutrients in samples collected prior to or during effluent application or time trends were evident in hillside wells Ch-5174 and Ch-5178 or in ground-water samples from control well Ch-5182. Median concentrations of dissolved nitrate $\mathrm{N}$ in water samples collected from hilltop well Ch-5172 and valley-bottom well Ch-5176 prior to and during effluent application were significantly different. Also, median concentrations of dissolved nitrite $\mathrm{N}$ in water samples collected from valley-bottom well Ch-5176 prior to and during effluent application were significantly different. The results of the Wilcoxon rank-sum test, the Mann-Kendall test for trends, and the median concentrations of $\mathrm{N}$ species in water samples collected from bedrock wells prior to and during effluent application are summarized in table 23.

Time trends for concentrations of dissolved $\mathrm{N}$ and dissolved nitrate were evident in water from wells Ch-5172 and Ch-5176. Because dissolved nitrate $\mathrm{N}$ made up 74 and 87 per- cent of dissolved $\mathrm{N}$ in water from wells Ch-5172 and Ch-5176, respectively, the trend analysis was done for dissolved nitrate$\mathrm{N}$ concentrations, not dissolved N. A statistically significant upward trend in concentration of dissolved nitrate $\mathrm{N}$ was evident in water from hilltop well Ch-5172 on the western application area (fig. 27) A statistically significant downward trend in concentration of dissolved nitrate $\mathrm{N}$ was evident in water from valley-bottom well Ch-5176 (fig. 27). No time trends were evident for dissolved nitrite $\mathrm{N}$ and dissolved ammonia $\mathrm{N}$ in water from all wells completed in the bedrock aquifer.

The spray-irrigated effluent increased the concentration of dissolved nitrate $\mathrm{N}$ in ground water in the hilltop application area. Although a statistically significant positive trend for nitrate $\mathrm{N}$ was evident, the median concentration increased by only $0.16 \mathrm{mg} / \mathrm{L}$. Concentrations of dissolved nitrate $\mathrm{N}$ in water collected from valley-bottom well Ch-5176 in the spent mushroom substrate area during effluent application decreased from concentrations prior to effluent application. The hydraulic loading of the effluent flushed the nitrate $\mathrm{N}$ from the spent mush-

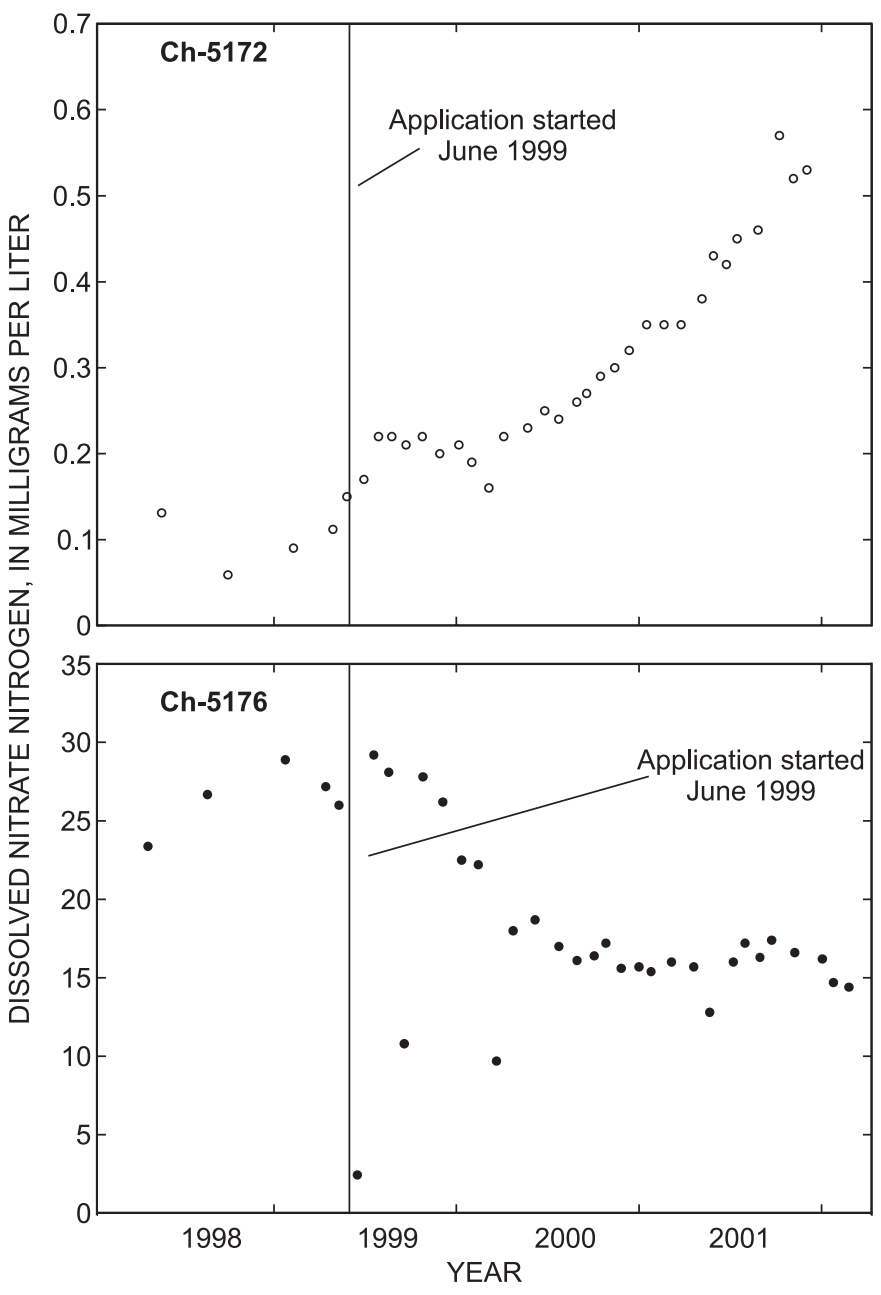

Figure 27. Concentration of dissolved nitrate nitrogen in water from hilltop bedrock well Ch-5172 and valley-bottom bedrock well Ch-5176, New Garden Township spray-irrigation site, Chester County, Pennsylvania, 1998-2001. 
Table 22. Summary of Wilcoxon rank-sum test, Mann-Kendall test for trends, and median values of $\mathrm{pH}$, water temperature, specific conductance, alkalinity, and dissolved oxygen in water from bedrock wells collected prior to and during effluent application, New Garden Township spray-irrigation site, Chester County, Pennsylvania, May 1998 through December 2001.

[Shaded areas indicate a significant difference between water samples collected prior to and during effluent application according to Wilcoxon rank-sum test results. —, no trend; U, significant upward trend; D, significant downward trend; ${ }^{\circ} \mathrm{C}$, degrees Celsius, $\mu \mathrm{S} / \mathrm{cm}$, microsiemens per centimeter; mg/L, milligrams per liter]

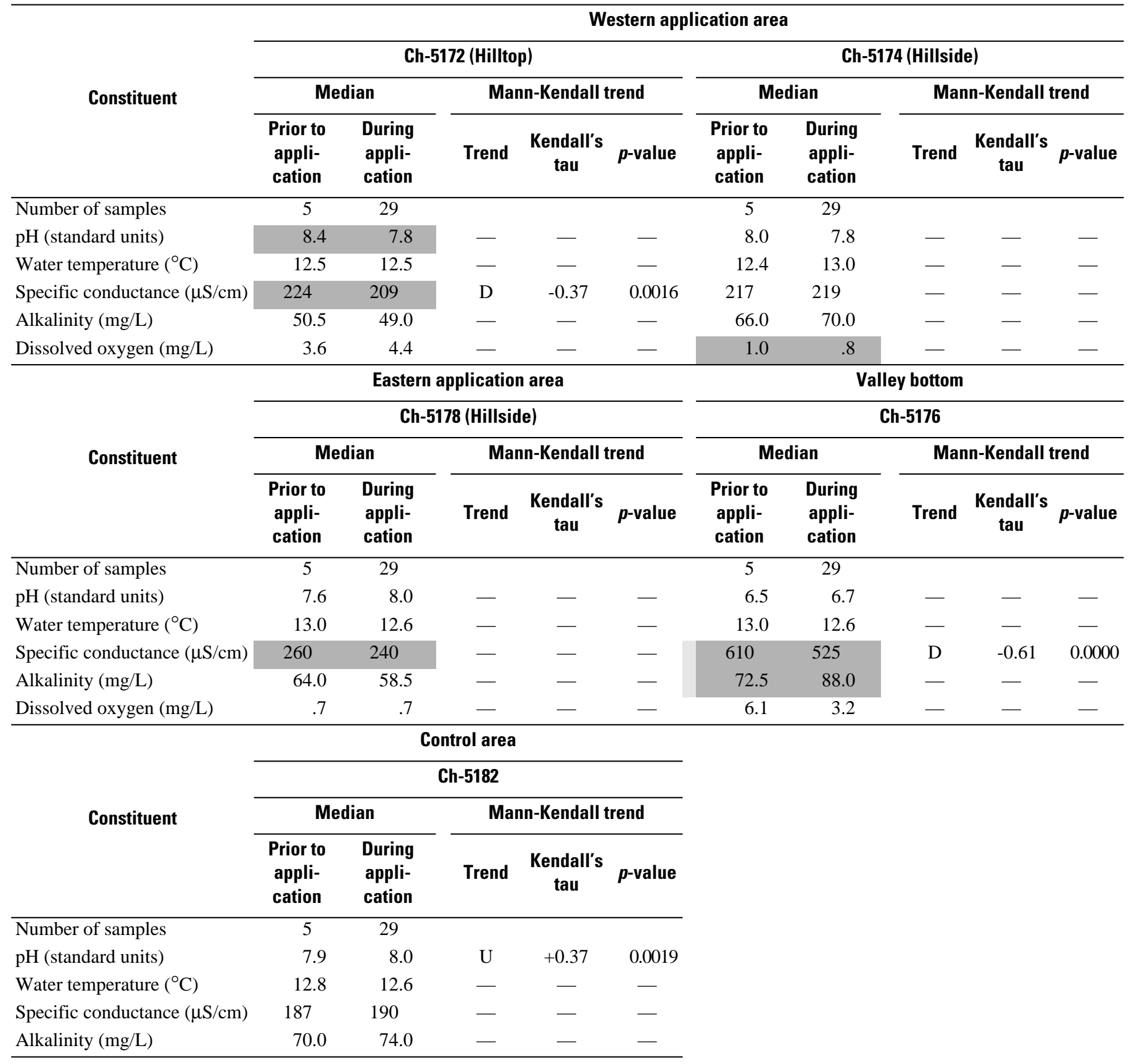


Table 23. Summary of Wilcoxon rank-sum test, Mann-Kendall test for trends, and median concentrations of dissolved nitrogen species in water from bedrock monitor wells collected prior to and during effluent application, New Garden Township spray-irrigation site, Chester County, Pennsylvania, May 1998 through December 2001.

[All constituent concentrations are in milligrams per liter. Shaded areas indicate a significant difference between water samples collected prior to and during effluent application according to Wilcoxon rank-sum test results. - , no trend; $\mathrm{U}$, significant upward trend; D, significant downward trend; <, less than]

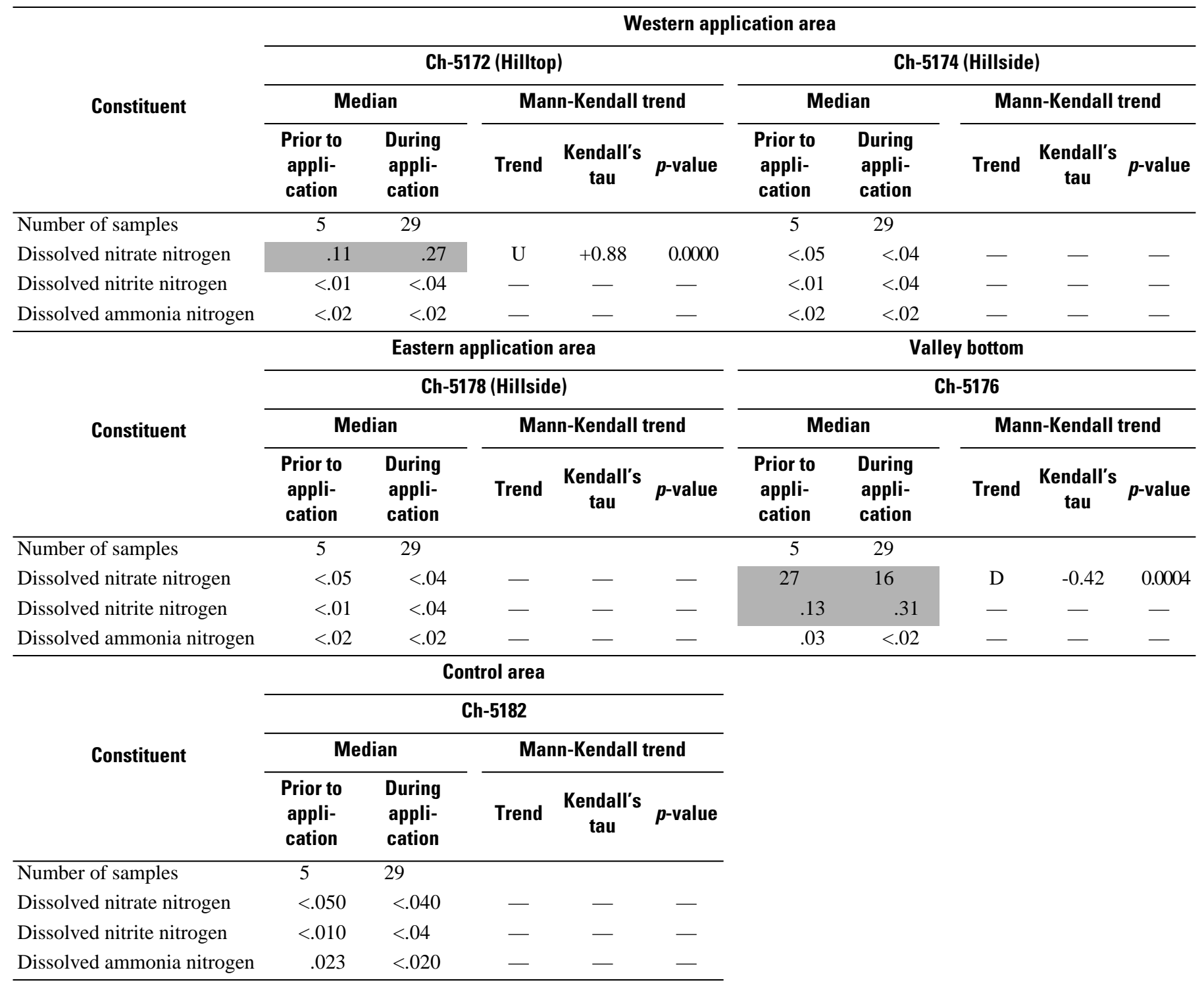

room substrate area and lowered the concentrations of dissolved nitrate N. Concentrations of dissolved nitrite $\mathrm{N}$ in water collected from well $\mathrm{Ch}-5176$ increased from the period prior to effluent application to the period during effluent application, but the upward time trend was not significant.

Dissolved $\mathrm{P}$ and dissolved orthophosphate $\mathrm{P}$ were found in low concentrations in water from all bedrock wells. Median concentrations of dissolved $\mathrm{P}$ and dissolved orthophosphate $\mathrm{P}$ were below detection limits in water from wells Ch-5172 and Ch-5174, which were in the western part of the application area, and control well Ch-5182. Median concentration of dissolved P and dissolved orthophosphate $\mathrm{P}$ in water from $\mathrm{Ch}-5178$, which was on the eastern application area were 0.13 and $<0.01 \mathrm{mg} / \mathrm{L}$, respectively. In water from the valley-bottom well Ch-5176, median concentrations of dissolved $\mathrm{P}$ and dissolved orthophosphate $\mathrm{P}$ were 0.016 and $0.013 \mathrm{mg} / \mathrm{L}$, respectively. Concentrations of dissolved $\mathrm{P}$ in water from well Ch-5172 and control well Ch-5182 are shown in figure 28. These concentrations through time are typical of dissolved $\mathrm{P}$ in water from all wells completed in the bedrock aquifer.

The dissolved $\mathrm{P}$ and dissolved orthophosphate $\mathrm{P}$ in the effluent did not affect ground water in the bedrock at the site. The median concentrations of dissolved $\mathrm{P}$ and orthophosphate $\mathrm{P}$ in the effluent were 2.52 and $2.04 \mathrm{mg} / \mathrm{L}$, respectively. The 


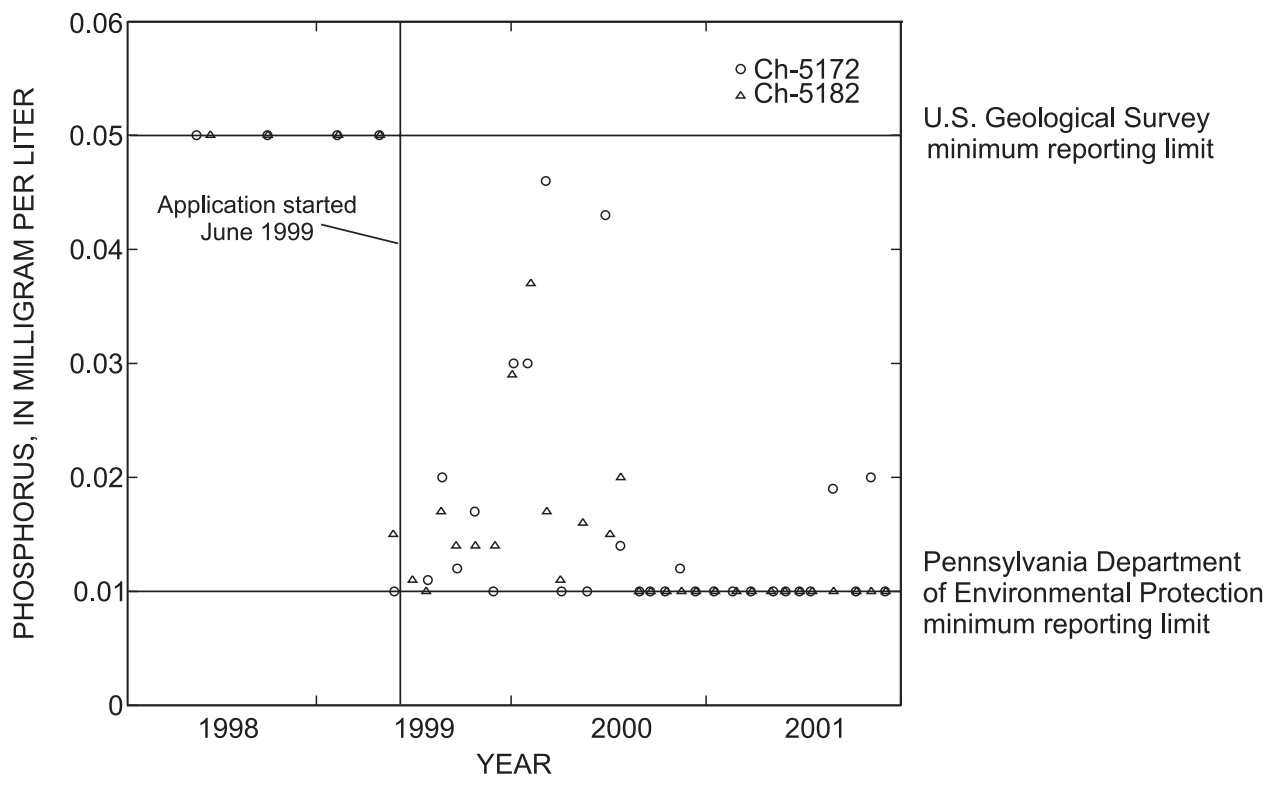

Figure 28. Concentration of dissolved phosphorus in water from bedrock wells Ch-5172 and Ch-5182, New Garden Township spray-irrigation site, Chester County, Pennsylvania, 1998-2001.

concentrations of these constituents in bedrock ground water did not increase over time.

\section{Major and Minor lons}

Increased concentrations of $\mathrm{Cl}$, which would indicate movement of spray-irrigated effluent to the bedrock aquifer, were only measured in water from western application hilltop well Ch-5172 (fig. 29). Cl concentrations did not increase in water from the hillside or the valley-bottom wells. Actually, $\mathrm{Cl}$ concentrations in water from hillside well Ch-5174 and valley bottom well Ch-5176 were trending downward. The cause of the downward trend in $\mathrm{Cl}$ concentrations in water from well Ch-5174 is unknown. The downward trend in $\mathrm{Cl}$ concentrations in water from valley-bottom well Ch-5176 could be from the increased hydraulic loading diluting the in situ water. Further evidence of this could be supported by the decreasing trend in sodium concentrations in water from this well.

In water from well Ch-5172, upward and downward trends in concentrations of various major ions were evident, but these trends may be part of a natural cycle. Reese and Lee (1998), in summarizing and analyzing trends for 12 years of ground-water quality monitoring data from southeastern Pennsylvania, concluded that concentrations in some analytes are increasing, whereas others are decreasing, which may be natural groundwater-quality cycles. Sulfate concentrations were trending upward in water from wells Ch-5174 and were trending downward in water from well Ch-5178. In water from control well Ch-5182, potassium concentrations were trending downward. These trends may be a natural occurring cycle. The spray-irrigated effluent did not affect water quality in bedrock wells on the hillside application area. The spray-irrigated effluent may have affected the water in the valley bottom because of dilution.

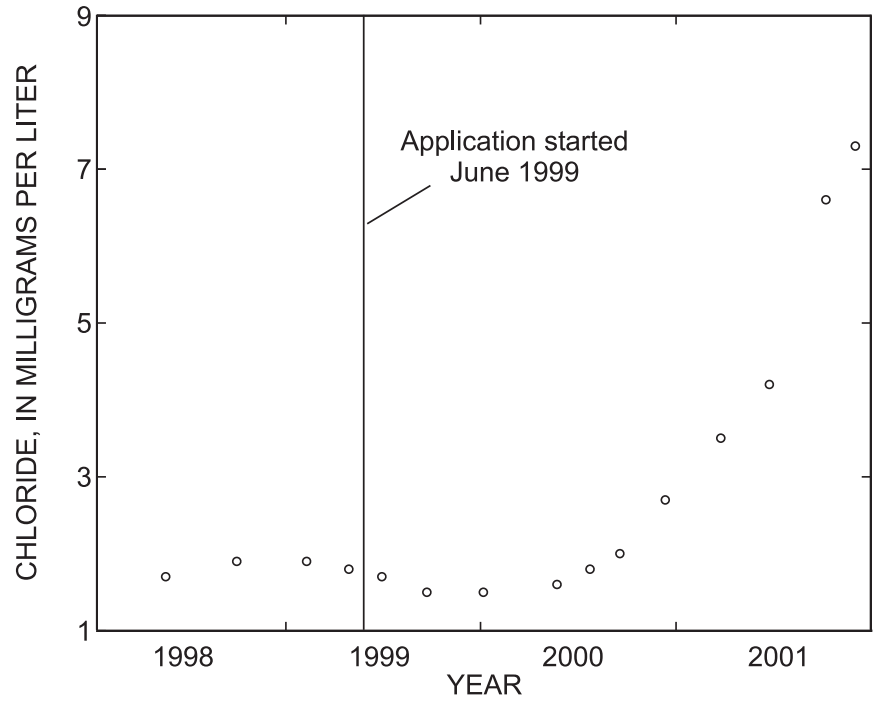

Figure 29. Chloride concentration in water from hilltop bedrock monitor well Ch-5172, New Garden Township spray-irrigation site, Chester County, Pennsylvania, 1998-2001.

The median concentrations of major and minor ions in water samples collected from bedrock monitor wells prior to and during effluent application and results of the Wilcoxon rank-sum test and the Mann-Kendall test for trends are summarized in table 24 .

\section{Metals and Other Trace Constituents}

Barium and strontium were detected in water from all bedrock wells (table 25). In the Red Clay Creek watershed, 
Table 24. Summary of Wilcoxon rank-sum test, Mann-Kendall test for trends, and median concentrations of dissolved major and minor ions in water from bedrock monitor wells collected prior to and during effluent application, New Garden Township spray-irrigation site, Chester County, Pennsylvania, May 1998 through December 2001.

[Shaded areas indicate a significant difference between water samples collected prior to and during effluent application according to Wilcoxon rank-sum test results. mg/L, milligrams per liter; $\mu \mathrm{g} / \mathrm{L}$, micrograms per liter; - , no trend; $\mathrm{U}$, significant upward trend; $\mathrm{D}$, significant downward trend; N, no samples collected; $<$, less than]

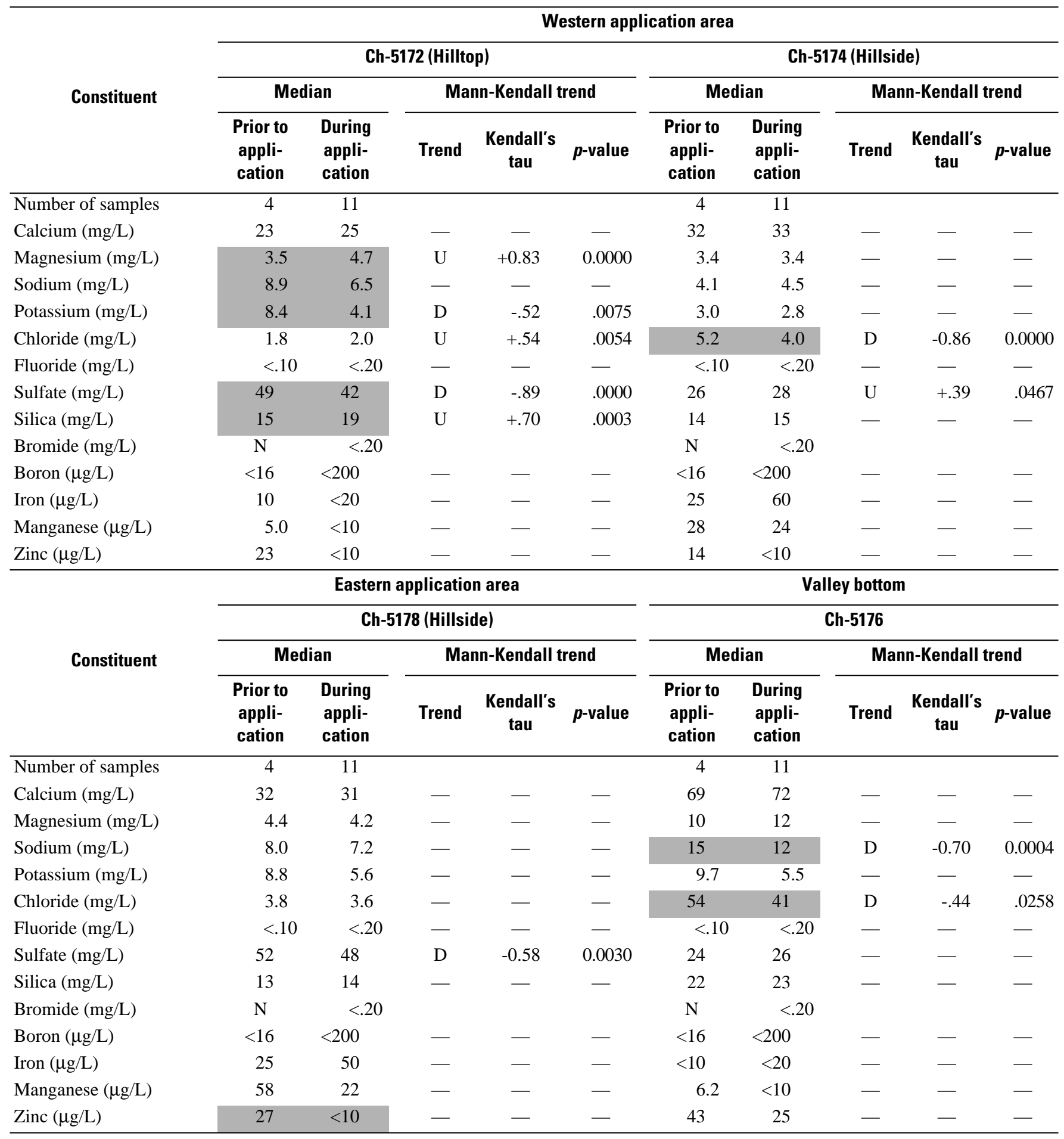


Table 24. Summary of Wilcoxon rank-sum test, Mann-Kendall test for trends, and median concentrations of dissolved major and minor ions in water from bedrock monitor wells collected prior to and during effluent application, New Garden Township spray-irrigation site, Chester County, Pennsylvania, May 1998 through December 2001.—Continued

[Shaded areas indicate a significant difference between water samples collected prior to and during effluent application according to Wilcoxon rank-sum test results. $\mathrm{mg} / \mathrm{L}$, milligrams per liter; $\mu \mathrm{g} / \mathrm{L}$, micrograms per liter; —, no trend; $\mathrm{U}$, significant upward trend; $\mathrm{D}$, significant downward trend; N, no samples collected; $<$, less than]

\begin{tabular}{|c|c|c|c|c|c|}
\hline \multirow{4}{*}{ Constituent } & \multicolumn{5}{|c|}{ Control area } \\
\hline & \multicolumn{5}{|c|}{ Ch-5182 } \\
\hline & \multicolumn{2}{|c|}{ Median } & \multicolumn{3}{|c|}{ Mann-Kendall trend } \\
\hline & $\begin{array}{l}\text { Prior to } \\
\text { appli- } \\
\text { cation }\end{array}$ & $\begin{array}{l}\text { During } \\
\text { appli- } \\
\text { cation }\end{array}$ & Trend & $\begin{array}{c}\text { Kendall's } \\
\text { tau }\end{array}$ & $p$-value \\
\hline Number of samples & 5 & 29 & & & \\
\hline Calcium (mg/L) & 27 & 29 & - & - & - \\
\hline Magnesium (mg/L) & 3.4 & 3.5 & - & - & - \\
\hline Sodium (mg/L) & 4.5 & 4.2 & - & - & - \\
\hline Potassium (mg/L) & 2.8 & 2.6 & $\mathrm{D}$ & -0.45 & 0.0222 \\
\hline Chloride (mg/L) & 3.2 & 3.1 & - & - & - \\
\hline Fluoride (mg/L) & $<.10$ & $<.20$ & - & - & - \\
\hline Sulfate (mg/L) & 15 & 14 & - & - & - \\
\hline Silica (mg/L) & 16 & 17 & - & - & - \\
\hline Bromide (mg/L) & $\mathrm{N}$ & $<.20$ & & & \\
\hline Boron $(\mu \mathrm{g} / \mathrm{L})$ & 18 & $<200$ & - & - & - \\
\hline Iron $(\mu \mathrm{g} / \mathrm{L})$ & 75 & 60 & - & - & - \\
\hline Manganese $(\mu \mathrm{g} / \mathrm{L})$ & 21 & 21 & - & - & - \\
\hline Zinc $(\mu \mathrm{g} / \mathrm{L})$ & 24 & $<10$ & - & - & - \\
\hline
\end{tabular}

Table 25. Summary of median concentrations of barium and strontium in water from deep bedrock monitor wells, May 1998 through December 2001, New Garden Township spray-irrigation site, Chester County, Pennsylvania.

[ $\mu \mathrm{g} / \mathrm{L}$, micrograms per liter; $\mathrm{n}$, number of samples]

\begin{tabular}{lccccc}
\hline Constituent & \multicolumn{5}{c}{ Median concentration, in micrograms per liter } \\
\cline { 2 - 6 } & $\begin{array}{c}\text { Ch-5172 } \\
(\mathbf{n}=\mathbf{5})\end{array}$ & $\begin{array}{c}\text { Ch-5174 } \\
(\mathbf{n}=\mathbf{5})\end{array}$ & $\begin{array}{c}\text { Ch-5176 } \\
(\mathbf{n}=\mathbf{5})\end{array}$ & $\begin{array}{c}\text { Ch-5178 } \\
(\mathbf{n}=\mathbf{5})\end{array}$ & $\begin{array}{c}\text { Ch-5182 } \\
(\mathbf{n}=\mathbf{5})\end{array}$ \\
\hline Barium $(\mu \mathrm{g} / \mathrm{L})$ & 7.5 & 17 & 300 & 35 & 11 \\
Strontium $(\mu \mathrm{g} / \mathrm{L})$ & 140 & 68 & 260 & 88 & 61 \\
\hline
\end{tabular}


median concentrations of barium and strontium in 16 water samples collected from wells completed in the felsic gneiss were 59 and $105 \mu \mathrm{g} / \mathrm{L}$, respectively (Senior, 1996). The average concentrations of barium and strontium in two effluent samples were 7.6 and $124 \mu \mathrm{g} / \mathrm{L}$, respectively (appendix 1, table 1-1). The average concentration of barium in the effluent was near or below the median concentrations of barium in all bedrock wells. Therefore, concentrations of barium detected at the site are from natural sources. The average concentration of strontium in the effluent was below the median concentrations of strontium in wells Ch-5172 and Ch-5176. Median concentrations of strontium in water from wells Ch-5174 and Ch-5178 were below the average concentration in the effluent, however, strontium concentrations in water from these wells did not increase throughout the study (Durlin and Schaffstall, 1999, 2000, 2001). Therefore, concentrations of strontium detected at the site are from natural sources. No other metals were reported above the minimum reporting limit in water samples from wells Ch-5174, Ch-5178, and Ch-5182. Nickel was detected in one sample at a concentration of $15.3 \mu \mathrm{g} / \mathrm{L}$ in water from $\mathrm{Ch}-5172$. Mercury was detected in one sample at a concentration of $0.51 \mu \mathrm{g} / \mathrm{L}$ in water from $\mathrm{Ch}-5176$. Of the detected metal constituents, none of the concentrations were attributable to the spray-irrigated effluent.

\section{Surface Water}

The pond is downgradient of the application area in the valley bottom, and the weir is downstream of the outlet of the pond (plate 1). Water samples at the weir were collected immediately downstream of the weir. There were no significant differences in median values or concentrations of physical properties and chemical constituents measured in the field in water samples collected from either the pond or downstream of the weir prior to or during effluent application. Also, there were no time trends or seasonal patterns of physical properties and chemical constituents measured in the field in water samples collected from either the pond or downstream of the weir prior to and during effluent application.

\section{Nutrients}

The differences in the median concentrations of total $\mathrm{N}$, dissolved $\mathrm{N}$, dissolved nitrate $\mathrm{N}$, dissolved nitrite $\mathrm{N}$, total ammonia $\mathrm{N}$, and dissolved ammonia $\mathrm{N}$ in water collected from the pond or downstream of the weir prior to or during effluent application were not significant (table 26). No time trends in $\mathrm{N}$ compounds were evident. However, a seasonal pattern in concentration of dissolved nitrate $\mathrm{N}$ in water from the pond and downstream of the weir was observed (fig. 30). Concentrations of dissolved nitrate $\mathrm{N}$ were higher from late fall to early spring and lower in the summer months because of nitrate $\mathrm{N}$ consumption by plants on land, biological activity in the soil, and algae in water.

Differences in the median concentrations of total $\mathrm{P}$, dissolved $\mathrm{P}$, and dissolved orthophosphate $\mathrm{P}$ in water collected from the pond or downstream of the weir prior to or during effluent application were not significant (table 26). No time trends or seasonal patterns in concentrations of $\mathrm{P}$ compounds in water samples from the pond or downstream of the weir were observed.

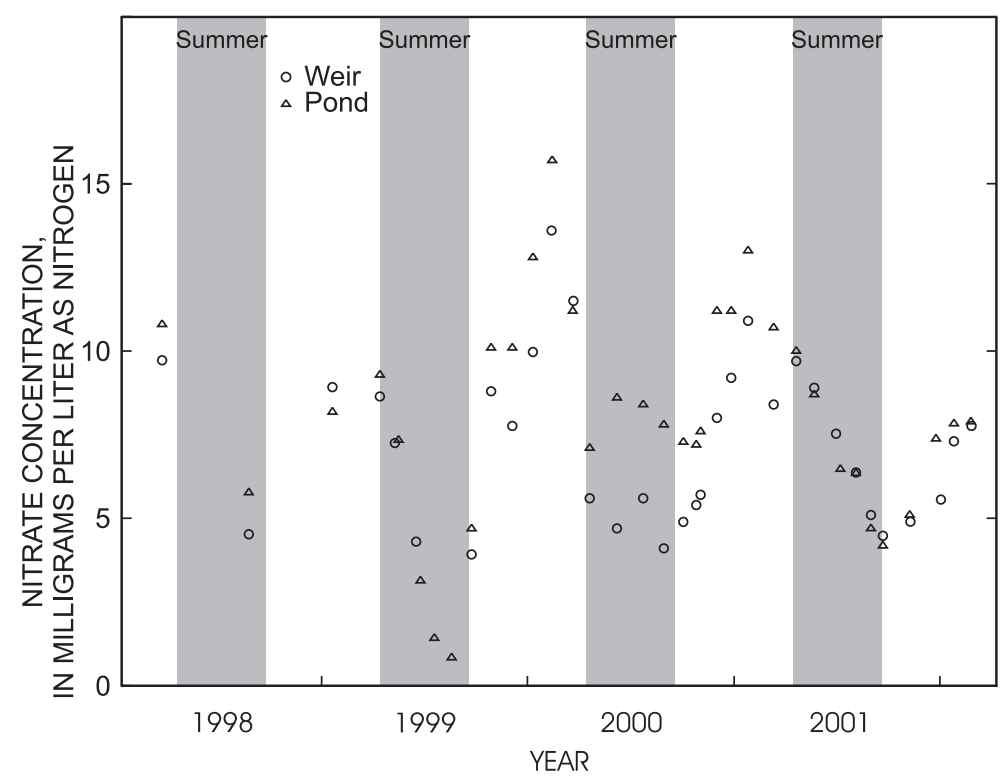

Figure 30. Concentrations of dissolved nitrate nitrogen in water from the pond and weir, New Garden Township spray-irrigation site, Chester County, Pennsylvania, 1998-2001. 
Table 26. Summary of concentrations of total and dissolved nitrogen and phosphorus species in water from the pond and immediately downstream of the weir collected prior to and during effluent application, New Garden Township spray-irrigation site, Chester County, Pennsylvania, May 1998 through December 2001.

[All units are in milligrams per liter; —, not applicable; <, less than]

\begin{tabular}{|c|c|c|c|c|c|c|c|c|c|c|c|c|}
\hline Site & \multicolumn{2}{|c|}{$\begin{array}{c}\text { Number } \\
\text { of } \\
\text { samples }\end{array}$} & $\begin{array}{l}\text { Median } \\
\text { prior to } \\
\text { appli- } \\
\text { cation }\end{array}$ & \multicolumn{3}{|c|}{ During application } & \multicolumn{2}{|c|}{$\begin{array}{c}\text { Number } \\
\text { of } \\
\text { samples }\end{array}$} & $\begin{array}{l}\text { Median } \\
\text { prior to } \\
\text { appli- } \\
\text { cation }\end{array}$ & \multicolumn{3}{|c|}{ During application } \\
\hline & \multicolumn{6}{|c|}{ Total nitrogen } & \multicolumn{6}{|c|}{ Dissolved nitrogen } \\
\hline \multirow[t]{2}{*}{ Pond } & 4 & 29 & 10 & 2.9 & 9.6 & 17 & - & 30 & - & 1.7 & 9.2 & 17 \\
\hline & \multicolumn{6}{|c|}{ Dissolved nitrate nitrogen } & \multicolumn{6}{|c|}{ Dissolved nitrite nitrogen } \\
\hline Weir & 5 & 28 & 8.6 & 3.9 & 6.8 & 14 & 5 & 28 & 0.03 & $<.02$ & .04 & .09 \\
\hline Pond & 5 & 30 & 8.2 & .84 & 7.8 & 16 & 5 & 30 & .04 & $<.04$ & .06 & .16 \\
\hline Pond & \multicolumn{6}{|c|}{ Total phosphorus } & \multicolumn{6}{|c|}{ Dissolved phosphorus } \\
\hline Weir & 5 & 28 & .06 & .03 & .08 & .15 & 5 & 28 & ${ }^{1}<.05$ & .01 & .05 & .14 \\
\hline Pond & 5 & 29 & .08 & .02 & .12 & .42 & 5 & 30 & $<.05$ & $2<.01$ & .02 & .04 \\
\hline \multicolumn{7}{|c|}{ Dissolved orthophosphate phosphorus } & & & & & & \\
\hline Weir & 5 & 28 & .03 & $<.01$ & .03 & .13 & & & & & & \\
\hline Pond & 5 & 30 & .01 & $<.01$ & .01 & .09 & & & & & & \\
\hline
\end{tabular}

\section{Major and Minor lons}

Manganese was the only major or minor ion with significant differences in concentrations for water collected from the pond or weir prior to and during effluent application (table 27). The median concentration of manganese in water collected from the pond prior to effluent application was $15 \mu \mathrm{g} / \mathrm{L}$, and the median concentration during effluent application was $95 \mu \mathrm{g} / \mathrm{L}$. However, no significant time trend in concentration of manganese was evident in water collected from the pond. The median concentration of manganese in water collected immediately downstream of the weir prior to effluent application was $19 \mu \mathrm{g} / \mathrm{L}$, and the median concentration during effluent application was $44 \mu \mathrm{g} / \mathrm{L}$. A significant upward trend in concentration of manganese was evident in water sampled downstream of the weir (fig. 31). The increase in manganese concentration in water samples collected prior to and during effluent application could be caused by organic material entering the pond that would establish reducing conditions with the reduced manganese going into solution. The spray-irrigated effluent may have increased the amount of organic material on the land surface that eventually was transported to the pond, however, the amount of organic material on the land surface was not part of this study.

\section{Metals and Other Trace Constituents}

Barium and strontium were detected in water from all samples from the pond. The median concentration of barium was $74 \mu \mathrm{g} / \mathrm{L}$, and the median concentration of strontium was $162 \mu \mathrm{g} / \mathrm{L}$, which were above the mean effluent concentrations. Both constituents occur naturally. Lithium was detected in one sample from the pond at a concentration of $74 \mu \mathrm{g} / \mathrm{L}$. This concentration of lithium may be the result of metals leaching from spent mushroom substrate. No other metals were reported above the minimum reporting limit.

Barium and strontium were detected in water from all samples collected downstream of the weir. The median concentration of barium was $78 \mu \mathrm{g} / \mathrm{L}$, and the median concentration of strontium was $168 \mu \mathrm{g} / \mathrm{L}$, which were above the mean effluent concentrations. Lithium was detected in two samples collected from downstream of the weir at concentrations of 48 and $25 \mu \mathrm{g} / \mathrm{L}$. Mercury was detected in one sample at a concentration of $0.43 \mu \mathrm{g} / \mathrm{L}$ in water from downstream of the weir. No other metals were reported above the minimum reporting limit. Lith- 


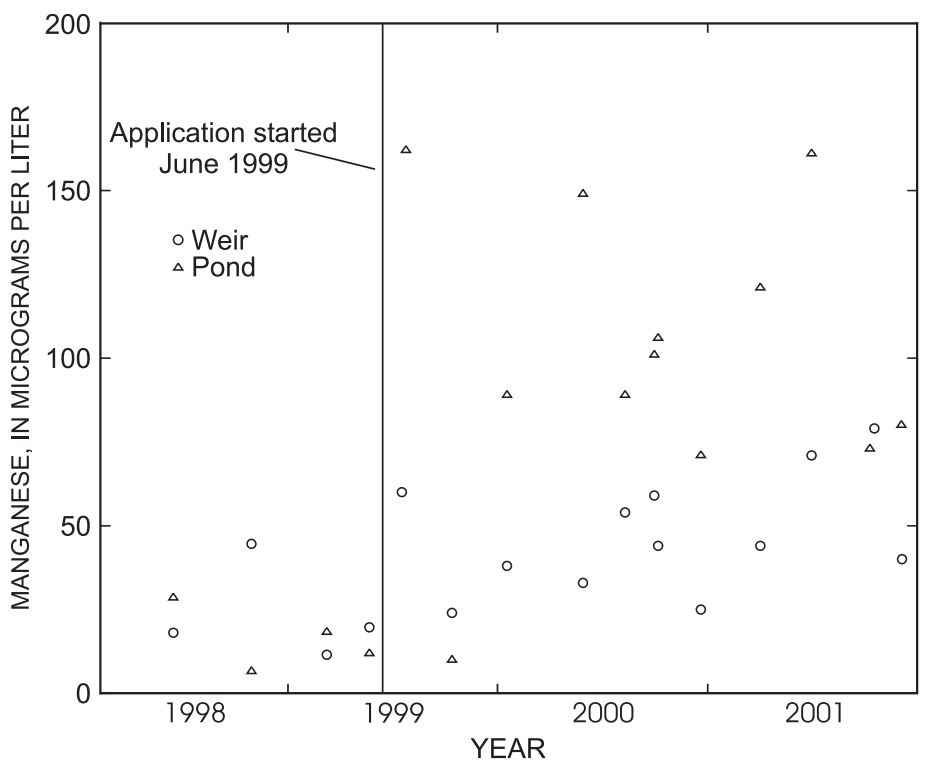

Figure 31. Concentrations of manganese in water from the pond and the weir, New Garden Township spray-irrigation site, Chester County, Pennsylvania, 1998-2001.

Table 27. Summary of median concentrations of major and selected minor ions in water from the pond and downstream of the weir collected prior to and during effluent application, New Garden Township spray-irrigation site, Chester County, Pennsylvania, May 1998 through December 2001.

[Shaded areas indicate a significant difference between water samples collected prior to and during effluent application according to Wilcoxon rank-sum test results. $\mathrm{mg} / \mathrm{L}$, milligrams per liter; $\mu \mathrm{g} / \mathrm{L}$, micrograms per liter; <, less than; 一, not applicable]

\begin{tabular}{|c|c|c|c|c|}
\hline \multirow[b]{2}{*}{ Constituent } & \multicolumn{2}{|c|}{ Weir } & \multicolumn{2}{|c|}{ Pond } \\
\hline & $\begin{array}{c}\text { Prior to } \\
\text { application }\end{array}$ & $\begin{array}{c}\text { During } \\
\text { application }\end{array}$ & $\begin{array}{c}\text { Prior to } \\
\text { application }\end{array}$ & $\begin{array}{c}\text { During } \\
\text { application }\end{array}$ \\
\hline Number of samples & 4 & 12 & 4 & 12 \\
\hline Calcium (mg/L) & 48 & 51 & 46 & 49 \\
\hline Magnesium (mg/L) & 11 & 12 & 10 & 11 \\
\hline Sodium (mg/L) & 8.2 & 8.2 & 7.8 & 8.4 \\
\hline Potassium (mg/L) & 4.0 & 4.3 & 3.9 & 3.6 \\
\hline Chloride $(\mathrm{mg} / \mathrm{L})$ & 30 & 32 & 28 & 28 \\
\hline Fluoride (mg/L) & $<.10$ & $<.20$ & $<.10$ & $<.20$ \\
\hline Sulfate (mg/L) & 35 & 34 & 34 & 35 \\
\hline Silica (mg/L) & 9.4 & 11 & 8.6 & 11 \\
\hline Bromide (mg/L) & - & $<.20$ & - & $<.20$ \\
\hline Boron $(\mu \mathrm{g} / \mathrm{L})$ & $<16$ & $<200$ & $<16$ & $<200$ \\
\hline Iron $(\mu \mathrm{g} / \mathrm{L})$ & $<10$ & $<20$ & $<10$ & $<20$ \\
\hline Manganese $(\mu \mathrm{g} / \mathrm{L})$ & 19 & 44 & 15 & 95 \\
\hline $\operatorname{Zinc}(\mu \mathrm{g} / \mathrm{L})$ & $<20$ & $<10$ & $<20$ & $<10$ \\
\hline
\end{tabular}


ium and mercury were not detected above the reporting limit in two samples collected from the effluent. Therefore, the metal constituents detected in water from the pond and downstream of the weir were not attributable to the spray-irrigated effluent.

\section{Evaluation of the Effects on Water Quality}

- Spray-irrigated effluent affected the water quality of the shallow aquifer on the hilltop of the application area. Concentrations of nitrate $\mathrm{N}$ and $\mathrm{Cl}$ increased in water from hilltop wells Ch-5173 and Ch-5180 (fig. 32), which are completed in the western and eastern application areas, respectively. Also, concentrations of calcium, magnesium, sodium, and potassium increased in water from well Ch-5180 but did not increase in water from well Ch-5173, probably because of the thicker unconsolidated sands in the western application area near the well than other areas. Because of the thicker sands, the western application area probably stores greater volumes of ground water, which might cause greater dilution of any effluent reaching the monitor wells at the base of the shallow aquifer. Even though the spray-irrigated effluent increased the concentration of nitrate $\mathrm{N}$ in water from well Ch-5173, the increase was small. The median concentration of nitrate $\mathrm{N}$ in 5 water samples collected from well Ch-5173 prior to effluent application was $0.23 \mathrm{mg} / \mathrm{L}$, and the median concentration of nitrate $\mathrm{N}$ in 29 water samples collected during effluent application was $0.50 \mathrm{mg} / \mathrm{L}$. The maximum concentration of the 29 samples did not exceed $1.0 \mathrm{mg} / \mathrm{L}$ of nitrate $\mathrm{N}$ in water from well Ch-5173. Median $\mathrm{Cl}$ concentration in 4 water samples collected from well Ch-5173 prior to effluent application was $1.6 \mathrm{mg} / \mathrm{L}$, and median $\mathrm{Cl}$ concentration in 11 samples collected during effluent application was $2.5 \mathrm{mg} / \mathrm{L}$. The maximum $\mathrm{Cl}$ concentration of the 29 samples was $7.8 \mathrm{mg} / \mathrm{L}$. Cl concentrations in water from well Ch-5173 were increasing throughout the

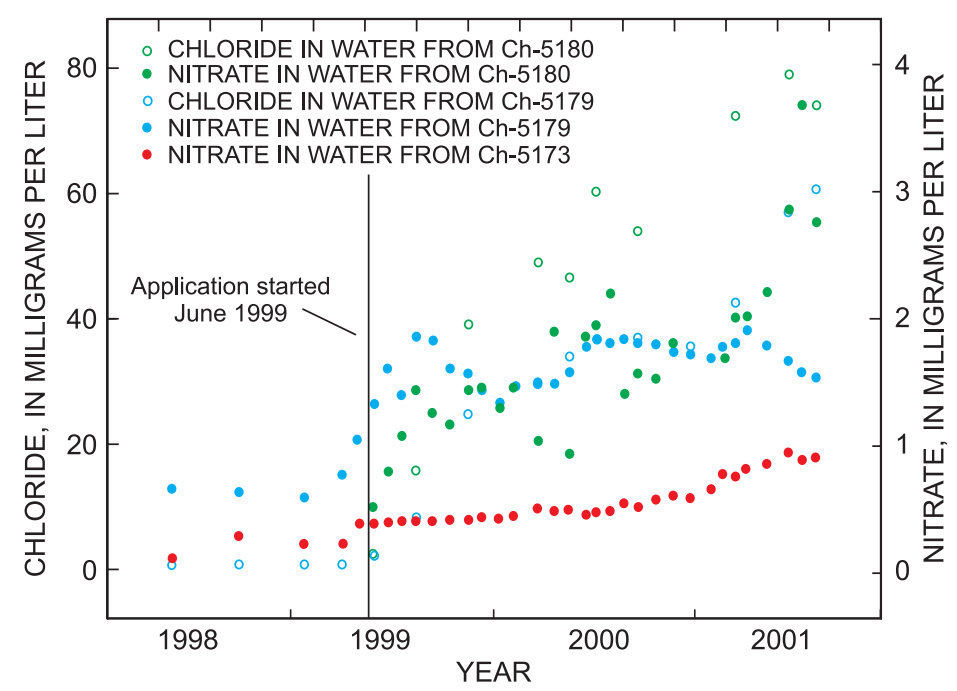

application of effluent. Because $\mathrm{Cl}$ is a conservative ion and the median $\mathrm{Cl}$ concentration of the effluent is $89.5 \mathrm{mg} / \mathrm{L}$, this trend should continue.

- Spray-irrigated effluent affected the water quality of the shallow aquifer on the hillside in the eastern part of the application area because of the low clay content in the unconsolidated sands. Concentrations of nitrate $\mathrm{N}$, $\mathrm{Cl}$, calcium, magnesium, sodium, and potassium increased in water from hillside well Ch-5179, which is completed in the eastern application area shallow aquifer (figs. 32 and 33). Spray-irrigated effluent did not appear to affect the shallow aquifer on the hillside in the western application area because of the higher clay content of the unconsolidated sands. The median concentration of nitrate $\mathrm{N}$ in 5 water samples collected from well Ch-5179 prior to effluent application was $0.66 \mathrm{mg} / \mathrm{L}$ and the median concentration of nitrate $\mathrm{N}$ in 29 water samples collected during effluent application was $1.7 \mathrm{mg} / \mathrm{L}$. The maximum concentration of the 29 samples did not exceed $2.0 \mathrm{mg} / \mathrm{L}$ of nitrate $\mathrm{N}$ in water from well Ch-5179. A marked increase occurred with respect to $\mathrm{Cl}$ concentrations. Median $\mathrm{Cl}$ concentration in 4 water samples collected from well Ch-5179 prior to effluent application was $0.80 \mathrm{mg} / \mathrm{L}$ and the median $\mathrm{Cl}$ concentration in 11 samples collected during effluent application was $36 \mathrm{mg} / \mathrm{L}$. The maximum $\mathrm{Cl}$ concentration of the 29 samples was $61 \mathrm{mg} / \mathrm{L}$. Cl concentrations in water from well Ch-5179 were increasing throughout the application period. Because $\mathrm{Cl}$ is a conservative ion and the median $\mathrm{Cl}$ concentration of the effluent is $89.5 \mathrm{mg} / \mathrm{L}$, this trend should continue.

- Spray-irrigated effluent affected the water quality of the shallow aquifer in the valley bottom. The sprayirrigated effluent decreased nitrate $\mathrm{N}$ concentrations and increased $\mathrm{Cl}$ concentrations in shallow ground water of the valley bottom near well Ch-5177. The median concentration of nitrate $\mathrm{N}$ in 5 water samples collected from well Ch-5177 prior to effluent applica-

Figure 32. Concentrations of nitrate nitrogen in water from hilltop application shallow wells Ch-5173 and Ch-5180, hillside application area shallow well $\mathrm{Ch}-5179$, and concentrations of chloride in water from wells $\mathrm{Ch}-5179$ and $\mathrm{Ch}-5180$, New Garden Township spray-irrigation site, Chester County, Pennsylvania, 1998-2001. 


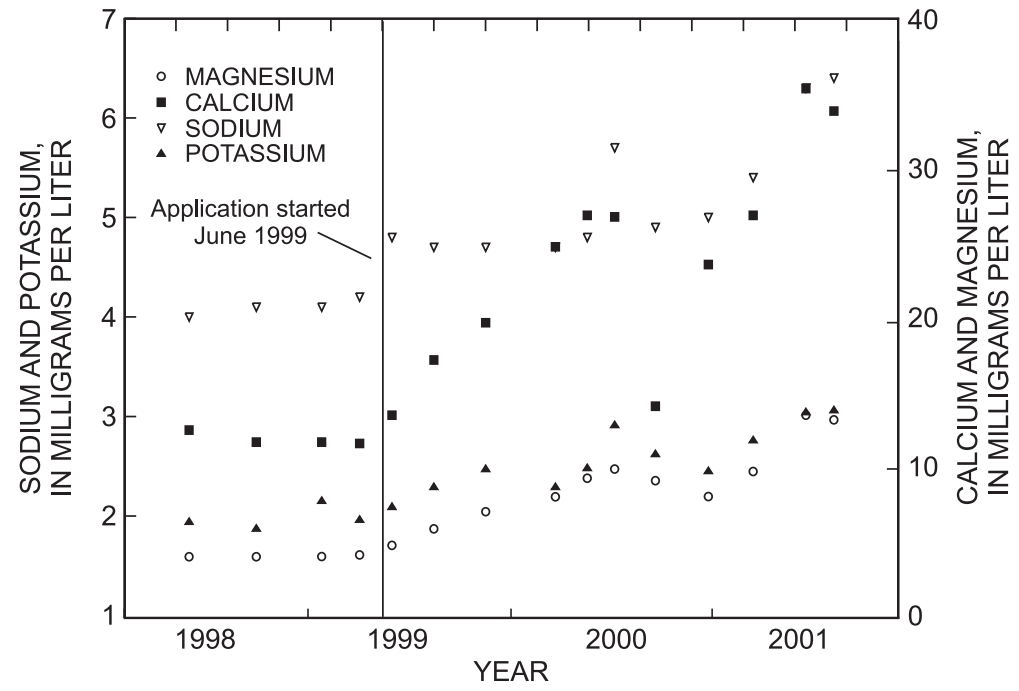

tion was $24 \mathrm{mg} / \mathrm{L}$, and the median concentration of nitrate $\mathrm{N}$ in 30 water samples collected during effluent application was $15 \mathrm{mg} / \mathrm{L}$. The area near well Ch-5177 contained spent mushroom substrate. The decrease in nitrate $\mathrm{N}$ concentrations was because the increased hydraulic loading with spray-irrigated effluent, which contained a lower concentration of nitrate $\mathrm{N}$ than insitu ground water, flushed the nitrate $\mathrm{N}$ from the area. The increase in $\mathrm{Cl}$ concentration in water from well Ch-5177 started near the end of calendar year 2000 and the concentrations increased through the end of the study.

- Spray-irrigated effluent affected the water quality of the bedrock aquifer on the hilltop application area and in the valley bottom. On the hilltop application area, concentrations of $\mathrm{Cl}$ and nitrate $\mathrm{N}$ increased in water from well Ch-5172, perhaps because the downward vertical head (water-level) gradient is greatest on the hilltop when compared to other areas in the watershed. The vertical head difference between the unconsolidated sand and bedrock aquifer on the hilltop averaged approximately $9 \mathrm{ft}$ and the vertical head difference on the hillside averaged approximately $3 \mathrm{ft}$ throughout the study period. The breakthrough of $\mathrm{Cl}$ appears to have taken place near the start of the 2001 calendar year (fig. 34). However, nitrate-N concentrations appeared to increase after spray irrigation began in June 1999, but the concentrations were low. Increasing concentrations of $\mathrm{Cl}$ and nitrate $\mathrm{N}$ in water from hilltop bedrock well Ch-5172 and shallow well Ch-5173 are shown in figure 34 . Because of the downward vertical head gradients on the eastern part of the application area and the water quality of the shallow aquifer showing effects of the spray-irrigated effluent, the water quality of the bedrock aquifer in the eastern application area most likely was affected by the spray-irrigated effluent. In the valley bottom, concentrations of nitrate $\mathrm{N}, \mathrm{Cl}$, and
Figure 33. Concentrations of calcium, magnesium, sodium, and potassium in water from eastern application area shallow well Ch-5179, New Garden Township spray-irrigation site, Chester County, Pennsylvania, 1998-2001.

sodium were trending downward in water from bedrock well Ch-5176 (fig. 35). The decreasing trends in these constituents perhaps result because of the increased hydraulic loading, which would dilute the ambient ground water.

- Spray-irrigated effluent did not increase the nutrient or other chemical constituent concentrations in the stream base flow leaving the watershed. Stormflow leaving the watershed was not assessed. Spray-irrigated effluent did not affect the water quality of the surface water in the pond. 
72 Effects of Spray-Irrigated Effluent on Water Quantity and Quality, and the Fate and Transport of Nitrogen
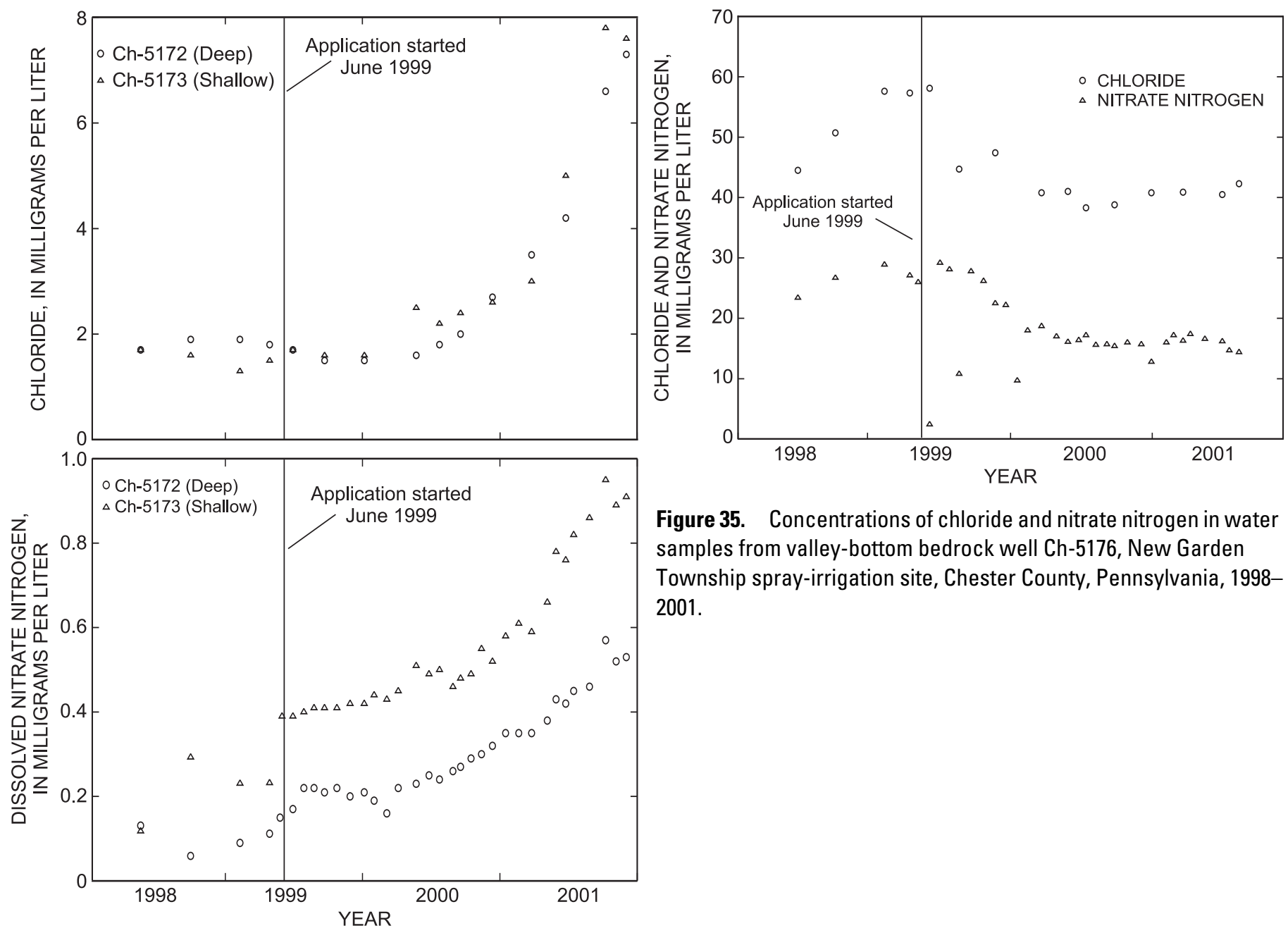

Figure 35. Concentrations of chloride and nitrate nitrogen in water samples from valley-bottom bedrock well Ch-5176, New Garden Township spray-irrigation site, Chester County, Pennsylvania, 19982001.

Figure 34. Concentrations of chloride and dissolved nitrate nitrogen in water samples from wells Ch-5172 and Ch-5173, New Garden Township spray-irrigation site, Chester County, Pennsylvania, 1998-2001. 


\section{Fate and Transport of Nitrogen}

$\mathrm{N}$ input, output, and storage compartments within the 20-acre subbasin at the New Garden Township spray-irrigation site were studied from spring 1999 through December 2001. Spray irrigation at the site began in June 1999; thus, background conditions prior to the site being used for spray irrigation were not documented. A seasonal $\mathrm{N}$ budget was developed for the subbasin with comparisons made to two other locations in the study area either unaffected or only slightly affected by spray irrigation at the site. This seasonal budget approach was used to determine how the input of $\mathrm{N}$ from spray irrigation affected the fate and transport of $\mathrm{N}$ within the 20 -acre subbasin. Seasonal estimates of $\mathrm{N}$ species for the different input, output, and storage compartments were compiled using a variety of sampling methods. Sampling frequency varied depending on the media and whether the location was within or outside the 20 -acre subbasin; however, results of sampling for all media were sufficient for the development of a seasonal $\mathrm{N}$ budget.

\section{Atmospheric Deposition}

Prior to determining seasonal atmospheric deposition rates for the 20-acre subbasin, exploratory data analysis indicated that the $\mathrm{N}$ deposition rate was not significantly related to explanatory variables that were available. The amount of $\mathrm{N}$ in wet deposition was not significantly related to season, precipi- tation intensity or duration, or the time interval between precipitation events. The amount of $\mathrm{N}$ in dry deposition was not related to the number of consecutive dry days prior to sample collection or season. Therefore, the method used to estimate $\mathrm{N}$ loads from wet and dry deposition involved interpolating between sample results to estimate $\mathrm{N}$ loads on days when samples were not collected. On days when precipitation amounts were less than 0.10 in., a comparison was conducted between estimated dry- and wet-deposition rates of $\mathrm{N}$ to determine at what precipitation amount the wet load exceeded the dry load. Precipitation events greater than 0.03 in. yielded higher estimates for wet deposition of $\mathrm{N}$ than for dry deposition. Thus, it was assumed that for precipitation events greater than 0.03 in., $\mathrm{N}$ deposited over the 20 acres was deposited by wet precipitation. If daily precipitation was less than or equal to 0.03 in., the estimated deposition of $\mathrm{N}$ for those days was assumed to come from dry deposition.

Data collected to determine the load of atmospheric $\mathrm{N}$ to the 20 -acre subbasin indicated the majority of $\mathrm{N}$ from the atmosphere was deposited during precipitation events (appendix 1, tables 1-2 and 1-3). Estimated loads for the time interval when wet- and dry-deposition samples were collected, November 1999 through September 2001, indicated about 75 percent of the load of atmospheric $\mathrm{N}$ was deposited during precipitation events (table 28). The estimated load of $\mathrm{N}$ to the 20-acre subbasin from wet precipitation from August 26, 1999 (the first wet-precipitation sample), through December 8, 2001 (the last wet-precipitation sample), was approximately $380 \mathrm{lb}$.

Table 28. Quarterly loads of nitrogen, ammonia nitrogen, nitrate nitrogen, and organic nitrogen deposited from wet and dry deposition over the 20 -acre subbasin, New Garden Township spray-irrigation site, Chester County, Pennsylvania, August 1999 through December 2001.

$[-$, data not available $]$

\begin{tabular}{|c|c|c|c|c|c|c|c|c|}
\hline \multirow{2}{*}{ Date } & \multicolumn{4}{|c|}{$\begin{array}{l}\text { Wet deposition, } \\
\text { in pounds of nitrogen }\end{array}$} & \multicolumn{4}{|c|}{$\begin{array}{l}\text { Dry deposition, } \\
\text { in pounds of nitrogen }\end{array}$} \\
\hline & Nitrogen & $\begin{array}{l}\text { Nitrate } \\
\text { nitrogen }\end{array}$ & $\begin{array}{c}\text { Ammonia } \\
\text { nitrogen }\end{array}$ & $\begin{array}{l}\text { Organic } \\
\text { nitrogen }\end{array}$ & Nitrogen & $\begin{array}{l}\text { Nitrate } \\
\text { nitrogen }\end{array}$ & $\begin{array}{c}\text { Ammonia } \\
\text { nitrogen }\end{array}$ & $\begin{array}{l}\text { Organic } \\
\text { nitrogen }\end{array}$ \\
\hline Aug.-Sept. 1999 & 41 & 7.5 & 12 & 21 & - & - & - & - \\
\hline Oct.-Dec. 1999 & 18 & 4.4 & 5.0 & 8.4 & 16 & 2.1 & 2.3 & 12 \\
\hline Jan.-Mar. 2000 & 72 & 28 & 26 & 18 & 5.8 & .97 & 2.2 & 2.7 \\
\hline Apr.-June 2000 & 52 & 20 & 19 & 13 & 20 & 3.9 & 1.1 & 15 \\
\hline July-Sept. 2000 & 44 & 16 & 16 & 12 & 12 & 3.8 & 1.1 & 6.7 \\
\hline Oct.-Dec. 2000 & 32 & 16 & 9.6 & 6.6 & 8.8 & 2.0 & .94 & 5.9 \\
\hline Jan.-Mar. 2001 & 31 & 14 & 9.8 & 6.4 & 7.2 & 3.2 & 1.6 & 2.4 \\
\hline Apr.-June 2001 & 47 & 22 & 18 & 6.7 & 12 & 4.9 & 2.5 & 4.1 \\
\hline July-Sept. 2001 & 36 & 18 & 16 & 1.5 & 23 & 4.6 & 2.6 & 15 \\
\hline Oct.-Dec. 2001 & 8 & 3.9 & 2.5 & 1.9 & 1.9 & .36 & 1.0 & .49 \\
\hline Totals $^{3}$ & 380 & 150 & 130 & 95 & 110 & 26 & 15 & 64 \\
\hline
\end{tabular}

\footnotetext{
${ }^{1}$ The first wet deposition sample was collected August 26, 1999, and the last collected December 8, 2001.

${ }^{2}$ The first dry deposition sample was collected November 2, 1999, and the last collected October 11, 2001.

${ }^{3}$ Columns may not sum to totals because of rounding.
} 


\section{Effects of Spray-Irrigated Effluent on Water Quantity and Quality, and the Fate and Transport of Nitrogen}

The estimated load of $\mathrm{N}$ from dry deposition from Nov. 2, 1999, through October 11, 2001, was $110 \mathrm{lb}$. The dry to wet ratio of $\mathrm{N}$ deposition is comparable to ratios compiled by Lawrence and others (2000) for 14 sites across the United States that ranged from 0.13 to 0.69 . The average monthly deposition of $\mathrm{N}$ to the 20-acre subbasin from November 1999 through September 2001 was approximately $20 \mathrm{lb}$. This monthly estimate of $20 \mathrm{lb}$ of $\mathrm{N}$ deposition over 20 acres exceeds estimates of wet and dry deposition of $\mathrm{N}$ for high-altitude sites in the western United States where the daily atmospheric loads were estimated to be anywhere from 0.01 to $0.02 \mathrm{lb}$ of $\mathrm{N}$ per acre (Sievering and others, 1992; Zeller and others, 2000). $\mathrm{N}$ deposition rates generally increase traveling from west to east across the United States because of increased power-plant and transportation emissions, in addition to increased animal agriculture

(Lawrence and others, 2000). Power-plant and transportation emissions are the primary source of nitrate $\mathrm{N}$ in the atmosphere, whereas animal production is thought to be the primary source of ammonia $\mathrm{N}$ in the atmosphere (Lawrence and others, 2000).

At the New Garden Township spray-irrigation site, the predominant form of $\mathrm{N}$ in atmospheric deposition varied depending on the media sampled. Forty percent of the total $\mathrm{N}$ in wet precipitation was nitrate $\mathrm{N}, 35$ percent was ammonia $\mathrm{N}$, and 25 percent was organic $\mathrm{N}$. Twenty-five percent of the total $\mathrm{N}$ in dry deposition was nitrate N, 15 percent was ammonia $\mathrm{N}$, and 60 percent was organic N. For combined wet and dry periods, approximately 35 percent of the total $\mathrm{N}$ deposited was nitrate $\mathrm{N}$; the remaining $\mathrm{N}$ was distributed approximately equally between ammonia $\mathrm{N}$ and organic N. Analyses of wet and dry samples did not detect nitrite $\mathrm{N}$, so it was assumed the amount of total $\mathrm{N}$ in the sample not accounted for in nitrate and ammonia $\mathrm{N}$ was organic in nature. The percentage of the load of atmospheric $\mathrm{N}$ in different forms is similar to results from other studies in the eastern United States. Scudlark and others (1998) estimated that atmospheric deposition inputs of $\mathrm{N}$ to the Chesapeake Bay watershed are 48 percent nitrate $\mathrm{N}, 31$ percent ammonium $\mathrm{N}$, and 21 percent organic N. Whitall and Paerl (2001) estimated that the wet deposition of $\mathrm{N}$ to a North Carolina Coastal Plain site was made up of 35 percent nitrate $\mathrm{N}, 33$ percent organic $\mathrm{N}$, and 32 percent ammonium $\mathrm{N}$.

\section{Effluent Nitrogen Input}

Effluent inputs of $\mathrm{N}$ to the 20 -acre subbasin were monitored from June 1999 through December 2001. During this period, approximately $135 \mathrm{Mgal}$ of effluent were applied to the spray-irrigation site. About 41 percent of this total volume fell within the 20-acre subbasin (table 29). Amount of effluent applied to the site varied by season because of the constraints on application during the colder months. From June 1999 through December 2001, 75 percent of the spray was applied to the 20-acre subbasin from April through September.

$\mathrm{N}$ loads from the spray-irrigated effluent to the 20 -acre subbasin obviously were affected by the seasonality of applications. The average monthly load of total $\mathrm{N}$ from April through
September was about $250 \mathrm{lb}$; the average monthly load of total $\mathrm{N}$ from October through March was about $90 \mathrm{lb}$. The spraying schedule at effluent irrigation sites is designed to maximize application during the growing season when plant uptake of nutrients takes place and evaporation rates are high.

The load of $\mathrm{N}$ applied to the spray-irrigation site decreased over time. The reason for this was a decrease in the volume of effluent applied over time (table 29). Fifty percent of the total$\mathrm{N}$ load to the 20-acre subbasin from June 1999 through December 2001 was applied by mid-April 2000. Only about 22 percent of the total-N load from June 1999 through December 2001 was applied during the last 12 months of the study.

Approximately 5,420 lb of $\mathrm{N}$ were applied to the 20 -acre subbasin through spray application from June 1999 through mid-December 2001 (table 29). Seventy-seven percent of this $\mathrm{N}$ was in the dissolved form (anything that would pass through a 0.45 micrometer filter), and the predominant dissolved $\mathrm{N}$ ion was nitrate, which accounted for about 52 percent of the load of total $\mathrm{N}$ or 67 percent of the load of dissolved $\mathrm{N}$. The remaining part of the $\mathrm{N}$ load was made up of organic $\mathrm{N}$ ( 28 percent of the load of total $\mathrm{N}$ ), ammonia $\mathrm{N}$ (14 percent), and nitrite $\mathrm{N}$ (5 percent). All the nitrite $\mathrm{N}$ and 95 percent of the ammonia $\mathrm{N}$ was in dissolved form; however, only 46 percent of the total amount of organic $\mathrm{N}$ was dissolved.

In order to try to determine the fate of $\mathrm{N}$ in the groundwater system after effluent application, $\mathrm{Cl}$ concentrations were measured for most effluent samples collected from the spigot (appendix 1, table 1-1). The total load of $\mathrm{Cl}$ applied to the 20acre subbasin through spray-irrigated effluent from June 1999 through mid-December 2001 was about 38,800 lb; the load of dissolved nitrate $\mathrm{N}$ was about 2,820 lb (table 29). A change in the ratio of nitrate $\mathrm{N}$ to $\mathrm{Cl}$ as effluent moves through the system could be used as indirect evidence for processes such as denitrification (if the ratio decreases) (Focht, 1978). The mean ratio of nitrate $\mathrm{N}$ to $\mathrm{Cl}$ for all effluent samples collected was 0.07 ; however, this ratio decreased over time (fig. 36). The median con-

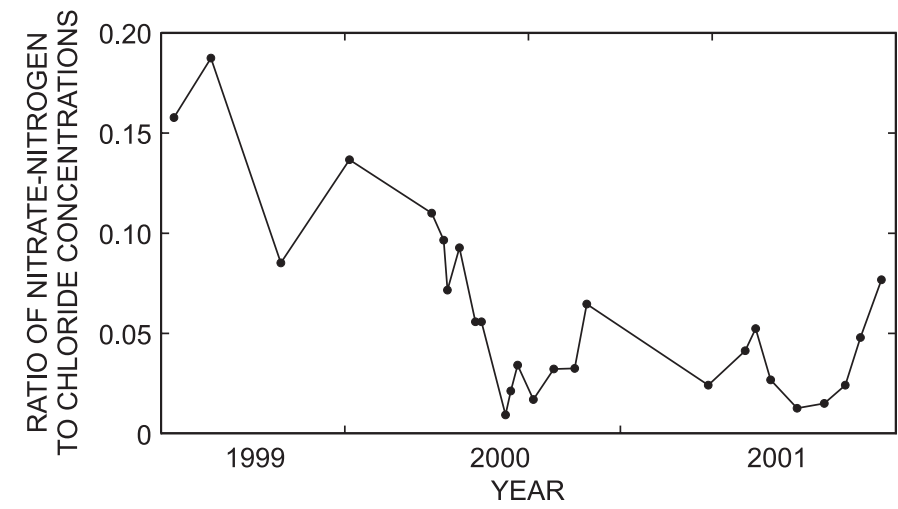

Figure 36. Ratio of nitrate-nitrogen to chloride concentrations in effluent samples, New Garden Township spray-irrigation site, Chester County, Pennsylvania, 1999-2001. 
Table 29. The total volume of effluent applied and the load of dissolved chloride, total and dissolved ammonia nitrogen, dissolved nitrate nitrogen, dissolved nitrite nitrogen, dissolved and total organic nitrogen, and dissolved and total nitrogen applied to the 20-acre subbasin from spray applications, New Garden Township spray-irrigation site, Chester County, Pennsylvania, June 1999 through December 2001.

[gal, gallons; lb, pounds; - , no data]

\begin{tabular}{|c|c|c|c|c|c|c|c|c|c|c|}
\hline Date & $\begin{array}{c}\text { Spray } \\
\text { volume } \\
\text { (gal) }\end{array}$ & $\begin{array}{l}\text { Chloride, } \\
\text { dissolved } \\
\text { (Ib) }\end{array}$ & $\begin{array}{c}\text { Nitrogen, } \\
\text { ammonia, } \\
\text { dissolved } \\
\text { (lb as N) }\end{array}$ & $\begin{array}{c}\text { Nitrogen, } \\
\text { ammonia, } \\
\text { total } \\
\text { (lb as } \mathrm{N} \text { ) }\end{array}$ & $\begin{array}{c}\text { Nitrogen, } \\
\text { nitrate, } \\
\text { dissolved } \\
\text { (Ib as N) }\end{array}$ & $\begin{array}{c}\text { Nitrogen } \\
\text { nitrite, } \\
\text { dissolved } \\
\text { (lb as N) }\end{array}$ & $\begin{array}{l}\text { Nitrogen, } \\
\text { organic, } \\
\text { dissolved } \\
\text { (Ib as N) }\end{array}$ & $\begin{array}{c}\text { Nitrogen } \\
\text { organic, } \\
\text { total } \\
\text { (Ib as } N \text { ) }\end{array}$ & $\begin{array}{l}\text { Nitrogen, } \\
\text { dissolved } \\
\text { (Ib) }\end{array}$ & $\begin{array}{l}\text { Nitrogen, } \\
\text { total } \\
\text { (Ib) }\end{array}$ \\
\hline June 1999 & $1,810,000$ & 1,220 & 24.8 & - & 215 & 6.46 & - & - & - & 281 \\
\hline July 1999 & $2,970,000$ & 1,940 & 28.4 & 23.2 & 351 & 11.9 & 39.7 & 49.0 & 354 & 451 \\
\hline Aug. 1999 & $3,140,000$ & 1,930 & 25.2 & 25.2 & 307 & 7.92 & 29.1 & 55.3 & 369 & 395 \\
\hline Sept. 1999 & $3,110,000$ & 1,790 & 10.7 & 10.8 & 219 & 21.2 & 12.2 & 78.3 & 263 & 329 \\
\hline Oct. 1999 & $3,080,000$ & 1,690 & 26.2 & 27.3 & 161 & 35.0 & 36.0 & 142 & 258 & 365 \\
\hline Nov. 1999 & $1,940,000$ & 1,080 & 13.9 & 14.6 & 130 & 5.54 & 25.0 & 36.4 & 174 & 186 \\
\hline Dec. 1999 & $1,030,000$ & 581 & 1.43 & 1.46 & 79.3 & 1.22 & 12.8 & 21.3 & 94.7 & 103 \\
\hline Jan. 2000 & 828,000 & 470 & 1.23 & 1.33 & 63.9 & 1.68 & 9.53 & 16.3 & 76.3 & 83.2 \\
\hline Feb. 2000 & 0 & 0 & 0 & 0 & 0 & 0 & 0 & 0 & 0 & 0 \\
\hline Mar. 2000 & $2,860,000$ & 1,810 & 106 & 114 & 178 & 5.64 & 22.8 & 53.5 & 313 & 352 \\
\hline Apr. 2000 & $2,130,000$ & 1,390 & 35.2 & 54.3 & 145 & 8.11 & 19.2 & 35.6 & 207 & 243 \\
\hline May 2000 & $4,240,000$ & 2,850 & 34.7 & 37.8 & 258 & 6.05 & 47.7 & 93.7 & 346 & 395 \\
\hline June 2000 & $2,370,000$ & 1,700 & 37.8 & 41.2 & 95.4 & 8.35 & 28.3 & 48.2 & 170 & 193 \\
\hline July 2000 & $5,160,000$ & 3,870 & 37.8 & 44.5 & 125 & 16.4 & 58.6 & 187 & 238 & 373 \\
\hline Aug. 2000 & $3,040,000$ & 2,590 & 24.3 & 28.4 & 65.6 & 14.8 & 40.0 & 157 & 145 & 266 \\
\hline Sept. 2000 & 426,000 & 358 & .603 & 2.51 & 8.42 & 2.54 & 5.49 & 31.7 & 17.0 & 45.2 \\
\hline Oct. 2000 & $1,690,000$ & 1,700 & 1.07 & 1.28 & 54.8 & 11.0 & 21.4 & 55.2 & 88.2 & 122 \\
\hline Nov. 2000 & 822,000 & 803 & .884 & 1.04 & 42.6 & 1.20 & 8.06 & 17.0 & 52.7 & 61.8 \\
\hline Dec. 2000 & 37,700 & 30.6 & .241 & .268 & 1.88 & 0 & .312 & .571 & 2.47 & 2.75 \\
\hline Jan. 2001 & 0 & 0 & 0 & 0 & 0 & 0 & 0 & 0 & 0 & 0 \\
\hline Feb. 2001 & 0 & 0 & 0 & 0 & 0 & 0 & 0 & 0 & 0 & 0 \\
\hline Mar. 2001 & 0 & 0 & 0 & 0 & 0 & 0 & 0 & 0 & 0 & 0 \\
\hline Apr. 2001 & 512,000 & 361 & 29.7 & 32.5 & 9.41 & 2.52 & 4.67 & 6.14 & 46.3 & 50.5 \\
\hline May 2001 & $1,700,000$ & 1,180 & 91.6 & 98.7 & 34.6 & 10.1 & 15.1 & 22.2 & 151 & 166 \\
\hline June 2001 & $3,370,000$ & 2,410 & 108 & 111 & 110 & 28.6 & 52.7 & 102 & 299 & 351 \\
\hline July 2001 & $2,820,000$ & 2,110 & 37.2 & 38.6 & 66.7 & 22.4 & 106 & 139 & 232 & 267 \\
\hline Aug. 2001 & $2,910,000$ & 2,310 & 16.5 & 17.0 & 35.2 & 17.4 & 54.1 & 81.4 & 123 & 151 \\
\hline Sept. 2001 & $2,000,000$ & 1,600 & 7.71 & 7.88 & 22.1 & 11.3 & 38.1 & 55.6 & 79.2 & 96.8 \\
\hline Oct. 2001 & 472,000 & 376 & 1.68 & 1.76 & 7.42 & 2.02 & 9.86 & 17.2 & 21.0 & 28.4 \\
\hline Nov. 2001 & 658,000 & 502 & 3.01 & 3.16 & 24.2 & 2.05 & 10.6 & 23.0 & 39.8 & 52.4 \\
\hline Dec. 2001 & 631,000 & 103 & .214 & .226 & 7.69 & .727 & 3.25 & 5.46 & 11.9 & 14.1 \\
\hline Total $^{1}$ & $55,800,000$ & 38,800 & 706 & 740 & 2,820 & 262 & 711 & 1,530 & 4,170 & 5,420 \\
\hline
\end{tabular}

${ }^{1}$ Columns may not sum to totals because of rounding. 
Table 30. Mean soil concentrations of total nitrogen, nitrate nitrogen, and ammonium nitrogen for soil samples collected in the six different soil-sampling areas for depths of $0-8,>8-24,>24-48,0-48$ inches, New Garden Township spray irrigation site, Chester County, Pennsylvania, April 1999 through October 2001.

\begin{tabular}{|c|c|c|c|c|}
\hline $\begin{array}{c}\text { Soil-sampling } \\
\text { areas }\end{array}$ & $\begin{array}{c}\text { Depth } \\
\text { (inches) }\end{array}$ & $\begin{array}{c}\text { Total nitrogen } \\
\text { (milligrams per } \\
\text { kilogram) }\end{array}$ & $\begin{array}{c}\text { Nitrate nitrogen } \\
\text { (milligrams per } \\
\text { kilogram) }\end{array}$ & $\begin{array}{l}\text { Ammonium nitrogen } \\
\text { (milligrams per } \\
\text { kilogram) }\end{array}$ \\
\hline \multirow[t]{4}{*}{ Upper } & $0-8$ & 1,800 & 8.8 & 2.8 \\
\hline & $>8-24$ & 400 & 3.5 & 2.6 \\
\hline & $>24-48$ & 140 & 2.9 & 2.2 \\
\hline & $0-48$ & 500 & 4.1 & 2.4 \\
\hline \multirow[t]{4}{*}{ Middle } & $0-8$ & 1,500 & 7.7 & 2.7 \\
\hline & $>8-24$ & 430 & 3.4 & 2.3 \\
\hline & $>24-48$ & 160 & 2.9 & 2.2 \\
\hline & $0-48$ & 460 & 3.9 & 2.3 \\
\hline \multirow[t]{4}{*}{ Lower } & $0-8$ & 2,400 & 11. & 3.2 \\
\hline & $>8-24$ & 620 & 4.7 & 2.7 \\
\hline & $>24-48$ & 250 & 3.3 & 2.6 \\
\hline & $0-48$ & 720 & 5.1 & 2.8 \\
\hline \multirow[t]{4}{*}{ Bottom } & $0-8$ & 2,600 & 6.8 & 3.9 \\
\hline & $>8-24$ & 720 & 3.5 & 3.6 \\
\hline & $>24-48$ & 330 & 2.9 & 2.5 \\
\hline & $0-48$ & 840 & 3.8 & 3.1 \\
\hline \multirow[t]{4}{*}{ Control (1) } & $0-8$ & 2,500 & 7.5 & 4.5 \\
\hline & $>8-24$ & 1,800 & 3.5 & 3.6 \\
\hline & $>24-48$ & 300 & 3.3 & 2.8 \\
\hline & $0-48$ & 1,200 & 4.1 & 3.4 \\
\hline \multirow[t]{4}{*}{ Control (2) } & $0-8$ & 1,800 & 4.9 & 1.8 \\
\hline & $>8-24$ & 800 & 3.5 & 1.6 \\
\hline & $>24-48$ & 400 & 3.2 & 1.3 \\
\hline & $0-48$ & 770 & 3.6 & 1.5 \\
\hline
\end{tabular}

centration of nitrate $\mathrm{N}$ decreased from 5.85 to $2.38 \mathrm{mg} / \mathrm{L}$ from 2000 to 2001; the median $\mathrm{Cl}$ concentrations remained virtually unchanged $(88 \mathrm{mg} / \mathrm{L}$ in 2000 and $90.4 \mathrm{mg} / \mathrm{L}$ in 2001).

Samples of effluent were collected at the spigot in October 1999, July 2001, and November 2001 and analyzed for N isotopes (appendix 1, table 1-1). Values for $\delta^{15} \mathrm{~N}$ (nitrate) ranged from $10.1 \%$ (nitrate- $\mathrm{N}$ concentration of $4.3 \mathrm{mg} / \mathrm{L}$ ) for the November 2001 sample to $15.7 \%$ (nitrate-N concentration of $6.8 \mathrm{mg} / \mathrm{L}$ ) for the October 1999 sample. These $\delta^{15} \mathrm{~N}$ values are typical for nitrate $\mathrm{N}$ found in human wastewater (Heaton, 1986). The different values for $\delta^{15} \mathrm{~N}$ at the spigot could be because of processes such as biological conversion of nitrate $\mathrm{N}$ to organic $\mathrm{N}$, denitrification, or mineralization of organic $\mathrm{N}$ (Karr and others, 2001).

\section{Solid-Soil Nitrogen Storage}

The largest storage compartment for $\mathrm{N}$ at the study site was the solid soil matrix. Soil samples were collected from six separate areas at the study site (fig. 37). Three of these areas, designated as Lower (lower part of the spray field), Bottom (bottom of the 20-acre subbasin but outside of a spray field), and Control (1), had spent mushroom substrate present over some of the area (fig. 37). About 25 percent of the surface area for soil-sample locations Lower and Control (1) was covered with spent mushroom substrate; 30 percent of Bottom was covered with spent mushroom substrate. This was reflected in the mean concentrations of total $\mathrm{N}$ for these areas, especially for samples collected from the 0 to 8 in. depth interval (fig. 38). Mean concentrations of total $\mathrm{N}$ for the $0-8$ in. depth interval for these three areas - Lower, Bottom, and Control (1) -were $2,400,2,600$, and $2,500 \mathrm{mg} / \mathrm{kg}$, respectively (table 30 ). The mean concentrations of total $\mathrm{N}$ for the $0-8 \mathrm{in}$. depth interval for Lower, Bottom, and Control (1) were about 40 to 90 percent higher than concentrations for four farm sites in Lancaster for the same depth interval (Koerkle and others, 1997). All other areas (Upper, Middle, and Control (2)) had mean concentrations of total $\mathrm{N}$ below $2,000 \mathrm{mg} / \mathrm{kg}$; these concentrations averaged about 3 percent higher than the concentrations reported by Koerkle and others (1997) for the farm sites in Lancaster 


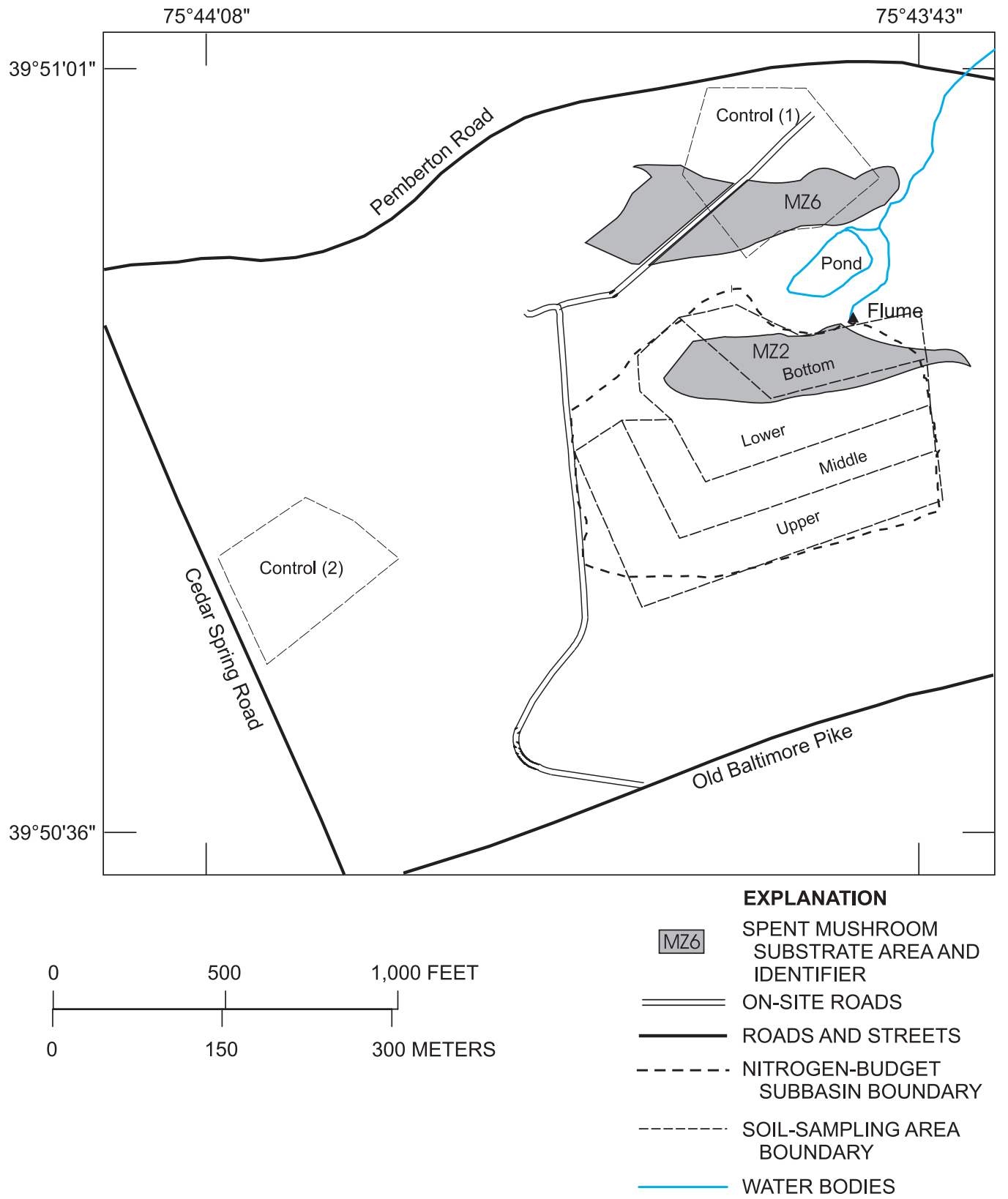

Figure 37. Location of soil-sampling areas and known spent mushroom substrate areas, New Garden Township spray-irrigation site, Chester County, Pennsylvania. 
78 Effects of Spray-Irrigated Effluent on Water Quantity and Quality, and the Fate and Transport of Nitrogen
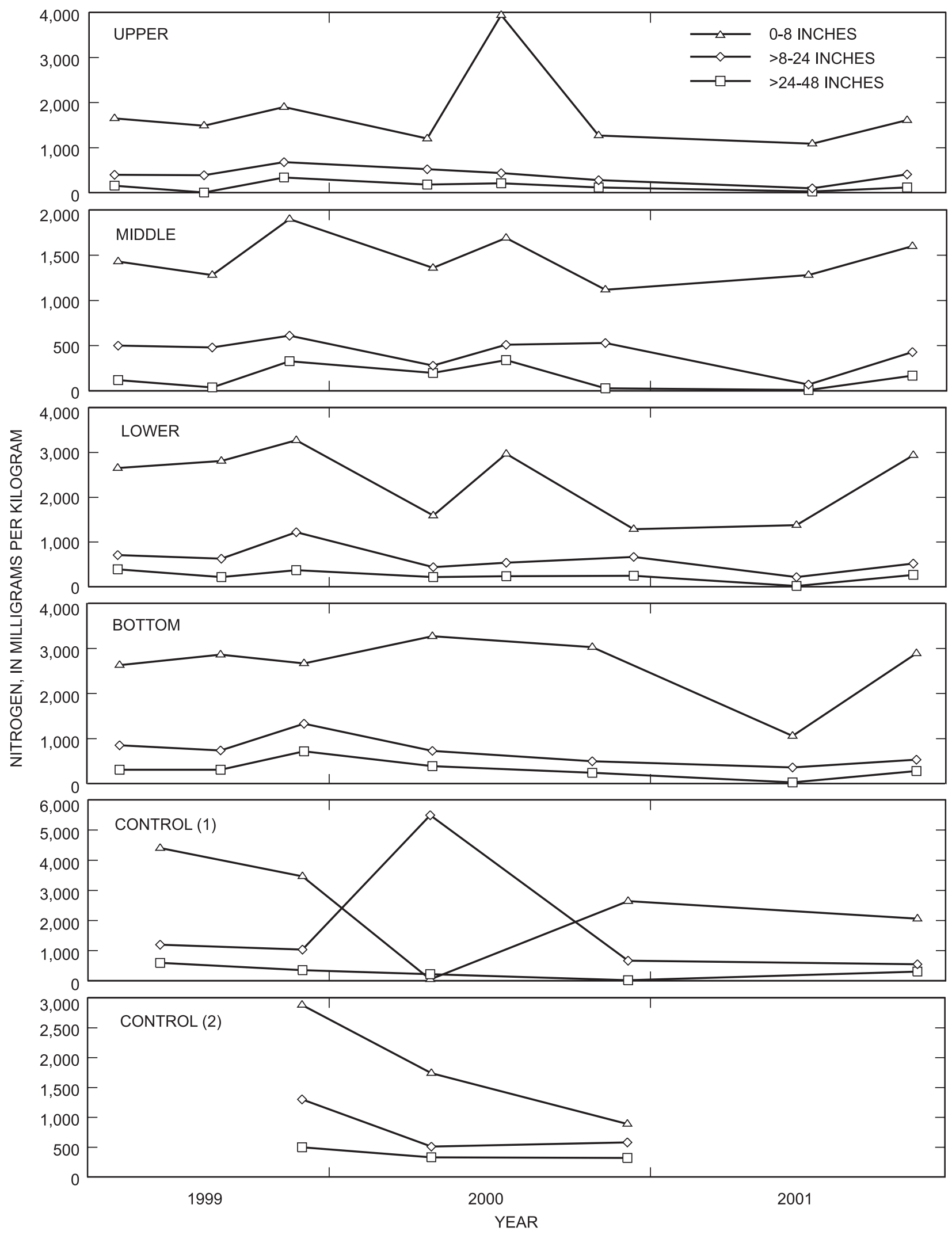

Figure 38. Concentration of nitrogen per unit mass of soil for soil samples collected from depths of 0-8 inches, $>8-24$ inches, and >24-48 inches, New Garden Township spray-irrigation site, Chester County, Pennsylvania, 1999-2001. 
County, Pa. The comparison to the farm sites indicated that areas with spent mushroom substrate had higher total $\mathrm{N}$ concentrations because of limited plant harvest and $\mathrm{N}$ removal. The farm sites had more $\mathrm{N}$ harvested, and organic $\mathrm{N}$ pools could not accumulate. Soil samples collected at two forested sites in Pennsylvania (C.A. Cravotta, III, U.S. Geological Survey, written commun., 2003) had higher total $\mathrm{N}$ concentrations than any of the six areas sampled at the spray-irrigation site, again indicating that plant removal has a large effect on total $\mathrm{N}$ pools in the soil. Soil samples collected from the $0-8$ in. depth interval within the spent mushroom substrate deposition areas indicated concentrations of $\mathrm{N}$ were $8,600 \mathrm{mg} / \mathrm{kg}$ (for the spent mushroom substrate in Lower and Bottom areas, hereafter identified as MZ2) and $13,000 \mathrm{mg} / \mathrm{kg}$ (for the spent mushroom substrate near and within Control (1), hereafter identified as MZ6)

(appendix 1, table 1-4). The N data for MZ2 and MZ6, along with the higher concentrations of total carbon and extractable $\mathrm{Cl}$ for MZ6 and the lower redox potential for MZ2, indicated the spent mushroom substrate at MZ2 was older. The location of MZ2 (total area equal to 2.25 acres) within the 20 -acre subbasin likely caused modification in the quality of subsurface drainage water as the water moved downgradient from the spray field to the swale and eventually discharged through the flume.

The vast majority of the $\mathrm{N}$ in the solid-soil phase was organic for samples collected from April 1999 through October 2001. The average percentage of total $\mathrm{N}$ in organic form was approximately 96-97 percent for all the soil samples collected. It is typical that the surface soil layers contain over 90 percent of $\mathrm{N}$ in organic form (Stevenson, 1982a). Nitrate $\mathrm{N}$ and ammonium $\mathrm{N}$ accounted for the remaining $\mathrm{N}$ fraction (table 30 ). For agricultural sites in Lancaster County, Pa., Koerkle and others (1997) found that about 2 percent of the total $\mathrm{N}$ in the solid-soil phase to a depth of $4 \mathrm{ft}$ was in the form of nitrate and ammonium. The distribution pattern of solid-soil $\mathrm{N}$ down to a depth of $4 \mathrm{ft}$ was fairly consistent for each of the locations sampled. Highest concentrations were identified in the $0-8 \mathrm{in}$. depth interval; concentrations decreased with depth (fig. 38). Decreasing concentrations of $\mathrm{N}$ with an increase in depth is common for most soils (Stevenson, 1982b). The mean concentration of $\mathrm{N}$ for all samples (except for the samples collected in MZ2 and MZ6) collected from the 0-8 in. depth interval was $2,100 \mathrm{mg} / \mathrm{kg}$ of $\mathrm{N}$; the mean concentration of $\mathrm{N}$ for the $>24-48$ in. depth interval was $240 \mathrm{mg} / \mathrm{kg}$. Highest concentrations of nitrate $\mathrm{N}$ and ammonium $\mathrm{N}$ also were found at the surface; the lowest concentrations were in the >24-48 in. depth interval (figs. 39 and 40); however, the percentage of the total $\mathrm{N}$ in the form of nitrate and ammonium increased with an increase in depth. Thus, as the total $\mathrm{N}$ concentration decreased with an increase in depth, the percentage of the amount of $\mathrm{N}$ in plant-available forms (nitrate $\mathrm{N}$ and ammonium $\mathrm{N}$ ) increased. One probable cause for this result is the plant uptake of nitrate $\mathrm{N}$ and ammonium $\mathrm{N}$ from the $0-8 \mathrm{in}$. depth interval. The highest concentrations of nitrate $\mathrm{N}$ were evident for the two spent mushroom substrate samples, MZ2 and MZ6. These samples had nitrate-N concentrations of 103 and $256 \mathrm{mg} / \mathrm{kg}$, respectively. The only other soil sample that had a nitrate- $\mathrm{N}$ concentration exceeding $10 \mathrm{mg} / \mathrm{kg}$ was the $0-8 \mathrm{in}$. depth sample for the Bottom location $(11.3 \mathrm{mg} / \mathrm{kg})$. For the MZ2 and MZ6 samples, even though plant uptake was occurring, the mineralization of $\mathrm{N}$ from the large organic $\mathrm{N}$ pool available from the deposition of spent mushroom substrate exceeded the plant uptake rate, thus, accumulating available N. Generally, the mineralization of organic $\mathrm{N}$ to nitrate $\mathrm{N}$ and ammonium $\mathrm{N}$ occurs at a rate of 2-3 percent per year (Brady, 1974, p. 426).

Time trends in solid-soil $\mathrm{N}$ concentrations varied depending on $\mathrm{N}$ species and sample location. Time trends in the concentrations of total $\mathrm{N}$ and nitrate $\mathrm{N}$ in soil were not evident from samples collected at any of the six fields (figs. 38 and 39) (see fig. 37 for sample locations). Significant increasing time trends were evident for concentrations of ammonium $\mathrm{N}$ for some depths and sampling locations within the 20 -acre subbasin (fig. 40). Increasing trends in ammonium $\mathrm{N}$ retained in the solid-soil matrix could be attributed to (1) increased soil moistures, (2) decreased redox potentials, or (3) increased ammonium $\mathrm{N}$ retention. Increased soil moistures caused by spray-irrigated effluent would decrease the availability of oxygen in the soil, which causes decreased redox potential in the soils. Significant decreasing time trends in redox potentials (fig. 41) were evident for samples collected in the Upper, Middle, and Lower locations. Decreasing redox potential would inhibit nitrification, a process that converts ammonium ions to nitrate (Brady, 1974). Another factor that could cause increased retention of the ammonium ion could be the input of negative ions into the system through spray-irrigated effluent. Added anions to a soil system typically increases the capacity of the system to retain cations (such as ammonium) (Nommik and Vahtras, 1982).

The redox potential of the soil increased with an increase in depth; thus, reductive processes (such as denitrification) had a higher potential of occurring near the surface. This trend in redox with depth could be because of high concentrations of organic carbon near the surface that could help to tie up oxygen in the heterotrophic biomass. Another possibility was that the particle-size distribution in the soil affected the redox. Personal observation during soil-sample collection indicated that the soil, in areas unaffected by spent mushroom substrate, had a higher distribution of fines (silt and clay) near the soil surface. Fine materials could hold more water than coarse material, and anoxic conditions could more readily develop or be present. It was typical to intersect predominantly sand below a depth of $2-3 \mathrm{ft}$.

The mass of $\mathrm{N}$ to a depth of $4 \mathrm{ft}$ was determined for each sampling date and each soil-sampling area using concentration data and soil bulk-density data (table 31 ). The first soil samples were collected prior to spray irrigation in spring 1999, and final samples were collected in October 2001. The summed masses for the sample locations for the $0-48 \mathrm{in}$. depth interval indicated the mass of $\mathrm{N}$ in the solid-soil matrix did not change from spring 1999 to October 2001 because of spray irrigation or any other factors that could affect soil chemistry. The highest mass of $\mathrm{N}$ per unit area to a depth of $4 \mathrm{ft}$ was in the Control (1) location. The average mass of $\mathrm{N}$ to a depth of $4 \mathrm{ft}$ for this location was 


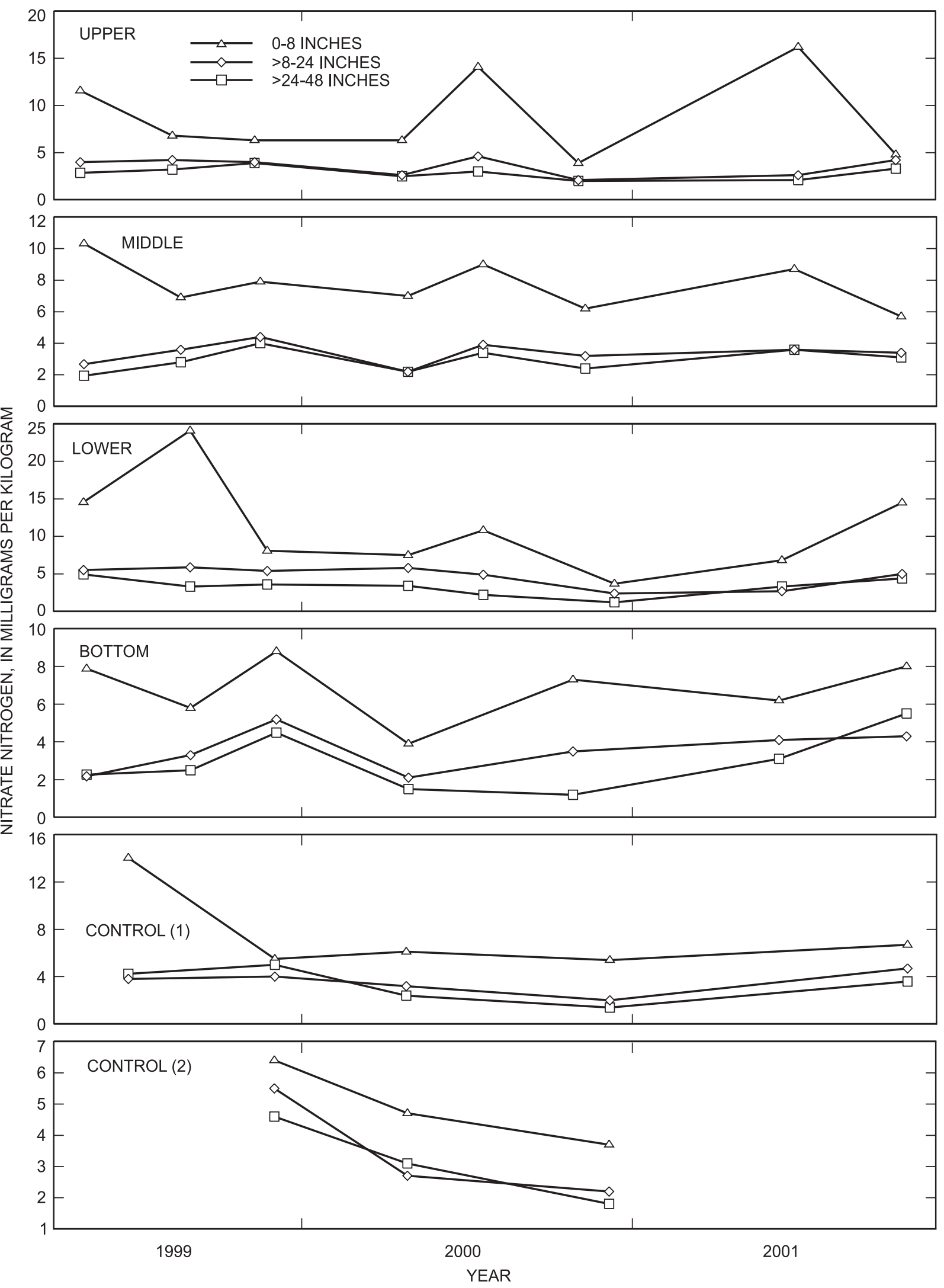

Figure 39. Concentration of nitrate nitrogen per unit mass of soil for soil samples collected from depths of 0-8 inches, >8-24 inches, and >24-48 inches, New Garden Township spray-irrigation site, Chester County, Pennsylvania, $1999-2001$. 


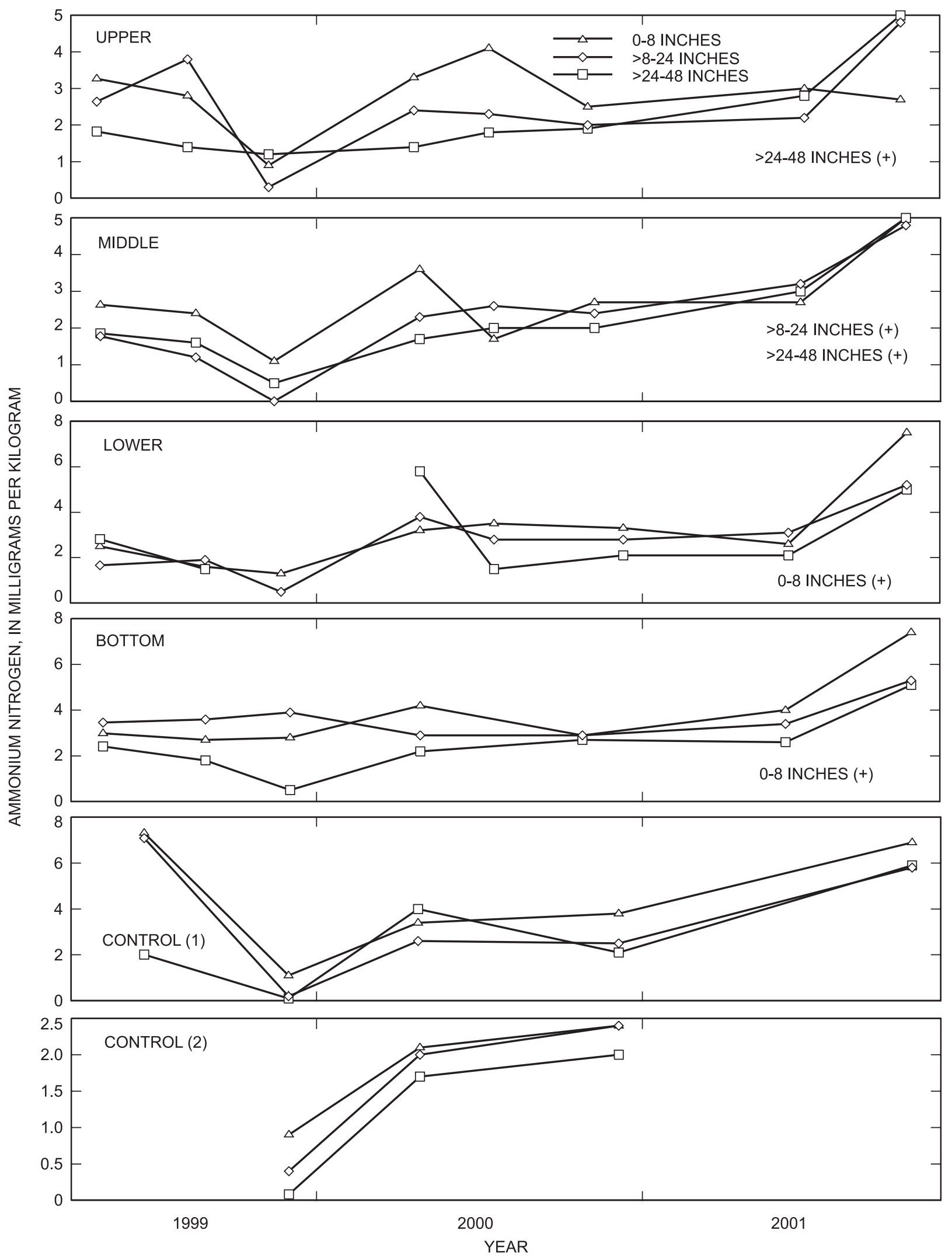

Figure 40. Concentration of ammonium nitrogen per unit mass and identification of significant time trends in ammonium nitrogen for soil samples collected from depths of 0-8 inches, >8-24 inches, and >24-48 inches, New Garden Township spray-irrigation site, Chester County, Pennsylvania, 1999-2001. (“(+)" indicates a significant increasing trend. Significant trends over time were based on an alpha equal to 0.05 .) 


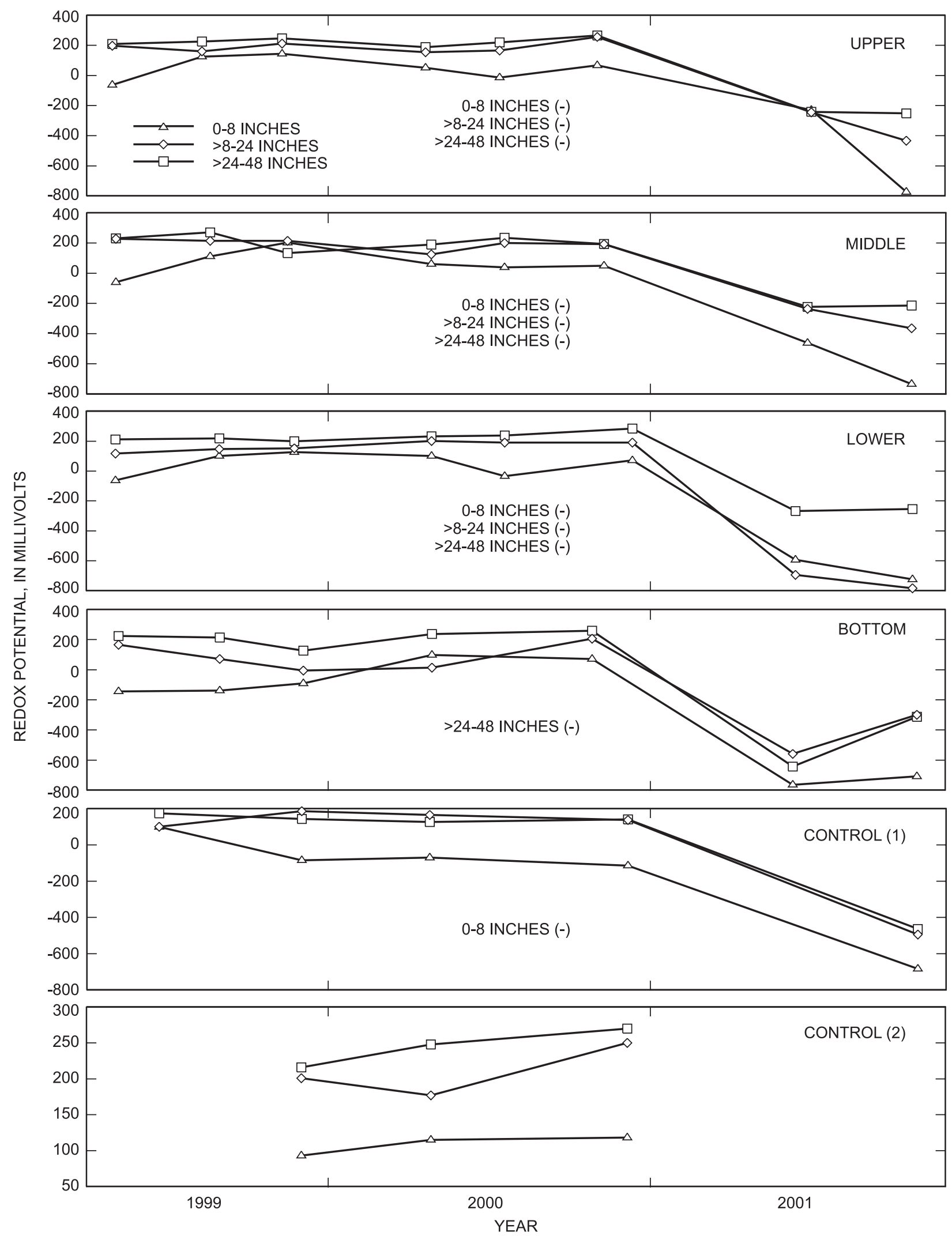

Figure 41. Oxidation-reduction potential (redox) and identification of significant time trends in redox for soil samples collected from depths of 0-8 inches, >8-24 inches, and >24-48 inches, New Garden Township spray-irrigation site, Chester County, Pennsylvania, 1999-2001, 1999-2001. (“(-)" indicates a significant decreasing trend. Significant trends over time were based on an alpha equal to 0.05 .) 
Table 31. Total estimated masses of nitrogen, nitrate nitrogen, and ammonium nitrogen in the solid-soil matrix to a depth of 4 feet for the six different soil-sampling areas, New Garden Township spray-irrigation site, Chester County, Pennsylvania, 1999-2001.

[Soil-sampling areas are shown on figure 37. —, no data]

\begin{tabular}{|c|c|c|c|c|c|c|c|c|c|}
\hline \multirow[b]{2}{*}{$\begin{array}{c}\text { Soil-sampling } \\
\text { area }\end{array}$} & \multirow[b]{2}{*}{ Constituent } & \multicolumn{8}{|c|}{ Mass of constituent in the solid-soil matrix, in pounds } \\
\hline & & $\begin{array}{c}\text { Spring } \\
1999\end{array}$ & $\begin{array}{c}\text { Summer } \\
1999\end{array}$ & $\begin{array}{l}\text { Fall } \\
1999\end{array}$ & $\begin{array}{l}\text { Spring } \\
2000\end{array}$ & $\begin{array}{c}\text { Summer } \\
2000\end{array}$ & $\begin{array}{l}\text { Fall } \\
2000\end{array}$ & $\begin{array}{c}\text { Summer } \\
2001\end{array}$ & $\begin{array}{l}\text { Fall } \\
2001\end{array}$ \\
\hline \multirow{3}{*}{$\begin{array}{l}\text { Upper } \\
\quad(5.83 \text { acres })\end{array}$} & Nitrogen & 41,000 & 32,000 & 62,000 & 40,000 & 75,000 & 31,000 & 19,000 & 39,000 \\
\hline & Nitrate nitrogen & 410 & 370 & 390 & 280 & 460 & 210 & 390 & 340 \\
\hline & Ammonium nitrogen & 210 & 220 & 77 & 180 & 210 & 180 & 240 & 410 \\
\hline \multirow{3}{*}{$\begin{array}{l}\text { Middle } \\
\qquad(3.96 \text { acres })\end{array}$} & Nitrogen & 27,000 & 22,000 & 40,000 & 24,000 & 36,000 & 22,000 & 13,000 & 28,000 \\
\hline & Nitrate nitrogen & 210 & 220 & 290 & 180 & 270 & 200 & 260 & 220 \\
\hline & Ammonium nitrogen & 120 & 95 & 26 & 130 & 130 & 140 & 190 & 300 \\
\hline \multirow{3}{*}{$\begin{array}{l}\text { Lower } \\
\quad(5.25 \text { acres })\end{array}$} & Nitrogen & 66,000 & 58,000 & 86,000 & 39,000 & 59,000 & 43,000 & 22,000 & 59,000 \\
\hline & Nitrate nitrogen & 520 & 570 & 390 & 390 & 350 & 160 & 290 & 490 \\
\hline & Ammonium nitrogen & 190 & 130 & 30 & 390 & 180 & 200 & 200 & 440 \\
\hline \multirow{3}{*}{$\begin{array}{l}\text { Bottom } \\
\quad(3.06 \text { acres })\end{array}$} & Nitrogen & 38,000 & 38,000 & 58,000 & 43,000 & - & 33,000 & 13,000 & 34,000 \\
\hline & Nitrate nitrogen & 150 & 160 & 260 & 100 & - & 130 & 190 & 270 \\
\hline & Ammonium nitrogen & 140 & 130 & 95 & 130 & - & 140 & 150 & 270 \\
\hline \multirow{3}{*}{$\begin{array}{l}\text { Control (1) } \\
\quad(5.30 \text { acres })\end{array}$} & Nitrogen & - & 100,000 & 77,000 & 150,000 & - & 46,000 & - & 48,000 \\
\hline & Nitrate nitrogen & - & 410 & 350 & 240 & - & 160 & - & 330 \\
\hline & Ammonium nitrogen & - & 340 & 21 & 250 & - & 180 & - & 450 \\
\hline \multirow{3}{*}{$\begin{array}{l}\text { Control (2) } \\
\quad(3.79 \text { acres) }\end{array}$} & Nitrogen & - & - & 70,000 & 37,000 & - & 31,000 & - & - \\
\hline & Nitrate nitrogen & - & - & 330 & 200 & - & 140 & - & - \\
\hline & Ammonium nitrogen & - & - & 19 & 120 & - & 140 & - & - \\
\hline
\end{tabular}

about 15,900 lb/acre; for the Middle location, the average mass of $\mathrm{N}$ was approximately $6,700 \mathrm{lb} / \mathrm{acre}$. The higher mass of $\mathrm{N}$ per unit area for Control (1) was because of the presence of spent mushroom substrate.

$\mathrm{N}$ masses below a depth of $4 \mathrm{ft}$ were estimated in order to determine the total amount of $\mathrm{N}$ in the solid-soil matrix (table 32). Because of the sharp decline in $\mathrm{N}$ concentrations with depth, the total mass of $\mathrm{N}$ per volume of soil was predicted to be markedly lower below a depth of $4 \mathrm{ft}$. Nonlinear regression models were generated relating bulk density and $\mathrm{N}$ concentration to depth for soil samples collected for the $0-8$ in., >824 in., and >24-48 in. depth intervals. Extrapolation of the nonlinear regression models to competent bedrock provided estimates for $\mathrm{N}$ mass. Given that the estimates were based on data from upper horizons, it follows that the higher estimates for $\mathrm{N}$ mass below $4 \mathrm{ft}$ were predicted for soil-sample areas where the highest concentrations of $\mathrm{N}$ actually were measured. The $\mathrm{N}$ masses from $4 \mathrm{ft}$ to competent bedrock were estimated by varying the bulk densities for the top (4 ft below land surface) and bottom (depth of competent bedrock) of the section. The bulk densities for the top were determined from the bulk-density data collected for the >24-48 in. depth interval for that particular field. The bulk densities for the bottom were estimated from Brady (1974). This technique gave a range of $\mathrm{N}$ masses for each field, as presented in table 32 . The highest mass of $\mathrm{N}$ per unit volume of soil for depths below $4 \mathrm{ft}$ were predicted in the
Table 32. Range of estimates for the total mass of nitrogen stored in the solid-soil matrix for depths of 4 feet to the depth of competent bedrock for the four different soil-sampling areas within the 20-acre subbasin, New Garden Township spray-irrigation site, Chester County, Pennsylvania, April 1999 through October 2001.

[Soil-sampling areas are shown on figure 37]

\begin{tabular}{lccc}
\hline $\begin{array}{c}\text { Soil-sampling } \\
\text { area }\end{array}$ & $\begin{array}{c}\text { Area } \\
\text { (acres) }\end{array}$ & $\begin{array}{c}\text { Depth } \\
\text { (feet) }\end{array}$ & $\begin{array}{c}\text { Nitrogen mass } \\
\text { (pounds) }\end{array}$ \\
\hline Upper & 5.83 & 4 to 62 & $20,000-40,000$ \\
Middle & 3.96 & 4 to 59 & $20,000-50,000$ \\
Lower & 5.25 & 4 to 56.5 & $50,000-60,000$ \\
Bottom & 3.06 & 4 to 35 & $30,000-70,000$ \\
\hline
\end{tabular}




\section{Effects of Spray-Irrigated Effluent on Water Quantity and Quality, and the Fate and Transport of Nitrogen}

Bottom area, with the $\mathrm{N}$ mass per unit volume decreasing to the top of the 20-acre subbasin where the Upper and Middle areas were located. The range of $\mathrm{N}$ mass per unit volume for the $0-$ $4 \mathrm{ft}$ depth interval was $0.037 \mathrm{lb} / \mathrm{ft}^{3}$ (Middle area) to $0.68 \mathrm{lb} / \mathrm{ft}^{3}$ (Bottom area). The range of estimated $\mathrm{N}$ mass per unit volume for depths below $4 \mathrm{ft}$ to competent bedrock was $0.0020 \mathrm{lb} / \mathrm{ft}^{3}$ (Upper area) to $0.012 \mathrm{lb} / \mathrm{ft}^{3}$ (Bottom area).

\section{Soil-Water Nitrogen Storage}

Changes in the storage of $\mathrm{N}$ within the soil-water matrix were monitored from June 1999 through December 2001. Monitoring of soil water was conducted using a network of soil-suction lysimeters. Soil-suction lysimeters capture micropore soil water or water held in the soil matrix through capillary forces (Parizek and Lane, 1970). Water that is not held by capillary forces, such as macropore flow or total soil saturation with vertical downward movement, is not captured by soil-suction lysimeters because the amount of tension applied to the suction lysimeter can not overcome the downward forces moving the water through the matrix. Therefore, changes in the soil-water storage of $\mathrm{N}$ for the 20 -acre subbasin were based on micropore water. Considering that macropore flow or gravitational flow is more transient in the system than micropore water, it is reasonable to base changes in soil-water storage on micropore water.

The concentration of dissolved $\mathrm{N}$ for samples collected from the lysimeter network indicated considerable variation across the study site. Concentrations of dissolved $\mathrm{N}$ ranged from non-detect values of less than $0.06 \mathrm{mg} / \mathrm{L}$ for lysimeter Ch-5219 to $78 \mathrm{mg} / \mathrm{L}$ for lysimeter Ch-5448 (fig. 42). Lysimeter Ch-5219, installed at a depth of $3 \mathrm{ft}$ below land surface, was about $200 \mathrm{ft}$ downgradient of spray field 2. Lysimeter Ch-5449, also $3 \mathrm{ft}$ below land surface, was immediately outside of spray field 2 in an area historically used for spent mushroom substrate disposal (plate 1 and table 9). The large difference in concentrations between lysimeters Ch-5448 and Ch-5449 indicate that, even though both were below spent mushroom substrate, the substrate layer above lysimeter Ch-5448 was applied more recently than the layer above lysimeter Ch-5449. The downgradient movement of mineralized $\mathrm{N}$ from the substrate layer above lysimeter Ch-5448 was evident from the data collected for lysimeter nest Lys\#4. Concentrations of dissolved $\mathrm{N}$ increased with depth in nest Lys\#4, ranging from median values of $0.61 \mathrm{mg} / \mathrm{L}$ for lysimeter Ch-5567 (depth of $3 \mathrm{ft}$ ) to $1.9 \mathrm{mg} / \mathrm{L}$ for lysimeter Ch-5570 (depth of $15 \mathrm{ft}$ ), which indicated more of the mineralized $\mathrm{N}$ from the spent mushroom substrate was being recovered by the lysimeters with an increase in depth. Water samples from lysimeter nest Lys\#5 also indicated an increasing concentration of dissolved $\mathrm{N}$ with an increase in depth; concentrations of dissolved $\mathrm{N}$ ranged from $0.98 \mathrm{mg} / \mathrm{L}$ for lysimeter Ch-5571 (depth of $3 \mathrm{ft}$ ) to $10 \mathrm{mg} / \mathrm{L}$ for lysimeter Ch-5574 (depth of $15 \mathrm{ft}$ ). The data for lysimeter nest Lys\#5 indicate a source of spent mushroom substrate near the lysimeter nest, and the deepest lysimeter in the nest, Ch-5574, is the lysimeter most affected by the mineralization of organic $\mathrm{N}$ in the spent mushroom substrate. A local resident (Kevin
McCarthy, oral commun., 2000) did indicate the presence of a spent mushroom substrate zone near the northwest corner of the study area, but this substrate zone was not mapped. Lysimeters within the spray fields (lysimeter nests Lys\#1 and Lys\#2) indicated a range of dissolved $\mathrm{N}$ concentrations of $0.3 \mathrm{mg} / \mathrm{L}$ for Ch-5211 in September 2001 to 24 mg/L for Ch-5213 in February 2000.

Spatial differences and depth differences within a lysimeter nest for dissolved $\mathrm{N}$ concentrations also were evident within the 20-acre subbasin. Median concentrations for dissolved $\mathrm{N}$ ranged from $1.0 \mathrm{mg} / \mathrm{L}$ for lysimeter Ch-5211 to $3.4 \mathrm{mg} / \mathrm{L}$ for lysimeter Ch-5213 for lysimeter nest Lys\#1; for nest Lys\#2, median concentrations ranged from $2.0 \mathrm{mg} / \mathrm{L}$ for lysimeter Ch-5215 to $3.4 \mathrm{mg} / \mathrm{L}$ for lysimeter Ch-5217. For both nests, the lowest concentrations for dissolved $\mathrm{N}$ were at a depth of $3 \mathrm{ft}$, and highest median concentrations were at a depth of $11 \mathrm{ft}$. Both of these nests also indicated significant decreasing time trends in the concentration of dissolved $\mathrm{N}$ for all except for the deepest lysimeters (table 33). Lysimeter nest Lys\#3 indicated dramatic differences in concentrations of dissolved $\mathrm{N}$ with depth. The median concentration of dissolved $\mathrm{N}$ for lysimeter Ch-5219 was $0.16 \mathrm{mg} / \mathrm{L}$; the median concentration for lysimeter Ch-5566 (at a depth of $13 \mathrm{ft}$, the deepest lysimeter in the nest) was $11 \mathrm{mg} / \mathrm{L}$. The mean concentration for all the data collected for the three lysimeters in nest Lys\#3 below lysimeter Ch-5219 was about $10 \mathrm{mg} / \mathrm{L}$ of dissolved $\mathrm{N}$. The linear distance between lysimeter nests Lys\#2 and Lys\#3 was approximately $380 \mathrm{ft}$. The primary reason for major differences in concentrations of dissolved $\mathrm{N}$ between lysimeter nests Lys\#1 and Lys\#2 in comparison to lysimeter nest Lys\#3 was the presence of a layer of spent mushroom substrate between nests Lys\#2 and Lys\#3. The layer extended from west to east across the field, a distance of about $700 \mathrm{ft}$ and a width of about 100-150 ft, covering an area of 2 acres (fig. 37). The depth of the layer ranged from about 0.5 to $1.0 \mathrm{ft}$. Lysimeter Ch-5449, the lysimeter directly beneath (at a depth of $3 \mathrm{ft}$ below land surface) this spent mushroom substrate layer, indicated a median concentration of $1.4 \mathrm{mg} / \mathrm{L}$ for dissolved $\mathrm{N}$, which was one of the lowest median concentrations for water samples from the entire lysimeter network. The data for lysimeters Ch-5449 and Ch-5219 indicate that the supply of $\mathrm{N}$ available from the spent mushroom substrate upgradient of lysimeter Ch-5219 is diminishing; however, the $\mathrm{N}$ mineralized from the substrate remains in the subsurface and apparently is being recovered from the lysimeters in nest Lys\#3 below an altitude of about $337 \mathrm{ft}$ above NGVD 29 (table 9), which was the altitude of the ceramic cup at the base of lysimeter Ch-5219.

Significant decreasing time trends in concentrations of dissolved $\mathrm{N}$ were evident for 9 of the 11 lysimeters within the 20 -acre subbasin and for 4 of the 9 lysimeters outside the subbasin (table 33). One lysimeter outside the 20 -acre subbasin, Ch-5574, indicated an increasing trend in concentrations of dissolved $\mathrm{N}$. The decreasing trends in concentrations of dissolved $\mathrm{N}$ within the 20-acre subbasin were not expected given that over $5,400 \mathrm{lb}$ of $\mathrm{N}$ was applied to the 20 -acre subbasin through spray irrigation from June 1999 through December 2001 (table 29). 


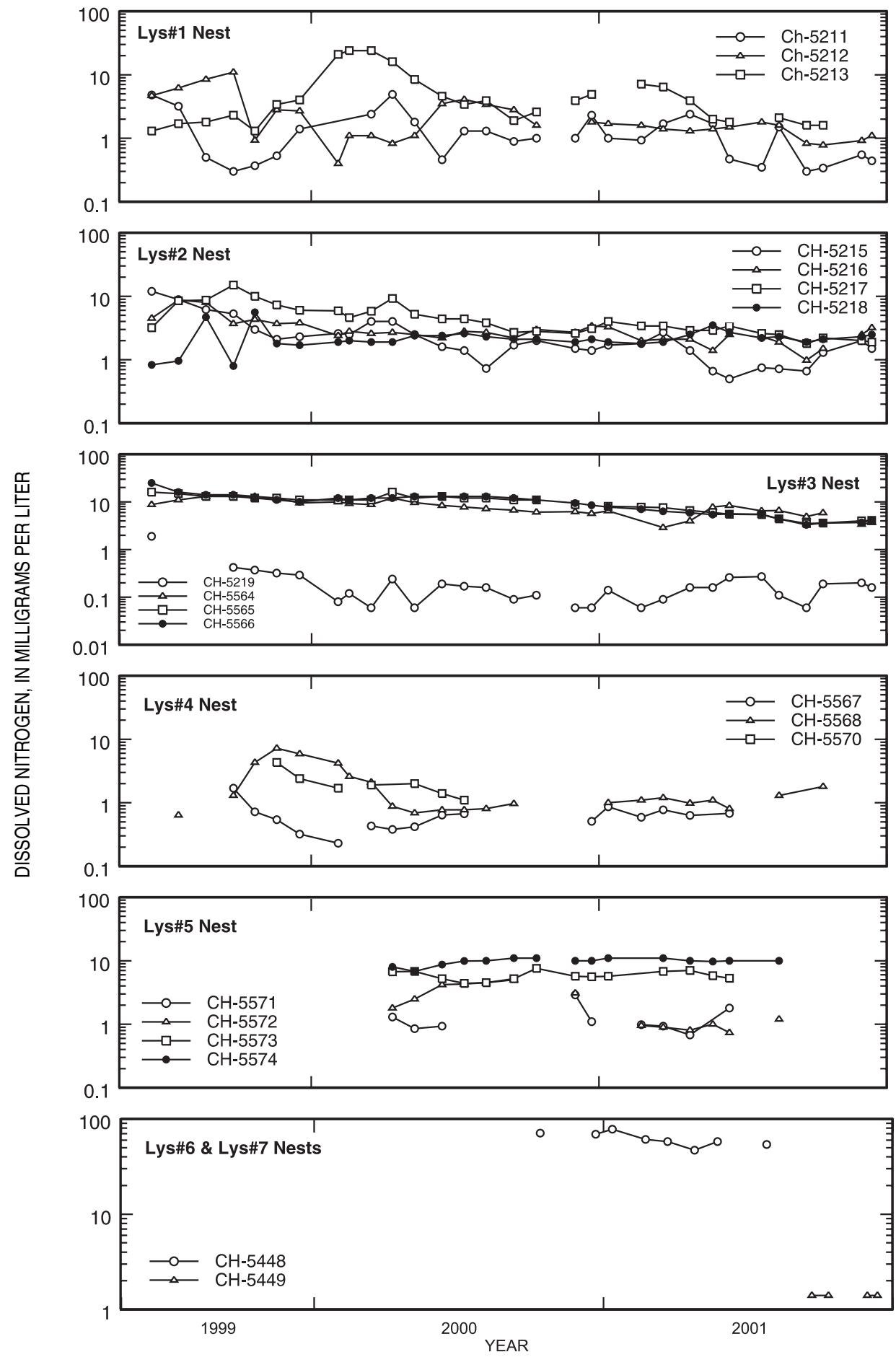

Figure 42. Concentrations of dissolved nitrogen for the network of soil-suction lysimeters, New Garden Township spray-irrigation site, Chester County, Pennsylvania, 1999-2001.

[Data gaps indicate no samples were collected because of either insufficient sample volume or frozen conditions.] 
Table 33. Regression equations relating concentrations of dissolved nitrogen and chloride to time (in days) for soil-suction lysimeter data, New Garden Township spray-irrigation site, Chester County, Pennsylvania, June 1999 through December 2001.

$[\mathrm{N}$, nitrogen, in milligrams per liter; $\mathrm{Cl}$, chloride, in milligrams per liter; all models shown are significant at alpha $=0.05$; the units for time are days, with time equal 1 for January 1,1960 , and time equal 15,340 for December 31, 2001]

\begin{tabular}{|c|c|c|c|}
\hline $\begin{array}{c}\text { Soil-suction } \\
\text { lysimeter } \\
\text { identification } \\
\text { number }\end{array}$ & Regression equation & $\begin{array}{c}\text { Number of } \\
\text { observations }\end{array}$ & $\begin{array}{c}\text { Adjusted } \\
\text { correlation } \\
\text { coefficient } \\
\left(\mathbf{R}^{2}\right)\end{array}$ \\
\hline \multicolumn{4}{|c|}{ Lysimeter nest Lys\#1 } \\
\hline \multirow[t]{2}{*}{ Ch-5211 } & $\mathrm{N}=25.37-0.00161$ (time) & 29 & 0.11 \\
\hline & $\mathrm{Cl}=-318.6+0.0254$ (time) & 29 & .13 \\
\hline \multirow[t]{2}{*}{ Ch-5212 } & $\mathrm{N}=72.57-0.00471$ (time) & 30 & .28 \\
\hline & $\mathrm{Cl}=-944.4+0.0671$ (time) & 31 & .69 \\
\hline Ch-5213 & $\mathrm{Cl}=-1396+0.0959$ (time) & 27 & .77 \\
\hline \multicolumn{4}{|c|}{ Lysimeter nest Lys\#2 } \\
\hline Ch-5215 & $\mathrm{N}=95.32-0.00623$ (time) & 31 & .46 \\
\hline \multirow[t]{2}{*}{ Ch-5216 } & $\mathrm{N}=59.69-0.00381$ (time) & 31 & .40 \\
\hline & $\mathrm{Cl}=-773.5+0.0567$ (time) & 31 & .45 \\
\hline \multirow[t]{2}{*}{ Ch-5217 } & $\mathrm{N}=121.8-0.00788$ (time) & 31 & .53 \\
\hline & $\mathrm{Cl}=-1146+0.0808($ time $)$ & 31 & .64 \\
\hline Ch-5218 & $\mathrm{Cl}=-1014+0.0705($ time $)$ & 31 & .85 \\
\hline \multicolumn{4}{|c|}{ Lysimeter nest Lys\#3 } \\
\hline \multirow[t]{2}{*}{ Ch-5219 } & $\mathrm{N}=8.478-0.000554$ (time) & 29 & .16 \\
\hline & $\mathrm{Cl}=36.72-0.00240($ time $)$ & 29 & .11 \\
\hline \multirow[t]{2}{*}{ Ch-5564 } & $\mathrm{N}=137.9-0.00874$ (time) & 30 & .67 \\
\hline & $\mathrm{Cl}=-113.3+0.00787$ (time) & 30 & .46 \\
\hline \multirow[t]{2}{*}{ Ch-5565 } & $\mathrm{N}=194.2-0.0124$ (time) & 30 & .85 \\
\hline & $\mathrm{Cl}=-364.4+0.0253$ (time) & 30 & .79 \\
\hline \multirow[t]{2}{*}{ Ch-5566 } & $\mathrm{N}=230.4-0.0148($ time $)$ & 31 & .78 \\
\hline & $\mathrm{Cl}=-373.7+0.0260($ time $)$ & 31 & .79 \\
\hline \multicolumn{4}{|c|}{ Lysimeter nest Lys\#4 } \\
\hline \multirow[t]{2}{*}{ Ch-5568 } & $\mathrm{N}=51.10-0.00332$ (time) & 22 & .16 \\
\hline & $\mathrm{Cl}=66.55-0.00439$ (time) & 22 & .26 \\
\hline Ch-5570 & $\mathrm{N}=139.0-0.00932$ (time) & 7 & .58 \\
\hline \multicolumn{4}{|c|}{ Lysimeter nest Lys\#5 } \\
\hline \multirow[t]{2}{*}{ Ch-5572 } & $\mathrm{N}=103.4-0.00676($ time $)$ & 13 & .44 \\
\hline & $\mathrm{Cl}=169.1-0.0110$ (time) & 13 & .89 \\
\hline Ch-5574 & $\mathrm{N}=-48.60+0.00391$ (time) & 15 & .21 \\
\hline \multicolumn{4}{|c|}{ Lysimeter nest Lys\#6 } \\
\hline Ch-5448 & $\mathrm{N}=1330-0.0843$ (time) & 8 & .52 \\
\hline
\end{tabular}


Concentrations of dissolved $\mathrm{Cl}$ indicated a significant increase for many of the lysimeters that also had significant decreasing trends in dissolved $\mathrm{N}$ (table 33 and fig. 43). This result indicates that spray-irrigated effluent was reaching the lysimeters because increasing $\mathrm{Cl}$ concentrations would be expected given that the load of $\mathrm{Cl}$ applied to the 20 -acre subbasin during the study period was about $38,800 \mathrm{lb}$ (table 29). None of the lysimeters outside the 20 -acre subbasin indicated a significant increase in concentrations of dissolved $\mathrm{Cl}$. This result was expected because virtually no $\mathrm{Cl}$ was measured in wet- or dry-deposition samples (appendix 1, tables 1-2 and 1-3).

Water samples from two of the lysimeters in nest Lys\#4 (Ch-5568 and Ch-5570) indicated significant decreases in concentrations of dissolved $\mathrm{N}$ (table 33). These trends are likely because of the chemical breakdown of spent mushroom substrate upgradient of this nest. Lysimeter Ch-5448 was directly beneath the spent mushroom substrate that was upgradient of nest Lys\#4. Lysimeter Ch-5448 indicated a decreasing trend in concentrations of dissolved $\mathrm{N}$ but all samples collected from this lysimeter exceeded concentrations of $45 \mathrm{mg} / \mathrm{L}$ for dissolved $\mathrm{N}$, indicating that the spent mushroom substrate at the site is losing $\mathrm{N}$ through mineralization. Spent mushroom substrate is a known source of $\mathrm{N}$ to underlying soils through leaching (Guo and others, 2000b).

The predominant form of $\mathrm{N}$ for the soil water sampled was nitrate $\mathrm{N}$, followed by $\operatorname{org}$ anic $\mathrm{N}$, ammonia $\mathrm{N}$, and nitrite $\mathrm{N}$; however, the ratio of dissolved nitrate $\mathrm{N}$ to $\mathrm{N}$ varied widely depending on the lysimeter location (fig. 44). Nitrate $\mathrm{N}$ accounted for 88 percent of the dissolved-N fraction for all the lysimeter data. Organic N (10 percent), ammonia N (about 1 percent), and nitrite $\mathrm{N}$ (about 1 percent) accounted for the remaining part of the dissolved $\mathrm{N}$ in the soil water sampled. The highest nitrate $\mathrm{N}$ to total $\mathrm{N}$ ratio was for lysimeter $\mathrm{Ch}-5448$; 93 percent of the dissolved $\mathrm{N}$ was nitrate $\mathrm{N}$. Conversely, for lysimeter Ch-5449, 90 percent of the dissolved $\mathrm{N}$ was organic. Ratios of the concentrations of dissolved nitrate $\mathrm{N}$ to dissolved $\mathrm{N}$ were affected by the proximity of the lysimeter to upgradient spent mushroom substrate layers. The high concentration of dissolved nitrate $\mathrm{N}$ and the high ratio of the concentration of dissolved nitrate $\mathrm{N}$ to dissolved $\mathrm{N}$ for lysimeter $\mathrm{Ch}-5448$ indicate the spent mushroom substrate above this lysimeter was fresh; conversely, the low concentration of dissolved nitrate $\mathrm{N}$ and the low ratio of the concentration of dissolved nitrate $\mathrm{N}$ to dissolved $\mathrm{N}$ for lysimeter $\mathrm{Ch}-5449$ indicated the spent substrate near that lysimeter was nearly mineralized.

Water samples from lysimeter nests Lys\#4 and Lys\#5 indicated variations in the ratio of the concentration of dissolved nitrate $\mathrm{N}$ to dissolved $\mathrm{N}$ with depth. The ratio of the concentration of dissolved nitrate $\mathrm{N}$ to dissolved $\mathrm{N}$ increased with depth for nests Lys\#4 and Lys\#5. For nest Lys\#4, only about 18 percent of dissolved $\mathrm{N}$ was in nitrate $\mathrm{N}$ form at $3 \mathrm{ft}$ below land surface; at $15 \mathrm{ft}$ below land surface, 79 percent of the dissolved $\mathrm{N}$ was nitrate N. For nest Lys\#5, 34 percent of the dissolved N was in nitrate $\mathrm{N}$ form for lysimeter Ch-5571; for lysimeter Ch-5574, about 90 percent of the dissolved $\mathrm{N}$ was nitrate $\mathrm{N}$. For nests Lys\#4 and Lys\#5, the increased ratio of the concentration of dissolved nitrate $\mathrm{N}$ to dissolved $\mathrm{N}$ and the increased concentrations of dissolved $\mathrm{N}$ with an increase in depth probably were caused by the deeper horizons intercepting mineralized $\mathrm{N}$ from spent mushroom substrate layers. However, the trend of increasing ratios of the concentrations of dissolved nitrate $\mathrm{N}$ to dissolved $\mathrm{N}$ with an increase in depth also was evident for nests Lys\#1 and Lys\#2, and neither of these nests were known to be downgradient from spent mushroom substrate. For nests Lys\#1 and Lys\#2, over 20 percent of the dissolved $\mathrm{N}$ for the most shallow lysimeter was in the organic form. The ratio of organic $\mathrm{N}$ decreased with depth, and more than 80 percent of the dissolved $\mathrm{N}$ was in the form of nitrate $\mathrm{N}$ below the most shallow lysimeters in nests Lys\#1 and Lys\#2. The decrease in the ratio of the concentrations of dissolved nitrate $\mathrm{N}$ to dissolved $\mathrm{N}$ with an increase in depth for nests Lys\#1 and Lys\#2 was either caused by natural soil processes that mineralize organic $\mathrm{N}$, uptake of more nitrate $\mathrm{N}$ near the soil surface by plants or chemoautotrophic organisms, and (or) mineralization of organic $\mathrm{N}$ induced by changes in the system caused by spray irrigation. Most soil profiles show increased concentrations of organic $\mathrm{N}$ (soluble and insoluble) near the soil surface (Stevenson, 1982a). Twenty-eight percent of the total-N load from spray irrigation from June 1999 through December 2001 was in organic form. The organic $\mathrm{N}$ in spray-irrigation water also helped to increase organic-N concentrations near the soil surface.

Time trends for the different forms of $\mathrm{N}$ were identified to help determine how $\mathrm{N}$ applied in spray-irrigated effluent was affecting micropore soil water. For the 13 lysimeters at the spray-irrigation site with significant decreases in concentrations of dissolved $\mathrm{N}$ over time, 10 also indicated significant decreases in nitrate $\mathrm{N}$ over time (fig. 45). Trends in nitrate $\mathrm{N}$ were expected for lysimeters showing significant time trends in concentrations of dissolved $\mathrm{N}$ because 88 percent of the dissolved $\mathrm{N}$ was nitrate $\mathrm{N}$. The mean concentrations of nitrate $\mathrm{N}$ for lysimeters Ch-5211 and Ch-5215, the most shallow lysimeters in the 20 -acre subbasin, were 1.38 and $2.62 \mathrm{mg} / \mathrm{L}$, respectively. The mean concentration of nitrate $\mathrm{N}$ in the spray-irrigated effluent applied during the course of the study was about $6 \mathrm{mg} / \mathrm{L}$. This indicated nitrate $\mathrm{N}$ was being lost or diluted by precipitation inputs prior to the effluent reaching the shallow lysimeters in the 20-acre subbasin.

Trends in concentrations of organic $\mathrm{N}$ also were evident (fig. 46). Significant decreasing time trends in organic $\mathrm{N}$ were evident for the most shallow lysimeters (Ch-5211 and Ch-5215) in each of the lysimeter nests in the spray field in the 20 -acre subbasin. The concentrations of dissolved organic $\mathrm{N}$ for lysimeters at $7 \mathrm{ft}$ below land surface in nests Lys\#1 and Lys\#2 were highest for the first samples collected (June 1999) from the lysimeters. The decreasing trend in organic $\mathrm{N}$ near the land surface indicated that processes to mineralize organic $\mathrm{N}$ became more prevalent near the surface throughout the course of the study. The mean concentration of dissolved organic $\mathrm{N}$ applied in spray-irrigated effluent during the study was $1.63 \mathrm{mg} / \mathrm{L}$. The mean concentrations of dissolved organic $\mathrm{N}$ for lysimeters Ch-5211 and Ch-5215 during the study were 0.34 and 

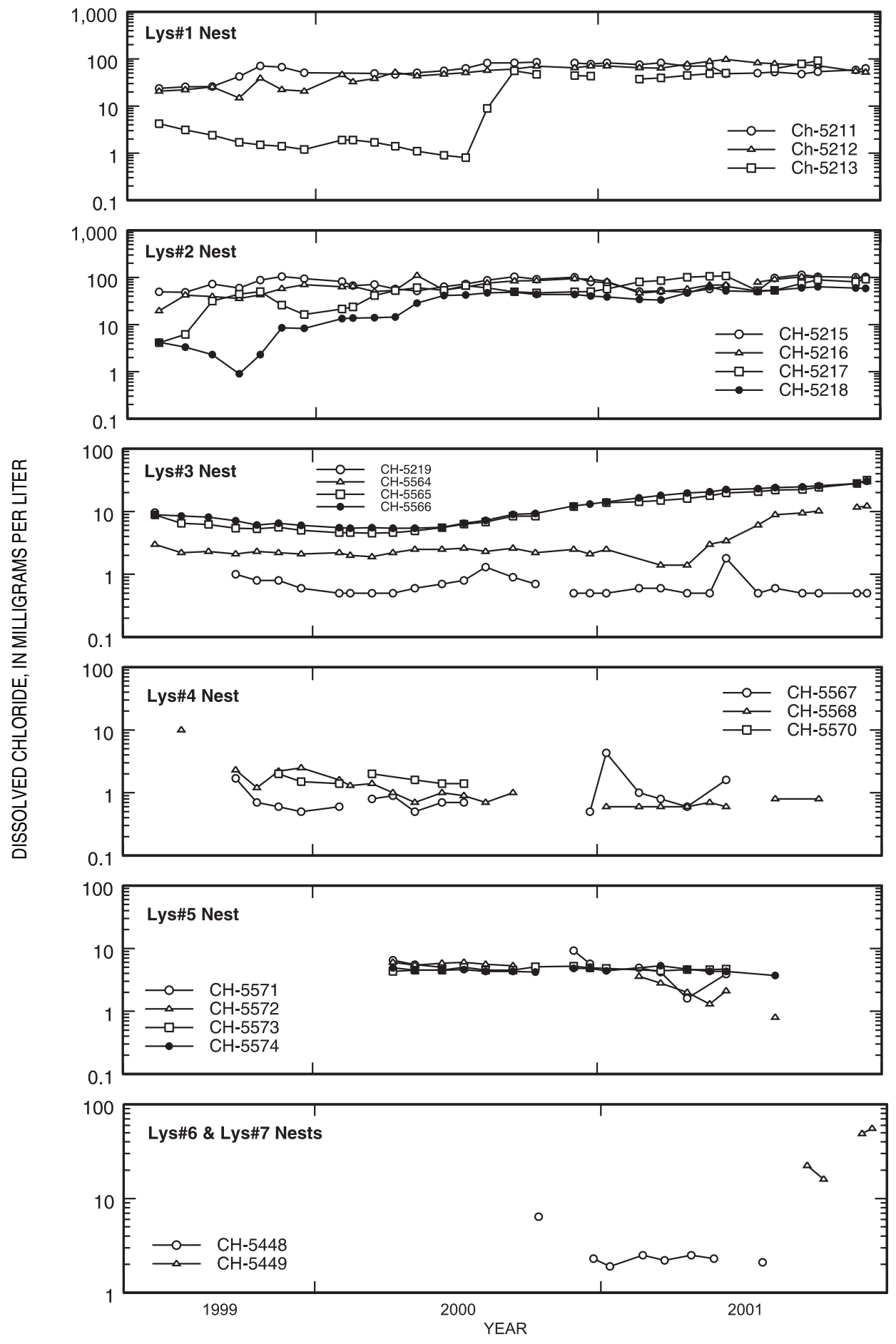

Figure 43. Concentrations of dissolved chloride for the network of soil-suction lysimeters, New Garden Township spray-irrigation site, Chester County, Pennsylvania, 1999-2001.

[Data gaps indicate no samples were collected because of either insufficient sample volume or frozen conditions.] 


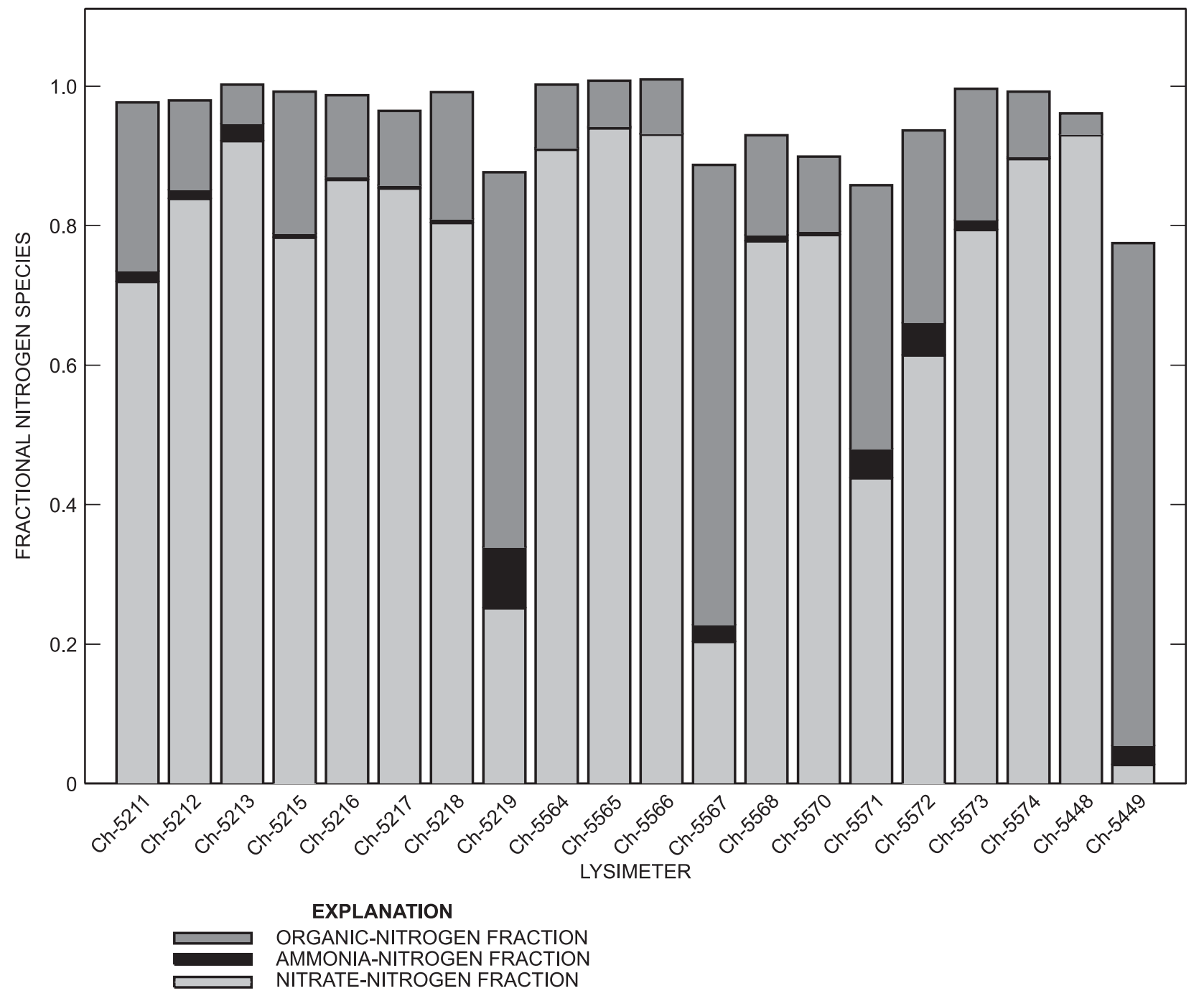

Figure 44. Different forms of nitrogen that make up the dissolved fraction for the network of soil-suction lysimeters, June 1999 through December 2001, New Garden Township spray-irrigation site, Chester County, Pennsylvania. 


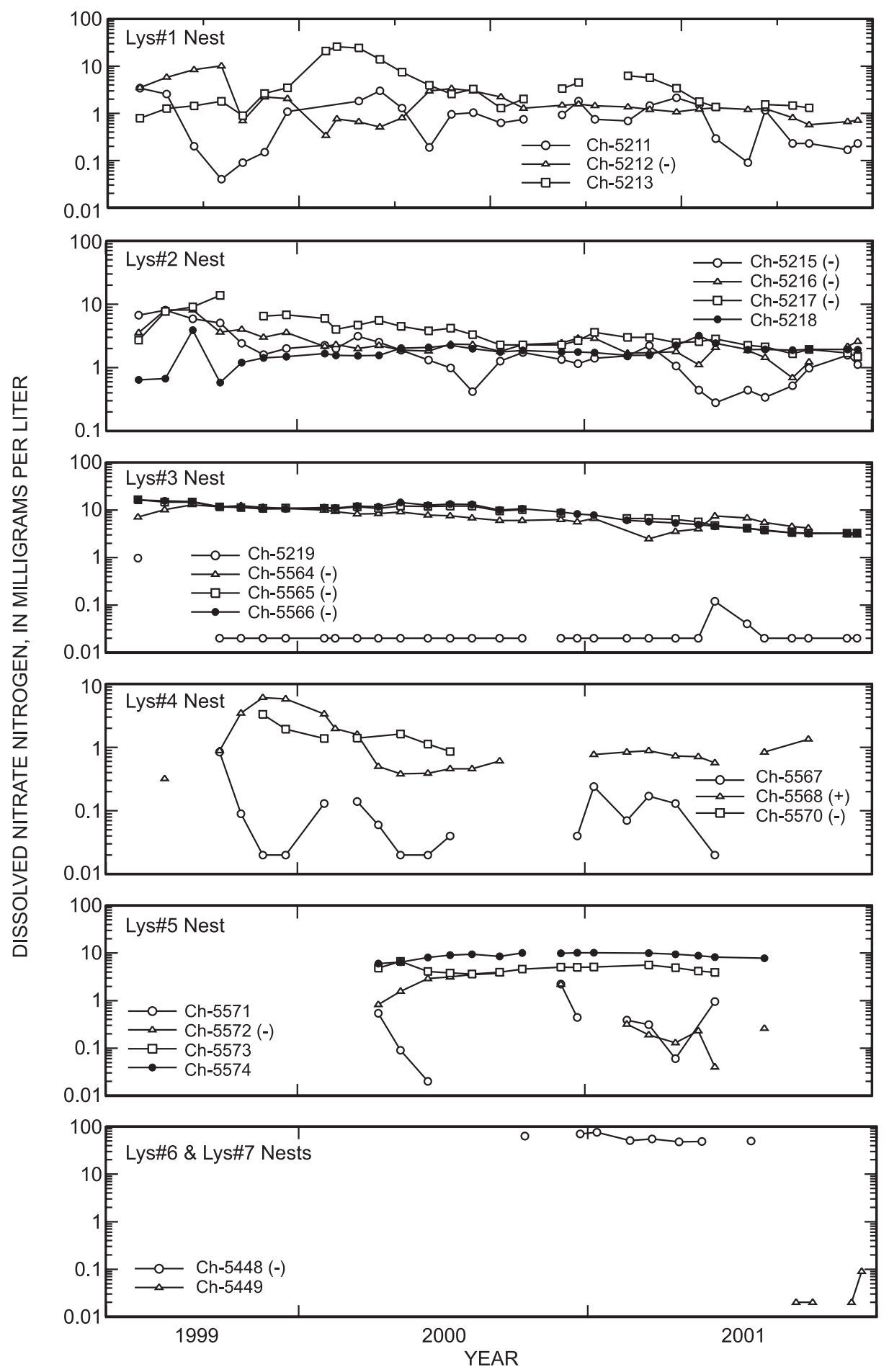

Figure 45. Concentrations of dissolved nitrate nitrogen and identification of significant time trends in nitrate nitrogen for the network of soil-suction lysimeters, New Garden Township spray-irrigation site, Chester County, Pennsylvania, 1999-2001. ['(-)' indicates a significant decreasing trend; ' $(+)$ ' indicates a significant increasing trend. Significant trends over time were based on an alpha equal to 0.05 . Data gaps indicate no samples were collected because of either insufficient sample volume or frozen conditions.] 

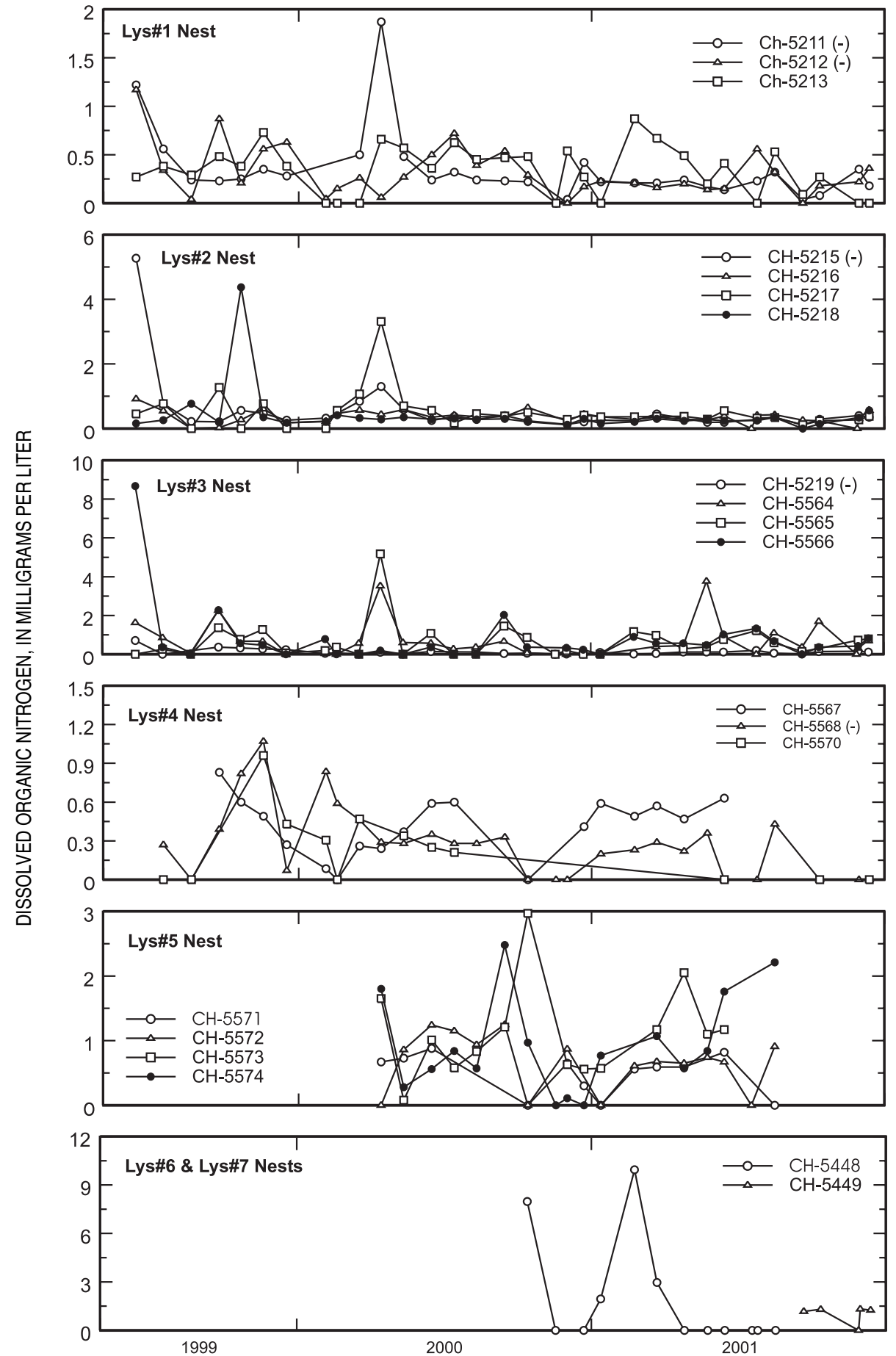

Figure 46. Concentrations of dissolved organic nitrogen and identification of significant time trends in organic nitrogen for the network of soil-suction lysimeters, New Garden Township sprayirrigation site, Chester County, Pennsylvania, 1999-2001. ['(-)' indicates a significant decreasing trend. Significant trends over time were based on an alpha equal to 0.05 . Data gaps indicate no samples were collected because of either insufficient sample volume or frozen conditions.] 


\section{Effects of Spray-Irrigated Effluent on Water Quantity and Quality, and the Fate and Transport of Nitrogen}

$0.54 \mathrm{mg} / \mathrm{L}$, respectively. Thus, some organic $\mathrm{N}$ from spray-irrigated effluent was being mineralized prior to the water reaching these lysimeters and (or) diluted by precipitation events.

The decreasing trends in nitrate $\mathrm{N}$ and the decreased concentration of organic $\mathrm{N}$ for shallow lysimeters over time within the 20-acre subbasin indicated processes in the upper part of the soil horizons were affecting the fate of $\mathrm{N}$ applied in the sprayirrigated effluent. The ratios in the concentrations of nitrate $\mathrm{N}$ to $\mathrm{Cl}$ also indicated significant decreases over time for all the lysimeters in the 20-acre subbasin except for Ch-5213, Ch-5219, and Ch-5449 (fig. 47). Only water samples from one lysimeter (Ch-5570) outside the 20-acre subbasin indicated a significant decrease in the ratio of the concentration of dissolved nitrate $\mathrm{N}$ to $\mathrm{Cl}$ over time. The decreased values for the ratio of dissolved nitrate $\mathrm{N}$ to $\mathrm{Cl}$ were expected given the significant time trends in dissolved $\mathrm{N}$ (decreasing) and $\mathrm{Cl}$ (increasing) from June 1999 through December 2001 for most of the lysimeters in the 20-acre subbasin (table 33). These trends indicated that spray-irrigated effluent was reaching the lysimeters, as evident by the increased concentrations of dissolved $\mathrm{Cl}$ over time. The decreasing time trends in nitrate $\mathrm{N}$ for the lysimeters indicated that, even though spray-irrigated effluent was reaching the lysimeters, the water had lost $\mathrm{N}$ as it traveled from land surface to a depth of $3 \mathrm{ft}$ below land surface, and this loss of $\mathrm{N}$ increased over time. Plant uptake of $\mathrm{N}$ and denitrification were likely causing the decreased nitrate- $\mathrm{N}$ concentrations over time. Spray application would tend to make conditions more anoxic over time as the soil became more saturated. Increased saturated conditions increased the likelihood of denitrification.

Soil-moisture data and the concentrations of dissolved $\mathrm{N}$ for the lysimeter network were used to determine if the storage of $\mathrm{N}$ in micropore soil water changed during the course of the study. The soil-moisture probe network began collecting data in September 1999; thus, no soil-moisture data were available prior to spray irrigation and no determination could be made as to the complete effect of spray irrigation on site soil-moisture conditions. It follows that the total mass of $\mathrm{N}$ in the soil-water matrix prior to spray irrigation also could not be determined. For sub-unit areas 2, 4, and 6 (fig. 7), data from the soil-moisture probe network were available from September 1999 through December 2001 for sub-unit area 2, and from September 1999 through June 2001 for sub-unit areas 4 and 6 (fig. 48). Soil-moisture values for September 1999 were elevated because of the remnants of Hurricane Floyd passing through the area on September 16, 1999. Estimated soil moistures were variable over time except for lysimeters at depth in nests Lys\#2 and Lys\#3. The deepest lysimeter for nest Lys\#2 (Ch-5218) was, according to water-level altitude data from well Ch-5175 (the shallow well next to lysimeter Ch-5218), below the top of the water table 80 percent of the time when samples were evacuated from the lysimeter and data were available from well Ch-5175. For nest Lys\#3, lysimeters Ch-5565 and Ch-5566 were below water-table altitudes each time a sample was collected when water-level data were available for Ch-5177. By definition, saturated conditions are present at or below the water table.

The mass of $\mathrm{N}$ and $\mathrm{Cl}$ in the micropore soil water indicated time trends similar to the concentration data for $\mathrm{N}$ and $\mathrm{Cl}$ for the micropore soil water (figs. 49 and 50). That is, estimates of mass for $\mathrm{N}$ and $\mathrm{Cl}$ were affected more by the concentration for the lysimeter at the particular depth than the soil moisture. Regression analysis indicated that soil moisture was not significantly related to concentrations of $\mathrm{N}$ and $\mathrm{Cl}$ in the soil water for lysimeters immediately adjacent to the soil-moisture probes (Ch-5211, Ch-5215, and Ch-5219). Relations between concentrations for deeper lysimeters and estimated soil moistures were not determined because confidence in the relation would be low considering that soil-moisture values were estimated for depths below 40 in.

The masses of $\mathrm{N}$ and $\mathrm{Cl}$ given in figures 49 and 50 represent the total mass in sub-unit areas 2, 4, and 6 for the specific depths. Summing these masses down to the bottom of the lysimeter network for any one area yielded the estimated total mass of $\mathrm{N}$ and $\mathrm{Cl}$ for the entire area (table 34). When comparing values from September 1999 to June 2001, reductions are indicated in the mass of stored $\mathrm{N}$ and increases in mass of stored $\mathrm{Cl}$. From September 1999 to June 2001, the estimated mass of $\mathrm{N}$ in subunit areas 2, 4, and 6 decreased by 73, 68, and 50 percent, respectively. Conversely, $\mathrm{Cl}$ masses during the same period increased in sub-unit areas 2, 4, and 6 by 186, 90, and 208 percent, respectively. The average highest mass of $\mathrm{N}$ per unit volume of soil was found in sub-unit area 6. The average mass of $\mathrm{N}$ estimated for sub-unit area 6 was about $0.00016 \mathrm{lb} / \mathrm{ft}^{3}$ of soil, whereas for sub-unit areas 2 and 4, the estimated amount of $\mathrm{N}$ was 0.000059 and $0.000066 \mathrm{lb} / \mathrm{ft}^{3}$ of soil, respectively. It is likely that the differences among sub-unit areas were caused at least partially by the zone of spent mushroom substrate bisecting the 20-acre subbasin between lysimeter nests Lys\#2 and Lys\#3. The total area covered by sub-unit areas 2, 4, and 6 was about 10 acres. In order to determine the amount of $\mathrm{N}$ and $\mathrm{Cl}$ either accumulated or lost from the micropore soil water, the values in table 34 should be doubled because the drainage area of the subbasin was 20 acres

The only lysimeter nest in the 20-acre subbasin that did not interact with water at or below the water table was nest Lys\#1 (the nest in sub-unit area 2) (fig. 51). Water levels for monitor well Ch-5173 were at least $24 \mathrm{ft}$ below land surface each time lysimeter samples were collected and data were available from Ch-5173. Over 60 percent of the samples collected in the deepest lysimeter (Ch-5218) for nest Lys\#2 were collected when the water-table altitude was above the altitude of the ceramic cup for lysimeter Ch-5218. Three of the four lysimeters in nest Lys\#3 were below the water-table altitude for most samples collected. This result indicated the lysimeter network for sub-unit areas 4 and 6 spanned the range of the unsaturated zone.

Because nest Lys\#1 did not span the range of the unsaturated zone in sub-unit area 2, the estimated mass of $\mathrm{N}$ needed to be determined for the zone extending from the bottom of the lysimeter network to a depth that was near the same altitude as the lowest water level recorded for well Ch-5173 after spray irrigation was initiated. The lowest water level recorded for well Ch-5173 after spray irrigation began was in March 2001 (34.51 ft on March 29). The lysimeter network spanned depths from 0 to $13 \mathrm{ft}$ for sub-unit area 2 . Given the minimum water 
Table 34. Total estimated masses of nitrogen and chloride in micropore soil water for sub-unit areas 2, 4, and 6, New Garden Township spray-irrigation site, Chester County, Pennsylvania, 1999-2001.

[Sub-unit areas are shown on figure 7. - , data not available; sub-unit area 2 was 1.9 acres and the mass of nitrogen was estimated to a depth of 13 feet; sub-unit area 4 was 6.5 acres and the mass of nitrogen was estimated to a depth of 17 feet; and sub-unit area 6 was 1.7 acres and the mass of nitrogen was estimated to a depth of 14.75 feet]

\begin{tabular}{|c|c|c|c|c|c|c|}
\hline \multirow{2}{*}{$\begin{array}{l}\text { Lysimeter sample- } \\
\text { collection date }\end{array}$} & \multicolumn{2}{|c|}{ Sub-unit area 2} & \multicolumn{2}{|c|}{ Sub-unit area 4} & \multicolumn{2}{|c|}{ Sub-unit area 6} \\
\hline & $\begin{array}{l}\text { Nitrogen } \\
\text { (pounds) }\end{array}$ & $\begin{array}{l}\text { Chloride } \\
\text { (pounds) }\end{array}$ & $\begin{array}{l}\text { Nitrogen } \\
\text { (pounds) }\end{array}$ & $\begin{array}{l}\text { Chloride } \\
\text { (pounds) }\end{array}$ & $\begin{array}{l}\text { Nitrogen } \\
\text { (pounds) }\end{array}$ & $\begin{array}{l}\text { Chloride } \\
\text { (pounds) }\end{array}$ \\
\hline 09/23/1999 & 85 & 420 & 660 & 3,900 & 240 & 94 \\
\hline $10 / 20 / 1999$ & 15 & 670 & 590 & 5,100 & 220 & 88 \\
\hline 11/17/1999 & - & - & - & - & 180 & 83 \\
\hline $12 / 16 / 1999$ & 53 & 510 & 350 & 5,100 & 200 & 77 \\
\hline 02/03/2000 & - & - & 310 & 4,300 & 190 & 75 \\
\hline 03/16/2000 & 170 & 560 & 310 & 4,500 & 190 & 75 \\
\hline $04 / 12 / 2000$ & 140 & 640 & 370 & 4,600 & 240 & 77 \\
\hline $05 / 10 / 2000$ & 75 & 630 & 460 & 4,600 & 210 & 81 \\
\hline $06 / 14 / 2000$ & - & - & 330 & 6,500 & 210 & 86 \\
\hline $07 / 12 / 2000$ & 56 & 760 & 260 & 5,200 & 200 & 98 \\
\hline 08/9/2000 & 55 & 980 & 290 & 6,600 & 200 & 110 \\
\hline $09 / 13 / 2000$ & 34 & 1,300 & 240 & 7,200 & 180 & 130 \\
\hline $10 / 12 / 2000$ & 33 & 1,300 & 220 & 7,200 & 170 & 120 \\
\hline $11 / 30 / 2000$ & - & 1,300 & 250 & 6,800 & 150 & 170 \\
\hline $12 / 21 / 2000$ & 59 & 1,300 & 220 & 7,600 & - & - \\
\hline $01 / 11 / 2001$ & - & - & 250 & 6,900 & 130 & 190 \\
\hline $02 / 22 / 2001$ & 57 & 1,100 & 280 & 6,800 & - & - \\
\hline $03 / 22 / 2001$ & 64 & 1,300 & 230 & 5,500 & 100 & 210 \\
\hline $04 / 25 / 2001$ & - & - & 260 & 5,700 & 100 & 230 \\
\hline $05 / 24 / 2001$ & 30 & 1,200 & 220 & 6,400 & 110 & 250 \\
\hline $06 / 14 / 2001$ & 23 & 1,200 & 210 & 7,400 & 120 & 290 \\
\hline
\end{tabular}




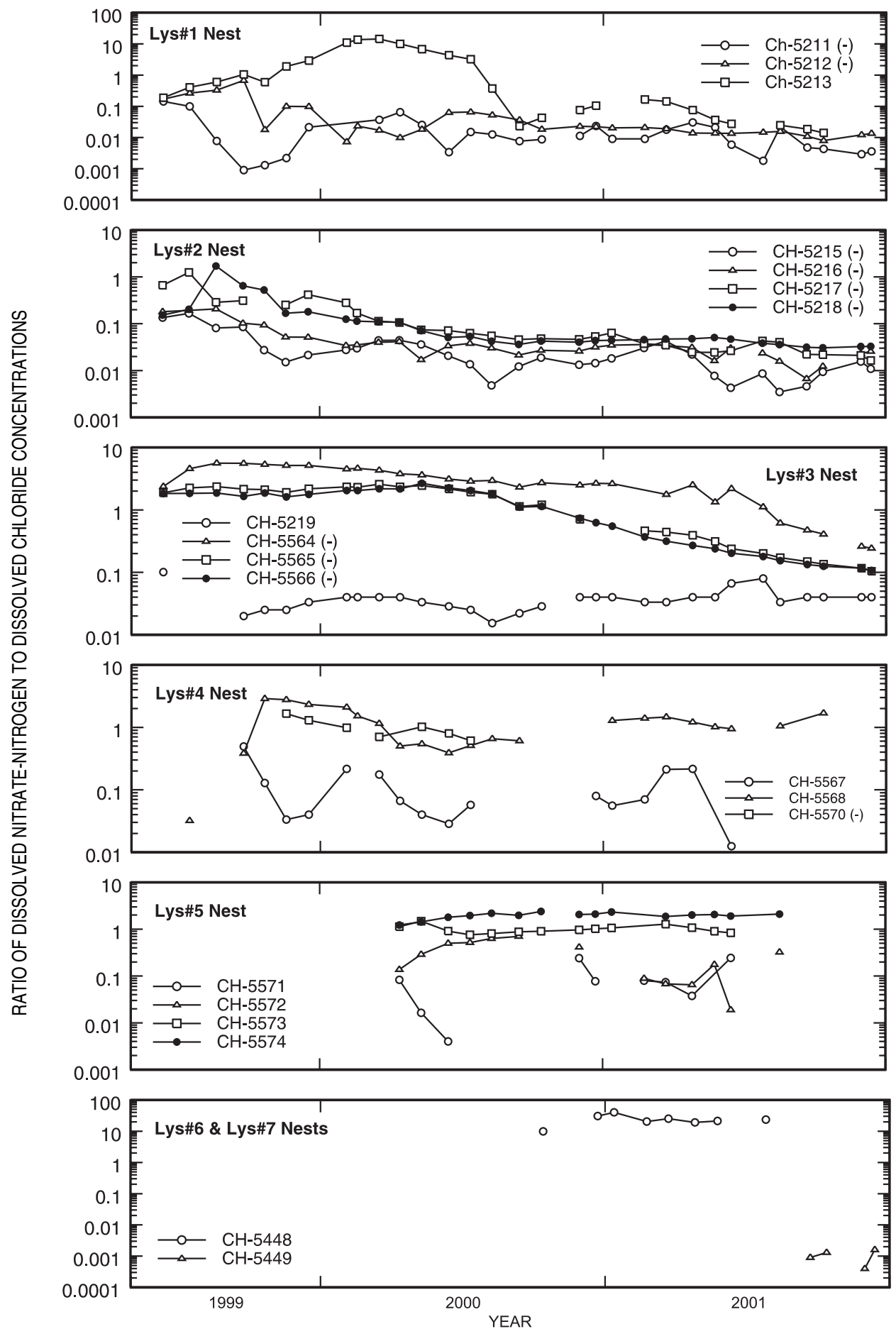

Figure 47. Ratio of nitrate-nitrogen to chloride concentrations and identification of significant time trends in the ratio of nitrate-nitrogen to chloride for the network of soil- suction lysimeters, New Garden Township spray-irrigation site, Chester County, Pennsylvania, 1999-2001.

$\left[{ }^{\prime}(-)^{\prime}\right.$ indicates a significant decreasing trend. Significant trends over time were based on an alpha equal to 0.05 . Data gaps indicate no samples were collected because of either insufficient sample volume or frozen conditions.] 


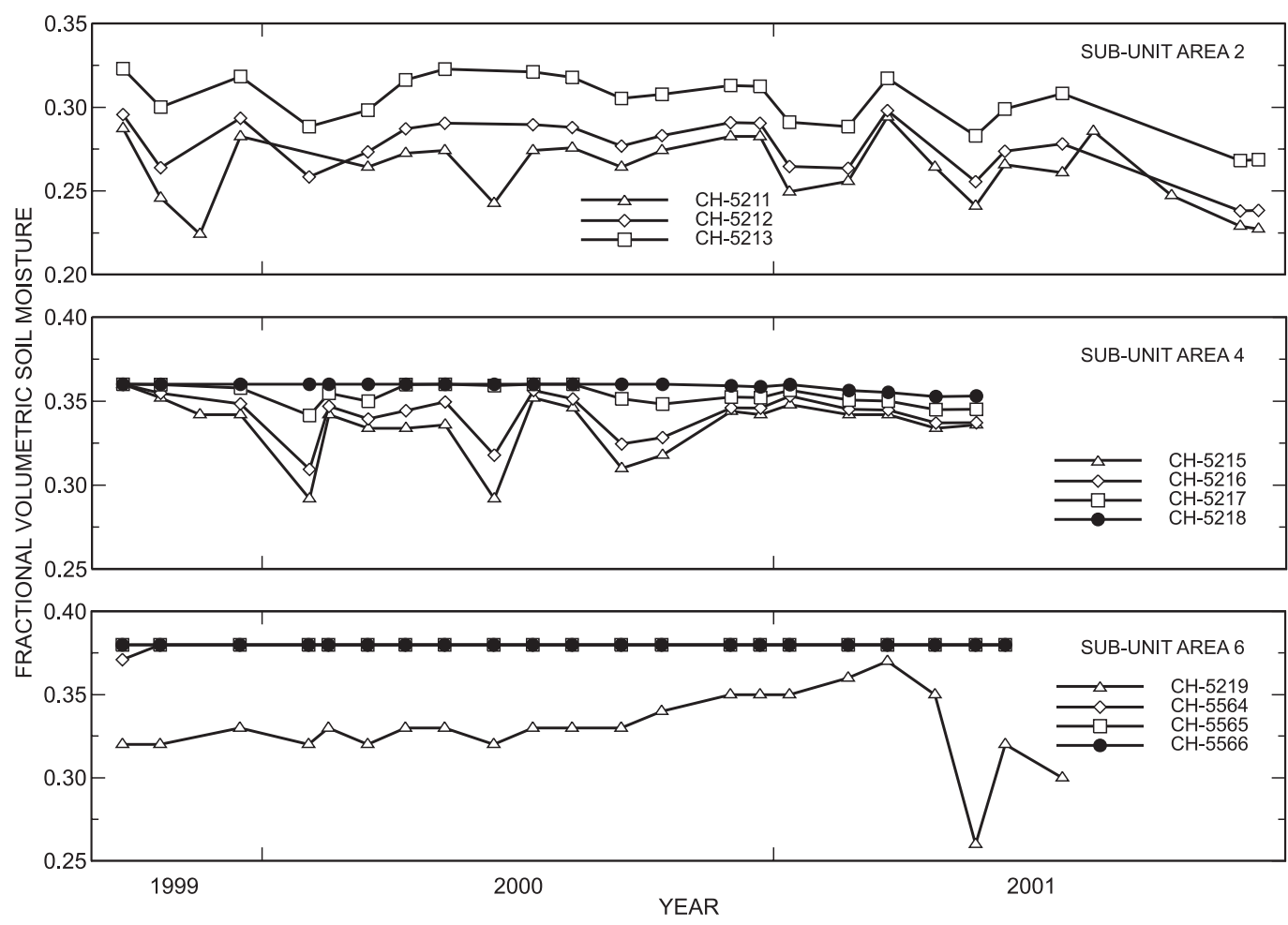

Figure 48. Estimated volumetric soil moistures at time of lysimeter sample collection for lysimeters in sub-unit areas 2, 4, and 6, New Garden Township spray-irrigation site, Chester County, Pennsylvania, 1999-2001.

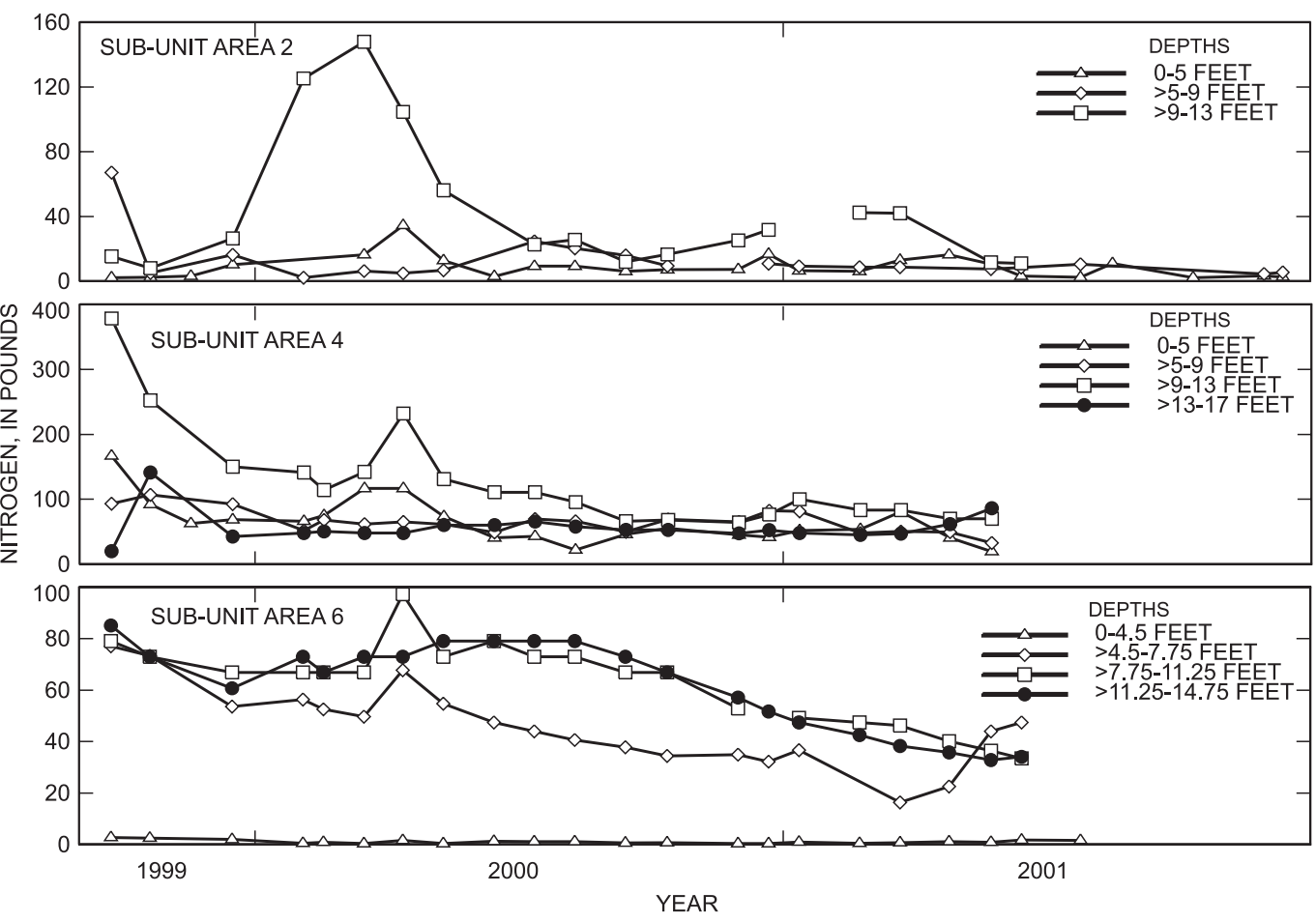

Figure 49. Estimated pounds of nitrogen in micropore soil water for sub-unit areas 2, 4, and 6 to depths of 13,17, and 14.75 feet, respectively, New Garden Township spray-irrigation site, Chester County, Pennsylvania, 1999-2001. [Data gaps indicate no samples were collected because of either insufficient sample volume or frozen conditions.] 

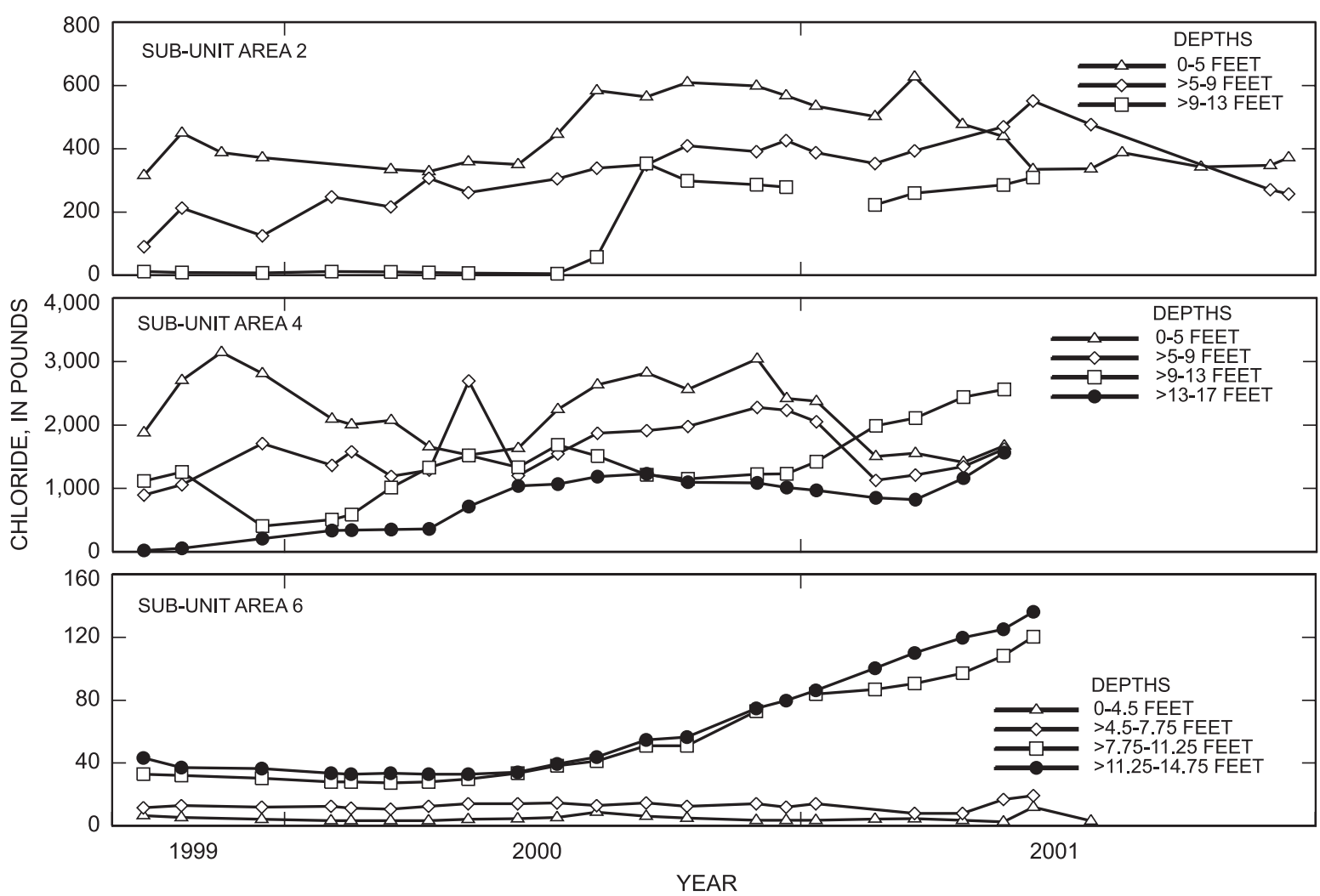

Figure 50. Estimated pounds of chloride in micropore soil water for sub-unit areas 2, 4, and 6 to depths of 13, 17, and 14.75 feet, respectively, New Garden Township spray-irrigation site, Chester County, Pennsylvania, 1999-2001.

[Data gaps indicate no samples were collected because of either insufficient sample volume or frozen conditions.] 


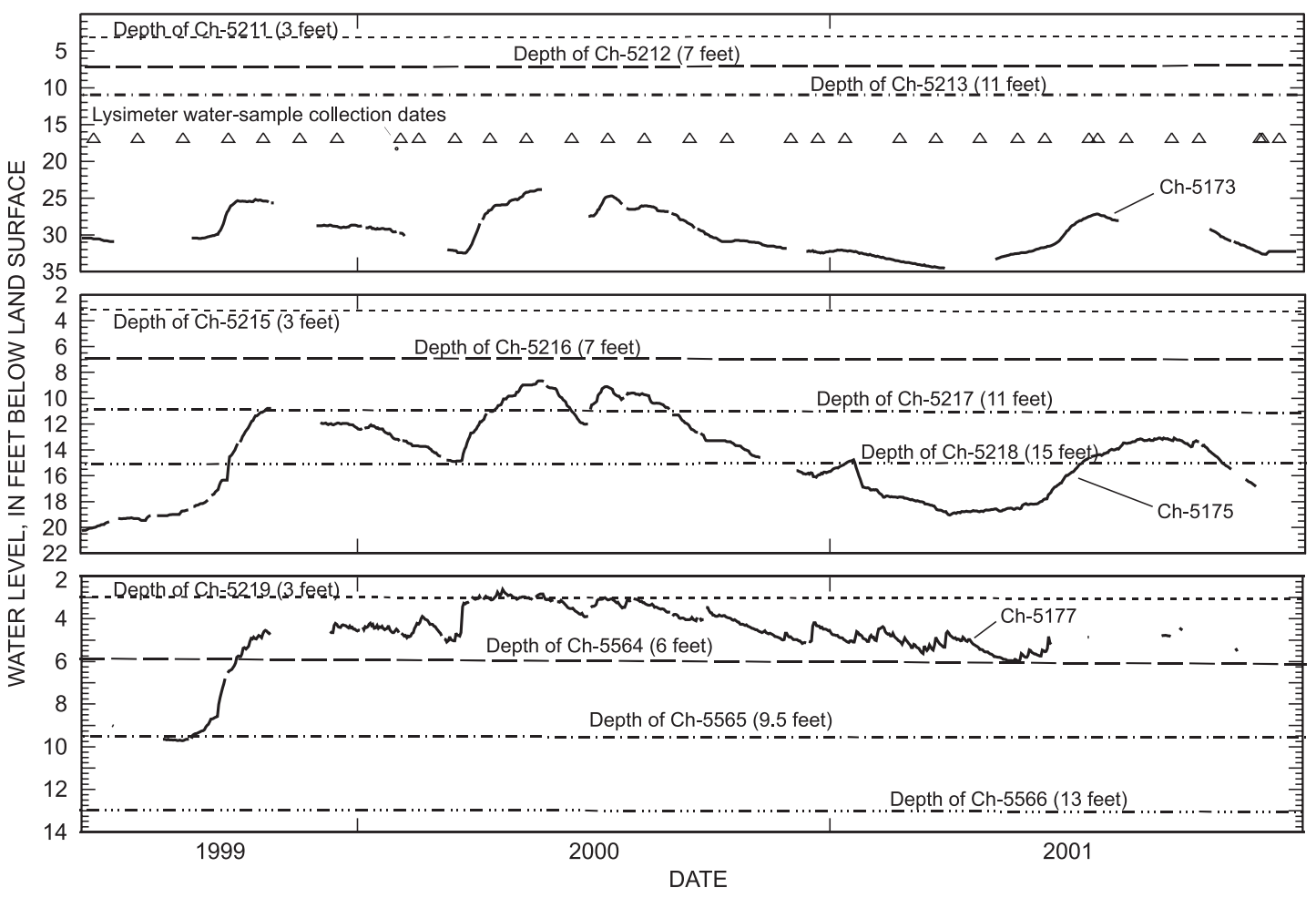

Figure 51. Daily water-level altitudes for wells Ch-5173, Ch-5175, and Ch-5177 and the dates when suction lysimeters were sampled, New Garden Township spray-irrigation site, Chester County, Pennsylvania, 19992001. [The altitude of suction lysimeters in nests Lys\#1, Lys\#2, and Lys\#3 are identified and matched with the shallow well adjacent to the lysimeter nest. Gaps indicate missing record.]

level recorded for well Ch-5173 during the study, it was deemed necessary to determine estimates for the mass of $\mathrm{N}$ from 13 to $33 \mathrm{ft}$ below land surface (table 35). Estimates of $\mathrm{N}$ masses were determined in $4 \mathrm{ft}$ increments and summed over the $20 \mathrm{ft}$ of vertical distance. The average mass of $\mathrm{N}$ estimated for this $20-\mathrm{ft}$ zone in sub-unit area 2 was about $0.000066 \mathrm{lb} / \mathrm{ft}^{3}$ of soil, which was comparable to the mass per volume of soil estimated for sub-unit area 2 for depths from 0 to $13 \mathrm{ft}$. From September 1999 to June 2001, there was estimated to be virtually no change in the mass of $\mathrm{N}$ stored in the micropore soil water for sub-unit area 2 for depths from 13 to $33 \mathrm{ft}$.

$\mathrm{N}$-isotope samples collected from the lysimeter network varied from $\delta^{15} \mathrm{~N}$ (nitrate) values of $-2.1 \%$ or lysimeter Ch-5568 to $15.1 \%$ for lysimeter Ch-5216 (table 36). The low value for lysimeter Ch-5568 was within the range of values expected for $\mathrm{N}$ in precipitation, indicating that this lysimeter (in Control (1) at a depth of $7 \mathrm{ft}$ ) was capturing $\mathrm{N}$ primarily from rainwater. However, the mean concentration of nitrate $\mathrm{N}$ for lysimeter Ch-5568 during the study was $1.50 \mathrm{mg} / \mathrm{L}$; the mean concentration of nitrate $\mathrm{N}$ for wet-deposition samples was $0.33 \mathrm{mg} / \mathrm{L}$. Thus, some $\mathrm{N}$ was reaching lysimeter Ch-5668 from natural soil processes and (or) evaporation of precipitation from the upper soil horizons was causing an increase in the concentration of nitrate $\mathrm{N}$. The upper end of the $\delta^{15} \mathrm{~N}$ (nitrate) values for the lysimeters was evident in two different samples collected from lysimeter Ch-5216. $\delta^{15} \mathrm{~N}$ (nitrate) values for lysim- eter Ch-5216 fell within the range of values that were determined for spray-irrigated effluent. Spray-irrigated effluent obviously was reaching lysimeter Ch-5216 given the increased concentration of $\mathrm{Cl}$ over time (table 33$). \delta^{15} \mathrm{~N}$ (nitrate) values for lysimeters Ch-5211 and Ch-5213 (nest Lys\#1) indicated that the nitrate $\mathrm{N}$ reaching the lysimeters was a mixture of different sources. It was apparent from $\mathrm{Cl}$ concentrations over time for lysimeters Ch-5211 and Ch-5213 that spray-irrigated effluent was reaching the lysimeters, but the low values for $\delta^{15} \mathrm{~N}$ (nitrate) indicated that the majority of the water did not originate from the spray-irrigated effluent. The two $\delta^{15} \mathrm{~N}$ (nitrate) values $(6.4 \%$ ) for lysimeter $\mathrm{Ch}-5448$ should be viewed as indicative of spent mushroom substrate leachate. The ceramic cup of lysimeter Ch-5448 was about $1 \mathrm{ft}$ below the largest zone of spent mushroom substrate deposited within the study area. The $\delta^{15} \mathrm{~N}$ (nitrate) values for nest Lys\#3 indicated those lysimeters were likely receiving a mix of nitrate $\mathrm{N}$ from spray-irrigated effluent, leachate from spent mushroom substrate, and leachate from soil formed indigenously at the site. Again, lysimeter nest Lys\#3 was downgradient of a zone of spent mushroom substrate and it was directly above the swale that was considered to be a discharge area for water within the 20acre subbasin. 
Table 35. Estimates of the mass of nitrogen in sub-unit area 2 for depths below land surface from 13 to $33 \mathrm{ft}$, New Garden Township spray-irrigation site, Chester County, Pennsylvania, 1999-2001.

\begin{tabular}{cc}
\hline $\begin{array}{c}\text { Lysimeter sample- } \\
\text { collection date }\end{array}$ & $\begin{array}{c}\text { Nitrogen mass } \\
\text { (pounds) }\end{array}$ \\
\hline $09 / 23 / 1999$ & 44 \\
$10 / 20 / 1999$ & 36 \\
$12 / 16 / 1999$ & 72 \\
$02 / 03 / 2000$ & 300 \\
$03 / 16 / 2000$ & 390 \\
& \\
$04 / 12 / 2000$ & 190 \\
$05 / 10 / 2000$ & 95 \\
$07 / 12 / 2000$ & 53 \\
$08 / 09 / 2000$ & 59 \\
$09 / 13 / 2000$ & 43 \\
& \\
$10 / 12 / 2000$ & 52 \\
$11 / 30 / 2000$ & 78 \\
$12 / 21 / 2000$ & 95 \\
$02 / 22 / 2001$ & 130 \\
& \\
$03 / 22 / 2001$ & 130 \\
$05 / 24 / 2001$ & 54 \\
$06 / 14 / 2001$ & 47 \\
\hline
\end{tabular}

Table 36. Results for nitrogen-isotope samples collected from the lysimeter network, New Garden Township spray-irrigation site, Chester County, Pennsylvania, November 2000-November 2001.

[Lysimeters are shown on plate 1]

\begin{tabular}{ccc}
\hline Date & Lysimeter & $\begin{array}{c}\delta^{15} \mathbf{N} \text { for Nitrate } \\
\text { (per mil) }\end{array}$ \\
\hline $11 / 16 / 2000$ & Ch-5211 & 0.8 \\
$11 / 16 / 2000$ & Ch-5213 & 2.3 \\
$11 / 16 / 2000$ & Ch-5448 & 6.4 \\
$11 / 16 / 2000$ & Ch-5565 & 8.1 \\
$11 / 16 / 2000$ & Ch-5568 & -2.1 \\
& & \\
$11 / 16 / 2000$ & Ch-5574 & 5.9 \\
$7 / 18 / 2001$ & Ch-5216 & 15.1 \\
$7 / 18 / 2001$ & Ch-5448 & 6.4 \\
$7 / 18 / 2001$ & Ch-5572 & 5.1 \\
& & \\
$11 / 27 / 2001$ & Ch-5564 & 8.4 \\
$11 / 27 / 2001$ & Ch-5216 & 14.5 \\
\hline
\end{tabular}

\section{Shallow Ground-Water Nitrogen Storage}

The storage of $\mathrm{N}$ and $\mathrm{Cl}$ within the ground-water system was estimated from the depth of the bottom of the lysimeter network to the depth of competent bedrock (table 37). The estimated storage of $\mathrm{N}$ and $\mathrm{Cl}$ was determined for sub-unit areas 2, 4, and 6 (fig. 7) using data for shallow wells Ch-5173, Ch-5175, and Ch-5177. Estimated N masses were previously estimated from the soil surface to the depth of the bottom of the lysimeter network (UPPERZONE) (stored in soil water) (table 34). Data from the depth of the bottom of the lysimeter network to the depth of competent bedrock (LOWERZONE) are presented in table 37. The highest average mass of $\mathrm{N}$ per unit volume of unconsolidated material in the LOWERZONE from June 1999 through December 2001 was estimated to be in sub-unit area $6\left(0.00036 \mathrm{lb} / \mathrm{ft}^{3}\right)$, followed by sub-unit area 4 $\left(0.000026 \mathrm{lb} / \mathrm{ft}^{3}\right)$ and sub-unit area $2\left(0.000022 \mathrm{lb} / \mathrm{ft}^{3}\right)$. The amount of $\mathrm{N}$ per unit volume stored in the LOWERZONE in sub-unit area 6 was more than twice the amount stored per unit volume in the UPPERZONE. Conversely, for sub-unit areas 2 and 4 , the estimated amount of $\mathrm{N}$ stored per unit volume was larger in the UPPERZONE than in the LOWERZONE. The estimated average mass of $\mathrm{Cl}$ per unit volume in the LOWERZONE $\left(0.00048 \mathrm{lb} / \mathrm{ft}^{3}\right)$ of sub-unit area 6 also was greater than that stored in the UPPERZONE $\left(0.00012 \mathrm{lb} / \mathrm{ft}^{3}\right)$.

As with $\mathrm{N}$, the estimated amount of $\mathrm{Cl}$ for sub-unit areas 2 and 4 was greater in the UPPERZONE $(0.00088$ and $0.0012 \mathrm{lb} / \mathrm{ft}^{3}$, respectively) than in the LOWERZONE $\left(0.000088\right.$ and $0.000053 \mathrm{lb} / \mathrm{ft}^{3}$, respectively).

The trends in the estimated storage values for the LOWERZONE in the different sub-unit areas indicated differences for each sub-unit area (table 37). Sub-unit area 2 indicated significant increasing trends in the estimated mass of $\mathrm{N}$ and $\mathrm{Cl}$ over time from June 1999 through December 2001. Nitrate N and $\mathrm{Cl}$ concentration data for shallow well Ch-5173 (sub-unit area 2) indicated significant increasing trends (figs. 20 and 25). Data for sub-unit area 4 indicated no significant trends in $\mathrm{N}$ and $\mathrm{Cl}$ mass, which was expected because nitrate- $\mathrm{N}$ and $\mathrm{Cl}$ concentration data for shallow well Ch-5175 (sub-unit area 4) indicated no significant trends (tables 18 and 20). Data for sub-unit area 6 (shallow well Ch-5177) indicated a significant decreasing trend in $\mathrm{N}$ mass and nitrate- $\mathrm{N}$ concentration and a significant increasing trend in $\mathrm{Cl}$ mass and concentration (see tables 18 and 20 for median concentration data). The trends in $\mathrm{N}$ and $\mathrm{Cl}$ mass for the LOWERZONE were not consistent with the trends from the UPPERZONE for sub-unit areas 2 and 4 . At the top of the 20-acre subbasin (sub-unit area 2), the UPPERZONE and LOWERZONE indicated significant increases in estimated $\mathrm{Cl}$ mass over time; however, there was not a significant increase of $\mathrm{N}$ mass in the UPPERZONE. The UPPERZONE in sub-unit areas 4 and 6 indicated significant increasing trends in the estimated $\mathrm{Cl}$ mass and decreasing trends in the estimated $\mathrm{N}$ mass. It was apparent that there was a discontinuity between water collected from the lysimeter nests and water captured during ground-water sampling in sub-unit areas 2 and 4 . Suction-lysimeter sampling pulls micropore soil water from the 
Table 37. Total estimated masses of nitrogen and chloride from the average depth of the water table to the depth of competent bedrock for sub-unit areas 2, 4, and 6, New Garden Township spray-irrigation site, Chester County, Pennsylvania, 1999-2001.

[Sub-unit areas are shown on figure 7. - , data not available; sub-unit area 2 was 1.9 acres and the mass of nitrogen was estimated from depths of 33 to 62 feet; sub-unit area 4 was 6.5 acres and the mass of nitrogen was estimated from depths of 17 to 56.5 feet; and sub-unit area 6 was 1.7 acres and the mass of nitrogen was estimated from depths of 14.75 to 35 feet; the date given in the table was the sample date for wells Ch-5173; wells Ch-5175 and Ch-5177 were sampled within 9 days of Ch-5173]

\begin{tabular}{|c|c|c|c|c|c|c|}
\hline \multirow[b]{2}{*}{ Date } & \multicolumn{2}{|c|}{ Sub-unit area 2} & \multicolumn{2}{|c|}{ Sub-unit area 4} & \multicolumn{2}{|c|}{ Sub-unit area 6} \\
\hline & $\begin{array}{l}\text { Nitrogen } \\
\text { (pounds) }\end{array}$ & $\begin{array}{l}\text { Chloride } \\
\text { (pounds) }\end{array}$ & $\begin{array}{l}\text { Nitrogen } \\
\text { (pounds) }\end{array}$ & $\begin{array}{l}\text { Chloride } \\
\text { (pounds) }\end{array}$ & $\begin{array}{l}\text { Nitrogen } \\
\text { (pounds) }\end{array}$ & $\begin{array}{l}\text { Chloride } \\
\text { (pounds) }\end{array}$ \\
\hline 06/01/1999 & 44 & - & 230 & - & 1,100 & - \\
\hline 06/30/1999 & 77 & 110 & 260 & 560 & 630 & 630 \\
\hline 07/29/1999 & 59 & - & 280 & - & 600 & - \\
\hline 08/25/1999 & 59 & - & 360 & - & 670 & - \\
\hline 09/22/1999 & 40 & 100 & 320 & 650 & 670 & 550 \\
\hline 10/25/1999 & 50 & - & 350 & - & 560 & - \\
\hline 11/29/1999 & 45 & - & 320 & - & 600 & - \\
\hline $01 / 06 / 2000$ & 43 & 100 & 350 & 600 & 600 & 560 \\
\hline $02 / 01 / 2000$ & 37 & - & 300 & - & 630 & - \\
\hline 03/06/2000 & 35 & - & 300 & - & 600 & - \\
\hline $04 / 05 / 2000$ & 37 & - & 320 & - & 700 & - \\
\hline $05 / 23 / 2000$ & 38 & 160 & 300 & 570 & 700 & 470 \\
\hline $06 / 26 / 2000$ & 41 & - & 320 & - & 700 & - \\
\hline $07 / 24 / 2000$ & 39 & 140 & 270 & 600 & 700 & 500 \\
\hline $08 / 29 / 2000$ & 36 & - & 220 & - & 670 & - \\
\hline 09/18/2000 & 46 & 150 & 250 & 520 & 630 & 580 \\
\hline $10 / 16 / 2000$ & 35 & - & 230 & - & 600 & - \\
\hline $11 / 13 / 2000$ & 46 & - & 230 & - & 530 & - \\
\hline $12 / 12 / 2000$ & 39 & 170 & 230 & 520 & 490 & 740 \\
\hline $01 / 16 / 2001$ & 50 & - & 240 & - & 460 & - \\
\hline $02 / 20 / 2001$ & 47 & - & 220 & - & 390 & - \\
\hline $03 / 26 / 2001$ & 43 & 180 & 200 & 480 & 390 & 870 \\
\hline 05/07/2001 & 83 & - & 240 & - & 340 & - \\
\hline 05/30/2001 & 61 & - & 240 & - & 200 & - \\
\hline $06 / 25 / 2001$ & 50 & 320 & 210 & 550 & 420 & 960 \\
\hline $07 / 16 / 2001$ & 57 & - & 230 & - & 340 & - \\
\hline $08 / 27 / 2001$ & 71 & - & 250 & - & 290 & - \\
\hline $10 / 09 / 2001$ & 77 & 500 & 270 & 570 & 270 & 960 \\
\hline $11 / 06 / 2001$ & 71 & - & 570 & - & 260 & - \\
\hline $12 / 03 / 2001$ & 77 & 490 & 300 & 590 & 250 & 1,000 \\
\hline
\end{tabular}


matrix. Ground-water sampling procedures involve pumping of the well and sampling as freshwater is drawn into the well from the water table. Suction-lysimeter water was expected to be in contact with soil particles more directly than ground water pulled into the wells during sampling. The water sampled from the wells was likely in fractures or pore spaces of the rock where the water was available for drawdown into the well during pumping. It is also unknown how long the traveltime is between surface infiltration of water and recharge down to the water table. There could be an appreciable lag period between water moving past the lysimeter nest and that same parcel of water reaching the shallow or deep wells in the 20-acre subbasin.

$\mathrm{N}$-isotope data collected from the monitor wells indicated variations across the study site. The two samples collected from well $\mathrm{Ch}-5173$ at the top of the 20 -acre subbasin gave identical $\delta^{15} \mathrm{~N}$ (nitrate) values of $1.3 \%$ for samples collected in June 1999 and November 2000 (table 38). The $\delta^{15} \mathrm{~N}$ (nitrate) values for well Ch-5173 were similar to the values for lysimeter Ch-5211 (0.8\%o) and lysimeter Ch-5213 (2.3\%o) (table 36), which were lysimeters near well Ch-5173. The lack of change in $\delta^{15} \mathrm{~N}$ (nitrate) values from June 1999 to November 2000 for well Ch-5173 indicated that the source of nitrate $\mathrm{N}$ to the shallow well did not change during the period. If nitrate $\mathrm{N}$ from spray-irrigated effluent was reaching well Ch-5173, $\delta^{15} \mathrm{~N}$ (nitrate) values should increase. The $\delta^{15} \mathrm{~N}$ (nitrate) values for effluent samples averaged about $13 \%$. Nitrate-N and dissolved-N concentrations for the sample collected from shallow well Ch-5173 in June 1999 were 0.39 and $0.69 \mathrm{mg} / \mathrm{L}$, respectively. Nitrate-N and dissolved-N concentrations for the sample collected from shallow well Ch-5173 in November 2000 were 0.55 and $0.72 \mathrm{mg} / \mathrm{L}$, respectively. Thus, the ratio of nitrate $\mathrm{N}$ to dissolved N increased from June 1999 to November 2000 with basically no increase in dissolved $\mathrm{N}$. The fraction of organic $\mathrm{N}$ decreased over the same period, which indicated that the increased nitrate- $\mathrm{N}$ concentration for well $\mathrm{Ch}-5173$ could have been caused by increased mineralization of organic $\mathrm{N}$.

The similarity in $\delta^{15} \mathrm{~N}$ (nitrate) values between lysimeters and wells was not evident in sub-unit area 4 . The $\delta^{15} \mathrm{~N}$ (nitrate) value for shallow well $\mathrm{Ch}-5175$ was $2.5 \%$, while values for lysimeter Ch-5216 averaged about $15 \%$. The difference in $\delta^{15} \mathrm{~N}$ values between shallow well Ch-5175 and lysimeter Ch-5216 indicated that the source of nitrate $\mathrm{N}$ for these sample locations was different. $\delta^{15} \mathrm{~N}$ values for lysimeter Ch-5216, in addition to trends and concentrations in $\mathrm{N}$ and $\mathrm{Cl}$, indicated that spray-irrigated effluent was a major contributor of nitrate $\mathrm{N}$ to lysimeter Ch-5216; conversely, data from well Ch-5175 indicated that this shallow well was not receiving appreciable amounts of nitrate $\mathrm{N}$ from spray-irrigated effluent. Nitrate-N and $\mathrm{Cl}$ concentration data for shallow well Ch-5175 indicated no significant trend over time (tables 18 and 20).
Table 38. Results for nitrogen-isotope samples collected from the monitor-well network, New Garden Township sprayirrigation site, Chester County, Pennsylvania, May 1999-November 2000.

\begin{tabular}{ccc}
\hline Date & $\begin{array}{c}\text { Monitor well } \\
\text { identification number }\end{array}$ & $\begin{array}{c}\delta^{15} \mathbf{N} \text { for nitrate } \\
\text { (per mil) }\end{array}$ \\
\hline $05 / 25 / 1999$ & Ch-5183 & 6.2 \\
$05 / 27 / 1999$ & Ch-5176 & 13.9 \\
$05 / 27 / 1999$ & Ch-5181 & 10.3 \\
$06 / 01 / 1999$ & Ch-5177 & 9.9 \\
$06 / 01 / 1999$ & Ch-5175 & 2.5 \\
$06 / 01 / 1999$ & Ch-5173 & \\
$12 / 02 / 1999$ & Ch-5721 & 1.3 \\
$12 / 02 / 1999$ & Ch-5722 & 8.2 \\
$11 / 13 / 2000$ & Ch-5173 & 1.3 \\
$11 / 20 / 2000$ & Ch-5177 & 8.5 \\
\hline
\end{tabular}

$\delta^{15} \mathrm{~N}$ (nitrate) values for monitor wells in sub-unit area 6 were affected by the spent mushroom substrate zone that lies above the wells. $\delta^{15} \mathrm{~N}$ (nitrate) data for shallow well Ch-5177 and the lysimeters in sub-unit area 6 were similar; values ranged from 8.1 to $9.9 \%$. Ch-5177 had higher $\delta^{15} \mathrm{~N}$ (nitrate) values than Ch-5175. Because Ch-5177 was downgradient of Ch-5175, it was unlikely that the higher $\delta^{15} \mathrm{~N}$ (nitrate) values were caused by more effluent reaching Ch-5177. Higher $\delta^{15} \mathrm{~N}$ (nitrate) values for Ch-5177 were likely caused by spent mushroom substrate. Denitrification of nitrate in the spent substrate can cause enrichment of $\delta^{15} \mathrm{~N}$ (nitrate) (Karr and others, 2001). $\delta^{15} \mathrm{~N}$ (nitrate) values for deep well Ch-5176 in sub-unit area 6 were higher than all other $\mathrm{N}$-isotope samples collected in subunit area 6. Water samples from deep well Ch-5176 indicated decreasing trends in both dissolved $\mathrm{N}$ and $\mathrm{Cl}$ from May 1999 through December 2001, and high concentrations for dissolved $\mathrm{N}(39 \mathrm{mg} / \mathrm{L}$ of nitrate $\mathrm{N}$ on May 27, 1999) prior to spray irrigation at the site (tables 23 and 24). Thus, the relatively high $\delta^{15} \mathrm{~N}$ (nitrate) values for deep well Ch-5176 were not caused by spray-irrigated effluent reaching the well. It was likely that the high concentrations of dissolved $\mathrm{N}$ for deep well Ch-5176 prior to spray irrigation was caused by spent mushroom substrate, and denitrification of nitrate $\mathrm{N}$ originating from spent mushroom substrate could produce the high $\delta^{15} \mathrm{~N}$ (nitrate) for deep well Ch-5176. 


\section{Volatilization}

The differences in the concentrations of dissolved ammonia $\mathrm{N}$ between the effluent and the PAN samples were used to quantify the loss of ammonia $\mathrm{N}$ through volatilization from the 20-acre subbasin. These samples were collected at the site from July 1999 through October 2001 (appendix 1, table 1-5). As expected, the concentrations of dissolved ammonia $\mathrm{N}$ were fairly similar between the effluent samples and the samples collected in the spray field using PANs (fig. 52). Except for one sampling event, two PAN samples were collected on each day samples were collected. The two values for the day were averaged in order to quantify the difference between concentrations of dissolved ammonia $\mathrm{N}$ for the effluent and the PANs.

Differences in concentrations of dissolved ammonia $\mathrm{N}$ between the effluent and the PANs were larger during the growing season (fig. 53). Seasonal differences in the volatilization of ammonia $\mathrm{N}$ from the spray-irrigated effluent were expected given the positive relation between ammonia volatilization and temperature identified in previous studies (Sommer and others, 1991; Sommer and Olesen, 1991). However, statistical tests to determine if any relation was present between differences in concentrations of dissolved ammonia $\mathrm{N}$ and meteorological factors, such as wind speed and air temperature, indicated no significant relations. The meteorological parameters were mea- sured at the site. During sample collection, wind speed ranged from about 1 to $12 \mathrm{mph}$ and air temperatures ranged from 2 to $26^{\circ} \mathrm{C}$. Defining the growing season as April through October, the mean and median difference (a positive difference indicated that effluent concentrations exceeded PAN concentrations) between effluent and PAN concentrations was 0.17 and $0.05 \mathrm{mg} / \mathrm{L}$ of dissolved ammonia $\mathrm{N}$, respectively. The mean difference was $0.19 \mathrm{mg} / \mathrm{L}$ of ammonia $\mathrm{N}$ if all differences less than zero were set equal to zero. It is reasonable to set negative differences to zero because ammonia- $\mathrm{N}$ concentrations in the PAN samples should not exceed ammonia-N concentrations in the effluent samples. The median ratio of ammonia- $\mathrm{N}$ concentrations in PAN samples to ammonia-N concentrations in the effluent samples was 0.83 for samples collected during the growing season; the mean ratio was 0.78 if ratios greater than one were set equal to one. The mean difference between effluent and PAN concentrations for samples collected during the dormant season was $-0.02 \mathrm{mg} / \mathrm{L}$ of dissolved ammonia $\mathrm{N}$.

Dissolved ammonia-N concentrations for PAN samples that exceeded dissolved ammonia- $\mathrm{N}$ concentrations for effluent samples could have been caused by either sample contamination or by changes in the concentration of dissolved ammonia $\mathrm{N}$ discharging from the spigot. That is, effluent and PAN samples were collected concurrently; however, it is possible that delaying sample collection by even a matter of seconds could affect

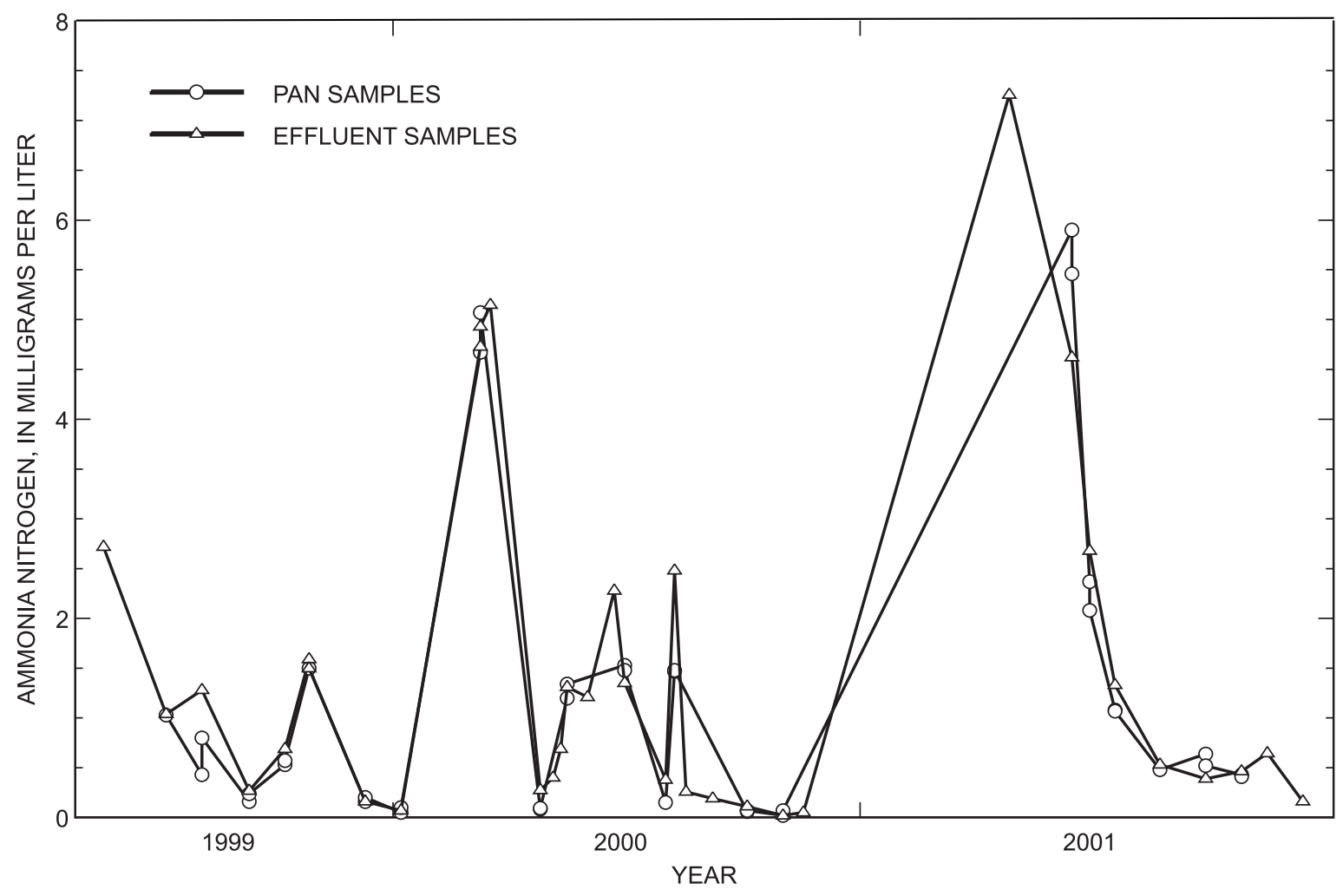

Figure 52. Concentrations of ammonia nitrogen in spray effluent and PAN (plastic containers placed on the spray fields) samples, New Garden Township spray-irrigation site, Chester County, Pennsylvania, 1999-2001. 


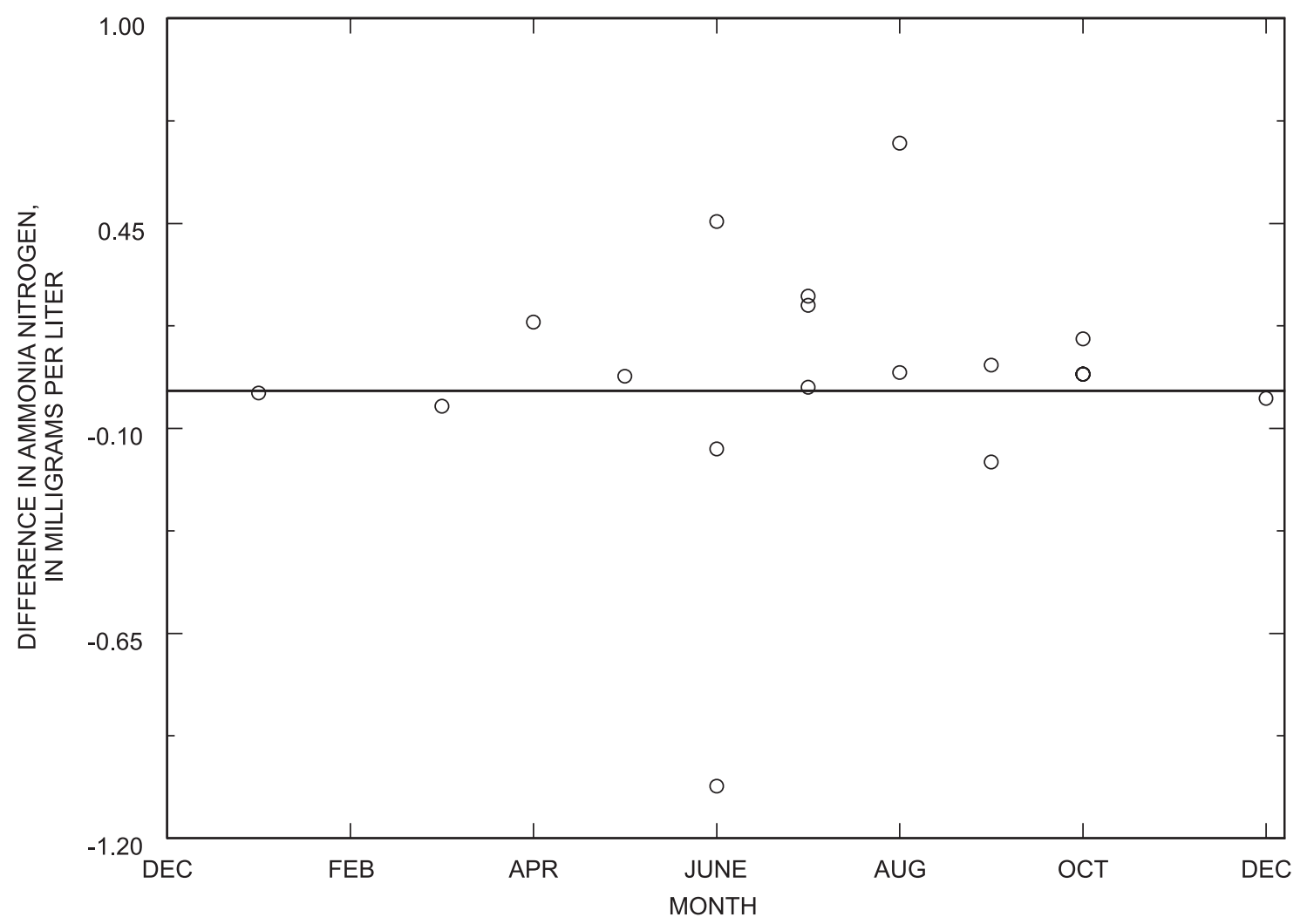

Figure 53. Monthly differences in concentrations of ammonia nitrogen in spray effluent and PAN (plastic containers placed on the spray fields) samples, New Garden Township spray-irrigation site, Chester County,

Pennsylvania.

[Differences are equal to the concentration of ammonia nitrogen for the effluent sample subtracted from the concentration of ammonia nitrogen for the PAN sample. If two PAN samples were collected on that day, the mean of those two values were used to determine the difference.]

concentrations in the sample. The extent of chemical variability over short time periods (less than 1 day) in water discharging from the spigot was not determined. Quality-control samples did not indicate any problems with ammonia contamination for PAN samples; thus, it was assumed that when ammonia-N concentrations in PAN samples exceeded ammonia-N concentrations in the effluent samples, the difference was caused by fluctuations in ammonia-N concentrations in the effluent during PAN and effluent sampling.

The quantity of $\mathrm{N}$ lost through ammonia volatilization from the site was estimated using mean or median differences between the effluent and PAN samples. To determine the quantity of $\mathrm{N}$ lost through ammonia volatilization, it was assumed that from November through March, no volatilization occurred. From April through October, it was assumed volatilization occurred. The estimates of the spigot $\mathrm{N}$ species load to the 20-acre subbasin was discussed earlier. These estimates were based on the interpolation of $\mathrm{N}$ loads on days when effluent samples were not collected. The estimated load of ammonia $\mathrm{N}$ from the effluent was used as the input to predict $\mathrm{N}$ losses through volatilization of ammonia $\mathrm{N}$. The total estimated amount of dissolved-ammonia $\mathrm{N}$ input to the 20-acre subbasin from application of spray-irrigated effluent from June 1999 through December 2001 was $706 \mathrm{lb}$, with 82 percent being applied during the growing season (table 29). Adjusting the ammonia-N concentrations to account for volatilization, load reductions because of volatilization can be estimated. Adjusting the growing-season ammonia- $\mathrm{N}$ concentrations by 0.05 (median difference between spigot and PAN samples) and $0.19 \mathrm{mg} / \mathrm{L}$ (mean difference between spigot and PAN samples), the estimated amount of $\mathrm{N}$ lost through volatilization was 12 and $65 \mathrm{lb}$, respectively. Adjusting the growing-season ammonia- $\mathrm{N}$ concentrations by multiplying the effluent concentrations by 0.78 (mean ratio between PAN ammonia- $\mathrm{N}$ to effluent ammonia-N concentrations) and 0.83 (median ratio), the estimated amount of $\mathrm{N}$ lost through volatilization was 122 and $92 \mathrm{lb}$, respectively. Thus, the estimated range of ammonia $\mathrm{N}$ lost through volatilization from the 20-acre subbasin was from 
12 to $122 \mathrm{lb}$. This was from 2 to 21 percent of the total amount of ammonia $\mathrm{N}$ applied during the growing season, or from 2 to 17 percent of the total amount of ammonia $\mathrm{N}$ applied during the entire study. Sharpe and Harper (1997) found that, prior to spray-irrigated effluent reaching the plant canopy or soil surface, about 13 percent of the ammonium $\mathrm{N}$ in swine effluent applied through a sprinkler system was lost to the atmosphere through ammonia volatilization. They also found that an additional 69 percent of the ammonium $\mathrm{N}$ was lost through volatilization after the effluent contacted either soil or plant surfaces. For this study, it was not possible to measure volatilization losses once the spray-irrigated effluent reached either soil or plant surfaces. During sample collection, PANs collected sprayirrigated effluent for about 15-30 minutes prior to sample processing. During this time, some ammonia volatilization likely occurred from the PAN. Ammonia volatilization also occurred from the time the effluent discharged the spray head until the water reached a surface. The ammonia volatilization from the PAN was thought to be a surrogate for volatilization that would occur from plant or soil surfaces before the water infiltrated the soil. Ammonia volatilization typically is not expected to occur to any appreciable extent once water infiltrates the soil (Meisinger and Jokela, 2000). It should also be noted that over a day of spraying, as the volume applied increases, the total percentage of spray-irrigated effluent intercepted by plant material would decrease. Virtually no ponding of effluent was ever evident at the site. Any ponding could increase volatilization rates. Given the potential for additional ammonia volatilization from water on plant surfaces, it is possible that the amount of $\mathrm{N}$ lost through ammonia volatilization was closer to the upper end (120 lb) of the range estimate.

\section{Plant Removal of Nitrogen}

The loss of $\mathrm{N}$ from the 20-acre subbasin by way of plant harvest indicated some deviation from year to year, but no significant effects because of spray irrigation were evident (table 39). Variations from year to year were primarily because of differences in the number of bales harvested. The $\mathrm{N}$ removed in dry plant matter (appendix 1, table 1-6) from within the 20 -acre subbasin did not show any increase over time.

Locations identified as Low and Middle (and one location outside the 20-acre subbasin, Control (1)) indicated significant decreases in the $\mathrm{N}$ concentration for plant matter (fig. 54). The mean $\mathrm{N}$ concentration for plant material collected within the 20 -acre subbasin was 2.36 percent $\mathrm{N}$, and the mean $\mathrm{N}$ concentration for control areas (Control (1) and Control (2)) was 2.30 percent $\mathrm{N}$. The removal of $\mathrm{N}$ per acre was similar for the fields in the 20-acre subbasin; however, removal of $\mathrm{N}$ from control fields indicated different removal rates. The amount of $\mathrm{N}$ removed from each of the four soil-sampling areas (Upper, Middle, Lower, and Bottom) averaged about $85 \mathrm{lb}$ per acre per year. The average amount of $\mathrm{N}$ removed from Control (1) and Control (2) was 100 and $60 \mathrm{lb}$ per acre per year, respectively. The higher amounts of $\mathrm{N}$ removed from Control (1) were likely
Table 39. Amount of nitrogen removed during plant harvest in the soil-sampling areas of the 20 -acre subbasin and control areas, New Garden Township spray-irrigation site, Chester County, Pennsylvania, 1999-2001.

\begin{tabular}{lccc}
\hline \multirow{2}{*}{$\begin{array}{c}\text { Soil-sampling areas } \\
\text { (acres) }\end{array}$} & \multicolumn{3}{c}{ Nitrogen harvested, in pounds } \\
\cline { 2 - 4 } & $\mathbf{1 9 9 9}$ & $\mathbf{2 0 0 0}$ & $\mathbf{2 0 0 1}$ \\
\hline Upper (5.83) & 510 & 460 & 550 \\
Middle (3.96) & 360 & 290 & 380 \\
Low (5.25) & 450 & 360 & 460 \\
Bottom (3.06) & 250 & 190 & 300 \\
Control (1) (5.30) & 550 & 470 & 600 \\
Control (2) (3.79) & 290 & 170 & 220 \\
\hline
\end{tabular}

caused by the presence of spent mushroom substrate in that field. The area of Control (1) was 25 percent covered with spent mushroom substrate at the surface. However, the topography (the spent mushroom substrate is at the top of the field) would cause chemical transport from the spent mushroom substrate zone to the rest of the field. This transport was evident in higher concentrations of $\mathrm{N}$ in the solid-soil matrix for this field relative to other fields (table 30). The lower removal rate of $\mathrm{N}$ from Control (2) could be because of the lack of moisture in that field relative to the other fields. Control (2) was in spray fields 4 and 5 , both of which were used sparingly during the study; thus, the soil moisture in this field would have been reduced relative to fields in the 20-acre subbasin. 


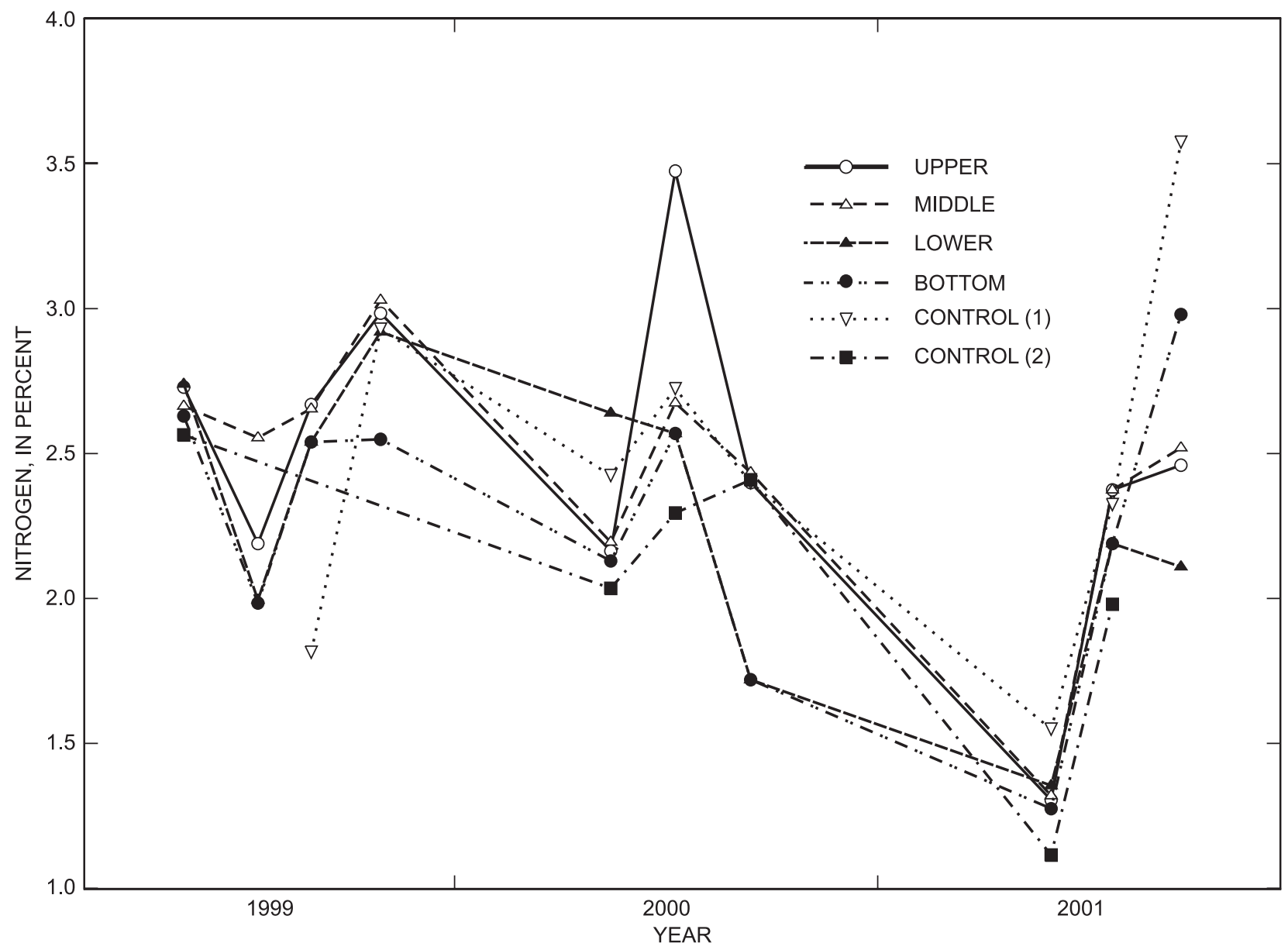

Figure 54. Concentrations of nitrogen in dry plant material harvested from different soil-sampling areas, New Garden Township spray-irrigation site, Chester County, Pennsylvania, 1999-2001.

\section{Discharge}

Water discharge from the 20-acre subbasin was monitored from the middle of June 1999 through December 2001 (fig. 55). The flume was installed in early June 1999. However, discharge from the 20-acre subbasin was not apparent until approximately August 23, 1999, even though spray irrigation at the site began in June 1999. Discharge below $0.001 \mathrm{ft}^{3} / \mathrm{s}$ is not shown on fig. 55. Discharge was not greater than $0.001 \mathrm{ft}^{3} / \mathrm{s}$ until August 1999. Discharge from the 20 -acre subbasin indicated a direct connection to spray application and precipitation. September 1999, which had the highest input of precipitation and effluent (19.8 in. over the 20 -acre subbasin), had the highest monthly mean discharge $\left(0.094 \mathrm{ft}^{3} / \mathrm{s}\right)$. Conversely, some of the lowest monthly mean discharges were from November through December 2001 (mean of $0.014 \mathrm{ft}^{3} / \mathrm{s}$ ) when only about 4 in. of spray-irrigated effluent and precipitation were input to the 20-acre subbasin.

Discharge through the flume was a mixture of water from two distinct processes within the 20 -acre subbasin. Initially, dry soil conditions were evident in the spring-summer of 1999 because of little precipitation. Spray applications, beginning in late May 1999, helped to saturate the soil. This application was followed by seepage of water at the base of the 20 -acre subbasin. This seepage was captured by the swale and transported through the flume. Seepage from the discharge zone at the base of the 20-acre subbasin occurred throughout the remainder of the study once seepage started to occur in June 1999. The other process that contributed flow to the flume was storm runoff. During storm events, water was transported to the flume by water infiltrating the soil and subsequently displacing antecedent moisture to the discharge zone. During the most intense storms, such as the precipitation from the remnants of Hurricane Floyd, overland flow of water to the swale also resulted.

Grab samples collected at the outlet of the flume were collected primarily during low-flow periods and are referred to as low-flow samples; however, two samples were collected during storm events (using $0.1 \mathrm{ft}^{3} / \mathrm{s}$ as the cutoff between low-flow and storm samples) (fig. 56). Grab samples collected during lowflow periods can be considered generally representative of water seeping from the 20-acre subbasin during non-storm events; however, some mixture of this seepage water with 

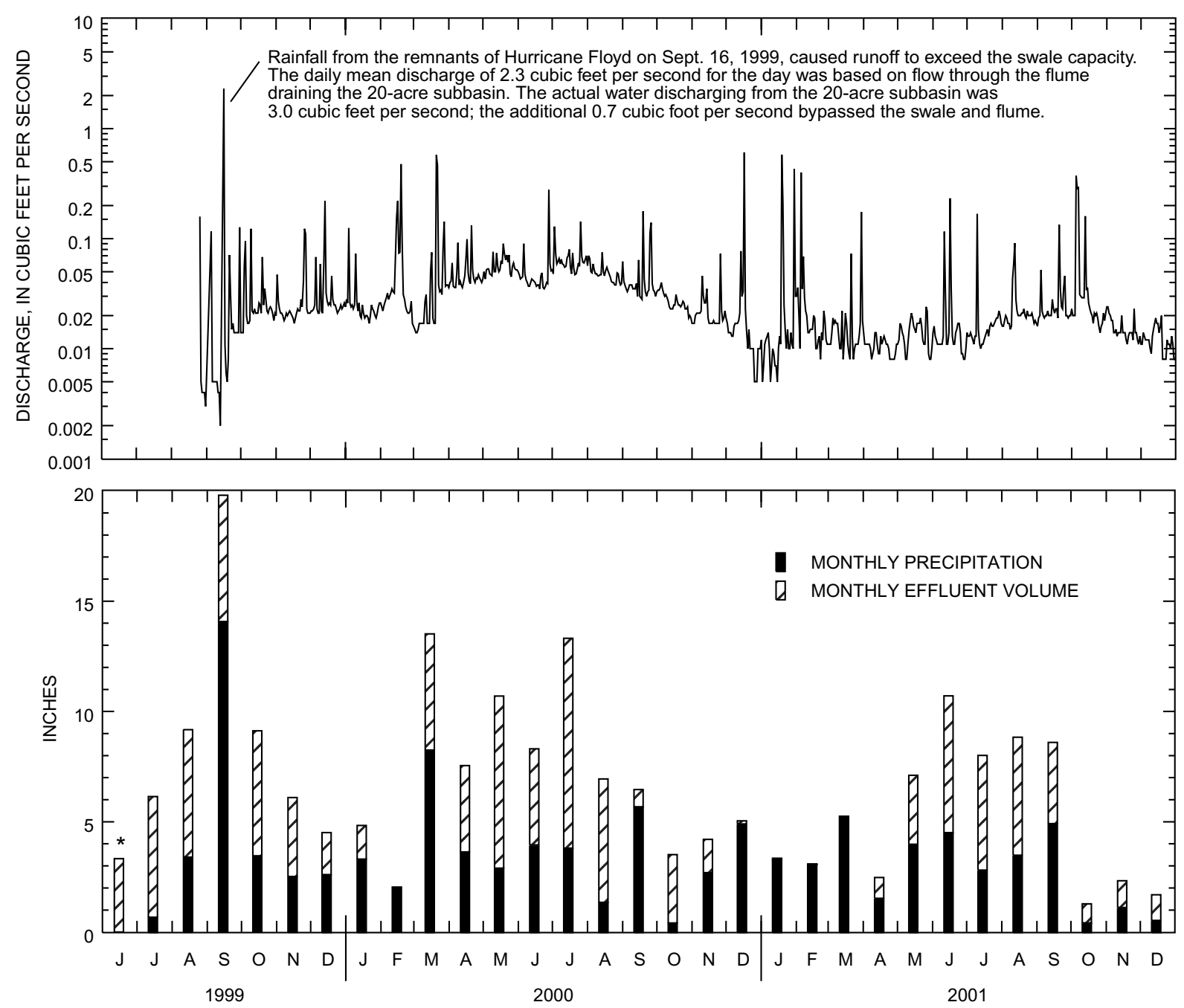

Figure 55. Hydrograph of daily values for discharge through the flume and monthly values for precipitation and volumes of spray-irrigated effluent, New Garden Township spray-irrigation site, Chester County, Pennsylvania, 1999-2001. [Units for effluent volumes are in inches over the 20 -acre subbasin. ${ }^{*}$, precipitation data not available for June 1999.] 


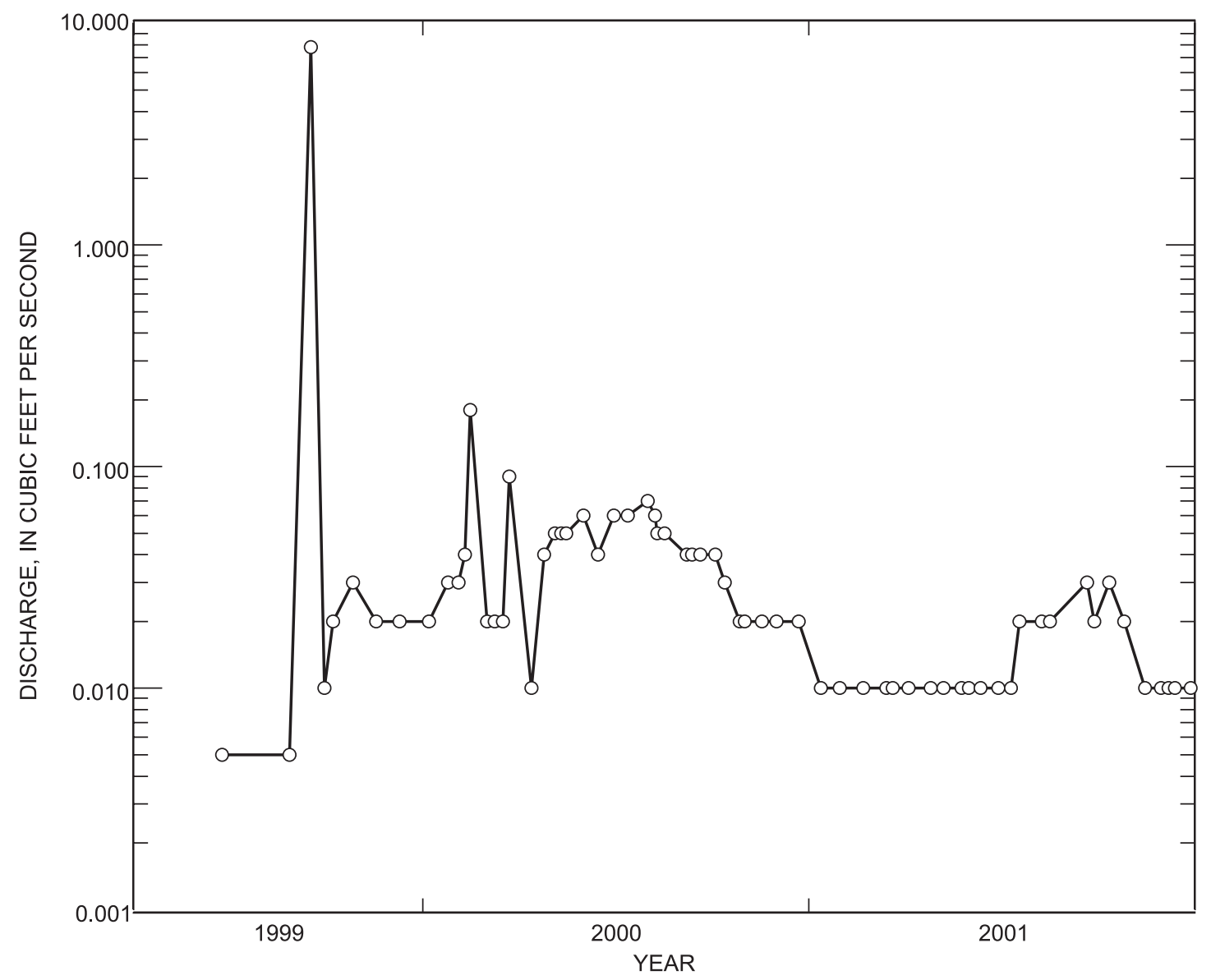

Figure 56. Instantaneous discharge at the time of grab-sample collection from the outlet of the flume draining the 20-acre subbasin, New Garden Township spray-irrigation site, Chester County, Pennsylvania, 19992001.

storm-induced runoff occurred if low-flow samples were collected during the initial rise of an event or during the stormrecession period. The concentrations of $\mathrm{N}$ did not show any relation to discharge for the grab samples collected; the lack of a relation primarily is the result of little variation in discharge for the samples collected. The mean discharge for samples collected in water year $2001\left(0.02 \mathrm{ft}^{3} / \mathrm{s}\right)$ was less than the mean discharge for samples collected in water year $2000\left(0.05 \mathrm{ft}^{3} / \mathrm{s}\right)$.

Low-flow samples collected at the outlet of the flume from June 1999 through December 2001 indicated a decreasing time trend in $\mathrm{N}$ concentrations and an increasing trend in $\mathrm{Cl}$ concentrations (figs. 57 and 58). The mean concentration of dissolved $\mathrm{N}$ in low-flow samples was $2.50 \mathrm{mg} / \mathrm{L}$ (2 samples), $1.42 \mathrm{mg} / \mathrm{L}$ (29 samples), $0.83 \mathrm{mg} / \mathrm{L}$ (25 samples), and $0.73 \mathrm{mg} / \mathrm{L}$ (7 samples) for water years 1999, 2000, 2001, and 2002, respectively. The decreasing time trend for dissolved $\mathrm{N}$ was caused by a significantly decreasing trend in nitrate $\mathrm{N}$ and organic $\mathrm{N}$ over time. Ninety-eight percent of the $\mathrm{N}$ for low-flow samples was in dis- solved form; 50 percent of the dissolved $\mathrm{N}$ was in organic- $\mathrm{N}$ form, 46 percent in nitrate- $\mathrm{N}$ form, and the remaining fraction in ammonia-N form. More sample to sample variation occurred in $\mathrm{N}$ concentrations for low-flow samples collected early (prior to April 2000) in the study compared to later (fig. 57). The highest dissolved ammonia- $N$ concentration detected $(0.55 \mathrm{mg} / \mathrm{L})$ in low-flow samples was collected on Feb. 14, 2000, during a snowmelt period. Additional variation in the $\mathrm{N}$-concentration data prior to April 2000 could be the result of changing soilmoisture conditions. As the study progressed, it is likely that soil moistures became more uniform over the study area; saturation became the dominant condition over time. These more uniform soil-moisture conditions may have helped to stabilize $\mathrm{N}$-concentration variability in low-flow samples over time. Saturated conditions would indicate a more reducing environment, and such conditions would promote denitrification. 


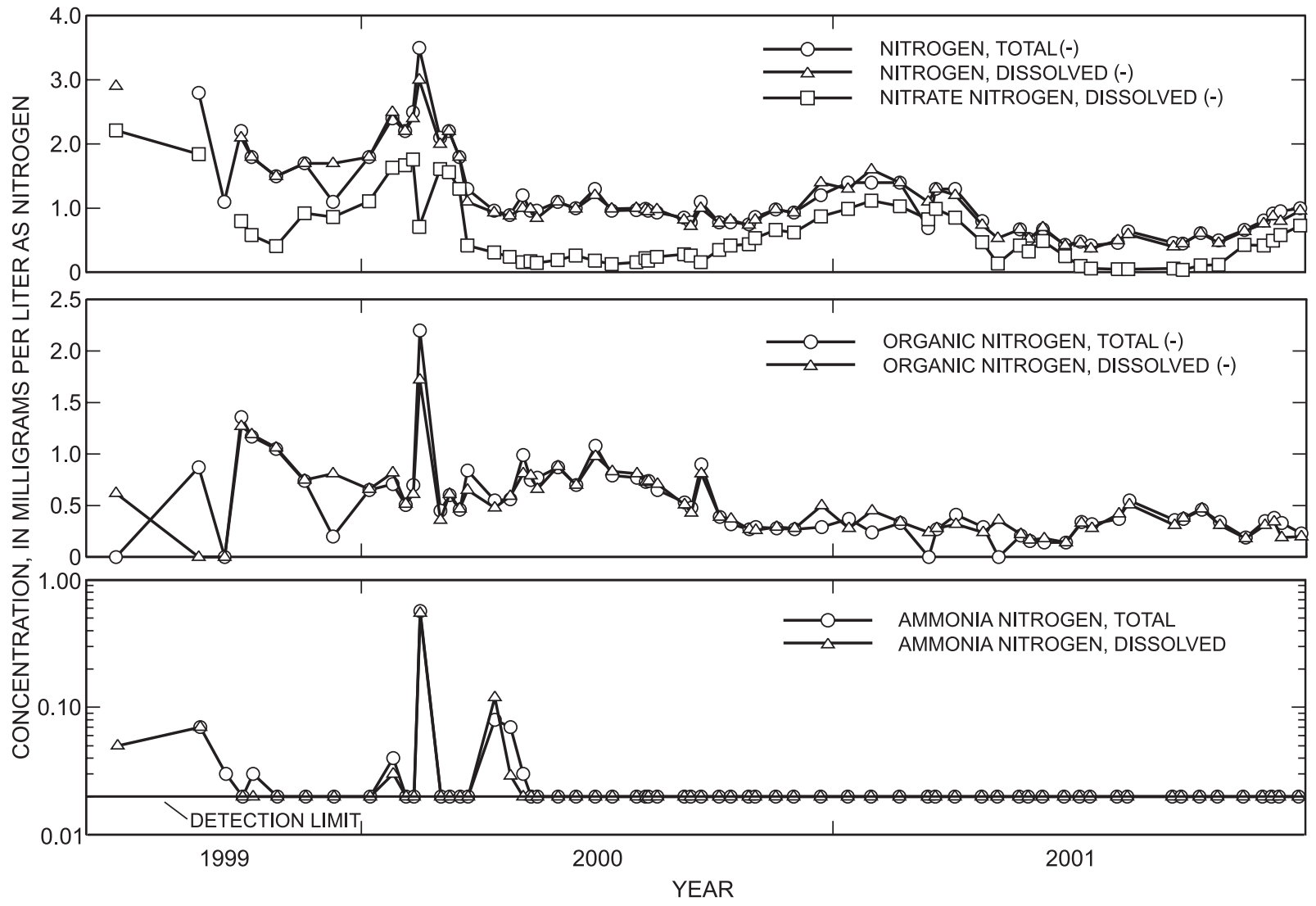

Figure 57. Concentrations of total and dissolved forms of nitrogen over time and identification of significant time trends for grab samples collected at the outlet of the flume, New Garden Township spray-irrigation site, Chester County, Pennsylvania, 1999-2001. ['(-)' indicates a significant decreasing trend. Significant trends over time were based on an alpha equal to 0.05 .]

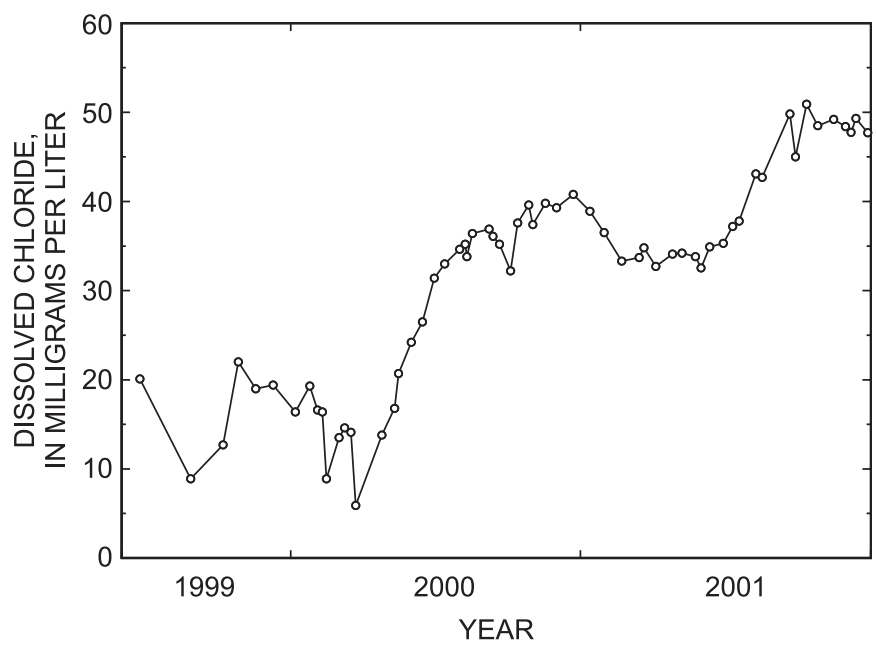

Figure 58. Concentration of dissolved chloride for grab samples collected at the outlet of the flume, New Garden Township sprayirrigation site, Chester County, Pennsylvania, 1999-2001. 
Contrary to the low-flow samples, stormflow samples collected at the outlet of the flume indicated increasing trends for concentrations of some N species from September 1999 through December 2001. The storm samples were collected at mean discharges (mean discharges for the storms sampled) ranging from $0.05 \mathrm{ft}^{3} / \mathrm{s}$ to $1.2 \mathrm{ft}^{3} / \mathrm{s}$ (fig. 59). The concentration of dissolved $\mathrm{N}$ indicated an insignificant increase over time; the increase was caused by significant increasing trends in the concentrations of dissolved nitrate $\mathrm{N}$ and ammonia $\mathrm{N}$ (fig. 60). Concentrations of dissolved $\mathrm{Cl}$ indicated a much greater increase than concentrations of dissolved $\mathrm{N}$ over the same time period (fig. 61). The regression of dissolved $\mathrm{N}$ over time ( $p$-value equal to 0.09) predicted an increase in dissolved $\mathrm{N}$ of $0.7 \mathrm{mg} / \mathrm{L}$ from September 1999 to December 2001. The regression model for dissolved $\mathrm{Cl}$ predicted a $30 \mathrm{mg} / \mathrm{L}$ increase in dissolved $\mathrm{Cl}$ over the same time period. The increasing trends in $\mathrm{N}$ species were most evident during the last 6 months of sampling, which coincided with storms sampled at higher mean discharges. However, except for concentrations of dissolved ammonia $\mathrm{N}$ showing a significant increase with an increase in discharge, no relation was evident between $\mathrm{N}$ species and discharge.

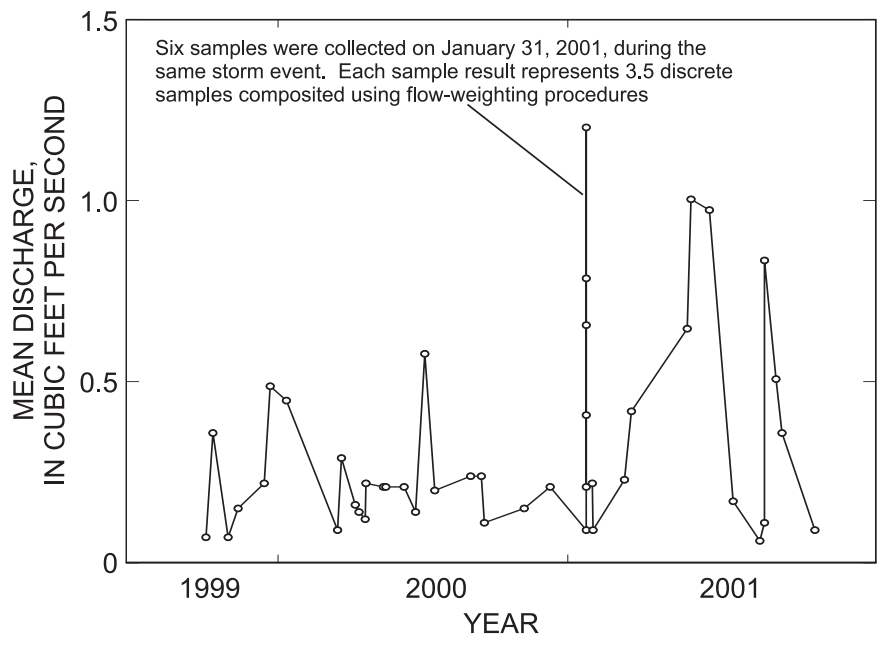

Figure 59. Mean discharge for storm events sampled at the flume draining the 20 -acre subbasin, New Garden Township spray-irrigation site, Chester County, Pennsylvania, 1999-2001.
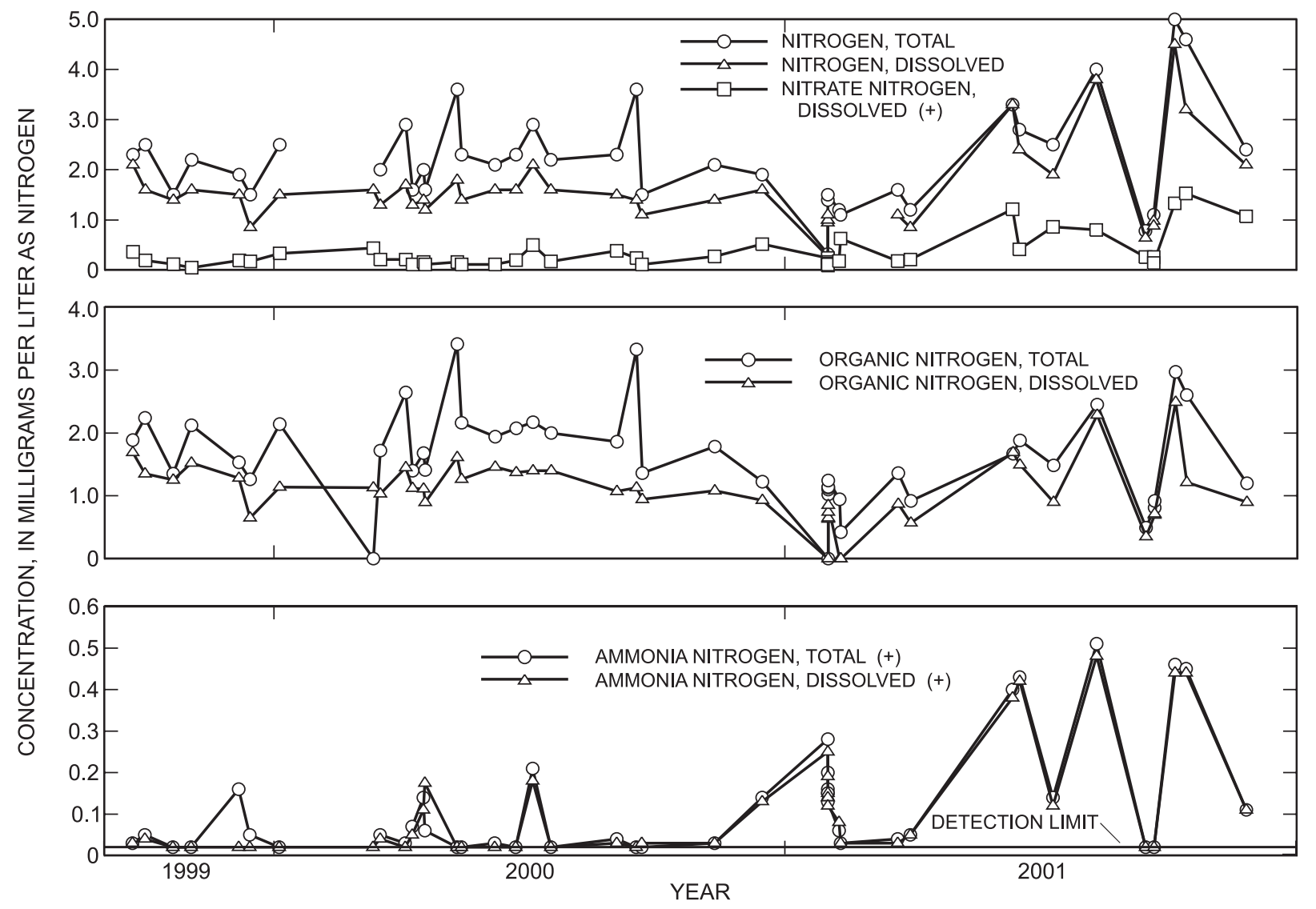

Figure 60. Concentrations of total and dissolved forms of nitrogen and identification of significant time trends for storm samples collected at the flume, New Garden Township spray-irrigation site, Chester County, Pennsylvania, 1999-2001. $\left[{ }^{\prime}(+)^{\prime}\right.$ indicates a significant increasing trend. Significant trends over time were based on an alpha equal to 0.05 .] 


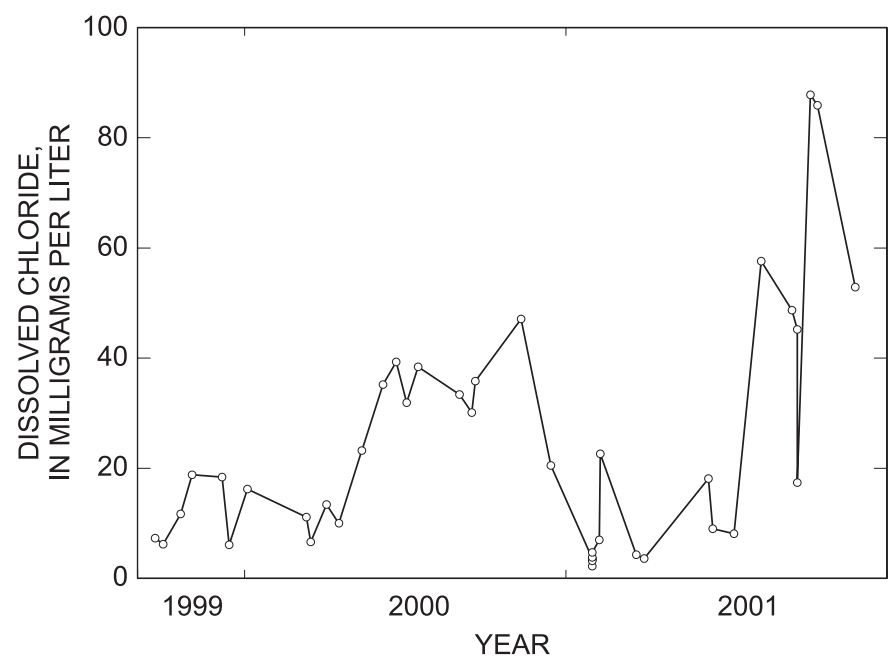

Figure 61. Concentration of dissolved chloride for storm samples collected at the flume, New Garden Township spray-irrigation site, Chester County, Pennsylvania, 1999-2001.

The concentrations and forms of $\mathrm{N}$ differed between lowflow and stormflow samples. The mean concentration of total and dissolved forms of $\mathrm{N}$ for storm samples was 2.13 and $1.60 \mathrm{mg} / \mathrm{L}$, respectively. The mean concentration of total and dissolved forms of $\mathrm{N}$ for low-flow samples was 1.16 and $1.14 \mathrm{mg} / \mathrm{L}$, respectively. Seventy-five percent of the concentration of total $\mathrm{N}$ was in dissolved form for storm samples, indicating transport of suspended materials from the 20-acre subbasin was limited. The dissolved and total forms of organic $\mathrm{N}$ comprised 72 and 76 percent, respectively, of the concentration of total $\mathrm{N}$ for storm samples; nitrate $\mathrm{N}$ and ammonia $\mathrm{N}$ accounted for 17 and 7 percent, respectively, of the concentration of total $\mathrm{N}$. Thus, a higher proportion of the concentration of total $\mathrm{N}$ was in organic-N form for stormflow samples compared to low-flow samples. The higher proportion of organic $\mathrm{N}$ in storm samples was partly because of transport of organic $\mathrm{N}$ from the zone of spent mushroom substrate directly upgradient of the swale draining the 20-acre subbasin. Samples collected from lysimeter Ch-5449 upgradient of the swale and within this spent mushroom substrate zone indicated that 90 percent of the dissolved $\mathrm{N}$ captured by this lysimeter was in organic form (fig. 44 ). The native soil not affected by application of spent mushroom substrate also was a source of organic $\mathrm{N}$ because 96 percent of the total $\mathrm{N}$ in soil samples collected over the study site was organic. During storm events, the subsurface movement of water likely captured $\mathrm{N}$ from these soil-matrix sources; conversely, during low flow, flow paths were primarily under these shallow zones with subsequent increases in the ratio of nitrate $\mathrm{N}$ to total $\mathrm{N}$ in low flow relative to stormflow. The mean ratio of nitrate $\mathrm{N}$ to $\mathrm{Cl}$ for low-flow and stormflow samples was 0.03 ; however, low-flow samples indicated a significant decreasing trend over time, whereas no trend was evident for stormflow samples (fig. 62). Mean values in the ratio of nitrate $\mathrm{N}$ to $\mathrm{Cl}$ for low-flow samples varied from a mean of 0.16 for two samples collected in September 1999 to 0.01 for seven samples collected

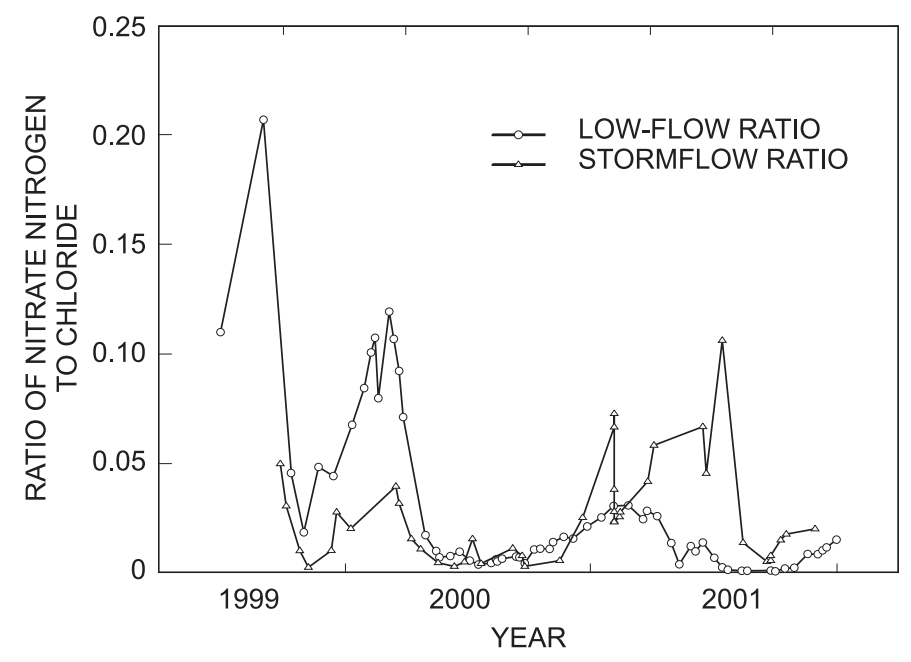

Figure 62. Ratio of nitrate-nitrogen to chloride concentrations for low-flow and stormflow samples collected at the flume, New Garden Township spray-irrigation site, Chester County, Pennsylvania, 1999-2001.

in water year 2002. The mean ratio of nitrate $\mathrm{N}$ to $\mathrm{Cl}$ for effluent samples was 0.07; thus, outflow from the 20 -acre subbasin was not trending towards values for the ratio of nitrate $\mathrm{N}$ to $\mathrm{Cl}$ that would be consistent with spray-irrigated effluent. Similar to suction-lysimeter data, the ratio of nitrate $\mathrm{N}$ to $\mathrm{Cl}$ for samples collected at the outlet of the flume indicated that nitrate $\mathrm{N}$ was being lost from the system as spray-irrigated effluent was moving through the soil system.

The low-flow data were used to estimate instantaneous loads of $\mathrm{N}$ being transported through the outlet of the flume. An instantaneous load is determined by multiplying the concentration by flow and assuming that both are constant for the day so that pounds per day of constituent can be estimated. Similar to low-flow concentration data, instantaneous loads of dissolved $\mathrm{N}$, nitrate $\mathrm{N}$, and total and dissolved forms of organic $\mathrm{N}$ indicated significant decreasing trends over time from June 1999 through December 2001 (fig. 63). The median instantaneous load of total and dissolved $\mathrm{N}$ lost from the 20-acre subbasin was 0.12 and $0.11 \mathrm{lb} / \mathrm{d}$, respectively. The means $(0.94$ and $0.20 \mathrm{lb} / \mathrm{d}$ for total and dissolved $\mathrm{N}$, respectively) were higher than the medians primarily because of the sample collected during the runoff event induced by the remnants of Hurricane Floyd on September 16, 1999. The daily loads of total and dissolved N estimated for September 16, 1999, were 46 and $2.9 \mathrm{lb} / \mathrm{d}$, respectively.

The amount of $\mathrm{N}$ being transported from the 20 -acre subbasin during storm events was determined using the mean concentration and mean stormflow for the storms sampled. The mean duration of the storms sampled was approximately 3.5 hours. Trends in the stormflow loss of $\mathrm{N}$ from the 20 -acre subbasin were similar to the trends for concentrations of $\mathrm{N}$ species in storm samples (fig. 64). Significant increasing trends from September 1999 through December 2001 in stormflow losses of dissolved $\mathrm{N}$, nitrate $\mathrm{N}$, ammonia $\mathrm{N}$, and total ammonia $\mathrm{N}$ were identified. The mean losses of total and dissolved forms 

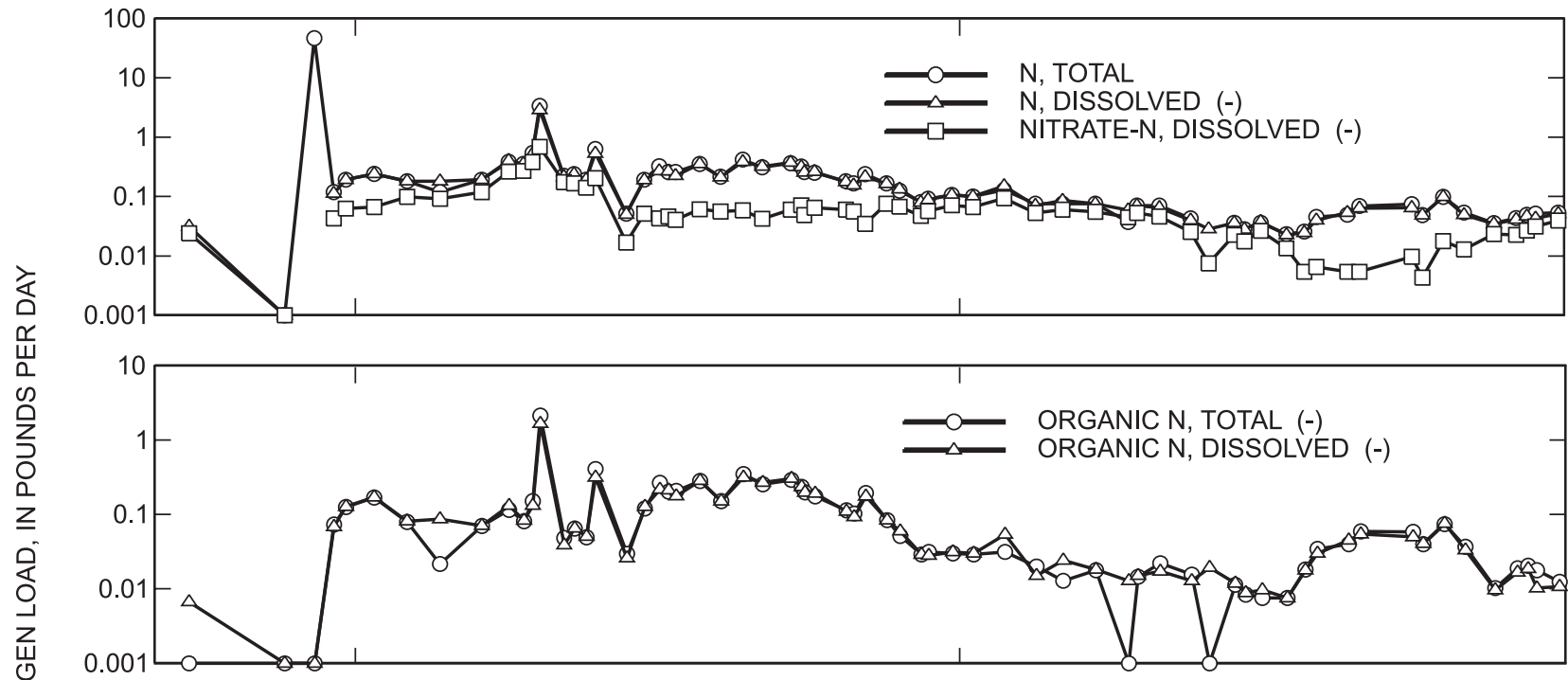

올

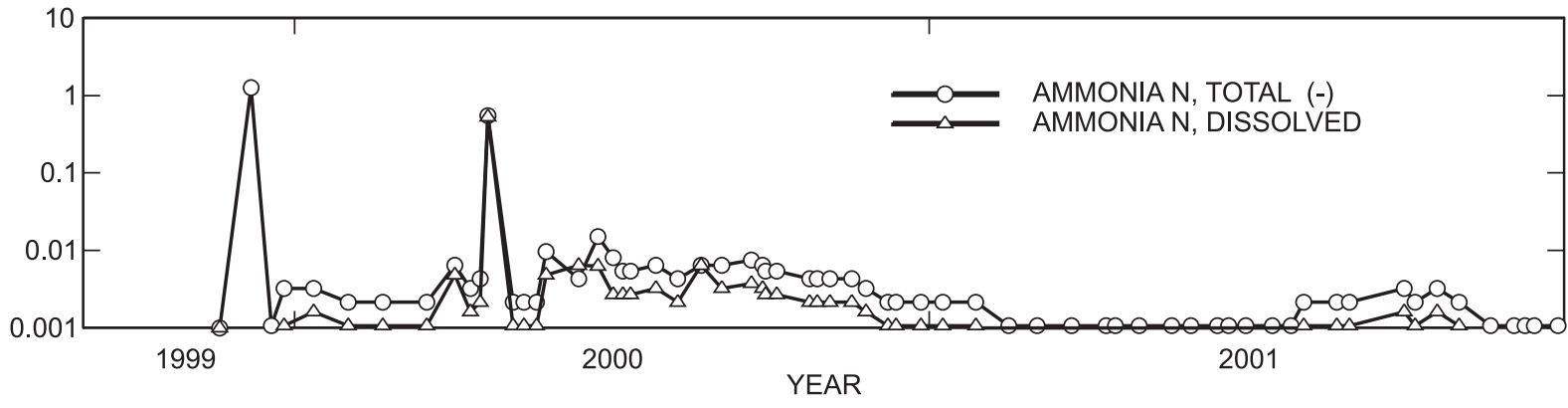

Figure 63. Instantaneous loads of total and dissolved forms of nitrogen and identification of significant time trends for grab samples collected at the outlet of the flume, New Garden Township spray-irrigation site, Chester County, Pennsylvania, 19992001. ['(-)' indicates a significant decreasing trend. Significant trends over time were based on an alpha equal to 0.05 .] 


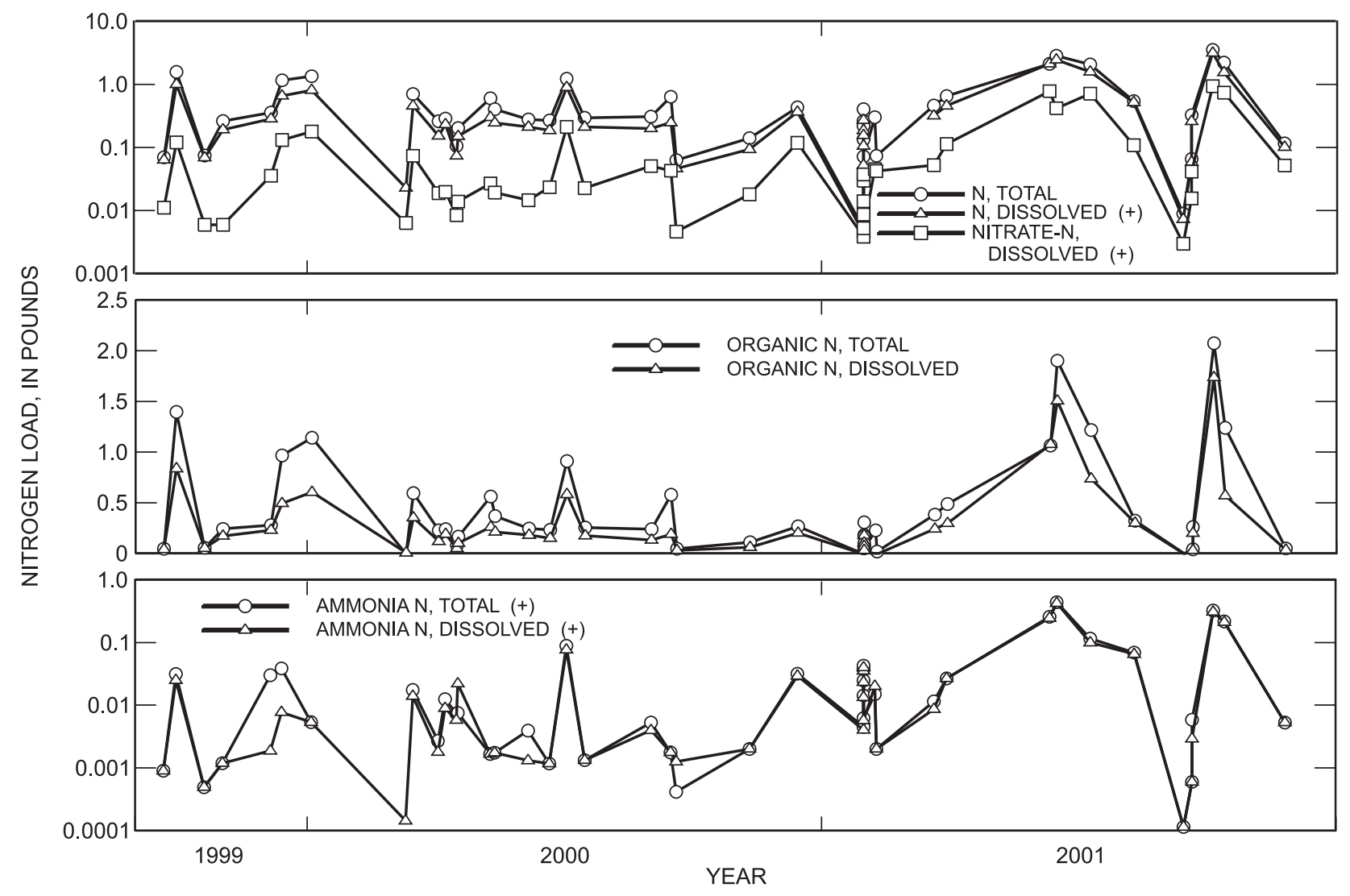

Figure 64. Loads of total and dissolved forms of nitrogen and identification of significant time trends for storm samples collected at the flume, New Garden Township spray-irrigation site, Chester County, Pennsylvania, 1999-2001. ['(+)' indicates a significant increasing trend. Significant trends over time were based on an alpha equal to 0.05 .]

of $\mathrm{N}$ during storm events sampled were 0.64 and $0.49 \mathrm{lb}$, respectively. The stormflow concentration data indicated that about 76 percent of the total $\mathrm{N}$ was organic $\mathrm{N}$. However, there was a significant decreasing time trend in the ratio of organic $\mathrm{N}$ to total $\mathrm{N}$ for storm samples, and a concurrent increasing trend in the ratio of nitrate $\mathrm{N}$ to total $\mathrm{N}$. For storm samples collected in water year 2000, the ratio of total and dissolved organic $\mathrm{N}$ to total $\mathrm{N}$ was 0.88 and 0.82 , respectively; for water year 2001 , the ratio of total and dissolved organic $\mathrm{N}$ to total $\mathrm{N}$ was 0.67 and 0.63 , respectively. The ratio of nitrate $\mathrm{N}$ to total $\mathrm{N}$ for storm samples increased from 0.09 to 0.23 from water year 2000 to 2001. The relative decrease in organic $\mathrm{N}$ during storm events over time was likely caused by application of spray-irrigated effluent. The zone of spent mushroom substrate directly upgradient of the swale was one source of organic $\mathrm{N}$ during storm events. The average percentage of nitrate $\mathrm{N}$ and organic $\mathrm{N}$ to total $\mathrm{N}$ in spray-irrigated effluent was 62 and 28 percent, respectively (table 29). Thus, the increased ratio over time of nitrate $\mathrm{N}$ to total $\mathrm{N}$ for storm samples was likely caused by the increased availability of spray effluent during storm events. Data from lysimeter Ch-5449, which was in the spent mushroom substrate zone immediately upgradient of the swale, indi- cated that 90 percent of the dissolved $\mathrm{N}$ fraction for water from this lysimeter was organic N. Storm runoff upgradient of the spent mushroom substrate zone had to travel through this spent mushroom substrate zone prior to reaching the swale. As application of spray-irrigated effluent and precipitation events occurred over time, the organic $\mathrm{N}$ in the spent mushroom substrate zone was, to some extent, displaced by nitrate $\mathrm{N}$ from spray-irrigated effluent. Even though suction lysimeter and low-flow data indicated $\mathrm{N}$ in the effluent was being lost from the system, it was possible during storm events that the infiltration of precipitation into the upper soil horizons helped to push nitrate $\mathrm{N}$ out of the system before the completion of denitrification processes in the soil.

The total loss of $\mathrm{N}$ from the 20-acre subbasin from July 1999 through December 2001 through the flume was approximately $250 \mathrm{lb}$ (table 40). Approximately $28 \mathrm{lb}$ (11 percent) of the total loss was caused by a pipe breakage at the site that permitted effluent, with some mixing with water in the upper parts of the soil matrix, to discharge directly from the site through the flume. If this $\mathrm{N}$ loss is subtracted from the total loss, then approximately 54 percent of the total $\mathrm{N}$ lost from the 20 -acre subbasin was during low flow. Similar to instantaneous load 
Table 40. Amount and forms of nitrogen transported during low flow and stormflow through the flume draining the 20-acre subbasin, New Garden Township spray-irrigation site, Chester County, Pennsylvania, July 1999 through December 2001.

\begin{tabular}{|c|c|c|c|c|c|c|c|c|c|c|c|c|c|c|}
\hline \multirow[t]{2}{*}{ Date } & \multicolumn{2}{|c|}{$\begin{array}{l}\text { Nitrogen, } \\
\text { total }\end{array}$} & \multicolumn{2}{|c|}{$\begin{array}{l}\text { Nitrogen, } \\
\text { dissolved }\end{array}$} & \multicolumn{2}{|c|}{$\begin{array}{c}\text { Nitrate } \\
\text { nitrogen, } \\
\text { dissolved }\end{array}$} & \multicolumn{2}{|c|}{$\begin{array}{c}\text { Organic } \\
\text { nitrogen, } \\
\text { total }\end{array}$} & \multicolumn{2}{|c|}{$\begin{array}{l}\text { Organic } \\
\text { nitrogen, } \\
\text { dissolved }\end{array}$} & \multicolumn{2}{|c|}{$\begin{array}{c}\text { Ammonia } \\
\text { nitrogen, } \\
\text { total }\end{array}$} & \multicolumn{2}{|c|}{$\begin{array}{l}\text { Ammonia } \\
\text { nitrogen, } \\
\text { dissolved }\end{array}$} \\
\hline & Low flow & Storm & Low flow & Storm & Low flow & Storm & Low flow & Storm & Low flow & Storm & Low flow & Storm & Low flow & Storm \\
\hline July 1999 & 1.91 & 0.00 & 1.91 & 0.00 & 1.39 & 0.00 & 0.47 & 0.00 & 0.47 & 0.00 & 0.04 & 0.00 & 0.04 & 0.00 \\
\hline Aug. 1999 & 1.82 & .94 & 1.82 & .68 & 1.23 & .66 & .54 & .00 & .54 & .00 & .04 & .03 & .04 & .02 \\
\hline Sept. 1999 & 3.29 & 16.46 & 3.19 & 11.90 & 1.51 & 10.38 & 1.70 & 1.65 & 1.61 & 1.07 & .05 & .43 & .04 & .29 \\
\hline Oct. 1999 & 5.41 & 2.80 & 5.39 & 2.05 & 1.66 & .22 & 3.63 & 2.52 & 3.63 & 1.77 & .08 & .04 & .03 & .04 \\
\hline Nov. 1999 & 5.35 & 2.49 & 5.35 & 1.91 & 2.60 & .17 & 2.65 & 2.16 & 2.65 & 1.70 & .06 & .13 & .03 & .01 \\
\hline Dec. 1999 & 6.32 & 2.95 & 6.32 & 1.84 & 3.44 & .33 & 2.77 & 2.45 & 2.77 & 1.45 & .07 & .13 & .04 & .02 \\
\hline Jan. 2000 & 7.81 & 2.01 & 7.81 & 1.21 & 5.05 & .27 & 2.63 & 1.72 & 2.63 & .92 & .10 & .01 & .07 & .01 \\
\hline Feb. 2000 & 9.25 & 14.14 & 8.77 & 13.41 & 5.87 & 9.60 & 2.98 & 4.36 & 2.54 & 3.63 & .34 & .11 & .29 & .06 \\
\hline Mar. 2000 & 5.44 & 15.28 & 5.12 & 9.56 & 3.07 & 1.42 & 2.21 & 13.44 & 1.90 & 7.78 & .09 & .30 & .07 & .23 \\
\hline Apr. 2000 & 5.80 & 2.45 & 5.49 & 1.73 & 1.66 & .16 & 3.63 & 2.18 & 3.33 & 1.37 & .39 & .17 & .39 & .17 \\
\hline May 2000 & 8.12 & 1.94 & 7.54 & 1.16 & 1.31 & .09 & 6.48 & 1.82 & 6.00 & 1.05 & .18 & .01 & .08 & .01 \\
\hline June 2000 & 6.91 & 4.32 & 6.70 & 3.11 & 1.37 & .55 & 5.29 & 3.57 & 5.13 & 2.38 & .12 & .18 & .08 & .15 \\
\hline July 2000 & 8.90 & 3.41 & 8.90 & 2.45 & 1.28 & .42 & 7.34 & 2.86 & 7.34 & 1.92 & .17 & .11 & .10 & .09 \\
\hline Aug. 2000 & 6.85 & .68 & 6.85 & .46 & 1.62 & .09 & 5.01 & .57 & 5.01 & .36 & .14 & .01 & .07 & .01 \\
\hline Sept. 2000 & 4.58 & 3.87 & 4.30 & 2.58 & 1.24 & .32 & 3.14 & 3.47 & 2.91 & 2.15 & .10 & .06 & .05 & .06 \\
\hline Oct. 2000 & 3.56 & .00 & 3.56 & .00 & 1.86 & .00 & 1.56 & .00 & 1.56 & .00 & .09 & .00 & .05 & .00 \\
\hline Nov. 2000 & 3.01 & .64 & 2.97 & .47 & 1.98 & .12 & .90 & .50 & .90 & .33 & .06 & .02 & .03 & .02 \\
\hline Dec. 2000 & 2.95 & 6.33 & 2.95 & 5.30 & 1.89 & 1.68 & .98 & 4.10 & .98 & 3.10 & .05 & .48 & .02 & .45 \\
\hline Jan. 2001 & 2.27 & 6.20 & 2.27 & 4.64 & 1.64 & .90 & .58 & 4.58 & .58 & 3.06 & .03 & .66 & .02 & .62 \\
\hline Feb. 2001 & 3.58 & 3.34 & 3.58 & 1.73 & 2.58 & .49 & .92 & 2.58 & .92 & .40 & .05 & .26 & .02 & .26 \\
\hline Mar. 2001 & 2.57 & 1.62 & 2.57 & 1.13 & 1.92 & .24 & .60 & 1.29 & .59 & .81 & .04 & .06 & .02 & .05 \\
\hline Apr. 2001 & 1.76 & .00 & 1.63 & .00 & 1.10 & .00 & .59 & .00 & .48 & .00 & .03 & .00 & .02 & .00 \\
\hline May 2001 & 1.43 & .00 & 1.42 & .00 & .70 & .00 & .65 & .00 & .65 & .00 & .05 & .00 & .02 & .00 \\
\hline June 2001 & 1.05 & 5.66 & 1.05 & 5.17 & .69 & 1.31 & .31 & 3.44 & .31 & 2.97 & .04 & .80 & .02 & .77 \\
\hline July 2001 & 1.06 & 2.10 & 1.01 & 1.59 & .21 & .72 & .75 & 1.24 & .72 & .75 & .05 & .12 & .02 & .10 \\
\hline Aug. 2001 & 1.73 & 2.62 & 1.65 & 2.49 & .16 & .53 & 1.44 & 1.61 & 1.40 & 1.49 & .06 & .33 & .03 & .31 \\
\hline Sept. 2001 & 1.56 & 1.11 & 1.42 & .96 & .17 & .23 & 1.26 & .82 & 1.15 & .67 & .06 & .04 & .03 & .03 \\
\hline Oct. 2001 & 1.80 & ${ }^{1} 27.92$ & 1.75 & 24.38 & .38 & 7.67 & 1.29 & 16.48 & 1.27 & 13.04 & .07 & 2.59 & .03 & 2.49 \\
\hline Nov. 2001 & 1.60 & .11 & 1.53 & .10 & .88 & .05 & .62 & .06 & .57 & .04 & .05 & .11 & .02 & .10 \\
\hline Dec. 2001 & 1.88 & .07 & 1.71 & .06 & 1.19 & .03 & .61 & .03 & .46 & .03 & .04 & .00 & .02 & .00 \\
\hline Total & 119.57 & 131.46 & 116.53 & 102.07 & 51.65 & 38.65 & 63.53 & 79.50 & 61.00 & 54.24 & 2.74 & 7.19 & 1.79 & 6.37 \\
\hline
\end{tabular}

${ }^{1}$ The entire stormflow load for October 2001 was due to pipe breakage in the spray-irrigation system. The pipe break occurred upgradient of the swale and effluent was discharging through the flume. Discharge exceeded the base-flow range; therefore, the load caused by this event was considered as stormflow. 
data, the monthly loads of $\mathrm{N}$ during low flow decreased over time. Every month in calendar year 2000 had a higher low-flow loss of total $\mathrm{N}$ than the same month in 2001. The low-flow loads of total $\mathrm{N}$ during 2000 and 2001 were 73 and $22 \mathrm{lb}$, respectively. The stormflow load of total $\mathrm{N}$ during 2001 ( $23 \mathrm{lb}$ without the pipe-breakage load) was less than 50 percent of the stormflow load for $2000(55 \mathrm{lb})$. Stormflow loads were affected primarily by major events, such as the remnants of Hurricane Floyd, which accounted for 84 percent of the stormflow load of total $\mathrm{N}$ for September 1999. Other major contributors to the stormflow load were a long-duration snowmelt event in February 2000 and a 4.5 in. rain event in March 2000. The loss of total $\mathrm{N}$ from the 20 -acre subbasin indicated a relation to $\mathrm{N}$ in the spray-irrigated effluent. Fifty percent of the total $\mathrm{N}$ applied in spray-irrigated effluent from June 1999 through December 2001 to the 20-acre subbasin occurred by mid-April 2000. Similarly, 45 percent of total N discharged through the flume from July 1999 through December 2001 was transported from the site by the end of April 2000. However, $\mathrm{N}$ concentrations in water discharging from the flume were much lower than concentrations of total $\mathrm{N}$ for the spray-irrigated effluent. The mean total- $\mathrm{N}$ concentration for low-flow and stormflow samples collected at the flume were 1.16 and $2.13 \mathrm{mg} / \mathrm{L}$, respectively. The mean total- $\mathrm{N}$ concentration for effluent samples was $11 \mathrm{mg} / \mathrm{L}$.

The proportion of the different forms of $\mathrm{N}$ in low-flow and stormflow loads varied during the study. Sixty percent of the load of total $\mathrm{N}$ in stormflow was organic $\mathrm{N}$; only 52 percent of the load of total $\mathrm{N}$ in low flow was organic $\mathrm{N}$. The added organic $\mathrm{N}$ for stormflow samples was caused partially by the increased transport of suspended materials during storm events. Seventy-eight percent of the load of total $\mathrm{N}$ during stormflow was dissolved; 97 percent of the load of total $\mathrm{N}$ during low flow was dissolved. For stormflow, most of the suspended $\mathrm{N}$ was organic. The majority of remaining $\mathrm{N}$ was nitrate $\mathrm{N}$; nitrate $\mathrm{N}$ accounted for 43 percent of the low-flow load of N; only 29 percent of the load of total $\mathrm{N}$ in stormflow was nitrate $\mathrm{N}$. Losses of ammonia $\mathrm{N}$ were about twice as high in stormflow than in low flow. Summing the low-flow and stormflow losses through the flume, approximately 57 percent of the load of total $\mathrm{N}$ was organic and 36 percent was nitrate N. During the study, the load of $\mathrm{N}$ applied in spray-irrigated effluent to the 20 -acre subbasin was 52 percent nitrate $\mathrm{N}$ and 28 percent organic $\mathrm{N}$. The higher proportion of organic $\mathrm{N}$ in water transported through the flume relative to spray-irrigated effluent was likely related to the higher concentration of organic $\mathrm{N}$ in the upper part of the soil horizon. Data from the solid-soil phase indicated the soil contained $\mathrm{N}$ in mostly organic form and concentrations of organic $\mathrm{N}$ decreased with depth. In addition, soils above the swale draining the flume were affected by deposition of spent mushroom substrate that increased concentrations of organic $\mathrm{N}$ relative to background concentrations. Also, the loss of nitrate $\mathrm{N}$ from the system through denitrification also would help to increase the ratio of organic $\mathrm{N}$ to nitrate $\mathrm{N}$ in discharge water.

Three $\mathrm{N}$-isotope samples were collected at the outlet of the flume during low flow (October 1999, January 2001, and November 2001). The sample collected in October 1999 had a lower $\delta^{15} \mathrm{~N}$ (nitrate) value (7.0\%o) than the other two samples (both equal to $11.8 \%$ ). The increase in $\delta^{15} \mathrm{~N}$ (nitrate) from $7.0 \%$ o to $11.8 \%$ o was likely because of spray-irrigated effluent mixing with water originating from precipitation events. Typical soil processes yield $\delta^{15} \mathrm{~N}$ (nitrate) values of 3-8\%o (Heaton, 1986; Hübner, 1986). The value of $\delta^{15} \mathrm{~N}$ (nitrate) for lysimeter Ch-5448 immediately beneath a spent mushroom substrate zone was $6.4 \%$ (table 36 ). Thus, the $\delta^{15} \mathrm{~N}$ (nitrate) value of $7.0 \%$ for the sample collected at the outlet of the flume in October 1999 was consistent with other data. The increase in $\delta^{15} \mathrm{~N}$ (nitrate) values from October 1999 through 2001 for samples collected at the outlet of the flume was likely caused by the movement of nitrate $\mathrm{N}$ from the spray-irrigated effluent to the flume outlet. The average $\delta^{15} \mathrm{~N}$ (nitrate) value for spray-irrigated effluent was $13.3 \%$. In addition, removal of nitrate $\mathrm{N}$ through denitrification would also cause an increase in $\delta^{15} \mathrm{~N}$ (nitrate) values (Karr and others, 2001).

\section{Underflow}

The estimated loss of $\mathrm{N}$ from the 20-acre subbasin by way of underflow was estimated from September 1999 through December 2001 (table 41). Concentrations of dissolved N from lysimeter nest Lys\#3 and shallow well Ch-5177 were used to estimate the amount of $\mathrm{N}$ leaving the site by way of underflow. Water-level data for shallow well Ch-5177 were not available until September 1999. Water levels for Ch-5177 were used to determine the saturated thickness of the water column down to the depth of competent bedrock. The estimated volume of water lost from the 20-acre subbasin by way of underflow was greatest for the period from April 2000 through August 2000. The average monthly estimated underflow loss from the 20 -acre subbasin from April through August 2000 was 670,000 gal. This underflow loss generally coincided with the highest effluent application rates. The two highest monthly effluent application rates were in May and July 2000 (table 29). The average monthly underflow loss from the 20-acre subbasin for September 1999 through December 2001 was 350,000 gal. The estimated volume of water lost by way of underflow also followed a similar pattern to the loss of water from the 20-acre subbasin by way of discharge through the flume, except for September 1999 when the remnants of Hurricane Floyd caused a large output of storm runoff (fig. 55). The total discharge of water leaving the 20-acre subbasin is the sum of the discharge moving through the flume plus estimated underflow. Only 5 percent of the total flow for September 1999 left the 20-acre subbasin by way of underflow. Estimated underflow accounted for 34 percent of the total flow from September 1999 through December 2001.

Even though approximately 66 percent of total discharge leaving the 20 acre-subbasin from September 1999 through December 2001 was through the flume, the loss of $\mathrm{N}$ by way of underflow was greater than the loss of $\mathrm{N}$ through the flume. The estimated average concentration of dissolved $\mathrm{N}$ in underflow leaving the 20-acre subbasin from September 1999 through 
December 2001 was $12 \mathrm{mg} / \mathrm{L}$. The average concentration of dissolved $\mathrm{N}$ in low-flow and stormflow samples collected at the outlet of the flume was 1.14 and $1.60 \mathrm{mg} / \mathrm{L}$, respectively. Thus, the average estimated concentration of dissolved $\mathrm{N}$ for underflow was about a magnitude higher than the concentrations in samples collected at the outlet of the flume.

Similar to samples collected at the outlet of the flume, there was a decrease over time in the mean estimated concentration of dissolved $\mathrm{N}$ leaving the 20 -acre subbasin by way of underflow (table 41). The mean estimated concentrations of dissolved $\mathrm{N}$ in underflow for water years 2000, 2001, and 2002 were $16,9.6$, and $6.2 \mathrm{mg} / \mathrm{L}$, respectively. The estimated monthly outputs of $\mathrm{N}$ in underflow generally indicated a decrease over time because of the downward trend in the estimated $\mathrm{N}$ concentrations in underflow. The highest 3-month output of $\mathrm{N}$ in underflow occurred from April through June 2000, with $270 \mathrm{lb}$ of $\mathrm{N}$ lost, while the lowest 3-month output occurred from Oct. 2001 through December 2001, when only $44 \mathrm{lb}$ of N was lost. The total amount of dissolved $\mathrm{N}$ leaving the site in underflow from September 1999 through December 2001 was $1,100 \mathrm{lb}$, whereas the total amount of dissolved $\mathrm{N}$ leaving the site through flume was 219 pounds from July 1999 through December 2001.

Nitrate $\mathrm{N}$ was the predominant form of dissolved $\mathrm{N}$ leaving the 20-acre subbasin by way of underflow. Approximately 94 percent of the estimated dissolved $\mathrm{N}$ in underflow leaving the 20-acre subbasin was in the form of nitrate, with the remaining fraction organic $\mathrm{N}$. Nitrate $\mathrm{N}$ accounted for only 41 percent of the dissolved $\mathrm{N}$ leaving the 20 -acre subbasin through the flume (table 40). The much higher fraction of organic $\mathrm{N}$ to dissolved $\mathrm{N}$ in water discharged through the flume was again indicative of the higher concentration of organic $\mathrm{N}$ in the upper soil horizons. The flume captured more water that moved through the upper soil horizons, whereas water leaving the site as underflow was moving through deeper soil horizons that contained less organic materials. This trend of decreasing concentrations of organic $\mathrm{N}$ with an increase in depth was evident in a comparison of samples collected from lysimeter nest Lys\#3.

The most shallow lysimeter in lysimeter nest Lys\#3 was Ch-5219 (table 9). Organic N accounted for approximately 52 percent of the dissolved $\mathrm{N}$ in samples collected from Ch-5219, whereas water samples from the three lysimeters below Ch-5219 in lysimeter nest Lys\#3 had only about 8 percent of dissolved $\mathrm{N}$ in organic form (fig. 44).

\section{Evaluation of the Fate and Transport of Nitrogen}

The fate and transport of $\mathrm{N}$ within the 20-acre subbasin at the New Garden spray-irrigation site was studied from spring 1999 through December 2001. Spray application at the site began in June 1999; thus, processes affecting $\mathrm{N}$ fate and transport prior to spray application at the site were not well documented. Nevertheless, $\mathrm{N}$ inputs, $\mathrm{N}$ outputs, and $\mathrm{N}$ storage compartments of the system were extensively studied and areas of the New Garden site not affected by spray irrigation were used to help understand pre-spray conditions.

- $\mathrm{N}$ inputs to the 20 -acre subbasin during the study period averaged about $190 \mathrm{lb}$ per month; about 91 percent of the $\mathrm{N}$ input was from spray-irrigated effluent and the remaining was from wet and dry deposition (table 42). Approximately 70 percent of the $5,420 \mathrm{lb}$ of N applied from June 1999 through December 2001 was inorganic $\mathrm{N}$ (nitrate, nitrite, and ammonia).

- Measured atmospheric deposition of $\mathrm{N}$ from August 1999 through December 2001 was 490 lb; 78 percent was deposited during precipitation events. The forms of $\mathrm{N}$ in atmospheric deposition were almost equally distributed between nitrate $\mathrm{N}$ (36 percent), organic $\mathrm{N}$ (33 percent), and ammonia $\mathrm{N}$ (30 percent). Inputs from precipitation were distributed relatively evenly throughout the year; spray-irrigation inputs were highest during the growing season (75 percent of the sprayirrigated effluent was applied from April through September). It was assumed that $\mathrm{N}$ fixation by microorganisms was zero over the course of the study.

- N outputs from the 20-acre subbasin during the study period averaged about $190 \mathrm{lb}$ per month (table 42). The primary $\mathrm{N}$ output component was plant harvest. Plant harvesting removed about 4,560 lb of $\mathrm{N}$ during the three growing seasons from 1999 to 2001 or about 77 percent of the total $\mathrm{N}$ output during the study period. Similar to spray-irrigation inputs, the removal of $\mathrm{N}$ through plant harvest was highest during the growing season. These data indicated the importance of plant harvesting at spray-irrigation sites.

- $\mathrm{N}$ output from underflow accounted for about 18 percent of the total $\mathrm{N}$ output from the 20 -acre subbasin (table 42). Approximately 94 percent of the dissolved $\mathrm{N}$ leaving the 20 -acre subbasin in underflow was in the form of nitrate with the remaining fraction organic $\mathrm{N}$. The average estimated monthly output of dissolved $\mathrm{N}$ in underflow was $38 \mathrm{lb}$. During the study period, the monthly amounts of $\mathrm{N}$ lost by way of underflow decreased, primarily because of decreased concentrations of dissolved $\mathrm{N}$ in the water column above competent bedrock at the base of the 20 -acre subbasin.

- $\mathrm{N}$ output from water discharging through the flume accounted for about 4 percent of the total $\mathrm{N}$ output from the 20 -acre subbasin. This discharge was a combination of overland and subsurface flow. Overland flow during storm events occurred infrequently. Generally, precipitation events increased soil moisture, with subsurface water being displaced downgradient to a discharge location (the swale) at the bottom of the 20-acre subbasin. Water discharging from the 20 -acre subbasin during non-storm events occurred over most of the study period. Fifty-two percent of the $\mathrm{N}$ in water discharged through the flume was during storm events. 
Table 41. Monthly estimates of the mass of dissolved $\mathrm{N}$ leaving the 20 -acre subbasin as underflow, the weighted $\mathrm{N}$ concentration for the saturated water column above competent bedrock, and the estimated volume of underflow leaving the 20-acre subbasin, New Garden Township spray-irrigation site, Chester County, Pennsylvania, September 1999 through December 2001.

[mg/L, milligrams per liter; --, not applicable]

\begin{tabular}{|c|c|c|c|}
\hline Date & $\begin{array}{l}\text { Nitrogen mass } \\
\text { (pounds) }\end{array}$ & $\begin{array}{c}\text { Weighted N } \\
\text { concentration } \\
\text { (mg/L) }\end{array}$ & $\begin{array}{c}\text { Underflow } \\
\text { (gallons) }\end{array}$ \\
\hline Sept. 1999 & 14 & 17 & 98,000 \\
\hline Oct. 1999 & 36 & 15 & 280,000 \\
\hline Nov. 1999 & 36 & 15 & 290,000 \\
\hline Dec. 1999 & 43 & 15 & 350,000 \\
\hline Jan. 2000 & 38 & 16 & 290,000 \\
\hline Feb. 2000 & 29 & 15 & 230,000 \\
\hline Mar. 2000 & 39 & 16 & 300,000 \\
\hline Apr. 2000 & 93 & 17 & 660,000 \\
\hline May 2000 & 110 & 16 & 820,000 \\
\hline June 2000 & 70 & 17 & 510,000 \\
\hline July 2000 & 92 & 16 & 680,000 \\
\hline Aug. 2000 & 95 & 16 & 710,000 \\
\hline Sept. 2000 & 42 & 15 & 330,000 \\
\hline Oct. 2000 & 68 & 14 & 570,000 \\
\hline Nov. 2000 & 33 & 12 & 320,000 \\
\hline Dec. 2000 & 14 & 12 & 150,000 \\
\hline Jan. 2001 & 11 & 11 & 110,000 \\
\hline Feb. 2001 & 19 & 9.8 & 240,000 \\
\hline Mar. 2001 & 19 & 9.3 & 250,000 \\
\hline Apr. 2001 & 21 & 8.7 & 290,000 \\
\hline May 2001 & 13 & 6.7 & 230,000 \\
\hline June 2001 & 32 & 8.1 & 480,000 \\
\hline July 2001 & 19 & 8.3 & 270,000 \\
\hline Aug. 2001 & 17 & 7.5 & 270,000 \\
\hline Sept. 2001 & 12 & 6.6 & 210,000 \\
\hline Oct. 2001 & 21 & 6.6 & 390,000 \\
\hline Nov. 2001 & 11 & 6.0 & 220,000 \\
\hline Dec. 2001 & 12 & 6.0 & 240,000 \\
\hline Total $^{1}$ & 1,100 & -- & $9,800,000$ \\
\hline
\end{tabular}

\footnotetext{
${ }^{1}$ Columns may not sum to total because of rounding.
} 
Table 42. Summary of inorganic and organic nitrogen inputs and outputs for the 20-acre subbasin, New Garden Township spray-irrigation site, Chester County, Pennsylvania, April 1999 through December 2001.

$[\mathrm{N}$, nitrogen; NA, not available; E, estimated]

\begin{tabular}{|c|c|c|c|c|c|c|c|c|c|}
\hline \multirow{3}{*}{ Date } & \multicolumn{4}{|c|}{ Inputs (pounds) } & \multicolumn{3}{|c|}{ Outputs (pounds) ${ }^{1}$} & \multirow{2}{*}{\multicolumn{2}{|c|}{ Underflow ${ }^{2}$}} \\
\hline & \multicolumn{2}{|c|}{ Deposition $^{3}$} & \multicolumn{2}{|c|}{ Effluent $^{4}$} & \multirow{2}{*}{$\begin{array}{c}\begin{array}{c}\text { Plant } \\
\text { harvest }^{5}\end{array} \\
\text { Organic N }\end{array}$} & \multicolumn{2}{|c|}{ Water discharge $^{6}$} & & \\
\hline & Inorganic N & Organic $\mathbf{N}$ & Inorganic N & Organic $\mathbf{N}$ & & Inorganic $\mathbf{N}$ & Organic N & $\begin{array}{c}\text { Inorganic } \\
\mathbf{N}\end{array}$ & Organic N \\
\hline Apr.-June 1999 & NA & NA & E246 & E35.0 & 410 & NA & NA & NA & NA \\
\hline Oct.-Dec. 1999 & 14 & 20 & 454 & 200 & 440 & 9.14 & 16.18 & 110 & 3.2 \\
\hline Jan.-Mar. 2000 & 57 & 21 & 365 & 69.8 & 0 & 26.59 & 27.34 & 100 & 3.4 \\
\hline Apr.-June 2000 & 44 & 28 & 654 & 177 & 410 & 6.57 & 22.97 & 260 & 9.5 \\
\hline July-Sept. 2000 & 37 & 19 & 309 & 376 & 890 & 5.90 & 22.39 & 220 & 4.9 \\
\hline July-Sept. 2001 & 41 & 16 & 239 & 276 & 1,320 & 3.06 & 7.12 & 41 & 6.6 \\
\hline Oct.-Dec. 2001 & 7.8 & 2.4 & 49.2 & 45.7 & 0 & 14.29 & 19.09 & 39 & 5.5 \\
\hline Totals $^{\top}$ & 330 & 160 & 3,860 & 1,560 & 4,560 & 108 & 143 & 1,000 & 51 \\
\hline
\end{tabular}

\footnotetext{
${ }^{1}$ Ammonia volatilization losses of $\mathrm{N}$ from July 1999 through December 2001 were estimated to be 12-122 pounds; losses occurred from April through October of each year.

${ }^{2}$ Underflow estimates for $\mathrm{N}$ output were available from Sept. 1999 through Dec. 2001

${ }^{3}$ Data collection for atmospheric deposition began in August 1999.

${ }^{4}$ Data collection for effluent input began in June 1999.

${ }^{5}$ First plant harvest was in May 1999.

${ }^{6}$ Data collection at flume outlet began in late June 1999; therefore, the first complete month of data collection was July 1999.

${ }^{7}$ Columns may not sum to totals because of rounding.
}

The predominant forms of $\mathrm{N}$ lost in water discharge were organic and nitrate $\mathrm{N}$ (57 and 36 percent of the total $\mathrm{N}$ loss in water discharge, respectively).

- Ammonia volatilization was not found to have an appreciable effect on the $\mathrm{N}$ budget for the 20-acre subbasin. Ammonia volatilization only occurred during the growing season, and $\mathrm{N}$ losses by this mechanism were estimated to be about 1 percent of the total $\mathrm{N}$ output.

- $\mathrm{N}$ storage in the 20-acre subbasin is summarized in table 43 . $\mathrm{N}$ stored in the solid-soil phase was the predominant form of $\mathrm{N}$ in the 20 -acre subbasin. The average amount of $\mathrm{N}$ in the solid-soil phase over the entire 20-acre subbasin for soil depths of $0-4 \mathrm{ft}$ was $170,000 \mathrm{lb}$. It was estimated that at least another $120,000 \mathrm{lb}$ of $\mathrm{N}$ were in the solid-soil phase below $4 \mathrm{ft}$ to competent bedrock. Approximately 98-99 percent of $\mathrm{N}$ in the $0-4 \mathrm{ft}$ depth interval was in organic form, which becomes available to plants after mineralization to nitrate $\mathrm{N}$ and ammonium $\mathrm{N}$, but only at a rate of 23 percent per year. The mass of available forms of $\mathrm{N}$ increased with depth, which is reflective of plant uptake of $\mathrm{N}$ from soils in the root zone.

- The plant-available (inorganic) mass of $\mathrm{N}$ in the solidsoil phase increased from spring 1999 to fall 2001 (table 43). The mass of $\mathrm{N}$ as ammonium increased from approximately $700 \mathrm{lb}$ in spring 1999 to $1,600 \mathrm{lb}$ in fall 2001 (at depths of 0-4 ft). Concentrations of nitrate ions in the solid-soil phase basically indicated no change over the same period. Unlike nitrate, which is transported through the soil system relatively rapidly, ammonium ions are retained in the soil. The large increase from 1999 to 2001 is more than the amount of ammonium added to the system from spray-irrigated effluent. Mineralization of organic $\mathrm{N}$ could also help to increase concentrations of ammonium $\mathrm{N}$ in the solidsoil phase.

- Variability in concentrations of total $\mathrm{N}$ in the solid-soil phase were likely because of an insufficient number of discrete soil samples submitted for chemical analyses and subsampling techniques at the soils laboratory. 
Table 43. Summary of inorganic and organic nitrogen storage for the 20-acre subbasin, New Garden Township spray-irrigation site, Chester County, Pennsylvania, April 1999 through December 2001.

[N, nitrogen; NA, not available]

\begin{tabular}{|c|c|c|c|c|c|c|}
\hline \multirow[t]{2}{*}{ Date } & \multicolumn{2}{|c|}{$\begin{array}{l}\text { Solid soil } \\
\text { (0-4 feet) } \\
\text { (pounds) }\end{array}$} & \multicolumn{2}{|c|}{$\begin{array}{l}\text { Soil water } \\
\text { (pounds) }^{2}\end{array}$} & \multicolumn{2}{|c|}{$\begin{array}{l}\text { Ground water } \\
\text { (pounds) })^{3}\end{array}$} \\
\hline & Inorganic N & Organic $\mathbf{N}$ & Inorganic N & Organic $\mathbf{N}$ & Inorganic N & Organic $\mathbf{N}$ \\
\hline Apr.-June 1999 & 2,200 & 190,000 & NA & NA & 1,600 & 680 \\
\hline July-Sept. 1999 & 2,100 & 160,000 & 1,900 & 210 & 1,600 & 430 \\
\hline Oct.-Dec. 1999 & 1,700 & 270,000 & 1,200 & 92 & 1,700 & 220 \\
\hline Jan.-Mar. 2000 & NA & NA & 2,000 & 120 & 1,800 & 190 \\
\hline Apr.-June 2000 & 2,000 & 160,000 & 1,400 & 270 & 1,900 & 180 \\
\hline July-Sept. 2000 & NA & NA & 940 & 130 & 1,800 & 140 \\
\hline Oct.-Dec. 2000 & 1,500 & 140,000 & 920 & 110 & 1,500 & 140 \\
\hline Jan.-Mar. 2001 & NA & NA & 960 & 130 & 1,200 & 110 \\
\hline Apr.-June 2001 & 2,100 & 72,000 & 680 & 120 & 1,000 & 210 \\
\hline July-Sept. 2001 & NA & NA & NA & NA & 1,000 & 200 \\
\hline Oct.-Dec. 2001 & 3,000 & 170,000 & NA & NA & 990 & 430 \\
\hline
\end{tabular}

${ }^{1}$ The solid soil was sampled to a depth of 4 feet. It was estimated that below 4 feet to competent bedrock, the total mass of $\mathrm{N}$ in the 20 -acre subbasin was from 120,000 to 240,000 pounds.

${ }^{2}$ Soil-water storage values are averages for the particular time period. Suction-lysimeter data were collected from June 1999 through December 2001; however, soil-moisture data were available only from September 1999 through June 2001.The mass of N in soil water was estimated from the land surface to the mean water-table altitude below the lysimeter nest, or, if the lysimeter nest was completed below the water table, the $\mathrm{N}$ mass was estimated to the bottom of the lysimeter nest.

${ }^{3}$ Ground-water storage values are averages for the particular time period. Data are presented from June 1999 through December 2001.The mass of $\mathrm{N}$ in ground water was estimated from the top of the water table to the depth of competent bedrock; however, if the lysimeter nest was lower in altitude than the mean water level, the $\mathrm{N}$ mass estimated in ground water was from the bottom of the lysimeter nest to the depth of competent bedrock.

Each field was sampled intensively, but composited samples were submitted to the soils laboratory for analyses. From these composited samples ( $250 \mathrm{~g}$ samples), the soil laboratory retrieved approximately $1 \mathrm{~g}$ for analysis. Replicates were submitted to the laboratory and these indicated variability between replicates of 22 percent for total-N analyses (table 12).

- $\mathrm{N}$ stored in the soil water and shallow ground water substantially decreased over the study period in the 20 -acre subbasin. Direct comparisons are difficult because of the different time intervals of sample collection for both compartments; however, starting and ending values for both compartments indicated reductions in the mass of stored $\mathrm{N}$ of 60 and 40 percent, respectively, for soil water and ground water. The primary form of $\mathrm{N}$ in soil water and ground water within the 20-acre subbasin was nitrate. Approximately 86-87 percent of $\mathrm{N}$ in soil water and ground water to the depth of competent bedrock was in the form of nitrate $\mathrm{N}$; the remaining part was primarily organic $\mathrm{N}$. The reduction in $\mathrm{N}$ storage for ground water was par- tially attributed to the decreased nitrate- $\mathrm{N}$ concentration for the shallow well at the bottom of the 20-acre subbasin. Water samples from this well had elevated nitrate- $\mathrm{N}$ concentrations caused by spent mushroom substrate. Application of spray-irrigated effluent helped to flush this nitrate out of the system.

The $\mathrm{N}$ budget equation given earlier is

$$
\begin{gathered}
\mathrm{N}_{(\text {atm })}+\mathrm{N}_{(\text {spray })}=\mathrm{N}_{(\text {vol })}+\mathrm{N}_{(p l t)}+\mathrm{N}_{(f l o w)}+\mathrm{N}_{(\text {und })}+\Delta \mathrm{N}_{(\text {soil })} \\
+\Delta \mathrm{N}_{(s w)}+\Delta \mathrm{N}_{(g w)} .
\end{gathered}
$$

In order to use this equation, some manipulation of data presented in tables 42 and 43 was required:

- The total amount of measured atmospheric $\mathrm{N}$ deposited on the 20-acre subbasin was $490 \mathrm{lb}$. If the average monthly rate of deposition is added to this number to account for data gaps, then about $580 \mathrm{lb}$ was deposited to the 20-acre subbasin from June 1999 through December 2001. 


\section{Effects of Spray-Irrigated Effluent on Water Quantity and Quality, and the Fate and Transport of Nitrogen}

- The estimated range of $\mathrm{N}$ loss from the 20-acre subbasin through ammonia volatilization was from 12 to $120 \mathrm{lb}$ from 1999 through 2001. For the $\mathrm{N}$ budget calculation, it was assumed that $60 \mathrm{lb}$ of $\mathrm{N}$ were lost through volatilization.

- Only the inorganic fraction of the solid-soil phase was used to estimate the change is soil N. It was assumed that the organic $\mathrm{N}$ fraction did not change.

- The earliest and latest available storage values for the soil water and ground water (table 43) were used to compute change in storage for these compartments.

Given the components listed above, the N-budget equation for the 20-acre subbasin from June 1999 through December 2001 is

$$
\begin{gathered}
\mathrm{N}_{(\text {atm })}(580)+\mathrm{N}_{(\text {spray })}(5,420)+\Delta \mathrm{N}_{(\text {soil })}(-800)+\Delta \mathrm{N}_{(\text {sw })} \\
(+1,310)+\Delta \mathrm{N}_{(\text {gw })}(+860)= \\
\mathrm{N}_{(\text {vol })}(60)+\mathrm{N}_{(\text {plt })}(4,560)+\mathrm{N}_{(\text {flow })}(250)+\mathrm{N}_{(\text {und })}(1,060) .
\end{gathered}
$$

Based on the estimates for the individual components of the nitrogen budget, the amount of nitrogen input and released from storage exceeded the amount of nitrogen lost from the basin by $1,440 \mathrm{lb}$. This imbalance results from overestimating the inputs or underestimating outputs (or a combination of both) and reflects the difficulty in accurately quantifying all terms in the nitrogen budget. If the change in storage terms are removed from the mass balance equation, the net input exceeds the net output by $70 \mathrm{lb}$. The loss of $\mathrm{N}$ was most evident in the soil-water and shallow ground-water storage compartments. The reduced mass of $\mathrm{N}$ in soil water and shallow ground water during the study period could be caused by either denitrification, conversion of $\mathrm{N}$ in soil water to insoluble $\mathrm{N}$ in the solid-soil phase, or displacement of the soil water and ground water with water less concentrated with $\mathrm{N}$. It is likely that some $\mathrm{N}$ lost from the system was through denitrification. On the basis of nitrate-N to $\mathrm{Cl}$ ratios, $\mathrm{N}$-isotope data, and redox potentials, it appeared denitrification was occurring. Spray irrigation could promote denitrification by saturating the soils and, thus, increasing the anoxic conditions in the soil system. Conversion of soluble forms of $\mathrm{N}$ to insoluble forms of $\mathrm{N}$ would cause a decrease in concentrations of $\mathrm{N}$ in soil water and increase concentrations of $\mathrm{N}$ in the solid-soil phase. This conversion was evident in the decrease of $\mathrm{N}$ in soil water $(1,310 \mathrm{lb})$ and the increase of $\mathrm{N}$ in the solid-soil phase $(800 \mathrm{lb})$ during the study period. Another factor that affected the $\mathrm{N}$ budget was the presence of spent mushroom substrate in the 20-acre subbasin. Application of spray-irrigated effluent displaced the high nitrate water at the bottom of the 20acre subbasin out of the system during the study period. The displaced water was transported away from the 20 -acre subbasin either through underflow or discharge through the flume.
The maximum permitted application rates at the New Garden Township spray-irrigation site generally were based on hydraulic loads. Maximum permitted N loads from spray-irrigated effluent were based on the maximum hydraulic load and an assumed total-N concentration of $20 \mathrm{mg} / \mathrm{L}$. For this site and permit, the total-N concentration only included inorganic forms of N. Most permits for spray-application sites in Pennsylvania define total $\mathrm{N}$ as both inorganic and organic forms. From June 1999 through December 2001, the theoretical maximum $N$ load for the 20-acre subbasin was approximately 13,000 lb (of inorganic $\mathrm{N}$ ). The actual $\mathrm{N}$ applied to the system during this same period was 3,860 lb of inorganic $\mathrm{N}$ and 1,560 of organic $\mathrm{N}$. Thus, the maximum $\mathrm{N}$ load was not realized, which was expected, especially because the average inorganic-N concentration of spray-irrigated effluent during the study period was $8.2 \mathrm{mg} / \mathrm{L}$ (11.8 mg/L for both inorganic and organic $\mathrm{N})$. Also, the actual volume of effluent applied to the 20 -acre subbasin from June 1999 through December 2001 was approximately 56 Mgal. This volume was 70 percent of the allowable maximum volume.

The spray site was designed so that some $\mathrm{N}$ applied during spray application would be taken up by orchardgrass. As stated earlier, the site was predominantly orchardgrass, but numerous other species were present. An economical N application rate for orchardgrass is $150 \mathrm{lb} /$ acre (Hall, 2000). Over 20 acres and three growing seasons, this would amount to 9,000 lb of N. The amount of $\mathrm{N}$ removed from plant harvest during the three growing seasons of 1999-2001 was 4,560 lb. This exceeded the amount of inorganic $\mathrm{N}$ applied through spray-irrigated effluent by $700 \mathrm{lb}$. $\mathrm{N}$ input from atmospheric deposition and storage of $\mathrm{N}$ in the upper parts of the soil matrix supplied additional inorganic $\mathrm{N}$ to the plants.

$\mathrm{N}$ fate and transport indicated that spray irrigation did not cause increased loss of $\mathrm{N}$ in water discharging from the 20 -acre subbasin from June 1999 through December 2001. That is, no increasing trend in $\mathrm{N}$ losses from the 20 -acre subbasin was apparent during the study period. There was also no net increase in the storage of inorganic $\mathrm{N}$ in subsurface compartments. Approximately 30 percent of the permitted maximum inorganic $\mathrm{N}$ load was applied to the 20-acre subbasin from June 1999 through December 2001. Plant uptake of $\mathrm{N}$ was the primary factor in minimizing the loss of $\mathrm{N}$ from the 20 -acre subbasin. Study results indicated that spray irrigation at the New Garden site was a better method of removing wastewater from the treatment facility than discharging the water directly to a surface-water source. 


\section{Summary}

The U.S. Geological Survey (USGS), in cooperation with the Pennsylvania Department of Environmental Protection, Chester County Water Resources Authority, and the New Garden Township Sewer Authority, conducted a study from October 1997 through December 2001 to assess the effects of spray irrigating secondary treated sewage effluent on a small watershed in New Garden Township, Chester County, Pa. The study determined the effects the spray-irrigated effluent had on ground-water and surface-water quantity and quality of the small watershed and assessed the fate and transport of $\mathrm{N}$. Annual and monthly water budgets were determined and $\mathrm{N}$ loading fate and transport were tracked. In the annual and monthly water budgets, evapotranspiration and recharge estimates were determined and evaluated.

Annual water budgets for the study watershed and Red Clay Creek watershed above the USGS streamflow-gaging station (01479820) near Kennett Square, Pa., were calculated to determine if the Red Clay Creek watershed could serve as a control watershed or a watershed not affected by the spray application. Annual water budgets for the study watershed and the Red Clay Creek watershed were determined for a period prior to effluent application, May 1998 through April 1999. Evapotranspiration in the study watershed totaled 24.8 in., which accounted for 70 percent of precipitation.

Evapotranspiration in the Red Clay Creek watershed totaled 24.2 in., which accounted for 68 percent of precipitation.

Because the evapotranspiration totals of the two watersheds were comparable for the period prior to effluent application, it was assumed that the Red Clay Creek watershed could serve as an unaffected control watershed.

Annual water budgets for the study watershed and the Red Clay Creek watershed were determined for two years 2000 and 2001 during effluent application. In the study watershed, evapotranspiration totaled 32.9 in. in 2000 and 32.5 in. in 2001, which accounted for 50 and 64 percent of precipitation and applied effluent, respectively. In the Red Clay Creek watershed, evapotranspiration totaled 23.6 in. in 2000 and 24.3 in. in 2001, which accounted for 55 and 67 percent of precipitation, respectively.

On an annual basis, the spray irrigation increased the recharge to the watershed. Annual recharge estimates for Red Clay Creek watershed above the USGS streamflow-gaging station (01479820) near Kennett Square in 2000 and 2001 totaled 12.5 and 6.6 in., respectively. Annual recharge estimates for the study watershed in 2000 and 2001 totaled 21.3 and 10.9 in. Compared to the annual recharge estimates for the Red Clay Creek near Kennett Square, the spray irrigation increased annual recharge in the study watershed by approximately 8.8 in. in 2000 and 4.3 in. in 2001. The 8.8-in. increase in 2000 represented a 70-percent increase in recharge in the study watershed above that of the Red Clay Creek watershed. The 8.8-in. increase in recharge for 2000 represented 39 percent of the annual applied effluent, which totaled 22.5 in. The 4.3-in. increase in 2001 represents a 65-percent increase in recharge above that of the Red Clay Creek watershed. The 4.3-in. increase in recharge for 2001 represented 30 percent of the annual applied effluent, which totaled $14.4 \mathrm{in}$. Over a 2-year period, the spray irrigation increased recharge 65-70 percent above Red Clay Creek watershed, and the increased recharge equaled 30-39 percent of the applied effluent.

A method was developed to determine a monthly water budget. The monthly water budget differed from an annual water budget with the addition of estimating the monthly change in soil-moisture storage in the study watershed. To serve as a check of the monthly water-budget method, the calculated monthly evapotranspiration values were compared to monthly total crop-referenced evapotranspiration values that were calculated by the modified Penman-Monteith equation, where meteorological parameters measured on the application field are used. It was assumed that the calculated values of monthly evapotranspiration from the monthly water-budget equation would represent actual evapotranspiration from the watershed and crop-referenced evapotranspiration would represent potential evapotranspiration. However, the calculated evapotranspiration values, which were assumed to be actual evapotranspiration, also included the accumulation of errors in measuring, estimating, or determining all coefficients in the monthly waterbudget equation. The largest errors were in the determination of the volume of water stored in the unsaturated zone because of the numerous estimations and assumptions used in the development of the determination. In 12 of 28 months, the calculated evapotranspiration was within \pm 25 percent of the crop-referenced evapotranspiration.

The developed monthly water-budget method was less reliable during months when extreme climatic conditions occurred because of the temporal limitations of the data analysis. All analyses, particularly estimates of changes in groundwater and soil-moisture storage, were calculated using data measured on the first day of the month. The effects of previous monthly antecedent conditions, such as snowfall or large amounts of rainfall that occur near the end of the previous month, manifest in the following month but are not properly accounted for in this method. Snowfall that occurs during a month but does not melt until the end of the month or the following month have adverse effects on the estimates of monthly soil-moisture storage. Because of the combination of errors and the temporal limitations of the data analysis, some negative monthly evapotranspiration values were calculated. The negative calculated evapotranspiration for February 2001 resulted from a snow event on Feb. 22 and a rainfall event on Feb. 25 that dramatically increased the measured percent soil moisture at the end of the month. The high measured percent soil moisture at the end of the month combined with the receding water table caused an overestimate of soil-moisture storage for February 2001. The increased soil-moisture storage was because of climatic events that occurred during the month.

In order to possibly lessen the temporal climatic variability, which occurs on a monthly basis, the values of monthly calculated and crop-referenced evapotranspiration were summed 
over calendar years 2000 and 2001. For calendar year 2000, the cumulative calculated evapotranspiration was 32.4 in. and the crop-referenced evapotranspiration was $30.7 \mathrm{in}$., which is a difference of 5.5 percent. For calendar year 2001, the cumulative calculated evapotranspiration was $33.7 \mathrm{in}$. and the crop-referenced evapotranspiration was $31.5 \mathrm{in}$., which is a difference of 6.8 percent. Therefore, the developed method and results may be better applied on a cumulative annual basis when evaluating evapotranspiration.

On a monthly basis from September 1999 through December 2001, recharge estimates equalled or exceeded 3.5 in. per month for September 1999, March, April, May, and July 2000, and June 2001. In southeastern Pennsylvania, recharge rates typically are higher in the spring months of March, April, and May, when evapotranspiration rates are low and percent soil moisture in the unsaturated zone is high. The elevated recharge rates for July 2000 and June 2001 (when compared to other monthly rates) were the result of the spray-irrigated effluent. Precipitation and applied effluent for July 2000 totaled 8.7 in. and for June 2001 totaled $7.7 \mathrm{in}$., which are nearly double the 30-year precipitation normals for those months. However, high monthly volumes of applied effluent did not always relate directly to increased monthly recharge. For September 2001, precipitation totaled $4.91 \mathrm{in}$. and applied effluent totaled $1.91 \mathrm{in}$. Although the September 2001 precipitation total was above normal, $4.35 \mathrm{in}$. of the total monthly precipitation fell in just 3 days, which was probably too short a duration to sufficiently increase soil moisture and allow recharge. Recharge depends on the antecedent soil moisture and the volume and timing of applied effluent with respect to the timing of precipitation events. For this reason, the actual amount of spray-irrigated effluent that recharges the ground-water system is difficult to quantify.

The spray-irrigated effluent is increasing base flow in the watershed. The magnitude of the increase appears to be related to the time of year when the application rates are increased. During the late fall through winter and into the early spring period, when application rates were low, base flow increased by approximately 50 percent over the period prior to effluent application. During the early spring through summer to the late fall period, when application rates are high, base flow increased by approximately 200 percent from the period prior to effluent application.

Spray-irrigated effluent affected the water quality of the shallow aquifer on the hilltop application area and on the eastern hillside application areas where the underlying unconsolidated sands have a low clay content. Concentrations of nitrate $\mathrm{N}$ and $\mathrm{Cl}$ increased in water from hilltop wells Ch-5173 and Ch-5180; these wells are completed in the western and eastern application areas, respectively. Median concentrations of nitrate $\mathrm{N}$ and $\mathrm{Cl}$ in water collected from well Ch-5173 prior to effluent application were $0.23 \mathrm{mg} / \mathrm{L}$ (milligrams per liter) and $1.6 \mathrm{mg} / \mathrm{L}$, respectively. Median application period concentrations of nitrate $\mathrm{N}$ and $\mathrm{Cl}$ in water from well $\mathrm{Ch}-5173$ were $0.50 \mathrm{mg} / \mathrm{L}$ and $2.5 \mathrm{mg} / \mathrm{L}$, respectively. No samples were collected from well Ch-5180 prior to effluent application because the well was dry until after application began. Significantly increasing trends in concentrations of nitrate $\mathrm{N}$ and $\mathrm{Cl}$ were seen in water from wells Ch-5173 and Ch-5180. Concentrations of nitrate $\mathrm{N}$ and $\mathrm{Cl}$ increased in water from hillside well Ch-5179, which is completed in the shallow aquifer underlying the eastern application area. Median concentrations of nitrate $\mathrm{N}$ and $\mathrm{Cl}$ in water collected from well $\mathrm{Ch}-5179$ prior to effluent application were $0.66 \mathrm{mg} / \mathrm{L}$ and $0.80 \mathrm{mg} / \mathrm{L}$, respectively. Median application period concentrations of nitrate $\mathrm{N}$ and $\mathrm{Cl}$ in water from well Ch-5179 were $1.7 \mathrm{mg} / \mathrm{L}$ and $36 \mathrm{mg} / \mathrm{L}$, respectively.

The magnitude of change in water-quality concentrations between the periods prior to and during effluent application for certain constituents was associated with the thickness of the shallow aquifer. The thickness of the shallow aquifer in the eastern part of the application area ranged from 32 to $39 \mathrm{ft}$ thick and in the western part ranged from 57 to $62 \mathrm{ft}$ thick. Wells Ch-5180 and Ch-5179 were in the eastern application area, and concentrations of calcium, magnesium, sodium, and potassium increased in water from these wells during the application period. Concentrations of calcium, magnesium, sodium, and potassium did not increase in water from well Ch-5173, which indicated increasing nitrate $\mathrm{N}$ and $\mathrm{Cl}$ concentrations during the application period. The thicker sands probably correspond to greater volumes of stored water, and the water in the western application area may not be as well mixed as in the eastern application area where the sands are thinner and lesser amounts of water are stored.

On the hillside western part of the application area, the underlying unconsolidated material was thick and had a high clay content, the ground-water quality did not show any effects from the spray-irrigated effluent. The spray-irrigated effluent did affect the water in well Ch-5177, which was in the valley bottom downgradient and outside the application area. The spray-irrigated effluent did not increase nitrate $\mathrm{N}$ concentrations in water from well Ch-5177 but actually decreased nitrate $\mathrm{N}$ concentrations. The increased hydraulic loading with sprayirrigated effluent, which had lower concentrations of nitrate $\mathrm{N}$ $(<15 \mathrm{mg} / \mathrm{L}$ ) than the shallow ground water (concentrations as high as $24 \mathrm{mg} / \mathrm{L}$ ), flushed the higher nitrate $\mathrm{N}$ concentrated water from the valley bottom near well Ch-5177. Also, $\mathrm{Cl}$ concentration in water from valley bottom well Ch-5177 increased, which was probably the result of the breakthrough of $\mathrm{Cl}$ from the spray-irrigated effluent.

Spray-irrigated effluent affected the water quality of the bedrock aquifer on the hilltop application area and in the valley bottom. On the hilltop application area, concentrations of $\mathrm{Cl}$ and nitrate $\mathrm{N}$ increased in water from well $\mathrm{Ch}-5172$, perhaps because the downward vertical head (water-level) difference is greatest on the hilltop when compared to other areas in the watershed. The vertical head difference on the hilltop averaged approximately $9 \mathrm{ft}$, and the vertical head difference on the hillside averaged approximately $3 \mathrm{ft}$ throughout the study period. Concentrations of $\mathrm{Cl}$ and nitrate $\mathrm{N}$ increased in water from well Ch-5172, which is on the hilltop. Although the water quality in the hillside bedrock wells did not show any effects from the 
spray irrigation, because of the downward vertical head differences on the hillsides and the water quality of the overlying shallow aquifer, which does show affects from the spray irrigation, the water quality of the bedrock aquifer on the hillsides likely will be affected by the spray-irrigated effluent in the future. In the valley bottom, the spray-irrigated effluent had an opposite effect on bedrock ground water. Concentrations of nitrate $\mathrm{N}, \mathrm{Cl}$, and sodium were trending downward in water from bedrock well $\mathrm{Ch}-5176$. The decreasing trends in these constituents perhaps is because of the increased hydraulic loading which would dilute the in-situ ground water.

Although nitrate levels increased in wells on the application area, the concentrations were below the effluent concentration levels. The median concentration of nitrate $\mathrm{N}$ in the applied effluent was $5.8 \mathrm{mg} / \mathrm{L}$. A combination of plant uptake, biological activity, and denitrification may be the processes accounting for the nitrate- $\mathrm{N}$ concentrations in shallow ground water being lower than in the effluent. $\mathrm{Cl}$ concentrations in shallow ground water in the eastern application area approached the median effluent input $\mathrm{Cl}$ concentrations. The median $\mathrm{Cl}$ concentration of the effluent was $90 \mathrm{mg} / \mathrm{L}$. The $\mathrm{Cl}$ concentrations in water from wells Ch-5180 and Ch-5179 were 74 and $61 \mathrm{mg} / \mathrm{L}$ in samples collected in December 2001, which was when data collection ended. $\mathrm{Cl}$ concentrations in water from hilltop western application area well Ch-5173 increased but were an order of magnitude less than the input effluent concentration. The $\mathrm{Cl}$ concentration in water from a sample collected in December 2001 was $7.6 \mathrm{mg} / \mathrm{L}$.

As of the end of this investigation in December 2001, the water quality of the pond or the stream base flow leaving the watershed was not affected by the spray-irrigated effluent with respect to concentrations of nutrients or other chemical constituents. Stormflow or loads were not assessed. However, because the shallow aquifer under the application area and in the valley bottom was affected, the water quality of the pond and stream base flow will most likely be affected in the future, but the timing could not be determined in this investigation.

The effects of effluent application on $\mathrm{N}$ fate and transport were studied in a 20-acre subbasin within the small watershed. Effluent application of 5,420 lb of $\mathrm{N}(3,840 \mathrm{lb}$ of inorganic and $1,580 \mathrm{lb}$ of organic N) from June 1999 through December 2001 did not increase $\mathrm{N}$ losses in water discharging from the 20 -acre subbasin. $\mathrm{N}$ is lost from the system through plant harvest, discharge of water from the 20 -acre subbasin, and ammonia volatilization during spray-effluent application. The storage of inorganic $\mathrm{N}$ in subsurface compartments did not increase during this same period.

Inputs to the 20-acre subbasin during the study period averaged about $190 \mathrm{lb}$ per month; about 91 percent was from spray-irrigated effluent and the remaining was from atmospheric deposition. The predominant forms of $\mathrm{N}$ in applied effluent were nitrate $\mathrm{N}$ ( 52 percent), organic $\mathrm{N}$ ( 28 percent), and ammonia $\mathrm{N}$ (14 percent). Measured $\mathrm{N}$ input from atmospheric deposition was $490 \mathrm{lb}$ from August 1999 through December 2001; 78 percent was during precipitation events. Spray-irrigation inputs were highest during the growing season (75 percent of the spray was applied from April through September). Regulatory limits on spray irrigation during the winter months limited the potential for application during the winter. Monthly $\mathrm{N}$ inputs from spray-irrigated effluent were markedly less after April 2000. Eleven months into the 31-month field study (spray irrigation was monitored from June 1999 through December 2001), 50 percent of the total $\mathrm{N}$ load from spray-irrigated effluent had already been applied to the system.

The primary $\mathrm{N}$ output from the 20 -acre subbasin was from plant harvesting. Plant harvesting removed about 4,560 lb of $\mathrm{N}$ during the three growing seasons from 1999 to 2001. This amount was about 77 percent of the total $\mathrm{N}$ output during the study period. Seventy-five percent of the effluent (about $4,100 \mathrm{lb}$ of $\mathrm{N}$ or $2,900 \mathrm{lb}$ of inorganic $\mathrm{N}$ ) was applied from April through September. Assuming that only the inorganic-N portion of the applied effluent was available to plants, the additional $\mathrm{N}$ taken up by plants was from the storage of $\mathrm{N}$ in the soil matrix. These data indicated the importance of plant harvesting at spray-irrigation sites and the importance of timing applications with plant growth so that some of the applied $\mathrm{N}$ is recovered by plants.

The other $\mathrm{N}$ outputs from the system, water discharge and ammonia volatilization, accounted for the remaining 23 percent of the $\mathrm{N}$ output from the 20 -acre subbasin. $\mathrm{N}$ output from underflow accounted for about 18 percent (or about 1,060 lb) of the total $\mathrm{N}$ output from the 20 -acre subbasin. Approximately 94 percent of the dissolved $\mathrm{N}$ leaving the 20 -acre subbasin in underflow was in the form of nitrate with the remaining fraction organic N. Water that was not captured by the flume, yet was discharged from the 20-acre subbasin, was considered underflow. Water discharge through the flume accounted for about 4 percent (or about $250 \mathrm{lb}$ of $\mathrm{N}$ ) of the total $\mathrm{N}$ output from the 20 -acre subbasin. Water discharge through the flume was a mixture of water seeping from subsurface zones during nonstorm periods. During storm events, water predominantly moved to the swale through subsurface zones. Overland flow did occur at the site but was primarily during large storm events such as the precipitation from the remnants of Hurricane Floyd. The primary forms of $\mathrm{N}$ in water discharged from the site were organic $\mathrm{N}$ (57 percent) and nitrate $\mathrm{N}$ (36 percent); 52 percent of the $\mathrm{N}$ in water discharged through the flume was during storm events. Ammonia volatilization was another seasonally dependent component that only occurred during the growing season when air temperatures were higher. Loss of $\mathrm{N}$ through ammonia volatilization was estimated to be about $60 \mathrm{lb}$ during the study period. Ammonia volatilization could increase appreciably if spray-irrigation water was allowed to pond on the land surface. Ponding was not evident at the New Garden site.

$\mathrm{N}$ stored in the solid-soil phase was the predominant form of $\mathrm{N}$ in the 20 -acre subbasin. The average amount of $\mathrm{N}$ in the solid-soil phase over the entire 20-acre subbasin for soil depths of 0-4 ft was $170,000 \mathrm{lb}$; it was estimated that at least another $120,000 \mathrm{lb}$ of $\mathrm{N}$ were in the solid-soil phase below $4 \mathrm{ft}$ to competent bedrock. Approximately $98-99$ percent of $\mathrm{N}$ in the $0-4 \mathrm{ft}$ depth interval was in organic form. It was difficult to determine to what extent the organic-N pool in the solid-soil phase was 
affected by effluent application because of the large variability inherent in the soil-chemistry data. Inorganic forms of $\mathrm{N}$ in the solid-soil phase from $0-4 \mathrm{ft}$ indicated an increase from spring 1999 to fall 2001. The mass of inorganic forms of $\mathrm{N}$ increased with depth, indicating that plant uptake was likely reducing concentrations of available $\mathrm{N}$ near the land surface. The mass of ammonium $\mathrm{N}$ increased from approximately $700 \mathrm{lb}$ in spring 1999 to $1,600 \mathrm{lb}$ in fall 2001 (at depths of 0-4 ft). Concentrations of nitrate ions in the solid-soil phase basically indicated no change over the same period. Unlike nitrate, which is transported through the soil system relatively rapidly, ammonium ions are retained in the soil. The large increase in ammonium from 1999 to 2001 is more than the amount of ammonium added to the system from effluent. Mineralization of organic N to inorganic forms of $\mathrm{N}$ could also help to increase concentrations of ammonium in the solid-soil phase. Generally, mineralization of organic $\mathrm{N}$ to nitrate and ammonium occurs at a rate of 2-3 percent per year.

$\mathrm{N}$ stored in the soil water and shallow ground water substantially decreased over the study period in the 20-acre subbasin. The mass of $\mathrm{N}$ in the soil water and shallow ground-water compartments in spring-summer 1999 was about twice as much as the mass of $\mathrm{N}$ for the last samples collected in 2001. The primary form of $\mathrm{N}$ in soil water and ground water within the 20-acre subbasin was nitrate. Approximately 86-87 percent of $\mathrm{N}$ in soil water and ground water to the depth of competent bedrock was in the form of nitrate $\mathrm{N}$. The mass of $\mathrm{N}$ in shallow ground water was reduced, even though shallow monitor wells at the top of the 20-acre subbasin indicated significant increases in concentrations of nitrate $\mathrm{N}$ during the study period. These increased concentrations (less than $1 \mathrm{mg} / \mathrm{L}$ increases) at the top of the 20-acre subbasin were overwhelmed by the reduction in nitrate concentrations for the well (Ch-5177) at the bottom of the 20-acre subbasin. The nitrate- $\mathrm{N}$ concentrations for samples collected in June 1999 and December 2001 from Ch-5177 were 16.3 and $6.2 \mathrm{mg} / \mathrm{L}$, respectively. This well had water with elevated nitrate-N concentrations (above background levels) because of the presence of spent mushroom substrate immediately upgradient of the well. Effluent application helped to flush this nitrate out of the ground-water system, thus, decreasing the mass of stored $\mathrm{N}$ in the shallow ground-water system.

The amount of effluent $\mathrm{N}$ applied to the 20 -acre subbasin during the study period was about 30 percent of the maximum load of inorganic $\mathrm{N}$ allowed by the site permit. The permit was written to exclude organic $\mathrm{N}$ from the maximum load calculations. The volume of water applied to the site was 70 percent of the allowable hydraulic load. Thus, even though concentrations of inorganic $\mathrm{N}$ did not approach the theoretical values used to compute the allowable maximum $\mathrm{N}$ load, the maximum hydraulic load would have been reached well before the maximum $\mathrm{N}$ load could be applied. Therefore, the theoretical maximum $\mathrm{N}$ load for this site could not have been realized given the actual concentrations of inorganic $\mathrm{N}$ in the effluent. This spray site was designed so that some $\mathrm{N}$ applied during spray application would eventually be removed from the site through harvesting of plant material. The amount of $\mathrm{N}$ removed from plant harvest during the three growing seasons of 1999-2001 was 4,560 lb. This amount exceeded the amount of inorganic $\mathrm{N}$ applied through spray application by $700 \mathrm{lb}$.

The $\mathrm{N}$ balance for the site indicated that spray irrigation did not increase $\mathrm{N}$ losses in water discharging from the 20 -acre subbasin during the study period. The storage of inorganic $\mathrm{N}$ in subsurface compartments did not increase. Plant uptake of $\mathrm{N}$ appeared to be the primary factor in minimizing the loss of $\mathrm{N}$ from the 20-acre subbasin. Harvesting of plant materials removed 4,560 lb of $\mathrm{N}$ during the study. This amount exceeded the inorganic-N load applied in effluent and the additional input from atmospheric deposition; thus, some $\mathrm{N}$ taken up by plants was supplied by subsurface storage compartments. Given that an economical application rate of $\mathrm{N}$ for orchardgrass is $150 \mathrm{lb}$ per acre (amounting to 9,000 lb of inorganic $\mathrm{N}$ over 3 years and 20 acres), it is likely that additional $\mathrm{N}$ could have been applied to the 20-acre subbasin without causing large increases in $\mathrm{N}$ loss in water discharging from the ground-water system. This assumes that the $\mathrm{N}$ would be applied during the growing season, and the harvesting of the plant material would be maximized. Older vegetation does not grow as vigorously as younger vegetation, and harvesting at shorter time intervals would increase the $\mathrm{N}$ uptake of the plant community. The other factors that likely helped to reduce $\mathrm{N}$ losses through water discharge were soil processes. On the basis of nitrate- $\mathrm{N}$ to $\mathrm{Cl}$ ratios, $\mathrm{N}$ isotope data, and redox potential, it appeared that denitrification occurred in the shallow part of the soil system. Spray irrigation, besides providing the nitrate to initiate the process, could also promote denitrification by increasing the anoxic conditions in the soil system. Increasing soil moisture generally increases anoxic conditions. Another process in the soil that could inhibit transport of $\mathrm{N}$ from the 20-acre subbasin was conversion of $\mathrm{N}$ from soluble to insoluble forms. For example, the biological uptake of nitrate or ammonium would reduce soluble forms of $\mathrm{N}$ and retain the $\mathrm{N}$ within the solid-soil matrix.

Study of N fate and transport at the New Garden Township spray-irrigation site indicated that the landscape can be used to filter $\mathrm{N}$ out of the water prior to discharge from the groundwater system. Application of additional $\mathrm{N}$ beyond what was applied during this study may increase the loss of $\mathrm{N}$ from the system; however, more $\mathrm{N}$ could also be taken up by the plant community and it is likely that hydraulic limitations on application rates would be realized prior to any appreciable increases in the loss of $\mathrm{N}$ from the system. Study results indicated that spray irrigation at the New Garden site was a better method of removing wastewater from the treatment facility than discharging the water directly to a surface-water source.

\section{Acknowledgments}

The authors would like to thank New Garden Township Board of Supervisors and the New Garden Township Sewer Authority for their cooperation and access to the site. Also, New Garden Township Sewer Authority facility manager Bill 
"Radar" O'Connell is acknowledged for his ongoing assistance onsite throughout the project. Also, the authors would like to thank URS technical and engineering staff for their onsite assistance and report review comments.

The authors thank the PaDEP for the support, cooperation, and contribution of staff and resources over the course of the entire project from field data collection and laboratory services through technical reviews of the report. In particular, acknowledgments to PaDEP field personnel Beth Theroff, Kelly Sweeney, and John Zwalinsky. The authors would like to thank the CCWRA for the support, cooperation, and contributions throughout the entire project and the Chester County Health Department for the assistance in obtaining well permits and report review.

The authors would like to thank Larry Hepner, Delaware Valley College, for his technical consultation and report review. The authors would like to thank USGS Pennsylvania District personnel Kenneth Eden, Kevin Grazul, Todd Spanish, Marla Stuckey, Samuel Fishel, and Michele Koch. Their assistance in field data collection and data processing and management was greatly appreciated. Also, the authors would like to thank John Rote, USGS personnel, for his analysis and interpretation of the streamflow records.

\section{References Cited}

Allen, R.G., Pereira, L.S., Raes, Dirk, and Smith, Martin, 1998, Crop evapotranspiration-Guidelines for computing crop water requirements: Food and Agricultural Organization of the United Nations Irrigation and drainage paper 56, 11 chaps.

Barton, L., McLay, C.D.A., Schipper, L.A., and Smith, C.T., 1999, Denitrification rates in a wastewater-irrigated forest soil in New Zealand: Journal of Environmental Quality, v. 28, no. 6, p. 2008-2014.

Brady, N.C., 1974, The nature and properties of soils (8th ed.): New York, Macmillian Publishing Co., 639 p.

Chester County, 1996, Landscapes-Managing change in Chester County 1996-2020, Comprehensive plan policy element: West Chester, Pa., 138 p.

Chester County Planning Commission, 1990, Utilization of spray irrigation in wastewater treatment: Chester County Planning Commission Planning Bulletin 40, 23 p.

Durlin, R.R. and Schaffstall, W.P., 2000, Water-resources data, Pennsylvania, water year 1999_-Volume 1, Delaware River Basin: U.S. Geological Survey Water-Data Report PA-99-1, $571 \mathrm{p}$.

Durlin, R.R. and Schaffstall, W.P., 2001, Water-resources data, Pennsylvania, water year 2000-Volume 1, Delaware River Basin: U.S. Geological Survey Water-Data Report PA-00-1, $652 \mathrm{p}$.

Durlin, R.R. and Schaffstall, W.P., 2002, Water-resources data, Pennsylvania, water year 2001-Volume 1, Delaware River Basin: U.S. Geological Survey Water-Data Report PA-01-1,
Fahey, T.J., Williams, C.J., Rooney-Varga, J.N., Cleveland, C.C., Postek, K.M., Smith, S.D., and Bouldin, D.R., 1999, Nitrogen deposition in and around an intensive agricultural district in central New York: Journal of Environmental Quality, v. 28, no. 5, p. 1585-1600.

Farnsworth, R.K., Thompson, E.S., and Peck, E.L., 1982, Evaporation atlas for the contiguous 48 United States: U.S. Department of Commerce, National Oceanic and Atmospheric Administration, National Weather Service, NOAA Technical Report NWS 33, 26 p. 4 pl.

Firestone, M.K., 1982, Biological denitrification, in Stevenson, F.J., ed., Nitrogen in agricultural soils, Agronomy Monograph no. 22: Madison, Wis., The American Society of Agronomy-Crop Science Society of America-Soil Science Society of America, p. 289-326.

Focht, D.D., 1978, Methods for analysis for denitrification in soils, in Nielsen, D.R., and MacDonald, J.G., eds., Nitrogen in the environment, volume 2, Soil-plant-nitrogen relationships: New York, Academic Press, p. 433-490.

Freeze, R.A. and Cherry, J.A., 1979, Groundwater: New Jersey, Prentice-Hall, 604 p.

Freney, J.R., Jr., Simpson, J.R., and Denmead, O.T., 1983, Volatilization of ammonia, in Freney, J.R., and Simpson, J.R., eds., Gaseous loss of nitrogen from plant-soil systems: Boston, Martinus Nijhoff / Dr. W. Junk Publishers, p. 1-32.

Guo, M., Chorover, J., and Fox, R.H., 2000a, Effects of spent mushroom substrate weathering on the chemistry of underlying soils: Journal of Environmental Quality, v. 30, no. 6, p. 2127-2134.

Guo, M., Chorover, J., Rosario, R., and Fox, R.H., 2000b, Leachate chemistry of field-weathered spent mushroom substrate: Journal of Environmental Quality, v. 30, no. 6, p. $1699-1709$.

Hall, M.H., 2000, Orchardgrass: Penn State College of Agricultural Sciences, Agricultural Research and Cooperative Extension, Agronomy Facts 25, 3 p.

Havelka, U.D., Boyle, M.G., and Hardy, R.W.F., 1982, Biological nitrogen fixation, in Stevenson, Frank J., ed., Nitrogen in agricultural soils, Agronomy Monograph no. 22: Madison, Wisconsin, The American Society of Agronomy-Crop Science Society of America-Soil Science Society of America, p. 365-422.

Heaton, T.H.E., 1986, Isotopic studies of nitrogen pollution in the hydrosphere and atmosphere-A review: Chemical Geology (Isotope Geoscience Section), v. 59, no. 1, p. 87102.

Heebner, D., and Toran, L., 2000, Sensitivity analysis of threedimensional stready-state and transient spray irrigation models: Ground Water, v. 38, no. 1, p. 20-28.

Helsel, D.R., and Hirsch, R.M., 1992, Statistical methods in water resources: New York, Elsevier, 522 p.

Hem, J.D., 1985, Study and interpretation of the chemical characteristics of water: U.S. Geological Survey Water-Supply Paper 2254, $263 \mathrm{p}$.

Hinson, T.H., Hoover, M.T., and Evans, R.O., 1995, Sand lined trench septic system performance on wet, clayey soils, in 
Collins, Eldridge, ed., On-site wastewater treatment, Proceedings of the seventh international symposium on individual and small community sewage systems: St. Joseph, Michigan, American Society of Agricultural Engineers, p. 245-255.

Hübner, H., 1986, Isotope effects of nitrogen in the soil and biosphere, in Fritz, P., and Fontes, J. Ch., eds., Handbook of environmental isotope geochemistry, volume 2, The terrestrial environment, B: New York, Elsevier, p. 361-425.

Karr, J.D., Showers, W.J., Gilliam, J.W., and Andres, A.S., 2001, Tracing nitrate transport and environmental impact from intensive swine farming using delta nitrogen15: Journal of Environmental Quality, v. 30, no. 4, p. 1163-1175.

Komor, S.C., and Anderson, H.W., Jr., 1993, Nitrogen isotopes as indicators of nitrate sources in Minnesota sand-plain aquifers: Ground Water, v. 31, no. 2, p. 260-270.

Knowles, R., 1981, Denitrification, in Paul, E.A., and Ladd, J.N., eds., Soil Biochemistry, volume 5: New York, Marcel Dekker, Inc., p. 323-369.

Knowles, R., 1982, Denitrification: Microbiological Reviews, v. 46, no. 1, p. 43-70.

Koerkle, E.H., Gustafson-Minnich, L.C., and Bilger, M.D., 1997, Surface-water quality changes after 5 years of nutrient management in the Little Conestoga Creek headwaters, Pennsylvania, 1989-91: U.S. Geological Survey WaterResources Investigations Report 97-4048, 43 p.

Kunkle, W.M., 1963, Soil survey of Chester and Delaware Counties, Pennsylvania: U.S. Department of Agriculture, Soil Conservation Service, ser. 1959, no. 19, 124 p.

Langland, M.J., 1992, Atmospheric deposition of ammonia from open manure-storage lagoons in south-central Pennsylvania: The Environmental Professional, v. 14, no. 1, p. 28-37.

Lawrence, G.B., Goolsby, D.A., Battaglin, W.A., and Stensland, G.J., 2000, Atmospheric nitrogen in the Mississippi

River Basin-Emissions, deposition and transport: The Science of the Total Environment, v. 248, no. 2-3, p. 87-99.

Létolle, Réne, 1980, Nitrogen-15 in the natural environment, in Fritz, P., and Fontes, J. Ch., eds., Handbook of environmental isotope geochemistry, volume 1, The terrestrial environment, A: New York, Elsevier Scientific Publishing Company, p. 407-433.

Mariotti, A., Landreau, A., and Simon, B., $1988,{ }^{15} \mathrm{~N}$ isotope biogeochemistry and natural denitrification process in groundwater-Application to the chalk aquifer of northern France: Geochimica et Cosmochimica Acta, v. 52, no. 7, p. 1869-1878.

McGuinness, J.L., Harrold, L.L., and Amerman, C.R., 1961, Hydrogeologic nature of streamflow on small watersheds: Journal of the Hydraulics Division, Proceedings of the American Society of Civil Engineers, v. 87, no. HY 1, p. 1-13.

Meisinger, J.J., and Jokela, W.E., 2000, Ammonia volatilization from dairy and poultry manure, in Managing nutrients and pathogens from animal agriculture: Ithaca, N.Y.,
Natural Resource, Agriculture, and Engineering Service (NRAES) NRAES-130, p. 334-354.

Monnett, G.T., Reneau, R.B., Jr., and Hagedorn, C., 1995, Effects of domestic wastewater spray irrigation on denitrification rates: Journal of Environmental Quality, v. 24, no. 5, p. 940-946.

National Oceanic and Atmospheric Administration, 2002, Monthly station normals of temperature, precipitation, and heating and cooling degree days 1971-2000: National Oceanic and Atmospheric Administration Climatography of the United States, no. 81, 9 p.

Nommik, H., and Vahtras, K., 1982, Retention and fixation of ammonium and ammonia in soils, in Stevenson, F.J., ed., Nitrogen in agricultural soils, Agronomy Monograph no. 22: Madison, Wis., The American Society of AgronomyCrop Science Society of America-Soil Science Society of America, p. 123-171.

Olmsted, F.H., and Hely, A.G., 1962, Relation between ground water and surface water in Brandywine Creek basin, Pennsylvania: U.S. Geological Survey Professional Paper 417-A, $21 \mathrm{p}$.

Parizek, R.R., and Lane, B.E., 1970, Soil-water sampling using pan and deep pressure-vacuum lysimeters: Journal of Hydrology, v. 11, no. 1, p. 1-21.

Payne, W.J., 1981, Denitrification: New York, John Wiley \& Sons, $214 \mathrm{p}$.

Pennsylvania 21st Century Environment Commission, 1998, Report of the Pennsylvania 21st Century Environment Commission, http://www.21stcentury.state.pa.us, 92 p.

Pennsylvania State University, College of Earth and Mineral Science, 2003, Pennsylvania State Climatologist: accessed January 24, 2005, at URL http://pasc.met.psu.edu/PA_Climatologist/index.php.

Pettyjohn, W.A., and Henning, Roger, 1979, Preliminary estimate of ground-water recharge rates, related streamflow and water quality in Ohio: Ohio State University Water Resources Center Project Completion Report Number 552, $323 \mathrm{p}$.

Postgate, J.R., 1982, The fundamentals of nitrogen fixation: Cambridge, Massachusetts, Cambridge University Press, $252 \mathrm{p}$.

Poth, C.W., 1968, Hydrology of the metamorphic and igneous rocks of central Chester County, Pennsylvania:

Pennsylvania Geological Survey, 4th ser., Water Resources Report 25, 84 p.

Rantz, S.E., and others, 1982, Measurement and computation os streamflow-Volume 2. Computation of Discharge: U.S. Geological Survey Water-Supply Paper 2175, p. 285-631.

Reese, S.O., and Lee, J.L., comps., 1998, Summary of groundwater quality monitoring data (1985-1997) from Pennsylvania's ambient and fixed station network monitoring program-Selected groundwater basins in southwestern, southcentral and southeastern Pennsylvania: Harrisburg, Pa., Commonwealth of Pennsylvania, Department of Environmental Protection, 30 p. plus appendixes.

Ryden, J.C., Lund, L.J., and Whaley, S.A., 1981, Direct measurement of gaseous nitrogen losses from an effluent irriga- 
tion area: Journal of the Water Pollution Control Federation, v. 53, no. 12, p. 1677-1682.

Scudlark, J.R., Russell, K.M., Galloway, J.N., Church, T.M., and Keene, W.C., 1998, Organic nitrogen in precipitation at the Mid-Atlantic U.S. Coast-Methods evaluation and preliminary measurements: Atmospheric Environment, v. 32, no. 10, p. 1719-1728.

Searcy, J.K., and Hardison, C.H., 1960, Double-mass curves: U.S. Geological Survey Water-Supply Paper 1541-B, 66 p.

Senior, L.A., 1996, Ground-water quality and its relation to hydrogeology, land use, and surface-water quality in the Red Clay Creek Basin, Piedmont Physiographic Province, Pennsylvania and Delaware: U.S. Geological Survey Water-Resources Investigations Report 96-4288, 122 p.

Sharpe, R.R., and Harper, L.A., 1997, Ammonia and nitrous oxide emissions from sprinkler irrigation applications of swine effluent: Journal of Environmental Quality, v. 26, no. 6, p. 1703-1706.

Sievering, H., Burton, D., and Caine, N., 1992, Atmospheric loading of nitrogen to alpine tundra in the Colorado front range: Global Biogeochemical Cycles, v. 6, no. 4, p. 339346.

Sloto, R.A, 1994, Geology, hydrology, and ground-water quality of Chester County, Pennsylvania: Chester County Water Resources Authority Water-Resource Report 2, 129 p.

Sloto, R.A., and Crouse, M.Y., 1996, HYSEP-A computer program for streamflow hydrograph separation and analysis: U.S. Geological Survey Water-Resources Investigations Report 96-4040, 46 p.

Smith, M., Allen, R., Monteith, J.L., Perrier, A., Pereira, L.S., and Segeren, 1992, Report on the expert consultation on revision of FAO methodologies for crop requirements: Food and Agriculture Organization of the United Nations, Land and Water Development Division, Rome, Italy, 59 p.

Smith, M., Allen, R., and Pereira, L.S., 1997, Revised FAO methodolgy for crop water requirements: Food and Agriculture Organization of the United Nations, Land and Water Development Division, Rome, Italy

Sommer, S.G., and Olesen, J.E., 1991, Effects of dry matter content and temperature on ammonia loss from surfaceapplied cattle slurry: Journal of Environmental Quality, v. 20 , no. 3 , p. 679-683.

Sommer, S.G., Olesen, J.E., and Christensen, B.T., 1991, Effects of temperature, wind speed and air humidity on ammonia volatilization from surface applied cattle slurry: Journal of Agricultural Science, Cambridge, v. 117, no. 1, p. $91-100$.

Sopper, W.E., 1976, Renovation of municipal wastewater for groundwater recharge by the living filter method, in Tourbier, J., and Pierson, R.W., Jr., eds., Biological control of water pollution: University of Pennsylvania Press, p. 269-282.

Stevenson, F.J., 1982a, Organic forms of soil nitrogen, in Stevenson, F.J., ed., Nitrogen in agricultural soils, Agronomy Monograph no. 22: Madison, Wis., The American Society of Agronomy-Crop Science Society of America-Soil Science Society of America, p. 67-122.
Stevenson, F.J., 1982b, Origin and distribution of nitrogen in soil, in Stevenson, F.J., ed., Nitrogen in agricultural soils, Agronomy Monograph no. 22: Madison, Wis., The American Society of Agronomy-Crop Science Society of AmericaSoil Science Society of America, p. 1-42.

Thorstenson, D.C., 1984, The concept of electron activity and its relation to redox potentials in aqueous geochemical systems: U.S. Geological Survey Open-File Report 84-072, $45 \mathrm{p}$.

Tofflemire, T.J., 1976, Land application of wastewater: Journal - Water Pollution Control Federation, v. 48, no. 6, p. 1180-1191.

U.S. Geological Survey, 1997 to present, National field manual for the collection of water-quality data: U.S. Geological Survey Techniques of Water-Resources Investigations, book 9, chaps. A1-A9, 2 v., variously paged. [Also available online at http://water.usgs.gov/owq/FieldManual/Chapters originally were published from 1997 to 1999; updates and revisions are ongoing and are summarized at http://water.usgs.gov/owq/FieldManual/mastererrata.html

Vogel, K.L., and Reif, A.G., 1993, Geohydrology and simulation of ground-water flow in the Red Clay Creek Basin, Chester County, Pennsylvania and New Castle County, Delaware: U.S. Geological Survey Water-Resources Investigations Report 93-4055, 111 p.

Ward, J.R. and Harr, C.A., 1990, Methods for collection and processing of surface-water and bed-material samples for physical and chemical analyses: U.S. Geological Survey Open-File Report 90-140, 71 p.

Whitall, D.R., and Paerl, H.W., 2001, Spatiotemporal variability of wet atmospheric nitrogen deposition to the Neuse River Estuary, North Carolina: Journal of Environmental Quality, v. 30, no. 5, p. 1508-1515.

Witt, E.C., III, Hippe, D.J., and Giovannitti, R.M., 1992, Evaluation of nutrient quality assurance data for Alexanders and Mount Rock Spring Basins, Cumberland County, Pennsylvania: U.S. Geological Survey Open-File Report 92-165, 31 p.

Woodward-Clyde, 1995, Walton spray site hydrogeological evaluation report, New Garden Township, Chester County, Pennsylvania: Blue Bell, Pa., 10 p. + appendixes.

Woodward-Clyde, 1996, Walton spray site hydrogeological evaluation report, New Garden Township, Chester County, Pennsylvania, Addendum No. 1: Blue Bell, Pa., 6 p.

Young, J.L., and Aldag, R.W., 1982, Inorganic forms of nitrogen in soil, in Stevenson, F.J., ed., Nitrogen in agricultural soils, Agronomy Monograph no. 22: Madison, Wisconsin, The American Society of Agronomy-Crop Science Society of America-Soil Science Society of America, p. 43-66.

Zeller, K., Harrington, D., Riebau, A., and Donev, E., 2000, Annual wet and dry deposition of sulfur and nitrogen in the snowy range, Wyoming: Atmospheric Environment, v. 34, no. 11 , p. 1703-1711. 


\section{Glossary}

A

Albedo The fraction of light that is reflected by a body or surface.

Aliquot An equal part.

Alpha (statistical) The probability of rejecting the statistical hypothesis tested when, in fact, that hypothesis is true. For most tests, it is customary to set alpha $(\alpha)$ at 0.05 .

Amphibolite (facies) Rock composed largely or dominantly of minerals of the amphibole group. The term has been applied to rocks of either igneous or metamorphic origin.

Anisotropic Having some physical property that varies with direction.

Anoxic (anaerobic) Greatly deficient in oxygen.

Antecedent conditions The conditions present in the basin at the beginning of a runoff period.

Anthropogenic Of, relating to, or resulting from the influence of human beings on nature.

Aquifer (unconfined, semi-confined, and confined) A water-bearing stratum of permeable rock, sand, or gravel.

Aquifer test A test to determine hydrologic properties of the aquifer involving the withdrawal of measured quantities of water from or addition of water to a well and the measurement of resulting changes in head in the aquifer both during and after the period of discharge or additions.

Assimilative capacity (of streams) The capacity of a body of water to cleanse itself; its capacity to receive waste waters or toxic materials without deleterious effects and without damage to aquatic life or humans who consume the water.

Atmospheric deposition (wet \& dry) When the air pollution hits the earth surface. Air pollution washed out of the sky by rain or snow is called "wet deposition." When air pollution deposits without benefit of rain its called "dry deposition."
Atmospheric vapor deficit The difference between saturation vapor pressure and ambient vapor pressure.

Auger \& auger boring A screwlike boring tool resembling a carpenter's auger bit but much larger, usually motor-driven, designed for use in clay, soil, and other relatively unconsolidated near-surface materials.

\section{B}

Base flow (low flow) That part of the stream discharge that is not attributable to direct runoff from precipitation or melting snow; it is usually sustained by ground-water discharge.

Base-flow recession curve A hydrograph showing the decrease of the runoff rate after rainfall or the melting of snow. Direct runoff and base runoff are usually given separate curves because they recede at different rates.

Bedrock (competent) A general term for the rock, usually solid, that underlies soil or other unconsolidated, superficial material.

Bedrock well As used in this report, a well that has been screened in the bedrock.

Bentonite An absorptive and colloidal clay used especially as a sealing agent.

Biomass The amount of living material in a particular area, stated in terms of the weight or volume of organisms per unit area or of the volume of the environment.

Blank sample Samples collected and analyzed to ensure that environmental samples have not been contaminated by the overall data-collection process. The blank solution used to develop specific types of blank samples is a solution that is free of the analytes of interest. Any measured value in a blank sample for an analyte that was absent in the blank solution is believed to be due to contamination.

Bulk precipitation Atmospheric deposition collected in an open funnel in a location not affected by the vegetation canopy. Bulk precipitation will collect both wet and dry deposition incident upon the funnel.

Butyrate (tube) Rigid tubing with excellent dimensional stability. Properties include ease of fabrication, high impact strength, and excellent transparency. It is strong, tough, and durable and can be cut and sawed with standard equipment. 
C

Capillary forces The molecular forces that cause the movement of water through small spaces.

Capillary fringe The lower subdivision of the unsaturated zone immediately above the water table in which the interstices are filled with water under pressure less than that of the atmosphere, being continuous with the water below the water table but held above it by capillary forces.

Carbonate rock A rock consisting chiefly of carbonate minerals, such as limestone, dolomite, or carbonate.

Chemoautotrophic Said of an organism that obtains nourishment from chemical reactions of inorganic substances.

Churn splitter A container specifically designed to composite and split surface-water samples for trace-element analysis.

Composite(d) To make composite or into something composite.

Crystalline rock An inexact but convenient term designating an igneous or metamorphic rock, as opposed to a sedimentary rock. A rock consisting wholly of relatively large mineral grains.

\section{D}

Data logger An electronic memory device that accepts information from instruments and records it for future use, usually in a form that can be read with the help of a personal computer.

Deionized water Water that has all dissolved ions removed.

Delineation The physical boundary of something.

Denitrification (1) The loss or removal of nitrogen or nitrogen compounds,

Discharge (streamflow) The volume of water (or more broadly, volume of fluid including solid- and dissolved-phase material), that passes a given point in a given period of time.

Discharge area An area in which ground water is discharged to the land surface, surface water, or atmosphere.
Distilled water Water that has been treated by boiling and condensation to remove solids, inorganics, and some organic chemicals.

Double-mass curve A plot of the accumulation over time of one variable in relation to the accumulation over time of a second variable.

Downgradient Down slope.

\section{E}

Evapotranspiration (ET) The combined loss of water from a given area by evaporation from the land and transpiration from plants.

Potential ET The amount of water that could be evaporated and transpired if there was plenty of water available.

Calculated ET In the conext of this report, the calculated evapotranspiration is the result of the monthly water-budget equation.

Crop-referenced ET The evapotranspiration from a hypothetical grass reference crop with specific characteristics.

Explanatory variables A variable that affects or explains the value of the dependent variable.

Exponentially Expressible or approximately expressible by an exponential function; characterized by or being an extremely rapid increase.

Extrapolate (1) To use known facts as the starting point from which to draw inferences or draw conclusions about something unknown or (2) to estimate a value that falls outside a range of known values, for example, by extending a curve on a graph.

\section{$\mathbf{F}$}

Flume An artificial inclined channel used for conveying water for a specific purpose.

\section{G}

Geographic information system (GIS) A system of hardware and software used for storage, retrieval, mapping, and analysis of geographic data.

Geologic contact A plane or irregular surface between two types or ages of rock.

Gneiss A foliated rock formed by regional metamorphism, in which bands or lenticles of granular minerals alternate with bands or lenticles in which minerals having flaky or elongate prismatic habits predominate. 
Gravimetric soil-water

content Measurement of the soil-water content by weight.

Gravitational flow Downward movement of water by the force of gravity.

Gravity yield The gravity yield of a rock or soil after saturation or partial saturation is the ratio of (a) the volume of water it will yield by gravity to (b) its own volume during the period of ground-water recession. ${ }^{1}$

Ground-water discharge (1) flow of water from the zone of saturation; (2) the water released from the zone of saturation; (3) the quantity of water released.

Ground-water-flow path (conceptual) The path of the movement, or flow, of water in the zone of saturation, whether naturally or artificially induced.

Ground-water mounding A raised area in a water table or other potentiometric surface created by ground-water recharge.

Ground-water recharge The process of water addition to the saturated zone or the volume of water added by the process.

Ground-water storage (1) The quantity of water in the zone of saturation; (2) water available only from storage as opposed to capture.

Ground-water underflow As used in this report, ground water that is not being captured as base flow leaving the watershed.

H

Heterotrophic Said of an organism that nourishes itself by utilizing organic material to synthesize its own living matter.

Homogeneous(ly) A characteristic of a medium in which material properties are identical everywhere.

Hydraulic conductivity The rate of flow of water in gallons per day through a cross section of 1 square foot under a unit hydraulic gradient, at the prevailing temperature.

Hydraulic loading The volume of effluent applied through spray irrigation.
Hydrograph separation Methodology used to separate the hydrograph of discharge into components of base flow and runoff.

Igneous rock Rock that solidified from molten or partly molten material.

Inorganic blank water Water used for quality-control samples in which no analytes are present above laboratory reporting limits.

Interpolate To estimate values of a function between two known values.

Interquartile range A measure of spread or dispersion. It is the difference between the 75th percentile and the 25 th percentile.

Isopach map A map showing isolines that connect points of equal thickness of a geological stratum formation or group of formations.

Isotope (nitrogen, stable) Any of two or more species of atoms of a chemical element with the same atomic number and nearly identical chemical behavior but with differing atomic mass or mass number and different physical properties.

L

Leaching (soil) The removal of material in solution from soil.

Leguminous plants A family of plants bearing nodules on the roots that contain nitrogenfixing bacteria.

Lysimeter (suction) A device for measuring percolation and leaching losses from a column of soil under controlled conditions.

M

Metamorphic rock Any rock derived from pre-existing rocks by mineralogical, chemical, and (or) structural changes, essentially in the solid state, in response to marked changes in temperature, pressure, shearing stress, and chemical environment, generally at depth.

Mica schist A schist whose essential constituents are mica and quartz, and whose schistosity is mainly due to the parallel arrangement of mica flakes.

\footnotetext{
${ }^{1}$ Glossary definition taken verbatim from Rasmussen, W.C., and Andreasen, G.E., 1959, Hydrologic budget of the Beaverdam Creek basin, Maryland: U.S. Geological Survey Water-Supply Paper 1472, 106 p.
} 
Mineralization The process or processes by which a mineral or minerals are introduced into a rock, resulting in a valuable or potentially valuable deposit.

Mottle(s) A spot, blotch, or patch of color occurring on the surface of a sediment or soil.

N

Nitrification The oxidation (as by bacteria) of ammonium slats to nitrites and the further oxidation of nitrites to nitrates.

Nitrogen fixation The biological process by which molecular atmospheric nitrogen is converted into a chemical compound that is essential for plant growth.

Nonparametric Statistical methods that do not require assumptions about the form of the underlying distribution.

Normalized To make normal, as by a transformation of variables.

\section{0}

Oxidation A chemical reaction in which oxygen is added to an element or compound. $\mathbf{P}$

Particle density The mass per unit volume of the soil particles. It is usually expressed in grams per cubic centimeter.

Percentile A value on a scale of 100 that indicates the percent of a distribution that is equal to or below it.

Peristaltic pump Pump used for collecting samples from shallow wells and surface water. The pump is designed to take a manual sample and has the ability to backflush the sample hose once the sample collection is finished.

Plant uptake The accumulation of nutrients by plant roots or other tissues.

Porosity The ratio, usually expressed as a percentage, of the total volume of voids of a given porous medium to the total volume of the porous medium.

Porous media Something that allows water to pass through it.

Pressure transducer A transducer that converts pressure to an analog electrical signal.

$\boldsymbol{p}$-value The probability of obtaining a given outcome due to chance alone. For example, a significance level of $\mathrm{p}<=0.05$ implies that 5 times out of 100 the result could have occurred by chance.

\section{0}

Quartzite A very hard but unmetamorphosed sandstone, consisting chiefly of quartz grains that have been so completely and solidly cemented with secondary silica that the rock breaks across or through the grains rather than around them.

\section{R}

Radiant energy Energy emitted from the sun in the form of electromagnetic waves.

Recharge area An area in which water reaches the zone of saturation by surface infiltration.

Redox potential A measure of the availability of electrons for transfer between molecules. The availability of electrons determines the solubility of many chemicals and also affects the types of organisms that can live in the system.

Reference sample Solutions or materials having a known composition that is certified by a laboratory. Samples of reference material are submitted for analysis to ensure that an analytical method is accurate for the known properties of the reference material.

Regression (analysis, model) A process for determining the statistical relation between a random variable and one or more independent variables that is used to predict the value of the random variable.

Replicate sample A set of environmental samples collected in a manner such that the samples are thought to be essentially identical in composition. Replicate samples are collected and analyzed to establish the amount of variability in the data contributed by some part of the collection and analytical process.

Residual The difference between results obtained by observation and by computation from a formula or between the mean of several observations and any one of them.

\section{Runoff (surface, overland, stormflow)}

(1) That part of the precipitation, snow melt, or irrigation water that appears in uncontrolled surface streams, rivers, drains or sewers. Runoff may be classified according to speed of appearance after rainfall or melting snow as 
direct runoff or base runoff, and according to source as surface runoff, storm interflow, or ground-water runoff. (2) Runoff is the movement of landwater to the oceans, chiefly in the form of rivers, lakes, and streams. Runoff consists of precipitation that neither evaporates, transpires, nor penetrates the surface to become ground water.

\section{S}

Saprolite A soft, earthy, typically clay-rich, thoroughly decomposed rock, formed in place by chemical weathering of igneous, sedimentary, and metamorphic rocks.

Saturated soil (moisture) That part of the soil in which all voids are filled with water under pressure greater than atmospheric.

Secondary treated sewage effluent The second step in most wastewater-treatment systems, in which bacteria break down the organic parts of sewage wastes; usually accomplished by bringing the sewage and bacteria together in trickling filters or in the activated sludge process.

Seepage (fair-weather) (1) the fluid discharged at a seep; (2) the amount of fluid discharged at a seep.

Shaft encoder A device typically used to measure water level. This sensor is based on the clockwise/counterclockwise rotation of a pulley. As water level rises and falls, a float sitting on the water surface moves with the water. A wire or metal tape connects the float around a pulley and is held taut by a counterweight on the other end.

Shallow well As used in this report, a well that has been screened in the unconsolidated material.

Sinusoidal Of, relating to, shaped like, or varying according to a sine curve or sine wave.

Soil horizons Layers of soil. The actual geological material composing each horizon may vary because of deposition of materials by wind, water, and other processes.

Soil test pit An excavation to evaluate and characterize soil horizons.

Soil bulk density The ratio of the mass of soil to its total volume (solids and pores together).
Soil-moisture deficit The quantity of water from rainfall or irrigation needed to return a soil to field capacity; for example, the maximum water-holding capacity when free drainage can occur.

Soil profile (matrix) A vertical section of the earth's highly weathered upper surface often showing various distinct layers, or horizons.

Soluble Susceptible of being dissolved in or as if in a liquid and especially water.

Specific gravity The heaviness of a substance compared to that of water, and it is expressed without units.

Specific yield The ratio of the volume of water which the porous medium, after being saturated, will yield by gravity to the volume of the porous medium.

Spent mushroom substrate The soil-like material remaining after a crop of mushrooms. Spent substrate is high in organic matter making it desirable for use as a soil amendment or soil conditioner.

Split replicate sample A type of replicate sample in which an environmental sample is split into subsamples contemporaneous in time and space.

Statistically significant Infers that an observation was unlikely to have occurred by chance alone. Statistical significance is commonly based on a $p$-value less than or equal to 0.05 . Below this level, the smaller the $p$-value, the greater the statistical significance.

Stormflow The runoff reaching stream channels immediately after rainfall or snow melting.

Stratigraphic Relating to the way in which rock strata are arranged, and the chronology of their formation.

Systematically Done methodically, carried out in a methodical and organized manner.

\section{U}

Unconsolidated material (aquifer) The loose material that covers the land surfaces of the Earth and supports the growth of plants.

Unsaturated zone The zone between the land surface and the water table. 
V

Volatilization To pass off in vapor.

Volumetric sol-moisture content An estimate of the volume of water stored in the unsaturated zone of the study watershed.

Volumetric soil-water content The percent moisture in the soil measured by the soil-moisture probes.

W

Water table The upper surface of a zone of saturation except where that surface is formed by a confining unit.

Weir A dam in a stream or river to raise the water level or divert its flow. 



\section{Appendix 1}

Results of chemical and physical analyses of effluent, wet and dry deposition, soil, pan, and plant samples collected at the New Garden Township spray-irrigation site, Chester County, Pennsylvania, 1999-2001. 
Table 1-1. Results of chemical and physical analyses of effluent samples collected at the New Garden Township spray-irrigation site, Chester County, Pennsylvania, May 1999 through December 2001.

$\left[\mu \mathrm{S} / \mathrm{cm}\right.$, microsiemen per centimeter at 25 degrees Celsius; ${ }^{\circ} \mathrm{C}$, degrees Celsius; $\mathrm{mg} / \mathrm{L}$, milligrams per liter; $\mathrm{CaCO}_{3}$, calcium carbonate; mv, millivolts; $\mathrm{N}$, nitrogen, \%o, per mil; $\mathrm{P}$, phosphorus; $\mu \mathrm{g} / \mathrm{L}$, micrograms per liter; —, no data; <, less than]

\begin{tabular}{|c|c|c|c|c|c|c|c|c|}
\hline Date & Time & $\begin{array}{c}\text { pH, } \\
\text { field } \\
\text { (standard } \\
\text { units) }\end{array}$ & $\begin{array}{c}\text { Specific } \\
\text { conductance, } \\
\text { field } \\
(\mu \mathrm{S} / \mathrm{cm})\end{array}$ & $\begin{array}{c}\text { Water } \\
\text { temperature, } \\
\text { field } \\
\left({ }^{\circ} \mathrm{C}\right)\end{array}$ & $\begin{array}{c}\text { Oxygen, } \\
\text { dissolved } \\
\text { (mg/L) }\end{array}$ & $\begin{array}{c}\text { Alkalinity, } \\
\text { field } \\
\text { (mg/L as } \\
\mathrm{CaCO}_{3} \text { ) }\end{array}$ & $\begin{array}{c}\text { Oxidation- } \\
\text { reduction } \\
\text { potential } \\
\text { (mv) }\end{array}$ & $\begin{array}{c}\text { Solids, } \\
\text { residue } \\
\text { at } 180^{\circ} \mathrm{C} \text {, } \\
\text { dissolved } \\
\text { (mg/L) }\end{array}$ \\
\hline 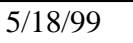 & 1230 & 6.9 & 706 & 14.7 & - & - & - & 466 \\
\hline 7/6/99 & 1015 & 6.9 & 726 & 23.7 & 1.2 & 103 & - & 518 \\
\hline $8 / 3 / 99$ & 0800 & 8.4 & 723 & 25.8 & 6.4 & - & - & - \\
\hline 9/9/99 & 1015 & 9.2 & 686 & 24.5 & - & - & - & - \\
\hline 10/7/99 & 0945 & 9.4 & 580 & 17.1 & 7.9 & - & - & 112 \\
\hline $10 / 26 / 99$ & 1150 & 7.5 & 612 & 13.3 & 5.3 & - & - & - \\
\hline $12 / 9 / 99$ & 0835 & 7.8 & 603 & 6.8 & - & - & - & - \\
\hline $1 / 6 / 00$ & 1115 & 8.7 & 623 & 6.2 & 13.7 & - & - & 424 \\
\hline 3/8/00 & 1300 & 7.4 & 710 & 7.4 & 9.2 & - & - & - \\
\hline $3 / 16 / 00$ & 1100 & - & - & - & - & - & - & - \\
\hline $4 / 24 / 00$ & 1100 & 7.8 & 625 & 11.5 & 6.9 & - & - & 46 \\
\hline $5 / 4 / 00$ & 1010 & 7.3 & 653 & 12.2 & .3 & - & - & - \\
\hline $5 / 10 / 00$ & 0930 & 7.1 & 659 & - & - & - & - & - \\
\hline $5 / 15 / 00$ & 0830 & 7.4 & 660 & 14.6 & .3 & - & - & - \\
\hline $5 / 31 / 00$ & 1010 & 7.4 & 641 & 17.6 & 1.0 & - & - & - \\
\hline $6 / 21 / 00$ & 1030 & 7.4 & 696 & - & - & - & - & - \\
\hline $6 / 29 / 00$ & 0900 & 8.4 & 653 & 22.0 & 1.7 & - & - & - \\
\hline $7 / 31 / 00$ & 0845 & 10.2 & 654 & - & - & - & - & - \\
\hline $8 / 7 / 00$ & 0850 & 9.1 & 711 & 23.7 & .5 & - & - & - \\
\hline $8 / 16 / 00$ & 0830 & 9.7 & 709 & 23.1 & 9.6 & - & - & - \\
\hline $9 / 6 / 00$ & 0900 & 9.8 & 699 & 20.4 & 11.4 & - & - & - \\
\hline $10 / 3 / 00$ & 1030 & 10.1 & 581 & - & - & - & - & - \\
\hline $10 / 31 / 00$ & 0930 & 9.9 & 655 & 9.6 & 14.1 & - & - & - \\
\hline $11 / 16 / 00$ & 0945 & 9.5 & 645 & 7.2 & 15.0 & - & - & - \\
\hline $4 / 26 / 01$ & 0930 & 7.1 & 652 & 10.7 & .8 & - & - & - \\
\hline $6 / 14 / 01$ & 0800 & 6.9 & 700 & 18.0 & .6 & - & - & 368 \\
\hline 6/28/01 & 0800 & 8.2 & 669 & 21.8 & .7 & - & - & - \\
\hline $7 / 18 / 01$ & 0915 & 9.2 & 622 & 24.8 & 5.2 & - & - & - \\
\hline $8 / 22 / 01$ & 0815 & 9.6 & 633 & 25.2 & 6.6 & - & - & - \\
\hline $9 / 27 / 01$ & 0830 & 9.6 & 627 & 19.0 & 5.2 & - & - & - \\
\hline $10 / 25 / 01$ & 0800 & 9.6 & 622 & 15.3 & 7.1 & - & - & - \\
\hline 11/14/01 & 0910 & 9.5 & 644 & 8.2 & 7.2 & - & - & - \\
\hline $12 / 12 / 01$ & 1120 & 7.7 & 669 & 8.5 & 8.5 & - & 206 & 428 \\
\hline
\end{tabular}


Table 1-1. Results of chemical and physical analyses of effluent samples collected at the New Garden Township spray-irrigation site, Chester County, Pennsylvania, May 1999 through December 2001.-Continued

$\left[\mu \mathrm{S} / \mathrm{cm}\right.$, microsiemen per centimeter at 25 degrees Celsius; ${ }^{\circ} \mathrm{C}$, degrees Celsius; $\mathrm{mg} / \mathrm{L}$, milligrams per liter; $\mathrm{CaCO}_{3}$, calcium carbonate; mv, millivolts; $\mathrm{N}$, nitrogen, \%o, per mil; $\mathrm{P}$, phosphorus; $\mu \mathrm{g} / \mathrm{L}$, micrograms per liter; - , no data; <, less than]

\begin{tabular}{|c|c|c|c|c|c|c|c|c|c|c|}
\hline Date & $\begin{array}{c}\text { Nitrogen } \\
\text { ammonia, } \\
\text { dissolved } \\
\text { (mg/L } \\
\text { as N) }\end{array}$ & $\begin{array}{c}\text { Nitrogen } \\
\text { ammonia, } \\
\text { total } \\
\text { (mg/L } \\
\text { as } \mathrm{N})\end{array}$ & $\begin{array}{c}\text { Nitrogen, } \\
\text { dissolved } \\
\text { (mg/L) }\end{array}$ & $\begin{array}{c}\text { Nitrogen, } \\
\text { total } \\
\text { (mg/L) }\end{array}$ & $\begin{array}{l}\text { Nitrogen } \\
\text { nitrate, } \\
\text { dissolved } \\
\text { (mg/L } \\
\text { as N) }\end{array}$ & $\begin{array}{l}\text { Nitrogen } \\
\text { nitrite, } \\
\text { dissolved } \\
\text { (mg/L } \\
\text { as } \mathrm{N} \text { ) }\end{array}$ & $\begin{array}{c}{ }^{15} \mathrm{~N} /{ }^{14} \mathrm{~N} \\
\text { nitrate } \\
\text { fraction } \\
\text { water } \\
(\%)\end{array}$ & $\begin{array}{l}\text { Phos- } \\
\text { phate, } \\
\text { ortho, } \\
\text { dissolved } \\
\text { (mg/L } \\
\text { as P) }\end{array}$ & $\begin{array}{c}\text { Phos- } \\
\text { phorus, } \\
\text { dissolved } \\
\text { (mg/L) }\end{array}$ & $\begin{array}{c}\text { Phos- } \\
\text { phorus, } \\
\text { total } \\
\text { (mg/L) }\end{array}$ \\
\hline $5 / 18 / 99$ & 2.72 & - & - & 18 & 13.0 & 0.073 & - & 2.89 & - & - \\
\hline 7/6/99 & 1.04 & 1.05 & 19 & 19 & 15.0 & .630 & - & 3.22 & 3.26 & 3.37 \\
\hline $8 / 3 / 99$ & 1.28 & 1.24 & 16 & 17 & 12.9 & .250 & - & 2.42 & 3.55 & 3.70 \\
\hline 9/9/99 & .270 & .27 & 10 & 11 & 9.20 & .420 & - & .860 & .910 & 1.31 \\
\hline $10 / 7 / 99$ & .690 & .71 & 9.7 & 17 & 5.60 & 2.06 & - & 1.34 & 1.44 & 8.52 \\
\hline $10 / 26 / 99$ & 1.54 & 1.62 & 10 & 11 & 6.80 & .570 & 15.70 & 3.86 & 3.84 & 4.24 \\
\hline $12 / 9 / 99$ & .160 & $<.02$ & 11 & 12 & 9.23 & .110 & - & 3.03 & 3.70 & 4.12 \\
\hline $1 / 6 / 00$ & .070 & .08 & 11 & 12 & 9.30 & .250 & - & 2.81 & 5.33 & 5.42 \\
\hline $3 / 8 / 00$ & 4.83 & 5.08 & 14 & 15 & 7.70 & .180 & - & 2.86 & 3.92 & 5.36 \\
\hline $3 / 16 / 00$ & 5.15 & 5.30 & 13 & 15 & 7.00 & .200 & - & 1.54 & 3.24 & 4.43 \\
\hline $4 / 24 / 00$ & .274 & 1.93 & 11 & 13 & 8.80 & .620 & - & 2.75 & 2.92 & 3.48 \\
\hline $5 / 4 / 00$ & .400 & .40 & 11 & 13 & 8.90 & .150 & - & 2.54 & 2.72 & 3.11 \\
\hline $5 / 10 / 00$ & .690 & .80 & 9.3 & 11 & 7.61 & .100 & - & - & - & - \\
\hline $5 / 15 / 00$ & 1.31 & 1.43 & 8.3 & 9.5 & 5.80 & .145 & - & - & - & - \\
\hline $5 / 31 / 00$ & 1.21 & 1.20 & 11 & 12 & 7.70 & .230 & - & 2.76 & 3.08 & 3.14 \\
\hline $6 / 21 / 00$ & 2.28 & 2.39 & 9.0 & 8.8 & 4.80 & .330 & - & 3.05 & 3.23 & 3.36 \\
\hline $6 / 29 / 00$ & 1.35 & 1.63 & 7.9 & 11 & 4.80 & .580 & - & 2.45 & 2.33 & 3.45 \\
\hline $7 / 31 / 00$ & .380 & .40 & 3.0 & 6.2 & .880 & .170 & - & .130 & .260 & 1.17 \\
\hline $8 / 7 / 00$ & 2.48 & 2.55 & 7.1 & 13 & 2.17 & .700 & - & 1.28 & 1.24 & 2.42 \\
\hline $8 / 16 / 00$ & .260 & .26 & 5.8 & 7.7 & 3.52 & .590 & - & .430 & .600 & 1.56 \\
\hline 9/6/00 & .190 & 1.16 & 4.3 & 17 & 1.82 & .600 & - & .330 & .360 & 12.5 \\
\hline $10 / 3 / 00$ & .110 & .12 & 5.3 & 7.4 & 2.90 & .940 & - & .570 & .710 & 2.11 \\
\hline $10 / 31 / 00$ & $<.020$ & $<.02$ & 8.2 & 11 & 5.85 & $<1.00$ & - & 1.09 & 1.18 & 2.43 \\
\hline $11 / 16 / 00$ & .050 & .07 & 7.5 & 8.4 & 6.40 & .070 & - & 1.28 & 1.37 & 2.27 \\
\hline $4 / 26 / 01$ & 7.26 & 7.94 & 11 & 12 & 2.03 & .610 & - & 2.67 & 2.86 & 3.30 \\
\hline $6 / 14 / 01$ & 4.62 & 4.71 & 10 & 11 & 3.43 & .950 & - & 2.04 & 3.54 & 3.72 \\
\hline $6 / 28 / 01$ & 2.68 & 2.76 & 12 & 14 & 4.72 & 1.14 & - & 4.48 & 4.94 & 4.60 \\
\hline 7/18/01 & 1.33 & 1.39 & 10 & 11 & 2.38 & .920 & 14.20 & .503 & .619 & 2.00 \\
\hline $8 / 22 / 01$ & .530 & .54 & 3.8 & 5.0 & 1.22 & .670 & - & .432 & .663 & 1.39 \\
\hline $9 / 27 / 01$ & .390 & .40 & 5.8 & 6.7 & 1.44 & .690 & - & .564 & .680 & 1.68 \\
\hline $10 / 25 / 01$ & .460 & .50 & 4.5 & 7.8 & 2.32 & .275 & - & .284 & .367 & 1.33 \\
\hline 11/14/01 & .650 & .68 & 7.2 & 9.2 & 4.33 & .335 & 10.10 & .643 & .737 & 1.58 \\
\hline $12 / 12 / 01$ & .160 & .17 & 11 & 13 & 7.14 & .680 & - & 2.62 & 2.95 & 3.21 \\
\hline
\end{tabular}


Table 1-1. Results of chemical and physical analyses of effluent samples collected at the New Garden Township spray-irrigation site, Chester County, Pennsylvania, May 1999 through December 2001.-Continued

$\left[\mu \mathrm{S} / \mathrm{cm}\right.$, microsiemen per centimeter at 25 degrees Celsius; ${ }^{\circ} \mathrm{C}$, degrees Celsius; $\mathrm{mg} / \mathrm{L}$, milligrams per liter; $\mathrm{CaCO}_{3}$, calcium carbonate; mv, millivolts; $\mathrm{N}$, nitrogen, $\%$, per mil; P, phosphorus; $\mu \mathrm{g} / \mathrm{L}$, micrograms per liter; —, no data; <, less than]

\begin{tabular}{|c|c|c|c|c|c|c|c|c|c|c|c|}
\hline Date & $\begin{array}{l}\text { Calcium, } \\
\text { dissolved } \\
(\mathrm{mg} / \mathrm{L})\end{array}$ & $\begin{array}{l}\text { Chloride, } \\
\text { dissolved } \\
\text { (mg/L) }\end{array}$ & $\begin{array}{c}\text { Mag- } \\
\text { nesium, } \\
\text { dissolved } \\
\text { (mg/L) }\end{array}$ & $\begin{array}{l}\text { Potas- } \\
\text { sium, } \\
\text { dissolved } \\
\text { (mg/L) }\end{array}$ & $\begin{array}{c}\text { Silica, } \\
\text { dissolved } \\
\text { (mg/L as } \\
\left.\mathrm{SiO}_{2}\right)\end{array}$ & $\begin{array}{c}\text { Sodium, } \\
\text { dissolved } \\
\text { (mg/L) }\end{array}$ & $\begin{array}{c}\text { Sulfate, } \\
\text { dissolved } \\
\text { (mg/L } \\
\left.\text { as } \mathrm{SO}_{4}\right)\end{array}$ & $\begin{array}{c}\text { Fluoride, } \\
\text { dissolved } \\
\text { (mg/L) }\end{array}$ & $\begin{array}{l}\text { Bromide, } \\
\text { dissolved } \\
\text { (mg/L) }\end{array}$ & $\begin{array}{c}\text { Carbon, } \\
\text { organic, } \\
\text { dissolved } \\
\text { (mg/L as C) }\end{array}$ & $\begin{array}{c}\text { Carbon, } \\
\text { organic, } \\
\text { total } \\
\text { (mg/L as C) }\end{array}$ \\
\hline $\begin{array}{l}5 / 18 / 99 \\
\end{array}$ & 39.4 & 82.4 & 21.2 & 15.2 & 6.8 & 56.5 & 52.9 & 0.5 & - & 14 & 20 \\
\hline 7/6/99 & 41.5 & 80.0 & 23.1 & 16.2 & 7.9 & 58.6 & 58.6 & .5 & 0.21 & 16 & - \\
\hline $8 / 3 / 99$ & - & - & - & - & - & - & - & - & - & - & - \\
\hline 9/9/99 & - & - & - & - & - & - & - & - & - & - & - \\
\hline $10 / 7 / 99$ & 32.0 & 65.7 & 17.5 & 17.1 & 8.8 & 51.1 & 56.0 & .4 & .32 & 12 & 16 \\
\hline $10 / 26 / 99$ & - & - & - & - & - & - & - & - & - & - & - \\
\hline $12 / 9 / 99$ & - & - & - & - & - & - & - & - & - & - & - \\
\hline $1 / 6 / 00$ & 41.7 & 68.0 & 19.8 & 16.6 & 8.9 & 47.7 & 58.8 & .5 & $<.20$ & 14 & - \\
\hline $3 / 8 / 00$ & - & - & - & - & - & - & - & - & - & - & - \\
\hline $3 / 16 / 00$ & - & - & - & - & - & - & - & - & - & - & - \\
\hline $4 / 24 / 00$ & 39.9 & 80.0 & 17.3 & 16.8 & 11.3 & 53.3 & 51.6 & .4 & $<.20$ & 14 & - \\
\hline $5 / 4 / 00$ & - & - & - & - & - & - & - & - & - & - & - \\
\hline $5 / 10 / 00$ & - & 78.8 & - & - & - & - & - & - & - & - & - \\
\hline $5 / 15 / 00$ & - & 81.0 & - & - & - & - & - & - & - & - & - \\
\hline $5 / 31 / 00$ & - & 83.0 & - & - & - & - & - & - & - & - & - \\
\hline $6 / 21 / 00$ & - & 86.0 & - & - & - & - & - & - & - & - & - \\
\hline $6 / 29 / 00$ & - & 86.0 & - & - & - & - & - & - & - & - & - \\
\hline $7 / 31 / 00$ & - & 94.1 & - & - & - & - & - & - & - & - & - \\
\hline $8 / 7 / 00$ & - & 102 & - & - & - & - & - & - & - & - & - \\
\hline $8 / 16 / 00$ & - & 103 & - & - & - & - & - & - & - & - & - \\
\hline 9/6/00 & - & 107 & - & - & - & - & - & - & - & - & - \\
\hline $10 / 3 / 00$ & - & 90.0 & - & - & - & - & - & - & - & - & 17 \\
\hline $10 / 31 / 00$ & - & 180 & - & - & - & - & - & - & - & - & - \\
\hline $11 / 16 / 00$ & - & 99.0 & - & - & - & - & - & - & - & - & 13 \\
\hline $4 / 26 / 01$ & - & 84.0 & - & - & - & - & - & - & - & - & 14 \\
\hline $6 / 14 / 01$ & 37.8 & 83.0 & 16.5 & 15.8 & 7.9 & 58.8 & 41.0 & .5 & $<.20$ & 15 & - \\
\hline $6 / 28 / 01$ & - & 90.0 & - & - & - & - & - & - & - & - & - \\
\hline 7/18/01 & - & 89.0 & - & - & - & - & - & - & - & - & 17 \\
\hline $8 / 22 / 01$ & - & 97.0 & - & - & - & - & - & - & - & - & - \\
\hline $9 / 27 / 01$ & - & 95.7 & - & - & - & - & - & - & - & - & 11 \\
\hline $10 / 25 / 01$ & - & 96.4 & - & - & - & - & - & - & - & - & - \\
\hline $11 / 14 / 01$ & - & 90.4 & - & - & - & - & - & - & - & - & 17 \\
\hline $12 / 12 / 01$ & 40.0 & 93.0 & 17.0 & 17.0 & 7.3 & 62.9 & 55.2 & .7 & $<.20$ & 11 & 18 \\
\hline
\end{tabular}


Table 1-1. Results of chemical and physical analyses of effluent samples collected at the New Garden Township spray-irrigation site, Chester County, Pennsylvania, May 1999 through December 2001.-Continued

$\left[\mu \mathrm{S} / \mathrm{cm}\right.$, microsiemen per centimeter at 25 degrees Celsius; ${ }^{\circ} \mathrm{C}$, degrees Celsius; $\mathrm{mg} / \mathrm{L}$, milligrams per liter; $\mathrm{CaCO}_{3}$, calcium carbonate; mv, millivolts; $\mathrm{N}$, nitrogen, \%o, per mil; P, phosphorus; $\mu \mathrm{g} / \mathrm{L}$, micrograms per liter; —, no data; <, less than]

\begin{tabular}{|c|c|c|c|c|c|c|c|c|c|c|}
\hline Date & $\begin{array}{l}\text { Aluminum, } \\
\text { dissolved } \\
(\mu \mathrm{g} / \mathrm{L})\end{array}$ & $\begin{array}{l}\text { Antimony, } \\
\text { dissolved } \\
(\mu \mathrm{g} / \mathrm{L})\end{array}$ & $\begin{array}{c}\text { Arsenic, } \\
\text { dissolved } \\
(\mu \mathrm{g} / \mathrm{L})\end{array}$ & $\begin{array}{c}\text { Barium, } \\
\text { dissolved } \\
(\mu \mathrm{g} / \mathrm{L})\end{array}$ & $\begin{array}{c}\text { Boron, } \\
\text { dissolved } \\
(\mu \mathrm{g} / \mathrm{L})\end{array}$ & $\begin{array}{l}\text { Cadmium, } \\
\text { dissolved } \\
(\mu \mathrm{g} / \mathrm{L})\end{array}$ & $\begin{array}{c}\text { Chromium, } \\
\text { dissolved } \\
(\mu \mathrm{g} / \mathrm{L})\end{array}$ & $\begin{array}{c}\text { Copper, } \\
\text { dissolved } \\
(\mu \mathrm{g} / \mathrm{L})\end{array}$ & $\begin{array}{c}\text { Iron, } \\
\text { dissolved } \\
(\mu \mathbf{g} / \mathbf{L})\end{array}$ & $\begin{array}{c}\text { Iron, } \\
\text { total recov- } \\
\text { erable } \\
(\mu \mathrm{g} / \mathrm{L})\end{array}$ \\
\hline $5 / 18 / 99$ & $<10$ & - & - & - & 171 & - & - & - & 70 & - \\
\hline 7/6/99 & - & - & - & - & $<200$ & - & - & - & 50 & - \\
\hline $8 / 3 / 99$ & - & - & - & - & - & - & - & - & - & - \\
\hline 9/9/99 & - & - & - & - & - & - & - & - & - & - \\
\hline $10 / 7 / 99$ & - & $<2.00$ & 5.4 & 4.9 & $<200$ & $<0.20$ & $<4.0$ & 7.2 & $<20$ & - \\
\hline $10 / 26 / 99$ & - & - & - & - & - & - & - & - & - & - \\
\hline $12 / 9 / 99$ & - & - & - & - & - & - & - & - & - & - \\
\hline $1 / 6 / 00$ & - & - & - & - & 216 & - & - & - & 40 & - \\
\hline $3 / 8 / 00$ & - & - & - & - & - & - & - & - & - & - \\
\hline $3 / 16 / 00$ & - & - & - & - & - & - & - & - & - & - \\
\hline $4 / 24 / 00$ & 39 & - & - & - & $<200$ & - & - & - & 60 & - \\
\hline $5 / 4 / 00$ & - & - & - & - & - & - & - & - & - & - \\
\hline $5 / 10 / 00$ & - & - & - & - & $<200$ & - & - & - & - & - \\
\hline $5 / 15 / 00$ & - & - & - & - & $<200$ & - & - & - & - & - \\
\hline $5 / 31 / 00$ & - & - & - & - & - & - & - & - & - & - \\
\hline $6 / 21 / 00$ & - & - & - & - & - & - & - & - & - & - \\
\hline $6 / 29 / 00$ & - & - & - & - & - & - & - & - & - & - \\
\hline $7 / 31 / 00$ & - & - & - & - & - & - & - & - & - & - \\
\hline $8 / 7 / 00$ & - & - & - & - & - & - & - & - & - & - \\
\hline $8 / 16 / 00$ & - & - & - & - & - & - & - & - & - & - \\
\hline $9 / 6 / 00$ & - & - & - & - & - & - & - & - & - & - \\
\hline $10 / 3 / 00$ & - & - & - & - & - & - & - & - & 750 & 800 \\
\hline $10 / 31 / 00$ & - & - & - & - & - & - & - & - & - & - \\
\hline $11 / 16 / 00$ & - & - & - & - & - & - & - & - & $<20$ & 440 \\
\hline $4 / 26 / 01$ & - & - & - & - & - & - & - & - & 40 & 120 \\
\hline $6 / 14 / 01$ & 35 & - & - & - & 249 & - & - & - & 70 & - \\
\hline $6 / 28 / 01$ & - & - & - & - & - & - & - & - & - & - \\
\hline $7 / 18 / 01$ & - & - & - & - & - & - & - & - & $<20$ & 30 \\
\hline $8 / 22 / 01$ & - & - & - & - & - & - & - & - & - & - \\
\hline 9/27/01 & - & - & - & - & - & - & - & - & $<20$ & 60 \\
\hline $10 / 25 / 01$ & - & - & - & - & - & - & - & - & - & - \\
\hline $11 / 14 / 01$ & - & - & - & - & - & - & - & - & 20 & 640 \\
\hline $12 / 12 / 01$ & 23 & $<2.00$ & $<4.0$ & 10.3 & 310 & $<.20$ & $<4.0$ & 9.4 & 20 & - \\
\hline
\end{tabular}


Table 1-1. Results of chemical and physical analyses of effluent samples collected at the New Garden Township spray-irrigation site, Chester County, Pennsylvania, May 1999 through December 2001.-Continued

$\left[\mu \mathrm{S} / \mathrm{cm}\right.$, microsiemen per centimeter at 25 degrees Celsius; ${ }^{\circ} \mathrm{C}$, degrees Celsius; $\mathrm{mg} / \mathrm{L}$, milligrams per liter; $\mathrm{CaCO}_{3}$, calcium carbonate; mv, millivolts; $\mathrm{N}$, nitrogen, \%o, per mil; P, phosphorus; $\mu \mathrm{g} / \mathrm{L}$, micrograms per liter; —, no data; <, less than]

\begin{tabular}{|c|c|c|c|c|c|c|c|c|c|}
\hline Date & $\begin{array}{c}\text { Lead, } \\
\text { dissolved } \\
(\mu \mathrm{g} / \mathrm{L})\end{array}$ & $\begin{array}{c}\text { Manganese, } \\
\text { dissolved } \\
(\mu \mathrm{g} / \mathrm{L})\end{array}$ & $\begin{array}{c}\text { Manganese, } \\
\text { total } \\
\text { recoverable } \\
(\mu \mathrm{g} / \mathrm{L})\end{array}$ & $\begin{array}{l}\text { Lithium, } \\
\text { dissolved } \\
(\mu \mathrm{g} / \mathrm{L})\end{array}$ & $\begin{array}{l}\text { Mercury, } \\
\text { dissolved } \\
(\mu \mathrm{g} / \mathrm{L})\end{array}$ & $\begin{array}{c}\text { Nickel, } \\
\text { dissolved } \\
(\mu \mathrm{g} /)\end{array}$ & $\begin{array}{c}\text { Selenium, } \\
\text { dissolved } \\
(\mu \mathrm{g} / \mathrm{L})\end{array}$ & $\begin{array}{c}\text { Strontium, } \\
\text { dissolved } \\
(\mu \mathrm{g} / \mathrm{L})\end{array}$ & $\begin{array}{c}\text { Zinc, } \\
\text { dissolved } \\
(\mu \mathrm{g} / \mathrm{L})\end{array}$ \\
\hline $5 / 18 / 99$ & - & 171 & - & - & - & - & - & - & 83 \\
\hline 7/6/99 & - & 129 & - & - & - & - & - & - & 134 \\
\hline $8 / 3 / 99$ & - & - & - & - & - & - & - & - & - \\
\hline 9/9/99 & - & - & - & - & - & - & - & - & - \\
\hline $10 / 7 / 99$ & $<1.00$ & 16.0 & - & $<25.0$ & $<0.20$ & 17.6 & $<7.0$ & 118 & 70 \\
\hline $10 / 26 / 99$ & - & - & - & - & - & - & - & - & - \\
\hline $12 / 9 / 99$ & - & - & - & - & - & - & - & - & - \\
\hline $1 / 6 / 00$ & - & $<10.0$ & - & - & - & - & - & - & 55 \\
\hline 3/8/00 & - & - & - & - & - & - & - & - & - \\
\hline 3/16/00 & - & - & - & - & - & - & - & - & - \\
\hline $4 / 24 / 00$ & - & 34.0 & - & - & - & - & - & - & 919 \\
\hline $5 / 4 / 00$ & - & - & - & - & - & - & - & - & - \\
\hline $5 / 10 / 00$ & - & - & - & - & - & - & - & - & 91 \\
\hline $5 / 15 / 00$ & - & - & - & - & - & - & - & - & 300 \\
\hline $5 / 31 / 00$ & - & - & - & - & - & - & - & - & 59 \\
\hline $6 / 21 / 00$ & - & - & - & - & - & - & - & - & 69 \\
\hline $6 / 29 / 00$ & - & - & - & - & - & - & - & - & 159 \\
\hline $7 / 31 / 00$ & - & - & - & - & - & - & - & - & $<10$ \\
\hline $8 / 7 / 00$ & - & - & - & - & - & - & - & - & 75 \\
\hline 8/16/00 & - & - & - & - & - & - & - & - & 15 \\
\hline 9/6/00 & - & - & - & - & - & - & - & - & 34 \\
\hline $10 / 3 / 00$ & - & 83.0 & 82 & - & - & - & - & - & $<10$ \\
\hline $10 / 31 / 00$ & - & - & - & - & - & - & - & - & 20 \\
\hline $11 / 16 / 00$ & - & $<10.0$ & 41 & - & - & - & - & - & 20 \\
\hline $4 / 26 / 01$ & - & 135 & 154 & - & - & - & - & - & 122 \\
\hline $6 / 14 / 01$ & - & 193 & - & - & - & - & - & - & 159 \\
\hline $6 / 28 / 01$ & - & - & - & - & - & - & - & - & 15 \\
\hline 7/18/01 & - & 30.0 & 56 & - & - & - & - & - & $<10$ \\
\hline $8 / 22 / 01$ & - & - & - & - & - & - & - & - & $<10$ \\
\hline 9/27/01 & - & $<10.0$ & 36 & - & - & - & - & - & $<10$ \\
\hline $10 / 25 / 01$ & - & - & - & - & - & - & - & - & $<10$ \\
\hline $11 / 14 / 01$ & - & $<10.0$ & 310 & - & - & - & - & - & 21 \\
\hline $12 / 12 / 01$ & $<1.00$ & $<10.0$ & - & $<25.0$ & $<.20$ & 14.9 & $<7.0$ & 130 & 100 \\
\hline
\end{tabular}


Table 1-2. Results of chemical analyses of wet-precipitation samples collected at the New Garden Township spray-irrigation site, Chester County, Pennsylvania, August 1999 through December 2001.

$[\mu \mathrm{S} / \mathrm{cm}$, microsiemens per centimeter at 25 degrees Celsius; mg/L, milligrams per liter; $\mathrm{N}$, nitrogen, $\mathrm{P}$, phosphorus; $\mathrm{C}$, carbon; $\mu \mathrm{g} / \mathrm{L}, \mathrm{micrograms}$ per liter; —, no data; <, less than]

\begin{tabular}{|c|c|c|c|c|c|c|c|c|c|c|}
\hline Date & Time & $\begin{array}{c}\text { pH, field } \\
\text { (standard } \\
\text { units) }\end{array}$ & $\begin{array}{c}\text { Specific } \\
\text { conduct- } \\
\text { ance } \\
(\mu \mathrm{S} / \mathrm{cm})\end{array}$ & $\begin{array}{l}\text { Chloride, } \\
\text { dissolved } \\
\text { (mg/L) }\end{array}$ & $\begin{array}{c}\text { Nitrogen, } \\
\text { ammonia, } \\
\text { dissolved } \\
\text { (mg/L } \\
\text { as N) }\end{array}$ & $\begin{array}{c}\text { Nitrogen, } \\
\text { ammonia, } \\
\text { total } \\
\text { (mg/L } \\
\text { as N) }\end{array}$ & $\begin{array}{l}\text { Nitrogen, } \\
\text { dissolved } \\
\text { (mg/L) }\end{array}$ & $\begin{array}{c}\text { Nitrogen, } \\
\text { nitrate, } \\
\text { dissolved } \\
\text { (mg/L } \\
\text { as N) }\end{array}$ & $\begin{array}{c}\text { Nitrogen, } \\
\text { nitrate, } \\
\text { total } \\
\text { (mg/L } \\
\text { as N) }\end{array}$ & $\begin{array}{c}\text { Nitrogen, } \\
\text { nitrite, } \\
\text { dissolved } \\
\text { (mg/L } \\
\text { as N) }\end{array}$ \\
\hline 08/15/1999 & 0800 & - & - & - & - & 0.85 & - & - & 1.17 & - \\
\hline 08/26/1999 & 0745 & 4.9 & 7 & $<0.5$ & - & .20 & - & - & .08 & - \\
\hline 09/30/1999 & 0800 & 4.8 & 9 & .8 & - & .10 & - & - & .11 & - \\
\hline $11 / 03 / 1999$ & 0700 & - & - & 1.4 & - & .09 & - & - & .05 & - \\
\hline $12 / 06 / 1999$ & 1000 & 5.8 & 10 & $<.5$ & - & .18 & - & - & .15 & - \\
\hline $02 / 03 / 2000$ & 1000 & 5.1 & - & .8 & - & .04 & - & - & .17 & - \\
\hline 02/09/2000 & 0900 & 6.0 & 10 & .7 & - & .19 & - & - & .17 & - \\
\hline $03 / 11 / 2000$ & 2000 & 4.7 & 28 & .9 & - & .59 & - & - & .62 & - \\
\hline $04 / 18 / 2000$ & 0800 & 4.2 & 54 & 1.0 & - & .58 & - & - & .64 & - \\
\hline $05 / 11 / 2000$ & 0910 & 4.6 & - & $<.5$ & - & .46 & - & - & .41 & - \\
\hline $06 / 22 / 2000$ & 0940 & 4.8 & 14 & $<.5$ & - & .25 & - & - & .24 & - \\
\hline $07 / 26 / 2000$ & 1215 & 5.1 & 7 & $<.5$ & - & .04 & - & - & .11 & - \\
\hline 08/15/2000 & 0800 & 6.1 & 12 & .5 & 0.260 & - & 1.1 & 0.290 & - & $<0.040$ \\
\hline 09/13/2000 & 1240 & - & - & .6 & - & .46 & - & - & .32 & - \\
\hline $10 / 19 / 2000$ & 0800 & - & - & 3.4 & - & .75 & - & - & 1.09 & - \\
\hline $12 / 14 / 2000$ & 0930 & 5.0 & 19 & 1.2 & - & .15 & - & - & .30 & - \\
\hline $01 / 22 / 2001$ & 1000 & 7.3 & 24 & 1.7 & .140 & - & .46 & .250 & - & $<.040$ \\
\hline $01 / 30 / 2001$ & 1800 & 7.4 & 18 & .6 & - & .29 & - & - & .21 & - \\
\hline 03/16/2001 & 1000 & - & - & $<.5$ & - & .20 & - & - & .54 & - \\
\hline $03 / 21 / 2001$ & 1800 & 5.4 & 6 & .7 & - & .06 & - & - & .09 & - \\
\hline $05 / 22 / 2001$ & 1600 & 4.2 & 45 & .6 & - & .43 & - & - & .49 & - \\
\hline 07/10/2001 & 1700 & 3.6 & 69 & $<.5$ & - & .49 & - & - & .66 & - \\
\hline 09/20/2001 & 1700 & - & - & $<.5$ & - & .19 & - & - & .14 & - \\
\hline $12 / 08 / 2001$ & 2200 & 4.4 & 27 & $<.5$ & - & .30 & - & - & .53 & - \\
\hline
\end{tabular}


Table 1-2. Results of chemical analyses of wet-precipitation samples collected at the New Garden Township spray-irrigation site, Chester County, Pennsylvania, August 1999 through December 2001._Continued

$[\mu \mathrm{S} / \mathrm{cm}$, microsiemens per centimeter at 25 degrees Celsius; mg/L, milligrams per liter; N, nitrogen, $\mathrm{P}$, phosphorus; $\mathrm{C}$, carbon; $\mu \mathrm{g} / \mathrm{L}$, micrograms per liter; - , no data; <, less than]

\begin{tabular}{|c|c|c|c|c|c|c|c|c|c|c|}
\hline Date & Time & $\begin{array}{l}\text { Nitrogen, } \\
\text { nitrite, } \\
\text { total } \\
\text { (mg/L as N) }\end{array}$ & $\begin{array}{c}\text { Nitrogen, } \\
\text { total } \\
\text { (mg/L) }\end{array}$ & $\begin{array}{c}\text { Carbon, } \\
\text { organic, } \\
\text { total } \\
\text { (mg/L as C) }\end{array}$ & $\begin{array}{c}\text { Boron, } \\
\text { dissolved } \\
(\mu \mathrm{g} / \mathrm{L})\end{array}$ & $\begin{array}{l}\text { Boron, total } \\
\text { recoverable } \\
\quad(\mu \mathrm{g} / \mathrm{L})\end{array}$ & $\begin{array}{l}\text { Iron, total } \\
\text { recoverable } \\
\quad(\mu \mathrm{g} / \mathrm{L})\end{array}$ & $\begin{array}{c}\text { Manganese, } \\
\text { total } \\
\text { recoverable } \\
(\mu \mathrm{g} / \mathrm{L})\end{array}$ & $\begin{array}{c}\text { Zinc, } \\
\text { dissolved } \\
(\mu \mathrm{g} / \mathrm{L})\end{array}$ & $\begin{array}{c}\text { Zinc, total } \\
\text { recoverable } \\
(\mu \mathrm{g} / \mathrm{L})\end{array}$ \\
\hline 08/15/1999 & 0800 & $<0.04$ & 5.3 & - & - & - & - & - & - & - \\
\hline 08/26/1999 & 0745 & $<.04$ & .64 & $<1.0$ & - & $<200$ & $<20$ & 13 & - & $<10$ \\
\hline 09/30/1999 & 0800 & $<.04$ & .39 & - & - & - & - & - & - & $<10$ \\
\hline 11/03/1999 & 0700 & $<.04$ & .34 & - & - & - & - & - & - & $<10$ \\
\hline 12/06/1999 & 1000 & $<.04$ & .59 & - & - & - & - & - & - & $<10$ \\
\hline 02/03/2000 & 1000 & $<.01$ & .33 & - & - & - & - & - & - & 14 \\
\hline 02/09/2000 & 0900 & $<.04$ & .79 & - & - & - & - & - & - & 12 \\
\hline 03/11/2000 & 2000 & $<.04$ & 1.6 & 2.3 & - & $<200$ & 100 & $<10$ & - & $<10$ \\
\hline 04/18/2000 & 0800 & $<.04$ & 1.3 & - & - & - & - & - & - & 14 \\
\hline 05/11/2000 & 0910 & $<.04$ & 1.6 & - & - & - & - & - & - & 17 \\
\hline 06/22/2000 & 0940 & $<.04$ & .55 & - & - & - & - & - & - & 65 \\
\hline 07/26/2000 & 1215 & $<.04$ & .35 & - & - & - & - & - & - & 21 \\
\hline 08/15/2000 & 0800 & - & - & - & $<200$ & - & - & - & 462 & - \\
\hline 09/13/2000 & 1240 & $<.04$ & 1.0 & - & - & - & - & - & - & 15 \\
\hline $10 / 19 / 2000$ & 0800 & $<.04$ & 2.1 & - & - & - & - & - & - & 528 \\
\hline $12 / 14 / 2000$ & 0930 & $<.04$ & .62 & - & - & - & - & - & - & 91 \\
\hline 01/22/2001 & 1000 & - & - & - & $<200$ & - & - & - & 11 & - \\
\hline $01 / 30 / 2001$ & 1800 & $<.04$ & .66 & 1.8 & - & $<200$ & 30 & $<10$ & - & 102 \\
\hline 03/16/2001 & 1000 & $<.04$ & .83 & - & - & - & - & - & - & 61 \\
\hline $03 / 21 / 2001$ & 1800 & $<.04$ & .29 & 1.3 & - & $<200$ & 20 & $<10$ & - & 95 \\
\hline 05/22/2001 & 1600 & $<.04$ & 1.1 & - & - & - & - & - & - & 149 \\
\hline 07/10/2000 & 1700 & $<.04$ & 1.2 & 2.6 & - & $<200$ & $<20$ & $<10$ & - & 10 \\
\hline 09/20/2001 & 1700 & $<.04$ & .34 & $<1.0$ & - & $<200$ & 20 & $<10$ & - & 11 \\
\hline 12/08/2001 & 2200 & $<.04$ & 1.1 & - & - & - & - & - & - & $<10$ \\
\hline
\end{tabular}


Table 1-3. Results of chemical analyses of dry-deposition samples collected at the New Garden Township spray-irrigation site, Chester County, Pennsylvania, November 1999 through October 2001.

[L, liters; mg/L, milligrams per liter; $\mu \mathrm{g} / \mathrm{L}$, micrograms per liter; N, nitrogen; C, carbon; —, no data; <, less than]

\begin{tabular}{|c|c|c|c|c|c|c|c|}
\hline Date & Time & $\begin{array}{c}\text { Rinse } \\
\text { volume } \\
\text { (L) }\end{array}$ & $\begin{array}{c}\text { Deposition } \\
\text { interval } \\
\text { (days) }^{2}\end{array}$ & $\begin{array}{c}\text { Nitrogen, } \\
\text { ammonia, } \\
\text { total } \\
\text { (mg/L as N) }\end{array}$ & $\begin{array}{c}\text { Nitrogen, } \\
\text { nitrate, } \\
\text { total } \\
\text { (mg/L as } \mathrm{N} \text { ) }\end{array}$ & $\begin{array}{c}\text { Nitrogen, } \\
\text { nitrite, total } \\
\text { (mg/L as N) }\end{array}$ & $\begin{array}{c}\text { Nitrogen, } \\
\text { total } \\
\text { (mg/L) }\end{array}$ \\
\hline $11 / 02 / 1999$ & 0705 & 1.2 & 3.89 & 0.08 & 0.08 & $<0.04$ & 0.62 \\
\hline 01/19/2000 & 1000 & 1.1 & 8.88 & .08 & .04 & $<.04$ & .26 \\
\hline 03/16/2000 & 1005 & 1.2 & 3.07 & .04 & $<.04$ & $<.04$ & $<.06$ \\
\hline 05/10/2000 & 1050 & 1.1 & 1.98 & $<.02$ & .06 & $<.04$ & .32 \\
\hline 09/11/2000 & 1100 & .8 & 5.01 & .05 & .14 & $<.04$ & .27 \\
\hline $10 / 31 / 2000$ & 0810 & 1.4 & 4.88 & $<.02$ & $<.04$ & $<.04$ & .16 \\
\hline $04 / 26 / 2001$ & 1040 & 1.5 & .92 & $<.02$ & $<.04$ & $<.04$ & $<.06$ \\
\hline 06/27/2001 & 1200 & 1.2 & 2.10 & .02 & .04 & $<.04$ & .16 \\
\hline 09/18/2001 & 1200 & 1.5 & 1.06 & $<.02$ & $<.04$ & $<.04$ & .11 \\
\hline $10 / 11 / 2001$ & 1130 & 1.4 & 2.10 & .08 & $<.04$ & $<.04$ & $<.06$ \\
\hline
\end{tabular}

${ }^{1}$ Rinse volume is the amount of inorganic free water used to capture particles on the surface of the bulk-deposition sampler.

${ }^{2}$ The deposition interval is the length of time between cleaning the bulk-deposition sampler and retrieving a dry-deposition sample.

\begin{tabular}{|c|c|c|c|c|c|c|c|}
\hline Date & Time & $\begin{array}{c}\text { Chloride, } \\
\text { dissolved } \\
\text { (mg/L) }\end{array}$ & $\begin{array}{l}\text { Carbon, } \\
\text { organic, } \\
\text { total } \\
\text { (mg/L as C) }\end{array}$ & $\begin{array}{c}\text { Boron, total } \\
\text { recoverable } \\
(\mu \mathrm{g} / \mathrm{L})\end{array}$ & $\begin{array}{c}\text { Iron, total } \\
\text { recoverable } \\
(\mu \mathrm{g} / \mathrm{L})\end{array}$ & $\begin{array}{c}\text { Manganese, } \\
\text { total } \\
\text { recoverable } \\
(\mu \mathrm{g} / \mathrm{L})\end{array}$ & $\begin{array}{c}\text { Zinc, total } \\
\text { recoverable } \\
(\mu \mathrm{g} / \mathrm{L})\end{array}$ \\
\hline $11 / 02 / 1999$ & 0705 & $<0.5$ & - & - & - & - & $<10$ \\
\hline $01 / 19 / 2000$ & 1000 & $<.5$ & - & - & - & - & $<10$ \\
\hline $03 / 16 / 2000$ & 1005 & $<.5$ & - & - & - & - & $<10$ \\
\hline $05 / 10 / 2000$ & 1050 & $<.5$ & - & - & - & - & $<10$ \\
\hline $09 / 11 / 2000$ & 1100 & $<.5$ & - & - & - & - & $<10$ \\
\hline $10 / 31 / 2000$ & 0810 & $<.5$ & - & - & - & - & 11 \\
\hline $04 / 26 / 2001$ & 1040 & $<.5$ & 1.1 & $<200$ & 50 & $<10$ & 27 \\
\hline $06 / 27 / 2001$ & 1200 & .6 & - & - & - & - & 18 \\
\hline 09/18/2001 & 1200 & $<.5$ & $<1.0$ & $<200$ & $<20$ & $<10$ & $<10$ \\
\hline $10 / 11 / 2001$ & 1130 & $<.5$ & - & - & - & - & $<10$ \\
\hline
\end{tabular}


Table 1-4. Chemical and physical properties of soil samples collected at the New Garden Township spray-irrigation site, New Garden Township, Pennsylvania, April 1999 through October 2001.

$\left[\mathrm{g} / \mathrm{cm}^{3}\right.$, grams per cubic centimeter; mv, millivolts; $\mathrm{mg} / \mathrm{kg}$, milligrams per kilogram; $\mathrm{N}$, nitrogen; $\mathrm{CaCO}_{3}$, calcium carbonate; ppm, parts per million; >, greater than; <, less than; - , no data]

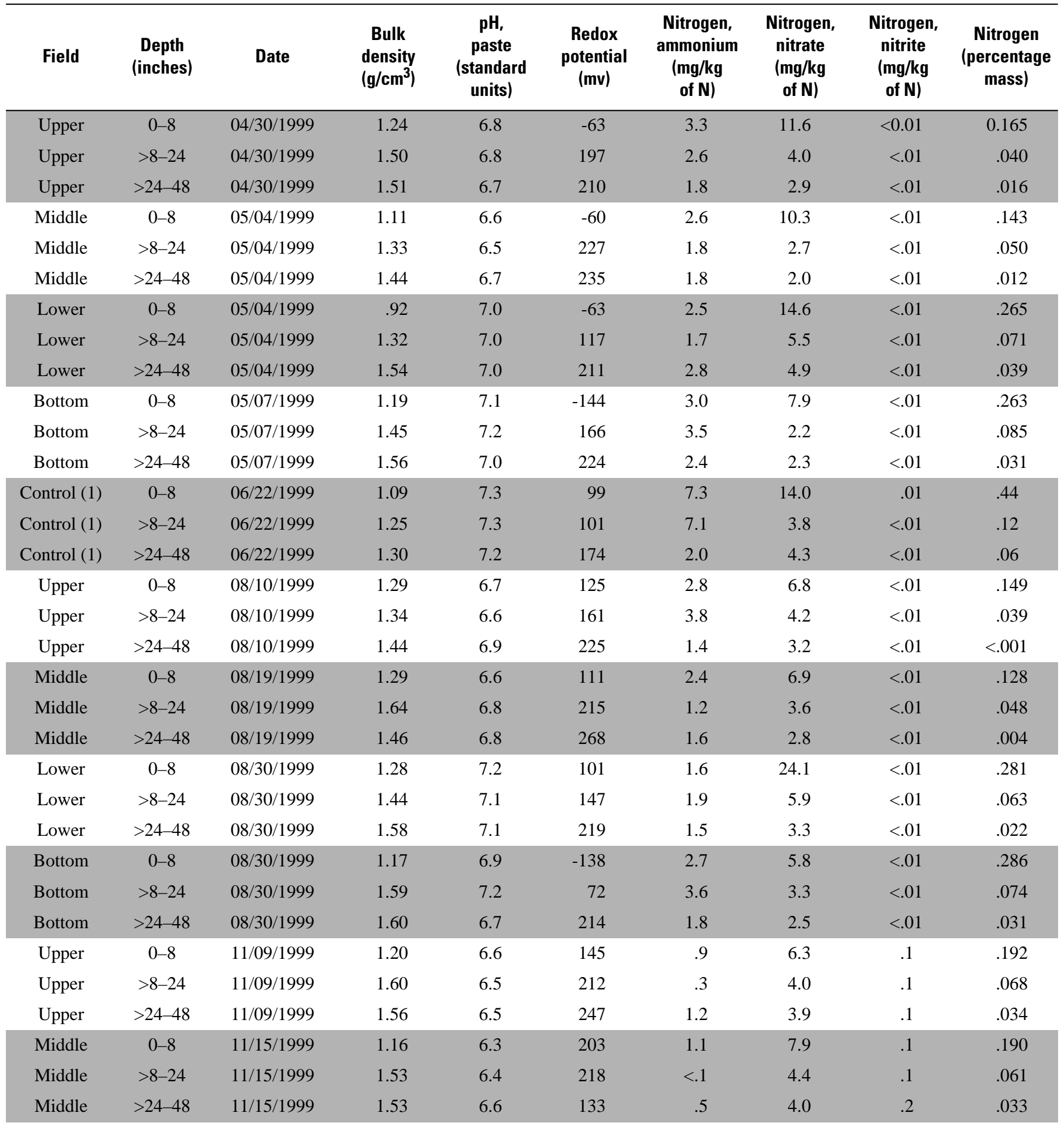


Table 1-4. Chemical and physical properties of soil samples collected at the New Garden Township spray-irrigation site, New Garden Township, Pennsylvania, April 1999 through October 2001.-Continued

$\left[\mathrm{g} / \mathrm{cm}^{3}\right.$, grams per cubic centimeter; mv, millivolts; $\mathrm{mg} / \mathrm{kg}$, milligrams per kilogram; $\mathrm{N}$, nitrogen; $\mathrm{CaCO}_{3}$, calcium carbonate; ppm, parts per million; >, greater than; $<$, less than; - , no data]

\begin{tabular}{|c|c|c|c|c|c|c|c|c|}
\hline Field & $\begin{array}{c}\text { Depth } \\
\text { (inches) }\end{array}$ & Date & $\begin{array}{c}\text { Carbon } \\
\text { (percentage } \\
\text { mass) }\end{array}$ & $\begin{array}{c}\mathrm{CaCO}_{3} \\
\text { equivalents } \\
\text { (percentage } \\
\text { mass) }\end{array}$ & $\begin{array}{c}\text { Chloride } \\
\text { (water } \\
\text { extractable, } \\
\text { mg/kg) }\end{array}$ & $\begin{array}{c}\text { Iron } \\
\text { (extractable, } \\
\text { ppm) }{ }^{1}\end{array}$ & $\begin{array}{c}\text { Manganese } \\
\text { (extractable, } \\
\text { ppm) }{ }^{1}\end{array}$ & $\begin{array}{c}\text { Zinc } \\
\text { (extractable, } \\
{\text { ppm })^{1}}^{1}\end{array}$ \\
\hline Upper & $0-8$ & 04/30/1999 & 1.60 & 0.6 & 86.6 & 40.7 & 12.3 & 1.90 \\
\hline Upper & $>8-24$ & 04/30/1999 & .370 & .3 & 89.7 & 12.8 & 2.93 & .15 \\
\hline Upper & $>24-48$ & 04/30/1999 & .180 & .2 & 57.6 & 6.85 & 1.47 & .06 \\
\hline Middle & $0-8$ & 05/04/1999 & 1.45 & .2 & 79.2 & 47.0 & 10.1 & 2.53 \\
\hline Middle & $>8-24$ & 05/04/1999 & .340 & .3 & 75.7 & 14.3 & 3.71 & .28 \\
\hline Middle & $>24-48$ & 05/04/1999 &. .272 & .3 & 88.6 & 7.70 & 1.20 & .11 \\
\hline Lower & $0-8$ & 05/04/1999 & 2.47 & .5 & 11.7 & 9.60 & 9.21 & 7.85 \\
\hline Lower & $>8-24$ & 05/04/1999 & .663 & .2 & 44.2 & 31.5 & 3.98 & 1.48 \\
\hline Lower & $>24-48$ & 05/04/1999 & .334 & .3 & 110.9 & 13.9 & 2.58 & .34 \\
\hline Bottom & $0-8$ & 05/07/1999 & 2.44 & .5 & 98.7 & 78.3 & 10.4 & 5.88 \\
\hline Bottom & $>8-24$ & 05/07/1999 & .648 & .3 & 117.4 & 23.1 & 4.23 & .39 \\
\hline Bottom & $>24-48$ & 05/07/1999 & .374 & .3 & 82.6 & 15.6 & 1.76 & .11 \\
\hline Control (1) & $0-8$ & 06/22/1999 & 3.97 & .4 & 115 & 135 & 14.4 & 14.6 \\
\hline Control (1) & $>8-24$ & 06/22/1999 & .73 & .3 & 102 & 46.4 & 5.66 & 1.53 \\
\hline Control (1) & $>24-48$ & 06/22/1999 & .29 & .2 & 143 & 20.9 & 3.25 & .50 \\
\hline Upper & $0-8$ & 08/10/1999 & - & - & - & - & - & - \\
\hline Upper & $>8-24$ & 08/10/1999 & - & - & - & - & - & - \\
\hline Upper & $>24-48$ & 08/10/1999 & - & - & - & - & - & - \\
\hline Middle & $0-8$ & 08/19/1999 & - & - & - & - & - & - \\
\hline Middle & $>8-24$ & 08/19/1999 & - & - & - & - & - & - \\
\hline Middle & $>24-48$ & 08/19/1999 & - & - & - & - & - & - \\
\hline Lower & $0-8$ & 08/30/1999 & - & - & - & - & - & - \\
\hline Lower & $>8-24$ & 08/30/1999 & - & - & - & - & - & - \\
\hline Lower & $>24-48$ & 08/30/1999 & - & - & - & - & - & - \\
\hline Bottom & $0-8$ & 08/30/1999 & - & - & - & - & - & - \\
\hline Bottom & $>8-24$ & 08/30/1999 & - & - & - & - & - & - \\
\hline Bottom & $>24-48$ & 08/30/1999 & - & - & - & - & - & - \\
\hline Upper & $0-8$ & 11/09/1999 & 1.66 & .53 & 153 & 55.7 & 11.7 & 3.98 \\
\hline Upper & $>8-24$ & 11/09/1999 & .39 & .69 & 119 & 19.5 & 3.95 & .50 \\
\hline Upper & $>24-48$ & 11/09/1999 & .13 & .81 & 91.5 & 14.9 & 2.01 & .30 \\
\hline Middle & $0-8$ & 11/15/1999 & 1.61 & .56 & 139 & 109 & 12.3 & 3.54 \\
\hline Middle & $>8-24$ & 11/15/1999 & .41 & .49 & 101 & 21.8 & 4.54 & .56 \\
\hline Middle & $>24-48$ & 11/15/1999 & .02 & .51 & 62.1 & 16.1 & 1.84 & .47 \\
\hline
\end{tabular}

${ }^{1}$ Iron, manganese, and zinc were extracted with Ammonium bicarbonate diethylenetriaminepentaacetic acid (AB-DTPA). 
Table 1-4. Chemical and physical properties of soil samples collected at the New Garden Township spray-irrigation site, New Garden Township, Pennsylvania, April 1999 through October 2001.-Continued

$\left[\mathrm{g} / \mathrm{cm}^{3}\right.$, grams per cubic centimeter; mv, millivolts; $\mathrm{mg} / \mathrm{kg}$, milligrams per kilogram; $\mathrm{N}$, nitrogen; $\mathrm{CaCO}_{3}$, calcium carbonate; ppm, parts per million; >, greater than; <, less than; - , no data]

\begin{tabular}{|c|c|c|c|c|c|c|c|c|c|}
\hline Field & $\begin{array}{c}\text { Depth } \\
\text { (inches) }\end{array}$ & Date & $\begin{array}{c}\text { Bulk } \\
\text { density } \\
\left(\mathrm{g} / \mathrm{cm}^{3}\right)\end{array}$ & $\begin{array}{c}\text { pH, } \\
\text { paste } \\
\text { (standard } \\
\text { units) }\end{array}$ & $\begin{array}{c}\text { Redox } \\
\text { potential } \\
\text { (mv) }\end{array}$ & $\begin{array}{c}\text { Nitrogen, } \\
\text { ammonium } \\
\text { (mg/kg } \\
\text { of } \mathrm{N})\end{array}$ & $\begin{array}{c}\text { Nitrogen, } \\
\text { nitrate } \\
\text { (mg/kg } \\
\text { of } \mathrm{N} \text { ) }\end{array}$ & $\begin{array}{c}\text { Nitrogen, } \\
\text { nitrite } \\
\text { ( } \mathrm{mg} / \mathrm{kg} \\
\text { of } \mathrm{N} \text { ) }\end{array}$ & $\begin{array}{c}\text { Nitrogen } \\
\text { (percentage } \\
\text { mass) }\end{array}$ \\
\hline Lower & $0-8$ & $11 / 23 / 1999$ & 1.25 & 7.2 & 127 & 1.3 & 8.1 & 0.2 & 0.327 \\
\hline Lower & $>8-24$ & 11/23/1999 & 1.38 & 6.9 & 152 & .5 & 5.4 & .1 & .122 \\
\hline Control (1) & $>8-24$ & 12/01/1999 & 1.37 & 7.0 & 186 & .2 & 4.0 & .2 & .104 \\
\hline Control (1) & $>24-48$ & 12/01/1999 & 1.28 & 7.0 & 144 & .1 & 5.0 & .4 & .035 \\
\hline Control (2) & $0-8$ & 12/01/1999 & 1.19 & 7.2 & 93 & .9 & 6.4 & .1 & .288 \\
\hline Control (2) & $>8-24$ & 12/01/1999 & 1.56 & 7.0 & 201 & .4 & 5.5 & .2 & .130 \\
\hline Bottom & $>24-48$ & 12/03/1999 & 2.61 & 6.9 & 127 & .5 & 4.5 & .2 & .072 \\
\hline Upper & $0-8$ & $04 / 20 / 2000$ & 1.30 & 6.7 & 51.5 & 3.3 & 6.3 & $<.01$ & .120 \\
\hline Upper & $>8-24$ & 04/20/2000 & 1.49 & 6.6 & 155 & 2.4 & 2.6 & $<.01$ & .052 \\
\hline Upper & $>24-48$ & 04/20/2000 & 1.39 & 6.7 & 198 & 1.4 & 2.5 & $<.01$ & .018 \\
\hline Control (1) & $0-8$ & $04 / 24 / 2000$ & 1.14 & 7.1 & -69.9 & 3.4 & 6.1 & $<.01$ & .005 \\
\hline Control (1) & $>8-24$ & $04 / 24 / 2000$ & 1.52 & 7.1 & 166 & 2.6 & 3.2 & $<.01$ & .549 \\
\hline Control (1) & $>24-48$ & $04 / 24 / 2000$ & 1.32 & 7.1 & 126 & 4.0 & 2.4 & $<.01$ & .022 \\
\hline Middle & $0-8$ & $04 / 26 / 2000$ & 1.28 & 6.9 & 61 & 3.6 & 7.0 & $<.01$ & .136 \\
\hline Bottom & $0-8$ & 04/27/2000 & 1.13 & 7.1 & 99 & 4.2 & 3.9 & $<.01$ & .327 \\
\hline Bottom & $>8-24$ & 04/27/2000 & 1.53 & 7.0 & 13.8 & 2.9 & 2.1 & $<.01$ & .073 \\
\hline Bottom & $>24-48$ & $04 / 27 / 2000$ & 1.49 & 6.9 & 238 & 2.2 & 1.5 & $<.01$ & .039 \\
\hline Lower & $0-8$ & $04 / 27 / 2000$ & 1.18 & 7.1 & 101 & 3.2 & 7.5 & $<.01$ & .159 \\
\hline Lower & $>8-24$ & 04/27/2000 & 1.53 & 6.8 & 201 & 3.8 & 5.8 & $<.01$ & .044 \\
\hline Lower & $>24-48$ & $04 / 27 / 2000$ & 1.57 & 6.9 & 244 & 5.8 & 3.4 & $<.01$ & .022 \\
\hline
\end{tabular}


Table 1-4. Chemical and physical properties of soil samples collected at the New Garden Township spray-irrigation site, New Garden Township, Pennsylvania, April 1999 through October 2001.-Continued

$\left[\mathrm{g} / \mathrm{cm}^{3}\right.$, grams per cubic centimeter; mv, millivolts; $\mathrm{mg} / \mathrm{kg}$, milligrams per kilogram; $\mathrm{N}$, nitrogen; $\mathrm{CaCO}_{3}$, calcium carbonate; ppm, parts per million; >, greater than; <, less than; - , no data]

\begin{tabular}{|c|c|c|c|c|c|c|c|c|}
\hline Field & $\begin{array}{c}\text { Depth } \\
\text { (inches) }\end{array}$ & Date & $\begin{array}{c}\text { Carbon } \\
\text { (percentage } \\
\text { mass) }\end{array}$ & $\begin{array}{c}\mathrm{CaCO}_{3} \\
\text { equivalents } \\
\text { (percentage } \\
\text { mass) }\end{array}$ & $\begin{array}{c}\text { Chloride } \\
\text { (water } \\
\text { extractable, } \\
\text { mg/kg) }\end{array}$ & $\begin{array}{c}\text { Iron } \\
\text { (extractable, } \\
\text { ppm) }{ }^{1}\end{array}$ & $\begin{array}{c}\text { Manganese } \\
\text { (extractable, } \\
\text { ppm) }{ }^{1}\end{array}$ & $\begin{array}{c}\text { Zinc } \\
\text { (extractable, } \\
\text { ppm) }{ }^{1}\end{array}$ \\
\hline Lower & $0-8$ & $11 / 23 / 1999$ & 2.76 & 1.03 & 98.3 & 140 & 16.3 & 10.0 \\
\hline Lower & $>8-24$ & 11/23/1999 & .70 & .52 & 75.3 & 52.4 & 5.14 & 1.46 \\
\hline Lower & $>24-48$ & 11/23/1999 & .22 & $<.01$ & 136 & 21.6 & .97 & .41 \\
\hline Control (1) & $0-8$ & 12/01/1999 & 2.76 & .64 & 183 & 153 & 13.5 & 10.4 \\
\hline Control (1) & $>8-24$ & 12/01/1999 & .44 & .38 & 73 & 33.1 & 3.91 & .96 \\
\hline Control (1) & $>24-48$ & 12/01/1999 & .14 & .09 & 95 & 17.5 & 1.63 & .36 \\
\hline Control (2) & $0-8$ & 12/01/1999 & 2.16 & .52 & 168 & 140 & 9.32 & 5.60 \\
\hline Control (2) & $>8-24$ & 12/01/1999 & .77 & .48 & 97.3 & 62.3 & 4.40 & 1.87 \\
\hline Control (2) & $>24-48$ & 12/01/1999 & .20 & 1.02 & 58.3 & 17.9 & .67 & .38 \\
\hline Bottom & $0-8$ & $12 / 03 / 1999$ & 2.56 & .69 & 152 & 151 & 14.7 & 7.69 \\
\hline Bottom & $>8-24$ & 12/03/1999 & 1.04 & .28 & 157 & 104 & 9.76 & 1.98 \\
\hline Bottom & $>24-48$ & 12/03/1999 & .31 & .25 & 86.7 & 39.4 & 2.11 & .69 \\
\hline Upper & $0-8$ & $04 / 20 / 2000$ & - & - & - & - & - & - \\
\hline Upper & $>8-24$ & $04 / 20 / 2000$ & - & - & - & - & - & - \\
\hline Upper & $>24-48$ & $04 / 20 / 2000$ & - & - & - & - & - & - \\
\hline Control (1) & $0-8$ & $04 / 24 / 2000$ & - & - & - & - & - & - \\
\hline Control (1) & $>8-24$ & $04 / 24 / 2000$ & 一 & - & - & - & - & 一 \\
\hline Control (1) & $>24-48$ & $04 / 24 / 2000$ & - & - & - & - & - & - \\
\hline Middle & $0-8$ & $04 / 26 / 2000$ & - & - & - & - & - & - \\
\hline Middle & $>8-24$ & $04 / 26 / 2000$ & 一 & - & - & - & - & - \\
\hline Middle & $>24-48$ & $04 / 26 / 2000$ & - & - & - & - & - & - \\
\hline Control (2) & $0-8$ & $04 / 26 / 2000$ & - & - & - & - & - & - \\
\hline Control (2) & $>8-24$ & $04 / 26 / 2000$ & 一 & - & 一 & - & 一 & 一 \\
\hline Control (2) & $>24-48$ & $04 / 26 / 2000$ & - & - & - & - & - & - \\
\hline Bottom & $0-8$ & $04 / 27 / 2000$ & - & - & - & - & - & - \\
\hline Bottom & $>8-24$ & $04 / 27 / 2000$ & - & - & - & - & - & - \\
\hline Bottom & $>24-48$ & $04 / 27 / 2000$ & - & - & - & - & - & - \\
\hline Lower & $0-8$ & $04 / 27 / 2000$ & - & - & - & - & - & - \\
\hline Lower & $>8-24$ & $04 / 27 / 2000$ & - & - & - & - & - & - \\
\hline Lower & $>24-48$ & $04 / 27 / 2000$ & - & - & - & - & - & - \\
\hline
\end{tabular}

${ }^{1}$ Iron, manganese, and zinc were extracted with Ammonium bicarbonate diethylenetriaminepentaacetic acid (AB-DTPA). 
Table 1-4. Chemical and physical properties of soil samples collected at the New Garden Township spray-irrigation site, New Garden Township, Pennsylvania, April 1999 through October 2001.-Continued

$\left[\mathrm{g} / \mathrm{cm}^{3}\right.$, grams per cubic centimeter; mv, millivolts; $\mathrm{mg} / \mathrm{kg}$, milligrams per kilogram; $\mathrm{N}$, nitrogen; $\mathrm{CaCO}_{3}$, calcium carbonate; ppm, parts per million; >, greater than; <, less than; - , no data]

\begin{tabular}{|c|c|c|c|c|c|c|c|c|c|}
\hline Field & $\begin{array}{c}\text { Depth } \\
\text { (inches) }\end{array}$ & Date & $\begin{array}{c}\text { Bulk } \\
\text { density } \\
\left(\mathrm{g} / \mathrm{cm}^{3}\right)\end{array}$ & $\begin{array}{c}\text { pH, } \\
\text { paste } \\
\text { (standard } \\
\text { units) }\end{array}$ & $\begin{array}{c}\text { Redox } \\
\text { potential } \\
\text { (mv) }\end{array}$ & $\begin{array}{l}\text { Nitrogen, } \\
\text { ammonium } \\
\text { (mg/kg } \\
\text { of } \mathrm{N})\end{array}$ & $\begin{array}{c}\text { Nitrogen, } \\
\text { nitrate } \\
\text { (mg/kg } \\
\text { of } \mathrm{N} \text { ) }\end{array}$ & $\begin{array}{l}\text { Nitrogen, } \\
\text { nitrite } \\
\text { (mg/kg } \\
\text { of } \mathrm{N} \text { ) }\end{array}$ & $\begin{array}{c}\text { Nitrogen } \\
\text { (percentage } \\
\text { mass) }\end{array}$ \\
\hline Upper & $0-8$ & $07 / 13 / 2000$ & 1.25 & 6.8 & -13.5 & 4.1 & 14.1 & 0.2 & 0.394 \\
\hline Upper & $>8-24$ & $07 / 13 / 2000$ & 1.43 & 6.5 & 194 & 2.3 & 4.6 & .2 & .044 \\
\hline Middle & $>8-24$ & $07 / 18 / 2000$ & 1.43 & 6.6 & 200 & 2.6 & 3.9 & .2 & .051 \\
\hline Middle & $>24-48$ & $07 / 18 / 2000$ & 1.46 & 6.6 & 235 & 2.0 & 3.4 & .2 & .034 \\
\hline Lower & $0-8$ & 07/19/2000 & 1.22 & 7.1 & -34 & 3.5 & 10.8 & .2 & .297 \\
\hline Lower & $>8-24$ & 07/19/2000 & 1.34 & 6.7 & 190 & 2.8 & 4.9 & .2 & .054 \\
\hline Bottom & $>24-48$ & $10 / 26 / 2000$ & 1.37 & 6.9 & 259 & 2.7 & 1.2 & .3 & .024 \\
\hline Upper & $0-8$ & $11 / 01 / 2000$ & 1.32 & 7.1 & 68 & 2.5 & 3.9 & .1 & .127 \\
\hline Upper & $>8-24$ & $11 / 01 / 2000$ & 1.46 & 6.6 & 256 & 2.0 & 2.1 & .2 & .028 \\
\hline Upper & $>24-48$ & $11 / 01 / 2000$ & 1.52 & 6.7 & 265 & 1.9 & 2.0 & .1 & .012 \\
\hline Middle & $0-8$ & $11 / 08 / 2000$ & 1.36 & 6.9 & 49 & 2.7 & 6.2 & .1 & .112 \\
\hline Middle & $>8-24$ & $11 / 08 / 2000$ & 1.45 & 6.7 & 192 & 2.4 & 3.2 & .1 & .053 \\
\hline Middle & $>24-48$ & $11 / 08 / 2000$ & 1.40 & 6.6 & 194 & 2.0 & 2.4 & .1 & .003 \\
\hline Control (1) & $0-8$ & $12 / 05 / 2000$ & 1.41 & 7.2 & -114 & 3.8 & 5.4 & .1 & .264 \\
\hline Lower & $0-8$ & $12 / 11 / 2000$ & 1.29 & 6.8 & 72 & 3.3 & 3.7 & .1 & .129 \\
\hline Lower & $>8-24$ & $12 / 11 / 2000$ & 1.38 & 6.8 & 191 & 2.8 & 2.4 & .1 & .067 \\
\hline Lower & $>24-48$ & $12 / 11 / 2000$ & 1.47 & 6.8 & 284 & 2.1 & 1.2 & .1 & .025 \\
\hline MZ2 & $0-8$ & $03 / 20 / 2001$ & - & 7.0 & -704 & 7.5 & 159 & $<.1$ & .799 \\
\hline MZ2 & $0-8$ & 03/20/2001 & - & 6.8 & -2244 & 4.4 & 46.3 & $<.1$ & .917 \\
\hline MZ6 & $0-16$ & 03/20/2001 & - & 7.1 & -364 & 7.3 & 298 & $<.1$ & 1.438 \\
\hline MZ6 & $0-16$ & 03/20/2001 & - & 7.2 & -544 & 7.3 & 213 & $<.1$ & 1.155 \\
\hline
\end{tabular}


Table 1-4. Chemical and physical properties of soil samples collected at the New Garden Township spray-irrigation site, New Garden Township, Pennsylvania, April 1999 through October 2001.-Continued

$\left[\mathrm{g} / \mathrm{cm}^{3}\right.$, grams per cubic centimeter; mv, millivolts; $\mathrm{mg} / \mathrm{kg}$, milligrams per kilogram; $\mathrm{N}$, nitrogen; $\mathrm{CaCO}_{3}$, calcium carbonate; ppm, parts per million; >, greater than; <, less than; - , no data]

\begin{tabular}{|c|c|c|c|c|c|c|c|c|}
\hline Field & $\begin{array}{c}\text { Depth } \\
\text { (inches) }\end{array}$ & Date & $\begin{array}{c}\text { Carbon } \\
\text { (percentage } \\
\text { mass) }\end{array}$ & $\begin{array}{c}\mathrm{CaCO}_{3} \\
\text { equivalents } \\
\text { (percentage } \\
\text { mass) }\end{array}$ & $\begin{array}{c}\text { Chloride } \\
\text { (water } \\
\text { extractable, } \\
\text { mg/kg) }\end{array}$ & $\begin{array}{c}\text { Iron } \\
\text { (extractable, } \\
\text { ppm) }^{1}\end{array}$ & $\begin{array}{c}\text { Manganese } \\
\text { (extractable, } \\
\text { ppm) }\end{array}$ & $\begin{array}{c}\text { Zinc } \\
\text { (extractable, } \\
{\text { ppm })^{1}}^{1}\end{array}$ \\
\hline Upper & $0-8$ & $07 / 13 / 2000$ & 4.03 & - & 112 & 49.4 & 19.3 & 1.9 \\
\hline Upper & $>8-24$ & $07 / 13 / 2000$ & .408 & - & 96.6 & 19.0 & 7.40 & $<.1$ \\
\hline Upper & $>24-48$ & $07 / 13 / 2000$ & .212 & - & 83.6 & 10.2 & 3.20 & $<.1$ \\
\hline Middle & $0-8$ & $07 / 18 / 2000$ & 1.80 & - & 84.8 & 63.0 & 16.4 & 3.5 \\
\hline Middle & $>8-24$ & $07 / 18 / 2000$ & .379 & - & 90.0 & 18.6 & 5.80 & .1 \\
\hline Middle & $>24-48$ & $07 / 18 / 2000$ & .112 & - & 120 & 10.8 & 2.50 & $<.1$ \\
\hline Lower & $0-8$ & $07 / 19 / 2000$ & 2.66 & - & 138 & 113 & 16.2 & 8.1 \\
\hline Lower & $>8-24$ & $07 / 19 / 2000$ & .403 & - & 90.2 & 22.1 & 5.40 & .1 \\
\hline Lower & $>24-48$ & $07 / 19 / 2000$ & .180 & - & 112 & 13.2 & 1.60 & $<.1$ \\
\hline Bottom & $0-8$ & $10 / 26 / 2000$ & 2.86 & - & 13.0 & 174 & 10.1 & 12.6 \\
\hline Bottom & $>8-24$ & $10 / 26 / 2000$ & .432 & - & 22.8 & 40.8 & 3.20 & .51 \\
\hline Bottom & $>24-48$ & $10 / 26 / 2000$ & .156 & - & 21.7 & 20.8 & 1.04 & .08 \\
\hline Upper & $0-8$ & $11 / 01 / 2000$ & 1.32 & - & 24.2 & 50.9 & 10.3 & 1.16 \\
\hline Upper & $>8-24$ & $11 / 01 / 2000$ & .247 & - & 37.0 & 17.6 & 1.82 & .07 \\
\hline Upper & $>24-48$ & $11 / 01 / 2000$ & .126 & - & 29.9 & 15.7 & .89 & .02 \\
\hline Middle & $0-8$ & $11 / 08 / 2000$ & 1.13 & - & 20.7 & 54.5 & 5.63 & 1.44 \\
\hline Middle & $>8-24$ & $11 / 08 / 2000$ & .317 & - & 23.6 & 18.8 & 2.94 & .12 \\
\hline Middle & $>24-48$ & $11 / 08 / 2000$ & .074 & - & 10.3 & 14.4 & .87 & .18 \\
\hline Control (1) & $0-8$ & $12 / 05 / 2000$ & .436 & - & 18.1 & 25.4 & 3.12 & .65 \\
\hline Control (1) & $>8-24$ & $12 / 05 / 2000$ & 2.70 & - & 13.8 & 127 & 9.20 & 9.27 \\
\hline Control (1) & $>24-48$ & $12 / 05 / 2000$ & .127 & - & 17.3 & 13.7 & 1.40 & .31 \\
\hline Control (2) & $0-8$ & $12 / 05 / 2000$ & .979 & - & 15.0 & 62.8 & 4.92 & 1.66 \\
\hline Control (2) & $>8-24$ & $12 / 05 / 2000$ & .318 & - & 11.7 & 32.3 & 2.22 & .39 \\
\hline Control (2) & $>24-48$ & $12 / 05 / 2000$ & .151 & - & 12.6 & 22.5 & .89 & .18 \\
\hline Lower & $0-8$ & $12 / 11 / 2000$ & 1.32 & - & 35.9 & 112 & 11.0 & 2.31 \\
\hline Lower & $>8-24$ & $12 / 11 / 2000$ & .521 & - & 16.2 & 26.6 & 6.31 & .32 \\
\hline Lower & $>24-48$ & $12 / 11 / 2000$ & .158 & - & 18.7 & 21.7 & 2.33 & .05 \\
\hline MZ2 & $0-8$ & $03 / 20 / 2001$ & 8.12 & - & 43.0 & 241 & 12.1 & 29.0 \\
\hline MZ2 & $0-8$ & 03/20/2001 & 14.3 & - & 49.6 & 148 & 2.46 & 37.9 \\
\hline MZ6 & $0-16$ & 03/20/2001 & 9.12 & - & 65.4 & 309 & 13.1 & 28.2 \\
\hline MZ6 & $0-16$ & 03/20/2001 & 11.8 & - & 137 & 190 & 11.4 & 31.1 \\
\hline
\end{tabular}

${ }^{1}$ Iron, manganese, and zinc were extracted with Ammonium bicarbonate diethylenetriaminepentaacetic acid (AB-DTPA). 
Table 1-4. Chemical and physical properties of soil samples collected at the New Garden Township spray-irrigation site, New Garden Township, Pennsylvania, April 1999 through October 2001.-Continued

$\left[\mathrm{g} / \mathrm{cm}^{3}\right.$, grams per cubic centimeter; mv, millivolts; $\mathrm{mg} / \mathrm{kg}$, milligrams per kilogram; $\mathrm{N}$, nitrogen; $\mathrm{CaCO}_{3}$, calcium carbonate; ppm, parts per million; >, greater than; <, less than; - , no data]

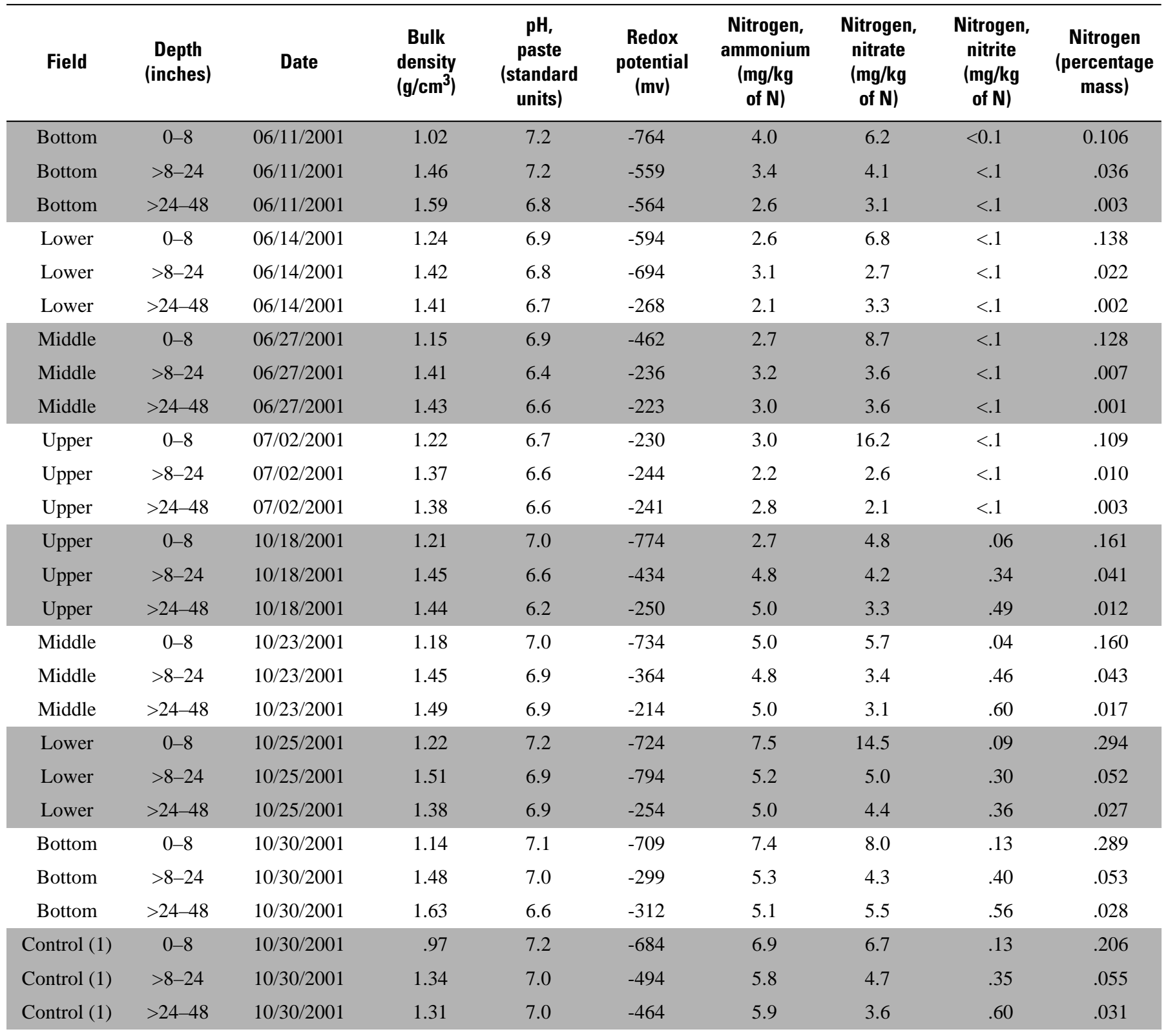


Table 1-4. Chemical and physical properties of soil samples collected at the New Garden Township spray-irrigation site, New Garden Township, Pennsylvania, April 1999 through October 2001.—Continued

$\left[\mathrm{g} / \mathrm{cm}^{3}\right.$, grams per cubic centimeter; mv, millivolts; mg/kg, milligrams per kilogram; $\mathrm{N}$, nitrogen; $\mathrm{CaCO}_{3}$, calcium carbonate; ppm, parts per million; >, greater than; <, less than; - , no data]

\begin{tabular}{|c|c|c|c|c|c|c|c|c|}
\hline Field & $\begin{array}{c}\text { Depth } \\
\text { (inches) }\end{array}$ & Date & $\begin{array}{c}\text { Carbon } \\
\text { (percentage } \\
\text { mass) }\end{array}$ & $\begin{array}{c}\mathrm{CaCO}_{3} \\
\text { equivalents } \\
\text { (percentage } \\
\text { mass) }\end{array}$ & $\begin{array}{c}\text { Chloride } \\
\text { (water } \\
\text { extractable, } \\
\text { mg/kg) }\end{array}$ & $\begin{array}{c}\text { Iron } \\
\text { (extractable, } \\
\text { ppm) }^{1}\end{array}$ & $\begin{array}{c}\text { Manganese } \\
\text { (extractable, } \\
\text { ppm) })^{1}\end{array}$ & $\begin{array}{c}\text { Zinc } \\
\text { (extractable, } \\
\text { ppm })^{1}\end{array}$ \\
\hline Bottom & $0-8$ & $06 / 11 / 2001$ & 1.231 & - & 32.6 & 81.6 & 10.7 & 6.93 \\
\hline Bottom & $>8-24$ & $06 / 11 / 2001$ & .679 & - & 37.9 & 29.2 & 4.26 & .40 \\
\hline Bottom & $>24-48$ & 06/11/2001 & .168 & - & 47.6 & 32.6 & 2.36 & .21 \\
\hline Lower & $0-8$ & 06/14/2001 & 1.555 & - & 530 & 51.8 & 8.51 & 1.66 \\
\hline Lower & $>8-24$ & 06/14/2001 & .382 & - & 42.6 & 18.1 & 5.83 & .25 \\
\hline Lower & $>24-48$ & 06/14/2001 & .122 & - & 56.6 & 12.4 & 1.44 & .06 \\
\hline Middle & $0-8$ & 06/27/2001 & 1.513 & - & 104 & 47.9 & 15.0 & 2.41 \\
\hline Middle & $>8-24$ & 06/27/2001 & .206 & - & 59.2 & 9.43 & 2.50 & .08 \\
\hline Middle & $>24-48$ & 06/27/2001 & .083 & - & 78.9 & 6.84 & .72 & .52 \\
\hline Upper & $0-8$ & 07/02/2001 & 1.257 & - & 218 & 37.1 & 2.34 & 1.01 \\
\hline Upper & $>8-24$ & 07/02/2001 & .385 & - & 50.2 & 11.8 & 3.10 & .09 \\
\hline Upper & $>24-48$ & 07/02/2001 & .152 & - & 40.3 & 8.11 & .92 & $<.01$ \\
\hline Upper & $0-8$ & $10 / 18 / 2001$ & 1.520 & - & 33.7 & 41.8 & 10.6 & 1.33 \\
\hline Upper & $>8-24$ & $10 / 18 / 2001$ & .244 & - & 22.9 & 16.7 & 3.28 & .57 \\
\hline Upper & $>24-48$ & $10 / 18 / 2001$ & .160 & - & 36.5 & 11.4 & 4.12 & .22 \\
\hline Middle & $0-8$ & $10 / 23 / 2001$ & 1.700 & - & 7.2 & 61.1 & 9.11 & 2.65 \\
\hline Middle & $>8-24$ & $10 / 23 / 2001$ & .297 & - & 28.5 & 21.3 & 3.68 & .28 \\
\hline Middle & $>24-48$ & $10 / 23 / 2001$ & .215 & - & 28.7 & 15.1 & 2.59 & .20 \\
\hline Lower & $0-8$ & $10 / 25 / 2001$ & 2.788 & - & 35.6 & 141 & 11.7 & 12.8 \\
\hline Lower & $>8-24$ & $10 / 25 / 2001$ & .417 & - & 20.2 & 37.3 & 3.54 & .70 \\
\hline Lower & $>24-48$ & $10 / 25 / 2001$ & .226 & - & 33.3 & 23.3 & 2.01 & .42 \\
\hline Bottom & $0-8$ & 10/30/2001 & 2.672 & - & 11.9 & 135 & 13.2 & 7.41 \\
\hline Bottom & $>8-24$ & 10/30/2001 & .475 & - & 6.0 & 39.2 & 3.23 & 1.09 \\
\hline Bottom & $>24-48$ & $10 / 30 / 2001$ & .178 & - & 14.9 & 29.4 & .99 & .17 \\
\hline Control (1) & $0-8$ & $10 / 30 / 2001$ & 1.951 & - & 5.2 & 88.8 & 10.1 & 4.77 \\
\hline Control (1) & $>8-24$ & $10 / 30 / 2001$ & .418 & - & 3.3 & 29.6 & 3.78 & .92 \\
\hline Control (1) & $>24-48$ & 10/30/2001 & .201 & - & 5.0 & 22.7 & 3.03 & .52 \\
\hline
\end{tabular}

\footnotetext{
${ }^{1}$ Iron, manganese, and zinc were extracted with Ammonium bicarbonate diethylenetriaminepentaacetic acid (AB-DTPA).
} 
Table 1-5. Results of chemical analyses of PAN samples collected at the New Garden Township spray-irrigation site, Chester County, Pennsylvania, July 1999 through 0 ctober 2001.

[mg/L, milligrams per liter; $\mu \mathrm{S} / \mathrm{cm}$, microsiemen per centimeter at 25 degrees Celsius; ${ }^{\circ} \mathrm{C}$, degrees Celsius; $\mathrm{N}$, nitrogen; $\mathrm{P}$, phosphorus; $\mathrm{C}$, carbon; $\mu \mathrm{g} / \mathrm{L}$, micrograms per liter;,- no data; <, less than]

\begin{tabular}{|c|c|c|c|c|c|c|c|c|c|c|c|c|}
\hline Date & Time & $\begin{array}{c}\text { Oxygen, } \\
\text { dissolved } \\
\text { (mg/L) }\end{array}$ & $\begin{array}{c}\text { pH, } \\
\text { field } \\
\text { (standard } \\
\text { units) }\end{array}$ & $\begin{array}{c}\text { Specific } \\
\text { conductance } \\
(\mu \mathrm{S} / \mathrm{cm})\end{array}$ & $\begin{array}{l}\text { Temperature, } \\
\text { water } \\
\left({ }^{\circ} \mathrm{C}\right)\end{array}$ & $\begin{array}{l}\text { Calcium, } \\
\text { dissolved } \\
\text { (mg/L) }\end{array}$ & $\begin{array}{c}\text { Magnesium, } \\
\text { dissolved } \\
\text { (mg/L) }\end{array}$ & $\begin{array}{l}\text { Potasium, } \\
\text { dissolved } \\
\text { (mg/L) }\end{array}$ & $\begin{array}{l}\text { Sodium, } \\
\text { dissolved } \\
\text { (mg/L) }\end{array}$ & $\begin{array}{c}\text { Bromide, } \\
\text { dissolved } \\
\text { (mg/L) }\end{array}$ & $\begin{array}{l}\text { Chloride, } \\
\text { dissolved } \\
\text { (mg/L) }\end{array}$ & $\begin{array}{c}\text { Flouride, } \\
\text { dissolved } \\
\text { (mg/L) }\end{array}$ \\
\hline $07 / 06 / 1999$ & 1030 & - & 7.6 & 768 & - & - & - & - & - & - & 84.0 & - \\
\hline 08/03/1999 & 0845 & - & - & - & - & - & - & - & - & - & 96.0 & - \\
\hline 08/03/1999 & 0915 & 8.9 & 8.4 & 741 & 20.1 & - & - & - & - & - & 95.0 & \\
\hline 09/09/1999 & 1045 & - & - & - & - & - & - & - & - & - & 91.0 & \\
\hline 09/09/1999 & 1130 & - & 9.1 & 701 & 25.6 & - & - & - & - & - & 94.0 & \\
\hline 10/07/1999 & 1000 & - & 9.3 & 588 & - & 33.4 & 18.0 & 16.6 & 51.5 & 0.30 & 67.5 & 0.4 \\
\hline 10/07/1999 & 1030 & - & 9.3 & 584 & - & 34.2 & 18.5 & 15.9 & 52.6 & .33 & 66.3 & .4 \\
\hline $10 / 26 / 1999$ & 1230 & - & 7.7 & 612 & - & - & - & - & - & - & 70.0 & - \\
\hline $10 / 26 / 1999$ & 1315 & - & 7.8 & 615 & - & - & - & - & - & - & 70.0 & - \\
\hline $12 / 09 / 1999$ & 0900 & - & 7.9 & 607 & - & - & - & - & - & - & 72.4 & - \\
\hline 12/09/1999 & 0925 & - & 8.0 & 606 & - & - & - & - & - & - & 70.4 & - \\
\hline 01/06/2000 & 1145 & - & 8.6 & 631 & - & - & - & - & - & - & 68.0 & - \\
\hline 01/06/2000 & 1245 & - & 8.7 & 633 & - & - & - & - & - & - & 69.0 & - \\
\hline 03/08/2000 & 1330 & - & 7.8 & 707 & - & - & - & - & - & - & 52.0 & - \\
\hline 03/08/2000 & 1340 & - & 8.0 & 718 & - & - & - & - & - & - & 77.0 & - \\
\hline $04 / 24 / 2000$ & 1130 & - & 8.2 & 624 & - & - & - & - & - & - & 80.0 & - \\
\hline $04 / 24 / 2000$ & 1000 & - & 8.2 & 627 & - & - & - & - & - & - & 80.0 & - \\
\hline 05/15/2000 & 0910 & - & 8.0 & 652 & - & - & - & - & - & - & 81.0 & - \\
\hline $05 / 15 / 2000$ & 0940 & - & 8.0 & 623 & - & - & - & - & - & - & 82.0 & - \\
\hline 06/29/2000 & 0915 & - & - & - & - & - & - & - & - & - & 87.0 & - \\
\hline 06/29/2000 & 0925 & - & 8.6 & 690 & - & - & - & - & - & - & 86.0 & - \\
\hline $07 / 31 / 2000$ & 0900 & - & 10.1 & 652 & - & - & - & - & - & - & 94.0 & - \\
\hline $07 / 31 / 2000$ & 0915 & - & 10.2 & 653 & - & - & - & - & - & - & 95.0 & - \\
\hline 08/07/2000 & 0900 & - & 9.0 & 711 & - & - & - & - & - & - & 99.0 & - \\
\hline 08/07/2000 & 0910 & - & 9.0 & 714 & - & - & - & - & - & - & 98.0 & - \\
\hline
\end{tabular}


Table 1-5. Results of chemical analyses of PAN samples collected at the New Garden Township spray-irrigation site, Chester County, Pennsylvania, July 1999 through October 2001.-Continued

[mg/L, milligrams per liter; $\mu \mathrm{S} / \mathrm{cm}$, microsiemen per centimeter at 25 degrees Celsius; ${ }^{\circ} \mathrm{C}$, degrees Celsius; $\mathrm{N}$, nitrogen; $\mathrm{P}$, phosphorus; $\mathrm{C}$, carbon; $\mu \mathrm{g} / \mathrm{L}$, micrograms per liter; —, no data; <, less than]

\begin{tabular}{|c|c|c|c|c|c|c|c|c|c|c|c|c|}
\hline Date & Time & $\begin{array}{c}\text { Silica, } \\
\text { dissolved } \\
\text { (mg/L as } \\
\mathrm{SiO}_{2} \text { ) }\end{array}$ & $\begin{array}{c}\text { Sulfate, } \\
\text { dissolved } \\
\text { (mg/L } \\
\left.\text { as } \mathrm{SO}_{4}\right)\end{array}$ & $\begin{array}{c}\text { Solids, } \\
\text { Residue } \\
\text { at } 180^{\circ} \mathrm{C} \\
(\mathrm{mg} / \mathrm{L})\end{array}$ & $\begin{array}{c}\text { Ammonia, } \\
\text { dissolved } \\
\text { (mg/L } \\
\text { as } N)\end{array}$ & $\begin{array}{c}\text { Ammonia, } \\
\text { total } \\
\text { (mg/L } \\
\text { as N) }\end{array}$ & $\begin{array}{c}\text { Nitrogen, } \\
\text { dissolved } \\
\text { (mg/L) }\end{array}$ & $\begin{array}{c}\text { Nitrate, } \\
\text { dissolved } \\
\text { (mg/L as N) }\end{array}$ & $\begin{array}{c}\text { Nitrite, } \\
\text { dissolved } \\
\text { (mg/L } \\
\text { as } \mathrm{N} \text { ) }\end{array}$ & $\begin{array}{c}\text { Nitrogen, } \\
\text { total } \\
\text { (mg/L) }\end{array}$ & $\begin{array}{l}\text { Phos- } \\
\text { phorus, } \\
\text { dissolved } \\
\text { (mg/L) }\end{array}$ & $\begin{array}{c}\text { Phos- } \\
\text { phorus } \\
\text { ortho, } \\
\text { dissolved } \\
\text { (mg/L as } \mathrm{P} \text { ) }\end{array}$ \\
\hline $07 / 06 / 1999$ & 1030 & - & - & - & 1.03 & 0.66 & 18 & 15.0 & 0.67 & 19 & - & - \\
\hline 08/03/1999 & 0845 & - & - & - & .43 & .58 & 16 & 13.8 & .26 & 19 & - & - \\
\hline 08/03/1999 & 0915 & - & - & - & .80 & .79 & 17 & 13.8 & .26 & 17 & - & - \\
\hline 09/09/1999 & 1045 & - & - & - & .16 & .17 & 10 & 9.40 & .31 & 12 & - & - \\
\hline 09/09/1999 & 1130 & - & - & - & .24 & .18 & 10 & 9.30 & .30 & 11 & - & - \\
\hline 10/07/1999 & 1000 & 8.4 & 56 & 334 & .53 & .55 & 9.4 & 5.71 & 1.99 & 10 & 1.45 & 1.42 \\
\hline 10/07/1999 & 1030 & 8.0 & 56 & 356 & .57 & .57 & 9.5 & 5.70 & 2.01 & 9.9 & 1.54 & 1.41 \\
\hline $10 / 26 / 1999$ & 1230 & - & - & - & 1.50 & 1.56 & 10 & 6.80 & .58 & 11 & - & - \\
\hline $10 / 26 / 1999$ & 1315 & - & - & - & 1.50 & 1.51 & 10 & 6.70 & .59 & 10 & - & - \\
\hline 12/09/1999 & 0900 & - & - & - & .16 & .16 & 11 & 8.95 & .13 & 11 & - & - \\
\hline 12/09/1999 & 0925 & - & - & - & .20 & .16 & 11 & 8.85 & .20 & 11 & - & - \\
\hline 01/06/2000 & 1145 & - & - & - & .05 & .08 & 10 & 9.90 & .21 & 12 & - & - \\
\hline 01/06/2000 & 1245 & - & - & - & .10 & .08 & 11 & 9.30 & .21 & 12 & - & - \\
\hline 03/08/2000 & 1330 & - & - & - & 4.67 & 4.84 & 14 & 7.60 & .16 & 15 & - & - \\
\hline 03/08/2000 & 1340 & - & - & - & 5.07 & 5.26 & 14 & 7.70 & .19 & 15 & - & - \\
\hline $04 / 24 / 2000$ & 1130 & - & - & - & .084 & .14 & 11 & 9.00 & .69 & 13 & - & - \\
\hline $04 / 24 / 2000$ & 1000 & - & - & - & .094 & .14 & 11 & 9.00 & .64 & 13 & - & - \\
\hline $05 / 15 / 2000$ & 0910 & - & - & - & 1.20 & 1.23 & 8.8 & 6.10 & .21 & 9.6 & - & - \\
\hline $05 / 15 / 2000$ & 0940 & - & - & - & 1.34 & 1.34 & 8.3 & 5.60 & .20 & 9.4 & - & - \\
\hline 06/29/2000 & 0915 & - & - & - & 1.53 & 1.55 & 7.2 & 3.84 & .75 & 8.0 & - & - \\
\hline 06/29/2000 & 0925 & - & - & - & 1.48 & 1.50 & 8.0 & 5.00 & .35 & 8.7 & - & - \\
\hline $07 / 31 / 2000$ & 0900 & - & - & - & .15 & .08 & 2.7 & .870 & .21 & 4.7 & - & - \\
\hline $07 / 31 / 2000$ & 0915 & - & - & - & .15 & .12 & 2.7 & .900 & .23 & 4.5 & - & - \\
\hline 08/07/2000 & 0900 & - & - & - & 1.47 & 1.58 & 5.6 & 2.14 & .68 & 9.6 & - & - \\
\hline 08/07/2000 & 0910 & - & - & - & 1.48 & 1.51 & 5.3 & 2.08 & .71 & 9.3 & - & - \\
\hline
\end{tabular}


Table 1-5. Results of chemical analyses of PAN samples collected at the New Garden Township spray-irrigation site, Chester County, Pennsylvania, July 1999 through October 2001.-Continued

[mg/L, milligrams per liter; $\mu \mathrm{S} / \mathrm{cm}$, microsiemen per centimeter at 25 degrees Celsius; ${ }^{\circ} \mathrm{C}$, degrees Celsius; $\mathrm{N}$, nitrogen; $\mathrm{P}$, phosphorus; $\mathrm{C}, \mathrm{carbon} ; \mu \mathrm{g} / \mathrm{L}, \mathrm{micrograms}$ per liter; -, no data; <, less than]

\begin{tabular}{|c|c|c|c|c|c|c|c|c|c|c|c|c|}
\hline Date & Time & $\begin{array}{c}\text { Phos- } \\
\text { phorus, } \\
\text { total } \\
\text { (mg/L) }\end{array}$ & $\begin{array}{c}\text { Carbon, } \\
\text { organic, } \\
\text { dissolved } \\
\text { (mg/L as C) }\end{array}$ & $\begin{array}{c}\text { Carbon, } \\
\text { organic, } \\
\text { total } \\
\text { (mg/L as C) }\end{array}$ & $\begin{array}{c}\text { Antimony, } \\
\text { dissolved } \\
(\mu \mathrm{g} / \mathrm{L})\end{array}$ & $\begin{array}{c}\text { Arsenic, } \\
\text { dissolved } \\
(\mu \mathrm{g} / \mathrm{L})\end{array}$ & $\begin{array}{c}\text { Barium, } \\
\text { dissolved } \\
(\mu \mathrm{g} / \mathrm{L})\end{array}$ & $\begin{array}{c}\text { Boron, } \\
\text { dissolved } \\
(\mu \mathrm{g} / \mathrm{L})\end{array}$ & $\begin{array}{c}\text { Cadmium, } \\
\text { dissolved } \\
(\mu \mathrm{g} / \mathrm{L})\end{array}$ & $\begin{array}{c}\text { Chromium, } \\
\text { dissolved } \\
(\mu \mathrm{g} / \mathrm{L})\end{array}$ & $\begin{array}{c}\text { Copper, } \\
\text { dissolved } \\
(\mu \mathrm{g} / \mathrm{L})\end{array}$ & $\begin{array}{c}\text { Iron, } \\
\text { dissolved } \\
(\mu \mathrm{g} / \mathrm{L})\end{array}$ \\
\hline $07 / 06 / 1999$ & 1030 & - & - & - & - & - & - & $<200$ & - & - & - & - \\
\hline 08/03/1999 & 0845 & - & - & - & - & - & - & 204 & - & - & - & - \\
\hline 08/03/1999 & 0915 & - & - & - & - & - & - & 211 & - & - & - & - \\
\hline 09/09/1999 & 1045 & - & - & 12 & - & - & - & $<200$ & - & - & - & $<20$ \\
\hline 09/09/1999 & 1130 & - & - & 12 & - & - & - & $<200$ & - & - & - & $<20$ \\
\hline $10 / 07 / 1999$ & 1000 & 1.81 & 12 & 12 & $<2.00$ & 4.7 & 5.9 & $<200$ & $<0.20$ & $<4.0$ & 9.0 & 30 \\
\hline $10 / 07 / 1999$ & 1030 & 1.66 & 12 & 14 & $<2.00$ & 5.2 & 7.3 & $<200$ & $<.20$ & $<4.0$ & 7.0 & 40 \\
\hline $10 / 26 / 1999$ & 1230 & - & - & - & - & - & - & $<200$ & - & - & - & - \\
\hline $10 / 26 / 1999$ & 1315 & - & - & - & - & - & - & 206 & - & - & - & - \\
\hline 12/09/1999 & 0900 & - & - & - & - & - & - & $<200$ & - & - & - & - \\
\hline 12/09/1999 & 0925 & - & - & - & - & - & - & $<200$ & - & - & - & - \\
\hline $01 / 06 / 2000$ & 1145 & - & - & 21 & - & - & - & $<200$ & - & - & - & 20 \\
\hline $01 / 06 / 2000$ & 1245 & - & - & 23 & - & - & - & $<200$ & - & - & - & 40 \\
\hline 03/08/2000 & 1330 & - & - & - & - & - & - & $<200$ & - & - & - & - \\
\hline 03/08/2000 & 1340 & - & - & - & - & - & - & 200 & - & - & - & - \\
\hline $04 / 24 / 2000$ & 1130 & - & - & - & - & - & - & $<200$ & - & - & - & - \\
\hline $04 / 24 / 2000$ & 1000 & - & - & - & - & - & - & $<200$ & - & - & - & - \\
\hline $05 / 15 / 2000$ & 0910 & - & - & - & - & - & - & $<200$ & - & - & - & - \\
\hline $05 / 15 / 2000$ & 0940 & - & - & - & - & - & - & $<200$ & - & - & - & - \\
\hline $06 / 29 / 2000$ & 0915 & - & - & - & - & - & - & $<200$ & - & - & - & - \\
\hline $06 / 29 / 2000$ & 0925 & - & - & - & - & - & - & $<200$ & - & - & - & - \\
\hline $07 / 31 / 2000$ & 0900 & - & - & - & - & - & - & 202 & - & - & - & - \\
\hline $07 / 31 / 2000$ & 0915 & - & - & - & - & - & - & $<200$ & - & - & - & - \\
\hline 08/07/2000 & 0900 & - & - & - & - & - & - & 223 & - & - & - & - \\
\hline 08/07/2000 & 0910 & - & - & - & - & - & - & 239 & - & - & - & - \\
\hline
\end{tabular}


Table 1-5. Results of chemical analyses of PAN samples collected at the New Garden Township spray-irrigation site, Chester County, Pennsylvania, July 1999 through October 2001.-Continued

[mg/L, milligrams per liter; $\mu \mathrm{S} / \mathrm{cm}$, microsiemen per centimeter at 25 degrees Celsius; ${ }^{\circ} \mathrm{C}$, degrees Celsius; $\mathrm{N}$, nitrogen; $\mathrm{P}$, phosphorus; $\mathrm{C}$, carbon; $\mu \mathrm{g} / \mathrm{L}$, micrograms per liter; —, no data; <, less than]

\begin{tabular}{|c|c|c|c|c|c|c|c|c|c|c|c|}
\hline Date & Time & $\begin{array}{c}\text { Iron, } \\
\text { total } \\
\text { recoverable } \\
(\mu \mathrm{g} / \mathrm{L})\end{array}$ & $\begin{array}{c}\text { Lead, } \\
\text { dissolved } \\
(\mu \mathrm{g} / \mathrm{L})\end{array}$ & $\begin{array}{c}\text { Lithium, } \\
\text { dissolved } \\
\text { ( } \mu \mathrm{g} / \mathrm{L})\end{array}$ & $\begin{array}{c}\text { Manganese, } \\
\text { dissolved } \\
(\mu \mathrm{g} / \mathrm{L})\end{array}$ & $\begin{array}{c}\text { Manganese, } \\
\text { total } \\
\text { recoverable } \\
(\mu \mathrm{g} / \mathrm{L})\end{array}$ & $\begin{array}{c}\text { Mercury, } \\
\text { dissolved } \\
(\mu \mathrm{g} / \mathrm{L})\end{array}$ & $\begin{array}{c}\text { Nickel, } \\
\text { dissolved } \\
(\mu \mathrm{g} / \mathrm{L})\end{array}$ & $\begin{array}{c}\text { Selenium, } \\
\text { dissolved } \\
(\mu \mathrm{g} / \mathrm{L})\end{array}$ & $\begin{array}{c}\text { Strontium, } \\
\text { dissolved } \\
(\mu \mathrm{g} / \mathrm{L})\end{array}$ & $\begin{array}{c}\text { Zinc, } \\
\text { dissolved } \\
(\mu \mathrm{g} / \mathrm{L})\end{array}$ \\
\hline $07 / 06 / 1999$ & 1030 & - & - & - & - & - & - & - & - & - & 45 \\
\hline 08/03/1999 & 0845 & - & - & - & - & - & - & - & - & - & 11 \\
\hline 08/03/1999 & 0915 & - & - & - & - & - & - & - & - & - & 11 \\
\hline 09/09/1999 & 1045 & 50 & - & - & $<10.0$ & $<10$ & - & - & - & - & $<10$ \\
\hline 09/09/1999 & 1130 & 60 & - & - & $<10.0$ & $<10$ & - & - & - & - & $<10$ \\
\hline 10/07/1999 & 1000 & - & $<1.00$ & $<25.0$ & 19.0 & - & $<0.20$ & 17.9 & $<7.0$ & 117 & $<10$ \\
\hline 10/07/1999 & 1030 & - & $<1.00$ & $<25.0$ & 18.0 & - & $<.20$ & 18.3 & $<7.0$ & 112 & 11 \\
\hline $10 / 26 / 1999$ & 1230 & - & - & - & - & - & - & - & - & - & 24 \\
\hline $10 / 26 / 1999$ & 1315 & - & - & - & - & - & - & - & - & - & 29 \\
\hline 12/09/1999 & 0900 & - & - & - & - & - & - & - & - & - & 32 \\
\hline 12/09/1999 & 0925 & - & - & - & - & - & - & - & - & - & 28 \\
\hline $01 / 06 / 2000$ & 1145 & 130 & - & - & $<10.0$ & 42 & - & - & - & - & 31 \\
\hline 01/06/2000 & 1245 & 120 & - & - & $<10.0$ & 38 & - & - & - & - & 30 \\
\hline 03/08/2000 & 1330 & - & - & - & - & - & - & - & - & - & 46 \\
\hline 03/08/2000 & 1340 & - & - & - & - & - & - & - & - & - & 47 \\
\hline $04 / 24 / 2000$ & 1130 & - & - & - & - & - & - & - & - & - & 39 \\
\hline $04 / 24 / 2000$ & 1000 & - & - & - & - & - & - & - & - & - & 40 \\
\hline $05 / 15 / 2000$ & 0910 & - & - & - & - & - & - & - & - & - & 35 \\
\hline $05 / 15 / 2000$ & 0940 & - & - & - & - & - & - & - & - & - & 33 \\
\hline $06 / 29 / 2000$ & 0915 & - & - & - & - & - & - & - & - & - & 20 \\
\hline $06 / 29 / 2000$ & 0925 & - & - & - & - & - & - & - & - & - & 16 \\
\hline $07 / 31 / 2000$ & 0900 & - & - & - & - & - & - & - & - & - & $<10$ \\
\hline $07 / 31 / 2000$ & 0915 & - & - & - & - & - & - & - & - & - & $<10$ \\
\hline 08/07/2000 & 0900 & - & - & - & - & - & - & - & - & - & 75 \\
\hline 08/07/2000 & 0910 & - & - & - & - & - & - & - & - & - & 75 \\
\hline
\end{tabular}


Table 1-5. Results of chemical analyses of PAN samples collected at the New Garden Township spray-irrigation site, Chester County, Pennsylvania, July 1999 through October 2001.-Continued

[mg/L, milligrams per liter; $\mu \mathrm{S} / \mathrm{cm}$, microsiemen per centimeter at 25 degrees Celsius; ${ }^{\circ} \mathrm{C}$, degrees Celsius; $\mathrm{N}$, nitrogen; $\mathrm{P}$, phosphorus; $\mathrm{C}$, carbon; $\mu \mathrm{g} / \mathrm{L}$, micrograms per liter; -, no data; <, less than]

\begin{tabular}{|c|c|c|c|c|c|c|c|c|c|c|c|c|}
\hline Date & Time & $\begin{array}{l}\text { Oxygen, } \\
\text { dissolved } \\
\text { (mg/L) }\end{array}$ & $\begin{array}{c}\text { pH, } \\
\text { field } \\
\text { (standard } \\
\text { units) }\end{array}$ & $\begin{array}{c}\text { Specific } \\
\text { conductance } \\
(\mu \mathrm{S} / \mathrm{cm})\end{array}$ & $\begin{array}{c}\text { Temperature, } \\
\text { water } \\
\text { (deg C) }\end{array}$ & $\begin{array}{c}\text { Calcium, } \\
\text { dissolved } \\
\text { (mg/L) }\end{array}$ & $\begin{array}{c}\text { Magnesium, } \\
\text { dissolved } \\
\text { (mg/L) }\end{array}$ & $\begin{array}{c}\text { Potasium, } \\
\text { dissolved } \\
\text { (mg/L) }\end{array}$ & $\begin{array}{l}\text { Sodium, } \\
\text { dissolved } \\
\text { (mg/L) }\end{array}$ & $\begin{array}{c}\text { Bromide, } \\
\text { dissolved } \\
\text { (mg/L) }\end{array}$ & $\begin{array}{c}\text { Chloride, } \\
\text { dissolved } \\
\text { (mg/L) }\end{array}$ & $\begin{array}{c}\text { Flouride, } \\
\text { dissolved } \\
\text { (mg/L) }\end{array}$ \\
\hline $10 / 03 / 2000$ & 1045 & 8.8 & 10 & 573 & 20.5 & - & - & - & - & - & 94.0 & - \\
\hline $10 / 03 / 2000$ & 1100 & 9.0 & 9.9 & 577 & 20.1 & - & - & - & - & - & 92.0 & - \\
\hline $10 / 31 / 2000$ & 0945 & - & 9.6 & 719 & - & - & - & - & - & - & 128 & - \\
\hline $10 / 31 / 2000$ & 1000 & - & 9.7 & 666 & - & - & - & - & - & - & 113 & - \\
\hline $06 / 14 / 2001$ & 0815 & - & 7.6 & 700 & - & - & - & - & - & - & 91.0 & - \\
\hline $06 / 14 / 2001$ & 0830 & - & 7.7 & 702 & - & - & - & - & - & - & 91.0 & - \\
\hline 06/28/2001 & 0900 & - & 7.6 & 677 & - & - & - & - & - & - & 90.0 & - \\
\hline $06 / 28 / 2001$ & 0915 & - & 7.8 & 682 & - & - & - & - & - & - & 90.0 & - \\
\hline 07/18/2001 & 0940 & - & 9.1 & 622 & - & - & - & - & - & - & 89.0 & - \\
\hline $07 / 18 / 2001$ & 0948 & - & 9.1 & 624 & - & - & - & - & - & - & 89.0 & - \\
\hline $08 / 22 / 2001$ & 0830 & - & 9.6 & 629 & - & - & - & - & - & - & 96.0 & - \\
\hline $08 / 22 / 2001$ & 0835 & - & 9.6 & 631 & - & - & - & - & - & - & 97.7 & - \\
\hline $09 / 27 / 2001$ & 0845 & - & 9.3 & 621 & - & - & - & - & - & - & 94.5 & - \\
\hline $09 / 27 / 2001$ & 0850 & - & 9.3 & 623 & - & - & - & - & - & - & 93.4 & - \\
\hline $10 / 25 / 2001$ & 0815 & - & 9.8 & 625 & - & - & - & - & - & - & 95.8 & - \\
\hline $10 / 25 / 2001$ & 0820 & - & 9.7 & 624 & - & - & - & - & - & - & 94.3 & - \\
\hline
\end{tabular}


Table 1-5. Results of chemical analyses of PAN samples collected at the New Garden Township spray-irrigation site, Chester County, Pennsylvania, July 1999 through October 2001.-Continued

[mg/L, milligrams per liter; $\mu \mathrm{S} / \mathrm{cm}$, microsiemen per centimeter at 25 degrees Celsius; ${ }^{\circ} \mathrm{C}$, degrees Celsius; $\mathrm{N}$, nitrogen; $\mathrm{P}$, phosphorus; $\mathrm{C}$, carbon; $\mu \mathrm{g} / \mathrm{L}$, micrograms per liter; —, no data; <, less than]

\begin{tabular}{|c|c|c|c|c|c|c|c|c|c|c|c|c|}
\hline Date & Time & $\begin{array}{c}\text { Silica, } \\
\text { dissolved } \\
\text { (mg/L as } \\
\left.\mathrm{SiO}_{2}\right)\end{array}$ & $\begin{array}{c}\text { Sulfate, } \\
\text { dissolved } \\
\text { (mg/L } \\
\left.\text { as } \mathrm{SO}_{4}\right)\end{array}$ & $\begin{array}{c}\text { Solids, } \\
\text { Residue } \\
\text { at } 180 \\
\operatorname{deg} \mathrm{C} \\
\text { (mg/L) }\end{array}$ & $\begin{array}{c}\text { Ammonia, } \\
\text { dissolved } \\
\text { (mg/L } \\
\text { as N) }\end{array}$ & $\begin{array}{c}\text { Ammonia, } \\
\text { total } \\
\text { (mg/L } \\
\text { as } N \text { ) }\end{array}$ & $\begin{array}{c}\text { Nitrogen, } \\
\text { dissolved } \\
\text { (mg/L) }\end{array}$ & $\begin{array}{c}\text { Nitrate, } \\
\text { dissolved } \\
\text { (mg/L as N) }\end{array}$ & $\begin{array}{c}\text { Nitrite, } \\
\text { dissolved } \\
\text { (mg/L } \\
\text { as } \mathrm{N})\end{array}$ & $\begin{array}{c}\text { Nitrogen, } \\
\text { total } \\
(\mathrm{mg} / \mathrm{L})\end{array}$ & $\begin{array}{l}\text { Phos- } \\
\text { phorus, } \\
\text { dissolved } \\
\text { (mg/L) }\end{array}$ & $\begin{array}{c}\text { Phos- } \\
\text { phorus } \\
\text { ortho, } \\
\text { dissolved } \\
\text { (mg/L as } \mathrm{P} \text { ) }\end{array}$ \\
\hline $10 / 03 / 2000$ & 1045 & - & - & - & 0.060 & 0.07 & 5.2 & 2.92 & .95 & 6.4 & - & - \\
\hline $10 / 03 / 2000$ & 1100 & - & - & - & .070 & .07 & 5.0 & 2.93 & .94 & 6.3 & - & - \\
\hline $10 / 31 / 2000$ & 0945 & - & - & - & $<.020$ & .02 & 8.1 & 5.99 & $<1.00$ & 10 & - & - \\
\hline $10 / 31 / 2000$ & 1000 & - & - & - & .070 & .11 & 7.8 & 5.87 & $<.04$ & 9.2 & - & - \\
\hline 06/14/2001 & 0815 & - & - & - & 5.90 & 6.02 & 3.6 & 3.15 & .58 & 3.8 & 3.92 & 2.39 \\
\hline $06 / 14 / 2001$ & 0830 & - & - & - & 5.46 & 5.83 & 11 & 3.17 & .47 & 12 & 3.85 & 2.33 \\
\hline $06 / 28 / 2001$ & 0900 & - & - & - & 2.37 & 2.42 & 11 & 4.71 & 1.12 & 12 & 4.62 & 4.60 \\
\hline $06 / 28 / 2001$ & 0915 & - & - & - & 2.08 & 2.11 & 14 & 4.80 & 1.09 & 15 & 4.67 & 4.51 \\
\hline 07/18/2001 & 0940 & - & - & - & 1.08 & 1.11 & 6.4 & 2.42 & .91 & 6.3 & .658 & .544 \\
\hline $07 / 18 / 2001$ & 0948 & - & - & - & 1.07 & 1.10 & 7.3 & 2.43 & .86 & 7.4 & .631 & .505 \\
\hline $08 / 22 / 2001$ & 0830 & - & - & - & .48 & .50 & 3.5 & 1.19 & .65 & 5.8 & .667 & .470 \\
\hline $08 / 22 / 2001$ & 0835 & - & - & - & .48 & .49 & 3.9 & 1.23 & .67 & 4.8 & .724 & .523 \\
\hline 09/27/2001 & 0845 & - & - & - & .64 & .65 & 4.6 & 1.10 & .67 & 6.7 & .780 & .724 \\
\hline 09/27/2001 & 0850 & - & - & - & .52 & .52 & 4.1 & 1.23 & .75 & 6.1 & .789 & .685 \\
\hline $10 / 25 / 2001$ & 0815 & - & - & - & .43 & .43 & 4.5 & 2.30 & .32 & 7.0 & .429 & .317 \\
\hline $10 / 25 / 2001$ & 0820 & - & - & - & .41 & .41 & 4.4 & 2.29 & .33 & 6.8 & .412 & .324 \\
\hline
\end{tabular}


Table 1-5. Results of chemical analyses of PAN samples collected at the New Garden Township spray-irrigation site, Chester County, Pennsylvania, July 1999 through

October 2001.-Continued

[mg/L, milligrams per liter; $\mu \mathrm{S} / \mathrm{cm}$, microsiemen per centimeter at 25 degrees Celsius; ${ }^{\circ} \mathrm{C}$, degrees Celsius; $\mathrm{N}$, nitrogen; $\mathrm{P}$, phosphorus; $\mathrm{C}$, carbon; $\mu \mathrm{g} / \mathrm{L}, \mathrm{micrograms}$ per liter; - , no data; <, less than]

\begin{tabular}{|c|c|c|c|c|c|c|c|c|c|c|c|c|}
\hline Date & Time & $\begin{array}{l}\text { Phos- } \\
\text { phorus, } \\
\text { total } \\
\text { (mg/L) }\end{array}$ & $\begin{array}{c}\text { Carbon, } \\
\text { organic, } \\
\text { dissolved } \\
\text { (mg/L as C) }\end{array}$ & $\begin{array}{c}\text { Carbon, } \\
\text { organic, } \\
\text { total } \\
\text { (mg/L as C) }\end{array}$ & $\begin{array}{c}\text { Antimony, } \\
\text { dissolved } \\
(\mu \mathrm{g} / \mathrm{L})\end{array}$ & $\begin{array}{c}\text { Arsenic, } \\
\text { dissolved } \\
(\mu \mathrm{g} / \mathrm{L})\end{array}$ & $\begin{array}{c}\text { Barium, } \\
\text { dissolved } \\
(\mu \mathrm{g} / \mathrm{L})\end{array}$ & $\begin{array}{c}\text { Boron, } \\
\text { dissolved } \\
(\mu \mathrm{g} / \mathrm{L})\end{array}$ & $\begin{array}{c}\text { Cadmium, } \\
\text { dissolved } \\
(\mu \mathrm{g} / \mathrm{L})\end{array}$ & $\begin{array}{c}\text { Chromium, } \\
\text { dissolved } \\
(\mu \mathrm{g} / \mathrm{L})\end{array}$ & $\begin{array}{c}\text { Copper, } \\
\text { dissolved } \\
(\mu \mathrm{g} / \mathrm{L})\end{array}$ & $\begin{array}{c}\text { Iron, } \\
\text { dissolved } \\
(\mu \mathrm{g} / \mathrm{L})\end{array}$ \\
\hline $10 / 03 / 2000$ & 1045 & - & - & - & - & - & - & 222 & - & - & - & - \\
\hline $10 / 03 / 2000$ & 1100 & - & - & - & - & - & - & 214 & - & - & - & - \\
\hline $10 / 31 / 2000$ & 0945 & - & - & - & - & - & - & 243 & - & - & - & - \\
\hline $10 / 31 / 2000$ & 1000 & - & - & - & - & - & - & 232 & - & - & - & - \\
\hline 06/14/2001 & 0815 & 4.09 & - & - & - & - & - & - & - & - & - & - \\
\hline $06 / 14 / 2001$ & 0830 & 4.01 & - & - & - & - & - & - & - & - & - & - \\
\hline 06/28/2001 & 0900 & 4.73 & - & - & - & - & - & - & - & - & - & - \\
\hline 06/28/2001 & 0915 & 4.77 & - & - & - & - & - & - & - & - & - & - \\
\hline 07/18/2001 & 0940 & 1.98 & - & - & - & - & - & - & - & - & - & - \\
\hline 07/18/2001 & 0948 & 2.00 & - & - & - & - & - & - & - & - & - & - \\
\hline $08 / 22 / 2001$ & 0830 & 1.44 & - & - & - & - & - & - & - & - & - & - \\
\hline $08 / 22 / 2001$ & 0835 & 1.40 & - & - & - & - & - & - & - & - & - & - \\
\hline 09/27/2001 & 0845 & 1.69 & - & - & - & - & - & - & - & - & - & - \\
\hline 09/27/2001 & 0850 & 1.68 & - & - & - & - & - & - & - & - & - & - \\
\hline $10 / 25 / 2001$ & 0815 & 1.29 & - & - & - & - & - & - & - & - & - & - \\
\hline $10 / 25 / 2001$ & 0820 & 1.28 & - & - & - & - & - & - & - & - & - & - \\
\hline
\end{tabular}


Table 1-5. Results of chemical analyses of PAN samples collected at the New Garden Township spray-irrigation site, Chester County, Pennsylvania, July 1999 through October 2001.-Continued

[mg/L, milligrams per liter; $\mu \mathrm{S} / \mathrm{cm}$, microsiemen per centimeter at 25 degrees Celsius; ${ }^{\circ} \mathrm{C}$, degrees Celsius; $\mathrm{N}$, nitrogen; $\mathrm{P}$, phosphorus; $\mathrm{C}$, carbon; $\mu \mathrm{g} / \mathrm{L}$, micrograms per liter; —, no data; <, less than]

\begin{tabular}{|c|c|c|c|c|c|c|c|c|c|c|c|}
\hline Date & Time & $\begin{array}{c}\text { Iron, } \\
\text { total } \\
\text { recoverable } \\
(\mu \mathrm{g} / \mathrm{L})\end{array}$ & $\begin{array}{c}\text { Lead, } \\
\text { dissolved } \\
(\mu \mathrm{g} / \mathrm{L})\end{array}$ & $\begin{array}{l}\text { Lithium, } \\
\text { dissolved } \\
\text { ( } \mu \mathrm{g} / \mathrm{L})\end{array}$ & $\begin{array}{c}\text { Manganese, } \\
\text { dissolved } \\
(\mu \mathrm{g} / \mathrm{L})\end{array}$ & $\begin{array}{c}\text { Manganese, } \\
\text { total } \\
\text { recoverable } \\
(\mu \mathrm{g} / \mathrm{L})\end{array}$ & $\begin{array}{l}\text { Mercury, } \\
\text { dissolved } \\
(\mu \mathrm{g} / \mathrm{L})\end{array}$ & $\begin{array}{c}\text { Nickel, } \\
\text { dissolved } \\
(\mu \mathrm{g} / \mathrm{L})\end{array}$ & $\begin{array}{c}\text { Selenium, } \\
\text { dissolved } \\
(\mu \mathrm{g} / \mathrm{L})\end{array}$ & $\begin{array}{c}\text { Strontium, } \\
\text { dissolved } \\
(\mu \mathrm{g} / \mathrm{L})\end{array}$ & $\begin{array}{c}\text { Zinc, } \\
\text { dissolved } \\
(\mu \mathrm{g} / \mathrm{L})\end{array}$ \\
\hline $10 / 03 / 2000$ & 1045 & - & - & - & - & - & - & - & - & - & $<10$ \\
\hline $10 / 03 / 2000$ & 1100 & - & - & - & - & - & - & - & - & - & $<10$ \\
\hline $10 / 31 / 2000$ & 0945 & - & - & - & - & - & - & - & - & - & 14 \\
\hline $10 / 31 / 2000$ & 1000 & - & - & - & - & - & - & - & - & - & 11 \\
\hline 06/14/2001 & 0815 & - & - & - & - & - & - & - & - & - & 56 \\
\hline $06 / 14 / 2001$ & 0830 & - & - & - & - & - & - & - & - & - & 52 \\
\hline 06/28/2001 & 0900 & - & - & - & - & - & - & - & - & - & 15 \\
\hline 06/28/2001 & 0915 & - & - & - & - & - & - & - & - & - & 26 \\
\hline 07/18/2001 & 0940 & - & - & - & - & - & - & - & - & - & $<10$ \\
\hline 07/18/2001 & 0948 & - & - & - & - & - & - & - & - & - & $<10$ \\
\hline 08/22/2001 & 0830 & - & - & - & - & - & - & - & - & - & $<10$ \\
\hline 08/22/2001 & 0835 & - & - & - & - & - & - & - & - & - & $<10$ \\
\hline 09/27/2001 & 0845 & - & - & - & - & - & - & - & - & - & $<10$ \\
\hline 09/27/2001 & 0850 & - & - & - & - & - & - & - & - & - & 158 \\
\hline $10 / 25 / 2001$ & 0815 & - & - & - & - & - & - & - & - & - & $<10$ \\
\hline $10 / 25 / 2001$ & 0820 & - & - & - & - & - & - & - & - & - & $<10$ \\
\hline
\end{tabular}


Table 1-6. Nitrogen-concentration data for plant samples collected immediately prior to, during, or immediately after cutting for harvest at the New Garden Township spray-irrigation site, Chester County, Pennsylvania, May 1999 through September 2001.

\begin{tabular}{|c|c|c|}
\hline $\begin{array}{l}\text { Soil-sampling } \\
\text { area }\end{array}$ & Date & $\begin{array}{c}\text { Nitrogen } \\
\text { (in percentage mass) }\end{array}$ \\
\hline Upper & $05 / 12 / 1999$ & 2.58 \\
\hline Upper & 05/12/1999 & 2.88 \\
\hline Middle & 05/12/1999 & 2.39 \\
\hline Middle & 05/12/1999 & 2.94 \\
\hline Lower & 05/12/1999 & 2.62 \\
\hline Lower & 05/12/1999 & 2.86 \\
\hline Bottom & 05/12/1999 & 2.61 \\
\hline Bottom & 05/12/1999 & 2.65 \\
\hline Control (2) & 05/12/1999 & 2.65 \\
\hline Control (2) & 05/12/1999 & 2.48 \\
\hline Upper & 07/15/1999 & 2.09 \\
\hline Upper & 07/15/1999 & 2.29 \\
\hline Middle & 07/15/1999 & 2.68 \\
\hline Middle & 07/15/1999 & 2.43 \\
\hline Lower & 07/15/1999 & 2.02 \\
\hline Lower & 07/15/1999 & 1.97 \\
\hline Bottom & 07/15/1999 & 1.92 \\
\hline Bottom & 07/15/1999 & 2.05 \\
\hline Upper & 08/30/1999 & 2.53 \\
\hline Upper & 08/30/1999 & 2.81 \\
\hline Middle & 08/30/1999 & 2.61 \\
\hline Middle & 08/30/1999 & 2.70 \\
\hline Lower & 08/30/1999 & 2.60 \\
\hline Lower & 08/30/1999 & 2.48 \\
\hline Control (1) & 08/30/1999 & 2.04 \\
\hline Control (1) & 08/30/1999 & 1.59 \\
\hline Upper & $10 / 29 / 1999$ & 3.06 \\
\hline Upper & 10/29/1999 & 2.91 \\
\hline Middle & 10/29/1999 & 3.00 \\
\hline Middle & 10/29/1999 & 3.06 \\
\hline Lower & 10/29/1999 & 2.86 \\
\hline Lower & 10/29/1999 & 2.98 \\
\hline Bottom & 10/29/1999 & 2.51 \\
\hline Bottom & 10/29/1999 & 2.59 \\
\hline Control (1) & 10/29/1999 & 2.83 \\
\hline Control (1) & 10/29/1999 & 3.03 \\
\hline Upper & $05 / 15 / 2000$ & 2.40 \\
\hline Upper & $05 / 15 / 2000$ & 1.93 \\
\hline Middle & $05 / 15 / 2000$ & 1.93 \\
\hline Middle & $05 / 15 / 2000$ & 2.46 \\
\hline Lower & $05 / 15 / 2000$ & 2.55 \\
\hline Lower & $05 / 15 / 2000$ & 2.73 \\
\hline Bottom & $05 / 15 / 2000$ & 2.14 \\
\hline Bottom & $05 / 15 / 2000$ & 2.12 \\
\hline Control (1) & $05 / 15 / 2000$ & 2.38 \\
\hline Control (1) & $05 / 15 / 2000$ & 2.47 \\
\hline Control (2) & $05 / 15 / 2000$ & 1.95 \\
\hline Control (2) & $05 / 15 / 2000$ & 2.12 \\
\hline
\end{tabular}

\begin{tabular}{|c|c|c|}
\hline $\begin{array}{c}\text { Soil-sampling } \\
\text { area }\end{array}$ & Date & $\begin{array}{c}\text { Nitrogen } \\
\text { (in percentage mass) }\end{array}$ \\
\hline Upper & $07 / 10 / 2000$ & 3.50 \\
\hline Upper & 07/10/2000 & 3.45 \\
\hline Middle & 07/10/2000 & 3.16 \\
\hline Middle & 07/10/2000 & 2.19 \\
\hline Lower & 07/10/2000 & 2.65 \\
\hline Lower & 07/10/2000 & 2.49 \\
\hline Control (1) & 07/10/2000 & 2.58 \\
\hline Control (1) & 07/10/2000 & 2.87 \\
\hline Control (2) & 07/10/2000 & 2.41 \\
\hline Control (2) & 07/10/2000 & 2.18 \\
\hline Upper & 09/13/2000 & 2.51 \\
\hline Upper & 09/13/2000 & 2.29 \\
\hline Middle & 09/13/2000 & 2.31 \\
\hline Middle & 09/13/2000 & 2.56 \\
\hline Lower & 09/13/2000 & 1.28 \\
\hline Lower & $09 / 13 / 2000$ & 2.16 \\
\hline Control (1) & $09 / 13 / 2000$ & 2.49 \\
\hline Control (1) & 09/13/2000 & 2.31 \\
\hline Control (2) & 09/13/2000 & 2.34 \\
\hline Control (2) & 09/13/2000 & 2.48 \\
\hline Upper & $05 / 31 / 2001$ & 1.39 \\
\hline Upper & $05 / 31 / 2001$ & 1.22 \\
\hline Middle & $05 / 31 / 2001$ & 1.62 \\
\hline Middle & 05/31/2001 & 1.02 \\
\hline Lower & 05/31/2001 & 1.39 \\
\hline Lower & $05 / 31 / 2001$ & 1.32 \\
\hline Bottom & $05 / 31 / 2001$ & 1.28 \\
\hline Bottom & 05/31/2001 & 1.27 \\
\hline Control (1) & $05 / 31 / 2001$ & 1.54 \\
\hline Control (1) & $05 / 31 / 2001$ & 1.56 \\
\hline Control (2) & $05 / 31 / 2001$ & 1.22 \\
\hline Control (2) & 05/31/2001 & 1.01 \\
\hline Upper & $07 / 23 / 2001$ & 2.25 \\
\hline Upper & $07 / 23 / 2001$ & 2.50 \\
\hline Lower & $07 / 23 / 2001$ & 2.40 \\
\hline Lower & $07 / 23 / 2001$ & 1.98 \\
\hline Control (1) & 07/23/2001 & 2.25 \\
\hline Control (1) & $07 / 23 / 2001$ & 2.40 \\
\hline Control (2) & $07 / 23 / 2001$ & 1.68 \\
\hline Control (2) & 07/23/2001 & 2.28 \\
\hline Upper & 09/20/2001 & 2.62 \\
\hline Upper & 09/20/2001 & 2.30 \\
\hline Middle & 09/20/2001 & 2.98 \\
\hline Middle & 09/20/2001 & 2.06 \\
\hline Lower & 09/20/2001 & 1.70 \\
\hline Lower & 09/20/2001 & 2.52 \\
\hline Bottom & 09/20/2001 & 2.86 \\
\hline Bottom & 09/20/2001 & 3.10 \\
\hline Control (1) & 09/20/2001 & 3.41 \\
\hline Control (1) & 09/20/2001 & 3.74 \\
\hline
\end{tabular}

